\author{
Universidade de São Paulo \\ Instituto de Física \\ Instituto de Química \\ Instituto de Biociências \\ Faculdade de Educação
}

MARCIA TIEMI SAITO

\title{
A gênese e o desenvolvimento da relação entre Física Quântica e misticismo e suas contribuições para o Ensino de Ciências
}



MARCIA TIEMI SAITO

\title{
A gênese e o desenvolvimento da relação entre Física Quântica e misticismo e suas contribuições para o Ensino de Ciências
}

\author{
Versão Corrigida \\ (Versão original encontra-se na unidade que aloja o Programa de Pós-graduação)
}

Tese apresentada ao Programa de Pós-graduação Interunidades em Ensino de Ciências da Universidade de São Paulo para a obtenção do título de Doutora em Ciências.

Área de concentração: Ensino de Física

Orientador: Prof. Dr. Ivã Gurgel 
Autorizo a reprodução e divulgação total ou parcial deste trabalho, por qualquer meio convencional ou eletrônico, para fins de estudo e pesquisa, desde que citada a fonte.

FICHA CATALOGRÁFICA

Preparada pelo Serviço de Biblioteca e Informação do Instituto de Física da Universidade de São Paulo

Saito, Marcia Tiemi

A gênese e o desenvolvimento da relação entre física quântica e misticismo e suas contribuições para o ensino de ciências. São Paulo, 2019.

Tese (Doutorado) - Universidade de São Paulo. Instituto de Física

Orientador: Prof. Dr. Ivã Gurgel

Área de Concentração: Ensino de Física.

Unitermos: 1. Física - Estudo e ensino; 2. Física quântica - Estudo e ensino; 3. Misticismo; 4. Ludwik Fleck; 5. Alfabetização científica. 
Para Fernando, Meu companheiro em todos os momentos. 



\section{Agradecimentos}

Ao longo dos anos que compreenderam a realização desta pesquisa, enfrentei diversos momentos de dificuldades e alegrias, de conquistas e superações e, por conta disso, posso afirmar, sem sombra de dúvida, que este trabalho é uma vitória. Nesse período, inúmeras pessoas contribuíram para que esses momentos pudessem ser enfrentados da melhor forma possível. Impossível nomear todas elas, mas o seu apoio, de alguma forma, está refletido nestas páginas e a elas eu só tenho um sentimento: gratidão.

Em primeiro lugar, gostaria de agradecer ao meu orientador Ivã Gurgel, por sempre ter acreditado e confiado plenamente no meu trabalho, pelo seu incentivo e paciência na minha migração da área de pesquisa em Física, para a área de Ensino de Ciências, pelas suas contribuições na minha formação, quando minhas reflexões iniciais sobre Educação ainda eram permeadas por sensos comuns, mas, principalmente, pelo seu lado humano, que permitiu com que a nossa relação se tornasse também uma relação de amizade.

Agradeço também ao Prof. Michel Paty, a quem a minha admiração e respeito não cabem em palavras, por ter se aberto às minhas reflexões filósoficas e acreditado no meu potencial, desde a época em que minhas pesquisas ainda eram na área da Física, por ter me recebido e orientado em Paris, durante o doutorado sanduíche, mas, principalmente, por sempre ter me inspirado com suas profundas reflexões filosóficas e com sua imensa humildade.

Aos professores, também de grande admiração, Osvaldo Pessoa Jr, Olival Freire Jr e Mauro Condé, pelas suas contribuições e críticas a este trabalho. Aos professores João Zanetic, Cristiano Mattos, Maurício Pietrocola, Maria Regina Kawamura que me influenciaram e inspiraram ao longo da minha formação no Ensino de Ciências e, portanto, de alguma forma, contribuíram com este trabalho.

Agradeço ao meu companheiro Fernando Benitez, por estar ao meu lado e me apoiar sempre em todos os sentidos, e nunca ter permitido que o desânimo entrasse em nossas vidas, mesmo nos momentos mais difíceis. Juntos, nesse período, superamos um câncer e, juntos, superaremos qualquer coisa.

Agradeço aos meus pais, por sempre me apoiarem em todas as minhas conquistas, me tornei o que sou, em grande parte, por vocês. À minha irmã e à minha família, pela amizade e pelo apoio. 
Aos meus colegas e amigos do TeHCo, nosso grupo de pesquisa, com quem os debates e troca de ideias sempre foram muito valiosos e contribuíram para a formação de boa parte da minha visão de mundo. Aos meus amigos do IFUSP, do PIEC e da FEUSP, pela convivência, troca de ideias, risadas e momentos agradáveis.

Aos colegas e professores do laboratório SPHERE, que me acolheram na minha estadia em Paris, durante o doutorado sanduíche. Aos meus amigos da Maison du Brésil, que tornaram essa estadia única e inesquecível.

Aos meus colegas de trabalho do IFPR, que me apoiaram e tornaram viável a minha ida à França. Aos meus alunos, que me orgulham e me motivam a continuar trabalhando pela Educação.

Aos meus amigos Marília, Carol, Thays e Gabriel, que, mesmo longe, estão sempre perto.

À CAPES pelo apoio financeiro a essa pesquisa e ao meu estágio de doutorado sanduíche na Université de Paris 7 - Denis Diderot.

Ao Programa Interunidades em Ensino de Ciências da USP e ao Instituto Federal do Paraná, pelo apoio a essa pesquisa. 


\section{Resumo}

SAITO, Marcia Tiemi. A gênese e o desenvolvimento da relação entre Física Quântica e misticismo e suas contribuições para o Ensino de Ciências. Tese (Doutorado em Ensino de Fisica) - Ensino de Ciências (Física, Química e Biologia), Universidade de São Paulo, São Paulo, 2018.

Desde o seu surgimento, o termo "Alfabetização Científica" (AC) vem sido amplamente discutido e (re)significado e, apesar da sua necessidade e importância serem consideradas um consenso na área de Ensino de Ciências (EC), ainda há pouco consenso a respeito do seu significado e dos seus objetivos. Em uma análise dos argumentos utilizados na busca desse consenso, nota-se a presença de aspectos que não levam em conta os fatores sociais que influenciam a ciência, a apropriação e a circulação do conhecimento científico em meios nãocientíficos. Partindo-se dessa problemática, o presente trabalho busca analisar um exemplo concreto de uma teoria científica, que foi apropriada e adquiriu novos significados e interpretações, ao circular no meio sociocultural e as suas possíveis contribuições para o EC. Trata-se dos diferentes usos e interpretações da Física Quântica (FQ) que vêm sido feitos nas últimas décadas em meios não-científicos, os quais culminaram no fenômeno cultural denominado misticismo quântico. Assim, este trabalho se baseará na epistemologia de Ludwik Fleck acerca da circulação do conhecimento, para investigar as origens históricosociais e os processos de difusão da FQ e a gênese e o desenvolvimento da sua relação com o misticismo. A partir dessa análise, foi possível perceber que a circulação do conhecimento científico é inerente ao desenvolvimento da Ciência e que a formação da relação entre a FQ e o misticismo teve a sua origem na circulação do conhecimento dentro do próprio coletivo de pensamento dos pesquisadores em Fundamentos da FQ e nos debates entre os fundadores dessa teoria. Dessa forma, se evidencia a fragilidade de alguns pressupostos implícitos nos argumentos utilizados em favor da $\mathrm{AC}$, como a necessidade e a preocupação com a aquisição de um corpo fechado e estático de conhecimento, o qual exerceria o papel de proteger os indivíduos de alguns males existentes na sociedade. Também foi possível criticar as posturas combativas de caráter dogmático com relação às pseudociências, as quais aproximam algumas tendências da $\mathrm{AC}$ dos coletivos de pensamento de caráter dogmático e as afasta dos coletivos de pensamento de caráter científico.

Palavras-chave: Física Quântica, misticismo, Ludwik Fleck, Alfabetização Científica 


\begin{abstract}
SAITO, Marcia Tiemi. Genesis and development of the relationship between Quantum Physics and mysticism and its contribution to Science Teaching. Tese (Doutorado em Ensino de Fisica) - Ensino de Ciências (Física, Química e Biologia), Universidade de São Paulo, São Paulo, 2018.

Since its emergence, the term "Scientific Literacy" (SL) has been widely discussed and (re)defined. But, in spite of its recognized and consensual importance in Science Teaching (ST), there is still a lack of consensus about the real aim and the meaning of SL. Besides of that, analyzing the arguments used in discussions about SL, we can observe that people usually do not take account of the social aspects that influence science, and knowledge appropriation and dissemination, especially in non-scientific environments. Thus, in the present work, we aim to analyze a concrete example of a scientific theory that has been appropriated and acquired new meanings and interpretations in circulating in the socialcultural environment, and its contributions to ST. The example choiced was the different uses and interpretations of Quantum Physics (QP) that emerged in the last decades in non-scientific communities, and culminated in the cultural phenomenon called quantum mysticism. In the analysis, we used Ludwik Fleck's epistemology about the circulation of knowledge to investigate the social-historical sources of the diffusion processes of QP and the genesis and development of its relationship with mysticism. It was concluded that scientific knowledge dissemination is an inherent process of scientific development, and that the relationship between QP and mysticism has its sources in the circulation of knowledge in the thought collective of researchers working in QP foundations itself, including debates between the founding fathers of this theory. Therefore, the weakness of some implicit assumptions used in the arguments in favor of SL was exposed. Some of these arguments are about the need and concern on the acquisition of a static and enclosed corpus of knowledge, which is supposed to prevent people from some social harmness. We could also criticize combative attitudes with dogmatic characteristics toward pseudosciences, which brings some tendencies of SL closer to thought collectives with dogmatic characteristics and moves them away from thought collectives with scientific characteristics.
\end{abstract}

Keywords: Quantum physics, mysticism, Ludwik Fleck, scientific literacy 


\section{Lista de abreviaturas e siglas}

AC

DLP

EC

EPR

ESP

EUA

FC

FM

FQ

MC

MQ

$\mathrm{NdC}$

TOL

TQ

URSS

VTQ
Alfabetização Científica

Daneri-Loinger-Prosperi

Ensino de Ciências

Einstein-Podolsky-Rosen

Extrasensory Perception

Estados Unidos da América

Física Clássica

Física Moderna

Física Quântica

Mecânica Clássica

Mecânica Quântica

Natureza da Ciência

Teorias Objetivas Locais

Teoria Quântica

União das Repúblicas Socialistas Soviéticas

Velha Teoria Quântica 


\section{SUMÁRIO}

Resumo I

Abstract II

1 Introdução: Física quântica, misticismo e Ensino de Ciências.

1.1 Delineando um problema no Ensino de Ciências: a Alfabetização Científica em questão . 7

1.2 Misticismo quântico, Natureza da Ciência e circulação do conhecimento científico

1.3 Panorama da pesquisa

Ludwik Fleck: uma perspectiva histórico-social para a gênese e o desenvolvimento de um fato científico

2.1 Vida e obra 17

2.2 Principais conceitos de Fleck 20

2.3 A gênese e o desenvolvimento dos fatos científicos 31

2.4 Fleck e a circulação do saber. 35

2.5 Fleck e o problema da demarcação na ciência 46

2.6 Um olhar fleckiano sobre a presente pesquisa..... 55

A gênese da relação histórico-social entre Física Quântica e misticismo 58

3.1 Breve resumo histórico da gênese e do desenvolvimento da Física Quântica e dos debates sobre os seus fundamentos

3.1.1 A Física no final do século XIX. 59

3.1.2 O início da Física Quântica: de 1900 a 1916. 61

3.1.3 O caminho para a elaboração da Mecânica Quântica: de 1917 a 1926 68

3.1.4 As interpretações do formalismo da Mecânica Quântica: de 1927 em diante..... 73

3.2 Principais debates sobre os Fundamentos da Física Quântica: um olhar mais aprofundado. 
3.2.1 Causalidade e determinismo na Física Quântica

3.2.2 Completude, realismo e não-localidade na Física Quântica

3.2.3 O problema da medição e o papel da consciência

3.3 Algumas das diferentes interpretações da Física Quântica............................................. 121

3.3.1 Interpretação ondulatória.

3.3.2 Interpretação hidrodinâmica 125

3.3.3 Interpretação da Complementaridade

3.3.4 Interpretação causal de de Broglie-Bohm 135

3.3.5 Interpretação de Muitos Mundos de Everett-DeWitt

3.3.6 Interpretação dos Coletivos Estatísticos.

3.4 A formação e a estrutura do coletivo de pensamento dos pesquisadores em Fundamentos da Física Quântica..... 156

3.4.1 Gênese do coletivo de pesquisadores em Física Quântica 156

3.4.2 Desenvolvimento do coletivo de pesquisadores em Física Quântica 160

3.4.3 Desdobramento e caracterização do coletivo dos pesquisadores em Fundamentos da Física Quântica 167

3.5 Influências histórico-sociais na gênese da relação entre Física Quântica e misticismo .. 177

3.5.1 Neorromantismo no final do século XIX 178

3.5.2 A República de Weimar no período entreguerras 183

3.5.3 Contracultura hippie nos anos 1970 191

3.5.4 Movimento da Nova Era e Neoesoterismo 203

3.5.5 Físicos com inclinações místicas 209

3.6 As protoideias que antecederam a relação entre $\mathrm{FQ}$ e misticismo 231 
4.1 Delineando a noção de misticismo quântico

4.2 Os principais autores precursores do fenômeno cultural do Misticismo Quântico

4.2.1 Fritjof Capra e $O$ Tao da Física

4.2.2 Deepak Chopra e A Cura Quântica

4.2.3 Amit Goswami, O Universo autoconsciente e O Médico Quântico..

4.3 A circulação das ideias e a formação da relação entre misticismo e Física Quântica ..... 292

4.4 O misticismo quântico e o problema da demarcação

4.5 Rediscutindo a noção de "misticismo quântico" 324 Considerações finais e reflexões sobre as possíveis implicações para o Ensino de Ciências 329 


\section{Introdução: Física quântica, misticismo e Ensino de}

\section{Ciências}

\subsection{Delineando um problema no Ensino de Ciências: a Alfabetização \\ Científica em questão}

Desde o seu surgimento, na década de 1950, o termo "Alfabetização Científica" (AC) tem sido amplamente discutido e (re)significado ao longo dos anos e, atualmente, a necessidade e a importância da $\mathrm{AC}$ podem ser consideradas um consenso na área de Ensino de Ciências (EC), de tal forma que alcançá-la se tornou um dos principais objetivos da Educação Científica e das políticas educacionais em diversos países (Singh e Singh, 2016; Hodson, 2014; Laugksch, 2000; UNESCO, 2010; Holbrook e Rannikmae, 2009; NRC, 1996; AAAS, 1989). Os argumentos utilizados para defendê-la normalmente ressaltam a necessidade de o ensino dialogar com os problemas sociais e de uma formação geral ampla que permita aos estudantes relacionarem os conhecimentos científicos com a sua atuação como sujeitos no mundo. Sendo assim, demandam a democratização do acesso ao conhecimento científico, com a finalidade de formar cidadãos críticos, que exerçam a sua cidadania de forma mais ativa e independente, tomando decisões conscientes sobre assuntos de interesse público, que envolvam o conhecimento científico. Nessa linha de argumentos, fica clara, portanto, a dimensão social dos objetivos da AC e a crença de que uma sociedade alfabetizada cientificamente poderia lidar melhor com os problemas sociais que enfrenta. Já seguindo uma linha de argumentação mais voltada para o âmbito individual, também se costuma ressaltar a importância de se entender os conceitos científicos para a aplicação no cotidiano dos estudantes, na resolução de problemas e em questões práticas do dia-a-dia, além de aprender a enxergar o valor da ciência, tanto como parte importante da cultura humana, a qual está em constante desenvolvimento, como com relação às suas aplicações tecnológicas (Holbrook e Rannikmae, 2009; Roberts, 2007; Laugksch, 2000).

No entanto, apesar do consenso sobre a importância e das defesas em torno da AC, alguns autores reconhecem que esse termo se tornou mais um slogan, um termo propagandístico e um discurso comum, rodeado de jargões - como "Ciência para todos", "Ciência para a vida", "Ciência vinculada ao cotidiano", entre outros - para atrair as 
atenções em prol da Educação Científica, do que um termo utilizado de forma homogênea pelos educadores em ciências (Singh e Singh, 2016; DeBoer, 2000; Laugksch, 2000; Shamos, 1995). A principal fragilidade desse termo está na falta de consenso a respeito do seu significado, dos objetivos da AC e do que significa ser um indivíduo alfabetizado cientificamente (Roberts, 2007). De fato, pode-se considerar que este termo carece de uma definição mais precisa desde a sua origem (DeBoer, 2000; Bybee, 1997), e que, desde então, diversos autores buscam minimizar as controvérsias acerca do assunto e encontrar denominadores comuns sobre o que acreditam ser AC e quais devem ser seus objetivos (Singh e Singh, 2016; Holbrook e Rannikmae, 2009; Roberts, 2007; DeBoer, 2000; Laugksch, 2000; Collins, 1998). Roberts (2007), inclusive, faz uma caricatura de duas visões opostas de um contínuo de visões sobre a AC: de um dos lados, o autor situa a visão que privilegia o conhecimento científico em si - ou seja, os produtos e processos das ciências naturais -, a qual defende que o indivíduo alfabetizado cientificamente é aquele que conhece bem esses processos e produtos e sabe utilizá-los em seus contextos; já do outro lado, ele situa a visão que privilegia o conhecimento sobre a ciência e seu funcionamento, a qual defende que o indivíduo alfabetizado cientificamente é aquele que é capaz de utilizar esse conhecimento para exercer conscientemente sua cidadania e atuar nas práticas sociais.

Contudo, através desse processo de tentar encontrar pontos comuns entre diferentes visões educacionais para o EC - algumas delas, inclusive, incompatíveis entre si - é que as contradições entre um ensino que visa uma maior criticidade e um ensino mais tradicional, centrado nos conteúdos, começam a aparecer. Uma delas se reflete na tentativa de elaborar listas com os conhecimentos, habilidades e competências que um indivíduo deveria ter para ser considerado alfabetizado cientificamente (Singh e Singh, 2016; Fives et al., 2014; Holbrook e Rannikmae, 2009). Por um lado, trata-se de uma tentativa de reunir e sistematizar as discussões realizadas ao longo do tempo sobre o assunto, além de buscar o que há de comum entre elas. Por outro lado, no entanto, essas listas, muitas vezes longas e exaustivas, refletem uma visão educacional a partir da qual existiria uma gama de conhecimentos mínimos que deveriam ser atingidos por um indivíduo para que ele possa ser considerado alfabetizado cientificamente. Assim, nota-se a existência de um pressuposto implícito de que haveria uma fronteira clara entre indivíduos alfabetizados e não alfabetizados cientificamente, desconsiderando, de certa 
forma, que a $\mathrm{AC}$ é um processo contínuo e, provavelmente, sem um ponto final determinado. Outro sintoma contraditório nesse debate é a forma como alguns argumentos são utilizados para defender a importância da AC. Um dos principais argumentos utilizados nesse sentido se refere à importância em saber distinguir a ciência da nãociência, e é utilizado de forma representativa nas seguintes citações:

A importância de saber diferenciar a ciência da pseudociência ou de desenvolver a consciência de que a ciência não é aplicável para a resolução de todos os problemas da sociedade é reconhecido como sendo importante no mundo de horóscopos, de uma mídia dramática e manchetes propagandísticas de hoje (Holbrook \& Rannikmae, 2009, p. 285, tradução livre).

Uma maior familiaridade com a natureza e as descobertas científicas também irá ajudar o indivíduo a resistir às informações pseudocientíficas. Um público desinformado é muito vulnerável a ideias enganosas como, por exemplo, dietas ou medicina alternativas (Royal Society, 1985, p. 10, tradução livre).

Em ambas as citações, é possível notar, em primeiro lugar, uma concepção de caráter essencialista, refletida na preocupação com a aquisição de um conhecimento ou uma habilidade específica: saber distinguir aquilo que é científico daquilo que não é, como se esse fosse um conhecimento bem definido e delimitado. Em segundo lugar, nota-se uma concepção de caráter pragmático, na qual esse conhecimento não é apresentado como algo que possui valor por si só, mas que deve ter uma determinada finalidade ou aplicação: a de saber, reconhecer aquilo que se quer fazer passar por científico - as chamadas pseudociências - e poder resistir a elas. Por fim, também fica clara a concepção de que os indivíduos que não possuem esse conhecimento estariam vulneráveis às vicissitudes do mundo - em particular, àquelas relacionadas ao mau uso da ciência -, de tal forma que esse conhecimento teria a capacidade de, em alguma medida, proteger esses indivíduos de um mal externo.

Certamente, os limites entre a ciência e a não-ciência é um tema importante, capaz de promover uma maior criticidade com relação à ciência, suas particularidades e seu funcionamento, e merece, portanto, discussões, análises e reflexões profundas. No entanto, ao assumir que saber distinguir esses limites é um conhecimento que deve ser adquirido, supõe-se implicitamente que eles são bem definidos e que, uma vez adquirido esse conhecimento, bastaria aplicá-lo. Trata-se de uma postura limitada, que não leva em 
conta a complexidade do fazer científico, dos seus limites e dos elementos envolvidos em temas que perpassam as fronteiras entre o científico e o não-científico. Além disso, ao ressaltar a aplicabilidade ou uma possível finalidade para esse suposto conhecimento adquirido, não se leva em conta que o próprio processo de discussão desse tema é capaz de promover um senso crítico nos indivíduos, e que o processo não precisa estar finalizado para que esse senso crítico seja adquirido em alguma medida. Portanto, a discussão e a reflexão sobre esse tema, quando realizados em profundidade, seriedade e com abertura para críticas e argumentos diversos, possuem um valor em si, sem necessidade de uma aplicação ou finalidade específica. Por fim, ao considerar que o conhecimento dos limites entre ciência e não-ciência poderia proteger os indivíduos em questões relacionadas ao mau uso da ciência - um pressuposto que poderia remeter a uma postura de combate dogmático com relação a esses usos -, além de desconsiderar a capacidade crítica dos estudantes ao considerá-los vulneráveis, não se leva em conta a não neutralidade presente nesse debate; que dificilmente seria possível definir um corpo de conhecimento neutro, capaz de exercer a função de proteção; e que, na demarcação entre ciência e não-ciência, é possível apenas pontuar alguns aspectos desses limites, sem traçar uma linha precisa.

Os dois exemplos citados - o das listas com os conhecimentos, habilidades e competências que um indivíduo deve ter para ser considerado alfabetizado cientificamente e o argumento da necessidade em saber distinguir a ciência da não-ciência - não refletem a amplitude completa do debate em torno da $\mathrm{AC}$ e seus objetivos. Porém, são exemplos ilustrativos das possíveis contradições entre um ensino tradicional, centrado nos conteúdos, e um que visa promover a criticidade, que podem surgir quando se tenta conciliar visões educacionais opostas. Em ambos os exemplos, é possível notar que existe a premissa implícita de que ser alfabetizado cientificamente pressupõe a aquisição de um corpo fechado de conhecimentos e que, após essa aquisição, esses conhecimentos se manteriam com a mesma significação de sua origem, sendo que o indivíduo apenas o utilizaria ao longo de sua vida. Sendo assim, esse corpo de conhecimentos - que pode se referir tanto ao conteúdo da ciência em si e suas aplicações, como sobre a ciência e seu funcionamento - teria a propriedade de ser estático e bem definido, mantendo-se intacto no indivíduo após a sua aquisição, podendo apenas ser complexificado, eventualmente, com alguns acréscimos. Além disso, ambos os exemplos dão destaque ao caráter individual do processo educacional em detrimento do social. No primeiro deles, mesmo 
que alguns conhecimentos, habilidades e competências estejam relacionados com a atuação do indivíduo na sociedade, ainda sim, trata-se de competências individuais, as quais os sujeitos deveriam adquirir para poder ser considerados alfabetizados cientificamente. Já no segundo, além da preocupação com a aquisição individual de um determinado conhecimento, há a preocupação de que esse indivíduo se proteja dos males que podem existir na sociedade, em vez de atuar nela, para que tais males deixem de existir. Esse último aspecto desconsidera a capacidade crítica e de atuação dos sujeitos e foge de uma das propostas iniciais da $\mathrm{AC}$, de buscar uma sociedade alfabetizada cientificamente, a fim de que ela possa lidar melhor com os problemas sociais que enfrenta. Em suma, ambos os exemplos, apesar de não representarem todas as tentativas de conciliação entre visões educacionais opostas, ilustram bem os perigos e as contradições nas quais se podem recair com essa tentativa.

Dito tudo isso, torna-se importante definir a perspectiva educacional a ser adotada neste trabalho. Essa perspectiva visa promover uma maior criticidade nos sujeitos, para que eles se emancipem intelectualmente e atuem na sociedade não de forma individual, visando atender apenas a interesses privados, mas buscando uma atuação coletiva, problematizando e refletindo sobre questões de interesse social, especificamente as relacionadas ao conhecimento científico. Assim, se terá como perspectiva a busca de uma sociedade que não seja apenas a soma de indivíduos alfabetizados cientificamente, mas de uma sociedade alfabetizada cientificamente que possa, em alguma medida, lidar melhor com os conhecimentos científicos socialmente difundidos e os problemas relacionados a estes.

Dessa forma, este trabalho terá como tema central a relação entre o conhecimento e a sociedade, particularmente, os processos de circulação do conhecimento científico. Esse tema será explorado tomando-se como ponto de partida o questionamento do pressuposto apontado anteriormente de que indivíduos, para serem considerados alfabetizados cientificamente, devem adquirir um corpo de conhecimento fechado, estático e bem definido, o qual, uma vez adquirido, manteria-se intacto, com a mesma significação de origem, sofrendo apenas alguns acréscimos e sendo aplicado ao longo da vida. Algumas abordagens e entendimentos sobre a AC já levam em conta a interação dos indivíduos com o conhecimento e o contexto específico em que os sujeitos estão inseridos (Laugksch, 
2000; Miller, 1983; Branscomb, 1981), de tal forma que o conhecimento nos mesmos é passível de ser modificado. Apesar disso, essas abordagens não levam em conta que o próprio conhecimento científico ou sobre a ciência pode ser influenciado e modificado pelo contexto sociocultural.

Assim, este trabalho propõe uma mudança de perspectiva. Ao invés de buscar traçar um caminho que leve a uma nova definição do que seriam sujeitos alfabetizados cientificamente, propõe-se um estudo sobre como um determinado saber pode desempenhar diferentes papéis na sociedade. Esta proposta tem como pressuposto uma visão de linguagem que vê a emergência de significados em sua prática, algo que nega a possibilidade de definições de caráter essencialista. Esses apontamentos, portanto, nos remetem às seguintes questões a serem exploradas neste trabalho: Como se dá a relação entre o conhecimento científico e os diferentes contextos socioculturais? Como esse conhecimento é entendido, assimilado e propagado em meios não científicos? Como ele pode ser modificado ao circular nesse meio? Quais as consequências da circulação do conhecimento para a Educação Científica?

Além desses questionamentos, dentro do contexto da Educação Científica, em especial, com relação ao argumento sobre a importância em saber diferenciar a ciência da não-ciência como uma habilidade específica e determinada e à alusão a uma postura de combate dogmático contra as chamadas pseudociências, por parte de alguns defensores da AC, este trabalho propõe as seguintes reflexões: É de fato papel da Educação Científica adotar uma postura de combate ao surgimento e a difusão de concepções consideradas não-científicas, muitas vezes tão dogmaticamente quanto os alvos de suas críticas? Qual é a origem histórico-social dessas concepções? Em uma perspectiva de educação crítica e socialmente emancipadora, qual seria a postura mais adequada a ser adotada com relação a essas concepções?

A partir desses questionamentos, uma investigação sobre: i) a natureza da circulação do conhecimento, especificamente sobre a gênese, a difusão e o desenvolvimento de conceitos científicos que adquirem significados e usos em diferentes meios socioculturais; ii) os limites entre o científico e o não-científico; iii) as possíveis consequências desse estudo para o EC se fazem necessárias. Pretende-se que as investigações propostas nos 
ajudem a refletir sobre os objetivos, métodos e ao que de fato é possível esperar da AC, visando uma educação socialmente crítica e emancipadora.

\subsection{Misticismo quântico, Natureza da Ciência e circulação do conhecimento científico}

Partindo dessas reflexões, podemos destacar os diferentes usos e interpretações dos conceitos e da teoria da Física Quântica (FQ) que vêm sido feitos nas últimas décadas em meios que transcendem o âmbito da Física. Esses usos se manifestam na popularização da palavra "quântica", e podem ser notados em uma simples busca no Google, a qual exibe cerca de 9 milhões de entradas para a medicina quântica; 3 milhões para cura ou terapia quântica; 6 milhões para psicologia quântica, 3 milhões para mente quântica e quase o mesmo número para o tantra quântico (Cruz, 2011). Essa ampla popularização de uma teoria física tão específica, em áreas tão diversificadas externas ao seu âmbito de origem, pode ser considerada um verdadeiro fenômeno cultural. E, devido ao fato de que, na maioria das vezes, a palavra "quântica" aparece vinculada a uma espécie de misticismo ou espiritualismo, esse fenômeno acabou ficando conhecido como "misticismo quântico" (Grim, 1982; Pessoa, 2011). Segundo Pessoa (2011, p. 298), esse fenômeno é permeado por interpretações que se inserem na tradição do naturalismo animista, que adotam um idealismo subjetivista ou partem de elementos religiosos, e faz parte de um movimento sociocultural que ressurgiu nas décadas de 1980-1990, herdeiro da "contracultura" das décadas de 1960-1970, chamado de "Nova Era" ou "Neoesoterismo" (Heelas, 1996; Magnani, 1999).

Por parte das comunidades dos físicos e dos educadores em ciências, não raro, esse fenômeno é recebido com uma postura de rechaço, ridicularização ou um combate dogmático. Porém, diante dessa postura, por um lado, torna-se interessante destacar pelo menos dois aspectos relacionados a esse fenômeno: (1) temas populares como estes possuem a capacidade de exercer um fascínio sobre os estudantes e despertar o seu interesse acerca de assuntos relacionados às ciências; (2) as origens desse fenômeno se situam na própria elaboração da FQ, nos debates relacionados ao papel da consciência no resultado de experimentos, e nas influências do pensamento oriental e de correntes filosóficas idealistas em alguns físicos que participaram na elaboração dessa teoria, como Wolfgang Pauli, Niels Bohr, Erwin Schrödinger, David Bohm, Eugene Wigner, entre 
outros (Wilber, 1984; Pessoa, 2001; Marin, 2009; Freire Jr, 2015). A partir dessas influências e debates, presentes até hoje nas diferentes interpretações da FQ, a possibilidade de a mente poder interferir na matéria despertou grande interesse e ganhou visibilidade em comunidades externas à comunidade dos físicos, resultando, mais tarde, no fenômeno cultural do misticismo quântico. Por outro lado, apesar desses aspectos relevantes - tanto para o EC, quanto para uma melhor compreensão do fenômeno em si -, não se pode perder de visto o cuidado para que não recaia em uma concepção relativista, a qual consideraria que o conhecimento veiculado pelo misticismo quântico possui o mesmo valor e confiabilidade que o conhecimento científico.

Sendo assim, em primeiro lugar, a postura educacional mais adequada para lidar com esse fenômeno não parece ser a de se negar a discutí-lo, a de ridicularização ou uma postura de combate dogmático. Em segundo lugar, esse fenômeno se apresenta como um exemplo concreto de uma teoria específica do âmbito científico, que foi apropriada e difundida em diferentes meios socioculturais, adquirindo novos usos e significados ao circular neles, e se mostra como um interessante estudo de caso, a partir do qual as questões relacionadas com a circulação do conhecimento científico e com AC e seus objetivos podem ser exploradas. Esse estudo também toca em questões relacionadas à Natureza da Ciência $(\mathrm{NdC})$ e aos limites entre o que pode ser considerado científico ou não - o chamado problema da demarcação -, uma vez que os usos da FQ normalmente apresentados pelo misticismo quântico são considerados como não-científicos ou pseudocientíficos, por boa parte das comunidades dos físicos e dos educadores em ciências. Dessa forma, este trabalho se propõe a um estudo mais aprofundado desse debate e da gênese e do desenvolvimento desse fenômeno cultural, por considerar que ele possui o potencial de contribuir para as reflexões acerca de qual seria a postura mais adequada a ser adotada pelos educadores em ciências em relação a esse tipo de temáticas, tendo em vista uma Educação Científica socialmente crítica e emancipadora.

\subsection{Panorama da pesquisa}

Partindo das reflexões apresentadas, o objetivo deste trabalho será estudar o caso específico do fenômeno cultural do misticismo quântico, a fim de tentar compreender como os conceitos de uma teoria científica específica - no caso, a FQ - podem ser entendidos e apropriados, ganhando novos significados e usos, ao circular em meios não 
científicos. Além disso, pretende-se analisar como os usos e apropriações de uma teoria científica, realizados por determinados grupos sociais podem ser aceitos ou não pela comunidade científica correspondente e considerados como parte da ciência. A partir dessa análise, pretende-se contribuir para o debate sobre os limites entre o científico e o não-científico (problema de demarcação) e seus reflexos em meios socioculturais, contribuindo, assim, para o entendimento sobre a $\mathrm{NdC}$ e para uma reflexão acerca da postura dos educadores em ciências frente a esses usos.

O referencial teórico que será utilizado no estudo proposto será a epistemologia do médico e filósofo da ciência polonês Ludwik Fleck. Esse autor analisa a gênese e o desenvolvimento dos fatos científicos, a partir de uma perspectiva histórico-social e cultural. Em sua análise, Fleck também analisa como o saber circula entre os diferentes coletivos de pensamento e como estes interagem entre si, sejam eles coletivos científicos ou não. Sendo assim, sua epistemologia se mostra uma referência promissora para a análise da gênese e do desenvolvimento da relação entre FQ e misticismo, que posteriormente culminou no fenômeno cultural do misticismo quântico. Dessa forma, no próximo capítulo deste trabalho, será feita uma síntese da epistemologia de Fleck e seus principais conceitos.

Em seguida, no capítulo 3, a epistemologia e os conceitos fleckianos serão utilizados para analisar a gênese da relação entre FQ e misticismo. Primeiramente, será feito um mapeamento histórico, buscando encontrar as diferentes influências no surgimento dessa relação, investigando suas raízes desde os seus primórdios, passando por um breve histórico do desenvolvimento da FQ, pelos principais debates entre os seus fundadores, pelas diferentes interpretações dessa teoria física e, finalmente, pelas influências históricosociais e filosóficas, que ajudaram a fortalecer essa relação, até a culminação no fenômeno cultural do misticismo quântico.

Ainda no capítulo 3 será feita uma caracterização do coletivo de pensamento dos pesquisadores em Fundamentos da FQ, parte da pesquisa em Física, a fim de, posteriormente, traçar as principais diferenças com relação ao coletivo de pensamento dos místicos quânticos. Por fim, se buscará caracterizar as protoideias - um conceito fleckiano conveniente a esse estudo - que remeteriam à origem do fenômeno do misticismo quântico. 
Embora não fosse a pretensão inicial, este capítulo se tornou bastante longo. Considerou-se válido elaborar uma síntese a mais completa possível do desenvolvimento da FQ e do misticismo associado a ela. Isso ocorreu não somente porque esta narrativa é a base da análise epistemológica realizada com base na obra de Fleck, mas por esta tese se inserir no campo da Educação em Ciências e contar com leitores que esperam poder se familiarizar com o episódio por meio deste texto. Assim, as subseções 3.1, 3.2, 3.3 e 3.5 configuram-se como uma ampla revisão sobre o desenvolvimento histórico do tema tratado.

No capítulo 4, tomando-se como base a perspectiva de Fleck, será feita a análise do desenvolvimento da relação entre a FQ e o misticismo. Para isso, se tomará como ponto de partida a revisão das principais pesquisas sobre o misticismo quântico e um delineamento inicial da noção que caracteriza esse fenômeno cultural. Em seguida, será feita uma análise da vida, de algumas obras e das influências dos principais autores precursores desse fenômeno - notadamente Fritjof Capra, Deepak Chopra e Amit Goswami. A seguir, a epistemologia fleckiana será utilizada para analisar como a circulação das ideias de diferentes áreas, em especial da FQ e das filosofias orientais, contribuíram na formação da relação dessa teoria com o misticismo. Também se utilizará a epistemologia do filósofo da ciência polonês para analisar se o misticismo quântico pode ser considerado um novo coletivo de pensamento, quais seriam as suas características e o que o diferenciaria dos coletivos de pensamento científicos, em especial, da Física. Por fim, as análises realizadas servirão de base para acrescentar novos elementos e contribuições para um delineamento mais detalhado da noção de misticismo quântico.

Finalmente, no capítulo 5, será feita uma reflexão acerca das implicações desse estudo para o EC, em especial, sobre como o estudo da circulação do conhecimento científico pode contribuir para o debate acerca da AC e seus objetivos, dentro de uma perspectiva de educação socialmente crítica e emancipadora. 


\section{Ludwik Fleck: uma perspectiva histórico-social para a gênese e o desenvolvimento de um fato científico}

\subsection{Vida e obra}

Ludwik Fleck nasceu na cidade de Lwów, à época, pertencente à Polônia e atualmente à Ucrânia, em 11 de julho de 1896. Sua família era de origem judia e seus pais, Maurycy e Sabina Fleck, dedicavam-se a negócios de médio porte, relacionados à pintura. Naquela época, a cidade estava ocupada pelo estado multiétnico austro-húngaro que, no entanto, concedia às suas regiões certa autonomia. Ludwik Fleck cresceu, então, por um lado, imerso em meio à cultura nacional polonesa e, por outro, em uma cidade influenciada pela ciência e pela cultura de Viena (Schäfer \& Schnelle, 2010).

Em meio a esse contexto, em 1914, Fleck concluiu o ginásio polonês, dominando tanto sua língua materna, o polonês, quanto o alemão. E, nesse mesmo ano, ingressou no curso de medicina da Universidade Jan Kazimierz, o qual concluiu com um doutorado em clínica geral. Entre 1920 e 1939, Fleck trabalhou em diversas universidades e laboratórios, desenvolvendo pesquisas na área de microbiologia e aprimorando métodos de diagnóstico de diversas doenças, entre elas, a sífilis e a tuberculose. Nesse período, ele publicou ao todo 37 trabalhos científicos, em revistas médicas conceituadas (Schäfer \& Schnelle, 2010).

Com o estalar da Segunda Guerra Mundial, Lwów passou a pertencer ao poder da União Soviética e foi ocupada pela Alemanha nazista nos últimos dias de junho de 1941. Nessa ocasião, Fleck foi deportado com sua esposa e filho para o gueto judeu da cidade, onde ainda sim, sob as mais precárias condições, deu continuidade às suas atividades de pesquisa, desenvolvendo um novo procedimento para uma vacina contra tifo, doença causadora de grandes epidemias na época. Em seguida, a SS tomou conhecimento da importância de Fleck como pesquisador em microbiologia, o prendeu e o obrigou a trabalhar no desenvolvimento de vacinas contra tifo em laboratórios nos campos de concentração de Auschwitz e Buchenwald, nos anos de 1943 e 1944, respectivamente. Contudo, apesar da situação de vulnerabilidade em que se encontrava, Fleck não admitiu colaborar passivamente com o exército nazista e, em Buchenwald, juntamente com outros prisioneiros, tramou um plano de sabotagem, fabricando uma vacina sem efeito, que foi 
fornecida em grande quantidade à SS, e uma pequena parcela de vacinas com efeito, que foi fornecida a prisioneiros do campo. Fleck, sua esposa e seu filho foram os únicos de sua família que conseguiram sobreviver à guerra (Schäfer \& Schnelle, 2010).

Com o término da guerra, Fleck teve que ficar internado vários meses no hospital, para recuperar sua saúde, quando finalmente pôde voltar à Polônia, onde voltou a trabalhar em suas pesquisas, passando por várias universidades, nas cidades de Lublin, Wroclaw e Varsóvia. O período entre 1946 e 1957 representou a fase mais produtiva de Fleck, onde ele constituiu um grande grupo de pesquisa e vários colaboradores, orientou cerca de 50 teses de doutorado e uma série de dissertações de mestrado, publicou 87 artigos em revistas renomadas e participou de diversos congressos em vários países, um deles, inclusive, no Brasil. No entanto, no ano de 1957, Fleck teve sua saúde afetada novamente, com a descoberta de um linfoma - um câncer que se origina nos linfonodos - após a investigação das causas de um infarto, que havia sofrido no ano anterior. Então, nesse mesmo ano, muda-se com sua esposa para Israel, a fim de ficar mais próximo de seu filho, que morava na Palestina desde o final da guerra. Em Israel, ele passa por dois núcleos de pesquisa, dentre eles, a Faculdade de Medicina da Hebrew University, em Jerusalém, porém suas dificuldades com o idioma hebraico e seu estado de saúde debilitado fizeram com que sua atuação fosse mais limitada. Ludwik Fleck morre no dia 05 de junho de 1961, aos 64 anos, na cidade de Ness-Ziona (Schäfer \& Schnelle, 2010).

Fleck nunca foi somente um médico microbiologista, cresceu em um universo cultural e intelectual que valorizava a figura do erudito e, por conta disso, apesar da sua vida conturbada, dedicava suas horas de lazer ao estudo de diferentes áreas do conhecimento, em especial, à leitura em História e Filosofia da Ciência. A influência científica e cultural de Viena sobre Lwów fazia com que o clima científico nessa região fosse intenso e interdisciplinar, e com que a Escola de Filosofia Lwów-Varsóvia sofresse influência direta do Círculo de Viena, adquirindo uma orientação neopositivista, entre os anos de 1895 a 1930. Fleck, no entanto, transitava por outros círculos científicos, que se reuniam ativamente em sua cidade, nas áreas de biologia, bioquímica, matemática e medicina, além de fazer leituras sistemáticas de autores como Durkheim, Jerusalem, Levy-Bruhl e sobre a teoria da Gestalt (Delizoicov et al., 2002). Por conta de suas publicações em Filosofia da Ciência, Fleck pode ser considerado um herdeiro e continuador das gerações 
de médicos-filósofos poloneses, que compunham uma escola de pensamento, que se propunha a pensar a medicina na Polônia, em função das condições peculiares que esse país vivia na final do século XIX: a Escola Polonesa de Filosofia da Medicina (Löwy, 1990; Delizoicov et al., 2002).

A primeira publicação de Fleck em Filosofia da Ciência, em 1927, é originária de uma exposição feita por ele, no ano anterior, na Sociedade dos amigos da história da medicina de Lwów, intitulada "Sobre algumas peculiaridades do pensamento médico" (Fleck, [1927]1986; Schäfer \& Schnelle, 2010). Esse artigo demonstra o quanto Fleck refletia sobre sua própria prática na medicina e o quanto ele se inspirou nela, para desenvolver sua epistemologia. Após essa publicação, se seguiram mais alguns artigos e seu principal livro "Gênese e desenvolvimento de um fato científico" (Fleck, [1935]2010), publicado em 1935, onde ele desenvolve sua epistemologia de maneira mais detalhada, a partir do estudo da gênese do conceito de sífilis e dos seus métodos de diagnóstico posteriores. Nesse livro, Fleck se coloca em franca oposição ao neopositivismo do Círculo de Viena epistemologia dominante à época - por valorizar aspectos históricos, sociais, culturais e psicológicos, em seus estudos sobre o processo de produção do conhecimento e na caracterização de seus principais conceitos (Delizoicov et al., 2002).

Contudo, apesar da originalidade das ideias fleckianas, e do seu reconhecimento como um dos mais importantes teóricos da História, Filosofia e Sociologia da Ciência nos dias atuais, o seu livro não recebeu o devido reconhecimento na época de sua publicação, ficando a sua leitura restrita praticamente à área médica, e sendo condenado a um ostracismo de mais de trinta anos (Nogueira, 2012; Carneiro, 2012). Essa marginalidade de suas ideias ocorreu devido a diversas razões: pela pequena triagem da primeira edição de seu livro, provavelmente ocorrida pelo fato dele ser judeu, em um período e contexto de crescente anti-semitismo (Delizoicov et al., 2002); pelas próprias dificuldades oriundas da guerra; pelo fato de Fleck nunca ter abandonado sua carreira científica para se dedicar exclusivamente à História e Filosofia da Ciência, dedicando-se a elas apenas nas horas vagas, mas principalmente pela grande inovação contida em suas ideias, em um contexto epistemológico pouco propício à sua recepção, onde a corrente de pensamento hegemônica era o neopositivismo do Círculo de Viena, que se pautava no modelo de funcionamento das ciências exatas (Nogueira, 2012; Condé, 2010). 
A principal obra de Fleck só foi (re)descoberta e ganhou visibilidade com uma citação de Thomas Kuhn, no prefácio de seu livro "A estrutura das revoluções científicas", publicado em 1962, em que o autor reconhece que Fleck antecipou muitas de suas ideias. A partir de então, sua obra foi traduzida para o idioma inglês e publicada em 1979, com um prefácio do próprio Kuhn, posteriormente, em 1980, é publicada uma $2^{\text {a }}$ edição em alemão. Atualmente, existem especialistas no pensamento fleckiano em diversos países do mundo (Delizoicov et al., 2002), particularmente, no Brasil, Fleck teve grande repercussão principalmente nas áreas de saúde e EC (Lorenzetti et al., 2013).

\subsection{Principais conceitos de Fleck}

Mais do que uma Filosofia da Ciência, restrita à análise dos processos de formulação das teorias e das interações entre sujeito e objeto, como costumava se pensar o desenvolvimento do conhecimento até a sua época, Fleck inova com uma abordagem acima de tudo sociológica. Em oposição ao pensamento neopositivista, a partir do qual os condicionamentos sociais seriam um mal, que ofuscariam a objetividade, Fleck defende que esses condicionamentos, na verdade, perpassam todas as etapas de produção do conhecimento, e mais do que isso, ele afirma:

Qualquer teoria do conhecimento que não leva em conta esse condicionamento social de todo conhecimento é uma brincadeira. Quem, entretanto, considera o condicionamento social como um mal necessário, como uma lamentável imperfeição humana a ser combatida, não sabe que, sem esse condicionamento, o conhecimento simplesmente não é possível (Fleck, [1935]2010, p. 86).

Por conta dessa concepção, Fleck valoriza os coletivos e arranjos sociais e acredita que somente uma comunidade ou um coletivo de pensamento, e não os indivíduos, possui a real força de estabelecer e promover o conhecimento (Carneiro, 2012). Além disso, Fleck não desconsidera o potencial e a subjetividade individuais na formulação do conhecimento, mas ressalta que essa atuação será sempre limitada pelas condições sociais em que se inserem, ao afirmar que "as façanhas pessoais (...) só têm durabilidade quando exercem um efeito sugestivo, isto é, quando surgem num momento social favorável" (Fleck, [1935]2010, p. 88).

Assim, Fleck se opõe a qualquer teoria do conhecimento que considere o processo do conhecimento como uma relação binária entre sujeito e objeto, ou entre o ator do 
conhecimento e algo a ser conhecido, defendendo que o respectivo estado do saber deve entrar como terceiro fator fundamental nessa relação. Pois as relações históricas e estilísticas presentes no saber necessariamente mediam a interação entre o objeto e o processo do conhecimento, nas suas palavras: “algo já conhecido influencia a maneira do conhecimento novo; o processo do conhecimento amplia, renova e refresca o sentido do conhecido" (Fleck, [1935]2010, p. 81). Para ele, o portador comunitário desse terceiro elemento é o coletivo de pensamento, o qual define como:

Se definirmos o coletivo de pensamento como a comunidade das pessoas que trocam pensamentos ou se encontram numa situação de influência recíproca de pensamentos, temos, em cada umas dessas pessoas, um portador do desenvolvimento histórico de uma área de pensamento, de um determinado estado do saber e da cultura, ou seja, de um estilo específico de pensamento. Assim, o coletivo de pensamento representa o elo na relação que procurávamos (Fleck, [1935]2010, p. 82, grifos do autor).

Segundo Fleck, o coletivo de pensamento surge sempre que duas ou mais pessoas trocam ideias, quando essa conversa "leva a um estado em que cada uma delas manifesta ideias que não seria capaz de produzir sozinha ou em outra companhia" (Fleck, [1935]2010, p. 87). Ele explica que, nesse estado, surge uma "atmosfera particular", na qual as pessoas, a partir da compreensão e mal-entendidos mútuos, formam um pensamento que não pertence a nenhum dos dois individualmente, mas ao pequeno coletivo de duas pessoas. Caso uma terceira pessoa se una a eles, a atmosfera anterior desaparece, juntamente com a sua força criativa particular, porém surge uma nova, dando origem a um novo coletivo de pensamento. No entanto, estes seriam apenas coletivos momentâneos ou casuais de pensamento, os coletivos estáveis, ou relativamente estáveis que são os de maior interesse para a teoria do conhecimento fleckiana - se formam em torno de grupos maiores, socialmente organizados, quando o coletivo possui regularidade na troca de ideias, partilha dos problemas que lhes interessam, dos métodos empregados a resolvê-los e dos critérios para se analisar o observado, quando existe uma certa cumplicidade entre seus membros e um culto comum de ideal de verdade, assim, se constituem como um coletivo de pensamento, possuidor de um estilo de pensamento próprio (Delizoicov et al., 2002). Nesse contexto, Fleck define a principal característica do coletivo de pensamento: o seu estilo de pensamento. 
O estilo de pensamento, assim como qualquer estilo, consiste numa determinada atmosfera (Stimmung) e sua realização. Uma atmosfera (Stimmung) possui dois lados inseparáveis: ela é a disposição (Bereitschaft) para um sentir seletivo e para um agir direcionado correspondente. Ela gera formas de expressão adequadas: religião, ciência, arte, costumes, guerra, etc., de acordo com a predominância de certos motivos coletivos e dos meios coletivos investidos. Podemos, portanto, definir o estilo de pensamento como a percepção direcionada em conjunção com o processamento correspondente no plano mental e objetivo. Esse estilo é marcado por características comuns dos problemas, que interessam a um coletivo de pensamento; dos julgamentos, que considera como evidentes e dos métodos, que aplica como meios do conhecimento. É acompanhado, eventualmente, por um estilo técnico e literário do sistema do saber (Fleck, [1935]2010, p. 149, grifos do autor).

O estilo de pensamento não é apenas esse ou aquele matiz dos conceitos e essa ou aquela maneira de combiná-los. Ele é uma coerção definida de pensamento e mais: a totalidade das disposições mentais, a disposição para uma e não para outra maneira de perceber e agir (Fleck, [1935]2010, p. 110).

Por estar inserido em um coletivo, o estilo de pensamento acaba passando por um fortalecimento social ao longo do tempo, fortalecimento que é engendrado pelos próprios indivíduos que o possuem, e que, por sua vez, carregam a sua carga histórica. Dessa forma, por ser uma percepção direcionada, um sentir e agir seletivos, o estilo de pensamento se transforma em uma espécie de coerção sobre os indivíduos do coletivo, definindo aquilo "que não pode ser pensado de outra maneira" (Fleck, [1935]2010, p. 150). Assim, o estilo de pensamento pode ser entendido como um "sistema de referência", ou balizas de orientação, por meio das quais o indivíduo seria conduzido a respostas, de acordo com as possibilidades consentidas por ele (Nogueira, 2012). Ele reúne, então, tanto a individualidade de cada pesquisador, quanto os métodos e estilos de resolução de problemas comuns a um grupo e período histórico determinado, atuando como uma espécie de catalizador entre conhecimentos e tradições do passado, com as técnicas e sistematizações do presente (Carneiro, 2012).

A partir de um olhar atento à definição de estilo de pensamento, é possível ver que Fleck foi bastante influenciado pela psicologia da forma (Gestaltpsychologie). Para ele, somente o estilo de pensamento dá as bases para um "olhar direcionado", uma disposição apta a possibilitar a atribuição de significados ao mundo, de acordo com o sistema de referência a ele atrelado (Nogueira, 2012). Sendo assim, Fleck descreve as duas principais 
formas nas quais a observação pode se apresentar, no âmbito do conhecimento: o ver inicial e pouco claro e o ver formativo, com a percepção da forma imediata. A primeira delas, o ver inicial e impreciso, ainda é sem estilo, não-orientado, caótico:

(...) motivos parciais confusos, caoticamente acumulados e de vários estilos, e disposições (Stimmungen) contraditórias impulsionam o olhar não direcionado para lá e para cá: uma luta dos pontos de vista. Falta o factual, o fixo: as coisas podem ser vistas de uma maneira ou outra, quase de maneira arbitrária. Falta o chão, a coerção, a resistência, o "solo firme dos fatos" (Fleck, [1935]2010, p. 142).

Já o ver formativo, com a percepção da forma (Gestaltsehen) imediata só é possível através da introdução teórico-prática em uma área, além da experiência própria. Não se trata de um observar ingênuo, mas somente possível para os iniciados e para aqueles que adquiriram a capacidade prática de realizá-la (Schäfer \& Schnelle, 2010):

A percepção da forma (Gestaltsehen) imediata exige experiência (Erfahrensein) numa determinada área do pensamento: somente após muitas vivências, talvez após uma formação prévia, adquire-se a capacidade de perceber, de maneira imediata, um sentido, uma forma e uma unidade fechada. Evidentemente, perde-se, ao mesmo tempo, a capacidade de ver aquilo que contradiz a forma (Gestalt). Mas essa disposição à percepção direcionada é a parte mais importante do estilo de pensamento. Sendo assim, a percepção da forma é uma questão que pertence marcadamente ao estilo de pensamento (Fleck, [1935]2010, p. 142).

Fleck nos chama a atenção, então, que o aumento da habilidade de perceber a forma imediatamente, o ver formativo, se dá na mesma proporção da perda de observar o contraditório, de forma que, para se adquirir a predisposição de perceber o direcionado, se paga o preço de não mais poder perceber o heterogêneo (Schäfer \& Schnelle, 2010). Essa impossibilidade de percepção da forma diferente e de outros fatos fora do estilo de pensamento determina o que "não pode ser pensado de outra maneira", e pode dar origem ao que Fleck chama de harmonia das ilusões. Esse conceito se refere à existência de um sistema fechado e harmonioso, existente nos estilos de pensamento mais bem estabelecidos, com um ver formativo mais sólido, o qual gera uma realidade evidente, dentro da qual a "origem lógica de determinados elementos não pode ser mais encontrada" (Fleck, [1935]2010, p.80). Trata-se de um sistema de ideias relativamente eficaz, que promove uma intrínseca harmonia no estilo de pensamento, adaptando o cognoscente ao conhecido e a origem do conhecimento dentro da visão do estilo (Delizoicov et al., 2002). 
Esse sistema tende a persistir continuamente diante de tudo que o contradiga, a partir da anulação do considerado potencialmente incongruente por parte dos membros do coletivo, e mais do que isso, nas palavras de Fleck:

Não se trata de mera inércia, ou de cautela diante das inovações, mas de um procedimento ativo, que se divide nos seguintes graus de intensidade:

1. Uma contradição ao sistema parece ser impensável.

2. Aquilo que não cabe no sistema permanece desapercebido, ou,

3. é silenciado, mesmo sendo conhecido, ou,

4. mediante um grande esforço, é declarado como não contradizendo o sistema.

5. Percebem-se, descrevem-se e até se representam determinados estados das coisas que correspondem aos pontos de vista em vigor, que, por assim dizer, são sua realização - apesar de todos os direitos dos pontos de vista contraditórios (Fleck, [1935]2010, p. 69).

Para Fleck, é esse caráter fechado dos sistemas de opinião, que garante a harmonia interna e os efeitos recíprocos entre o conhecido, as coisas a serem conhecidas e os atores do conhecimento.

Outro conceito fleckiano importante, relacionado com o desenvolvimento histórico de um estilo de pensamento é o conceito de protoideia, o qual Fleck caracteriza como:

As protoideias devem ser consideradas como pré-disposições histórico-evolutivas (entwicklungsgeschichtliche Anlagen) de teorias modernas e sua gênese deve ser fundamentada na sociologia do pensamento (denksozial). (Fleck, [1935]2010, p. 66)

Ou seja, as protoideias seriam como pré-ideias, pré-científicas, mais ou menos vagas ou confusas, que se associariam com fatos científicos por meio de ligações evolutivas incontestáveis, sem que essas ligações pudessem ser legitimadas pelos conteúdos. São predisposições, que podem vir de contextos diversos e, quando revitalizadas no presente, podem ser avaliadas pelo indivíduo do coletivo de pensamento como uma possível fonte inspiradora na atribuição de significados coerentes com seu estilo de pensamento (Nogueira, 2012).

Fleck ilustra esse conceito com o exemplo da ideia de alteração sifilítica do sangue, que já existia séculos antes de ser comprovada cientificamente, na forma de uma opinião pública de que o sangue dos sifilíticos era impuro. Porém, ele ressalta que nem todo fato científico atual provém de uma protoideia e que nem toda protoideia dará origem a um 
fato científico. Assim, ele fundamenta a sua opinião de que "o passado continua vivo", a partir das tradições legadas dos estilos de pensamento ancestrais, "nos conceitos herdados, nas abordagens de problemas, nas doutrinas das escolas, na vida cotidiana, na linguagem e nas instituições" (Fleck, [1935]2010, p. 61) e, consequentemente, constituirá as predisposições para as concepções futuras e argumenta que:

No que diz respeito a outras protoideias, como, por exemplo, a protoideia grega do átomo ou a dos elementos, mais uma vez não estamos em condições de decidir se, destacadas de seu contexto histórico, seriam corretas ou falsas, pois correspondem a outro coletivo e a outro estilo de pensamento (Denkstil). Para o pensamento científico de hoje são inadequadas; para seus criadores certamente eram corretas (Fleck, [1935]2010, p. 67).

No entanto, para se distinguir de abordagens "convencionalistas" e se afastar da impressão de uma defesa de que o conhecimento seria uma construção social totalmente arbitrária, Fleck cunha dois outros conceitos, diretamente atrelados ao funcionamento do estilo de pensamento, são os acoplamentos ativos e acoplamentos passivos. O coletivo de pensamento possui um papel central nos primeiros, pois estes são resultados de situações consideradas "livremente inventadas", dependentes da escolha do indivíduo, nas quais todas as possibilidades tenderiam ao "subjetivo". Já os acoplamentos passivos são o resultado de situações consideradas obrigatoriamente ocorridas, independentemente da escolha do indivíduo membro de um determinado coletivo de pensamento, capazes de transmitir a impressão de "real", "efetivo", onde todas as possibilidades tenderiam ao que se considera como "objetivo" (Nogueira, 2012), nas palavras de Fleck:

Quando se leva em conta essas relações gerais da história cultural e as particulares da história do conhecimento, limita-se significativamente o convencionalismo. No lugar da escolha livre e racionalista, surgem condições específicas. Mesmo assim, encontram-se sempre no conteúdo do conhecimento outras relações que não se explicam psicologicamente (seja no plano individual, seja no coletivo), nem historicamente. Por isso, elas passam a impressão de serem relações "reais", "objetivas" ou "efetivas". Nós as denominamos de relações passivas, em oposição àquelas outras, que denominamos ativas (Fleck, [1935]2010, p. 50).

Fleck esclarece ainda que, diferentemente do que defendiam os neopositivistas, nenhuma proposição pode ser construída apenas com base em acoplamentos passivos, há sempre a presença de algo ativo. Além disso, ambos interferem mutuamente entre si, 
podendo ora ser considerados como acoplamentos passivos e ora como ativos, e trocar de papel posteriormente, não constituindo, portanto, categorias estáticas e separadas entre si. Segundo Fleck, "depende das propriedades do estilo de pensamento se algo se apresenta de maneira "ativa" ou "passiva" no processo do conhecimento" (Fleck, [1935]2010, p. 152). E acrescenta que, quanto mais se entra numa área científica, mais aumentam o número de elementos ativos do saber, uma vez que o vínculo com o coletivo de pensamento se fortalece e o indivíduo passa a adquirir as práticas, métodos e formas de enxergar os problemas característicos desse coletivo. Porém, à mesma medida, "cresce também o número de relações passivas, inevitáveis, pois a qualquer elemento ativo do saber corresponde um contexto coercitivo" (Fleck, [1935]2010, p. 131). Portanto, o aprofundamento em uma determinada área do conhecimento, gera um aumento no número de ambos, acoplamentos ativos e passivos.

Por fim, Fleck identifica características estruturais comuns a todos os coletivos de pensamento e, para descrevê-los, utiliza os conceitos de círculos exotérico e esotérico:

\begin{abstract}
Essa estrutura universal do coletivo de pensamento consiste no seguinte: em torno de qualquer formação do pensamento (...) forma-se um pequeno círculo esotérico e um círculo exotérico maior de participantes do coletivo de pensamento. Um coletivo de pensamento consiste em muitos desses círculos que se sobrepõem, e um indivíduo pertence a vários círculos exotéricos e poucos círculos esotéricos. Existe uma hierarquia gradual de iniciação e muitos fios que ligam tanto cada um dos níveis, quanto os diversos círculos. O círculo exotérico não possui uma relação imediata com aquela formação de pensamento, mas apenas através da intermediação do círculo esotérico. A relação da maioria dos participantes do coletivo de pensamento com as formações do estilo de pensamento reside, portanto, na confiança nos iniciados. Mas até esses iniciados não são, de maneira alguma, independentes: dependem mais ou menos, de maneira consciente ou inconsciente, da "opinião pública", isto é, da opinião do círculo exotérico (Fleck, [1935]2010, p. 157).
\end{abstract}

Sendo assim, no centro dos círculos esotéricos estariam situados os membros do coletivo de pensamento iniciados há mais tempo em determinada formação de pensamento, ou aqueles que possuem maior confiança e autoridade ao tratar dessa formação. Já nos círculos exotéricos, estariam situados os membros que também possuem participação na formação desse pensamento, porém de forma mais distanciada. Para ilustrar a relação entre ambos os círculos, Fleck faz uma comparação desta com a relação 
entre a elite e as massas: quando a primeira possui uma posição mais forte, ela procura se distanciar e se isolar da multidão, então, os segredos e o dogmatismo passam a dominar no funcionamento do coletivo de pensamento. Nesse caso, a elite "enfatiza a origem sobrenatural das ideias que ela representa, e a sua importância requer obediência e docilidade. (...) Esses coletivos são mais ou menos bem delimitados e conservadores: seus ideais se baseiam no passado, em eventos, poderes e revelações que aconteceram no passado" (Fleck, [1936]1986, p. 103, tradução livre), esse seria o caso atual dos coletivos de pensamento religiosos, por exemplo. Uma esquematização de um coletivo com essa característica é apresentada na Figura 1, onde o círculo esotérico, referente à elite, se encontra no núcleo e possui um tamanho bem menor com relação ao círculo exotérico, das massas. Além disso, ambos os círculos são separados por uma linha bem espessa, pois, conforme a descrição de Fleck, a elite procura se isolar da multidão e o acesso a esse grupo de pessoas é bem restrito. A separação entre as massas desse coletivo e a sua região externa também é separada por uma linha, porém de menor espessura. Essa representação busca expressar o fato de que, em geral, é possível adentrar esses coletivos, contudo, por vezes, essa entrada requer algum ritual de iniciação mais formal ou a execução de algumas práticas ou hábitos pré-determinados.

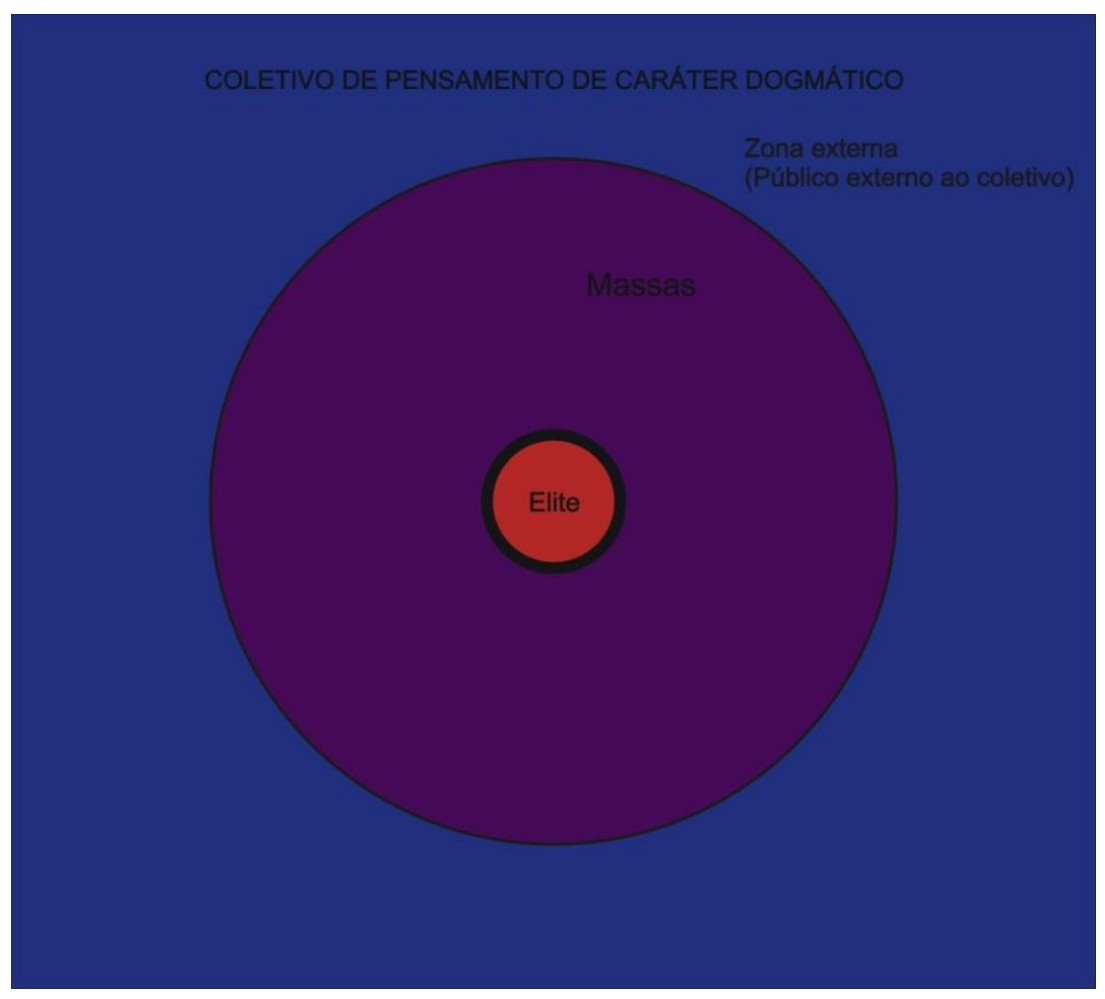

Figura 1: Coletivo de pensamento de caráter dogmático. 
Por outro lado, quando as massas é que possuem uma posição mais forte frente à elite, essa relação adquire um traço mais democrático, a opinião pública passa a ser lisonjeada e respeitada, e a elite tende a conservar a confiança das massas. Nesse caso, "o maior critério é a 'apreciação de todos'; todos podem e devem discutir cada verdade. Esses coletivos de pensamento possuem limites abertos e aceitam novos membros de bom grado" (Fleck, [1936]1986, p. 103, tradução livre). Segundo Fleck, essa é a situação na qual se encontra a maioria dos coletivos de pensamento das ciências naturais. Assim, de acordo com Fleck, no caso específico dos coletivos de pensamento científicos, a estrutura se organiza com um círculo esotérico e outro exotérico, cuja relação possui um caráter democrático, funcionando da seguinte forma:

O pesquisador altamente qualificado que trabalha de forma criativa num problema (em pesquisas sobre rádio, por exemplo), ocupa, enquanto "profissional especializado", o centro do círculo esotérico desse problema. Fazem parte desse círculo ainda os pesquisadores que trabalham com problemas afins, na qualidade de "profissionais gerais" - tais como os físicos, por exemplo. No círculo exotérico, encontram-se os "leigos mais ou menos instruídos". A repercussão da estrutura geral dos coletivos de pensamento, portanto, consiste, para a ciência, inicialmente na formação de uma oposição entre o saber especializado e o saber popular (Fleck, [1935]2010, p. 165, grifos do autor).

Essa estrutura proporciona a existência de uma relação constante entre esses dois círculos, de mútua dependência e fortalecimento das formações de pensamento conforme o estilo: por um lado, o saber popular - situado no círculo exotérico - confia no saber especializado - um produto do círculo esotérico - e exige dele um conhecimento seguro, uma vez que ele mesmo emerge deste saber, por outro, o mesmo saber popular é que forma a opinião pública a respeito do saber especializado, cristalizando, legitimando e propagando uma imagem simplificada deste. Consequentemente, o saber popular causa um efeito retroativo sobre os especialistas e, assim, ambos contribuem para o fortalecimento do estilo de pensamento científico. Essa relação de dependência mútua possibilita uma facilidade de circulação dos indivíduos entre os diferentes círculos desse coletivo, pois segundo Fleck:

O círculo exotérico consiste de pessoas leigas de quem nós temos uma "ciência popular" específica. As bordas deste círculo são abertas a todos, sua admissão não requer nenhuma cerimônia formal. (...) Os especialistas são quase sempre recrutados 
dentre os especialistas mais gerais (...). Um especialista geral é quase sempre recrutado dentre as pessoas com educação geral (Fleck, [1936]1986, pp. 105-106, tradução livre).

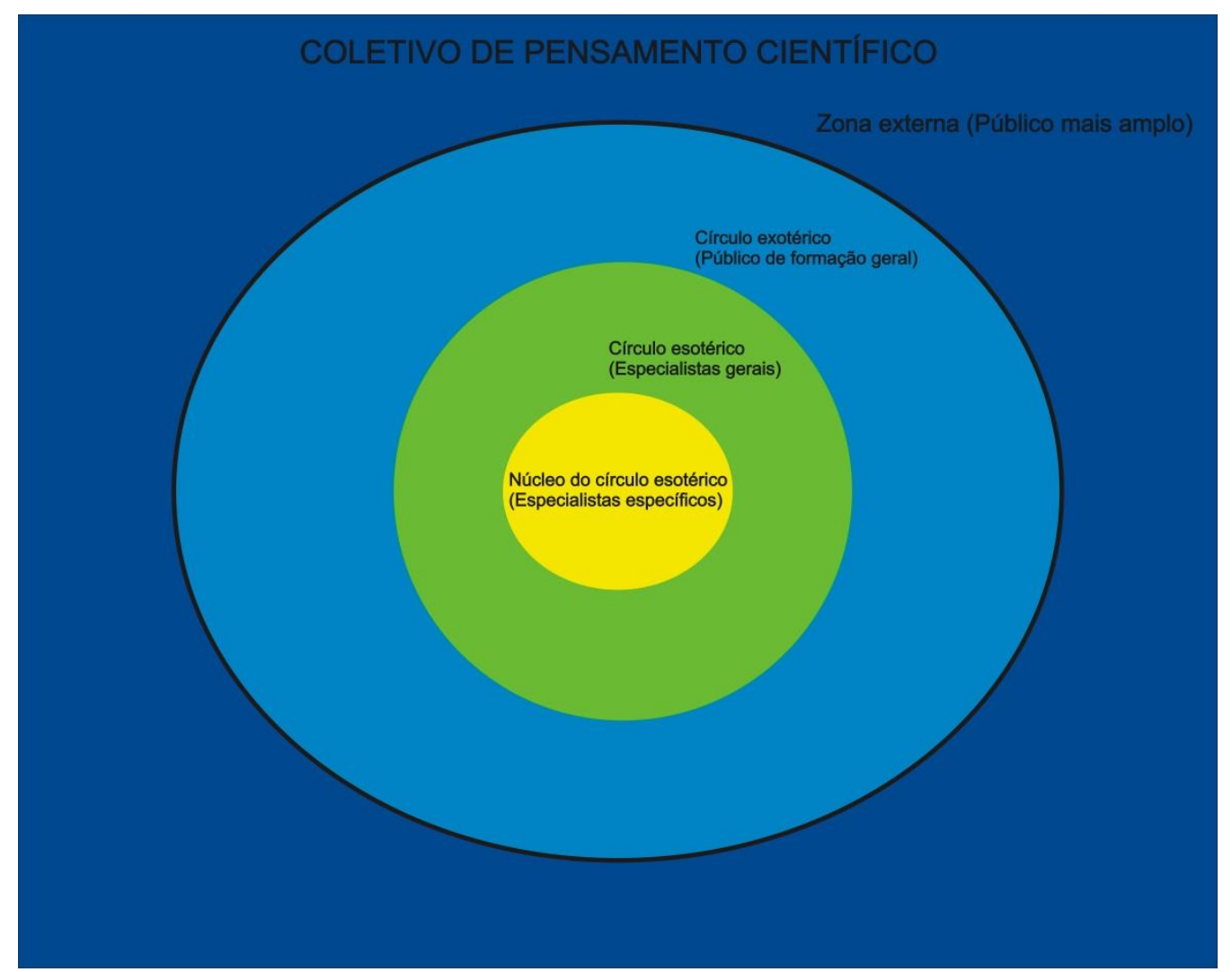

Figura 2: Coletivo de pensamento científico.

Essa relativa facilidade de circulação e ingresso dos indivíduos nos coletivos de pensamento científicos, entre outros aspectos, é que irá possibilitar o funcionamento de caráter democrático desse coletivo. Esse caráter será mais bem explorado na seção 2.5. No entanto, Fleck reconhece que existe uma dificuldade prática para o ingresso mais livre dos indivíduos provenientes do público mais amplo, externos a esse coletivo que, segundo ele, está vinculada à educação geral desse público. Dessa forma, levando-se em consideração essas características, buscou-se representar a estrutura desse coletivo na Figura 2, na qual o círculo esotérico (círculo verde), onde se situam os especialistas gerais, possui um núcleo (círculo amarelo), de área não muito menor do que o círculo ao seu redor, onde se situam os especialistas específicos. Ao redor do círculo esotérico (círculo verde), se encontra o círculo exotérico (círculo azul claro), onde se encontra o público de formação geral, o qual é separado de sua zona externa (região azul escura), na qual se encontra o público mais amplo, por uma linha mais espessa, a fim de ilustrar a dificuldade dos 
indivíduos provenientes dessa zona de adentrar esse círculo, por conta dos problemas vinculados à sua educação geral. A separação entre os outros círculos, internos ao coletivo de pensamento científico, são representados por linhas tênues, a fim de ilustrar a facilidade de mobilidade dos membros internos a esse coletivo entre as suas diferentes camadas.

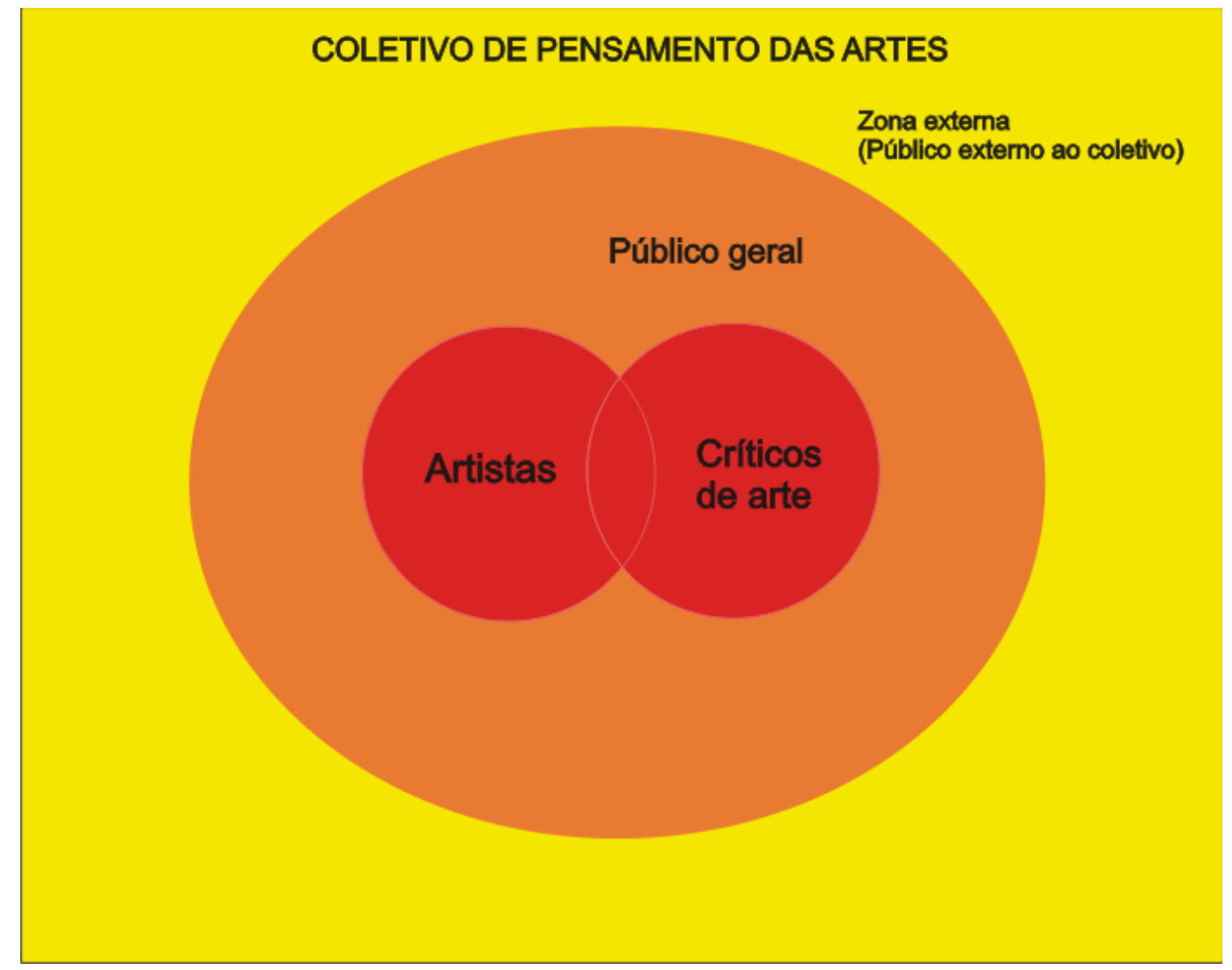

Figura 3: Coletivo de pensamento das artes.

Por fim, Fleck também considera a possibilidade da existência de coletivos de pensamento com uma estrutura mais complexa, com dois ou mais centros para o círculo esotérico ou duas áreas de círculos exotéricos, que se interseccionam parcialmente. De acordo com Fleck, esse seria o caso, por exemplo, do coletivo de pensamento das artes, onde o círculo esotérico possui dois centros, que se interseccionam parcialmente: o dos artistas e o dos críticos de arte; assim, o círculo exotérico possui duas áreas distintas: uma formada pelo público geral e os críticos de arte e a outra formada pelo público e os artistas. Nesse caso, Fleck chama a atenção para "o fato de o coletivo possuir dois centros torna impossível estabelecer uma postura dos indivíduos com relação aos produtos específicos do coletivo: ela sempre oscilará entre a simples admiração e o criticismo. Por 
conta dessa oscilação, os produtos do coletivo estão constantemente em um estágio de instabilidade" (Fleck, [1936]1986, p. 104, tradução livre). A estrutura desse tipo de coletivo é representada na Figura 3, onde os círculos esotéricos (círculos vermelhos), referentes aos artistas e aos críticos de arte, se encontram no centro e possuem uma área de intersecção entre si, na qual se situam os membros que são artistas e críticos de arte simultaneamente. Esses círculos esotéricos também possuem uma área não muito diferente da área do círculo exotérico (círculo laranja), onde se situa o público geral que aprecia arte, e são separados deste último por uma linha tênue, pois os círculos esotéricos não são muito restritos e a circulação dos indivíduos entre eles é relativamente fácil, uma vez que a arte está sempre em contato direto com o público geral e necessita desse público para o seu reconhecimento e apreciação, e, em princípio, qualquer indivíduo do público geral pode se tornar um crítico de arte ou artista, ainda que tenha sua crítica ou arte marginalizada pelo centro dos círculos esotéricos.

A possibilidade de coletivos de pensamento com estruturas mais complexas, com dois ou mais núcleos para o círculo esotérico, será de grande interesse para a presente pesquisa.

\subsection{A gênese e o desenvolvimento dos fatos científicos}

Fleck acredita que o surgimento e o desenvolvimento de um conhecimento só pode ser explicado histórica, sociológica e psicologicamente. E, se contrapondo ao neopositivismo do Círculo de Viena, acredita que nenhum conhecimento pode ser explicado unicamente pela lógica e sua fenomenologia, através de experimentos ou observações. Afinal, ele não acredita que uma observação possa ser neutra, isenta de uma teoria que a sustente, mais do que isso, para ele, toda observação possui uma história e está necessariamente vinculada a um estilo de pensamento. Além disso, ele se contrapõe à ideia do desenvolvimento do conhecimento pela simples acumulação de fatos, e acredita que a sua trajetória histórica está longe de ser a única possível.

(...) pelo menos três quartos, talvez a totalidade, do conteúdo das ciências são condicionados e podem ser explicados pela história do pensamento, pela psicologia e pela sociologia do pensamento. (...) É equivocado, no entanto, acreditar que se chega, de maneira simples e segura, ao conceito da entidade nosológica da "sífilis" com os recursos de hoje, mediante observações e experimentos, por mais retorcido e complicado que tenha sido o caminho histórico. (...) Também o conceito atual da 
entidade nosológica, por exemplo, é resultado de um desenvolvimento e não a única possibilidade lógica (Fleck, [1935]2010, p. 62).

Além disso, na análise do desenvolvimento do conhecimento, Fleck se opõe à ideia de "verdade" ou "erro" em si, ou uma verdade universal, a ser julgada fora de seu contexto histórico. Assim, qualquer ideia considerada como uma "verdade" ou um "erro" somente poderá ser considerada como tal, dentro de determinado contexto histórico, podendo passar por mudanças com o passar o tempo:

É completamente natural que esses ensinamentos [de um coletivo de pensamento] passem por mudanças constantes. (...) De um modo geral, é inapropriado tratar essas posições alinhadas a um determinado estilo, reconhecidas por um coletivo de pensamento inteiro e utilizadas com grande benefício como "verdade ou erro". Elas favoreceram o desenvolvimento e revelaram-se como satisfatórias. Foram ultrapassadas, não por estarem equivocadas, mas porque o pensamento se desenvolve (Fleck, [1935]2010, p. 109, grifos do autor).

Inclusive, ele ressalta que, ao longo da história da ciência, a partir de pressuposições que seriam consideradas "erros" fora de seu contexto histórico, foi possível construir diversos conhecimentos importantes. Mas que, muitas vezes, os cientistas tendem a racionalizar e idealizar esse processo, mostrando-o como um caminho "lógico":

Podemos, portanto, fazer a seguinte constatação, que pode ser considerada paradigma de muitas descobertas: a partir de pressuposições falsas e muitos primeiros experimentos irreproduzíveis surgiu, após muitos erros e desvios, uma descoberta importante. Os protagonistas da ação não têm mais como nos ensinar como esse processo se deu: racionalizam e idealizam o caminho. Entre as testemunhas oculares, algumas falam em coincidência feliz, e os bem-intencionados, em intuição genial (Fleck, [1935]2010, pp. 123-124, grifos do autor).

Ele também ressalta a importância da dimensão sociológica na construção de um conhecimento, e as influências sociais exercidas sobre ele. Para Fleck, somente uma predisposição social geral somada a uma predisposição específica interna ao coletivo de pensamento, pode dar as bases e propulsionar a pesquisa para a construção de um fato.

Havia uma grande predisposição social para os problemas da sífilis, provocada por velhas ideias pré-científicas (...). A essa predisposição geral se juntou ainda a específica, surgida da velha ideia da alteração sifilítica do sangue. Se a opinião pública não tivesse gritado tanto pela prova do sangue, os experimentos de Wassermann nunca teriam 
encontrado o eco social absolutamente necessário ao desenvolvimento da reação, à sua “elaboração técnica" e à acumulação da experiência coletiva. (...) Somente a atmosfera social criou o coletivo de pensamento no sentido mais estrito, que resultou, com a colaboração constante e as relações interativas dos membros, na experiência coletiva e na elaboração comunitária e anônima da reação (Fleck, [1935]2010, pp. 124-125).

Por conta desses fatores, para ele, a explicação da gênese e do desenvolvimento de um fato científico, necessariamente está vinculada a uma transformação no estilo de pensamento. E, para explicitar isso, ele começa definindo provisoriamente o que ele entende por "fato científico", posteriormente, ele incrementará essa definição de forma mais elaborada:

Podemos definir o fato científico provisoriamente como uma relação de conceitos conforme o estilo de pensamento, que, embora possa ser investigável por meio dos pontos de vista históricos e da psicologia individual e coletiva, nunca poderá ser simplesmente construída, em sua totalidade, por meio desses pontos de vista (Fleck, [1935]2010, p. 132, grifos do autor).

Assim, a chamada "descoberta" de um fato só pode ser entendida em uma relação mútua com o estilo de pensamento, como um aprender a fazer perguntas em um contexto específico, até que as observações estejam "adaptadas aos fatos”, ou:

até a tradição, a educação e o hábito terem gerado uma disposição para um sentir de agir de acordo com um estilo, isto é, um sentir e agir direcionados e restritos; até o ponto de a resposta estar, na maioria dos casos, pré-formada na pergunta e em que basta decidir-se apenas por um sim ou não ou por uma constatação numérica e até os métodos e aparelhos executarem a maior parte do pensamento para nós (Fleck, [1935]2010, p. 133, grifos do autor).

Então, Fleck utiliza os seus conceitos de ver inicial e ver formativo para analisar como se dá o processo da observação e elaboração de um fato científico, que, segundo ele, consiste em três etapas: (1) a percepção pouco clara e a inadequação da primeira observação; (2) a experiência irracional que forma novos conceitos e transforma o estilo; (3) a percepção da forma desenvolvida, reprodutível e conforme a um estilo. A primeira delas ocorre em um primeiro contato com o fenômeno, quando um material se apresenta de forma casual ou inesperada, nesse primeiro momento, ocorre o ver inicial, pouco claro, confuso e sem estilo. Fleck então explica que esse olhar inicial só vai adquirir uma forma a partir da reunião, por parte do pesquisador ou do coletivo de pensamento, do 
conhecimento já estabelecido historicamente pelo estilo de pensamento e adquirido pelo pesquisador, com o qual ele já possui uma certa familiaridade - o ver formativo - para então tentar interpretar o novo material que se lhe apresenta, dar-lhe uma forma e, finalmente, estabelecer o fato.

A primeira observação confusa em relação a qualquer estilo é semelhante a um caos de sentimentos: a estupefação, a busca por semelhanças, os testes e a retirada; a esperança e decepção. O sentimento, a vontade e o entendimento funcionam como uma unidade inseparável. O pesquisador fica tateando: tudo cede, não há nenhuma referência firme. Tudo é percebido como efeito artificial que obedece à própria vontade: cada formulação se dilui no próximo teste. Ele procura a resistência, a coerção do pensamento, em relação às quais ele poderia se sentir numa posição passiva. Da lembrança e da educação surgem ajudantes: no momento da procriação científica, o pesquisador personifica a totalidade de seus ancestrais físicos e mentais, de todos os amigos e inimigos, que favorecem e bloqueiam suas atividades. O trabalho do pesquisador consiste em diferenciar, no meio da confusão incompreensível, no caos que enfrenta, entre aquilo que obedece à sua vontade e aquilo que resulta de si mesmo e que resiste à sua vontade. Esse é o solo firme que ele, ou melhor, o coletivo de pensamento procura e não cansa de procurar. (...) A tendência geral do trabalho de conhecimento é, portanto: um máximo de coerção do pensamento (Denkzwang) com um mínimo de pensamento baseado na própria vontade.

Assim nasce o fato: primeiro um sinal de resistência no pensamento inicial caótico, depois uma certa coerção do pensamento e, finalmente, uma forma (Gestalt) a ser percebida de maneira imediata (Fleck, [1935]2010, p. 144, grifos do autor).

Assim, observa-se que somente a coerção exercida pelo estilo de pensamento é que permite a elaboração de um fato científico. Fleck ainda ressalta que esse processo não possui um início e nem um fim, e que sempre consistirá em um processo continuado, constantemente retrabalhado. E conclui que "qualquer descoberta empírica, portanto, pode ser concebida como complemento, desenvolvimento e transformação do estilo de pensamento" (Fleck, [1935]2010, p. 142).

Após a descrição desse processo, Fleck pode finalmente reelaborar a sua definição de fato como o "sinal de uma resistência (Aviso eines Widerstandes), que se opõe à voluntariedade livre do pensamento" (Fleck, [1935]2010, p. 151) - ou uma resistência ao ver arbitrário e sem forma - e descrever as suas propriedades e a sua relação com o coletivo de pensamento: 
(1) Cada fato tem que se alinhar ao interesse intelectual do respectivo coletivo de pensamento, pois somente há resistência onde existe alguma aspiração. (...) (2) A resistência tem que atuar enquanto tal no coletivo de pensamento e ser intermediado, a cada participante enquanto coação de pensamento e ainda enquanto forma (Gestalt) a ser vivenciada de maneira imediata. No processo de conhecimento, isso se manifesta como acoplamento dos fenômenos, que, em hipótese alguma, pode ser dissolvido de modo intracoletivo. (...) (3) O fato tem que ser expresso no estilo do coletivo de pensamento (Fleck, [1935]2010, pp. 151-152, grifos do autor).

Finalmente, ele também ressalta que um fato nunca é completamente independente de outros e que eles sempre repercutem retroativamente entre si, causando alterações e efeitos em um determinado campo, por menores que sejam, recriando o sistema de pensamento inteiro de um coletivo de pensamento e formando a "realidade fixa e autônoma" do mundo.

\footnotetext{
Assim se forma uma engrenagem universalmente coesa de fatos que se mantêm em equilíbrio mediante constantes efeitos recíprocos. Esse entrelaçamento interligado confere ao "mundo dos fatos" uma persistência maciça, causando a sensação de uma realidade fixa, da existência autônoma de um mundo. Quanto menos coeso é o sistema de um saber, tanto mais ele é mágico, tanto menos estável e mais miraculosa é a realidade: sempre de acordo com o estilo coletivo de pensamento (Fleck, [1935]2010, p. 154).
}

Portanto, um fato nasce de um longo processo histórico, muitas vezes anterior até mesmo à existência do próprio coletivo de pensamento, da reunião dos esforços desse coletivo e da coerção do pensamento exercida pelo estilo de pensamento, e será a base para a construção e desenvolvimento dos fatos futuros, compondo a "realidade" e a concepção de mundo desse coletivo.

\subsection{Fleck e a circulação do saber}

Para Fleck, a circulação do saber não é importante apenas para o desenvolvimento de um fato - pois é ela que o fortalecerá e o divulgará para o mundo, tornando-o socialmente reconhecido - mas também pode ser a fonte e origem de novos fatos e dos próprios estilos de pensamento. Isso porque a circulação do conhecimento é condição necessária para a complementação, ampliação, transformação e criação dos coletivos de pensamento. De fato, para Fleck, existem basicamente três fontes que condicionam os conteúdos concretos de cada estilo de pensamento: (1) a ideogênese pré-histórica ou as chamadas protoideias, 
existentes desde o período de início daquele estilo, ou desde o período de quando ele surgiu a partir de uma cisão ou de uma variante de outro estilo; (2) as mudanças advindas da contínua migração das ideias dentro do coletivo, ditadas por forças sociais atuando nele, como estilização, sistematização e legitimação; (3) constantes efeitos de outros estilos (Fleck, [1936]1986, p. 103). Todas essas fontes são provenientes da circulação das ideias, a qual, devido à estrutura dos coletivos de pensamento - organizada em círculos esotéricos e exotéricos - pode ocorrer de duas formas: intracoletiva, internamente a um coletivo de pensamento, ou intercoletiva, entre diferentes coletivos de pensamento.

A circulação intracoletiva pode ocorrer de várias formas, a primeira delas é através da educação, ou da introdução didática de um novato ao coletivo de pensamento. Ela funciona como uma espécie de benção de iniciação, pois todo coletivo de pensamento estável cultiva um certo fechamento na sua forma e no seu conteúdo, possuindo dispositivos legais, costumes e linguagens específicas, ou pelo menos um vocabulário peculiar, os quais fecham a comunidade de pensamento formalmente, mesmo não sendo de forma absoluta, uma vez que somente os iniciados possuem familiaridade com esses hábitos. Assim, Fleck explica que qualquer introdução didática seria literalmente uma “condução para dentro" ou uma suave coação, análoga às iniciações conhecidas pela etnologia e pela história cultural:

A iniciação em um estilo de pensamento, portanto também a introdução em uma ciência são epistemologicamente análogas àquelas iniciações que conhecemos da etnologia e da história cultural. Não surtem apenas um efeito formal: o Espírito Santo desce no novato, e algo até então invisível se lhe torna visível. Esse é o efeito da assimilação de um estilo de pensamento (Fleck, [1935]2010, p. 155).

Por ser realizada por um iniciado no estilo de pensamento, portanto, uma autoridade, toda introdução didática em uma área envolve um tempo em que predomina um ensino puramente dogmático, até que o novato possa enxergar aquilo que "não pode ser pensado de outra maneira". Fleck chama a atenção que, em alguns casos, essa iniciação se torna tão difundida e natural, que "as pessoas se esquecem de tê-la recebido, uma vez que não têm contato com nenhum não iniciado" (Fleck, [1935]2010, p. 99), seria o caso da introdução nos fundamentos da Física, por exemplo. No entanto, esse conhecimento não pode ser entendido como uma estrutura "universalmente racional", trata-se apenas de um estágio momentâneo do saber, que permanece pouco claro sem o conhecimento de sua 
história, assim como a própria história permanece pouco clara sem o conhecimento de um estágio momentâneo específico. O especialista, portanto, seria aquele que possui uma formação específica e que já não escapa dos seus vínculos tradicionais e coletivos.

Por fim, Fleck ressalta que esses elementos, que já se estabeleceram e não são mais logicamente legitimáveis, não apenas são necessários para a introdução didática dos novatos em uma área, como também para dar continuidade a esse saber, e até mesmo para a legitimação dessa área.

Outra forma de circulação do saber intracoletiva acontece nos diálogos e trocas de ideias entre os próprios especialistas, ou seja, entre dois participantes em posição mentalmente igual de um mesmo coletivo de pensamento. Nesse caso, Fleck explica que, entre eles:

(...) há sempre um certo sentimento de solidariedade de pensamento a serviço de uma ideia transpessoal, o que produz uma dependência intelectual recíproca entre os indivíduos e uma atmosfera (Stimmung) comum: nenhuma questão, uma vez levantada, pode permanecer, em princípio, sem efeito; cada uma é ponderada e ocupa seu lugar dentro do estilo de pensamento. Esse companheirismo gerado pela atmosfera comum (Stimmungskameradschaft) pode ser sentido após alguns enunciados e somente ele possibilita uma verdadeira compreensão, sendo que, sem ele, as pessoas apenas desconversam (Fleck, [1935]2010, p. 158).

Ou seja, o companheirismo e a interdependência intelectual dos especialistas faz com que eles trabalhem em prol de algo maior, que é o conhecimento produzido pelo estilo de pensamento do qual eles fazem parte, e que, em princípio, transpassará e se autonomizará dos indivíduos. Isso faz com que eles compartilhem desse sentimento de solidariedade de pensamento, que não deve ser confundido com a solidariedade interpessoal, relacionada a questões éticas e morais, mas se refere a uma solidariedade em prol da construção de algo inerentemente coletivo, que tampouco é a soma das contribuições individuais de seus membros. Assim, os especialistas não contribuem apenas com conhecimentos separados e desconexos, mas com questões que mobilizarão todo o coletivo, a serem trabalhadas principalmente pelo grupo de especialistas. Por isso, Fleck afirma que nenhuma questão nesse grupo pode permanecer sem efeito, todas serão ponderadas e ocuparão um lugar no estilo de pensamento. 
A última forma de circulação do conhecimento intracoletiva se deve à relação entre o círculo esotérico e o exotérico. Conforme explicado anteriormente, essa é uma relação de interdependência análoga à relação sociológica entre a elite e as massas: por um lado, existe uma certa confiança no conhecimento que provém do círculo esotérico, por outro, esse conhecimento necessita do círculo exotérico, ou da opinião pública das massas, para se legitimar. Dependendo do quanto o círculo esotérico se fecha, um traço mais democrático, com maior participação do círculo exotérico, ou dogmático, com menor participação dele, se estabelece no coletivo de pensamento.

No caso específico do coletivo de pensamento científico, essa relação se dá entre o saber especializado (círculo esotérico) e o saber popular (círculo exotérico). No círculo exotérico, então, se encontram os "leigos mais ou menos instruídos" ou adultos com formação geral, que, por sua vez, praticam o que Fleck denomina de ciência popular. A ciência popular, para Fleck, é talvez o fator mais importante na circulação dos saberes, pois ela representa um fator de impacto genérico para qualquer conhecimento, uma vez que:

\begin{abstract}
(...) abastece a maior parte das áreas do saber de cada pessoa, e (...) o profissional mais meticuloso lhe deve muitos conceitos, muitas comparações e seus pontos de vista gerais, (...) todos utilizam em sua própria especialidade conceitos oriundos do repertório popular do saber. É em torno desses conceitos que constroem suas ciências especializadas, e, mais adiante, teremos a oportunidade de constatar permanentemente, nas profundezas dessas ciências, elementos do saber popular de outras áreas. Esses elementos foram muitas vezes decisivos para o conteúdo do saber especializado, predeterminando seu desenvolvimento por décadas (Fleck, [1935]2010, p. 165).
\end{abstract}

Fleck ainda considera a ciência popular um problema epistemológico, o qual a teoria do conhecimento nunca chegou a analisar em profundidade, por se preocupar apenas com a imagem fantasiosa e idealizada do conhecimento em detrimento do seu funcionamento real.

A ciência popular, para Fleck, consiste basicamente na ciência para não especialistas, e se caracteriza por propagar uma imagem artificialmente simplificada da ciência especializada, e explicá-la de forma esteticamente agradável e ilustrativa, omitindo os seus detalhes, restrições e complicações, mas principalmente suas polêmicas, opiniões contraditórias e os equívocos dos pesquisadores. Ela também apresenta uma avaliação 
apodítica dos fenômenos e das formulações, em que estes são classificados taxativamente como verdadeiros ou falsos, ou com a simples aprovação ou reprovação de determinados pontos de vista. Nela, a construção complicada e especializada dos pensamentos passa a ser apresentada como uma história simples e cristalina, como um simples fato, acarretando em uma convicção geral de que o pensamento não passa por um processo de desenvolvimento.

A ciência simplificada, ilustrativa e apodítica - estas são as marcas mais importantes do saber exotérico. No lugar da coerção específica de pensamento própria das comprovações, que tem que ser detectada por meio de um trabalho esforçado, surge uma imagem ilustrativa por meio da simplificação e da avaliação (Fleck, [1935]2010, p. 166, grifos do autor).

Ela descreve tudo como se os conceitos e as ideias existissem de antemão (...) e como se sua mera aplicação "consequente" levasse à descoberta; como se outros conceitos não fossem também possíveis. Assim, a verdade é transformada numa qualidade objetivamente existente, e os pesquisadores são divididos em duas classes: em caracteres pretos, que não acertam a verdade e os brancos, que a acertam (Fleck, [1935]2010, p. 169).

Fleck acrescenta ainda que a versão popular do conhecimento, enquanto "esquema geral”, não está equivocada, não apresenta erros conceituais ou teóricos, ela está de acordo com a visão do estilo de pensamento, apenas não corresponde ao saber extenso do especialista. E, quanto mais nos afastamos do centro do círculo esotérico, em direção à periferia do exotérico, mais essa imagem se intensifica e "o pensamento parece ser ainda mais dominado pela plasticidade (Anschaulichkeit) emotiva, que confere ao saber a segurança subjetiva da religiosidade ou do óbvio" (Fleck, [1935]2010, p. 171). Para dar um exemplo ilustrativo da ciência popular mais exotérica, Fleck conta:

Lembro-me de um exemplo dessa ciência grosseiramente popular: trata-se de uma reprodução que apresenta o fato higiênico da transmissão aérea. Um homem sentado, com um rosto cinza-roxo e emagrecido até o esqueleto, está tossindo. Com uma mão, ele mal consegue se apoiar no encosto da poltrona, com a outra, aperta o peito dolorido, Da boca aberta, os maus bacilos estão voando na forma de diabinhos... Uma criança corada encontra-se ao seu lado, sem desconfiar de nada. O bacilo-diabo chega cada vez mais perto da boca da criança... Metade símbolo, metade questão de fé, o diabo dessa figura é reproduzido em sua aparência física. Mas ele assombra também a ciência 
especializada, as visões da imunologia e suas imagens de combate e de defesa (Fleck, [1935]2010, p. 171).

Assim, por seu caráter simples, ilustrativo e apodítico, a ciência popular apresenta o conhecimento de uma forma mais sólida, acabada e segura, formando a opinião pública. Com a reunião do saber popular de varias áreas, forma-se uma visão de mundo (Weltanschauung), que irá compor o pano de fundo que determinará os traços gerais do estilo de pensamento original.

Certeza, simplicidade, plasticidade somente surgem do saber popular, pois o especialista busca nele a crença nesses valores enquanto ideal do saber. Aí reside a importância epistemológica geral da ciência popular (Fleck, [1935]2010, p. 168, grifos do autor).

A partir disso, completa-se um ciclo: o saber popular emerge do saber especializado, este, por sua vez, forma a visão de mundo que determina as características gerais do estilo de pensamento, causando, por conseguinte, um efeito retroativo no especialista. Dessa forma, é possível considerar o tráfego de ideias entre os círculos exotérico e esotérico do coletivo de pensamento científico como uma via de mão dupla: por um lado, a ciência popular aparece como uma simplificação derivada, por outro, aparece como origem e pano de fundo. O movimento para fora, emigratório, que vai do centro do círculo para a sua periferia é um simplificação, enquanto o movimento contrário, imigratório, que vai da periferia para o centro é um movimento de fonte ou de retroalimentação. $O$ saber exotérico serve como a base de legitimação do saber esotérico, ao mesmo tempo em que lhe fornece as noções e esquemas (linguísticos, perceptuais e mentais) básicos (Oliveira, 2012).

Assim, a circulação do saber intracoletiva, seja através da educação, da troca de ideias entre os especialistas ou através da relação de interdependência entre os círculos esotérico e exotérico, possui o papel de fortalecer o conhecimento produzido pelo estilo de pensamento, tornando-o seguro e propagando-o:

Todo tráfego de pensamento intracoletivo (intrakollektiven Denkverkehr), portanto, é dominado por um sentimento específico de dependência. A estrutura geral do coletivo de pensamento faz com que o tráfego intracoletivo de pensamento - pelo fato sociológico em si, sem consideração pelo conteúdo e pela legitimação lógica - leva ao fortalecimento das formações de pensamento (Denkgebilde): a confiança nos iniciados, 
a dependência por parte destes da opinião pública, a solidariedade intelectual dos pares, que estão a serviço da mesma ideia, são forças sociais alinhadas que criam uma atmosfera comum específica, proporcionando às formações de pensamento solidariedade e adequação ao estilo numa medida cada vez maior. Quanto maior ficar a distância temporal e espacial do círculo esotérico, quanto mais durar a mediação de um pensamento dentro do mesmo coletivo de pensamento, tanto mais seguro se apresenta. Quando o vínculo data da educação intelectual da infância, ou até mesmo de uma tradição antiga de várias gerações, ele ganha uma firmeza inabalável (Fleck, [1935]2010, p. 158, grifos do autor).

Detalhando um pouco mais as especificidades da circulação das ideias dentro do coletivo de pensamento científico, Fleck explora as formas de comunicação correspondentes a cada um dos seus estratos. De acordo com ele, nesse coletivo, os especialistas - alocados no centro do círculo esotérico - se expressam através das revistas e jornais científicos, já os especialistas gerais - alocados nas bordas do círculo esotérico se expressam através dos livros didáticos, enquanto que os livros populares ou de divulgação científica são voltados para o público leigo de formação geral - presente no círculo exotérico. No jornal científico, a ciência se apresenta com um caráter claramente pessoal e provisório: ela é a opinião do autor X, a qual é apresentada com muitas reservas, com um caráter provisional, modesto e com precaução, isso porque, para ser reconhecida, ela deve passar pelo julgamento de um numeroso e criterioso conselho. Já o livro didático modifica o julgamento subjetivo do autor para um fato comprovado, o qual é unificado ao sistema completo da ciência, reconhecido e ensinado, se tornando parte dos fatos fundadores e um princípio-guia para o que será investigado e aplicado posteriormente. Por fim, o livro popular, de divulgação científica, modifica o fato comprovado para uma forma diretamente perceptível, no qual as provas passam para o segundo plano, a autoridade se torna uma característica do discurso e as ideias adquirem um caráter impessoal, autônomo, tornando-se objetos (Fleck, [1936]1986, pp. 107-108). Todos esses meios de comunicação irão facilitar o tráfego de ideias intracoletivo da ciência.

Uma vez apresentadas as características da circulação do saber intracoletiva - em especial, as referentes ao coletivo de pensamento científico - podemos partir para a circulação intercoletiva, a qual, segundo Fleck, possui o papel de deslocar, alterar ou transformar o estilo de pensamento. O filósofo polonês explica que o tráfego de ideias entre dois estilos de pensamento distintos ocorre somente quando estes possuem algum 
traço comum, por menor que seja, e que, quanto maior a diferença entre eles, menor será esse tráfego, uma vez que os princípios e características de um coletivo alheio sempre são vistos com uma certa estranheza:

Os princípios de um coletivo alheio são percebidos - se é que são notados - como arbitrários, sua eventual legitimação, como petição de princípio. O estilo de pensamento alheio tem ares de misticismo, as questões rejeitadas por ele são consideradas exatamente como as mais importantes, as explicações como não comprovadoras ou errôneas e os problemas, muitas vezes, como brincadeira sem importância ou sem sentido. Fatos particulares e conceitos particulares - dependendo do parentesco entre os coletivos - são vistos como invenções livres, simplesmente ignoradas (como, por exemplo, "fatos espíritas" por parte das ciências exatas), ou - no caso de coletivos menos divergentes - são interpretados de maneira diferente, isto é, traduzidos e adotados numa outra linguagem de pensamento (como, por exemplo, os mesmos fatos espíritas por parte dos teólogos) (Fleck, [1935]2010, p. 160-161).

Dentro dessa limitação, a circulação das ideias entre diferentes coletivos de pensamento pode ocorrer por meio de qualquer elemento que circule entre eles e, dentre os muitos existentes, Fleck destaca as palavras e as pessoas. Para o filósofo polonês, as palavras possuem um status privilegiado, pois são um bem comum, que circula entre qualquer coletivo. Porém, ao mesmo tempo, cada vez que passam por um determinado coletivo, elas são marcadas de alguma forma pelo estilo de pensamento deste grupo, adquirindo um significado específico, e podendo dar origem a novas interpretações dos termos ou, até mesmo, a completa aniquilação do seu significado original:

A palavra como tal representa um bem intercoletivo peculiar: uma vez que a todas as palavras se lhes adere um matiz mais ou menos marcado pelo estilo de pensamento, que se altera na migração intercoletiva, elas circulam entre os coletivos sempre com uma certa alteração de seu significado. Compare-se as palavras "força", "energia" ou "teste" para um físico e para um filólogo ou um atleta (Fleck, [1935]2010, p. 161).

A troca de ideias intercoletiva é sempre conectada com uma modificação mais ou menos marcada das ideias. Quando passam de um coletivo a outro, as palavras mudam o seu significado, as ideias obtêm uma coloração estilística diferente, as sentenças recebem outro significado, as opiniões um novo valor. Se os coletivos são consideravelmente distantes entre si, a troca de ideias pode ser completamente impossível, e a transformação de uma ideia consiste, nesse caso, na sua completa destruição (Fleck, [1936]1986, p. 85). 
A circulação de ideias intercoletiva por meio das pessoas, por outro lado, ocorre, pois nenhum indivíduo fica restrito a um único coletivo de pensamento, geralmente as pessoas pertencem e circulam entre várias comunidades, atuando como veículo do tráfego de ideias entre elas. Fleck chama a atenção para o fato de que, do ponto de vista social, a uniformidade do pensamento em uma comunidade, conforme um determinado estilo de pensamento, é muito mais forte e sólida do que a estrutura lógica de pensamento de um único indivíduo. Pois este é capaz de separar e conviver com estilos de pensamento bem distintos entre si, inclusive, suportando elementos contraditórios de forma isolada. No entanto, quando os estilos de pensamento no indivíduo são mais próximos, essa separação se torna mais difícil:

Elementos logicamente contraditórios de pensamento de um indivíduo nem chegam a causar uma contradição psíquica, pois estão separados um do outro: determinadas configurações, por exemplo, são consideradas como questão de fé; outras, como questão do saber e ambos os âmbitos não se influenciam, mesmo se logicamente nem sequer essa separação possa ser legitimada. Também é muito mais frequente que uma pessoa participe de alguns coletivos de pensamento muito divergentes do que de alguns coletivos muito afins. (...) Quando os estilos de pensamento são muito diferentes, também podem preservar seu caráter fechado no mesmo indivíduo, mas, quando se trata de estilos de pensamento afins, essa separação se torna difícil: os atritos dos estilos de pensamento tornam a vizinhança impossível e condenam a pessoa à improdutividade ou à criação de um estilo peculiar limítrofe (Fleck, [1935]2010, p. 162).

No entanto, apesar da relativa uniformidade de pensamento existente em uma comunidade, justamente por seus membros participarem de diferentes coletivos de pensamento, Fleck admite a impossibilidade de uma completa concordância dos vários observadores, mesmo que treinados, com relação a determinado assunto. Essas divergências pontuais, existentes mesmo no contexto da observação científica, consiste em outra forma de circulação das ideias por meio das pessoas e permite o advento de novas percepções no interior do próprio estilo de pensamento (Carneiro, 2012, p. 49). Essas novas percepções, discordâncias e choques de ideias podem acarretar em novas leituras de um mesmo objeto ou na configuração de novos objetos, isto é, novas descobertas ou fatos, que, por sua vez, possibilitam mudanças e transformações nos estilos de pensamento ou criação de novos coletivos de pensamento. Conforme mencionado 
anteriormente, essa influência mútua entre diferentes coletivos se dará na proporção dos elementos em comum entre eles, da seguinte maneira:

Não existe basicamente nenhum contato entre coletivos completamente separados, isto é, aqueles que não possuem nada em comum. Se dois coletivos mais ou menos diferentes entram em conexão, então surge um coletivo comum - possivelmente com uma vida curta e bem pobre em conteúdo. Quanto mais estranhos entre si estes coletivos são, mais pobre em conteúdo será o coletivo comum: em determinadas condições ele terá somente um conteúdo bem primitivo: fisicamente e duramente reprimido. Se os coletivos são muito diferentes um do outro, qualquer contato ou influencia cessa (Fleck, [1936]1986, p. 105, tradução livre).

Sendo assim, a comunicação de ideias entre diferentes estilos de pensamento deve sempre levar em conta a linguagem, as normas e os costumes do coletivo de pensamento com quem se quer comunicar, para que possa haver entendimento mútuo. Para formular uma ideia para membros de outro coletivo é preciso transformá-la de modo a torná-la próxima do seu estilo, de tal forma que um coletivo de pensamento comum será criado, intermediário entre ambos, mais pobre em conteúdo, porém mais abrangente. Fleck denomina essa forma de comunicação de propaganda (Fleck, [1936]1986, p. 85). Segundo ele, a propaganda de uma ideia para os propósitos de um determinado coletivo de pensamento pode objetivar:

(1) a sua popularização, conforme os interesses dos leigos do coletivo; (2) informação a respeito dela, conforme os interesses de trocas entre os especialistas equivalentes; e, finalmente, (3) sua legitimação, dentro da estrutura do sistema de ideias do estilo, isto é, sua formulação oficial, válida para o coletivo como tal (Fleck, [1936]1986, p. 86, tradução livre).

Contudo, de acordo com Fleck, além do desejo de comunicação, a circulação de ideias intercoletiva também pode ser motivada e propulsionada por outras forças sociais, as quais podem resultar em alterações no pensamento não intencionais ou não previstas, muitas vezes, com uma completa mudança de significado, na qual apenas uma vaga e distante similaridade permanece. Fleck considera que essa circulação de ideias não intencional possui grande importância do ponto de vista da sociologia do pensamento e elenca alguns exemplos de efeitos que podem ser causados por esse movimento. $\mathrm{O}$ primeiro deles é a falsa popularização, a qual consiste na popularização acompanhada da corrupção das ideias originais como, por exemplo, quando os conhecimentos médicos são passados por 
auxiliares hospitalares sem o devido treinamento para as classes mais populares ou quando ideias científicas são distorcidas por jornalistas. Outro possível efeito é o que Fleck chama de apoteose do pensamento, que ocorre quando a ideia se torna um motivo místico ou inconcebível, sem a devida compreensão da sua razão ou origem, sendo impensadamente cultuada. Por fim, também pode acontecer uma caricaturização do pensamento, quando a ideia se torna ridícula e motivo de escárnio, enriquecendo a impressão de um estilo completamente alheio. Todos esses efeitos alteram os elementos dos estilos de pensamento, podendo fazer com que eles adquiram novos conteúdos e significados e, consequentemente, originando mudanças e transformações nos coletivos de pensamento (Fleck, [1936]1986, pp. 87-88). No entanto, essas alterações e transformações, causadas pela circulação das ideias entre os diferentes coletivos de pensamento, ocorrem de forma harmoniosa e sutil, em diferentes graus, podendo se estender por um longo período de tempo. Porém, são justamente essas alterações e migrações dos conceitos e significados que possibilitam as descobertas e a criação de novos fatos e, consequentemente, o desenvolvimento do conhecimento:

(...) qualquer tráfego intercoletivo de pensamentos traz consigo um deslocamento ou uma alteração dos valores de pensamento. Do mesmo modo que a atmosfera (Stimmung) comum dentro do coletivo de pensamento leva a um fortalecimento dos valores de pensamento, a mudança de atmosfera durante a migração intercoletiva provoca uma mudança desses valores em toda sua escala de possibilidades: da pequena mudança matizada, passando pela mudança completa de sentido até a aniquilação de qualquer sentido (...) descrevemos a migração do conceito de sífilis de uma comunidade de pensamento a outra, sempre com sua transformação e alteração harmoniosa do estilo inteiro de pensamento do novo coletivo, que surge mediante o entrelaçamento com seus conceitos. Essa alteração do estilo de pensamento - isto é, a alteração na disposição à percepção direcionada - oferece novas possibilidades de descobertas e cria novos fatos. Esse é o significado epistemológico mais importante do tráfego intercoletivo de pensamento (Fleck, [1935]2010, p. 161-162).

Por fim, novamente se contrapondo às teorias do conhecimento de sua época, Fleck conclui comparando a circulação e a transformação do saber com um corpo sólido e rígido se movendo no espaço: ele se desloca como um bloco de ideias, que vai se modificando aos poucos, conforme a interação com o meio. O deslocamento desse bloco possui muito mais força do que as contribuições individuais dos membros do coletivo de pensamento que o compõe. 
(...) tenho plena consciência do caráter fragmentário [desta] apresentação. Mas talvez seja suficiente para mostrar especialmente aos teóricos orientados pelas ciências exatas que a simples comunicação de um saber não é, de maneira alguma, comparável ao deslocamento de um corpo rígido no espaço euclidiano: nunca acontece sem transformação, mas sempre com uma modificação de acordo com determinado estilo; no caso intracoletivo, com o fortalecimento; no caso intercoletivo, com uma mudança fundamental. Quem não entender isso, nunca alcançará uma teoria positiva do conhecimento (Fleck, [1935]2010, p. 162-163).

\subsection{Fleck e o problema da demarcação na ciência}

Conforme explicado anteriormente, o problema da demarcação na ciência é aquele que busca caracterizar o que a diferencia de outras formas de conhecimento e traçar as fronteiras entre a ciência e a não-ciência, ou seja, entre aquilo que pode ser considerado científico e o que não pode.

Antes de explorar qual a concepção de Fleck a respeito desse problema, primeiramente, é necessário compreender como ele concebe o conhecimento e a sua concepção de verdade. O conhecimento, para o filósofo polonês, acima de tudo se desenvolve, ele está sempre em processo de construção, em constante movimento e mudança, inclusive, o conhecimento no estágio atual também passará por modificações, “pois não há, provavelmente, um fim do desenvolvimento do saber" (Fleck, [1935]2010, p. 110). Ele se coloca, ao mesmo tempo, contrário à ideia do conhecimento por acumulação e de que ele se desenvolve progressivamente para um fim, ou seja, à ideia de um progresso positivo do conhecimento, em que as concepções que sobrevivem são superiores ou melhores do que as antigas, de forma absoluta.

Trata-se, unicamente, de mostrar que até mesmo o saber especializado não apenas aumenta, mas também passa por mudanças fundamentais. Não queremos, contudo, contentar-nos com a constatação banal do caráter passageiro do saber humano (Fleck, [1935]2010, pp. 109-110, grifos do autor).

Ele também critica os teóricos do conhecimento de sua época, tanto aqueles com formação nas ciências exatas, como os filósofos do Círculo de Viena - por considerarem o pensamento humano como algo fixo e absoluto, livre de sentimentos e totalmente objetivo - quanto aqueles com formação nas humanidades, como os filósofos humanistas 
Jerusalem e Levy-Bruhl - por considerarem, de forma inversa, o fato como algo fixo e o pensamento humano como algo variável, para apresentar a sua concepção:

Na opinião desses filósofos, as nossas concepções atuais parecem estar numa oposição completa a todas as outras maneiras de pensar, como se nós, tornados inteligentes e clarividentes, por assim dizer, tivéssemos simplesmente nos livrado da prisão infantil do pensamento primitivo arcaico. Possuiríamos o "pensamento verdadeiro" e a "observação verdadeira" e, por isso mesmo, é verdadeiro o que declaramos como verdadeiro, sendo que aquilo que aqueles outros, os primitivos ou os velhos, os deficientes mentais ou as crianças declaram como verdadeiro, parece ser verdadeiro apenas para eles.

(...) Será que não podemos absolutamente dispensar o "fixo"? Tanto o pensamento quanto os fatos são variáveis. São variáveis apenas pelo fato de as mudanças no pensamento se revelarem na forma de fatos alterados e, de maneira inversa, fatos realmente novos poderem ser encontrados apenas mediante um pensamento novo (Fleck, [1935]2010, p. 94, grifos do autor).

Porém, ele alerta que sua posição não é a de um relativismo extremo, no qual o conhecimento simplesmente não seria possível, mas a de um reconhecimento de que tanto o conhecimento quanto os elementos que contribuem na sua construção mudam ao longo do desenrolar da história e de seu desenvolvimento.

Que não se compreendam as posições aqui expostas como ceticismo. Certamente, podemos saber muitas coisas. E, se não conseguirmos saber "tudo", de acordo com a velha receita, isso se deve simplesmente ao fato de o termo "tudo" não fazer muito sentido em nosso contexto. A cada nova descoberta, surge pela menos um novo problema: a análise do objeto conhecido como tal. Assim, o número dos problemas a serem resolvidos se torna infinito, e a designação "tudo" perde o sentido.

Da mesma maneira que não existe um "tudo", não existe um "último", algo fundamental que servisse de base para o conhecimento lógico. O saber, portanto, não se baseia em nenhum fundamento. A engrenagem das ideias e verdades somente se conserva mediante um movimento constante e efeitos recíprocos (Fleck, [1935]2010, p. 95, grifos do autor).

Com relação à concepção de verdade, Fleck acredita que não exista uma verdade universalmente válida, fixa, absoluta, para a qual todos os conhecimentos, de todos os estilos de pensamento, caminham de forma natural. Ele critica duramente essa concepção, apontando o caráter social e dependente dos sujeitos necessariamente vinculado a esse conceito: 
A noção de verdade em seu significado clássico, como um valor independente do sujeito cognitivo e das forças sociais, nos compele a aceitar a verdade como um ideal inalcançável, e a história da ciência nos ensina que nós não nos aproximamos desse ideal nem mesmo assintoticamente, pois o desenvolvimento da ciência não é unidirecional e não consiste somente na acumulação e novos elementos de informação, mas também em descartar as concepções antigas. Portanto, as teorias clássicas da cognição devem distinguir entre: (1) a ideal, inalcançável de verdade, (2) as "verdades" oficiais as quais "deveríamos" de alguma forma nos aproximar, (3) ilusões e equívocos. Ao mesmo tempo, elas devem admitir que não há um critério geral de verdade. (...) A epistemologia, que é a ciência dos estilos de pensamento e do seu desenvolvimento histórico e sociológico, considera que a verdade é o estágio mais avançado das mudanças do estilo de pensamento. Isso não simplifica o problema, mas o torna explorável (Fleck, [1936]1986, pp. 111-112, tradução livre, grifos do autor).

Para ele, existe somente a verdade permitida de se enxergar através dos limites impostos pelo estilo de pensamento, porém não se trata de uma verdade totalmente arbitrária ou convencionalmente estabelecida, mas uma verdade para a qual a "coerção do pensamento" nos leva, a única possível dentro de determinado estilo de pensamento.

A questão é como, com base em pressuposições falsas, de primeiros ensaios confusos, de muitos erros e desvios, pode surgir um conhecimento "verdadeiro". É possível responder a ela por meio de uma comparação: como todos os rios, apesar da direção inicial errônea, apesar de todos os desvios e meandros, encontram sempre o mar? Não existe um "mar em si", mas o lugar embaixo, o único onde as águas se juntam, chamase mar! Basta haver água suficiente no rio e ter um campo gravitacional para que os rios necessariamente encontrem o mar. $\mathrm{O}$ campo gravitacional corresponde à atmosfera que determina o rumo; a água corresponde ao trabalho de todo o coletivo de pensamento. Nada depende do rumo momentâneo de cada gota, pois o resultado decorre da direção geral da gravitação (Fleck, [1935]2010, p. 126, grifos do autor).

Assim, Fleck explica que qualquer conhecimento seria fruto de constatações obtidas passivamente, através da coerção exercida pelo estilo de pensamento, a partir de determinados pressupostos adotados ativamente, por um indivíduo ou um grupo, ambos membros do respectivo coletivo de pensamento. E a verdade seria a solução única de um problema de um determinado estilo de pensamento, obtida em um contexto históricosocial específico, também a partir da coerção exercida por esse mesmo estilo:

(...) enquanto durava, sempre uma única solução de um problema era conforme ao estilo. Tal solução conforme a um estilo, somente possível de forma singular, chama-se 
verdade. Ela não é "relativa" ou até mesmo "subjetiva" no sentido popular da palavra. Ela sempre - ou quase sempre - é totalmente determinada dentro de um estilo de pensamento. Nunca se pode dizer que o mesmo pensamento seja verdadeiro para A e falso para B. Se A e B pertencerem ao mesmo coletivo de pensamento, o pensamento é verdadeiro ou falso para ambos. Contudo, se pertencerem a coletivos de pensamento diversos, o pensamento não é o mesmo porque, para um dos dois, o pensamento deve ser pouco claro ou entendido por ele de maneira diferente. A verdade também não é convenção, mas um acontecimento no corte longitudinal no contexto do momento: coerção do pensamento conforme ao estilo (Fleck, [1935]2010, p. 150-151, grifos do autor).

No entanto, apesar da possível consequência filosófica dessa concepção ser a de que cada estilo de pensamento possuiria a sua própria verdade, isso não significa que não possa existir uma verdade comum às múltiplas realidades dos coletivos de pensamento, por mais que ela seja irregular, possua várias facetas e não seja universal. Na concepção de Fleck, isso seria possível através de uma epistemologia comparada. Por isso, Fleck dá tanta importância para a circulação intercoletiva do saber e para a ciência popular, lugar de onde qualquer individuo faz parte, onde se reúnem e se interseccionam os vários estilos de pensamento existentes, e que se constitui como chegada e partida de todos os conhecimentos produzidos por eles. Esses conhecimentos, por sua vez, ao circular pelo círculo exotérico da ciência popular, serão constantemente modificados e transformados, dando origem a novos estilos de pensamento. Para o filósofo polonês, a coerção de um estilo de pensamento particular "apenas se dissolve por meio de uma análise comparativa, revelando-se como coerção interna do estilo de pensamento" (Fleck, [1935]2010, p. 127), ou seja, apenas fazendo-se uma comparação entre os diferentes estilos de pensamento e uma análise histórico-social dos seus desenvolvimentos é possível transpor as barreiras da coerção interna de um determinado estilo. Somente assim seria possível uma teoria do conhecimento coerente, daí segue a sua defesa:

A fecundidade da teoria do coletivo de pensamento se evidencia justamente na possibilidade de comparar os modos de pensar primitivo, arcaico, infantil e psicótico e de analisá-los de maneira coerente. Em última instância, isso vale também para o modo de pensar de um povo, de uma classe, de um grupo qualquer. Considero o postulado de trabalhar com um máximo de experiência como a lei suprema do pensamento científico. Uma vez que se vislumbra a possibilidade de uma teoria comparada do conhecimento, ela se transforma em dever. O antigo ponto de vista, que não passa de constatações 
normativas do "mau" e "bom" pensamento, é ultrapassado (Fleck, [1935]2010, pp. 9495).

Assim, a proposta de Fleck de uma teoria comparada do conhecimento expressa a sua aspiração de formular uma teoria capaz de compreender as múltiplas realidades existentes, a qual, em suas palavras, consistiria de um projeto epistemológico de caráter científico, com forte conotação política e ética: uma "ciência fundamental", que promoveria a "tolerância", o "entendimento mútuo", tendo em vista uma ciência mais "humana" (Carneiro, 2012, p. 153):

A sociologia do pensamento deve ser desenvolvida como uma ciência fundamental, igual em valor à matemática. O problema da organização, planejamento, ensino e popularização [das ciências] deve ser baseado nessa nova disciplina. Estudos comparados acerca dos estilos tornarão os estudantes mais tolerantes em sua relação a estilos alheios, preparando-os para a coexistência; proponentes de diferentes estilos poderão apreciar [os estilos distintos] mutuamente e, mesmo, trabalhar em conjunto até [em] um nível sem entendimento mútuo (...) (Fleck, [1960]1986, p. 157, tradução livre).

A caracterização da sociologia do pensamento como uma "ciência fundamental" por Fleck, nessa citação, não deve ser entendida como uma verdade absoluta, autorrefutável no contexto de sua epistemologia, ou como um "fundamento" para as demais ciências, mas sim em termos de sua importância e valor. Isso porque a sua teoria comparada do conhecimento também seria um saber estilizado, engendrado e relacionado a um determinado estilo de pensamento (Carneiro, 2012, p. 155), com a diferença de que ela buscaria acessar os demais estilos de pensamento através de mediações comunicativas específicas e buscaria ganhar uma legitimidade e um status de conhecimento geral, a fim de criar um coletivo de pensamento comum, livre pelo criticismo e tolerância geral (Carneiro, 2012, p. 150).

Uma vez feitas essas considerações, pode-se partir para a análise do problema da demarcação na ciência. Para Fleck, a ciência também pode ser considerada um estilo de pensamento específico, com um coletivo de pensamento atrelado, com características similares aos outros coletivos. Assim, o coletivo de pensamento científico também cultiva um certo fechamento orgânico de sua comunidade, tanto na sua forma quanto no seu conteúdo, limitando os problemas que podem ser admitidos e trabalhados pelo estilo de pensamento. O coletivo, portanto, distingue entre aqueles problemas que podem ser 
considerados "problemas reais", dignos de atenção, e "pseudoproblemas" ou problemas falsos, sem importância. Em outras palavras, o coletivo, para reafirmar a sua identidade e características próprias, distingue a "ciência" da "pseudociência".

Paralelamente ao fechamento orgânico de cada comunidade de pensamento ocorre uma limitação dos problemas admitidos dentro do estilo de pensamento: muitos problemas são constantemente ignorados ou rejeitados por serem considerados sem importância ou sem sentido. As ciências exatas modernas também distinguem entre "problemas reais" e “pseudoproblemas". Dessa postura surge uma atribuição específica de valores e uma intolerância característica, que são traços comuns de qualquer comunidade fechada (Fleck, [1935]2010, pp. 155-156).

Porém, para além de se tratar apenas de uma questão de afirmação de uma identidade do coletivo e de uma escolha deliberada dos problemas que são admitidos ou não pelo estilo de pensamento, a diferenciação entre ciência e não-ciência se dá muito mais pelos valores e pela exigência da coerção de pensamento próprios do estilo científico de pensamento, do que uma escolha consciente baseada em um critério universal.

De fato, Fleck reconhece que uma característica que diferencia a ciência das outras formas de conhecimento é a sua busca por "um máximo de coerção de pensamento (Denkzwang) com um mínimo de pensamento baseado na própria vontade" (Fleck, [1935]2010, p. 144). Segundo ele, "para todas as ciências, a finalidade é a elaboração desse 'solo firme dos fatos"” (Fleck, [1935]2010, p. 145), em outras palavras, a ciência busca por um máximo número de elementos passivos no saber, em detrimento dos elementos ativos:

Os elementos passivos e ativos não podem ser distinguidos pelo viés histórico, nem pelo lógico. Não se inventa nem um conto de fadas que não contenha acoplamentos coercitivos. Nesse sentido, o mito se diferencia da ciência apenas pelo estilo: a ciência procura absorver em seu sistema, um máximo daqueles elementos passivos, sem consideração pela transparência; o mito contém apenas poucos desses elementos, porém na forma de uma composição artística (Fleck, [1935]2010, p. 145, grifos do autor).

Mesmo reconhecendo que não é possível elaborar um conhecimento ou a existência de um estilo que contenham somente elementos passivos, e que, inclusive, no decorrer da história e do desenvolvimento do saber, elementos passivos podem se apresentar na forma de ativos e vice-versa, Fleck ressalta essa característica do estilo de pensamento científico, 
em prezar pela busca da "coerção segura", da "percepção da forma de maneira imediata", em detrimento do livre pensar, baseado na própria vontade.

(...) quanto mais elaborada uma área do conhecimento, quanto mais desenvolvida, tanto menores as diferenças de opinião. (...) É como se, com o crescimento dos pontos nodais, o espaço livre diminuísse, como se surgissem outras resistências, como se o desdobramento livre do pensamento ficasse restrito (Fleck, [1935]2010, pp. 132-133).

Além disso, um valor que Fleck considera estar associado ao coletivo de pensamento científico é a democracia, e é justamente essa característica que ele reivindica para a sua própria teoria comparada do conhecimento, a qual considera como possuindo um caráter científico. Ele considera o pensamento típico das ciências naturais como possuindo um caráter democrático a fim de diferenciá-lo do pensamento de comunidades dogmáticas, como as de cunho religioso, por exemplo. Segundo ele, o coletivo de pensamento científico “(...) baseia-se na organização e permanece em seu controle, recusando o privilégio de procedência divina, e se pretende acessível e útil a todos" (Fleck, [1929]1986, p. 50, tradução livre). A ciência natural seria, em suma, a "arte de formar uma realidade democrática e guiar-se por ela e, portanto, ser constantemente reformulada por ela também" (Fleck, [1929]1986, p. 54, tradução livre). Fleck defende esse caráter para o coletivo de pensamento científico, pois "a ciência serve o "publico geral"” e "não há poderes secretos" nela, "não se pode referir [a ela] como uma missão obtida de círculos superiores" (Fleck, [1936]1986, p. 105, tradução livre). Ele também argumenta que:

O círculo exotérico consiste de pessoas leigas de quem nós temos uma "ciência popular" específica. As bordas deste círculo são abertas a todos, sua admissão não requer nenhuma cerimônia formal. A natureza democrática do coletivo científico se manifesta também no fato de que todo especialista em um determinado campo científico é um leigo na maioria dos outros campos, diferentemente do coletivo de pensamento religioso, onde os sacerdotes formam a totalidade da elite.

(...) O sistema democrático do coletivo de pensamento científico se mostra externamente - como é bem conhecido - em verdadeiros mecanismos democráticos, como congressos, imprensa cientifica, discussões cientificas, e no estabelecimento democrático das opiniões da "maioria dos pesquisadores", i.e., na produção da opinião pública.

(...) Os especialistas são quase sempre recrutados dentre os especialistas mais gerais, suas posições frequentemente são de uma natureza transitória: eles frequentemente mudam a sua especialidade e, tendo completado a sua pesquisa em determinada direção, 
eles retornam para os postos de especialistas gerais, com quem eles sempre mantêm o contato (Fleck, [1936]1986, pp. 105-106, tradução livre).

Dessa forma, antes de constituir um fim em si mesma, a democracia em Fleck - bem como a tolerância, a cooperação e a livre circulação de ideias, dela decorrentes constituem o meio para a realização de sua própria definição de ciência natural: atividade coletiva democrática capaz de engendrar continuamente concepções criativas, úteis, de valor heurístico, de tal forma que a radicalização desta atividade constitui seu próprio ideal e sua imagem de ciência (Carneiro, 2012, p. 155).

Assim, para Fleck, o caráter democrático da ciência, juntamente com a compreensão de que o conhecimento é passível de mudança e se desenvolve continuamente, é que permitirão o estilo de pensamento científico se diferenciar dos estilos de caráter dogmático e abandonar a ideia de uma verdade absoluta.

A compreensão disso [contínuo desenvolvimento histórico das ideias] irá ajudar os cientistas a permanecer ativos em suas concepções criativas. O estéril problema do idealismo e do materialismo esvaecerá. A verdade científica passará de algo rígido e estacionário a uma verdade dinâmica, passível de desenvolvimento, criativa, humana (Fleck, [1960]1986, p. 157, tradução livre).

No entanto, ele reconhece que existem dificuldades práticas para exercer a democracia por completo no coletivo de pensamento da ciência, as quais ele acredita que estão vinculadas principalmente à educação geral do público mais amplo:

Um especialista geral é quase sempre recrutado dentre as pessoas com educação geral. Por outro lado, nas condições sociais atuais, não há transições diretas entre o círculo dos leigos com educação geral e o "público mais amplo": a educação geral é adquirida antes da maturidade; aqueles que falharam em adquiri-la na escola geralmente permanecem no círculo do público não educado mais amplo. Uma vez que temos aqui a fronteira do estrato social mais difícil de ultrapassar, é aqui, naturalmente, que se encontram algumas das mais importantes violações dos princípios democráticos (do ponto de vista epistemológico).

(...) Essa fronteira do estrato social naturalmente não é absoluta: a educação científica ocorre também sem a ajuda da educação formal, no estrato do público geral, e pode acontecer de um leigo não educado adentrar no círculo dos leigos com educação geral mesmo após o seu período de maturidade. Ainda assim, a separação entre o público mais amplo e o com educação geral é bem clara. Isso resulta, em primeiro lugar, em 
uma certa discrepância entre o postulado principal da ciência que quer ser universal e a sua limitação significativa às bordas do coletivo (Fleck, [1936]1986, pp. 106- 107, tradução livre).

Por fim, outra característica que diferenciará o coletivo de pensamento científico dos outros coletivos é a sua linguagem característica. Conforme explicado anteriormente, cada coletivo de pensamento possui linguagem, tradições e práticas próprias, as quais são as marcas do estilo de pensamento correspondente e, mais do que isso, são elas é que estabelecem o sistema de referência a partir do qual os indivíduos do coletivo enxergarão e se relacionarão com o mundo. Sendo assim, o que é considerado como sendo científico, pelo coletivo de pensamento dos cientistas, é resultado das práticas e da tradição específica desse coletivo. Essa visão não é uma peculiaridade individual, mas coletiva, baseada na educação e em um treinamento específicos, os quais irão inserir os indivíduos na tradição histórica de práticas do coletivo, é essa visão que caracterizará o seu estilo de pensamento e, portanto, a sua linguagem característica. Assim, Fleck explica que a linguagem é uma das características que provoca um certo grau de fechamento do coletivo e, consequentemente, o diferencia dos outros, sendo a comunicação entre os coletivos somente possível na medida da sua similaridade:

Existem pessoas que podem se comunicar entre si, i.e., que pensam de alguma forma similarmente, pertencem, por assim dizer, ao mesmo coletivo de pensamento, e existem pessoas que são completamente incapazes de se compreender mutuamente, como se elas pertencessem a diferentes coletivos de pensamento. Cientistas, filólogos, teólogos ou cabalistas podem perfeitamente se comunicar entre si dentro dos limites dos seus coletivos, mas a comunicação entre um físico e um filólogo é difícil, entre um físico e um teólogo bem difícil, e entre um físico e um cabalista ou místico impossível. (...) Eles iriam conversar um ao lado do outro, mas não um com o outro. (...) O que, para um deles, é importante, até mesmo essencial, para o outro pode ser deixado de lado, sem valor para a discussão. O que é óbvio para um, é um absurdo para outro. O que é verdade (ou "verdade sublime") para um deles, é uma "invenção de base" (ou uma ilusão ingênua) para outro (Fleck, [1936]1986, pp. 81-82, tradução livre).

De acordo com Fleck, mesmo quando existem palavras em comum aos diferentes estilos de pensamento, elas terão significados diferentes para cada um. De tal forma que "é impossível traduzir exatamente os enunciados de um deles para a linguagem do outro" (Fleck, [1936]1986, p. 83, tradução livre). Ao mesmo tempo, toda vez que uma determinada palavra passa por um coletivo de pensamento, ela será interpretada, estilizada 
e modificada, podendo ganhar novos significados, sempre visando à adaptação a linguagem daquele coletivo.

Dessa forma, conclui-se que, na concepção fleckiana, não existe uma fronteira bem definida e rígida entre a ciência e a não-ciência. Existem apenas características que o coletivo de pensamento científico possui, preza e busca para si: ele se diferencia dos outros pelos seus valores, suas tradições, práticas e a exigência da máxima coerção do pensamento, própria do seu estilo de pensamento.

\subsection{Um olhar fleckiano sobre a presente pesquisa}

A perspectiva fleckiana também pode ser utilizada para entender a própria construção e elaboração da presente pesquisa. Os pesquisadores em EC e a área de pesquisa que eles formam podem ser entendidos como um coletivo e um estilo de pensamento, respectivamente, conforme observado por Martins (2016). Assim, o coletivo de pensamento de pesquisadores em EC possui uma forma própria de enxergar, compreender e direcionar os problemas que lhes compete, para atingir seus objetivos, ou seja, esse coletivo possui um estilo de pensamento que lhe é próprio. Portanto, pode-se dizer que a escolha do presente problema de pesquisa foi, de certa forma, condicionada historicamente pela maneira com que esse coletivo enxerga os seus objetos de pesquisa, assim como essa mesma pesquisa, em alguma medida, de forma retroativa, condicionará a maneira como outros pesquisadores enxergarão as pesquisas futuras relacionadas a esta. Vale ressaltar, também, que o objeto dessa pesquisa não é um objeto estático, já existente previamente no mundo, mas foi construído e possível de ser elaborado, somente através da visão de mundo proporcionada pelo estilo de pensamento da área em que está inserido. Sendo assim, em uma perspectiva fleckiana, o sujeito, o coletivo de pensamento e o objeto de estudo se complementam, em uma relação de influências e condicionamentos mútuos, não possuindo, portanto, realidades autônomas.

Considerando esses aspectos, a presente pesquisa se baseará na abordagem feita por Fleck em seu livro "Gênese e desenvolvimento de um fato científico". Primeiramente, será feita uma revisão histórica mais ampla da gênese do fenômeno cultural do misticismo quântico, partindo da época da construção da TQ, passando pelos debates sobre os seus fundamentos e pelos argumentos de seus fundadores, até o estabelecimento das relações dessa teoria com o misticismo oriental. A partir desse estudo, se buscará caracterizar o 
coletivo de pensamento dos físicos que trabalham em Fundamentos da FQ e mapear as principais protoideias que podem estar relacionadas à origem do fenômeno cultural do misticismo quântico. Em seguida, será feita a análise do desenvolvimento da relação entre FQ e misticismo, através do estudo da vida e da obra dos principais percursores do misticismo quântico e de como eles utilizam a FQ em seu discurso, a fim de caracterizar esse novo coletivo de pensamento e suas principais diferenças com relação ao coletivo de pensamento dos físicos que trabalham com Fundamentos da FQ. Finalmente, será feita a análise epistemológica da gênese e do desenvolvimento da relação entre FQ e misticismo, através do olhar fleckiano, a fim de explicitar em que medida o misticismo quântico foi condicionado histórica, sócio e culturalmente e tornar clara a sua estrutura coletiva, bem como a sua relação de influências mútuas com o meio sociocultural, caracterizando um verdadeiro estilo de pensamento.

Da perspectiva de Fleck, seria possível encontrar influências históricas no fenômeno cultural do misticismo quântico, mesmo antes do período de formulação da FQ, uma vez que um fenômeno como esse não possuiria um começo exato ou distinguível, talvez apenas um momento de início mais proeminente. No entanto, a presente análise ficará restrita a esse período, a fim de detalhá-lo melhor, apenas citando e localizando brevemente as possíveis influências ocorridas anteriormente a ele.

Por fim, é interessante notar que, aparentemente, as mudanças ocorridas na Física nas primeiras décadas de século $\mathrm{XX}$, com o advento da FQ, de alguma forma influenciaram Fleck na sua reflexão epistemológica (Carneiro, 2012, pp. 39-40). Isso fica evidente quando o filósofo polonês analisa a seguinte referência de Niels Bohr ao "postulado quântico", em seu artigo intitulado "Sobre a crise da realidade" (Fleck, [1929]1986, p. 53):

O postulado quântico significa que toda observação dos fenômenos quânticos constituem uma interação não-negligenciável com o instrumento de medição, e que nenhuma realidade física independente em seu sentido ordinário pode ser atribuída ao fenômeno ou aos meios de observação. De modo geral, o conceito de observação possui um elemento de arbitrariedade, no qual ele essencialmente depende de quais objetos devem ser incluídos no sistema que está sendo observado (Bohr, Naturwiss, 1928, n. 15, tradução livre). 
Ao fazer referência a essa citação de Bohr, Fleck defende que, em princípio, ela se aplicaria a todas as observações, de qualquer fenômeno, mas que essa relação mútua é na maioria das vezes negligenciável. Porém, em seguida, ele questiona:

E se o 'tratamento' dos fenômenos, com quaisquer que sejam os instrumentos, se prolongasse ao longo de séculos, o efeito não se tornaria significante? Observar, conhecer é sempre experimentar e, portanto, literalmente modificar o objeto de investigação (Fleck, [1929]1986, p. 53, tradução livre, grifos do autor).

Nessa passagem, contudo, Fleck não se refere às interações puramente físicas entre observadores e instrumentos de medição, mas sim às interações entre os estilos de pensamento (histórica e socialmente situados) e os seus objetos de estudo. Assim, indo muito além das intenções originais de Bohr, Fleck se inspira na interpretação bohriana dos fenômenos quânticos para reafirmar as suas próprias concepções acerca do desenvolvimento do conhecimento (Carneiro, 2012, p. 40), dando destaque ao papel da história na mudança de visão dos pesquisadores, na escolha dos seus problemas de pesquisa e na forma de abordá-los, assim como no papel recíproco destes na mudança na ciência e na própria "realidade" resultante dessa visão de mundo. Realidade esta entendida por Fleck como sendo uma realidade epistemológica, manifestada pela sua concepção da ideia de "crise", que nesse texto se refere a uma crise na "concepção ideal oficial" da ciência moderna (Carneiro, 2012, p. 41). Assim, para ser coerente com sua própria epistemologia, Fleck enxerga a emergente FQ apenas como um novo estilo de pensamento, fruto da história e passível de mudança, e de forma alguma um conhecimento final acerca de uma "realidade absoluta".

Essa leitura de Fleck acerca das mudanças que estavam ocorrendo na Física no início do século XX, além de ressaltar a sua concepção epistemológica, também chama a atenção para o potencial inspirador que o advento da FQ traz consigo, possibilitando, o surgimento de novas concepções, não somente com relação à Física, mas também com relação ao ato de observação, ao conhecimento e à realidade. Essas reflexões possibilitarão o surgimento de novos estilos de pensamento, através da sua circulação pelos diferentes coletivos de pensamento. É exatamente esse potencial e suas consequências históricas e sociais, que serão explorados nos próximos capítulos. 


\section{A gênese da relação histórico-social entre Física Quântica e misticismo}

\subsection{Breve resumo histórico da gênese e do desenvolvimento da Física Quântica e dos debates sobre os seus fundamentos}

A história da FQ, ao mesmo tempo em que possui episódios bem conhecidos e retratados por historiadores, também é permeada por diversos debates, influências e controvérsias que ainda merecem um olhar mais aprofundado. Nesta seção, não se pretende esmiuçar todos esses debates e controvérsias, mas apenas fazer um breve resumo do que se conhece acerca da gênese e do desenvolvimento da FQ e dos principais debates sobre os seus fundamentos. Esse breve resumo histórico se inicia com uma discussão acerca da concepção da maioria dos físicos no final do século XIX sobre o futuro das pesquisas em Física e com uma problematização da difundida história de que, nessa época, se acreditava que a Física estava praticamente acabada. Em seguida, se passará pelos principais episódios do desenvolvimento da FQ, desde as suas origens nos anos 1900 até meados dos anos 1980. Nas seções seguintes deste capítulo, se aprofundará um pouco mais nas questões filosóficas envolvidas nos debates ao longo do desenvolvimento dessa teoria e em algumas das suas diferentes interpretações, além de alguns contextos histórico-sociais específicos ao longo dessa história, que posteriormente, poderiam ter influenciado no estabelecimento da relação entre a FQ e o misticismo.

Para retratar brevemente a história da FQ, a mesma será separada em três estágios de elaboração, conforme Paty (2005), que toma como critério a forma como se dá a relação entre a interpretação física e a inteligibilidade dos fenômenos quânticos, em cada um desses estágios: no primeiro deles (de 1900 a 1916), a FQ foi constituída como um novo domínio para os fenômenos e sistemas físicos, mostrando a sua especificidade e correspondência a um campo do conhecimento próprio. Segundo o autor, esse período é caracterizado pela exploração, por um confronto entre a teoria clássica vigente naquele momento e os dados experimentais. Ele é marcado pelos modelos "semi-clássicos" dos fenômenos quânticos e se estende até o final de 1916, quando a primeira teoria "semiclássica" para o domínio quântico foi proposta por Einstein. Já o segundo período se estende dessa primeira teoria, em 1917, ao final do ano de 1926, quando se estabelece a 
Mecânica Quântica (MQ), propriamente dita. Esse período é marcado pela elaboração de ideias, conceitos e esquemas mais precisos do ponto de vista teórico e mais abrangentes do ponto de vista experimental. No entanto, o desenvolvimento da teoria nesse período se mostrou eficiente e poderoso com relação à formalização matemática, por um lado, mas com uma descrição física correspondente a essa formalização não muito clara, por outro. Por fim, o terceiro período se inicia em 1927, durando até os dias atuais, ele é caracterizado pelas tentativas de interpretar conceitualmente a estrutura teórica da MQ e pelos desenvolvimentos teóricos com relação à dinâmica dos processos quânticos. De acordo com Paty (2005), nesse período, a interpretação desejável não era expressa somente em termos de um novo conteúdo físico para as entidades matemáticas, como nas teorias físicas precedentes na história, mas ela lidava também com pressupostos e questões filosóficas relacionadas ao conhecimento científico, como, por exemplo, o status da observação com relação ao conhecimento e a realidade, a distinção entre sujeito e objeto, a causalidade e o determinismo.

\subsubsection{A Física no final do século XIX}

Quando se fala do estado da Física no final do século XIX, é comum se evocar a difundida ideia de que, devido ao grande sucesso da Mecânica Newtoniana em resolver os seus problemas, ela era considerada acabada e que era apenas uma questão de tempo resolver os problemas que ainda estavam em aberto (Badash, 1972). Dentro dessa concepção, a Física nessa época já estaria bem consolidada, firmemente construída sobre a visão de mundo mecanicista e determinista, de tal forma que os físicos estariam completamente despreparados para os adventos nos anos posteriores, como a descoberta dos raios-X, do elétron e da radioatividade e, especialmente, das verdadeiras revoluções provenientes do postulado do quantum de ação de Planck, em 1900 e da teoria da relatividade de Einstein, em 1905 (Kragh, 1999).

No entanto, o historiador dinamarquês Helge Kragh (1999) problematiza essa concepção, argumentando que, apesar de alguns físicos terem expressado esse sentimento explicitamente - como o experimentalista estadunidense Albert Michelson, que, em 1894, afirmou que "aparentemente, grande parte dos princípios fundamentais está firmemente estabelecida e os avanços futuros serão resolvidos principalmente pela rigorosa aplicação desses princípios para todos os fenômenos que vierem a ser descobertos" (Badash, 1972, 
p. 52, tradução livre) - é questionável o quanto esse sentimento estava difundido entre os físicos. Segundo ele, poucos físicos teóricos dos anos 1890 parecem ter aceitado a concepção de Michelson e, após as descobertas de Röntgen, Becquerel, Thomson e os Curies, até mesmo os físicos experimentais mais conservadores tiveram que reconhecer as suas limitações.

Kragh (1999) aponta também a ingenuidade de se pensar que a Mecânica Newtoniana permaneceu por cerca de cem anos como uma ortodoxia completamente aceita, argumentando, inclusive, que não havia nem mesmo uma visão de mundo comum a toda comunidade de físicos. Segundo o autor, a tendência não mecanicista mais importante era baseada na teoria eletromagnética, em especial, as baseadas na ideia da existência de um meio através do qual as forças se propagariam a uma velocidade finita: o éter. Algumas dessas teorias eram mais ambiciosas, e buscavam explicar o mundo somente com base nas estruturas e na dinâmica desse substrato, eram uma espécie de "teorias de tudo". Além dessas teorias, no último quarto deste século, também havia algumas tentativas de explicar ou revisar a lei da Gravitação de Newton, algumas delas eram baseadas em modelos da eletrodinâmica e outras em modelos da hidrodinâmica. Por fim, outra importante vertente que competia com a mecânica era a termodinâmica. Nessa época, se argumentava que essa área da Física não só era diferente da mecânica, em princípio, mas, inclusive, era superior a ela, se constituindo um fundamento mais satisfatório a partir do qual toda a Física poderia ser construída. De fato, a lei da conservação da energia era bem explicada em termos mecânicos, porém a segunda lei, por tratar de processos irreversíveis e assimétricos no tempo, fugiria do escopo das leis da mecânica.

De acordo com Kragh (1999, p. 7), nos anos 1890, havia uma discussão recorrente sobre a unidade da Física, a qual os físicos acreditavam deveria ser buscada, e não era evidente qual disciplina melhor serviria como fundamento para a sua construção. Assim, surgiram alguns programas de pesquisa que concorriam com a mecânica, como o programa na área da termodinâmica denominado "energicismo" ou "energeticismo" desenvolvido pelos alemães Georg Helm e Wilhelm Ostwald. Esse programa partia do princípio de que a energia era o conceito unificador mais importante e se considerava uma revolta contra o que eles chamavam de "materialismo científico", negavam o atomismo, além de outras representações mentais que consideravam como metafísicas e não tinham 
utilidade para explicar os fenômenos empíricos. Outros físicos de postura positivista, apesar de não estarem diretamente ligados ao programa energético, também criticavam as teorias e descrições da mecânica, em favor de uma descrição mais fenomenalista, como Pierre Curie, Ernst Mach e Heinrich Hertz. Outro programa que exerceu bastante influência, nos anos 1890, era aquele que investigava a relação entre o éter e a matéria, de fato, a ideia de que o éter era o substrato fundamental a partir do qual a matéria era constituída havia se tornado comum. Então, passou-se a buscar derivar as leis da mecânica, a partir das do eletromagnetismo. Em ambos os programas, o materialismo era descartado e se argumentava que a matéria era um epifenômeno. Contudo, além das tendências positivistas, também havia físicos com tendências mais idealistas, como o físico teórico britânico Joseph Larmor (1900), que imaginava um mundo baseado em um éter não material, transcendental e argumentava que esse substrato descrevia uma realidade oculta, não acessível diretamente aos sentidos. Para Kragh (1999, p. 10), essas tendências na Física teórica no final do século XIX eram mais do que o resultado de novas descobertas, mas refletiam uma mudança cultural na visão de mundo mais ampla, externa à Física, que marcou a época, um espírito muitas vezes classificado como neorromântico, caracterizado por um anti-materialismo generalizado.

Sendo assim, a partir da constatação da existência de diversas críticas e programas de pesquisa concorrentes à mecânica, no final do século XIX, Kragh (1999) defende que a nova Física, que surgiria no início do século XX, não surgiu em um contexto de uma visão de mundo newtoniana bem estabelecida e marcada somente por sucessos, mas que, por volta de 1905, essa visão mecanicista já estava sob ataque há mais de uma década.

\subsubsection{O início da Física Quântica: de 1900 a 1916}

O primeiro estágio da história da FQ, também conhecido como o período de elaboração da "Velha Teoria Quântica" (VTQ) (Jammer, 1966), tem seu início bem conhecido, no contexto da termodinâmica, nos estudos do famoso problema da "radiação de corpo negro", na década de 1890. Nesse problema, um corpo negro perfeito seria aquele que absorve toda a radiação que incide sobre ele, dessa forma, esse problema se refere às investigações do espectro de emissão de radiação eletromagnética de corpos aquecidos e despertava especial interesse por seu caráter generalizante, uma vez que o espectro possui o mesmo formato, independentemente do material que compõe o corpo 
irradiante, dependendo apenas da sua temperatura (Jammer, 1966). Além disso, esse problema também despertava um interesse, em especial, por parte da Alemanha, que ia além dos interesses acadêmicos, pois se pensava que isso traria um conhecimento que poderia ser útil para a iluminação e o aquecimento das indústrias (Kragh, 1999, p. 58).

O primeiro importante desenvolvimento teórico sobre esse problema foi a chamada "lei de deslocamento de Wien" (1894), seguida da "lei de radiação de Wien" (1896), as quais estabeleciam uma relação que definia a forma do espectro de radiação dentro de uma cavidade à uma determinada temperatura (corpo negro), e demonstravam, respectivamente, que a frequência máxima desse espectro é proporcional à temperatura do corpo negro e que as moléculas irradiadoras tinham velocidades que obedeciam a distribuição de Maxwell-Boltzmann. A comprovação experimental dessas leis foi feita por Paschen e Wanner, entre 1897 e 1899, para a luz no visível e para temperaturas de até $4000^{\circ} \mathrm{C}$. Então, entre 1898 e 1899, Max Planck desenvolveu uma derivação mais rigorosa da "lei de radiação de Wien", através da suposição de que a radiação de uma determinada frequência era gerada por osciladores harmônicos lineares oscilando na mesma frequência, e enquadrou essa lei no esquema explicativo da termodinâmica (Jammer, 1966). Planck era um especialista em termodinâmica e estava interessado na segunda lei e nas suas aplicações na Física e na Química. No início dos anos 1890, sua principal preocupação não era a física teórica, mas a termodinâmica química, para a qual ele procurava fornecer fundamentos mais rigorosos baseados na segunda lei. Planck acreditava firmemente na absoluta validade desta lei e não admitia que houvesse qualquer relação entre entropia e probabilidade. Seu programa de pesquisa era uma tentativa de explicar os processos irreversíveis com base estritamente na termodinâmica, sem introduzir qualquer hipótese estatística ou atomística, como nas hipóteses de seu colega Boltzmann (Kragh, 1999, p. $59)$.

No entanto, após a derivação de Planck para a "lei de radiação de Wien", entre 1899 e 1900, Lummer \& Pringsheim mediram desvios sistemáticos dessa lei para frequências mais baixas, na faixa do infravermelho. E, em junho de 1900, Lord Rayleigh mostrou uma derivação do espectro de radiação, a partir da aplicação do teorema de equipartição de energia às vibrações eletromagnéticas em uma cavidade, que posteriormente foi comprovado experimentalmente por Rubens \& Kurlbaum, para baixas frequências e altas 
temperaturas. Então, Planck foi obrigado a reelaborar a sua formulação anterior. Primeiramente, em uma reunião da Sociedade Alemã de Física, em 19 de outubro de 1900, ele apresentou uma interpolação entre as duas leis de radiação, para altas e baixas frequências e, em 14 de dezembro de 1900, em outra reunião da mesma sociedade, apresentou uma nova derivação para a lei de radiação, que partia de uma expressão para a entropia e supunha que a energia total do sistema é um múltiplo inteiro de "elementos de energia" $(E=h v)$. Em pouco tempo, essa expressão foi comprovada experimentalmente por Lummer \& Pringsheim e a "constante universal $h$ ", a partir da qual os elementos de energia eram múltiplos, pôde ser calculada. Assim, a nova expressão ficou conhecida como "lei de radiação de Planck" e esse trabalho já indicava que a emissão e a absorção de radiação por parte de osciladores se dava em "quanta" discretos de energia (Pessoa, 2010).

No entanto, em sua nova derivação da lei de radiação de dezembro de 1900, Planck não via a introdução de elementos de energia como significando a quantização da mesma, ou seja, que os osciladores poderiam ter somente valores discretos de energia. Ele considerava que a expressão $E=h v$ era apenas uma hipótese matemática sem significado físico por trás e acreditava que essa hipótese era temporária e que deveria ser removida na formulação final da teoria. O que importava para ele, nessa ocasião, era a surpreendente precisão da nova lei de radiação, confirmada mais tarde por vários experimentos (Kragh, 1999, p. 62).

Pouca atenção foi dada à introdução de $h$ até 1905. Nesse período, houve praticamente um completo silêncio sobre a hipótese dos quanta, apenas alguns poucos teóricos acreditavam que valia a pena entrar nos detalhes dos cálculos de Planck e se questionar sobre as causas da sua formulação estar correta. Um deles foi Hendrik A. Lorentz, que começou a trabalhar na teoria do corpo negro em 1903, e foi através dos seus estudos que a famosa "catástrofe do ultravioleta" da lei clássica de Rayleigh-Jeans ficou conhecida na comunidade de físicos. Com o sucesso das teorias microscópicas e dos elétrons, se acreditava que essas teorias seriam, de alguma forma, capazes de resolver os problemas da radiação de corpo negro. Por um tempo, Planck investiu na ideia de que a quantização da carga elétrica estava relacionada com a quantização da energia, no entanto, nenhuma tentativa de deduzir o quantum de ação dessa ideia ou de qualquer outra teoria pré- 
existente foi efetiva. Por mais de uma década, Planck acreditou que a sua lei da radiação poderia ser reconciliada com a mecânica clássica e a eletrodinâmica, ele sabia que havia uma espécie de quantização envolvida, mas não acreditava que ela se referia à energia de osciladores individuais, mas sim ao valor da energia total dos osciladores. Somente em 1908, ele se converte à ideia de que o quantum de ação era um fenômeno que não poderia ser entendido no âmbito da física clássica (Kragh, 1999, pp. 63-64).

Ao contrário de Planck, que se tornou revolucionário contra a sua vontade, Einstein reconheceu as implicações revolucionárias da hipótese dos quanta. E, em seu artigo de 1905, sobre o efeito fotoelétrico, supôs que a radiação possuía uma estrutura atômica discreta, uma hipótese que ia muito além daquela sugerida por Planck. Supôs também que a energia dos osciladores de emissão e absorção da luz só poderia ocorrer discretamente, com energias múltiplas de $h v$. Einstein era consciente da radicalidade de suas ideias, mas estava convencido da realidade dos quanta de luz (que mais tarde ganhariam o nome de fótons), e procurou demonstrar empiricamente a sua hipótese, através da previsão da relação entre $E$ e $v$ no efeito fotoelétrico. Assim, sua teoria não foi uma resposta a alguma anomalia, pois, por volta de 1905, o efeito fotoelétrico não era considerado problemático. Sua hipótese foi confirmada experimentalmente por Millikan somente em 1916, porém, inicialmente, teóricos e experimentais não aceitaram essa confirmação como uma evidência da hipótese de Einstein, mas apenas da sua equação. Por conta disso, esse trabalho de Einstein ganhou visibilidade apenas após a Primeira Guerra Mundial (Kragh, 1999, pp. 66-67; Pessoa, 2006a).

No fim da primeira década do século XX, a TQ ainda não era bem compreendida e era estudada seriamente somente por poucos físicos teóricos. Até 1906, Einstein era o único que procurava a natureza não-clássica da teoria de Planck, somente quatro anos mais tarde, os especialistas passaram a reconhecer a quantização da energia como algo real, que necessitava de um rompimento com a física clássica. Nessa época, os trabalhos em TQ passam a crescer consideravelmente (Kragh, 1999, p. 65).

A partir de então, o princípio de quantização de Planck passa a ser utilizado para explicar diferentes fenômenos. O primeiro deles, fora da área de radiação do corpo negro, foi a explicação de Einstein para o comportamento dos calores específicos de sólidos a baixas temperaturas. Desde 1876, já se conhecia que, para baixas temperaturas, havia 
desvios da Lei de Dulong-Petit, que relacionava a massa atômica de alguns elementos sólidos com o seu calor específico. Assim, em 1907, Einstein supôs que os átomos dos sólidos vibram independentemente com a mesma frequência e que a sua energia média é quantizada. Posteriormente, em 1912, essa abordagem foi aperfeiçoada por Peter Debye, que considerou os modos coletivos de vibração dos átomos dos sólidos. Esse problema contribuiu para trazer a TQ para áreas mais tradicionais da Física e torná-la conhecida entre os físicos que não estavam interessados ou não compreendiam o problema da radiação de corpo negro e, em 1913, havia mais publicações relacionados aos calores específicos dos sólidos do que a teoria da radiação de corpo negro. Dessa forma, a TQ passou a ser considerada mais seriamente por um número crescente de físicos (Kragh, 1999, pp. 69-70).

Posteriormente, a derivação da lei de radiação de Planck também teve que ser revista, pois, em 1906, Einstein mostrou que ela era inconsistente, pois era obtida a partir da teoria eletromagnética clássica, que pressupõe que os osciladores possuem uma energia que varia continuamente, ao mesmo tempo em que sua derivação se baseava em um tratamento estatístico que supunha energias discretas. Esse problema foi apresentado por Einstein em 1909, na conferência da Associação Alemã de Cientistas. Assim, Planck passou a tentar reformular novamente a sua derivação e o assunto passou a ser amplamente discutido em 1911, no $1^{\circ}$ Congresso de Solvay, na Bélgica (Pessoa, 2010). Solvay era um industrial e filantrópico belga, que conquistou sua fortuna ao inventar um novo método de produção de soda, ele possuía um grande interesse, ainda que de forma amadora, por física teórica. Esse interesse resultou na primeira de uma série de conferências sobre a problemática relação entre TQ, Teoria Cinética dos Gases e a Teoria da Radiação. Por mais de duas décadas, as Conferências de Solvay foram os encontros de maior prestígio científico entre os físicos. A $1^{\text {a }}$ Conferência de Solvay não resultou em novos insights importantes, mas as discussões ajudaram a estabelecer um entendimento comum sobre quais eram os problemas-chaves da TQ. Concordou-se que os enigmas do mundo quântico estavam longe de serem resolvidos e que o status da TQ permanecia insatisfatório (Kragh, 1999, pp. 70-72).

Apesar de todas essas discussões, a conversão maciça da comunidade científica em favor da TQ só aconteceu com o uso desta na elaboração do modelo atômico de Bohr e o 
seu sucesso em explicar as linhas espectrais emitidas pelo átomo de hidrogênio (Pessoa, 2006a). Bohr originalmente não estava interessado em teoria atômica, sua tese de doutorado havia sido em teoria dos elétrons nos metais, em 1911, na qual ele manifestou a sua opinião de que essa teoria era insatisfatória em seus detalhes e princípios. Para ele, forças de natureza completamente distintas das forças mecânicas usuais deveriam ser introduzidas para colocar a teoria dos metais em acordo com a estrutura interna dos átomos (Kragh, 1999, p. 53).

O modelo de Bohr se baseava na descoberta de 1910 de Rutherford \& Geiger que, através de experimentos de espalhamento, concluíram que o átomo possuía um núcleo duro. Nessa época, o modelo atômico mais aceito era o modelo de J.J. Thomson, do "bolo de ameixas". No entanto, Bohr discordava desse modelo, assim, entre 1911 e 1912, passou o ano acadêmico na Inglaterra, primeiro com Thomson em Cambridge e depois com Rutherford em Manchester, se debruçando sobre o modelo atômico de Rutherford, o qual lhe despertava bastante interesse. Em 1912, Bohr escreve o "Manchester memorandum", no qual ele comunica suas ideias a Rutherford. Nesse documento, ele sugere que o átomo seria estável mecanicamente se a energia cinética dos elétrons nas órbitas fossem obrigadas a serem proporcionais às suas frequências de rotação. Nessa ocasião, Bohr estava preocupado com a estabilidade mecânica do átomo, não com a eletrodinâmica. Em 1913, Bohr é questionado por um colega em Copenhagen sobre como as suas ideias se relacionavam com a fórmula de Balmer das linhas do átomo de $\mathrm{H}$, assunto sobre o qual surpreendentemente Bohr nunca havia pensado. No mesmo ano, Bohr publica seu famoso artigo "On the Constitution of atoms and molecules", no qual ele introduz a noção de estados estacionários, onde a mecânica é válida e a eletrodinâmica não, e assume que radiação é emitida ou absorvida quando o átomo passa entre os diferentes estados estacionários. Inspirado em Planck, Bohr também assume que a frequência da luz não se relaciona diretamente com as frequências dos elétrons orbitando, mas com a diferença de energia entre dois estados estacionários. A partir dessa simples premissa, Bohr conseguiu deduzir a fórmula de Balmer para as frequências do espectro de $\mathrm{H}$. A teoria de Bohr não era uma simples teoria de átomos de um único elétron, mas pretendia ser mais ambiciosa: Bohr aplicou sua teoria para átomos maiores que o $\mathrm{H}$ e para moléculas e acreditava que seus modelos poderiam fornecer uma explicação para a tabela periódica. Essa parte de sua teoria causou menos impacto, mas foi a $1^{\mathrm{a}}$ vez que modelos atômicos foram propostos 
para átomos reais. A força da teoria de Bohr se devia menos aos seus fundamentos teóricos, mas mais à sua confirmação experimental sobre uma ampla gama de fenômenos. O modelo de Bohr precisou ser estendido para explicar alguns fenômenos que não estavam contemplados, como a estrutura dupla da linha vermelha do espectro de H. Essa extensão foi feita por Sommerfeld em Munich, quem, entre 1915 e 1916, introduziu a relatividade especial na mecânica do átomo de Bohr. A concordância com os dados experimentais foi considerada uma confirmação do modelo de Bohr-Sommerfeld e também da relatividade (Kragh, 1999, pp. 54-57).

Finalmente, o primeiro estágio da breve História da FQ termina com a completa derivação da lei de radiação de Planck, em 1916, por Einstein. Essa derivação detalhava o balanceamento dos coeficientes de absorção e emissão induzida e espontânea da radiação, e pode ser considerada a primeira teoria sintética e semi-clássica dos quanta. Para realizála, Einstein partiu do quantum de ação de Planck e da formulação de Bohr para os níveis discretos dos átomos, com as frequências dos seus estados relativos, o que forneceu a probabilidade de transição por unidade de tempo entre dois estados. Dessa forma, expressando a condição para o equilíbrio termodinâmico, a uma dada temperatura, entre a radiação e a distribuição de estados moleculares, Einstein obteve como resultado a lei de radiação de Planck e a relação de frequências da radiação de transição do átomo de Bohr. O passo seguinte foi admitir que a radiação, que já possuía uma energia discreta, também era dotada de um momento discreto, o que proporcionava o completo caráter corpuscular da luz, ao mesmo tempo em que mantinha o seu caráter ondulatório. Isso o obrigou a admitir o comportamento dualista de onda-partícula para a radiação eletromagnética, dessa forma, o momento de radiação foi justificado pelo resultado obtido. Com isso, todas as características quânticas conhecidas até aquele momento haviam sido integradas em um esquema teórico consistente, que permitia obter as probabilidades de transição por unidade de tempo da emissão e da absorção da radiação eletromagnética, para uma dada energia, como função das amplitudes de transição dos estados atômicos. A deficiência, contudo, da relativa consistência dessa teoria era que as amplitudes de transição tinham que ser dadas empiricamente e que somente o acaso, através da distribuição estatística, daria a direção da radiação emitida (Paty, 2005). Ao perceber essa deficiência, Einstein chegou a mencionar que uma transição espontânea poderia ocorrer "sem excitação por 
parte de uma causa externa", o que levou Bohr a interpretá-las como sendo "acausais" (Pessoa, 2010).

Assim, podemos resumir esse início da História da Física Quântica como consistindo da exploração dos novos fenômenos que se apresentaram e da elaboração de conceitos que rompem com os anteriores, de tal forma que a teoria clássica já não era mais suficiente para explicar os novos elementos do conhecimento. Nesse período, o domínio quântico se constitui como tal e mostra a sua especificidade, na qual o seu campo de conhecimento se apresenta como irredutível às teorias prévias. Contudo, pode-se dizer que, nele, um novo conhecimento foi adquirido, porém não completamente compreendido, ou seja, esse conhecimento foi identificado como algo radicalmente novo, mas uma completa e profunda compreensão não estava disponível. Pois o conteúdo físico correspondente aos resultados obtidos experimentalmente não estava inserido em uma teoria completa e compreensível (Paty, 2005).

\subsubsection{O caminho para a elaboração da Mecânica Quântica: de 1917 a 1926}

A partir da aceitação da TQ por parte da comunidade científica, após a Primeira Guerra Mundial, entre os anos de 1919 a 1925, passaram a ser realizadas diversas pesquisas que levaram à MQ. Pode-se dizer que essas pesquisas foram guiadas principalmente pelo Princípio da Correspondência (Van der Waerden, 1967), introduzido por Bohr em 1918, para designar a correspondência que as previsões da FQ deveriam ter com a Física Clássica no limite de baixas frequências e números quânticos principais grandes. De fato, em 1913, Bohr já tinha consciência de que sua teoria atômica era apenas o inicio de um programa de pesquisa que iria levar para um território desconhecido. Bohr percebeu que sua teoria era incompleta, no sentido de que ela previa as frequências, mas não tinha nada a dizer sobre intensidades e polarizações dos espectros. Isso era uma deficiência séria, pois para comparar os espectros previstos teoricamente, com os obtidos experimentalmente, as intensidades deveriam ser conhecidas. Então, em 1918, Bohr elabora um importante memorial, no qual introduz o seu Princípio da Correspondência, o qual se tornaria a marca do início da sua escola em TQ. Conforme o entendimento de Bohr em torno de 1920, a essência desse princípio era: no limite de números quânticos grandes, as transições entre os diferentes estados estacionários não são muito diferentes das iniciais, o que resultará em frequências praticamente idênticas às esperadas 
classicamente, pela eletrodinâmica de Maxwell. Além disso, se alguma componente harmônica é zero, então a probabilidade de transição para aquele estado também será zero, ou seja, essa transição será "proibida". O Princípio da Correspondência foi principalmente uma invenção de Bohr, sendo, portanto, recebido com ceticismo na Alemanha, onde os princípios mais formais de Sommerfeld e seus procedimentos dedutivos eram vistos como mais promissores. Para Sommerfeld, o Princípio da Correspondência possuía um caráter "mágico", conforme ele escreve na primeira edição de sua obra Atombau (Kragh, 1999, pp. 156-157).

Por volta de 1920, o modelo atômico de Bohr-Sommerfeld, que havia tido grande aceitação por conta da sua concordância com os dados experimentais, começa a mostrar as suas limitações: para cada sucesso desse modelo, havia uma falha ou anomalia. Por um lado, o átomo de $\mathrm{H}$ era explicado de forma brilhante, porém, já com o próximo átomo mais simples (He), esse modelo apresentava problemas. Em 1923, Born e Heisenberg fizeram uma análise detalhada do átomo de He e concluíram que o espectro derivado da teoria diferia do observado experimentalmente, o que foi considerado por eles uma "catástrofe" (Darrigol, 1992, p. 177). Assim, por volta de 1924, havia um sentimento de crise na Física, que foi acompanhado do rompimento com procedimentos e metodologias tradicionais (Hentschel, 2009, p. 614). O acúmulo de anomalias, junto com a insatisfação generalizada com a estrutura conceitual e lógica da TQ existente, fez com que muitos físicos concluíssem que a teoria de Bohr-Sommerfeld estava irremediavelmente errada e devia ser substituída por outra. Por outro lado, devido ao seu sucesso anterior, havia um sentimento de que dificilmente ela estaria completamente errada e esperava-se que a nova TQ estaria relacionada com a antiga de forma análoga a um "Princípio da Correspondência" (Kragh, 1999, p. 159).

Esse era o contexto de transição entre a VTQ e a MQ propriamente dita. Até então, a VTQ havia sido cultivada em basicamente três centros de pesquisa: em Munique, onde Sommerfeld estabeleceu sua escola de grande importância; em Göttingen, por Born, que começou a pesquisar sobre a teoria atômica relativamente tarde, somente em 1921, quando se tornou professor; e em Copenhagen, com Bohr, que se tornou a força dominante nessa fase inicial da teoria atômica. O "Instituto de Bohr", como era chamado, foi fundado em 1921 e atraiu um grande número de visitantes de todo o mundo. Antes e 
depois da MQ, o Instituto de Bohr era reconhecido como sendo o grande centro da teoria atômica (Kragh, 1999, p. 159).

Assim, o caminho para a MQ se deu através da teoria da radiação, e se desenvolveu em duas linhas independentes: a Mecânica Matricial e a Mecânica Ondulatória. A linha de pesquisa da Mecânica Matricial foi levada adiante principalmente pelos jovens Werner Heisenberg e Wolfgang Pauli, que interagiam com os professores Max Born, Niels Bohr e Hendrik Kramers. A atitude adotada por essa abordagem era uma atitude positivista (ou “operacionalista”), a qual se recusava a falar de grandezas não-observáveis. Assim, não se prezava por um caráter "visual" dos modelos, mas se buscava uma descrição matemática que descrevia adequadamente os dados experimentais, através da manipulação de símbolos. A Mecânica Ondulatória, por outro lado, foi desenvolvida principalmente pelo austríaco Erwin Schrödinger, quem seguia uma abordagem realista, pois se prendia fortemente a modelos visualizáveis, associados à Física Ondulatória Clássica, e considerava que a teoria descreve adequadamente uma realidade não-observável por trás das aparências (Pessoa, 2006a).

O primeiro passo decisivo para a MQ se dá em 1924, quando Kramers e Heisenberg publicam a sua teoria da dispersão. Com a descoberta por Compton, em 1923, que pulsos monocromáticos de raios-X se comportavam como partículas, o problema da radiação havia se tornado agudo. Essa descoberta gerou preocupações em Copenhagen, onde Bohr ainda resistia firmemente à interpretação dos quanta de luz, ou fótons. Como alternativa, Bohr e Kramers desenvolveram a ideia de John Slater de uma teoria da radiação nãofotônica. A crescente crise na TQ foi discutida por Bohr, Kramers, Heisenberg e Pauli em um encontro em Copenhagen, em março de 1925. Então, alguns meses depois, de volta a Göttingen, Heisenberg encontra uma forma de formular uma MQ abstrata que prometia ser fundamental, logicamente consistente e livre das dificuldades enfrentadas pela teoria de Bohr-Sommerfeld. Heisenberg escreve o seu famoso artigo em setembro de 1925, que, segundo ele, seria "a base de uma MQ teórica fundada exclusivamente nas relações entre quantidades que são em princípio observáveis" (Kragh, 1999, p. 161). Contudo, a formulação de Heisenberg era altamente abstrata e difícil de entender, até mesmo pelo próprio Heisenberg. Então, em Göttingen, Born percebe que a multiplicação nãocomutativa de Heisenberg poderia ser escrita em termos de cálculos com matrizes, onde as 
variáveis quânticas eram representadas por estas. Com a percepção de que o cálculo matricial era perfeito para a MQ, Born estende a teoria de Heisenberg juntamente com o matemático Pascual Jordan e, em novembro de 1925, os três publicam um artigo que estabelece a Mecânica Matricial como uma base firme para a MQ. Paralelamente, muitos dos resultados da teoria de Heisenberg foram obtidos de forma independente por Dirac, na Universidade de Cambridge, porém sem o uso de matrizes. Sua versão algébrica para a MQ também era sofisticada e ficou conhecida como q-álgebra. Assim, em qualquer das duas versões, a MQ era mais impressionante do ponto de vista matemático do que empírico. Porém, por conta da falta de visualidade da nova MQ e do seu formalismo matemático não-usual, muitos físicos foram céticos para com ela. Além disso, por muito tempo, a MQ ficou restrita a reprodução de resultados já conhecidos, sem produzir um único novo fenômeno, o que agravou a falta de aceitação por parte da comunidade (Kragh, 1999, pp. 162-163).

Um dos físicos que não se sentiu atraído pela falta de visualidade da teoria de Heisenberg foi o austríaco Erwin Schrödinger. Schrödinger era professor de física na Universidade de Zurich, não pertencia à tradição Copenhagen-Göttingen-Munich e nunca mostrou interesse na teoria atômica ou em espectroscopia. Ele tinha conhecimento da nova teoria de Heisenberg, mas não era uma teoria que o atraía e nem o inspirava, ao contrário, seus métodos lhe pareciam muito difíceis, com uma álgebra transcendental, difíceis de visualizar. Então, em 1925, ele resolve estudar o trabalho de um físico francês, relativamente desconhecido até então, Louis de Broglie, cuja tese de 1924 sugeriu uma dualidade intrínseca entre matéria e ondas - a dualidade onda-partícula. De Broglie supunha a relação simples, mas especulativa $h v=m c^{2}$, a qual atribuía uma frequência de onda característica a uma partícula de massa m. Com essa proposta, de Broglie propunha uma interpretação ondulatória para a condição de quantização de Sommerfeld. Sua teoria não foi bem recebida e foi ignorada pela maioria dos físicos fora de Paris, pois, nessa época, a física teórica francesa tinha uma baixa reputação entre os físicos atômicos. No entanto, Einstein se interessou pelas ideias de de Broglie, citando-as em um artigo de fevereiro de 1925, e o resultado foi que elas chegaram ao conhecimento e foram assumidas por Schrödinger. Assim, a Mecânica Ondulatória de Schrödinger é publicada em janeiro de 1926, em quatro longos artigos, sob o título comum de "Quantização como um problema de autovalor", onde o físico austríaco introduz sua equação de onda, a qual 
descrevia o comportamento da função de onda $\Psi(\mathrm{r}, \mathrm{t})$ de diferentes formas, nenhuma delas refletindo o caminho original de sua formulação (Kragh, 1999, p. 164). O seu trabalho possuía um formalismo muito simples em termos de cálculos, adquirindo, por conta disso, um enorme sucesso. Além disso, ele tinha um formato mais compreensível em termos visuais, pois descrevia o átomo como possuindo uma onda de elétrons, que se espalhava em torno do núcleo, com uma carga elétrica distribuída de forma contínua no espaço. No entanto, essa interpretação realista apresentava alguns problemas, um deles era que a função de onda $\Psi(\mathrm{r}, \mathrm{t})$, para duas ou mais partículas, teria que ser definida em um espaço de mais de 3 dimensões. Então, em junho de 1926, Max Born apresentou outra interpretação para a função de onda $\Psi(\mathrm{r}, \mathrm{t})$ - a sua famosa interpretação probabilística na qual $\Psi(\mathrm{r}, \mathrm{t})$ não seria um campo que existe na realidade, mas uma função associada à probabilidade de encontrar a partícula em uma determinada posição, a qual seria calculada pelo $|\Psi(\mathrm{r}, \mathrm{t})|^{2}$ (Pessoa, 2006a). Essa interpretação foi rapidamente adotada por outros físicos, ganhando bastante importância. Ela introduziu na microfísica o elemento irredutível de probabilidade, o que implicava uma mudança no significado das leis naturais, porém não implicava que as leis causais não fossem mais fundamentais na Física (Kragh, 1999, p. 166).

A equivalência entre a Mecânica Matricial e a Ondulatória logo seria demonstrada por Schrödinger, no próprio ano de 1926. A mecânica de Schrödinger foi inicialmente recebida com ceticismo e até mesmo hostilidade pelos teóricos de Copenhagen e Göttingen. Eles tendiam a considerar a ênfase nas quantidades clássicas e na visualização um retrocesso. Por outro lado, eles reconheceram a força do sistema de Schrödinger após a prova de equivalência, de tal forma que a maioria deles adotou uma postura pragmática com relação às duas formulações da MQ. Uma teoria de transformação entre os formalismos foi obtida de forma independente por Dirac e Jordan, no final de 1926. Com essa teoria, a MQ havia obtido uma estrutura matemática elegante e as diferenças entre os dois formalismos perderam sua significância. Assim, após a elaboração da prova de equivalência entre a Mecânica Matricial e a Ondulatória, juntamente com a Regra de Born e a formalização do Princípio da Incerteza de Heisenberg, em 1927, o formalismo da TQ não-relativística finalmente foi consolidada (Kragh, 1999, p. 167). 
Dessa forma, nesse segundo estágio da História da FQ, essa teoria manifesta o seu poder teórico e prático, caminhando em uma direção que vai muito além dos seus propósitos puramente físicos. A partir da construção e da exploração do formalismo da FQ, foi possível obter as características mais profundas dos sistemas e fenômenos quânticos, como a dualidade onda-partícula, a indistinguibilidade de estados quânticos idênticos, seu comportamento probabilístico, e o Princípio da Incerteza. Nesse estágio, portanto, a TQ é dotada de uma consistência interna mais completa, na qual essas características são incorporadas, formando a MQ (Paty, 2005). Contudo, as discussões de fundamento sobre como interpretar esse formalismo ainda permanecem em aberto, até os dias de hoje, dando origem às suas diversas interpretações.

\subsubsection{As interpretações do formalismo da Mecânica Quântica: de 1927 em diante}

A MQ se espalhou bem rapidamente de Göttingen e outros centros de pesquisa onde foi construída originalmente. Do verão de 1925 à primavera de 1927, as publicações em MQ explodiram. O clima era de alta competição e, frequentemente, os resultados eram publicados de forma independente por diferentes físicos. Havia pesquisadores que desistiam de publicar em parceria, por medo de repressão de colegas rivais. Nesse jogo de publicação, os físicos alemães e seus aliados em Copenhagen tinham a vantagem do rápido acesso aos resultados publicados e não-publicados. Os americanos, por outro lado, normalmente tinham que esperar um mês a mais para poder ter acesso aos artigos publicados nas revistas alemãs. A MQ também tinha uma particularidade: boa parte dos seus colaboradores tinha um pouco mais de 20 anos de idade. Muitos desses jovens físicos brilhantes sentiam, arrogantemente, que a MQ pertencia a eles e que os físicos mais velhos eram incapazes de dominar a teoria (Kragh, 1999, p. 168).

Comparada com a relatividade, a MQ se desenvolveu e se disseminou muito rapidamente e, praticamente, não encontrou resistência. Porém a MQ atraiu pouco o interesse do grande público. Eddington foi um dos poucos cientistas que escreveu sobre a MQ para o público em geral. O primeiro livro didático dedicado especificamente à MQ parece ter sido o do físico de Cambridge George Birtwistle (1928), mas o livro mais influente e com maior sucesso foi sem dúvida do livro de Dirac, publicado em 1930, apesar de ser altamente abstrato e anti-pedagógico (Kragh, 1999, p. 170). 
Enquanto a VTQ não foi muito cultivada pelos físicos americanos, a nova MQ foi ansiosamente e positivamente recebida pela comunidade de físicos em forte crescimento. Durante a última metade dos anos 1920, os físicos americanos maturaram e subiram para uma posição de liderança no mundo da Física. Uma importante razão para essa rápida e suave recepção da MQ nos Estados Unidos da América (EUA) foram as visitas de jovens físicos americanos às universidades europeias e vice-versa. A última metade dos anos 1920 também foi marcada pelo deslocamento na estrutura interna da Física de um trabalho mais experimental para o teórico. Apesar de nenhum americano ter participado na fase criativa da MQ, eles rapidamente se inseriram no assunto e fizeram importantes contribuições para a fase seguinte. Entre eles, podemos citar Carl Eckart, John Slater, John Van Vleck, David Dennison, Robert Oppenheimer e Linus Pauling. Quando a MQ se consolidou, a física teórica era essencialmente restrita à Europa e América do Norte, somente mais tarde, ela chega ao Japão, onde decolou nos anos 1930, graças ao trabalho do físico japonês Yoshio Nishima, que passou os anos 1920 na Europa, e trabalhou seis anos com Bohr em Copenhagen. Os esforços de Nishima contribuíram na criação de uma forte escola de FQ teórica no Japão, no final dos anos 1930 (Kragh, 1999, pp. 171-172).

Após a publicação da mecânica matricial de Heisenberg, durante os anos seguintes a 1925, a pequena população de físicos quânticos estava ocupada não somente em desenvolver a teoria e aplicá-la a novas áreas, mas também em entender os seus fundamentos teóricos e conceituais. Implicitamente, e em alguns casos explicitamente, os físicos atuavam como filósofos. Schrödinger originalmente tentou interpretar a Mecânica Ondulatória eletrodinamicamente. Em 1926, o físico alemão Erwin Madelung desenvolveu um modelo hidrodinâmico e reproduziu alguns poucos resultados da teoria de Schrödinger. Esses modelos baseados em outras teorias físicas continuaram a ser sugeridos antes e depois da $2^{\mathrm{a}} \mathrm{GM}$, mas eles não tiveram muito sucesso e a maioria dos físicos não prestava muita atenção neles. No final de 1926, a interpretação probabilista de Born era a mais aceita pelos físicos, apesar das discussões sobre o seu entendimento preciso e das suas implicações (Kragh, 1999, p. 206).

De Broglie era um dos físicos que se mostrou relutante em aceitar a visão adotada pela maioria e, em 1927, ele propõe sua teoria alternativa da "dupla solução" ou da "ondapiloto", na qual uma partícula poderia ser descrita como um pacote concentrado de 
energia, correspondente uma determinada solução, essa partícula seria guiada por uma onda $\Psi(\mathrm{r}, \mathrm{t})$ correspondente (a onda-piloto), interpretada de acordo com a visão probabilista de Born. Assim, de Broglie foi capaz de formular uma teoria determinista da microfísica, sem abandonar completamente a percepção de Born sobre a natureza probabilista dos processos quânticos. No entanto, essa teoria de de Broglie foi severamente criticada por Pauli, no Congresso de Solvay, em 1927, e nem Schrödinger, nem Einstein deram suporte a ela. Desapontado, de Broglie abandonou sua teoria e, por volta de 1928, abraçou a interpretação de Copenhagen promovida por Born, Heisenberg, Bohr e outros. Por mais de duas décadas ele permaneceu fiel a essa interpretação. Somente em 1952, com a publicação de uma interpretação causal com alguns aspectos semelhantes à teoria da onda-piloto, por David Bohm, é que de Broglie retorna a uma versão modificada de sua teoria original e, a partir daí, toma o seu próprio rumo. Bohm era um físico americano que havia seguido um caminho não-ortodoxo e, em sua interpretação causal, baseada na existência de variáveis ocultas, introduz o que ele chama de "potencial quântico" e formula uma teoria quântica que, apesar de não-clássica, preserva algumas características clássicas, como partículas se movendo sobre trajetórias específicas de acordo com o princípio da causalidade. A teoria de Bohm foi ignorada e criticada como sendo desnecessária, Pauli, por exemplo, a enxergava como uma "metafísica artificial". Levou-se por volta de 25 anos até que sua teoria fosse amplamente discutida e reconhecida (Kragh, 1999, pp. 206-207).

Outra importante contribuição para a MQ, no ano de 1927, foi a formulação do famoso Princípio da Incerteza de Heisenberg, que na verdade implicam três relações distintas, as quais foram formuladas mais ou menos intuitiva e vagamente: a primeira delas se refere ao fato de que é impossível preparar estados onde a posição e o momento são simultaneamente e arbitrariamente bem localizados. Em cada estado, a distribuição de probabilidade desses observáveis possui larguras que obedecem a uma relação de incerteza; já a segunda implica que é impossível fazer medidas simultâneas da posição e do momento, mas é possível fazer medidas simultâneas aproximadas desses observáveis, com imprecisões que obedecem a uma relação de incerteza; por fim, a terceira afirma que é impossível medir a posição sem perturbar o momento e vice-versa. A imprecisão da medida da posição e o distúrbio da distribuição do momento obedecem a uma relação de incerteza. A primeira relação de incerteza de Heisenberg é comumente chamada também 
de relação de indeterminação, refletindo a interpretação de que ela expressa uma limitação objetiva na definição dos valores das quantidades não comutáveis e não somente uma limitação de acesso do nosso conhecimento sobre esses valores. Já as outras duas últimas relações de incerteza se mostraram muito mais difíceis de serem provadas e se tornarem precisas. Heisenberg somente ilustrou a sua validade através de experimentos de pensamento (como o experimento de raios gama e o de fenda dupla) (Busch e Falkenburg, 2009). Uma vez que o Princípio da Incerteza foi derivado do formalismo da MQ, ele foi aceito rapidamente por praticamente todos os físicos, sendo discutido e aprimorado por vários deles. Um deles foi Howard Roberson que, em 1929, provou uma versão mais geral dessas relações para qualquer par de variáveis conjugadas. Contudo, apesar da ampla aceitação desse princípio, ficou claro que uma coisa era aceitar a matemática e outra bem diferente era concordar com as suas implicações filosóficas. No seu artigo de 1927, Heisenberg deixou claro que isso significava que a causalidade deveria ser abandonada, não porque era ilegítimo inferir um efeito futuro a partir de uma causa no presente, mas porque um sistema físico nunca poderia ser definido de forma precisa, porque podemos conhecer o presente somente com algumas limitações dadas pela MQ, e também só podemos conhecer o futuro de forma inexata. Durante os anos 1930, essa questão foi discutida por muitos físicos e filósofos e trata-se de um assunto que ainda é objeto de discussão nos dias de hoje, mais de 70 anos depois (Kragh, 1999, pp. 208-209).

Ainda no ano de 1927, em um Congresso Internacional de Física em Como, Bohr apresenta o seu Princípio da Complementaridade, que começou a ser elaborado a partir do momento em que ele reconhece que o formalismo matemático da MQ deveria vir acompanhado de uma estrutura conceitual coerente, algo que para Bohr era uma premissa de qualquer teoria científica aceitável. O seu princípio leva em conta que as aplicações que normalmente fazemos da TQ envolvem três sistemas físicos: (1) O sistema a ser examinado; (2) Os equipamentos de medida pelos quais nós testamos as suas propriedades; (3) Nossos corpos físicos. Além disso, todos os três sistemas são compostos de átomos e, então, devem ser descritos em termos dos conceitos matemáticos da TQ. Porém, nossas observações são descritas em termos dos conteúdos das nossas experiências sensitivas, as quais, para os fenômenos considerados, são descritos pelos conceitos da Física Clássica. Por outro lado, de acordo com o Princípio da Incerteza, a localização de um objeto em um determinado ponto no espaço demanda uma falta de conhecimento 
sobre o momento, e vice-versa. Assim, a natureza da MQ nos força a rever a exigência de uma coordenação no espaço-tempo e da causalidade, de tal forma que as teorias clássicas aparecem como complementares entre si, mas exclusivas para cada descrição da natureza (Stapp, 2009). Ele enfatiza que no mundo quântico, ao contrário do clássico, pressupõe-se que a observação dos fenômenos envolve uma interação com o agente da observação que não pode ser negligenciada, a qual provoca inevitavelmente um distúrbio no sistema. Isso parece implicar que a distinção clássica entre observador e observado não poderia ser mais sustentada (Kragh, 1999, p. 210).

Diferentemente do Princípio da Incerteza de Heisenberg, que é uma consequência da MQ, o Princípio da Complementaridade de Bohr não o é. Esse princípio pode ser considerado uma doutrina mais ampla e menos bem definida, de natureza primariamente filosófica. A ideia da complementaridade não foi meramente uma generalização filosófica do princípio de Heisenberg, ela cresceu de reflexões sobre a TQ, as quais Bohr já tinha feito antes de Heisenberg começar seu trabalho. Dessa forma, o Princípio da Complementaridade se torna o pilar do que mais tarde se tornou conhecida como Interpretação de Copenhagen da MQ. O termo "Interpretação de Copenhagen" ainda não era utilizado nos anos 1930, ele entrou no vocabulário dos físicos somente em 1955, quando Heisenberg o utilizou para criticar certas interpretações não-ortodoxas da MQ. Muitos físicos importantes dos anos 1930, incluindo Pauli, Heisenberg, Jordan e Rosenfeld, se tornaram apoiadores entusiastas da filosofia da complementaridade de Bohr, a qual eles consideravam o verdadeiro núcleo da MQ. No entanto, é importante ressaltar que quase todos os físicos que adotaram a interpretação de Bohr tinham algum contato pessoal com ele ou tinham sido visitantes em seu instituto. Fora do círculo de Copenhagen, a recepção da filosofia da complementaridade foi consideravelmente fria e, em alguns casos, até mesmo hostil. Além disso, nem todos os estudantes no Instituto de Bohr se converteram para a filosofia da complementaridade. Um exemplo foi C. Moller, que foi estudante e permaneceu quase toda a sua vida ativa lá, ele estava familiarizado com esses argumentos, mas não tinha nenhum interesse nos problemas conceituais destacados por Bohr. Essa também era a atitude de muitos jovens que trabalhavam em FQ, especialmente nos EUA, onde a reputação de Bohr era mais limitada. Lá, problemas "filosóficos" não eram considerados atrativos, os físicos americanos tinham uma atitude mais pragmática e menos filosófica com relação à Física. Eles se concentravam em 
experimentos e cálculos específicos e, para esses propósitos, eles não precisavam do Princípio da Complementaridade. Assim, o Princípio da incerteza de Heisenberg foi adotado rapidamente por muitos físicos americanos, mas eles não mostraram nenhum interesse na complementaridade de Bohr. Dentre os 43 livros didáticos de MQ publicados entre 1928 e 1937, 40 tratavam do Princípio da incerteza e somente 8 mencionavam a complementaridade. Apesar de boa parte dos físicos do mundo não endossarem a interpretação de Copenhagen ou não ligarem para ela, a oposição a ela foi fraca e dispersa. Sejam quais foram as razões, o que aconteceu foi que, em meados de 1930, Bohr tinha estabelecido com sucesso a visão de Copenhagen como a filosofia dominante para a MQ (Kragh, 1999, pp. 210-211).

Por fim, também em torno do ano de 1927, se apresentou o que posteriormente ficaria conhecido como "problema da medição", o qual levantava a seguinte questão: como poderia acontecer de um estado que contém uma superposição de duas possibilidades se tornar somente uma? Os físicos primeiramente batizaram essa evolução como "a redução do pacote de ondas". Uma análise mais sofisticada foi sugerida por Bohr, assumindo que as medidas requeriam o uso de equipamentos macroscópicos e, apelando para a visão da complementaridade, esses equipamentos deveriam ser tratados pela FC. A comunicação, em sua visão, seria um requerimento para atingir a objetividade, e ela requer que a linguagem comum seja refinada pelos conceitos clássicos. O tratamento clássico dos aparelhos de medida seria uma condição para preservar a objetividade na pesquisa científica. Outra solução para esse problema foi sugerida por von Neumann, em uma trilogia de artigos publicados em 1927, seu trabalho se baseou em fundamentos matemáticos rigorosos, onde a estrutura matemática era baseada em vetores no espaço de Hilbert e operadores hermitianos. O marco histórico do seu trabalho foi a introdução de dois tipos de evolução temporal dos estados quânticos: o primeiro, descontínuo, nãocausal, atuando instantaneamente nos experimentos ou medidas. O segundo, contínuo e causal, governado pela equação de Schrödinger. No entanto, essa formulação levanta a seguinte questão: como, onde e quando a superposição se torna um vetor com apenas uma componente, que seria um autoestado da propriedade física de interesse? (Freire Jr, 2015, pp. 142-144). Von Neumann resolveu a questão levantada pela sua formulação apelando para a distinção entre os dois tipos de evolução dos estados quânticos e o papel do sujeito cosgnoscente, ou seja, o observador individual. Em qualquer medida, há necessariamente 
um momento que devemos dizer: “isso é percebido pelo observador". Então, em 1939, London e Bauer escrevem um ensaio conciso para tentar explicar a teoria da medida de von Neumann para leitores sem grandes habilidades matemáticas. A novidade do tratamento de London e Bauer era que eles afirmavam explicitamente que a redução da função de onda era um resultado da atividade consciente da mente humana. Von Neumann não havia incluído a consciência do observador na cadeia de medição. London e Bauer estavam conscientes das implicações de suas afirmações e argumentaram que esse apelo à consciência não levaria ao solipsismo. Nessa época, essa abordagem de London e Bauer não foi considerada subjetivista, foi somente nos anos 1960, nas mãos de Wigner que a audácia de suas afirmações foram revividas (Freire Jr, 2015, pp. 144-146).

Com todas essas questões, na segunda metade dos anos 1920, muitos europeus estavam profundamente preocupados com as implicações filosóficas da nova MQ, e dedicavam muito tempo discutindo o contexto mais amplo da teoria e seus estranhos efeitos não-clássicos. Para Bohr, Einstein, Heisenberg, Jordan e outros, era importante compreender esses aspectos, assim como resolver os problemas de ordem técnica. A atitude dos americanos, por outro lado, era totalmente diferente, eles não se importavam muito com os problemas filosóficos associados à MQ e adotavam um postura pragmática e inspirada no operacionalismo deixado pela "Lógica da Física Moderna", de Bridgman ${ }^{1}$. De acordo com essa atitude, somente os resultados experimentais importavam. $\mathrm{O}$ trabalho do físico, portanto, era fazer cálculos que pudessem ser verificados experimentalmente. Assim, o espírito de Copenhagen, atrelado ao Princípio da Complementariedade, deixou os americanos tão frios quanto deixou os físicos continentais animados (Kragh, 1999, p. 172). Então, entre os anos de 1920 e 1930, as ideias identificadas com a "visão ortodoxa" da MQ se popularizaram. A tendência positivista da abordagem desenvolvida por Heisenberg, Jordan, Born e Pauli não era a única em sintonia com o clima cultural na Europa continental entre as duas guerras, mas era a mais adequada para lidar com a mudança de paradigma que os fenômenos atômicos pareciam demandar. Os argumentos de Bohr eram tomados como garantia de que sua abordagem estava livre de

${ }^{1}$ Em 1927, o físico estadunidense Percy Williams Bridgman escreve o seu famoso livro "A Lógica da Física Moderna", no qual ele advoga uma posição metodológica para a Ciência que denomina “operacionalismo". Nessa concepção, até mesmo os conceitos mais básicos seriam definidos pelas operações ou processos pelos quais eles seriam detectados ou medidos. 
inconsistências e que poderia ser acomodada em uma estrutura conceitual coerente. A autoridade de Bohr, no entanto, não implicava nem uma adesão consciente, nem um entendimento claro de sua filosofia. Isso deu origem a uma imposição de ideias sobre a geração de físicos mais jovens, que, posteriormente, foi chamada de o "dogma de Copenhagen" ou a "visão ortodoxa". Esse rótulo surge, pois a defesa das ideias ortodoxas por determinados grupos de físicos, muitas vezes, não ocorria de forma elegante, seguindo as regras de uma discussão aberta e racional, uma atitude vaga entre seus defensores atuava como um cinturão protetor que evitava que os usuários dessa teoria encarassem as falhas nos seus fundamentos. Sob o rótulo de "ortodoxa" os seus dissidentes se referiam a atitude instrumentalista que rejeitava qualquer tentativa de prover um modelo pictórico coerente do mundo além dos alegados fenômenos quânticos (Freire Jr, 2015, p. 82-83).

Um dos físicos que, já nesse período, demonstrou o seu descontentamento com as novas interpretações que surgiam da FQ foi Einstein, que, em dezembro de 1926, escreve sua famosa carta a Born, onde expressa o seu "sentimento interno" de que está convencido que "Deus não joga dados". Então, nos anos seguintes, acontece talvez o mais famoso e mais romantizado episódio na história da física do século XX: o debate entre Einstein e Bohr sobre a interpretação da MQ. Na verdade, os dois físicos se encontraram pessoalmente poucas vezes, e a importância das suas discussões tem sido exagerada e romantizada em várias versões dessa história. No $5^{\circ}$ Congresso de Solvay, em outubro de 1927, Bohr, Dirac, Heisenberg, Pauli, Schrödinger e outros físicos discutiram os Fundamentos da MQ. Bohr discursou sobre as suas ideias sobre a complementaridade, as quais Einstein ouviu pela primeira vez e que não o convenceram. Einstein discutiu diversos experimentos de pensamento na esperança de demonstrar que as relações de incerteza não eram necessariamente válidas e que os fenômenos atômicos poderiam ser analisados em mais detalhes, que aqueles especificados pelas relações de Heisenberg. Quando Bohr mostrava que o argumento de Einstein era insustentável, Einstein vinha com outro experimento de pensamento, o qual Bohr novamente contrapunha. Não havia dúvida de que Bohr foi o "vencedor" das discussões de 1927, e que a maioria dos participantes reconheceu a força dos seus argumentos. Einstein admitiu que Bohr foi um grande debatedor, mas não que as suas visões eram corretas. Em uma carta a Schrödinger, Einstein descreveu a interpretação de Copenhagen de forma sarcástica, como "a filosofia tranquilizante de Heisenberg-Bohr ou religião?". A segunda rodada dos debates entre 
Bohr e Einstein aconteceu no Congresso de Solvay seguinte, em outubro de 1930. Os meios de refutação de Einstein foram os mesmos de antes, experimentos de pensamento. E o resultado dessa segunda rodada de debates foi o mesmo: a concepção de Bohr sobre a MQ foi fortalecida e o ceticismo de Einstein parecia ser injustificado. Até então, Einstein tinha a esperança de refutar a MQ, mostrando que as relações de incerteza estavam erradas. A sua crença final na causalidade era inabalável, e nos anos 1930, ele modificou o foco das suas objeções de inconsistência para a incompletude (Kragh, 1999, pp. 212-213).

Para outros físicos que não se sentiam satisfeitos com a Interpretação de Copenhagen, a possibilidade de variáveis ocultas se mostrava como uma possibilidade atrativa. No entanto, essa possibilidade foi analisada pelo matemático húngaro-americano John von Neumann, em seu livro de 1932 intitulado "Fundamentos Matemáticos da MQ", onde ele afirma ter provado que um entendimento causal da MQ, baseado em variáveis ocultas não seria possível. Em sua análise, ele mostra que conjuntos livres de dispersão não poderiam existir sem destruir as predições do formalismo, de tal forma que as relações assumidas na MQ teriam que falhar para as quantidades já assumidas. Assim, não seria uma questão de mera reinterpretação, mas o presente sistema da MQ teria que ser objetivamente falso, para que outra descrição não-estatística dos processos elementares fosse possível. Apesar de, em 1935, a matemática Grete Hermann ter contestado a precisão dessa prova (Crull e Bacciagaluppi, 2016), seu resultado não atingiu grandes repercussões e um sentimento geral de que a prova de impossibilidade de von Neumann estava correta e que não havia possibilidade de reproduzir os resultados do formalismo quântico usando variáveis ocultas predominava (Hiley, 2009). Por outro lado, o próprio von Neumann admitiu que existia uma pequena possibilidade da MQ estar errada, uma vez que, por ser uma teoria física, ela não poderia ser provada matematicamente. Ele argumenta que ninguém nunca pode dizer que uma teoria foi provada pela experiência, mas apenas que ela é o melhor conhecimento sistematizado da natureza. Apesar do cuidado de von Neumann, a sua prova matemática foi amplamente aceita e, em alguns casos, tomada como uma prova da Interpretação de Copenhagen. É discutível o quanto a prova de impossibilidade de von Neumann contribuiu para o processo da hegemonia de Copenhagen, porém se reconhece que ela contribuiu bastante, sendo frequentemente referida como a última palavra que importava. Somente em meados dos anos 1960, quando o debate sobre variáveis ocultas havia sido ressuscitado, é que o argumento de von Neumann foi revisto pelo o físico britânico John 
Bell, que mostrou que a alegada prova de von Neumann, de fato, não era uma regra que servia para todas as teorias que operavam com parâmetros ocultos (Kragh, 1999, pp. 214215).

Contudo, apesar da força adquirida pelo argumento de von Neumann na época de sua publicação, em 1935, Einstein publica juntamente com os físicos Boris Podolsky e Nathan Rosen, o artigo em que apresenta o famoso paradoxo EPR. Nele, os três físicos estudam uma função de onda na qual as posições de duas partículas 1 e 2 estão estritamente correlacionadas. Então, eles apresentam uma definição do que consideram a condição suficiente para a existência de um elemento da realidade física. Quando essa condição é aplicada às duas partículas correlacionadas, juntamente com o pressuposto tácito de que a medida de uma das partículas não pode causar um efeito instantâneo no resultado da outra - uma consequência da causalidade relativística para eventos separados espacialmente eles inferem que a posição e o momento são elementos da realidade física de ambas as partículas 1 e 2. Como não é possível obter esses elementos de realidade a partir da FQ, eles concluem que essa teoria é uma descrição incompleta da realidade física (Shimony, 2009). Bohr ficou bastante perturbado com o argumento EPR e começou imediatamente a elaborar um contra-argumento, que demorou um período de aproximadamente cinco meses. Ele rejeitou o critério de realidade física proposto pelo EPR, o qual considerou como inválido por causa do pressuposto de que o objeto e o aparelho de medida poderiam ser analisados em partes distintas. Isso não seria possível na visão de Copenhagen, na qual eles formavam um sistema único. Enquanto o argumento EPR se tornou extremamente famoso nos anos 1960, nos anos 1930, essa terceira rodada do debate Bohr-Einstein não despertou muito interesse entre os físicos. $\mathrm{O}$ artigo EPR não convenceu os físicos a abandonarem a Interpretação de Copenhagen e a impressão geral era que Bohr havia novamente respondido às objeções de Einstein satisfatoriamente, e que Einstein e seus aliados eram físicos conservadores. Não entanto, a grande maioria dos físicos permanecia desinteressada no debate. Somente alguns físicos com inclinação filosófica acharam a discussão EPR interessante, entre eles Schrödinger (Kragh, 1999, p. 217). 
Assim, entre os anos 1930 e o final dos anos 1940, a "monocracia da Escola de Copenhagen" $^{2}$ (Jammer, 1974, p. 250; Freire Jr, 2015, p. 21) na filosofia da MQ permaneceu com pouca contestação. Einstein, que havia sido um dos primeiros e mais influentes críticos, não renovou os seus ataques após as discussões do artigo EPR. Schrödinger desistiu da sua "interpretação ondulatória" de 1926, e as suas análises passaram a focar na interpretação epistêmica do vetor de estado, a qual ele considerava como sendo a "oficial". Até mesmo de Broglie repudiou sua teoria da onda-piloto e aderiu ao campo ortodoxo (Freire Jr, 2015, p. 83). Nesse período, também houve algumas contribuições com a intenção de clarificar alguns aspectos obscuros do postulado da projeção de von Neumann, onde se discutiu mais profundamente o chamado problema da medição. Essas contribuições incluíam alguns trabalhos que atribuíam um papel crucial para as faculdades mentais como a vontade e a consciência nos processos de medição. Para se afastar dessas propostas, Bohr enfatizava fortemente nos seus escritos o fato de que o processo físico de medida de forma alguma requeria um observador consciente. É provável que essa ênfase refletisse as suas preocupações de que a sua visão pudesse ser confundida com os que os sovietes, na União das Repúblicas Socialistas Soviéticas (URSS), consideravam como "fantasias idealistas". O papel do observador na estrutura epistemológica da complementaridade não era para ser entendida em termos de doutrinas idealistas, mas mais em conexão com uma análise pragmática com condições sob as quais é possível adquirir um conhecimento objetivo. A distinção funcional de Bohr entre o sistema objetivo e o instrumento de medida era apresentada como uma hipótese física intrínseca, de acordo com a qual os sistemas macroscópicos se comportam classicamente. A abordagem de Bohr apenas divida o mundo físico em um microcosmo quântico e outro clássico (Freire Jr., 2015, p. 86).

No início dos anos 1950, no entanto, a situação na qual vigorava a "monocracia da Escola de Copenhagen" começou a mudar. Em contradição com as décadas anteriores, um número de físicos pertencentes à nova geração era simpático às críticas à visão ortodoxa. O contexto social e cultural da pesquisa sobre os Fundamentos da FQ sofreu grandes

${ }^{2}$ O historiador da Física Max Jammer (1974, p. 250) utiliza o termo "monocracia da Escola de Copenhagen" para se referir à ampla aceitação da Interpretação da Complementaridade por parte dos físicos, praticamente sem ressalvas, entre os anos 1930 e 1940. A hegemonia dessa interpretação nesse período, posteriormente, tornou-a conhecida como a "interpretação ortodoxa" da Mecânica Quântica. 
mudanças após a Segunda Guerra Mundial e favoreceu o crescimento dessas críticas. No ocidente, a americanização da pesquisa e a influência de uma postura mais pragmática com relação à FQ não foram muito favoráveis para o entendimento das ideias de Bohr. Na URSS, essas ideias eram acusadas de promover tendências idealistas na ciência e foram praticamente banidas. As repercussões das polêmicas na URSS foram intensificadas pelo contexto da Guerra Fria. Os físicos marxistas foram pressionados a se posicionarem com relação às críticas à interpretação de Bohr e alguns deles apoiavam as interpretações "estocásticas" ou "estatísticas", as quais pareciam se encaixar melhor com a estrutura materialista do que a Complementaridade. No entanto, o maior desafio para a interpretação ortodoxa veio com a interpretação causal de David Bohm. Assim, na primeira metade dos anos 1950, as controvérsias giravam em torno da possibilidade de fornecer uma "interpretação causal" para a MQ. Já na segunda metade dessa década, os aspectos problemáticos do problema da medição na MQ começaram a receber atenção. $\mathrm{Na}$ segunda metade dos anos 1950, o crescimento dos estudos do problema da medição deu origem à "abordagem termodinâmica", desenvolvida por Gunther Ludwig, a qual trata o aparato de medida macroscópico como um sistema termodinâmico. Esse programa se propunha a explicar, dentro da estrutura da $\mathrm{MQ}$, o fato de que as medidas possuem resultados definidos. Após a morte de Bohr, aqueles discípulos que eram comprometidos com o materialismo, viram nesse programa uma possibilidade de prover um fundamento físico rigoroso para a abordagem de Bohr, resolvendo os maus entendidos em torno do alegado subjetivismo na Interpretação de Copenhagen (Freire Jr., 2015, pp. 83-85).

A interpretação causal de David Bohm, de 1952, se apresenta como o maior desafio para a interpretação ortodoxa justamente por produzir um contraexemplo para a prova de impossibilidade de von Neumann, mostrando que, na verdade, era possível reproduzir exatamente todos os resultados do formalismo quântico, atribuindo valores definidos para todas as variáveis dinâmicas - como posição, momento, etc. - era necessário somente assumir que os valores do conjunto complementar eram definidos, porém desconhecidos (variáveis ocultas). Não era necessário adicionar nenhuma variável exótica, mas apenas assumir que a partícula tinha todas as suas variáveis dinâmicas bem definidas com valores definidos. No entanto, após essa proposta de abordagem por Bohm, somente em 1965, Bell conseguiu apontar exatamente quais eram as limitações da prova de von Neumann e lançar uma generalização. Apesar de não haver uma forma matemática de excluir os tipos 
de teorias de variáveis ocultas introduzidos por Bohm, ainda há um considerável debate sobre se essas teorias são fisicamente viáveis. O que Bell foi capaz de mostrar foi que todas as teorias locais devem satisfazer uma desigualdade (as desigualdades de Bell), que não era satisfeita pelo formalismo quântico e, mais ainda, experimentos mostraram que esse formalismo violava essas desigualdades. De qualquer forma, a abordagem de Bohm aponta para a não-localidade, a qual há ainda uma relutância geral em ser aceita, mesmo nas teorias quânticas de campo mais amplas (Hiley, 2009). A interpretação causal de Bohm, de 1952, também veio acompanhada de uma crítica em termos filosóficos à Interpretação de Copenhagen: Bohm a acusa de ser guiada por um princípio de não postular a possível existência de entidades que não podem ser observadas. Ele também nota que esse princípio é derivado do "positivismo" ou "empirismo" do século XIX. As implicações filosóficas da proposta de Bohm dizem respeito não só a recuperação do determinismo, como um modo de descrever os fenômenos físicos, mas também à adoção de um ponto de vista realista com relação às teorias físicas, ambos descartados pela complementaridade. Mais tarde na sua carreira, em 1987, Bohm enfatiza que recuperar o determinismo não era a sua principal motivação, mas que a sua principal insatisfação era que a interpretação ortodoxa não poderia ir além dos fenômenos ou aparências. Assim, construir uma ontologia para explicar os fenômenos se tornaria um objetivo permanente na pesquisa de Bohm (Freire Jr, 2015, p. 22).

Outra interpretação que irá surgir nos anos 1950 é a Interpretação dos Estados Relativos de Hugh Everett, que posteriormente se tornaria a famosa Interpretação de Muitos Mundos de Everett-DeWitt. Everett era um estudante PhD norte-americano em Princeton e, em 1955, submete dois artigos para John Wheeler, seu orientador, que os recebe com grande entusiasmo. Wheeler, por ser um bohriano dedicado, tinha grande interesse de discutir a proposta de Everett com Bohr. Então, em 1956, Wheeler viaja para Copenhagen para discutir os rascunhos de Everett com Bohr e Petersen, de quem ele recebe várias críticas. A partir daí, se desenrola uma trama na qual Wheeler tenta conciliar as ideias de Everett com a Interpretação de Copenhagen. No entanto, as duas eram fundamentalmente inconciliáveis, o que acaba por minar a carreira do jovem físico, que desiste de seguir com as pesquisas em Física. Wheeler fez grandes esforços para que Everett e Bohr se encontrassem pessoalmente para discutir sua proposta, o que só aconteceu em 1959, quando Everett permaneceu em Copenhagen por seis semanas, mas 
não houve espaço para uma discussão real com Bohr. Em 1956 e 1957, Wheeler insistia que a formulação dos estados relativos não era uma teoria alternativa à abordagem ortodoxa, mas uma teoria que a generalizava. A recepção da teoria de Everett por parte de DeWitt, Wiener e Margenau foram favoráveis, mas Groenewold, Bohr e Petersen discordavam veementemente dessa abordagem, considerando que sua argumentação continha "algumas confusões com relação ao problema da medição" (Freire Jr, 2015, pp. 109-114). O que incomodava Bohr não eram tanto os aspectos técnicos do projeto de Everett, mas o conceito de conhecimento físico subjacente a ele. Everett, por outro lado, nunca se importou muito com a relação entre as suas ideias e a visão de Copenhagen, ele fazia parte de uma geração americana que estava fora do contexto intelectual e científico da Europa no período entre as duas guerras. Assim, Everett não hesitou em apontar o que considerava serem as limitações da abordagem de Bohr e mostrar que considerava a sua postura como dogmática e conservadora. Não houve um esforço da sua parte para atingir um entendimento mais profundo da estrutura filosófica da Complementaridade e não houve resistências de sua parte em procurar uma formulação da MQ na qual as reflexões de Bohr sobre a natureza do conhecimento científico poderiam ser simplesmente ignoradas (Freire Jr, 2015, p. 134). Contudo, em meio a um ambiente que permanecia sob a influência das ideias de Bohr, após a defesa de sua tese, em 1957, Everett desiste da carreira acadêmica e as suas ideias ficam relegadas ao esquecimento por ao menos 15 anos, passando a receber atenção somente a partir de 1970, quando DeWitt publica um artigo na revista Physics Today, onde contrasta a sua versão dos Muitos Mundos da Interpretação de Everett-Wheeler, com a Interpretação de Copenhagen e a abordagem mentalista de Wigner. O artigo deu origem a um debate caloroso, que marcou o começo da "redescoberta" do trabalho de Everett. Porém, Everett não fez parte desse debate. Em 1971, Everett consentiu a publicação de uma longa versão da sua tese em um pequeno livro de DeWitt, com a condição de que ele não tivesse nenhum trabalho de edição, provas, etc. Posteriormente, em 1977, Everett conheceu DeWitt pessoalmente e foi simpático à Interpretação de Muitos Mundos, aprovando a utilização da sua tese (Freire Jr, 2015, pp. 129-132). A Interpretação dos Estados Relativos de Everett basicamente postulava a existência de uma função de onda universal, a qual obedece uma equação de onda linear. Everett enfatiza que o significado de "realidade" deve ser entendido com base no seu uso na prática científica: "nenhuma construção mental deve ser considerada como 
mais real do que outras. Nós simplesmente temos mais confiança em algumas do que em outras". Assim, a "realidade" física é assumida como sendo a função de onda do universo inteiro, nela, não há lugar para entidades mentais e processos que excedem as bordas da FQ. Um observador, incluindo as suas percepções, é completamente caracterizado pelo seu estado físico, os observadores e seus estados mentais devem ser descritos por um vetor de estado. A função de onda universal inclui um modelo exaustivo de todos os observadores existentes e as suas interações com os sistemas observados. Não há dualismo na dinâmica de sua teoria, a função de onda universal evolui de acordo com processos contínuos e determinísticos (Freire Jr, 2015, pp. 99-101). A sua teoria nos fornece infinitos ramos e essa é a estrutura formal da qual nós temos que extrair as informações empíricas. Com isso, a tentativa de fornecer uma interpretação consistente para os seus ramos, por parte de outros pesquisadores, deu origem a uma família de diferentes abordagens que vai desde os muitos mundos e muitas mentes, até histórias consistentes e interpretações relacionais. No entanto, nos seus manuscritos de 1955, Everett parece levar a sério o processo de divisão dos ramos e os seus possíveis efeitos, ao afirmar: o próprio observador se desdobra em um determinado número de observadores, onda cada um vê um determinado resultado para a medida. O preço que deve ser pago para se ter uma teoria completa é o abandono do conceito de unicidade do observador, com as suas talvez desconcertantes implicações filosóficas (Freire Jr, 2015, pp. 106-107).

Além do surgimento dessas novas interpretações para a FQ e dos desafios à "monocracia da Escola de Copenhagen", nos anos 1950, também houve um crescimento no interesse pelo problema da medição, e as diferenças entre as visões de Bohr e von Neumann, que até então não haviam sido muito bem distinguidas, deram origem a duas linhas de pesquisa rivais acerca desse problema. Em 1938, Bohr e von Neumann participaram de uma conferência em Varsóvia, para discutir as novas teorias da física. Nessa ocasião, as diferenças de visão entre ambos foram registradas de forma sutil. Von Neumann apresentou sua prova contra a existência de variáveis adicionais em MQ e seus trabalhos sobre uma nova lógica para a MQ. Bohr indicou que ele preferia as formas lógicas convencionais. Von Neumann enfatizou que a distinção entre observador e sistema era arbitrária e que o observador poderia ser, portanto, tratado quanticamente. Bohr tinha uma abordagem mais física e von Neumann mais matemática. Nos anos 1950, lentamente, a visão de Bohr sobre a não possibilidade de se eliminar os conceitos clássicos no 
entendimento dos processos de medida começou a ser articulada como um insight físico e não apenas uma abordagem filosófica. Assim, esse problema foi sendo formulado em termos da necessidade de equipamentos macroscópicos nos processos de medida e no papel da amplificação como um processo termodinâmico irreversível nesses aparelhos (Freire Jr, 2015, pp. 146-147).

A primeira dica para a abordagem termodinâmica veio com Jordan, em 1949, que sugeriu que a macroscopicidade e a irreversibilidade deveriam ser considerados essenciais nas questões sobre as medições em TQ. Em 1953, Ludwig sugeriu levar em conta que, após a interação entre o objeto microscópico e o aparelho de medida, aconteceria uma amplificação termodinâmica do sinal, de onde viria a irreversibilidade nas medidas quânticas. Nessa proposta, amplificação significaria "um processo de avalanche iniciado pelo objeto físico de investigação". Mais tarde, em 1962, os físicos italianos Daneri, Loinger e Prosperi, formularam o que ficou conhecida como teoria DLP, eles consideraram que o equipamento de medida poderia ser considerado um corpo macroscópico em um estado termodinâmico metaestável. Ele seria acionado por pequenas perturbações advindas da interação com o microssistema a ser medido. Então, o aparelho de medida evoluiria para um estado termodinâmico estável. Isso implicaria que os colapsos da função de onda seriam efeitos termodinâmicos e que a MQ não seria aplicável a corpos macroscópicos (Freire Jr, 2015, pp. 147-148). Essa teoria era parte do que posteriormente ficou conhecido como Programa de Amplificação Termodinâmica, e seria defendida e utilizada mais fortemente por Léon Rosenfeld, um seguidor de Bohr e defensor da Interpretação da Complementaridade. Rosenfeld a utilizou como objeto em uma disputa com uma proposta, baseada na visão de von Neumann, formulada por Eugene Wigner.

Do outro lado dessa disputa, estavam Wigner e von Neumann. Ambos eram húngaros, se conheceram no colégio e se tornaram amigos desde então. Emigraram juntos para os EUA, para desenvolver em conjunto um programa de Física Matemática em Princeton, em 1930. Nos anos 1960, o prestígio de Wigner estava atingindo o seu ápice, seu reconhecimento estava crescendo com as suas contribuições para a Física Nuclear, incluindo a sua participação no Projeto Manhattan. Entre 1961 e 1963, Wigner publicou dois artigos que se tornariam as peças centrais das suas visões sobre os Fundamentos da 
MQ. Neles, ele revisou a distinção de von Neumann sobre os dois tipos de evolução dos estados quânticos, e tratou os aparelhos de medida quanticamente. No final, Wigner chega à mesma conclusão de London e Bauer: para eliminar a superposição de estados, é preciso admitir que a análise da medida quântica leva eventualmente para o papel da introspecção do observador, isto é, para quando a informação entra na mente do observador (Freire Jr, 2015, pp. 148-153). A conjectura de que a mente possui um papel essencial na descrição quântica das medidas foi um diferencial de Wigner para abordar o problema da medição. Seus argumentos tinham duas etapas: a primeira era assumir que o estado quântico muda toda vez que o observador obtém uma nova informação das observações. A segunda consistia em diferenciar entre as descrições quânticas das medidas com e sem observadores humanos. Para isso, Wigner se utiliza de um experimento idealizado, conhecido como o "amigo de Wigner", no qual ele sugere que você observe um objeto descrito quanticamente por uma combinação linear de dois estados, ajudado por um amigo. O seu amigo observa o objeto e, consequentemente, ele está em um dos dois estados e não mais em uma combinação linear deles. Antes que ele diga o resultado da observação, haverá um conflito entre a sua descrição do objeto e a do seu amigo. Aceitando que a sua descrição é a correta, você teria que admitir que seu amigo está em um estado de animação suspenso, antes dele responder sua questão. Essa é uma conclusão paradoxal. Então, para Wigner, a TQ é incapaz de incluir medidas ou ela não produz resultados consistentes se os observadores humanos são incluídos na descrição quântica. Assim, caso a TQ queira englobar não só objetos inanimados, mas também a vida e a mente, ela precisa ser modificada e Wigner propõe explicitamente procurar por uma equação não-linear do movimento. Os argumentos de Wigner implicavam uma questão mais sociológica e histórica: definir a interpretação ortodoxa da MQ e identificar seus protagonistas (Freire Jr, 2015, pp. 148-153). Os artigos de Wigner atraíram manifestações de suporte e de oposição. Abner Shimony e Satosi Watanabe reagiram de forma favorável a Wigner, porém um dos seus principais opositores foi o já citado seguidor de Bohr, Rosenfeld, motivado por sua identificação ideológica com o marxismo e pela defesa da complementaridade. Rosenfeld e Wigner tinham posicionamentos bem diferentes em relação a várias questões, politicamente, Wigner era conservador, seguidor do Partido Republicano e apoiador da política externa dos EUA, enquanto Rosenfeld era engajado com a filosofia marxista, desde os anos 1930. Nos anos 1940 a 1950, Rosenfeld participou 
ativamente de organizações e movimentos, seus registros políticos o levaram a duvidar se ele teria o seu visto garantido para visitar os EUA, em tempos de Guerra Fria. Para preservar o que ele acreditava ser o caráter dialético da complementaridade, ele criticou ambos físicos soviéticos e marxistas, como Blokhintsev e Bohm, que eram críticos da Complementaridade, e físicos como Heisenberg, que se inclinavam para o idealismo. Por inúmeras razões, políticas, ideológicas e filosóficas, que Rosenfeld não poderia aceitar uma visão como a de Wigner, que atribuía um papel central para a mente nos fenômenos físicos. Wigner e Rosenfeld também tinham estilos diferentes para abordar o problema da medição, Wigner dissecava o formalismo matemático da FQ, enquanto Rosenfeld, possivelmente seguindo Bohr, enfatizava a sua descrença em alcançar qualquer tratamento axiomático para as teorias físicas, argumentando que toda teoria física deve necessariamente utilizar conceitos que não podem, por princípio, ser analisados mais profundamente, uma vez que eles descrevem a relação entre os sistemas físicos e os seus meios de observação. Assim, na segunda metade dos anos 1960, Rosenfeld utiliza o trabalho dos italianos DLP para criticar a visão de Wigner, a disputa entre a visão dos dois físicos foi marcada por ataques argumentativos fortes. Wigner buscou aliados por todos os lados, sobretudo por sua forma não dogmática de lidar com os problemas relacionados aos Fundamentos da MQ e seu estilo de liderança e sua forma de exercer influência, Wigner conseguiu ampliar os debates em torno dos Fundamentos da MQ. Comparando os estilos de Wigner e Rosenfeld, com relação a essa questão, pode-se dizer que Wigner intencionalmente apoiou o amplo debate sobre os Fundamentos da MQ, enquanto Rosenfeld não intencionalmente contribuiu para a abertura desse debate, uma vez que ele acreditava que não haviam problemas a serem resolvidos. A disputa entre Wigner e Rosenfeld e os italianos passou a ser vista como uma evidência da existência de uma controvérsia sobre os Fundamentos da MQ e, pela primeira vez o nome "Escola de Princeton" foi utilizado para diferenciar a visão de Wigner da Escola de Copenhagen, representada por Rosenfeld. Assim, a monocracia de Copenhagen foi quebrada de dentro dela mesma (Freire Jr, 2015, pp. 153-166). A mudança no pensamento dos físicos sobre os Fundamentos da MQ, nos anos 1960 e início dos 1970, teve grande influência de Wigner, quem, tentando defender o que ele considerava a "ortodoxia quântica", na verdade acabou legitimando a hetorodoxia nesse assunto, tornando-o um dissidente. Durante os anos 1970, a comunidade estava mais ocupada com o tema das desigualdades de Bell e seus testes 
experimentais, enquanto Wigner estava interessado no problema da medição. Nos anos 1980 e 1990, o problema da medição evoluiu para a abordagem da decoerência, tendo os seus primeiros resultados experimentais em meados dos anos 1990 (Freire Jr, 2015, pp. 166-169). Wigner também contribuiu para o enfraquecimento do Programa de Amplificação Termodinâmica, com os seus argumentos de 1963, baseados na prova de impossibilidade, e com os seus argumentos juntamente com Jauch e Yanase, em 1967, baseados nos de Tausk de 1966, sobre as medidas de resultado negativo (Pessoa et al., 2008). Esse último argumento seria o seguinte: imagine um experimento no qual um objeto mecânico-quântico possui igual probabilidade de atingir dois detectores colocados em dois caminhos A e B. Agora suponha que o detector no caminho A seja removido e uma partícula seja enviada ao aparato. Se após um certo tempo o observador não ver nenhum sinal no detector do caminho $\mathrm{B}$, este conclui que a partícula viajou pela caminho A, o que levaria a um colapso ou a uma redução de estado. Porém, nenhuma amplificação ocorreu, o que mostra claramente que a amplificação não é uma condição necessária para a redução de estado ou colapso (Freire Jr, 2015, pp. 177-179).

Nesse contexto de queda da "monocracia da Escola de Copenhagen" e principalmente pela influência da interpretação causal de Bohm - já que a decisão de Bell em explorar a questão das variáveis ocultas veio da própria existência da interpretação de Bohm - Bell publica em 1965 o seu famoso teorema. O Teorema de Bell demonstra que toda uma classe de teorias sobre o mundo físico (Teorias Objetivas Locais - TOL) definidas pela conjunção de aparentemente 3 princípios gerais plausíveis, levam a previsões experimentais que, sob determinadas condições são inconsistentes com as previsões da MQ. As 3 hipóteses gerais, independentes entre si, sobre o mundo físico são: a localidade, a indução e o realismo. Desde 1972, centenas de experimentos baseados no Teorema de Bell foram realizados e, com algumas poucas exceções, os resultados foram sempre consistentes com as previsões da MQ. Assim, como uma consequência desse teorema, para manter a consistência com a MQ, deveríamos abandonar uma das três suposições (Leggett, 2009).

Após o desenvolvimento teórico, experimental e as questões técnicas relacionadas ao Teorema da Bell e seus testes, surgiram contribuições importantes de vários personagens para a área de Fundamentos da MQ. Esses personagens contribuíram para uma história de 
sucesso, que trouxe esse tema da marginalidade da Física, para o rol de pesquisas padrão. Essa história nos sugere que os Fundamentos da MQ, por um bom tempo, foi um trabalho para os dissidentes quânticos ${ }^{3}$ (Freire Jr., 2015, p. 3), lutando contra a atitude dominante entre os físicos segundo a qual as questões de Fundamentos da MQ já haviam sido resolvidas pelos pais fundadores dessa disciplina. No entanto, o terreno comum entre esses dissidentes quânticos era mínimo e estava focado somente na relevância da pesquisa em Fundamentos da MQ, já que esses cientistas apoiavam diferentes interpretações e escolhiam diferentes abordagens sobre esse assunto, em suas pesquisas. Aqui serão citados apenas alguns desses personagens e episódios dessa história. O período compreendido entre 1965 e 1969 se refere ao contexto no qual o Teorema de Bell foi produzido, seu conteúdo e sua recepção e impressão iniciais. Já no período entre 1969 e 1974, John Clauser e Abner Shimony propõem submeter esse teorema a testes experimentais viáveis, juntamente com o envolvimento de grupos americanos. O período entre 1975 e 1976 se refere ao reconhecimento profissional desses temas como temas de pesquisa. Em especial, a revista Epistemological Letters e o Encontro Erice, em 1976, podem ser considerados pontos de virada na aceitação da não-localidade quântica como um novo efeito físico, por possibilitarem, respectivamente, a discussão aberta de temas marginais nas pesquisas em Física e a existência de espaços de socialização entre físicos interessados nesses temas. O período entre 1976 e 1982 é caracterizado pelo desafio das mudanças experimentais e da forma de análise nos casos em que os fótons ainda estão em movimento, ainda não atingindo os detectores. É também o período em que Aspect anuncia os resultados dos seus experimentos, resultando em uma atitude de mudança entre os físicos na direção de um amplo reconhecimento da importância do Teorema de Bell. Assim, os físicos mudaram as suas visões a respeito dos Fundamentos da MQ e o tema das variáveis ocultas foi trazido para os laboratórios de ótica (Freire Jr, 2015, pp. 237-238). Dessa forma, as variáveis ocultas, tema considerado de cunho filosófico 30 anos antes,

\footnotetext{
${ }^{3}$ O historiador da Física Olival Freire Jr. (2015) utiliza o termo "dissidentes quânticos" para se referir aos personagens que desafiaram a atitude predominante entre físicos, no início dos anos 1950 até o final dos anos 1970, a qual considerava que as questões de Fundamentos da MQ já haviam sido resolvidas pelos pais fundadores dessa disciplina. Esses físicos, ao investigar essas questões em suas carreiras profissionais, contribuíram para que as pesquisas em Fundamentos da FQ deixassem de ser consideradas questões de ordem filosófica e se tornassem parte das pesquisas em Física.
} 
invadiu os laboratórios de ótica e ocupou um lugar na física convencional. Isso não significa que os físicos chegaram a um consenso completo sobre o significado desses experimentos e que as questões filosóficas foram resolvidas. De fato, a compatibilidade entre a MQ e a sua não-localidade, por um lado, e a relatividade especial, por outro, permaneceu objeto de disputa. Nesse meio tempo, apareceram demonstrações de que a MQ não poderia ser usada para trocar mensagens com velocidades maiores que a luz e foram construídos modelos de variáveis ocultas capazes de imitar as predições da MQ. Essa história nos mostra que o caminho da filosofia para a Física foi lento e sinuoso, e requereu não só boas ideias teóricas, habilidades experimentais e recursos tecnológicos, mas também uma mudança na atitude da comunidade de físicos sobre o status dos Fundamentos da MQ (Freire Jr, 2015, pp. 279-280).

De maneira geral, podemos caracterizar os anos 1970 como uma década de transição para a pesquisa sobre o Teorema de Bell, em particular, e para os Fundamentos da MQ, no geral, no qual os dissidentes quânticos tiveram que lutar contra a atitude dominante dos físicos de considerar as questões sobre os Fundamentos da MQ como já resolvidas. Alguns deles, como Bell, Clauser e Shimony criticavam duramente a interpretação da complementaridade. No entanto, essa talvez fosse uma das poucas coisas em comum entre os dissidentes, pois eles, em geral, apoiavam diferentes interpretações da MQ e escolheram diferentes abordagens e questões para a sua pesquisa. $\mathrm{O}$ fato de que o que havia de comum entre eles era a análise crítica, tanto teóricas quanto experimentais, dos Fundamentos da MQ, em vez do desenvolvimento de somente uma única interpretação alternativa, ou mesmo da defesa de uma única crença filosófica, é uma das fontes da sua força. Eles tinham a vantagem de um novo contexto profissional, já que a geração antiga dos pais fundadores da MQ já estava fora do campo de batalha. Eles também foram beneficiados pelas mudanças culturais do final dos anos 1960, o que abriu margem para críticas com relação à Ciência e no próprio interior dela. Assim, eles não apenas refletiram o seu tempo, mas também contribuíram para mudá-lo. Eles foram levados a essas questões não apenas por motivações cientificas, mas também filosóficas, pedagógicas e mesmo políticas. Tudo isso permitiu que, mais tarde, os Fundamentos da MQ, ou ao menos algumas pesquisas dessa área, entrassem na pesquisa em Física convencional (Freire Jr, 2015, pp. 280-281). 
Essa mudança de status dos Fundamentos da MQ foi um processo que levou mais de 30 anos, desde o início dos anos 1950, quando a interpretação causal de Bohm era considerada apenas uma questão para debates filosóficos, até os anos 1980, quando o campo ganhou o seu merecido reconhecimento. O ponto sem volta nessa mudança foram talvez os experimentos de Aspect, sobre o Teorema de Bell, no início dos anos 1980. Essa década foi uma época de transição, com os problemas de fundamentos passando de um tema marginal para um tema convencional das pesquisas em Física. Nos anos 1990, esse tema iria se tornar não somente parte da Física convencional, mas da emergência do campo de informação quântica. Em resumo, os anos 1950 podem ser vistos como a época em que os desafios para a dominante interpretação da complementaridade começaram a aparecer, com o surgimento da interpretação causal de Bohm e dos estados relativos de Everett para a MQ. Os anos 1960 foram marcados pelo reconhecimento da questão da medição em MQ como um problema, com as disputas entre Wigner e Rosenfeld marcando o primeiro embate dentro da ortodoxia da MQ. A década de 1970 foi a década dos experimentos sobre o Teorema de Bell. Nos anos 1980, a agenda se diversificou, os avanços tecnológicos permitiram o surgimento de novas interpretações e a renovação das antigas. Os avanços teóricos foram feitos em duas áreas diferentes: a transição da descrição quântica para a clássica, através da ideia de decoerência e as ideias iniciais relacionadas com o uso da MQ para melhorar computadores e a ciência computacional. Isso resultou no surgimento do campo da informação quântica, em meados dos anos 1990. Mesmo sem um foco temático específico, os anos 1980 e o início dos anos 1990 se destacaram, pois os avanços técnicos permitiram a implementação de diferentes experimentos de pensamento. Nessa época, a grande quantidade de novos experimentos testando as predições da MQ em domínios nunca imaginados anteriormente mobilizou os físicos, inclusive, muitos daqueles que não estavam interessados nos Fundamentos da MQ em si. As corporações também começaram a se interessar por esses temas, mesmo quando as aplicações ainda estavam longe de vista. No final dos anos 1980, a atenção da mídia se voltou para um novo domínio científico e tecnológico: a nanociência e a nanotecnologia. Em muitos casos, nos EUA, os mesmos cientistas que trabalhavam com dispositivos militares, perseguiam simultaneamente tópicos sobre fundamentos. Assim, a interpretação usual da história da Física do século XX - uma ciência experimental relacionada com aplicações tecnológicas - foi permeada com um tema como os Fundamentos da MQ. 
Dessa forma, no final dos anos 1980 e início dos 1990, todos os ingredientes necessários para a emergência da informação quântica como um campo diferenciado foram reunidos: o Teorema da Bell, as realizações teóricas e experimentais relacionadas com a decoerência e com as fronteiras clássico-quântico, novas técnicas e novos experimentos em Fundamentos da MQ, a proliferação de novas interpretações e renovação das antigas, os avanços no campo da ciência computacional, que mais tarde se juntaria com os Fundamentos da MQ para dar origem ao campo da informação quântica (Freire Jr, 2015, pp. 287-289).

Portanto, o terceiro e último estágio da gênese da FQ é marcado pelos debates e pelas tentativas de interpretar o formalismo da MQ, assim como pelo reconhecimento de que os problemas de Fundamentos da MQ são parte das pesquisas em Física. Comparando esse estágio com os dois primeiros, nestes últimos, o problema da interpretação dos conceitos parece ter ficado confinado às questões puramente físicas, levando a um refinamento cada vez maior destes e à sua elaboração teórica. Ao final desse processo, já no terceiro estágio, quando a TQ se mostrou autoconsistente e estável, o problema da interpretação sofre uma mudança intrínseca: sentia-se a necessidade de algo novo, algo fundamentalmente diferente das abordagens teóricas anteriores, de tal forma que foi necessário recorrer e reconsiderar as raízes filosóficas do próprio conhecimento físico. Assim, a interpretação desejável para a MQ passa a não se expressar somente em termos de um novo conteúdo físico para as entidades matemáticas, mas ela passa a lidar também com pressupostos e questões filosóficas relacionadas ao conhecimento científico (Paty, 2005). Isso fez com que os problemas de debates relacionados aos Fundamentos da MQ deixassem de ser considerados apenas problemas de ordem filosófica e passassem a ser considerados parte das pesquisas em Física.

\subsection{Principais debates sobre os Fundamentos da Física Quântica: um olhar mais aprofundado}

\subsubsection{Causalidade e determinismo na Física Quântica}

As noções de causalidade e determinismo acompanharam as ciências modernas e, em especial, a Física desde a sua formação, podendo ser consideradas como indissociáveis da própria ideia de ciência. No entanto, o seu uso corrente nos dias atuais tende 
frequentemente e erroneamente a confundi-las (Paty, 2004). Nesta seção, não se fará uma análise detalhada dessas noções, mas apenas serão pontuados alguns aspectos sobre elas.

A noção de causalidade na Física se consolida principalmente na mecânica clássica pós-newtoniana, adquirindo o sentido muito preciso de uma "causalidade temporal diferencial”, a qual se refere à transcrição exata e argumentada de uma causa física do movimento, e de sua mudança, em uma equação envolvendo as grandezas que o descrevem (Paty, 2004). Já a ideia de determinismo é proposta para generalizar a noção de causalidade física, levando-se em consideração as "condições iniciais" do sistema. Assim, conhecendo-se essas condições e as leis que regem os movimentos, de acordo com essa formulação clássica, seria possível em princípio deduzir o estado do sistema em qualquer momento do passado ou do futuro (Paty, 2003). Com o advento da FQ, essas noções serão colocadas em questão, tornando-se objetos de grandes debates.

Os debates sobre a causalidade e o determinismo na FQ começam principalmente com as publicações, em 1926, da Interpretação probabilista de Born para a MQ e, em 1927, do Princípio da Incerteza de Heisenberg. Na História da Ciência, ambos são frequentemente vistos como os pontos de virada, nos quais o indeterminismo entrou nos fundamentos da Física (Landsman, 2009).

Apesar de Born ter se envolvido diretamente com a formulação da Mecânica Matricial, ele ficou bastante impressionado com a abordagem de Schrödinger, principalmente por conta dos seus estudos dos fenômenos de colisão de partículas. No entanto, ele considerava que a Interpretação Ondulatória era insustentável, já que seus estudos apontavam para a natureza corpuscular dos elétrons (Jammer, 1974). Sendo assim, ele elabora a sua Interpretação probabilista, a qual considera que a função de onda determina um conjunto probabilístico, enquanto os resultados das medidas são os eventos individuais. Isso deu espaço para o surgimento de uma visão pragmática da dualidade onda-partícula, de acordo com a qual as ondas se mostram nas probabilidades quânticas e as partículas nos eventos individuais. $\mathrm{O}$ artigo de Born sugere também algumas ideias filosóficas por trás da Interpretação probabilista. Ele caracteriza a função de onda em termos de uma espécie de "campo", que guiaria a partícula, ou uma "onda-piloto" e a transferência de energia ou momento em termos de uma propagação corpuscular (Falkenburg e Mittelstaedt, 2009). A Interpretação probabilista também fornece a 
chamada Regra de Born, que estabelece uma ligação entre o formalismo matemático da TQ e os experimentos, essa regra é praticamente a única responsável por todas as previsões da FQ. Ela foi estabelecida por Born, no contexto da Teoria do Espalhamento, a sua aplicação para o operador posição é devido a Pauli, e a sua formulação mais geral é devida a von Neumann, seguida por contribuições posteriores de Dirac e Jordan. Basicamente, ela estabelece que um observável $a$ pode ser representado matematicamente por um operador auto-adjunto em um espaço de Hilbert $H$, assim, $a$ possui uma base ortonormal de autovetores, com os seus respectivos autovalores $\lambda_{\mathrm{i}}$. Uma suposição fundamental da Regra de Born é que a medida do observável $a$ irá fornecer um dos seus autovalores $\lambda_{\mathrm{i}}$ como resultado, e que a probabilidade de obter esse resultado será dada pelo módulo ao quadrado da função de onda $|\Psi(\mathrm{r}, \mathrm{t})|^{2}$, naquele estado. Outra possível formulação dessa regra é a seguinte: a probabilidade de transição $\mathrm{P}$ de um estado $\Psi_{1}$ para outro estado $\Psi_{2}$, ou a probabilidade de um "salto quântico" de $\Psi_{1}$ para $\Psi_{2}$ é dada pelo módulo ao quadrado da função de onda naquele estado. Essa formulação assume o "colapso da função de onda". Com essa regra, a Interpretação probabilista de Born da MQ pode ser considerada como aquela em que as afirmações empíricas sobre o conteúdo da teoria são dadas pela Regra de Born. No entanto, isso não é uma interpretação até que as noções de medida e probabilidade sejam especificadas. A concepção pragmática adotada pela maioria dos físicos é que as medidas são aquelas que os experimentais realizam em laboratório e que a probabilidade é interpretada como frequência. Porém, para ir além do pragmatismo, é preciso uma interpretação mais madura da MQ. Cada interpretação toca em alguma interpretação sobre a probabilidade e contém a sua própria perspectiva da Regra de Born (Landsman, 2009). Além disso, a derivação de Born da interpretação probabilista tem deficiências interpretativas cruciais. Primeiramente, probabilidades e frequências relativas empíricas são diferentes, pois probabilidades só podem ser identificadas com as frequências relativas no limite de infinitos eventos ou resultados de medidas. Em segundo lugar, não há explicação de como uma lei estatística pode emergir de uma interação entre sistemas quânticos individuais. Por fim, a MQ do espalhamento não pode explicar porque partículas individuais são detectadas (Falkenburg e Mittelstaedt, 2009).

Quando Born elabora a sua Interpretação probabilista, ele afirma explicitamente que “a Mecânica Ondulatória não nos fornece uma resposta à pergunta: Qual é precisamente o 
estado de uma partícula, após uma colisão? Ela apenas responde à pergunta: Qual é a probabilidade dela estar em um estado, após uma colisão?” (Jammer, 1974, p. 40). No entanto, ele deixa claro que "o movimento das partículas obedece às leis probabilísticas, porém a probabilidade em si se propaga de acordo com a lei da causalidade" (Jammer, 1974, p. 40). Sendo assim, sua interpretação rompe com o determinismo clássico, no sentido em que o estado exato de uma partícula após uma interação já não pode mais ser conhecido pelas leis da MQ, mas apenas é possível prever as probabilidades de que cada estado ocorra.

Em sua formulação, Born admite que foi influenciado pela concepção de Einstein sobre a relação entre as ondas do campo eletromagnético e os quanta de luz. Conforme a leitura de Born, Einstein via o campo ondulatório como uma espécie de "campo fantasma", cujas ondas guiavam os fótons - com características corpusculares - em seus caminhos, e cujas amplitudes de onda (ou intensidades) ao quadrado determinavam a probabilidade da presença dos fótons em determinados locais. Dessa forma, a Interpretação probabilista de Born deve sua existência a Einstein, quem, no entanto, ironicamente, mais tarde se tornaria um dos seus principais opositores (Jammer, 1974, p. 41). De fato, no próprio ano de 1926, Einstein escreve a sua famosa carta endereçada a Born, onde ele expressa seu "sentimento interno" de que "Deus não joga dados". A sua insatisfação com a interpretação estatística da FQ também deu origem ao artigo apresentado oralmente na Academia Prussiana de Ciências, em 1927, intitulado "A Mecânica Ondulatória de Schrödinger determina o movimento de um sistema de forma completa ou apenas no sentido estatístico?", no qual ele rascunha uma espécie de teoria de variáveis ocultas, similar a hidrodinâmica de Madelung. Porém, o próprio Einstein deve ter percebido que essa alternativa era insatisfatória e nunca submeteu o artigo para publicação (Kragh, 1999, p. 212). Posteriormente, Einstein volta as suas críticas da Interpretação probabilista para a incompletude da MQ.

É importante destacar aqui quais eram as bases das críticas de Einstein aos desenvolvimentos da FQ até esse momento, em particular, qual era a sua concepção de teoria física. Para Einstein, as características da FQ desenvolvidas até então, as quais, inclusive, ele havia contribuído fortemente - como a dualidade onda-partícula e a estatística não-clássica das partículas indiscerníveis - deveriam ser entendidas como 
traços dos fenômenos nos quais a TQ deveria se apoiar, porém, eles deveriam ser transcendidos numa formulação mais geral, pela elaboração de conceitos que iriam além, por exemplo, dos conceitos clássicos de onda e partícula. Ele esperava de uma teoria, entendida num sentido fundamental, que ela descrevesse sem ambiguidade a realidade física, e que ela se referisse a eventos tais como sistemas físicos individuais em interação, segundo uma causalidade espaço-temporal, compatível com a relatividade restrita. Assim, a dualidade e a probabilidade que figuravam a sua teoria semi-clássica de 1916 sempre lhe pareceram a marca de uma insuficiência teórica, mesmo sendo efetivas de um ponto de vista fenomenal. Por outro lado, a MQ que se desenvolvia nesse momento, não somente não se propunha a explicar essas características, através de conceitos mais elaborados, como também partia delas para desenvolver um formalismo matemático extremamente elaborado, porém, cuja significação física poderia ser obtida somente mediante regras de interpretação, as quais davam apenas um acesso indireto aos sistemas físicos representados. Talvez a principal dessas regras era justamente a Regra de Born, a qual foi erigida em "princípio" e, inclusive, compunha um dos "princípios" fundamentais da TQ. Tais princípios, no entanto, possuem implicações no plano filosófico, já que eles tornam a observação inerente à definição de um sistema físico, excluindo, portanto, a ideia de uma realidade física independente (Paty, 2008, pp. 105-106). Então, em 1953, em outra carta endereçada a Born, Einstein escreve: "Não me satisfaço com a ideia de que se possui uma maquinaria que permite profetizar, para a qual não se é capaz de dar um sentido claro" (Paty, 2008, p. 108). Dessa forma, para compreender o que Einstein quis dizer com sua famosa frase "Deus não joga dados", é preciso levar em conta todo o contexto de suas considerações precedentes. Ele, na verdade, se referia ao problema da realidade física, a qual, em sua concepção, deveria ser pensada e, portanto, descrita independentemente do ato de medida. Ele "defende o bom Deus contra a ideia de um pretenso jogo de dados contínuo" (Paty, 2008, p. 112), frisando que "o bom Deus" - ou, em outras palavras, o Real, a realidade, ou ainda a Natureza - é que estava no centro de suas observações sobre a interpretação da MQ. Vale chamar a atenção para a utilização da referência a um "jogo de dados", o que indica o seu cuidado, de maneira abreviada e de forte impacto, para designar um estado de coisas mais complexo do que a exigência simples e imediata de um determinismo ou a simples recusa das probabilidades. Assim, ele escrevia a Born "Você acredita no Deus que joga dados e eu, somente no valor de leis em um universo que existe 
objetivamente, que busco apreender de maneira selvagemente especulativa" (Paty, 2008, p. 113). Einstein evocava muitas vezes também a sua "fé profunda na inteligibilidade da natureza", "Deus, isto é, a Natureza" não se recusa à nossa inteligência, mas o caminho que "Ele" permite ao nosso conhecimento pela razão é longo, indireto e difícil, "o Senhor é sutil, mas não é mau", disse ele, em outra oportunidade. Por fim, em uma carta a Michele Besso, em 1950, ele relata "Em minha longa existência, aprendi uma coisa: é uma dificuldade dos diabos aproximar-se 'd'Ele', desde que se queira abandonar o que se encontra na superfície" (Paty, 2008, pp. 113-114). Portanto, pode-se considerar que as suas críticas não almejavam a recuperação de um determinismo clássico, pura e simplesmente, mas reivindicavam a busca de uma teoria que fosse além do que fosse possível observar, uma teoria que descrevesse a realidade física.

$\mathrm{O}$ outro importante aspecto da $\mathrm{MQ}$, que contribuiu para o início dos debates em torno da causalidade e do determinismo, foi o Princípio da Incerteza de Heisenberg. Conforme apresentado anteriormente, esse princípio foi elaborado a partir do próprio formalismo da $\mathrm{MQ}$, de tal forma que ele foi rapidamente aceito pela maioria dos físicos. No entanto, as implicações filosóficas propostas por Heisenberg não foram aceitas com tanta facilidade e ainda são objeto de debate até os dias de hoje.

As principais consequências do Princípio da Incerteza são os fatos de que é impossível preparar estados onde a posição e o momento são simultaneamente e arbitrariamente bem localizados, pois, em cada estado, a distribuição de probabilidade desses observáveis possui larguras que obedecem a uma relação de incerteza; também é impossível fazer medidas simultâneas da posição e do momento com precisão infinita, sendo possível apenas fazer medidas simultâneas aproximadas desses observáveis, com imprecisões que obedecem a uma relação de incerteza; e, por fim, é impossível medir a posição sem perturbar o momento e vice-versa (Busch e Falkenburg, 2009). Com isso, no próprio artigo de 1927, Heisenberg aponta que as suas relações de incerteza rompiam com a causalidade em sua formulação mais forte, que, segundo ele, seria ilustrada pela afirmação de que "o conhecimento exato do presente permite calcular o futuro". De acordo com ele, "não é a conclusão dessa afirmação que é falsa, mas a sua hipótese". Uma vez que não é possível conhecer de forma exata os valores inicias, consequentemente, não será possível por princípio estabelecer regras que prevejam os eventos futuros (Jammer, 1974, p. 75). 
Ou seja, um sistema físico nunca poderia ser definido de forma precisa, porque podemos conhecer o presente somente com algumas limitações dadas pela MQ, portanto, só podemos conhecer o futuro de forma inexata (Kragh, 1999, pp. 208-209)

Contudo, em 1929, Hugo Bergmann critica a interpretação de Heisenberg argumentando que uma afirmação condicional do tipo "se... então..." não é refutada com a invalidação da sua premissa ou hipótese, isto é, a falsidade da premissa de uma implicação não recai necessariamente na falsidade da implicação em si, a qual, no caso, seria a lei da causalidade. Assim, a MQ não refuta a lei da causalidade, no máximo, ela mostraria a sua inaplicabilidade. Heisenberg replica esse argumento baseando-se na sua visão positivista de então, argumentando que as especulações acerca da existência de um mundo "verdadeiro" no qual a lei da causalidade seria válida, para ele, não possuem valor ou sentido, já que a Física deve se limitar à descrição de relações entre percepções ou grandezas observáveis (Jammer, 1974, p. 76). Posteriormente, talvez pela influência de Einstein, Heisenberg abandona essa atitude positivista e, em dezembro de 1930, reformula a lei da causalidade da seguinte forma: "Se em um determinado instante todos os dados de um sistema são conhecidos, então é possível predizer sem ambiguidade o comportamento físico desse sistema também no futuro". No entanto, nesse momento, Heisenberg declara que não é a hipótese dessa sentença, mas a sua consequência que é falsa, uma vez que o conhecimento preciso dos dados de um sistema - isto é, a sua função de onda - admite apenas conclusões estatísticas. Assim, de acordo com ele, a lei da causalidade poderia ser reformulada da seguinte forma: "Se em um determinado instante de tempo todos os dados de um sistema são conhecidos, então existem, para qualquer momento posterior, experimentos cujos resultados podem ser previstos de forma exata, de tal forma que o sistema não fica submetido a nenhum outro distúrbio além daqueles necessários para a execução do experimento". Ele ainda adiciona: "Se uma regularidade desse tipo pode ainda ser considerada como causalidade ou não é uma questão meramente de gosto" (Jammer, 1974, p. 76). Outra tentativa de salvar o determinismo estrito e a causalidade tendo como pano de fundo o Princípio da Incerteza foi feita pelo filósofo francês Léon Brunschwicg, que defendeu que a realidade microscópica é regida rigorosamente pelas leis causais, enquanto que o indeterminismo expressado pelo princípio de Heisenberg é apenas aparente, sendo seus distúrbios causados apenas pelo ato de observar o objeto microscópico. Então, esse distúrbio, pensado como um processo físico, envolvendo trocas 
de energia, seria a causa da indeterminação. Assim, ele declara: "As relações de incerteza apenas significam que o determinismo dos fenômenos observados é nada mais do que uma abstração, porque ele é inseparável do determinismo pelo qual o ato de observação é regido" (Jammer, 1974, pp. 76-77).

Ainda sobre as consequências filosóficas das suas relações de incerteza, Heisenberg afirma, em 1931, que a FQ se mostra mais satisfatória do ponto de vista epistemológico do que a FC, pois uma teoria que é construída a partir de partículas elementares "pequenas", mas de magnitude finita, como elétrons e prótons, só seria coerente se ela, de alguma forma, despojasse de sentido quaisquer perguntas que questionassem o que ocorre em regiões menores do que essas partículas, o que de fato acontece com as relações de incerteza. Assim, a teoria seria epistemologicamente fechada nessas regiões (Jammer, 1974, p. 78).

Os debates apresentados são apenas ilustrativos das discussões que houveram acerca das consequências filosóficas da MQ sobre a causalidade e o determinismo na Física, em particular a respeito da Interpretação probabilista de Born e do Princípio da Incerteza de Heisenberg. Posteriormente a esses debates, foram elaboradas algumas interpretações causais ou deterministas da MQ, como a teoria da onda-piloto de de Broglie, a Interpretação causal de David Bohm e a Interpretação de Muitos Mundos de EverettDeWitt. Sendo assim, as discussões sobre a causalidade e o determinismo da FQ permanecem em aberto até os dias atuais.

\subsubsection{Completude, realismo e não-localidade na Física Quântica}

Conforme visto anteriormente, os debates em torno da completude da FQ se iniciam em 1927, com as críticas de Einstein à interpretação estatística, com seu artigo apresentado oralmente na Academia Prussiana de Ciências, intitulado "A Mecânica Ondulatória de Schrödinger determina o movimento de um sistema de forma completa ou apenas no sentido estatístico?" (Kragh, 1999, p. 212). Após isso, em outubro do mesmo ano, no $5^{\circ}$ Congresso de Solvay, acontecem os famosos debates entre Einstein e Bohr, nos quais Einstein demonstra a sua insatisfação com relação à Interpretação da Complementaridade apresentada por Bohr. Durante esses debates, Einstein faz uso de experimentos de pensamento em sua argumentação, a fim de mostrar que a concepção de Bohr seria inconsistente. No entanto, Bohr consegue contrapor todos os seus argumentos a 
acaba saindo como o "vencedor" desses debates, diante dos participantes. Nessa ocasião, Einstein admite que Bohr foi um grande debatedor, mas, ainda sim, não aceita as suas visões. A segunda rodada desse debate ocorre no Congresso de Solvay seguinte, em outubro de 1930. Nela, Einstein utiliza a mesma estratégia de argumentação, baseada em experimentos de pensamento, e Bohr novamente consegue rebater seus argumentos, de tal forma que a concepção de Bohr sobre a MQ foi fortalecida e o ceticismo de Einstein pareceu ser injustificado. Assim, nos anos 1930, Einstein modifica o foco das suas objeções de inconsistência para a incompletude da FQ (Kragh, 1999, pp. 212-213).

Nesse meio tempo, também surgiam tentativas de completar a MQ com teorias de variáveis ocultas. No entanto, essa possibilidade é enfraquecida com a publicação, em 1932, da prova de impossibilidade de von Neumann, na qual ele afirma ter provado que um entendimento causal da MQ, baseado em variáveis ocultas não seria possível, de tal forma que o sistema da MQ teria que ser objetivamente falso, para que uma descrição não-estatística dos processos elementares fosse possível. Essa prova assume que a função de onda $\Psi$, fornece a descrição mais completa do sistema envolvido, então, ela usa a regra da Interpretação probabilista de Born e assume que a probabilidade de encontrar o sistema em uma posição em determinado instante é dada pelo módulo ao quadrado da função de onda. Isso gera essencialmente uma teoria estatística, mas uma teoria estatística diferente das encontradas na MC, onde as variáveis dinâmicas são bem definidas, mas não são conhecidas. Ela também faz uso do Princípio da Incerteza de Heisenberg, onde, em um conjunto de variáveis complementares, se uma delas está bem definida, a outra está completamente indefinida. Além disso, assume que um conjunto de variáveis complementares não pode nem existir com valores numéricos desconhecidos. Assim, a estatística quântica não emerge de uma média sobre um conjunto de parâmetros desconhecidos, o que significa que essa estatística deve ter uma origem bem diferente da estatística clássica e que ela é totalmente diferente da estatística que surge da Mecânica Estatística, por exemplo. Com isso, von Neumann acredita ter provado que conjuntos livres de dispersão não poderiam existir sem destruir as predições do formalismo da MQ (Hiley, 2009). Apesar de terem sido levantadas algumas objeções contra essa prova de von Neumann, havia uma impressão geral de que ela estava correta. Assim, ela foi tomada, por muitos físicos, como uma prova da Interpretação de Copenhagen. No entanto, apesar da força dos argumentos de von Neumann, Einstein permaneceu insatisfeito com a 
interpretação que a MQ estava adquirindo. Ele chega, inclusive, em uma carta a Schrödinger, a descrever a interpretação de Copenhagen de forma sarcástica, como "a filosofia tranquilizante de Heisenberg-Bohr ou religião?" (Kragh, 1999, p. 213). E, em 1935, Einstein publica juntamente com os físicos Boris Podolsky e Nathan Rosen, o artigo no qual apresenta o famoso paradoxo EPR.

O paradoxo EPR tentava mostrar que a MQ, como descrição física da realidade, era incompleta. Para isso, os autores usaram duas hipóteses: o princípio de realidade $(\mathrm{R})$ e o princípio de localidade (L). Princípio R pressupunha que, se é possível prever com certeza (com probabilidade 1) o valor de uma quantidade física (correspondente ao resultado de um experimento), então existe um elemento da realidade física correspondente a essa quantidade. Já o princípio L pressupunha que, se dois elementos de realidade concernentes a um sistema estão separados a uma distância, então a medida de um deles não pode mudar o estado do outro de forma instantânea. Baseados em R e L, os autores formularam o seguinte experimento de pensamento: considere duas partículas $\mathrm{P}_{1}$ e $\mathrm{P}_{2}$ geradas juntas de uma mesma fonte e separadas em uma distância suficientemente grande. Um observador A recebe $\mathrm{P}_{1}$ e um observador $\mathrm{B}$ recebe $\mathrm{P}_{2}$ em cada uma das extremidades da distância que os separa. O observador A pode escolher livremente medir o spin de $\mathrm{P}_{1}$ na direção $\mathrm{z}$ ou na direção x. No entanto, sabe-se que, se a medida do spin de $\mathrm{P}_{1}$ na direção $\mathrm{z}$ resultar no valor +1 , então a medida subsequente do spin de $\mathrm{P}_{2}$ na mesma direção levará com certeza ao valor -1 . O observador A não pode medir simultaneamente os spins $\mathrm{x} e \mathrm{z}$, mas se ele pudesse sem que uma medição afetasse a outra, teríamos ao mesmo tempo, em cada uma das extremidades da distância entre A e B, um valor bem definido para o spin x e para o spin z. Nesse contexto, os autores seguem para a aplicação de R e L: uma vez que se assumiu que $\mathrm{P}_{1}$ e $\mathrm{P}_{2}$ estão a uma distância suficientemente grande, eles não podem interagir instantaneamente. Então, a premissa de L é satisfeita e a medida do spin de $\mathrm{P}_{1}$ não pode mudar a medida de $\mathrm{P}_{2}$ instantaneamente. Além disso, uma vez que o resultado da medida de $\mathrm{P}_{1}$ determina com probabilidade 1 o valor do observável spin $\left(\mathrm{s}_{2}=-\mathrm{s}_{1}\right)$, a premissa $\mathrm{R}$ é satisfeita. Dessa forma, conclui-se de $\mathrm{R}$ que o valor $\mathrm{s}_{2}$ é um elemento de realidade física de $\mathrm{P}_{2}$. No entanto, a $\mathrm{MQ}$ não permite determinar esse valor com probabilidade 1, o que faz com que os autores concluam que ela seria uma teoria incompleta. Contudo, na verdade, o argumento EPR não resulta na incompletude da MQ, 
mas em uma contradição. Assim, caso o formalismo da MQ seja considerado correto, é preciso escolher abandonar R ou L (ou os dois) (Mittelstaedt, 2009).

Após a publicação do artigo EPR, Bohr elaborou o seu contra-argumento, no qual ele rejeita o critério de realidade física utilizado pelos autores. Na visão de Copenhagen, esse critério seria inválido por causa do pressuposto de que o objeto e o aparelho de medida poderiam ser analisados em partes distintas, segundo Bohr, eles formavam um sistema único e inseparável. Dessa forma, o artigo EPR não convenceu os físicos a abandonarem a Interpretação de Copenhagen e a impressão geral da terceira rodada dos debates BohrEinstein era que Bohr havia novamente respondido às objeções de Einstein satisfatoriamente, e que Einstein e seus aliados eram físicos conservadores (Kragh, 1999, p. 217). No entanto, diante desse debate, as críticas de Einstein com relação à "incompletude" da FQ devem ser olhadas com mais cuidado. Na verdade, elas se referiam à sua impressão de que a FQ, tal qual estava sendo construída, seria insuficiente para descrever os objetos que ela trata e à sua insatisfação com relação aos seus fundamentos. Essa impressão refletia os sucessos que Einstein havia obtido com a sua teoria da relatividade geral, os quais ajudaram a definir a sua concepção de que a Física não poderia mais se contentar em ser uma mera descrição mais ou menos empírica da realidade, mas deveria buscar uma unidade mais alta entre a teoria da matéria elementar e a gravitação. Assim, segundo sua visão, era preciso que a FQ fosse, em algum grau, uma teoria fundamental e "completa" (Paty, 2008, p. 108). Suas críticas voltadas à Interpretação de Copenhagen, a qual era apresentada como sendo a interpretação "obrigatória" - daí a sua denominação como "interpretação ortodoxa" - se deviam ao seu caráter operacionalista e positivista. Por conta desse caráter, essa interpretação lhe parecia obscura, e se comportava como um manto colocado sobre a TQ para esconder as suas dificuldades conceituais. Bohr e Born, por outro lado, criticavam Einstein por sua filosofia e sua "metafísica" realistas. Porém, Einstein respondia a essas críticas apontando-lhes que eles também raciocinavam dentro de um quadro epistemológico, que dependia de uma posição filosófica a respeito do conhecimento. Assim, ele escreve em uma carta a Born, em 1950, dizendo "Você está convencido de que não existem leis (completas) para uma descrição 
completa, em conformidade com o princípio positivista Esse est percipi ${ }^{4}$ (Ser é ser percebido). Ora, isso é um programa, não ciência. É aí que se encontra a diferença fundamental de nossas posições" (Paty, 2008, p. 109). Essa afirmação de Einstein mostra que ele não queria renunciar à possibilidade de uma TQ que descrevesse uma "realidade física" independente dos atos de observação, o que não seria possível dentro da visão positivista da Interpretação de Copenhagen. O posicionamento de Einstein em sua carta a Born mostra também a sua preocupação em desvincular a argumentação física de suas posições filosóficas, buscando imaginar situações que seriam aceitáveis a todos, e que mostrassem o caráter incompleto da MQ. Foi justamente essa preocupação que o levou a formular o argumento EPR. Esse argumento identificou um conceito especificamente quântico, já incluído no formalismo da MQ, mas não explicitado: a não localidade. Sendo assim, as objeções de Einstein, em seus debates com Bohr, mais do que expressar um conservadorismo de sua parte, tiveram o papel de clarificar os conceitos quânticos. Dessa forma, apesar de Einstein não ter aceitado a não localidade, ele as esclareceu melhor do que ninguém. Esse esclarecimento contribuiu para que, posteriormente, em 1965, John Bell mostrasse, com suas desigualdades, que três hipóteses gerais sobre o mundo físico - a localidade, a indução e o realismo - levam a previsões experimentais que, sob determinadas condições, são inconsistentes com as previsões da MQ. A partir desse momento, somente a experiência permitiria contribuir na escolha entre essas hipóteses, o que foi possível com os experimentos de Alain Aspect, em 1982, que concluíram pela não localidade dos sistemas quânticos (Paty, 2008, pp. 108-112).

Assim, é possível ver que os argumentos de Einstein sobre o paradoxo EPR possuem uma estrutura, a qual leva em conta as noções de realidade, observação, determinismo, o caráter estatístico das representações e, por fim, a noção de teoria completa. Essa estrutura preza, em primeiro lugar, pela preservação da realidade física, independente do ato de medida. Em seguida, a sua exigência de completude teórica irá requerer para cada elemento caracterizado da realidade, a existência de uma grandeza teórica definida. Então, o princípio de localidade ou separabilidade permitirá designar um sistema físico real e

\footnotetext{
${ }^{4}$ Trata-se de uma frase do filósofo irlandês George Berkeley, que contribuiu para o avanço de sua teoria do "imaterialismo" (ou idealismo subjetivo), a qual nega a existência de substâncias materiais e defende que objetos não podem existir sem serem percebidos.
} 
falar do estado em que ele se encontra independentemente do fato observado ou não. Por fim, a conclusão sobre o não determinismo só irá se impor em último lugar, pelo uso do conjunto dos elementos que o precedem, culminando em uma demonstração da incompletude da TQ. Assim, seguindo a estrutura de pensamento e a elaboração dos argumentos de Einstein, é possível compreender a sua concepção de que "não seria possível desembaraçar-se do caráter estatístico da TQ atual acrescentando simplesmente algo a essa teoria sem mudar os conceitos fundamentais relativos à estrutura interna" (Paty, 2008, p. 113), de tal forma que, para ele, a solução para a incompletude da TQ não poderia vir senão da adoção de um ponto de vista radicalmente novo. Com isso, ele também se contrapunha às tentativas de completar a TQ com "variáveis ocultas" (Paty, 2008, pp. 112-113).

Com a prova de impossibilidade de von Neumann, de 1932, as tentativas de completar a FQ com teorias de variáveis ocultas perderam a sua força e só foram reavivadas em 1952, com a Interpretação causal de David Bohm. Essa interpretação era um contraexemplo para a prova de impossibilidade de von Neumann, e mostrava que, na verdade, era possível reproduzir exatamente todos os resultados do formalismo quântico, atribuindo valores definidos para todas as variáveis dinâmicas - como posição, momento, etc. - sendo necessário apenas assumir que os valores do conjunto complementar eram definidos, porém desconhecidos (variáveis ocultas). Apesar de von Neumann tentar assumir o menos possível sobre a MQ, o que ele assumiu não se aplicava a um grande número de possíveis teorias de variáveis ocultas, incluindo o modelo proposto por Bohm. Especificamente, ele partiu do pressuposto restrito de que as variáveis dinâmicas de um sistema deveriam ser simultaneamente autovalores de todos os operadores dinâmicos, eles comutando entre si ou não. No entanto, nós só podemos medir e, portanto, conhecer os valores de um subconjunto de operadores comutantes em uma determinada situação. Esse conjunto complementar só se torna autovalor quando as medidas correspondentes desses operadores são de fato realizadas. Isso é o que o modelo de Bohm faz, nele, essas novas medidas podem de fato mudar os valores das variáveis dinâmicas, então elas são nada mais que autovalores do primeiro conjunto de operadores. Nesse sentido, a medida é "participativa" e não passivamente revela o que já estava ali. Então, os valores atribuídos à partícula dependem de um determinado contexto definido pelo arranjo experimental dado. Isso apoia a visão de Bohr sobre a impossibilidade de uma separação estrita sobre o 
comportamento dos objetos atômicos e a interação com os instrumentos de medição, que servem para determinadas condições sob as quais os fenômenos aparecem. Assim, apesar de não haver uma forma matemática de excluir os tipos de teorias de variáveis ocultas introduzidos por Bohm, ainda há um considerável debate sobre se essas teorias são fisicamente viáveis (Hiley, 2009). No entanto, apesar desse aspecto comum entre as interpretações de Bohm e Copenhagen, a primeira é uma crítica ao positivismo da segunda e à sua postura de não considerar a possível existência de entidades que não podem ser observadas, pois Bohm, com sua proposta baseada em variáveis ocultas, visava não só a recuperação do determinismo, como também a adoção de um ponto de vista realista com relação às teorias físicas (Freire Jr, 2015, p. 22).

Somente em 1965, Bell, através da formulação de seu famoso teorema, conseguiu apontar exatamente quais eram as limitações da prova de von Neumann e lançar uma generalização dela. O Teorema de Bell demonstrou que as TOLs levam a previsões experimentais que, sob determinadas condições, são inconsistentes com as previsões da MQ. As 3 hipóteses gerais, independentes entre si, que determinam as TOLs são: 1. Localidade: central para a teoria da relatividade especial, na qual os eventos separados espacialmente não podem causar influência instantânea um sobre o outro; 2. Indução: é a premissa normal sobre a "flecha do tempo", na qual conjuntos físicos em MQ existentes em um tempo t>0 são definidos pelas suas experiências passadas e não pelo que vai acontecer em um tempo maior do que t. Em muitos artigos sobre o Teorema de Bell, esse postulado não é incluído, provavelmente devido à crença de que ele está subentendido em (1). 3. Realismo: é a afirmação de que cada partícula individual possui propriedades definidas, por exemplo, cada fóton carrega informação que determina ambos: como ele irá responder se for direcionado para o detector $\mathrm{X}$ e como ele irá responder se for direcionado para o detector Y, seria a hipótese de um realismo microscópico (3a). Uma formulação alternativa do postulado 3 seria a afirmação em favor de que as propriedades dos objetos microscópicos se referem diretamente (de fato ou em possibilidade) a eventos observados no nível macroscópico. Essa hipótese é chamada de Definição Macroscópica Contrafactual (MCFD) (3b). O ponto crucial sobre as desigualdades de Bell é que, para certos estados e configurações, elas são violadas pelas previsões da MQ. Desde 1972, com a publicação do trabalho de Freedman e Clauster, centenas de experimentos baseados no Teorema de Bell foram realizados e, com algumas poucas exceções, os resultados foram 
sempre consistentes com as previsões da MQ. Se assumirmos que as lacunas serão progressivamente fechadas e que os dados continuarão de acordo com as previsões da MQ, devemos concluir que as TOLs devem ser descartadas. Assim, permanece a questão: qual das 3 suposições devemos abandonar? Abandonar o postulado (1) seria entrar em conflito com os postulados básicos da relatividade especial, o que seria algo que os físicos práticos estariam extremamente resistentes em fazer. Obviamente, existe a possibilidade, defendida por muito físicos renomados, de que uma teoria final da Gravitação Quântica revelará que a relatividade especial é apenas uma descrição aproximada da realidade, então, o postulado (1) poderia falhar. Desafiar o postulado (2) seria abandonar nossas noções convencionais sobre a "flecha do tempo", essa perspectiva certamente não é atraente, muitos de nós simplesmente não saberia como fazer física sem essa suposição tão intrínseca. Por fim, abandonar o postulado (3) é provavelmente aquele que parece mais atraente aos físicos mais práticos ou com inclinação positivista. Eles diriam que nem a hipótese (3a) do realismo microscópico, nem a (3b) do MCFD se referem de fato ao mundo real. Essa conclusão é a que estaria mais próxima ao espírito da Interpretação de Copenhagen da MQ (Leggett, 2009).

Posteriormente, em 1982, Alain Aspect realiza seus experimentos, violando as desigualdades de Bell e apoiando a MQ. Neles, ele mostra que a não-localidade quântica ou emaranhamento, isto é, as correlações entre sistemas quânticos separados espacialmente, é um efeito particular da FQ. Esse efeito já havia sido percebido por Schrödinger no próprio ano de 1926, como uma consequência da estrutura matemática da MQ, nesse mesmo ano, Heisenberg explicou a estrutura energética do átomo de $\mathrm{He}$ utilizando estados que eram emaranhados. No entanto, somente com o experimento EPR, proposto em 1935, esse aspecto da estrutura matemática da MQ foi explicitamente discutido. Schrödinger reagiu a esse experimento ideal introduzindo o termo "emaranhamento" e perguntando a si mesmo se essa questão poderia ser confirmada experimentalmente ou não (Schrödinger, 1983, p. 161). Então, essa história se desenvolve passando pelo surgimento do Teorema de Bell e seus primeiros testes, até a aparição do espalhamento paramétrico de pares de fótons, no final dos anos 1980, os quais levaram ao aperfeiçoamento dos testes sobre o Teorema de Bell e à consequente entrada de questões sobre os Fundamentos da FQ, antes consideradas somente de cunho filosófico notadamente sobre completar a MQ com variáveis complementares e sobre a não- 
localidade - nos laboratórios, para testes experimentais. Esse movimento possibilitou o reconhecimento da área de Fundamentos da FQ como uma área legítima de pesquisas em Física (Freire Jr, 2015, pp. 236-237). Contudo, apesar dos testes experimentais indicarem a não-localidade como um efeito tipicamente quântico, a questão sobre qual das hipóteses das TOLs deve ser abandonada permanece em aberto.

\subsubsection{O problema da medição e o papel da consciência}

Conforme descrito anteriormente, em MQ, um sistema fechado é descrito por uma função de estado, que evolui no tempo de acordo com a equação de Schrödinger, de forma contínua e determinista. Essa função de estado, ao contrário da MC, fornece apenas as probabilidades de se obter diferentes resultados de uma medição. Assim, o resultado de uma medição não é obtido de forma determinista, e o novo estado no qual o sistema se encontrará dependerá necessariamente do resultado obtido na medição. Esta transição de estado descontínua e indeterminista, após uma medição, é descrita pelo postulado da projeção de von Neumann e é normalmente chamada de "colapso da função de onda" ou "redução de estado". O chamado "problema da medição" surge justamente da oposição entre a evolução contínua e determinista da função de estado, regida pela equação de Schrödinger, e a evolução descontínua e indeterminista descrita pelo postulado da projeção. Ou seja, esse problema levanta a seguinte questão: como acontece a transição de um estado que contém uma superposição de duas ou mais possibilidades para um estado que contém somente uma? Ou, como acontece o "colapso da função de onda" ou "redução de estado"? (Pessoa, 1992)

A primeira formulação do problema da medição, em geral, é atribuída ao trabalho de von Neumann, de 1932. No entanto, as suas raízes já se encontram nos primórdios da FQ, nos debates sobre a dualidade onda-partícula. Desde o início do século XX, a partir dos estudos com raios $\mathrm{X}$, sobre o efeito fotoelétrico e o sobre o efeito Compton, já se conhecia fenômenos em que a radiação ora apresentava aspectos ondulatórios, e ora corpusculares, a grande questão, então, era explicar porque a matéria tinha esse comportamento. Algumas respostas a essa questão foram desenvolvidas nos anos 1927 e 1928, atribuindo um papel especial para a observação na produção de mudanças em sistemas quânticos. Heisenberg, em 1927, foi talvez o primeiro a salientar o inevitável distúrbio causado pelo observador no sistema quântico observado. Um pouco mais tarde, Bohr escreveu a 
respeito da inevitável "interação" entre o "agente de observação" e o sistema quântico. Então, com o advento do formalismo ondulatório de Schrödinger, baseado em uma “função de onda $\Psi$ ", e da interpretação probabilista de Born, na qual o quadrado da função de onda fornece as probabilidades dos resultados de uma medição, Heisenberg introduz a noção de que as medições de posição "reduzem o pacote de onda" que representa a partícula. Assim, dentro desta interpretação "ondulatória-probabilística" da MQ, o paradoxo onda-partícula foi resolvido atribuindo-se ao ato da observação o poder de reduzir uma onda de probabilidade extensa para um pacote de onda estreito. No entanto, permanecia um problema: os conceitos de "observação", "medição" e "aparelho" não eram definidos de maneira inequívoca, de tal forma que não havia um consenso sobre onde exatamente se poderia traçar a fronteira entre o objeto e o sujeito. Essa arbitrariedade é justamente a raiz do que viria a ser chamado de "problema da medição" (Pessoa, 1992).

$\mathrm{Na}$ Interpretação da Complementaridade, este problema é evitado com a utilização da premissa de que existe uma separação entre os mundos micro e macroscópico, de tal forma que o aparelho macroscópico não é passível de descrição quântica, devendo, portanto, ser tratado e descrito pela linguagem da FC. Assim, nessa interpretação de caráter positivista, o problema da medição não se coloca, uma vez que não tem sentido fazer perguntas cujas respostas não são verificáveis. Já von Neumann propõe uma explicação criptodeterminista para o problema da medição. Diferentemente de Bohr, ele faz uso da hipótese segundo a qual o aparelho macroscópico de medição pode ser descrito como um sistema quântico, de tal forma que objeto e aparelho formariam um sistema quântico "composto". Porém, von Neumann faz também a separação entre o sistema quântico e o observador, que consistiria de um terceiro sistema, descrito classicamente. Então, ele formula a sua tese do conhecimento limitado, de acordo com a qual "o resultado de uma medição é indeterminado porque o estado do observador antes da medição não é conhecido de maneira exata" (Von Neumann, 1932, p. 438). Com essa tese, ele preserva o determinismo das leis naturais e argumenta que a imprevisibilidade dos resultados das medições individuais seria fruto do nosso conhecimento necessariamente limitado a respeito do estado inicial de sistemas em interação com o objeto, segundo essa concepção, se tal explicação fosse possível, as leis da MQ seriam "completas" sem a necessidade do postulado da projeção. Implicitamente a essa interpretação de von Neumann está a premissa de que o que caracteriza uma "observação" é a presença de um observador 
inteligente ou consciente. Assim, o postulado da projeção deve ser aplicado somente quando um ser inteligente faz uma observação (Pessoa, 1992).

Essa solução subjetivista para o problema da medição seria enunciada de forma mais clara por London e Bauer, em 1939, que defenderiam explicitamente que o colapso da função de onda só poderia ser explicado invocando-se a presença de um ser consciente, assim a consciência é que provocaria o colapso da função de onda, apesar dela não poder escolher qual seria o resultado da medição. Eles consideraram que a cadeia de observação consiste no objeto quântico, no aparelho de medição e no observador consciente, e que a superposição microscópica decorrente da evolução da função de onda de acordo com a equação de Schrödinger se estende para o aparelho de medição e para a consciência (Pessoa, 2001):

A função $\Psi(x, y, z)$ representa uma descrição máxima do "objeto" composto, consistindo do objeto efetivo $x$, do aparelho $y$ e do observador $z$; e contudo não sabemos em qual estado está o objeto $x$.

O observador tem uma impressão completamente diferente. Para ele é somente o objeto $x$ e o aparelho $y$ que pertencem ao mundo externo, ao que ele chama de "objetividade". Por contraste, ele tem consigo mesmo relações de caráter muito especial. Ele possui uma faculdade característica e bastante familiar que chamaremos de "faculdade de introspecção". Ele consegue acompanhar de instante para instante o curso de seu próprio estado. Em virtude deste "conhecimento imanente" ele atribui a si mesmo o direito de criar sua própria objetividade - isto é, cortar a cadeia de correlações estatísticas [...] declarando: "Eu estou no estado $w_{k}$ " [...]

Assim, não é uma misteriosa interação entre o aparelho e o objeto que produz um novo $\Psi$ para o sistema durante a medição. É somente a consciência de um "eu” que pode se separar da função prévia $\Psi(x, y, z)$ e, em virtude de sua observação, montar uma nova objetividade ao atribuir ao objeto de agora em diante uma nova função $\Psi(x)=u_{k}(x)$ (London e Bauer, 1939, pp. 251-252).

Outro físico importante que defendeu explicitamente que a consciência é essencial na observação foi Walter Heitler, em 1949, que analisou a possibilidade de se completar uma observação por meio de um aparelho auto-registrador, consistindo de duas telas fotográficas. Considerando a passagem de apenas uma partícula carregada, temos certeza (para eficiências de detecção de 100\%) que, após serem reveladas, ambas as chapas 
apresentarão uma marca aproximadamente no mesmo ponto do plano das chapas. Assim, seu argumento consistiu no seguinte (Pessoa, 2001):

[...] A primeira tela auto-registradora, por si só, não traz certeza para [o resultado de] observações futuras, a não ser que o resultado seja reconhecido por um ser consciente. Vemos, portanto, que aqui o observador aparece como uma parte necessária da estrutura inteira, e em sua plena capacidade enquanto ser consciente. A separação do mundo em uma "realidade externa objetiva" e "nós", os espectadores auto-conscientes, não pode mais ser mantida. Objeto e sujeito tornam-se inseparáveis um do outro [...] (Heitler, 1949, pp. 194-195).

Em uma obra traduzida para o português, durante a Segunda Guerra Mundial, Von Weizsäcker também apresenta a sua concepção relacionada ao problema da medição, segundo a qual a MQ renunciaria ao princípio de objetividade. Isso porque, de acordo com ele, a vontade do sujeito poderia afetar instantaneamente a realidade distante. Essa concepção se baseia em uma descoberta que ele fizera em 1931, ao analisar um microscópio de raio gama. Este instrumento permite medir ou a posição de um elétron, ou o seu momento linear, fazendo incidir nele radiação gama. Ajustando-se o microscópio com a tela detectora no "plano da imagem", determina-se a posição final do elétron, por outro lado, o ajustando com a tela no "plano focal", determina-se o momento linear final do elétron. Contudo, essa escolha sobre onde colocar a tela pode ser feita mesmo depois que o raio gama passou pela lente do microscópio. Assim, supondo-se que o elétron estivesse muito distante do microscópio, conforme a escolha da minha vontade livre, eu poderia fazer com que o estado final de um elétron seja uma onda esférica (medição de posição) ou uma onda plana (medição de momento linear): seria um "experimento de escolha demorada", no qual eu com a minha vontade livre escolheria o estado final do elétron detectado. Essa concepção de Von Weizsäcker pode ser categorizada como uma espécie de idealismo voluntarista (Pessoa, 2001).

Outro físico que contribuiu para os debates em torno do problema da medição foi John Wheeler, um dos seguidores das ideias de Bohr, que desenvolveu a noção de observador participante, que olha para si mesmo enquanto atua. Segundo sua concepção, que ficaria mais clara a partir de 1935, esse observador seria capaz de fazer com que o passado se atualizasse no presente. Para defender sua posição, Wheeler parte da Interpretação da Complementaridade, para também explorar os "experimentos de escolha demorada". 
Assim como Bohr, ele argumenta que só podemos atribuir um caráter ondulatório ou corpuscular a um experimento após realizar uma observação, antes da conclusão do experimento, portanto, não é possível atribuir uma das duas características. No entanto, para ele, o motivo para que isso ocorra seria a possibilidade de, após iniciado o experimento, podermos alterar o seu resultado: por exemplo, diante da propagação de uma onda esférica, seria possível colocar um anteparo com uma fenda dupla e observar um fenômeno ondulatório, ou colocar uma câmara de nuvens de Wilson e observar um fenômeno corpuscular. Assim, no instante em que se inicia o experimento, antes de inserir um dos dois detectores, o objeto quântico ainda não decidiu se "é onda" ou "é partícula", apenas após a finalização do experimento é possível dizer se a realidade no instante inicial era ondulatória ou corpuscular, dependendo da escolha realizada sobre qual dos detectores seria inserido. Dessa forma, de acordo com Wheeler, o passado se atualizaria no presente, pois já possuiria uma realidade indefinida, antes de concluído o experimento e a observação seria a responsável por alterar essa realidade passada para um aspecto ondulatório ou corpuscular. Essa posição pode ser enquadrada em um idealismo "criador", pois é a realidade passada que muda, não o nosso conhecimento sobre ela (Pessoa, 2001). Em suas palavras:

É errado pensar naquele passado como "já existindo" em todos os detalhes. O "passado" é teoria. O passado não tem existência enquanto ele não é registrado no presente. Ao decidirmos quais perguntas o nosso equipamento quântico de registro irá fazer no presente, temos uma escolha inegável sobre o que temos o direito de perguntar sobre o passado. (Wheeler, 1978)

Então, em 1935, Schrödinger elabora o seu famoso experimento de pensamento sobre o paradoxo do gato, cujo objetivo inicial era argumentar que a interpretação ortodoxa da MQ era uma teoria incompleta, já que ela levava a paradoxos. Contudo, o paradoxo do gato acaba por explorar também a possibilidade de estender o idealismo de algumas propostas para resolver o problema da medição para objetos macroscópicos. Nele, um gato é fechado dentro de uma caixa, juntamente com uma substância radioativa, a qual possui uma probabilidade $1 / 2$ de acionar um detector ligado a um "dispositivo diabólico", que funcionaria de maneira que, se o detector fosse disparado, o gato seria morto, caso contrário, se nenhuma radiação for detectada nesse intervalo de tempo, o gato permaneceria vivo. No entanto, sabe-se que o átomo radioativo é descrito como uma 
superposição de estados de emissão e não-emissão pela $\mathrm{MQ}$, e que o sistema como um todo está enclausurado em uma caixa, isolada do ambiente, então, infere-se que a evolução de todo o sistema seria descrita pela equação de Schrödinger. Assim, caso o gato esteja acoplado de maneira apropriada ao sistema quântico, é possível afirmar que a superposição se estenderá a ele, de tal forma que o sistema composto passa a estar em uma superposição, com uma amplitude correspondendo ao gato vivo somada à outra correspondente ao gato morto. Este estado paradoxal permaneceria até que uma observação fosse feita, ou seja, somente quando alguém olhasse dentro da caixa é que ocorreria uma redução de estado para gato vivo ou gato morto. Essa solução soa absurda, já que, em princípio, não existiriam tais superposições para objetos macroscópicos, portanto, a aceitação dessa conclusão levaria a uma extensão do idealismo para tais objetos (Pessoa, 2001).

Posteriormente, em 1962, o físico Eugene Wigner elabora uma extensão do paradoxo do gato de Schrödinger, que ficou conhecida como o problema do amigo de Wigner. Esse problema levaria a uma interpretação "solipsista" na qual a realidade do mundo não só seria afetada de maneira essencial pelo observador, como também seria diferente para cada sujeito diferente. Nessa extensão, o experimento do gato envolveria duas pessoas: um cientista, que não estaria envolvido diretamente com a medição, e seu amigo, quem seria o responsável pela observação. Então, o amigo estaria dentro de um laboratório hermeticamente isolado do ambiente, juntamente com a caixa contendo o gato. $\mathrm{O}$ cientista por outro lado, estaria do lado de fora do laboratório. Assim, na visão do amigo, haveria uma superposição de estados macroscópicos (gato vivo + gato morto) até o momento em que ele abrisse a caixa, efetuando uma observação e provocando um colapso. Contudo, na visão do cientista, o sistema envolvendo o gato e o seu amigo estaria em uma superposição do seguinte tipo: "gato morto e amigo vendo o gato morto" + "gato vivo e amigo vendo o gato vivo", de tal forma que o colapso ainda não aconteceu para o cientista, mas para o amigo sim. Uma consequência dessa situação, portanto, seria que a realidade não apenas pareceria diferente para cada sujeito, como ela seria de fato diferente. No entanto, Wigner não defendeu essa interpretação solipsista e, para resolver esse problema, ele conclui que o colapso ocorre sempre que uma consciência qualquer interage com o sistema quântico, em concordância com London e Bauer. Mais tarde, ele também irá propor que, em seres vivos, em especial naqueles com consciência, a equação 
de Schrödinger passaria a ter um termo adicional não-linear, que daria conta do colapso provocado pela consciência. Contudo, essa modificação na equação Schrödinger como solução para o problema da medição é aceita por poucos, de tal maneira que a interpretação subjetivista solipsista permanece como uma alternativa defensável no amplo espectro de interpretações idealistas para a TQ (Pessoa, 2001).

Outra solução radical ao problema da medição seria apresentada em 1957, por Hugh Everett, quem, com sua Interpretação dos Estados Relativos, irá se basear na ideia de que tudo é quântico, inclusive o observador, para aplicar a TQ ao universo como um todo, especialmente visando à utilização de sua interpretação no campo da cosmologia. Em sua proposta, não se pode falar em observadores externos que fazem medições e provocam colapsos, o universo como um todo e os seres humanos podem entrar em superposições. Assim, não há colapso algum e o próprio observador entra em superposição ao observar o ponteiro de um aparelho de medição, o qual, por sua vez, estaria em superposição devido à sua interação com o objeto macroscópico. Dessa forma, o observador se desdobra em duas "amplitudes" ou ramos do mundo e a amplitude que observou um dos autovalores da função de onda - isto é, o observador que se encontra em um dos ramos do mundo - não tem acesso às memórias da outra amplitude que observou o outro autovalor (o observador no outro ramo do mundo). Os observadores, então, existiriam em mundos paralelos e, cada vez que uma medição fosse realizada, o mundo se ramificaria em amplitudes diferentes, de tal forma que nós estaríamos habitando apenas um desses ramos dos muitos mundos existentes. Essa interpretação radicaliza o solipsismo do problema do amigo de Wigner: nesta última havia um mundo diferente para cada sujeito, já na interpretação de Everett o próprio sujeito se desdobra em vários e cada um vive em um dos possíveis mundos. Apesar da estranheza dessa interpretação, ela é defendida por muitos físicos respeitáveis, especialmente aqueles interessados em Cosmologia (Pessoa, 2001).

Paralelamente à ideia de que a mente humana seria capaz de provocar o colapso da função de onda, já na década de 1930, surge a hipótese que a FQ teria um papel essencial na constituição da mente. Ela foi defendida, entre outros, por Eddington, em 1932, em sua defesa do livre arbítrio: 
Se o átomo tem uma indeterminação, certamente a mente humana terá uma indeterminação igual; pois dificilmente poderíamos aceitar uma teoria que faz a mente ser mais mecanicista do que o átomo (Eddington, 1932, apud Jammer, 1966, p. 337).

Essa ideia também foi defendida mais fortemente pelo matemático Roger Penrose, em 1986, que partiu da hipótese de que o cérebro humano é capaz de computar funções nãorecursivas, o que o tornaria mais poderoso do que qualquer computador. A partir dessa constatação, ele desenvolve a sua concepção de que existiria alguma propriedade quântica ainda mal conhecida, que seria responsável por esta nossa grande capacidade intelectual. Paralelamente, o anestesiologista Stuart Hameroff desenvolve a hipótese de que microtúbulos presentes em todas as células, inclusive nos neurônios, teriam uma função cognitiva além da sua função estrutural e de transporte. Então, Penrose se junta a Hameroff e desenvolve uma terceira alternativa, segundo a qual no cérebro ocorreria um fenômeno denominado "condensados biológicos", o qual seria um fenômeno essencialmente quântico, que seria capaz de explicar a unidade da mente, por exibir “ordem de longo alcance" (Pessoa, 2001).

Após a Segunda Guerra Mundial, nos anos 1950, contudo, as abordagens idealistas ou subjetivistas para o problema da medição passam a perder sua influência, com o advento de abordagens que buscavam eliminar o observador humano da descrição quântica da natureza. Essas abordagens podem ser classificadas como "realistas" ou "objetivistas", pois concebem uma realidade que pode ser descrita mesmo na situação em que não haja observadores. Dentre essas abordagens, podemos destacar três principais: a Interpretação dos Coletivos Estatísticos, a interpretação causal de David Bohm e o chamado Programa de Amplificação Termodinâmica (Pessoa, 2001).

A Interpretação dos Coletivos Estatísticos foi desenvolvida nos EUA, onde predominava uma tradição pragmática, principalmente por Slater, Kemble e Margenau, e na URSS, influenciada pelo materialismo, por Blokhintsev e Terletskii, além de outros autores como Landé, Popper, Bunge e Ballentine. Trata-se de uma interpretação essencialmente corpuscular, nela, o vetor de estado nunca descreve um sistema individual, mas um coletivo estatístico de sistemas preparados identicamente. Kemble (1937, pp. 326329), fornece uma interpretação instrumentalista ou epistêmica para a função de onda, na qual o processo de redução dessa função refletiria apenas um processo mental no qual o 
sistema objeto é transferido de um coletivo inicial para um de seus sub-coletivos, seria uma espécie de "processo seletivo" referente ao ato de medição (Pessoa, 1992).

Já a Interpretação causal de David Bohm, de 1952, conforme citado anteriormente é uma interpretação determinista, baseada em variáveis ocultas, que postula a existência de partículas com posição e momentos bem definidos, as quais evoluem contínua e deterministicamente - estas se referem ao aspecto corpuscular dos fenômenos quânticos e são vinculadas a um potencial quântico não-local - referente ao aspecto ondulatório dos fenômenos. Essa interpretação possui algumas semelhanças com a teoria da onda piloto de de Broglie e também procura resolver o problema da medição através de uma modificação no formalismo da MQ (Pessoa, 1992).

Por fim, o Programa de Amplificação Termodinâmica procura substituir o papel fundamental ou legislador do sujeito humano por um papel semelhante desempenhado pelo aparelho de medição, formulando um mecanismo para a redução da função de estado no aparelho de medição macroscópico. Esse programa foi bem recebido por físicos próximos à Interpretação da Complementaridade, apesar dessa abordagem descrever o aparelho macroscópico como um sistema quântico. Segundo esse programa de pesquisa, o estágio da medição responsável pelo colapso do estado quântico seria a amplificação do sinal. Isso porque a medição de um sistema quântico necessariamente envolve um processo termodinâmico de amplificação de um sinal microscópico, que se passa em um sistema macroscópico (o aparelho de medição) e resulta em um registro também macroscópico (a posição de um ponteiro ou um registro em um computador), o qual seria irreversível, já que um registro obtido pelo sistema composto (objeto quântico + aparelho de medição) não poderia retornar ao estado inicial (anterior ao registro). Então, segundo essa explicação, a redução de estado se completa quando um registro macrofísico aparece a partir de um "processo de avalanche" irreversível, e o observador deixa de ser necessário para que essa redução ocorra. Esse programa de pesquisa objetivista foi lançado por Jordan, em 1949, onde ele enfatiza que uma medição seria um processo macrofísico real, que faz com que duas ondas percam a "coerência". Posteriormente, Ludwig, em 1953, argumenta que o processo de medição envolve um acoplamento entre o objeto microscópico e um aparelho macroscópico em um estado “metaestável”, resultando em um processo termodinâmico irreversível, cujo estado final fixa o resultado da medição. 
Este programa foi compartilhado pela maioria dos físicos preocupados com o processo de medição durante os anos 1950. O próprio Bohr passou a caracterizar a observação de um fenômeno atômico como sendo "baseada em registros obtidos por meio de dispositivos de amplificação apropriados com funcionamento irreversível” (Bohr, 1955, p. 73). É interessante notar que, implicitamente a essa abordagem, existe uma concepção criptodeterminista, uma vez que, em princípio, o resultado probabilístico de uma medição poderia ser obtido deterministicamente das condições iniciais desconhecidas no aparelho composto de muitas partículas. O auge desse programa de pesquisa foi, em 1962, com a teoria dos físicos italianos Daneri, Prosperi e Loinger (Teoria DLP), baseada em condições de ergodicidade. No entanto, ele acaba por enfraquecer nos anos 1960, principalmente por dois motivos. O primeiro deles foram as novas versões da prova de insolubilidade de von Neumann, nas quais, para um sistema composto isolado, não poderia haver uma maneira exata de gerar um comportamento clássico no aparelho de medição, após a sua interação com o sistema quântico microscópico. O segundo foi o argumento sobre a existência de "experimentos de resultado nulo", elaborados inicialmente por Renninger em 1959, lançado por Tausk em 1966 e divulgados por Jauch, Wigner e Yanase em 1967. Esse argumento se refere a experimentos nos quais, por exemplo, uma partícula pode rumar por dois caminhos A e B possíveis, no entanto, um detector é colocado em apenas um deles (suponhamos no caminho A). Supondo que o detector possui uma eficiência perfeita, caso nenhum sinal seja detectado, após um certo tempo, podemos concluir que a partícula rumou pelo caminho B. Essa situação equivale a um colapso da função de onda, porém não houve a amplificação de um sinal. Isso mostra que a amplificação não é uma condição necessária para a redução de estado (Pessoa, 2001).

Em seguida, nos anos 1960, uma abordagem para o problema da medição que atraiu muita atenção foi a abordagem das propriedades clássicas, defendida, por exemplo, por Jauch (1964). Essa abordagem, assim como o Programa de Amplificação Termodinâmica, buscava explicar o que ocorria durante o processo de medição, e era baseada no argumento de que o estado composto puro (objeto e aparelho), que evolui durante a medição, para o observador macroscópico, seria indistinguível da mistura final descrita após a aplicação do postulado da projeção (Pessoa, 1992). 
Já nos anos 1970, surgiram uma série de novas abordagens ao problema da medição, as quais podem ser agrupadas em três grandes grupos: as abordagens de aparelho infinito, a dos sistemas abertos e a dos processos estocásticos. As abordagens de aparelho infinito consistem na busca de soluções que se tornam exatas apenas no limite de um sistema aparelho com infinitos graus de liberdade, elas remontam ao trabalho de Dirac, de 1928, que apelou para esses sistemas para dar conta dos saltos quânticos. Já as abordagens de sistemas abertos se baseiam na ideia de que o sistema composto (objeto e aparelho) nunca pode ser completamente isolado do ambiente, de tal forma que não se pode atribuir um estado puro a este sistema. Porém, é possível supor que esse sistema se encontre em um estado puro no momento em que a interação como ambiente é iniciada, no entanto, nesse caso, a evolução deste estado puro não será unitária, o que viola uma das hipóteses das provas de insolubilidade. Assim, essas provas deixam de valer e abrem a possibilidade de encontrar uma solução para o problema da completeza em MQ. Um argumento que justificaria essa hipótese seria o de que os níveis de energia em um sistema macroscópico são extremamente densos, devido ao grande número de partículas acopladas (Zeh, 1970, p. 73), de forma que qualquer efeito externo tênue afetaria significativamente as probabilidades de transição, portanto, não existiriam sistemas fechados. Para tratar o problema da medição com essa abordagem, costuma-se levar em conta os efeitos estatísticos do ambiente nos sistemas quânticos, por exemplo, considerando que o próprio ambiente pode "efetuar medições" continuamente no aparelho, ou que a própria gravidade seria a responsável pelo colapso da função de onda. Essa noção de que o ambiente é capaz de realizar uma medição não requer a existência de observadores conscientes e faz com que o processo de redução de estado passe a ser um fenômeno físico objetivo, que transcende o ato de medição. Por fim, as abordagens dos processos estocásticos supõem que qualquer sistema quântico possui uma probabilidade muito pequena de sofrer uma localização espontânea. Para sistemas de poucas partículas tal localização ocorreria muito raramente, e praticamente não violaria da equação de Schrödinger, porém, para sistemas macroscópicos, compostos de um grande número de partículas emaranhadas, essa localização ocorreria com frequência. Isso explicaria porque a redução de estado só ocorre quando um aparelho macroscópico se acopla ao objeto quântico (Pessoa, 1992).

Dentro de todos esses debates e abordagens para tentar resolver o problema da medição, é importante ressaltar também que, para muitos autores preocupados com o 
processo de medição em MQ, não existe o "problema da medição". Essa opinião é compartilhada principalmente pelos proponentes da interpretação estatística da MQ e por aqueles que possuem uma visão mais instrumentalista da TQ. Segundo essa visão, a MQ seria uma teoria sobre a estatística de resultados de medições e não sobre propriedades intrínsecas de objetos físicos, assim, os seus adeptos rejeitam a existência de uma redução de estado, e o problema da medição não tem sentido. Outro aspecto importante a ser destacado é que, a partir dos anos 1980, uma série de experimentos foram desenvolvidos a fim de lançar luz ao problema da medição. Esses experimentos, entre outros aspectos, mostraram que a recombinação de feixes não destrói a coerência do feixe que foi separado, que a taxa de emissão radioativa no caso em que uma medição de energia é efetuada é diferente de quando se realiza tal medição, além de explorarem se a hipótese do princípio de superposição linear aplicado a sistemas quânticos também poderia ser aplicado a superposições macroscópicas (Pessoa, 1992). Sendo assim, o problema da medição deixa de ser uma questão meramente filosófica e passa a poder ser debatido a partir de resultados experimentais, os quais, por sua vez, influenciam na formulação das hipóteses e teorias desenvolvidas. Conclui-se, portanto, que o problema da medição, permanece um debate em aberto até os dias atuais, e que as discussões em torno de sua resolução passaram a contribuir fortemente para o desenvolvimento das pesquisas que envolvem os Fundamentos da MQ.

\subsection{Algumas das diferentes interpretações da Física Quântica}

Nesta seção, algumas das principais interpretações da FQ serão explicadas com um pouco mais de detalhe, a fim de clarificar alguns dos seus principais embasamentos filosóficos e o contexto histórico-social no qual foram elaboradas. Vale destacar, no entanto, que o número de interpretações da FQ tem crescido cada vez mais - Pessoa (2007-2011) havia contado 50 e acreditava que poderia chegar a uma centena -, o que indica que não parece haver perspectiva de que se chegue a um consenso a respeito de uma interpretação única.

\subsubsection{Interpretação ondulatória}

Conforme mencionado anteriormente, a Interpretação Ondulatória de Schrödinger para a MQ foi publicada a partir de janeiro de 1926, em uma série de quatro longos artigos, todos intitulados "Quantização como um problema de autovalor". No primeiro deles, o 
físico austríaco mostrou que a regra de quantização poderia ser substituída por uma exigência mais natural, que seria a existência de uma função espacial finita e de evolução unitária. Seis meses mais tarde, no seu quarto artigo, ele apresenta a sua famosa função de onda temporal, juntamente com uma teoria de perturbação dependente do tempo e algumas de suas aplicações. A equivalência entre os formalismos da sua interpretação e da MQ matricial de Heisenberg foi apresentada em fevereiro daquele mesmo ano pelo próprio Schrödinger. Mais tarde, essa equivalência foi mais bem esclarecida por von Neumann, que mostrou que a MQ poderia ser formalizada através de operadores hermitianos no espaço de Hilbert e que as teorias de Heisenberg e Schrödinger eram meros casos particulares desse formalismo (Jammer, 1974, p. 22).

A boa aceitação do formalismo ondulatório de Schrödinger, logo após a sua publicação, se deveu ao seu sucesso em descrever praticamente todos os fenômenos em espectroscopia conhecidos até então, como os efeitos Stark e Zeeman, além de uma ampla gama de fenômenos de espalhamento, como o efeito fotoelétrico, por exemplo. No entanto, esse formalismo ainda não poderia ser considerado uma teoria completa, capaz de caminhar sozinha, ele precisava conter ainda um conjunto de regras de correspondência e um princípio ou um modelo explicativo. O novo formalismo de Schrödinger continha, assim, proposições de nível primário, porém com um bom número de termos sem uma interpretação atrelada, como a função de onda, por exemplo. Essas proposições, por sua vez, permitiam deduzir outras de nível secundário, que envolviam parâmetros que poderiam ser associados com conceitos com significado empírico, como energia ou comprimentos de onda. $\mathrm{O}$ que se fazia necessário, então, além da possibilidade de novas regras de correspondência para os termos de nível primário, era principalmente um princípio explicativo ou um modelo unificador. Ambos os objetivos poderiam ser atingidos, mostrando que o formalismo F da Mecânica Ondulatória de Schrödinger poderia ser visto como sendo parte de um formalismo $\mathrm{F}^{*}$ de outra teoria $\mathrm{T}^{*}$, a qual seria interpretada de forma completa. Esse foi o método que Schrödinger seguiu na tentativa de proporcionar uma interpretação satisfatória ao formalismo da MQ (Jammer, 1974, pp. 2224).

Então, já na terceira comunicação do seu artigo histórico, Schrödinger se refere à função $\Psi$ como um campo mecânico escalar e, considerando o fato de que o sistema que 
ele estava discutindo na ocasião era o átomo de $\mathrm{H}$, o qual emite ondas eletromagnéticas, cuja frequência é igual à diferença de dois valores característicos dividida por $\mathrm{h}$, e para que fosse possível derivar as intensidades e polarizações das ondas consistentemente, Schrödinger pensou ser necessário atribuir um significado eletromagnético à função de onda $\Psi$. Em março de 1926, Schrödinger propõe a primeira correlação epistêmica entre o novo formalismo da MQ em termos da função de onda $\Psi$ e uma interpretação completamente operacionalizada da teoria clássica da radiação eletromagnética. No entanto, por conta da expressão referente à densidade de carga consistir da parte real de uma função imaginária, Schrödinger não pôde relacioná-la a um elemento da descrição do cenário físico, apesar dele estar convencido de que ela representava algo existente na realidade física. Nos desenvolvimentos posteriores da interpretação eletromagnética do seu formalismo, Schrödinger obtém resultados consistentes para os efeitos Zeeman e Stark para o átomo de $\mathrm{H}$ e para o caso geral das amplitudes de radiação para sistemas de $\mathrm{n}$ partículas e para as densidades de carga elétrica, representados como produtos de ondas. Esses sucessos levaram Schrödinger a interpretar a TQ como sendo simplesmente uma teoria clássica ondulatória, de tal forma que, na sua visão, a realidade física consistia de ondas apenas. Assim, ele rejeitou categoricamente a existência de níveis de energia discretos e saltos quânticos, argumentando que, na Mecânica Ondulatória, os autovalores discretos são autofrequências das ondas, mais do que energias. Uma justificativa para a sua rejeição do conceito de energia na microfísica foi dada em uma carta a Planck, em maio de 1926, onde ele escreve: “O conceito de 'energia' é algo que nós derivamos da experiência macroscópica e somente dessa experiência. Eu não acredito que ela possa ser assumida para a mecânica microscópica dessa forma, para falar de uma única oscilação parcial. A propriedade energética de uma oscilação parcial individual é a sua frequência" (Jammer, 1974, p. 29). Schrödinger nunca mudou esse ponto de vista. Três anos antes da sua morte, ele escreve um artigo intitulado "A energia pode ser considerada um conceito meramente estatístico?", no qual ele argumenta que a energia, assim como a entropia, possui um significado meramente estatístico e que o produto $h v$ para sistemas microscópicos não possui o significado macroscópico de energia (Jammer, 1974, pp. 2429).

Além disso, já desde a segunda comunicação do seu artigo histórico, Schrödinger tentou explicar como uma concepção puramente ondulatória da realidade física poderia 
dar conta da fenomenologia de partículas na Física, a qual ele enunciou em termos de pacotes de onda. Esses pacotes seriam grupos concisos de ondas moduladas, os quais não se espalhariam no espaço ao longo do tempo e, uma vez que o comprimento das ondas seria muito pequeno comparado com a largura da sua modulação, esses pacotes teriam a aparência de partículas pontuais. Assim, ele poderia sustentar a sua concepção de que a teoria ondulatória poderia ser estendida para dar conta, em termos de frequências e amplitudes, de todos os fenômenos quânticos conhecidos, incluindo aqueles que se eram considerados parte da Física de partículas, como o efeito Compton, por exemplo. Contudo, essa explicação só foi completamente estruturada em um artigo publicado antes da sua quarta comunicação histórica, intitulado "Sobre a transição contínua da mecânica micro para a mecânica macroscópica”, no qual ele apresentou as suas ideias sobre esse assunto, mostrando que o comportamento fenomenológico do oscilador harmônico linear pode ser completamente explicado em termos de autofunções ondulatórias da equação diferencial correspondente (Jammer, 1974, pp. 29-30).

Apesar de se apresentar como uma interpretação mais "natural" e "intuitiva" para a MQ, a proposta de Schrödinger enfrentou sérias dificuldades. Lorentz, em uma carta endereçada ao físico austríaco, por exemplo, expressou a sua preferência pela Mecânica Ondulatória em relação à matricial para sistemas de uma única partícula, por conta da sua "maior clareza intuitiva", no entanto, ele pontua que o pacote de onda que, ao se mover com uma velocidade de grupo, deveria representar uma "partícula", na sua concepção, “não poderia jamais permanecer unido e confinado a um pequeno volume ao longo de sua trajetória. A menor dispersão proveniente do meio poderia separá-lo na direção de propagação e, mesmo sem essa dispersão, ele sempre se espalhará cada vez mais ao longo da direção transversal. Por conta dessa inevitável dispersão, o pacote de ondas não parece ser muito apropriado para representar objetos, os quais nós queremos descrever como possuindo uma existência individual permanente" (Jammer, 1974, p. 31). Ainda assim, em uma carta direcionada a Planck, Schrödinger, após finalizar os seus cálculos a respeito do comportamento do pacote de onda como uma partícula, apresenta as suas expectativas: “eu acredito que seja apenas uma questão de desenvolvimento computacional para que seja possível conseguir as mesmas realizações para o elétron no átomo de H. A transição das oscilações microscópicas características para as 'órbitas' macroscópicas da MC será claramente visível e conclusões valiosas poderão ser tiradas sobre as relações de fase das 
oscilações correspondentes". Contudo, o otimismo exagerado de Schrödinger logo ficou evidente com a publicação do Princípio da Incerteza. Nessa ocasião, Heisenberg apontou que, caso as afirmações de Schrödinger estivessem corretas, "a radiação emitida por um átomo poderia ser expandida em uma série de Fourier, na qual as frequências dos harmônicos seriam múltiplos inteiros da frequência fundamental. No entanto, as frequências das linhas espectrais atômicas nunca são múltiplos dessa frequência, com exceção do caso especial do oscilador harmônico". Uma segunda dificuldade, não menos importante do que a primeira, da descrição ondulatória da realidade física, se refere à dimensão do espaço de configurações de $\Psi$. Essa dificuldade foi apontada por Lorentz e se deve ao fato de que, para um sistema de n partículas, a função de onda $\Psi$ se torna uma função de $3 n$ coordenadas de posição, o que requer uma representação em um espaço de 3n dimensões. Outras dificuldades que a interpretação realista da função de onda enfrentaria e que não estavam completamente claras na época são: (1) $\Psi$ é uma função complexa; (2) $\Psi$ sofre uma mudança descontínua durante o processo de medição; e (3) $\Psi$ depende do conjunto de observáveis escolhidos para a sua representação, por exemplo, sua representação no espaço dos momentos difere completamente da sua representação no espaço das posições. A primeira dessas últimas três dificuldades poderia, em princípio, ser resolvida pensando-se que toda função complexa é equivalente a um par de funções reais. Contudo, a necessidade das fases complexas para a explicação dos fenômenos de interferência em MQ ficou evidente quando Born propôs a sua interpretação probabilista da função $\Psi$. A segunda dificuldade seria muito debatida posteriormente e daria origem ao termo "redução do pacote de ondas", para descrever essa mudança abrupta de $\Psi$ para uma nova configuração. A discussão desse problema seria a vanguarda dos estudos de fundamentos, principalmente após o desenvolvimento de uma teoria da medição em MQ. Finalmente, a dependência de $\Psi$ com relação à representação foi uma consequência da teoria da transformação de Dirac-Jordan, a qual foi um desenvolvimento dos próprios resultados de Schrödinger (Jammer, 1974, pp. 31-33).

\subsubsection{Interpretação hidrodinâmica}

Enquanto a interpretação de Schrödinger para a MQ encontrava suporte principalmente na analogia com os fenômenos ondulatórios, a semelhança da equação de onda e suas implicações com as equações da hidrodinâmica formou a base para outra 
tentativa de dar conta dos fenômenos quânticos em termos de um modelo clássico contínuo: as interpretações hidrodinâmicas. A primeira interpretação hidrodinâmica foi proposta em 1926, por Erwin Madelung, professor de física teórica na Universidade de Frankfurt-am-Main, na qual ele, a partir da equação de Schrödinger, deriva uma equação com uma estrutura similar à equação da continuidade da hidrodinâmica e outras que permitem interpretar a evolução do sistema como um processo de fluxo hidrodinâmico, de tal forma que ele consegue formular uma interpretação tão intuitiva quanto a Interpretação Ondulatória. Assim, Madelung afirma que "aparentemente, o atual problema sobre os quanta encontrou a sua solução na hidrodinâmica da eletricidade continuamente distribuída com a densidade de massa sendo proporcional à densidade de carga", no entanto, ele admite, nessa ocasião, que nem todas as dificuldades puderam ser removidas. A primeira dificuldade dessa interpretação é que a expressão derivada para a energia total do sistema dependia apenas da densidade de carga local, enquanto ela deveria depender a distribuição de carga total. Além disso, ela não conseguia explicar os processos de absorção da radiação de forma satisfatória. Outra complicação de ordem conceitual dessa interpretação, que não foi mencionada por Madelung, se refere à tentativa de reduzir a Física atômica a uma teoria hidrodinâmica de um fluido não viscoso e não rotacional se movendo sob a ação de forças conservativas. Essa teoria baseada em uma noção idealizada de um fluido contínuo não poderia nunca ser aplicada de forma estrita a um fluido real, que seria o conjunto de moléculas discretas. Ou seja, incoerentemente, uma teoria que deliberadamente despreza a atomicidade estaria sendo utilizada para descrever o comportamento de átomos (Jammer, 1974, pp. 33-36).

Outras teorias hidrodinâmicas para a MQ foram propostas por Isakson, da Universidade Politécnica de São Petersburgo, e por Arthur Korn, da Universidade Técnica de Berlim. Logo após a publicação de Madelung, Isakson investigou sobre quais outras hipóteses a equação de Hamilton-Jacobi da MC levaria a equação de Schrödinger e, generalizando o tratamento para movimentos relativísticos, chegou a uma formulação que sugeria uma interpretação hidrodinâmica. No entanto, ele se deteve em comparar as suas conclusões com as de Madelung e se limitou a analisar os aspectos puramente matemáticos envolvidos. Korn, por outro lado, já havia publicado, em 1892, uma teoria hidrodinâmica da gravitação e da eletricidade, a qual ele posteriormente estendeu para a ótica e para a espectroscopia. Então, em 1927, ele propõe que a Mecânica Ondulatória de 
Schrödinger deveria ser interpretada como uma teoria hidrodinâmica de um fluido viscoso e compressível, chegando a uma formulação semelhante à de Madelung, sem citá-lo. A sua interpretação também enfrentava dificuldades, entre as quais, a inconsistência de que, para explicar os fenômenos eletromagnéticos, supõe-se que esse fluido seja incompressível, enquanto que a explicação proposta para dar conta dos fenômenos quânticos requer a sua compressibilidade (Jammer, 1974, pp. 36-38).

As tentativas em interpretar a MQ em termos de modelos hidrodinâmicos não ficaram restritas aos estágios iniciais de desenvolvimento dessa teoria. Posteriormente, houveram diversas propostas nesse sentido, entre elas, a de Oscar Buneman que, nos anos 1950, em uma série de artigos não publicados e nas suas aulas na Universidade de Cambridge, propôs modelos hidrodinâmicos para as nuvens de elétrons dos átomos e para os átomos em si e, mais adiante, desenvolveu sua concepção de "modelos de plasma". Também houveram extensões do modelo hidrodinâmico de Madelung, nos anos 1950, por Takehiko Takabayasi, no Japão, e por Mario Schenberg, no Brasil. Takabayasi faz referência a flutuações complicadas em um movimento a velocidade constante, a partir do qual ele explica como, devido ao potencial quântico, as trajetórias desviam das previstas classicamente. Já Schenberg recorre a um meio turbulento para essencialmente o mesmo propósito. Assim, ambos introduzem noções que ligam os modelos hidrodinâmicos deles com interpretações estocásticas. O mesmo se aplica à interpretação hidrodinâmica proposta por David Bohm e Jean-Pierre Vigier que, em seu modelo, propõem inomogeneidades em um fluido conservativo, que se comportariam como partículas e que estariam submetidas a perturbações aleatórias provenientes da interação de partículas com o meio subquântico. Ao postular esse meio, assumido como sendo completamente caótico, que escaparia à observação experimental e que estaria presente em todo lugar do espaço, Bohm e Vigier reavivem em alguma medida, uma concepção já desacreditada de éter. Outras investigações acerca do modelo hidrodinâmico foram realizadas por Lajos Janossy e Maria Ziegler-Naray, no Instituto Central de Pesquisas em Física de Budapest, na Hungria, onde eles mostram que a interpretação hidrodinâmica poderia ser estendida para o caso de uma partícula carregada se movendo sob a influência de um campo eletromagnético. Outras interpretações hidrodinâmicas para a MQ também foram desenvolvidas por H. P. Harjes, Ludwig G. Wallner (Jammer, 1974, pp. 49-52). 
Diante das semelhanças entre os formalismos das Interpretações Ondulatória e Hidrodinâmica, algumas pessoas poderiam ficar tentadas a argumentar que elas são, em última instância, idênticas ou ao menos equivalentes, já que elas se referem às mesmas relações matemáticas - no caso, a equação de Schrödinger. Contudo, apesar dessas semelhanças, que existem por elas partirem do mesmo ponto, elas devem ser vistas como sendo fundamentalmente diferentes: de acordo com Schrödinger, somente a função de onda $\Psi$ possui uma realidade física, já para Madelung, as entidades hidrodinâmicas é que correspondem a essa realidade (Jammer, 1974, p. 54).

\subsubsection{Interpretação da Complementaridade}

A Interpretação da Complementaridade irá surgir principalmente das discussões entre Bohr e Heisenberg, no final de 1926. Nesse período, Heisenberg morava no último andar do Instituto Niels Bohr e frequentemente era visitado por Bohr a altas horas da noite, a fim de discutir e entender melhor o problema da interpretação da MQ, o qual era a grande preocupação dos dois físicos. Em meio a essas discussões, logo ficaria clara a divergência de posições entre ambos: Heisenberg defendia que tanto a linguagem corpuscular quanto a linguagem ondulatória seriam satisfatórias para descrever os objetos quânticos, Bohr, por outro lado, insistia que ambas as linguagens, apesar de mutuamente exclusivas, eram necessárias para a descrição completa desses objetos. Então, em fevereiro de 1927, quando Bohr foi esquiar na Noruega, a separação momentânea entre os dois permitiu com que cada um desenvolvesse a sua interpretação, assim, Heisenberg formulou o seu Princípio da Incerteza e Bohr o seu Princípio da Complementaridade. Enquanto a formulação de Heisenberg baseava a definição de grandezas físicas em sua mensurabilidade, Bohr partia da definibilidade dessas grandezas, argumentando que grandezas complementares não podem ser definidas de maneira simultânea (Pessoa, 2003, p. 91).

Bohr apresentou suas ideias publicamente pela primeira vez, em setembro de 1927, no Congresso Internacional de Física em homenagem ao centenário da morte de Alessandro Volta, realizado na cidade italiana de Como, em uma palestra intitulada "O postulado quântico e o recente desenvolvimento da teoria atômica", na qual ele parte de uma comparação entre a descrição clássica - de acordo com a qual os fenômenos físicos podem ser observados sem sofrerem perturbações essenciais - e a descrição quântica, 
sujeita ao postulado quântico - de acordo com o qual todo processo atômico é caracterizado por uma descontinuidade essencial (Jammer, 1974, p. 86). Em suas palavras:

\begin{abstract}
Por um lado, a definição do estado de um sistema físico, como normalmente entendido, reivindica a eliminação de todos os distúrbios externos. Porém, nesse caso, de acordo com o postulado quântico, qualquer observação seria impossível e, acima de tudo, os conceitos de espaço e tempo perderiam o seu senso imediato. Por outro lado, para tornar uma observação possível, nós permitimos certas interações com agentes de medida adequados, não pertencentes ao sistema, de tal maneira que uma definição não ambígua do estado do sistema não será mais possível de forma natural, e não poderá mais haver causalidade no sentido usual da palavra. Assim, a natureza da TQ nos força a olhar para a coordenação espaço-tempo e a reivindicação de causalidade, cuja união caracteriza as teorias clássicas, como características complementares, porém exclusivas da descrição, simbolizando a idealização da observação e da definição, respectivamente (Bohr, 1927 apud Jammer, 1974, p. 87, tradução livre).
\end{abstract}

Essa afirmação, na qual Bohr introduz o termo "complementar" pela primeira vez, fazendo referência à "coordenação espaço-tempo" e à "reivindicação de causalidade" como sendo complementares uma à outra, contém a essência da versão inicial do que posteriormente ficaria conhecida como "Interpretação da Complementaridade" ou "Interpretação de Copenhagen" da MQ. É importante ressaltar, contudo, que a Interpretação da Complementaridade não é um conjunto de ideias único, rígido e bem definido, mas apenas um denominador comum para uma variedade de pontos de vista correlatos. Tampouco está relacionada com uma posição filosófica ou ideológica específica, ela foi defendida e propagada por adeptos das mais divergentes concepções filosóficas, variando desde o idealismo puro, passando pelo realismo crítico, pelo positivismo até o materialismo dialético (Jammer, 1974, p. 87). Além disso, esse ponto de vista não ficou confinado a uma interpretação da FQ, mas chegou a ser aplicado para outras áreas além da Física, como a questões biológicas, de psicologia, e questões culturais em geral. O próprio Bohr no Congresso Internacional de Ciências Antropológicas e Etnológicas, em 1938, defendeu que as emoções e percepções possuem uma relação complementar análoga às situações das medidas na Física atômica. Outros físicos associados à Escola de Copenhagen foram mais longe, como Jordan, por exemplo, que extrapolou a complementaridade para áreas como a psicologia, filosofia e biologia de uma forma tão exagerada que Bohr teve que vir a público e enfatizar que o conceito de 
complementaridade não tinha relação alguma com vitalismo e que não poderia ser utilizado para defender o antirracionalismo ou o solipsismo. A interpretação extrema de Jordan do processo de medição incluía a hipótese de que as observações não apenas perturbariam a quantidade medida, mas literalmente a produziriam (Kragh, 1999, p. 210).

Concentrando-nos, contudo, no conceito de complementaridade tal qual apresentado por Bohr, é importante pontuar que o físico dinamarquês nunca formulou uma definição explícita e rígida do termo "complementaridade". Dentre as suas afirmações, a mais próxima de uma definição foi feita em 1929, quando ele declara que o postulado quântico "nos força a adotar um novo modo de descrição designado como sendo complementar, no sentido de que qualquer aplicação dos conceitos clássicos impede o uso simultâneo de outros conceitos clássicos, os quais em conjunto são igualmente necessários para a elucidação dos fenômenos". Assim, de acordo com essa afirmação, modos de descrição ou descrições são complementares. Em outra ocasião, Bohr também afirma que "todo arranjo experimental que possibilita o registro de uma partícula atômica em um domínio limitado espaço-temporalmente requer unidades de medida fixadas e relógios sincronizados, os quais, a partir de sua própria definição, excluem o controle do momento e da energia transmitidos a eles. De modo inverso, qualquer aplicação não ambígua das leis dinâmicas de conservação na MQ requer que a descrição dos fenômenos envolva a renúncia do princípio de uma coordenação detalhada do espaço-tempo" (Jammer, 1974, pp. 95-96). Dessa forma, o termo "complementar" pode ser transferido para os modos de descrição associados com arranjos experimentais complementares, nos quais as descrições espaçotemporais e causais são complementares entre si. Por fim, o termo "complementar" também pode ser utilizado para os próprios parâmetros ou variáveis para os quais descrições complementares são formuladas, como, por exemplo, a coordenada posição e a variável momento são ditas complementares uma a outra. Essa última utilização do termo só pode ser feita, caso as variáveis sejam utilizadas em descrições correspondentes a arranjos experimentais complementares (Jammer, 1974, p. 97). Dessa forma, podemos distinguir três tipos de complementaridade na obra de Bohr: (1) complementaridade entre coordenação espaço-temporal e asserção da causalidade, a qual reconhece que um sistema isolado que conserva energia e momento satisfaz a causalidade, porém não pode ser observado e, portanto, não é possível associar uma posição espacial e um instante temporal a ele. Por outro lado, ao ser observado, um sistema passa a ter uma coordenação 
espaço-temporal, mas seu estado, após o processo de redução, não evoluiu a partir do estado anterior de acordo com a lei da causalidade. Posteriormente, contudo, Bohr abandona esse tipo de complementaridade, por ele fazer distinção entre observação e definição e ferir o princípio positivista de que só o que é observado é definível. (2) complementaridade entre partícula e onda, segundo a qual os aspectos ondulatório e corpuscular de um objeto quântico são revelados por arranjos experimentais mutuamente excludentes. Esse foi o tipo de complementaridade que Bohr passou a priorizar, especialmente após 1935. (3) complementaridade entre observáveis incompatíveis, como posição e momento, o qual difere do segundo tipo por considerar dois aspectos que são consistentes na FC e do primeiro tipo por não envolver uma oposição entre o observado e o não-observado (Pessoa, 2003, pp. 94-95). De acordo com Rosenfeld, um dos principais representantes da Escola de Copenhagen, a noção de complementaridade seria a resposta para a seguinte questão: o que fazemos quando somos confrontados com uma situação, na qual temos que utilizar dois conceitos mutuamente exclusivos ao mesmo tempo em que ambos são necessários para uma completa descrição dos fenômenos? Para ele, a “complementaridade denota uma relação de lógica, de um novo tipo, entre conceitos que são mutuamente exclusivos, e que, portanto, não podem ser considerados ao mesmo tempo - o que levaria a equívocos lógicos - mas que, não obstante, ambos devem ser utilizados a fim de fornecer uma descrição completa da situação" (Rosenfeld, 1961 apud Jammer, 1974, pp.104-105).

As primeiras formulações da Interpretação da Complementaridade continham diversas ambiguidades de vocabulário. De fato, foi provavelmente devido a essa vagueza em sua expressão e a flexibilidade conceitual que essa interpretação teve que sobreviver a sérias crises. Muitas dessas inconsistências se referiam às consequências epistemológicas e ontológicas envolvidas. Provavelmente a inconsistência mais séria se referia à explicação da "redução do pacote de onda" ou "ruptura" de descrição, conforme Bohr a denominava. Além de explicar essa característica com base na complementaridade, Bohr insistia em justificá-la pontuando que "toda observação introduz um novo elemento incontrolável", que "a magnitude do distúrbio causado pela medição é sempre desconhecida", e que "não podemos negligenciar a interação entre o objeto e o instrumento de observação". Essa “interferência com o curso dos fenômenos seria de uma natureza que nos privaria de fundamentar nossa descrição de modo causal", dessa forma, o indeterminismo na MQ não 
é visto como resultado de uma mudança de um cenário para o seu modo complementar, mas como resultado de uma característica operacional física. Foi justamente essa insistência em uma explicação operacional para a "redução do pacote de onda" que tornou a interpretação de Bohr mais vulnerável. Outra dificuldade conceitual da interpretação bohriana se refere a não obtenção de valores exatos para o conjunto das variáveis posição e momento de um objeto microscópico através da retrodição. Essa possibilidade foi admitida por Bohr em sua exposição em Como, onde ele afirmou que "a posição de um objeto individual em dois dados momentos pode ser medida com qualquer grau de precisão desejada, porém se, a partir dessa medida, queremos calcular a velocidade desse objeto da forma usual, deve-se ter consciência de que estamos lidando com uma abstração, a partir da qual não é possível obter uma informação não ambígua. Heisenberg, ao discutir um experimento de pensamento sobre o assunto acrescenta que "é uma questão de crença pessoal se para esse cálculo a respeito da história passada do elétron pode ser atribuída qualquer realidade física ou não". Outra dificuldade enfrentada pela Interpretação da Complementaridade se refere à conclusão de Bohr sobre o papel das medidas em MQ, o que frequentemente é citado como uma prova de que essa seria uma interpretação baseada no idealismo intersubjetivista. Ao se referir ao fato de que uma medida subsequente proíbe, em certo grau, o acesso a informação obtida através de uma medida prévia pelo seu significado preditivo, Bohr conclui que esses fatos "não apenas estabelecem um limite para a extensão da informação obtida por uma medida, como também estabelecem um limite para o significado que podemos atribuir a essa informação. Deparamo-nos aqui, sob uma nova forma, com a velha verdade de que, na nossa descrição da natureza, o propósito não é desvelar a real essência dos fenômenos, mas apenas rastrear, na medida do possível, as relações entre os diversos aspectos da nossa experiência" (Bohr, 1934 apud Jammer, 1974, p. 100). Por fim, Bohr também percebeu bem cedo que a sua Interpretação da Complementaridade pressupunha a necessidade do uso da terminologia clássica. Nos seus primeiros escritos, ele afirma que "apenas com a ajuda das ideias clássicas é possível prescrever um significado livre de ambiguidades para os resultados da observação”. Para Bohr, a necessidade de utilizar a linguagem da FC para discutir os fatos observacionais, se devia a nossa inabilidade de renunciar às formas usuais da nossa percepção, isso também torna improvável que as noções fundamentais da FC possam ser algum dia abandonadas para a descrição da experiência física (Jammer, 1974, pp. 98-100). Além disso, com a 
publicação do paradoxo EPR, em 1935, Bohr foi obrigado a refinar a sua interpretação e tornar mais explícita a complementaridade de arranjos experimentais. Assim, Bohr passou a dar ênfase ao "todo" do arranjo experimental, em sua definição do "fenômeno" quântico. De acordo com ele, “a lição essencial da análise de medições na TQ é pois a ênfase na necessidade, para dar conta do fenômeno, de levar em consideração o arranjo experimental como um todo, em completa conformidade com o fato de que toda interpretação não ambígua do formalismo quântico envolve a fixação das condições externas" (Bohr, 1939 apud Pessoa, 2003, p. 95).

As principais teses da Interpretação da Complementaridade podem ser resumidas através de uma síntese das visões de Bohr, Heisenberg, Pauli, Born, Dirac, Rosenfeld e outros considerados parte da chamada Escola de Copenhagen, as quais seriam (Pessoa, 2003, pp. 97-98):

1) Postulado Quântico: existe uma descontinuidade essencial na absorção e emissão de radiação pela matéria, inclusive no processo de medição. Tais processos acontecem em quanta de energia discretizados e de localização bem definida.

2) Linguagem Clássica: só é possível ter acesso ao mundo microscópico através de aparelhos macroscópicos, e a descrição da aparelhagem experimental e dos resultados das medições só pode ser feita na linguagem da FC.

3) Distúrbio interacional: como consequência do postulado quântico, é impossível controlar os distúrbios provocados no objeto microscópico pela interação com o aparelho de medição.

4) Positivismo: A TQ só trata das observações (ou medições) de objetos microscópicos, de forma que não faz sentido referir-nos a uma realidade independente do sujeito (observador).

5) Totalidade: para dar conta do fenômeno quântico, é preciso considerar não só o objeto quântico, mas também todo o aparelho experimental, incluindo partes localizadas à distância.

6) Complementaridade (dualidade onda-partícula): um experimento pode ser compreendido em um quadro corpuscular, ou em um quadro ondulatório, mas nunca nos 
dois ao mesmo tempo. Ou seja, se houver padrões de interferência, não pode haver inferência sobre trajetórias (retrodição), e vice-versa. Além dessa "exclusão mútua", essas duas descrições "exaurem” a descrição do objeto.

7) Grandezas incompatíveis: não é possível medir simultaneamente grandezas incompatíveis entre si, como posição e momento. Não faz sentido atribuir simultaneamente valores bem definidos para essas grandezas.

8) Quebra do determinismo: não faz sentido defender o determinismo no mundo microscópico. A imprevisibilidade observada em experimentos quânticos é expressa no formalismo pelo fato de que apenas podemos calcular probabilidades. As probabilidades são inelimináveis, não devendo ser interpretadas de forma meramente epistêmica.

9) Completeza: A descrição quântica, mesmo para objetos individuais é completa. Não faz sentido postular variáveis ocultas, dado que sua postulação não traz nenhuma previsão nova.

10) Simetria de representação: é igualmente aceitável representar um sistema nas representações de posição ou de momento. Nenhum observável tem privilégio ontológico, ao contrário do que ocorre na teoria da onda piloto, que privilegia a representação espacial.

No entanto, conforme mencionado anteriormente, a Interpretação da Complementaridade não pode ser vista como um bloco monolítico de visões, houveram algumas nuanças nas visões de seus defensores. Heisenberg, nos anos 1950, por exemplo, sem abandonar a noção de complementaridade, passou a defender que a função de onda $\Psi$ exprime uma potencialidade, no sentido aristotélico, relacionada a uma probabilidade "objetiva" que independe do estado de conhecimento do observador. Esta posição se aproxima da interpretação ondulatória sem, talvez, interpretar $\Psi$ de maneira tão literal. A respeito dos "saltos quânticos", da transição do "possível" ao "real", que ocorre durante o ato de observação, Heisenberg enfatizou que ela "toma lugar tão logo a interação do objeto com o instrumento de medida (e, portanto, com o resto do mundo) tenha se realizado; assim, ele nada tem a ver com o ato de registrar o resultado por parte da mente do observador" (Heisenberg, 1958 apud Pessoa, 2003, p. 96). Dessa forma, Heisenberg esclarece a sua interpretação para o colapso de $\Psi$, ao mesmo tempo em que ataca a 
solução subjetivista ao problema da medição, defendida por von Neumann, London e Bauer, entre outros. Porém, Heisenberg interpreta $\Psi$ de forma epistêmica e não deixa claro se as potencialidades seriam objetivas ou não, ao afirmar que "a mudança descontínua na função de probabilidade tem lugar com o ato de registro, pois é essa mudança descontínua do nosso conhecimento, no instante do registro, que tem por imagem a mudança descontínua da função de probabilidade" (Heisenberg, 1958 apud Pessoa, 2003, p. 97). Max Born também desenvolve uma visão que apresenta nuanças em relação aos outros membros da Escola de Copenhagen, ao flertar com a ideia da existência de uma espécie de "realidade intermediária", ao afirmar que "a questão de se as ondas são algo 'real' ou uma ficção para descrever e prever fenômenos de maneira conveniente é uma questão de gosto. Eu pessoalmente gosto de considerar uma onda de probabilidade, mesmo no espaço $3 \mathrm{~N}$-dimensional, como uma coisa real, como certamente mais do que um instrumento para cálculos matemáticos. Pois ela tem a característica de um invariante de observação" (Born, 1949 apud Pessoa, 2003, p. 97).

Diversos fatores favoreceram a popularização da Interpretação da Complementaridade, entre meados dos anos 1920 e 1930, e a culminação na chamada "monocracia da Escola de Copenhagen”, entre os anos 1930 e o final dos anos 1940, o que fez com que essa interpretação ficasse conhecida como "interpretação ortodoxa". Entre esses fatores estava a prova de impossibilidade de von Neumann, a qual foi considerada pela maioria dos físicos como uma confirmação das ideias de Bohr. Somente nos anos 1950 é que o contexto histórico-social da Guerra Fria iria favorecer o desenvolvimento de abordagens alternativas à interpretação ortodoxa e faria com que, posteriormente, essa interpretação fosse reconhecida como apenas mais uma das interpretações da FQ. Os fatores desse contexto que influenciaram no advento dessas interpretações foram principalmente a postura pragmática dos físicos americanos, que não favorecia uma análise filosófica mais aprofundada da proposta da Escola de Copenhagen e a filosofia marxista na URSS, onde as ideias de Bohr eram acusadas de promover tendências idealistas na ciência e foram praticamente banidas.

\subsubsection{Interpretação causal de de Broglie-Bohm}

Louis de Broglie era historiador de formação, porém, começa a se interessar pela Física, particularmente pela FQ e pela relatividade, através do contato com os fenômenos 
envolvendo os quanta de luz no laboratório particular de espectroscopia de difração de raios-X do seu irmão, o físico Maurice de Broglie. Em 1913, Louis de Broglie obtém o título de Licenciado em Ciências e, após a Primeira Guerra Mundial, quando teve que prestar serviços militares, passa a se dedicar a estudos experimentais com raios-X em colaboração com seu irmão. Seus primeiros trabalhos envolvendo os quanta de luz foram publicados em 1922, porém, somente em 1923, é que ele tenta fazer uma síntese entre as teorias ondulatória e corpuscular da luz, estendendo para partículas materiais a dualidade onda-partícula que Einstein havia proposto para a luz, em 1905, e postulando a existência de ondas de matéria. Assim, os seus trabalhos de 1923 constituíram a base para a elaboração da sua tese de doutorado, que constituiria um marco na história da TQ, intitulada "Pesquisas sobre a teoria dos quanta", a qual foi defendida em 1924, na Universidade de Paris-Sorbonne, sob a orientação de Paul Langevin. Contudo, ao se referir a essa tese, a maioria dos físicos lembra apenas do fato que ela atribui um comportamento ondulatório a uma partícula material e pouca atenção é dada ao desenvolvimento que ela faz de uma nova dinâmica, na qual a velocidade de uma partícula seria determinada por ondas-guia. Esta nova dinâmica se baseava na unificação dos princípios variacionais de Maupertuis e Fermat para produzir uma teoria capaz de sintetizar os dois conceitos aparentemente contraditórios de onda e partícula (Santos, 2011).

A ideia de associar ondas às partículas, posteriormente, iria influenciar na formulação da Mecânica Ondulatória de Schrödinger, porém, para de Broglie, o formalismo desenvolvido pelo físico austríaco, além de não ser capaz de dar conta de fenômenos individuais, era muito abstrato por considerar uma função de onda $\Psi$ propagando-se em um espaço de configurações de 3N dimensões. Então, em 1926, de Broglie publica o artigo intitulado "A mecânica ondulatória e a estrutura atômica da matéria e da radiação", onde apresenta pela primeira vez o que ele chama de "princípio da dupla solução", o qual consistia em considerar que a equação de propagação das ondas de matéria deveria admitir duas soluções, uma onda $\Psi$, de caráter probabilístico, responsável por descrever o comportamento de um feixe de partículas, e uma onda-u que, por conter uma singularidade, seria responsável por descrever cada partícula individualmente. No entanto, devido às dificuldades matemáticas em provar a existência das duas ondas e a relação entre elas, ao final de seu artigo, de Broglie propõe uma versão simplificada, a qual 
denomina "teoria da onda piloto", onde assume a existência da partícula material e da onda contínua, representada por $\Psi$, como possuindo realidades distintas, e postula que o movimento da partícula é determinado como uma função da fase da onda $\Psi$, através de sua fórmula-guia, ou seja, a onda contínua seria responsável por dirigir o movimento da partícula: ela seria uma onda-piloto (Santos, 2011).

Sendo assim, podemos identificar duas versões da teoria de de Broglie: (1) a primeira, mais sofisticada, seria a teoria da dupla solução, de acordo com a qual a equação de Schrödinger apresenta dois tipos de soluções: a função de onda $\Psi$, que fornece apenas informação estatística, e uma solução envolvendo singularidades, que representa a estrutura discreta da matéria e da radiação. A onda $\Psi$ seria "fictícia", ao passo que a onda de singularidade descreveria a "realidade física" sem sofrer colapsos, e ambas estariam ligadas pelo que de Broglie chamou de "postulado da concordância de fases", segundo o qual, ambas teriam a mesma fase em qualquer ponto do espaço-tempo. Contudo, na época de sua publicação, de Broglie considerou essa abordagem incompleta, por conseguir prová-la apenas para o caso da ausência de campos (partícula livre). (2) Já a sua teoria da onda piloto seria uma atitude provisória para a falta de uma justificativa mais completa para as suas hipóteses. Ela admitia a existência, enquanto realidades distintas, tanto de um ponto material, quanto de uma onda contínua representada pela função $\Psi$, que guiaria o movimento da partícula (Pessoa, 2006b, p. 233).

Os principais resultados de sua formulação foram a "fórmula de guiamento", que exprimia a velocidade com que a partícula era guiada pela onda, e o potencial quântico, que exprimia o guiamento que a onda-piloto exerce sobre a partícula (Pessoa, 2006b, pp. 233-234). Apesar da elegância e da visualização de sua abordagem, após uma série de críticas recebidas em uma apresentação das suas ideias no $5^{\circ}$ Congresso da Solvay, em 1927, principalmente por parte de Pauli, de Broglie foi levado a abandonar sua interpretação. Então, em 1928, ao ser indicado para professor na Faculdade de Ciências de Paris, de Broglie resolve abandonar a sua teoria e passa a trabalhar dentro do quadro da interpretação ortodoxa, pois considerou que não podia ensinar um ponto de vista que não tinha condições de justificar (Santos, 2011). As principais razões para esse abandono foram que o físico francês concluiu que a função de onda $\Psi$ não corresponde a uma realidade física, pois ela é descrita por meio de números complexos, não se propaga no 
espaço físico, mas em um espaço de configurações e sofre colapsos instantâneos. Como ela não correspondia a uma realidade física, ela seria somente a representação de uma probabilidade, no sentido clássico, mas, nesse caso, a teoria da onda-piloto se distanciaria ainda mais da FC, pois teríamos que admitir que o movimento de um corpúsculo seria determinado por movimentos possíveis que não se realizam. Além dessas dificuldades, nos anos seguintes, essa interpretação teria que enfrentar pelo menos dois problemas adicionais: a prova de impossibilidade de von Neumann e um tratamento adequado para o paradoxo EPR (Pessoa, 2006b, p. 235).

Somente após 25 anos de abandono, é que o dualismo realista de Louis de Broglie seria redescoberto e desenvolvido pelo norte-americano David Bohm. Bohm era candidato a $\mathrm{PhD}$ em Berkeley, durante a época da Segunda Guerra Mundial, sob a supervisão de Robert Oppenheimer, quando este já estava envolvido com o Projeto Manhattan. Em 1943, ele se torna membro do Partido Comunista e, por conta disso, passa por diversas dificuldades em sua carreira, sendo alvo de perseguição política na era do Macarthismo, durante a Guerra Fria. Diante dessa perseguição, ele opta por uma vida de exílio no Brasil, seguido de Israel e Inglaterra, seu passaporte chega a ser confiscado pelo governo norteamericano, e culmina na revogação da sua cidadania. Ao mesmo tempo em que alguns cientistas na URSS criticavam a Interpretação da Complementaridade por a considerarem idealista, eles não apoiaram o esforço de Bohm para a recuperação do determinismo, o que acabou frustrando-o. A promessa de Bohm de generalizar a sua abordagem para o domínio relativístico também não conseguiu ser realizada. Esses, entre outros fatores, levaram Bohm a mudar completamente suas inclinações intelectuais no final dos anos 1950, quando ele rompe com o marxismo, abandona a sua interpretação causal, se aproxima do pensamento oriental e começa o seu projeto de longa data de reformar a Física em torno dos temas de ordem e totalidade (Freire Jr, 2015, p. 17). Apesar de todas essas dificuldades, a interpretação causal de Bohm contribuiu fortemente com o desenvolvimento das pesquisas em Fundamentos da MQ, principalmente por instigar um exame mais aprofundado da prova de impossibilidade de von Neumann - justamente por consistir de um contraexemplo dessa prova - e por influenciar na elaboração posterior dos trabalhos de John Bell. 
$\mathrm{O}$ artigo em que Bohm apresenta a sua interpretação causal foi organizado em duas partes e publicado em 1952, na prestigiosa revista Physical Review, sob o título "Uma sugestão de interpretação da teoria quântica em termos de variáveis 'ocultas"”. Diferentemente dos outros críticos da MQ, a proposta de Bohm não só expressava as suas esperanças de retomar uma espécie de determinismo análogo ao da MC, através de uma descrição causal para os fenômenos atômicos, mas ele construiu de fato um modelo que assumia um objeto, como um elétron, é uma partícula com uma trajetória bem definida, o que significava que esse objeto possuía simultaneamente tanto uma posição como um momento bem definidos (Freire Jr, 2015, p. 21). Devido às suas suposições no âmbito da Física, o trabalho de Bohm possuía sérias implicações filosóficas, de acordo com ele:

Essa interpretação alternativa nos permite conceber cada sistema individual como estando em um estado precisamente definido, cujas mudanças com o tempo são determinadas por leis bem definidas, análogas (mas não idênticas) às equações clássicas do movimento. As probabilidades da MQ são vistas (como na mecânica estatística clássica) apenas como uma necessidade prática e não como a manifestação de uma carência inerente de uma determinação completa das propriedades da matéria no nível quântico (Bohm, 1952, p. 166, tradução livre).

Bohm conclui o seu artigo criticando a interpretação usual da MQ em termos filosóficos, acusando-a de ser guiada em grande parte "pelo princípio de não postular a possível existência de entidades que não podem ser observadas no momento", ou seja, por um "positivismo" ou "empiricismo". Ele ainda acrescenta que "a história da pesquisa científica é cheia de exemplos nos quais foi muito frutífero assumir que certos objetos ou elementos pudessem ser reais, muito antes que qualquer procedimento conhecido permitisse que eles fossem observados diretamente". Assim, as implicações filosóficas da proposta de Bohm se referiam não apenas à retomada do determinismo como um modo de descrição dos fenômenos físicos, mas também a adoção de um ponto de vista realista para com as teorias físicas, ambas descartadas pela Interpretação da Complementaridade (Freire Jr, 2015, p. 22).

Ao escrever a primeira parte do seu artigo, Bohm ainda não tinha conhecimento da abordagem similar feita anteriormente por de Broglie, até ele receber as críticas por parte de Pauli. Então, para responder a essas velhas críticas, ele escreve a segunda parte de seu artigo, onde apresenta uma teoria da medição em conformidade com sua interpretação 
dualista realista. Em sua interpretação, as variáveis ocultas seriam a posição e o momento das partículas e as medições seriam capazes de revelar as posições pré-existentes das mesmas, contudo, as medições de outros observáveis, como o momento, por exemplo, não seriam fidedignas. $\mathrm{O}$ grande avanço da teoria de Bohm em relação à de de Broglie foi o de ter levado em consideração as variáveis ocultas do aparelho de medição, ou do contexto experimental, postura conhecida como "contextualismo". Essa consideração, juntamente com o caráter não-local de sua interpretação, permitiram com que Bohm escapasse da prova de impossibilidade de von Neumann (Pessoa, 2006b, p. 236). O contato de de Broglie com a publicação do trabalho de Bohm reacendeu o seu interesse pelas suas ideias de juventude e fez com que ele retomasse de imediato as pesquisas com a sua antiga interpretação. Isso parece indicar que o físico francês nunca aceitou completamente a interpretação puramente probabilista, tendo convivido com ela somente enquanto não encontrou outra alternativa para a interpretação da Mecânica Ondulatória. Contudo, apesar da colaboração posterior entre os dois físicos, haviam algumas diferenças nas duas interpretações, como, por exemplo, de Broglie não concordava com Bohm em um aspecto essencial: a não atribuição de uma realidade física para a função de onda $\Psi$, tal como na teoria da onda piloto (Santos, 2011).

A síntese da formulação desses dois físicos deu origem ao formalismo da teoria de Broglie-Bohm. Nela, é possível identificar um termo referente a um potencial quântico, o qual dá origem a uma força de tipo não-clássica. Esse potencial possui uma série de propriedades inusitadas, quando comparado com os potenciais da MC: a primeira delas é que ele não diminui com a distância; a segunda é que ele permite uma alteração de estado "à distância", sempre que ocorre um colapso da função de onda $\Psi$, durante uma medição, ou seja, o potencial quântico é não-local; por fim, ele não possui uma fonte bem definida, como os potenciais usuais, que são gerados por massas, cargas, etc., isto é, ele possui uma natureza não-dinâmica. Com relação às trajetórias das partículas na mecânica de de Broglie-Bohm, elas possuem uma propriedade conhecida como "congruência", na qual, para cada ponto do espaço e para cada instante de tempo, só é possível passar uma trajetória. Outra característica dessa interpretação é que, ao contrário da interpretação ortodoxa, na qual existe uma simetria nas representações de coordenadas espaciais e de momentos, ela atribui um significado especial para a representação de coordenadas. A justificativa para esse privilégio seria a de que todas as medidas diretas em FQ são 
medidas de posição. No entanto, ao mesmo tempo em que essa característica dispensa a noção de colapso no problema da medição, ela implica que as medições de momento não são fidedignas, ou seja, uma medição (indireta) de momento em geral fornece um valor diferente daquele prescrito pela teoria. $\mathrm{O}$ valor medido para observável momento, então, tem que ser determinado pela função de onda associada à partícula e pela posição em que ela se encontrava em repouso, ambas antes da medição. Outra importante característica da interpretação causal é que ela é uma teoria criptodeterminista, devido ao fato de que, nela, os resultados imprevisíveis das medições quânticas teriam, na verdade, causas bem determinadas, porém parcialmente desconhecidas. A causa observável seria o estado (ou potencial) quântico, enquanto que as variáveis ocultas seriam a posição e o momento da partícula. Além disso, ela considera que, quando ocorre uma medição, a interação com o aparelho de medição também envolve as variáveis ocultas deste. Como a medição de observáveis incompatíveis envolve necessariamente arranjos experimentais diferentes, conclui-se que as variáveis ocultas do aparelho serão diferentes para cada medição. Portanto, por ser uma teoria na qual, para descrever o resultado de uma medição, é necessário considerar o contexto experimental, ela possui uma propriedade denominada de “contextualismo ambiental” (Pessoa, 2006b, pp. 238-245).

Além de caracterizar os aspectos da teoria de Broglie-Bohm, é importante detalhar também as diferenças nas visões de seus dois fundadores. Uma delas, já citada anteriormente, é que de Broglie e seus discípulos, nos anos 1950, passam a defender que as ondas representadas por $\Psi$ teriam uma realidade física e se propagariam no espaço físico de 3 dimensões (mesmo aquelas associadas a mais de uma partícula), ao passo que, para Bohm a propagação de $\Psi$ se dá no espaço de configurações. Isso implica que, na concepção de de Broglie, deveriam existir ondas vazias, o que levaria a alguns resultados diferentes daqueles previstos pela MQ usual. Essas previsões foram testadas pelo grupo de L. Mendel, na Universidade de Rochester, e o resultado foi consistente com a MQ, o que acabou por enfraquecer a hipótese de ondas em 3 dimensões. Outra diferença entre as visões de de Broglie e Bohm se refere à descrição do fóton. Para de Broglie, fótons são partículas (ou "singularidades" na teoria da dupla solução) associadas à onda $\Psi$, enquanto que, para Bohm, a luz não possui uma partícula associada. As razões para Bom rejeitar a ideia de que bósons (como os fótons) tivessem trajetórias estão relacionadas com dificuldades formais de se associar um operador de posição à luz, especialmente no 
domínio relativístico. Assim, Bohm argumenta que um detector de fótons sempre envolve a presença de elétrons, as quais seriam as verdadeiras partículas, dessa forma, são as posições desses elétrons que seriam detectadas. Por fim, nos anos 1960, Bohm se torna um tanto quanto crítico com relação à sua teoria de 1952, principalmente devido à dificuldade em estendê-la para o domínio relativístico. Então, nos anos 1970, ele se volta à ideia de universo indiviso, baseada em uma concepção que ele havia desenvolvido antes de sua teoria de 1952, a qual consistia de uma leitura realista da noção de "totalidade" de Bohr e que defendia que um objeto quântico não pode ser isolado do resto do universo, de forma que o mundo não poderia ser analisado corretamente em partes distintas. O universo como um todo seria, assim, uma unidade única e indivisível. A partir dessa concepção, então, Bohm passa a desenvolver um modelo "holográfico" para tratar a natureza sem recair na análise das suas partes, cunhando o termo "ordem implícita" para designar a ordem contida, por exemplo, em um holograma, no qual cada ponto contém informação de toda imagem, e que se torna "explícita" quando o holograma é apropriadamente iluminado (Pessoa, 2006b, pp. 245-247).

\subsubsection{Interpretação de Muitos Mundos de Everett-DeWitt}

As interpretações da MQ apresentadas anteriormente eram dualistas, no sentido de que elas postulavam dois modos fundamentalmente diferentes para o comportamento das funções de estado (um comportamento contínuo e determinista, regido pela função de onda, e um descontínuo e não determinista, obtido pelo postulado da projeção), além de tornar a possibilidade de uma observação, ou medida, dependente da existência de um aparelho macroscópico ou um observador humano externo ao sistema. Nos anos 1950, porém, os esforços em torno da busca de uma formulação de uma TQ para a relatividade geral, especialmente no campo da cosmologia, começaram a se intensificar e se reconheceu que a ideia da quantização de um sistema fechado como o universo da relatividade geral ou a ideia de uma função de estado do universo como um todo poderia ser fisicamente aceitável ou, até mesmo, uma concepção necessária. Assim, uma TQ da relatividade geral demandava uma mudança na teoria quântica da medição: era necessário identificar o observador ou o aparelho de medida como parte de um sistema total e, ao mesmo tempo, rejeitar a ideia de uma mudança descontínua ou um "colapso" do pacote de onda. Uma interpretação monista para a TQ desse tipo foi, então, proposta por Hugh Everett, em 1957. Sua formulação baseada em "estados relativos” era uma reformulação 
da MQ elaborada a fim de eliminar a necessidade não somente de aparelhos de observação macroscópicos clássicos, ou observadores externos, mas também eliminar interpretações operacionais a priori do formalismo, assim, ele reivindicava que o formalismo matemático é que deveria definir a sua própria interpretação (Jammer, 1974, pp. 507-508).

Dessa forma, Everett parte das seguintes hipóteses básicas: (1) Qualquer sistema físico sujeito a uma observação externa pode ser considerado como parte de um sistema maior isolado; (2) Sempre existe uma função de onda suficientemente complexa capaz de fornecer uma descrição matemática completa de todo e qualquer sistema físico isolado, inclusive do próprio universo. A interpretação dessa função de onda será fornecida após um exame da estrutura lógica e matemática da teoria; (3) A evolução desta função de onda é linear e unitária em qualquer situação. A formulação everettiana também pode ser considerada determinista, pois todo sistema físico é completamente descrito por uma entidade matemática cujo valor em qualquer tempo está perfeitamente determinado pelo seu valor inicial, também não há qualquer referência a probabilidades, o que contrasta com a aparente aleatoriedade dos resultados de uma medida quântica em um sistema físico, cujo estado inicial é conhecido e apenas a sua probabilidade de ocorrência pode ser conhecida. Nela, o estado final, resultante da evolução dos estados, é uma superposição de vários ramos onde cada um deles contém os respectivos estados relativos ao sistema medido e seus aparelhos de medida. Dessa forma, em cada ramo, não há ambiguidade sobre o resultado que foi medido. E, para que o aparelho macroscópico assinale um resultado legível de medida, é necessário que os ramos não se superponham, evitando, assim, uma possível interferência entre eles. Portanto, semelhantemente a interpretação causal de de Broglie-Bohm, a hipótese de colapso é desnecessária, pois só há um subsistema físico correspondente ao observador. Porém, seu estado não é unívoco e absoluto, ele é relativo ao estado do sistema observado, de tal forma que o observador só percebe um destes estados e os outros são completamente indiferentes para ele, o que, no entanto, não significa que eles não existam, eles apenas não são percebidos (Neto, 2010, pp. 76-79).

A história da elaboração dessa interpretação é repleta de percalços e dificuldades, que acabam por fazer com que Everett desista da carreira acadêmica e das pesquisas em Física, deixando os desenvolvimentos posteriores de sua teoria por conta de Bryce DeWitt 
e outros interessados em sua teoria. Hugh Everett III se graduou em engenharia química na Universidade Católica da América, onde ele também fez um curso intitulado "Introdução à epistemologia", o único curso formal em filosofia ou psicologia que ele chegou a fazer (Jammer, 1974, p. 508). Em 1953, ele ingressa na Universidade de Princeton, onde apresenta habilidades matemáticas excepcionais. Nesse mesmo ano, ele cursa uma disciplina de MQ com Robert Dicke e, em 1955, ele passa os exames gerais e começa a sua pesquisa de doutorado com o tema "Interpretação de correlação da MQ", sob a orientação de John Wheeler. Nessa época, Wheeler já era uma figura importante em Princeton, ele havia feito importantes contribuições para a Física Nuclear e participado do Projeto Manhattan. Porém, quando ele conheceu Everett, entre 1954 e 1955, ele estava apenas começando a sua pesquisa em cosmologia. Wheeler conheceu Bohr em meados dos anos 1930 e, em 1939, Bohr visita Princeton e os dois começam uma colaboração para a elaboração de uma teoria da fissão baseada no modelo da gota líquida, assim, eles permanecem amigos até a morte de Bohr. Wheeler tinha grande admiração por Bohr e descrevia a Interpretação da Complementaridade como "a concepção filosófica mais revolucionária dos dias atuais". Por isso, a sua decisão de discutir as ideias de Everett pessoalmente com Bohr mostra o quanto ele estava impressionado por elas. De fato, as cartas de Wheeler mostram que ele tinha grande apreço por Everett (Freire Jr, 2015, pp. 87-88).

Em meio a esse contexto, em 1955, Everett apresenta uma prévia de sua interpretação em dois artigos para Wheeler, que os recebe com entusiasmo. No entanto, Wheeler, por ser um bohriano dedicado, tinha grande interesse de discutir a proposta de Everett com Bohr, então, em 1956, ele viaja para Copenhagen nesse intuito. A proposta acaba por receber várias críticas, as quais Wheeler busca responder com uma longa defesa de Everett, que objetiva dispersar a impressão de que sua proposta criticava a abordagem ortodoxa. Wheeler também fez grandes esforços para que Everett e Bohr se encontrassem pessoalmente, o que só aconteceu em 1959, quando Everett ficou em Copenhagen por seis semanas, porém, nessa ocasião, não houve espaço para uma discussão real com Bohr sobre a sua proposta. Entre 1956 e 1957, Wheeler buscou de todas as formas mostrar que a formulação dos estados relativos não era uma teoria alternativa a abordagem ortodoxa, mas uma teoria que a generalizava. No entanto, Groenewold, Bohr e Petersen discordaram veementemente dessa abordagem, considerando que ela continha "algumas confusões com 
relação ao problema da medição" (Freire Jr, 2015, pp. 109-114). Bryce DeWitt, por outro lado, já não tinha simpatia pela interpretação de Copenhagen e, quando teve contato com a formulação de Everett, em 1957, ficou estarrecido com as suas ideias, principalmente por reconhecer o potencial que elas poderiam ter na estrutura do programa de pesquisa em gravitação quântica. Então, em 1970, ele publica um artigo na revista Physics Today, onde ele contrasta a sua versão dos muitos mundos da Interpretação de Everett-Wheeler, com a interpretação de Copenhagen e a abordagem mentalista de Wigner. Esse artigo deu origem a um debate caloroso, que marcou o começo da "redescoberta" do trabalho de Everett. Porém, Everett não fez parte desse debate, por conta das diversas frustrações e dificuldades enfrentadas por sua teoria, então, em 1971, ele "lava as suas mãos" e consente a publicação de uma longa versão da sua tese em um pequeno livro de DeWitt, com a condição de que ele não tivesse nenhum trabalho de edição, reformulação ou provas de qualquer espécie. Uma das dificuldades enfrentadas por Everett veio por parte de seu próprio orientador: de acordo com DeWitt, após a publicação do artigo na Physics Today, Wheeler prontamente renegou Everett. De fato, em 1977, Wheeler declara que ele ainda sentia que a teoria de Everett foi uma das contribuições mais importantes feitas para a MQ nas últimas décadas, mas que ele achava difícil aceitá-la. Apesar disso, Wheeler continuou a prestar atenção às ideias de Everett e nunca desistiu de trabalhar com ele novamente. Os artigos que ele publicou nos anos 1970 e 1980 refletem o seu esforço de atingir uma compreensão satisfatória e apropriada da generalização da visão de Copenhagen (Freire Jr, 2015, pp. 129-132).

O que incomodava Bohr, na verdade, não eram tanto os aspectos técnicos do projeto de Everett, mas o conceito de conhecimento físico subjacente a ele. Esse descontentamento de Bohr atrelado à influência que ele exercia sobre Wheeler pode ter sido um dos motivos da inibição do entusiasmo deste para com as ideias de Everett e da sua atitude vacilante, nos anos 1970. Everett, por outro lado, nunca se importou muito com a relação entre as suas ideias e a visão de Copenhagen, ele fazia parte de uma geração norte-americana que estava fora do contexto intelectual e científico da Europa no período entreguerras. Então, ele apontou o que considerava serem as limitações da abordagem de Bohr e classificou a postura da Escola de Copenhagen como sendo dogmática e conservadora. Assim, não houve um esforço da sua parte para atingir um entendimento mais profundo da estrutura filosófica da complementaridade e ele não hesitou em procurar 
uma formulação da MQ na qual as reflexões de Bohr sobre a natureza do conhecimento científico pudessem ser simplesmente ignoradas (Freire Jr, 2015, p. 134).

As principais críticas de Everett com relação à Interpretação da Complementaridade, as quais ele classificava como características "irritantes" dessa teoria eram: a sua completa dependência da FC a priori, o que exigia um estudo adequado dos processos de medida e que impede, em princípio, qualquer dedução da FC a partir da FQ, e a existência de uma dualidade que adere ao conceito de "realidade" para a física macroscópica, mas a proíbe esse mesmo conceito para a física microscópica. Além disso, a abordagem everettiana possuía algumas características próximas à das teorias de variáveis ocultas, como, por exemplo, a sua concepção acerca das teorias físicas, na qual estas deveriam fornecer um modelo exaustivo do mundo, além da busca por estratégias para encaixar o indeterminismo quântico nelas. Contudo, para Everett, os processos fundamentais da natureza poderiam ser tanto determinísticos quanto estocásticos, suas objeções eram somente com relação a sistemas mistos, nos quais o caráter do sistema muda com o simples ato de observar. Outras diferenças com relação a esse tipo de teorias é que Everett acreditava que os vetores de estado poderiam sozinhos fornecer um modelo exaustivo do universo, ele também parecia concordar com Schrödinger que a demanda por uma descrição não-subjetiva para a MQ era inevitável, por fim, para ele, as probabilidades surgiam com a formulação convencional, como uma consequência da redução de estado, e esta requeria a intervenção de um observador externo, o que impediria a possibilidade de uma descrição objetiva (Freire Jr., 2015, pp. 96-99).

Além disso, para Everett, qualquer teoria física é uma construção lógica, ou modelo, consistindo de símbolos e regras para a sua manipulação, apenas alguns desses elementos são associados a elementos do mundo percebido. Dessa forma, termos como "realidade" devem ser entendidos com base no seu uso na prática científica, de acordo com ele, "nenhuma construção mental deve ser considerada como mais real do que outras, nós simplesmente temos mais confiança em algumas do que em outras". Como seu "modelo conceitual de universo" postula a existência de uma função de onda universal, que obedece uma equação de onda linear, a "realidade" física é assumida como sendo a função de onda do universo inteiro. Quando Everett fala de "modelo", ele se refere a uma "descrição objetiva" da "realidade", nela, não há lugar para entidades mentais e processos 
que excedem as bordas da FQ. Assim, um observador, incluindo as suas percepções, é completamente caracterizado pelo seu estado físico, os observadores e seus estados mentais devem ser descritos por um vetor de estado. A função de onda universal inclui um modelo exaustivo de todos os observadores existentes e as suas interações com os sistemas observados. Everett também dizia que toda teoria possui uma "parte interpretativa", que são as regras que colocam alguns elementos da parte formal em correspondência com o mundo percebido. Em sua teoria, Everett está comprometido com um ideal de unidade, simplicidade e completude. Em primeiro lugar, não há dualismo na sua dinâmica, pois a função de onda universal evolui de acordo com processos contínuos e determinísticos. Em segundo lugar, a simplificação é supostamente atingida pela não introdução de variáveis "artificiais" suplementares. Assim, Everett acredita que sua teoria é capaz de construir uma "descrição objetiva", porque ela fornece uma estrutura simbólica que conecta qualquer valor possível de um determinado observável a um estado particular do universo completo, segundo ele, o que a MQ descreve seriam as correlações que ocorrem na natureza (Freire Jr, 2015, pp. 99-102). Nas últimas duas décadas, contudo, alguns comentadores apontaram algumas deficiências na Interpretação de Everett: possivelmente, não há necessidade de um postulado estatístico para "interpretar" cada ramo da função de onda universal individualmente, isto é, para definir quais acontecimentos no "mundo percebido" aquele ramo particular descreve. A teoria nos fornece infinitos ramos e essa seria a estrutura formal da qual nós temos que extrair as informações empíricas, essa seria justamente o que Everett chama da "parte interpretativa" da teoria. A partir dessas discussões, juntamente com a tentativa de fornecer uma interpretação consistente para os ramos, surgiu uma família de diferentes abordagens que vai desde os muitos mundos e muitas mentes, até histórias consistentes e interpretações relacionais (Freire Jr, 2015, p. 106).

Esses debates em torno da parte interpretativa da teoria de Everett nos levam a refletir sobre o estatuto ontológico dos ramos, problema que Everett evita sistematicamente, por considerar que se trata apenas de um problema de linguagem. No entanto, nos seus manuscritos de 1955, ele parece levar a sério o processo de divisão e os seus possíveis efeitos, ao afirmar que o próprio observador se desdobra em um determinado número de observadores, onde cada um observa um determinado resultado para a medida, e que o preço que deve ser pago para se ter uma teoria completa é o "abandono do conceito de 
unicidade do observador, com as suas talvez desconcertantes implicações filosóficas”. Nessa ocasião, inclusive, Wheeler escreve para Everett dizendo que ele deveria reformular essa interpretação, para evitar "interpretações místicas errôneas" por parte de leitores despreparados. Para Wheeler, as referências da teoria de Everett a ramos e desdobramentos do observador eram uma mera questão de forma (Freire Jr, 2015, pp. 106-107).

Portanto, com base nessas concepções de Everett, é possível compreender as principais discordâncias entre as suas ideias e as do grupo de Copenhagen: para esse grupo, a formulação de Everett parecia um "limbo simbólico", que não tinha nenhuma conexão com a prática experimental, já que, segundo eles, o formalismo da MQ não pode ser bem definido sem um arranjo experimental adequado. Em contrapartida, para Everett, a interpretação da função de onda ortodoxa era confusa e injustificada, já que dotava os símbolos preditivos de uma conotação descritiva, que eles não deveriam exprimir. Bohr não admitia que os vetores de estado pudessem fornecer um modelo completo do mundo, mas que apenas expressavam as probabilidades de ocorrência dos eventos observáveis individuais, sob condições experimentais bem definidas, assim, o posicionamento de Everett era visto por eles como um vestígio de uma forma de pensar clássica. Apesar disso, tanto Everett quanto Bohr consideravam que um sistema físico não poderia ser dotado de propriedades "em absoluto". Porém, Everett pensava que, o único jeito de atingir a relatividade fundamental entre as propriedades era não introduzindo aspectos subjetivos e dualísticos na Física, Bohr, por outro lado, acreditava que esse conceito só seria atingido dispensando a ideia de que as medidas revelavam propriedades que são definidas independentemente do contexto experimental. Para ele, um vetor de estado atribuído a um sistema só adquire um significado experimental quando estiver relacionado a autovalores de algum observável e a operações através das quais o observável pode ser medido. Já a teoria de Everett pode ser olhada como uma tentativa de "objetificar" os aspectos relacionais da abordagem de Bohr. Nela, a "relatividade com relação ao contexto" da visão pragmática de Bohr é substituída pela "relatividade dos estados", cujos resultados das correlações podem ser inteiramente representados com um modelo simbólico de universo. Assim, após uma medição, não há um resultado que seja mais "real" do que outro a priori, todos os resultados são "reais" e estão relacionados com algum estado no universo. Isso, na concepção de Everett, elimina a necessidade de 
"processos mágicos" que projetam o vetor de estado em um subespaço, o qual seria revelado pelo processo de medição. No entanto, nenhum "processo mágico" é requerido pela abordagem de Bohr também, pois, para ele, os vetores de estado são apenas símbolos preditivos, que servem para antecipar os resultados a serem obtidos em um contexto bem definido: se um contexto sofre uma mudança "objetiva", ele o faz apenas após a medição ser registrada. Além disso, para o grupo de Copenhagen, a principal lacuna da teoria de Everett era que ela falhava em reconhecer o papel fundamental da irreversibilidade em Física, contida no processo de medição. Para eles, após um resultado de uma medida ter sido registrado de forma permanente, ele não pode ser mais modificado. Esse aspecto seria uma propriedade irreversível e só pode ter lugar em um sistema de aquisição macroscópico. Para Everett, a forma como o grupo de Copenhagen considerava a irreversibilidade de um processo de medida era extremamente insatisfatório e misterioso, ele considerava esse processo como uma espécie de "irreversibilidade mágica". Essa questão foi discutida principalmente com Rosenfeld, em um contexto influenciado pelas controvérsias de 1960, nas quais Bohr, que faleceu em 1962, não participou. Rosenfeld explica que a regra de redução não é mais do que um jeito formal de expressar o registro de um resultado idealizado, sem o qual o fenômeno não está bem definido. Segundo ele, a regra de redução não requer um postulado $a d$ hoc, mas pode ser deduzido em princípio de considerações termodinâmicas aplicadas a sistemas macroscópicos (Freire Jr, 2015, pp. 115-120).

Outra importante crítica de Everett à Interpretação de Copenhagen se refere ao fato de que, nela, a dedução dos fenômenos clássicos a partir dos quânticos seria impossível, simplesmente porque nenhuma afirmação significativa pode ser feita sem um aparato clássico preexistente para servir como estrutura de referência. Assim, na concepção de Everett, esse raciocínio de Bohr impõe limites arbitrários sobre o escopo da MQ. Para ele, a FC deveria ser derivada da FQ e os conceitos clássicos deveriam ser substituídos pelos conceitos quânticos. No entanto, para Bohr, essa visão de Everett era uma ilusão, uma vez que não poderíamos nem dar sentido à teoria sem depender de uma prática experimental bem definida. Nesse ponto, contudo, Wheeler enxergava uma vantagem da teoria de Everett em relação à complementaridade, pois ela não requeria em sua formulação nenhuma referência a conceitos clássicos, ela seria, portanto, uma teoria conceitualmente auto-consistente. Um dos argumentos usados por Wheeler, na defesa da teoria de Everett é 
o de que o "mundo veio primeiro", ou seja, a Física não deve se ajustar à linguagem disponível (da FC), mas a linguagem é que deve evoluir de acordo com o desenvolvimento da Física (Freire Jr, 2015, pp. 120-124).

Após Everett abrir mão de sua teoria, por volta de 1971, ela passou a ser desenvolvida por outros pesquisadores, sendo DeWitt o mais importante e conhecido deles. Os desenvolvimentos posteriores da interpretação dos estados relativos de Everett se referiam principalmente à interpretação do significado dos ramos nessa teoria, uma vez que se observava que esses ramos poderiam descrever diferentes realidades possíveis, oriundas da medida de um observável e, portanto, poderiam conter também diferentes estados dos observadores, já que estes percebem apenas um dos valores possíveis e não o conjunto completo de possibilidades. Para DeWitt, os diferentes ramos representam diferentes sistemas físicos, de tal forma que haveria uma multiplicidade de universos, contidos em uma única função de onda universal, a qual se ramifica cada vez que uma medida quântica é realizada. No entanto, essa ramificação de universos é contestada por alguns autores, que argumentam que ela aconteceria apenas na região onde os subsistemas interagem, deixando o resto do universo inalterado. Entretanto, é possível argumentar que essa bifurcação poderia, em princípio, se estender por todo o universo através de sucessivas interações entre vizinhos. Outro questionamento com relação a essa interpretação seria se ela não violaria a conservação da energia, o qual pode ser contornado com o argumento de que os diferentes universos não interferem entre si e nenhum deles é ciente da existência do outro, de maneira que, no interior de cada um deles, a conservação da energia é válida. A existência destes universos paralelos é considerada seriamente por diversos autores (Neto, 2010, pp. 79-80).

Outra abordagem para interpretar o significado dos ramos de Everett seria considerar que eles representariam as "mentes" do observador, onde a palavra "mente" se refere a uma sequência de dados razoavelmente robustos, armazenados no sistema físico que caracteriza o observador, constituindo a sua "memória". Contudo, essa abordagem, denominada interpretação de várias mentes da MQ, invade os terrenos da neurociência e da filosofia, suscitando inúmeras discussões. Além dessa, há uma abordagem intermediária entre as várias mentes e os vários universos: a abordagem dos vários mundos. Para alguns autores, os muitos mundos são mais próximos das mentes, para 
outros, dos universos. Para Lev Vaidman, por exemplo, a noção de mundo é algo subjetivo ao observador, apenas o universo, que contém todos os mundos possíveis, não seria subjetivo. Dessa forma, a noção de mundo é definida pela mente do observador e se refere a uma cadeia local de eventos que ele percebe e constitui algo que ele denomina como tal. Esta definição é muito próxima da noção de mente, porém Vaidman vai além, afirmando que a percepção de um observador é estimulada por sensações originadas de interações físicas, as quais seriam locais. Por isso, um mundo que faz sentido para o observador não pode ser constituído de estados não localizados, ou seja, não existe um mundo sensível não-local. Observadores que pudessem perceber apenas estados não localizados teriam desvantagem sobre os que veem estados localizados, pois estes são estáveis por interações físicas locais e os outros não. Um estado puro não local se transforma em uma mistura pela decoerência causada por interações físicas locais, por isso, são instáveis. Como a entropia de uma mistura é maior que a de um estado puro, há perda de informação para este observador durante esse processo. Assim, apenas a observação de mundos locais é capaz de gerar informação estável para os observadores. $\mathrm{O}$ papel da decoerência nesta abordagem, portanto, é justificar a inexistência de observadores com percepções não-locais. Por fim, uma interpretação mais radical que a de DeWitt, baseada na existência de vários universos é proposta por David Deutsch. Ele defende que existem tantos universos quanto o número de configurações possíveis de todos os graus de liberdade de partículas e campos envolvidos em todas as transições quânticas que já aconteceram no universo, e a união de todos estes universos é denominada de multiverso. Ele defende ainda que os fenômenos quânticos de interferência aparecem quando alguns desses muitos universos existentes se tornam idênticos, o que acontece com muito mais frequência no regime microscópico, onde os universos diferem com respeito a um número bastante reduzido de graus de liberdade. Por mais estranho que essa proposta possa parecer, ela permitiu com que Deutsch provasse resultados em computação quântica que não foram possíveis de se obter com outras teorias quânticas, além disso, na área da cosmologia, ela propiciou um argumento engenhoso para explicar o valor da constante cosmológica (Neto, 2010, pp. 80-83).

Essas diversas abordagens para a teoria de Everett mostram que ela pode ser interpretada tanto como uma teoria de várias mentes, como uma teoria de vários universos. A primeira possibilidade, à primeira vista, poderia parecer mais simples e 
econômica, pois só há um sistema físico e vários estados da mente, ou mundos subjetivos, e as ramificações em mundos só acontecem quando há interações envolvendo medidas com artefatos macroscópicos. Entretanto, uma formulação mais precisa dessa possibilidade exigiria um aprofundamento maior em assuntos como neurociência, biologia, psicologia e filosofia. A segunda possibilidade, por outro lado, é bem mais ampla no sentido físico e exige a aceitação da existência de inúmeros universos físicos além do que percebemos, além de cada processo quântico no multiverso dar origem a novos universos. Contudo, esta visão é bem menos dependente de conceitos estranhos à Física e abre caminhos de raciocínio que permitem resolver problemas na Física dos mais variados tipos, além de propor novos experimentos. Esse dilema, portanto, nos mostra que o debate acerca da teoria de Everett permanece em aberto (Neto, 2010, p. 88).

\subsubsection{Interpretação dos Coletivos Estatísticos}

Conforme mencionado nas seções anteriores, a Interpretação dos Coletivos Estatísticos é uma interpretação essencialmente corpuscular, que considera que o vetor de estado não fornece uma descrição de um sistema individual, mas de um conjunto de sistemas identicamente, ou pelo menos similarmente, preparados. Ela foi inicialmente proposta por Einstein, em 1927, no $5^{\circ}$ Congresso de Solvay, no intuito de contornar as dificuldades conceituais que surgiam quando se considera que a redução do pacote de ondas é descrita em termos de uma interpretação que associa funções de onda a sistemas individuais. De fato, durante toda a sua vida, Einstein foi adepto à interpretação estatística para o formalismo existente, apesar de ter tido sempre a esperança de que, algum dia, se construísse uma teoria "completa" para os fenômenos microscópicos, a qual fosse estabelecida a partir de uma base conceitual diferente da MQ e na qual esta última fosse apenas uma aproximação estatística. Ele chega a afirmar, em 1936, que "a função $\Psi$ de forma alguma descreve uma condição que pode ser atribuída a um sistema individual: em vez disso, ela está relacionada a muitos sistemas, a 'um coletivo de sistemas' no sentido a mecânica estatística" (Jammer, 1974, p. 440). Por conta dessa posição de Einstein, a tese de que a MQ prevê somente as frequências relativas dos resultados de medidas realizadas sobre um coletivo de sistemas identicamente preparados é por vezes chamada de "hipótese de Einstein", em contraste com a "hipótese de Born", de acordo com a qual a MQ prevê a probabilidade de um resultado de uma medição realizada sobre um sistema individual. No entanto, vale ressaltar que Born chega a escrever para Einstein afirmando que ele 
concordava com a sua interpretação para a função de onda e que, em sua opinião, a diferença entre as suas visões não era essencial, mas apenas uma questão de linguagem (Jammer, 1974, p. 441).

$\mathrm{O}$ primeiro, entre os especialistas em MQ, a endossar a interpretação estatística foi provavelmente John Clarke Slater, em 1928, em um simpósio sobre MQ na American Physical Society, onde ele declarou que a "Mecânica Ondulatória é uma extensão não da Mecânica Newtoniana usual, mas da Mecânica Estatística; e essa simples observação é suficiente para explicar muitos dos seus diversos enigmas” (Jammer, 1974, p. 442). Segundo ele, por ser uma teoria estatística, a Mecânica Ondulatória lidaria com conjuntos, os quais seriam descritos por funções de distribuição em um espaço no qual, apesar de ser diferente do espaço de fase da Mecânica Estatística usual (principalmente devido ao Princípio da Incerteza), seria essencialmente similar a ele. Outro defensor da Interpretação dos Coletivos Estatísticos foi Edwin Kemble que, inclusive, escreve um livro didático baseado nela. Ele chega a declarar que “quando dizemos que um 'estado' de um elétron em movimento é descrito por $\Psi$, isso significa que um conjunto de um grande número de elétrons preparados similarmente terá propriedades estatísticas descritas por essa função, e que nós não podemos conhecer mais sobre um elétron individual do que o fato de que ele pertence a um potencial adequadamente preparado e escolhido com essas características" (Jammer, 1974, p. 442). Por muitas décadas, a Interpretação dos Coletivos Estatísticos recebeu pouca aceitação, apesar dos argumentos proferidos por Einstein, Popper, Slater, Kemble, entre outros. Ela só foi receber um apoio maior nos anos 1950, principalmente na URSS, onde a Interpretação da Complementaridade de Bohr foi rejeitada por ser considerada uma filosofia idealista e, portanto, incompatível com o materialismo dialético, de tal forma que a interpretação estatística passou a se mostrar como uma interessante alternativa. Nesse contexto, seus principais defensores foram Konstantin Nikolskii e Dimitrii Blokhintsev, quem escreveu um livro didático ${ }^{5}$ que, posteriormente, se tornou muito popular, no qual ele rejeita a interpretação de Bohr e Heisenberg e apresenta uma interpretação da TQ baseada na Interpretação dos Coletivos Estatísticos. Posteriormente,

\footnotetext{
${ }^{5}$ D.I. Blokhintsev. Vvedenie o Koantovuiu Mekhaniku, G.I.T.T.L., Moscow, Leningard, 1940. Trata-se de um livro didático universitário, cuja tradução do título em português seria "Introdução à Mecânica Quântica".
} 
Blokhintsev detalha um pouco melhor a sua interpretação estatística, definindo os coletivos como infinitas sequências de microssistemas idealmente preparados identicamente, cada um dos quais se encontrando na mesma configuração macroscópica M, assim, o ambiente macro de alguma forma determinaria o estado de movimento, ou simplesmente "estado" do sistema microscópico. A função de onda $\Psi$ seria a quantidade que caracteriza o conjunto quântico completamente, no sentido de que o seu conhecimento nos permite calcular todas as probabilidades dos diferentes resultados das medições. Sendo assim, ela seria uma característica objetiva do conjunto quântico, ela não determina a estatística de uma medida em particular, mas apenas a estatística do conjunto quântico como um todo (Jammer, 1974, pp. 443-447).

Nessa mesma época, nos países ocidentais, a Interpretação dos Coletivos Estatísticos tinha poucos adeptos, principalmente por conta da monocracia de Copenhagen, que vigorava nesse período, e pela força da prova de impossibilidade de von Neumann, a qual ainda era vista como conclusiva a respeito da impossibilidade da existência de teorias de variáveis ocultas. Apesar da interpretação estatística não ser uma teoria de variáveis ocultas, se argumentava que ela seria um primeiro passo em direção a uma teoria que descrevesse o comportamento de sistemas individuais, assim, esperava-se que essa teoria para qual se caminhava deveria ser necessariamente uma teoria de variáveis ocultas. Alguns adeptos mais afincos da interpretação estatística foram Karl Popper e Alfred Landé. Popper, já no início dos anos 1930, propôs uma interpretação estatística para as relações de Heisenberg e nunca abandonou esse ponto de vista. Ele defendia que os problemas nos quais a MQ é aplicada são essencialmente problemas estatísticos e, portanto, requeriam respostas estatísticas. De acordo com ele, os vetores no espaço de Hilbert fornecem informações estatísticas a partir das quais não é possível fazer inferências preditivas a respeito do comportamento individual das partículas. Assim, a MQ não versaria sobre a probabilidade exata de medidas individuais, por exemplo, de posição e momento, apesar dessas medições serem indispensáveis para testar as previsões da teoria. Popper também criticava a postura da Escola de Copenhagen em identificar a distribuição estatística com uma propriedade física dos elementos de um conjunto, pois, segundo ele, as distribuições seriam propriedades dos conjuntos, mas não propriedades dos elementos dos conjuntos. Essa confusão entre os conceitos, para ele, seria o que levaria à emergência de noções como a "dualidade onda-partícula" e, consequentemente, à 
Interpretação da Complementaridade. Posteriormente, Popper modifica a sua concepção original sobre a MQ com a sua interpretação da probabilidade como sendo, na verdade, uma propensão, a qual seria uma propriedade física inerente ao arranjo experimental como um todo, para medidas que pudessem ser repetidas. Assim a função de onda determinaria a propensão dos estados de uma partícula, isto é, os pesos dos seus possíveis estados. Já Landé irá contribuir para essa interpretação, mostrando a sua maior compatibilidade com o caráter corpuscular dos fenômenos quânticos. Ele também escreve um livro didático de $\mathrm{MQ}^{6}$, no qual declara que "a questão da MQ é tentar reconciliar a contradição entre dois conceitos clássicos": o de partícula e o de onda, fornecendo a equivalência entre as descrições dos fenômenos físicos em ambos os termos (Jammer, 1974, p. 453). De fato, Landé mostra com grande detalhe como as teorias ondulatória e corpuscular levam a resultados idênticos para vários processos como o espalhamento de Thomson de raios-X e o efeito Zeeman. Posteriormente, Landé se tornaria um dos mais ardentes oponentes à Interpretação de Copenhagen. $\mathrm{Na}$ sua visão, a interpretação ortodoxa, declarando dogmaticamente que a dualidade onda-partícula seria irremovível, acaba por elevá-la a um posto de princípio fundamental. Assim, essa interpretação apenas nos falaria a respeito da existência de um problema difícil de ser resolvido, em vez de propor uma solução através dos meios e métodos da física teórica em si. Então, insatisfeito com as explicações fornecidas pela Interpretação de Copenhagen, Landé achou necessário propor uma interpretação baseada em princípios que, em sua concepção, fossem os mais simples, plausíveis e evidentes possíveis, esses princípios fundamentais seriam a continuidade, simetria e invariância. Assim, em contraste com a Interpretação Ondulatória de Schrödinger e com a Interpretação dualista de Bohr, ele propõe uma versão corpuscular da Interpretação dos Coletivos Estatísticos. Essa interpretação não permaneceria livre de críticas, as quais se voltavam principalmente na dificuldade dessa interpretação explicar os fenômenos de caráter notadamente ondulatório. No entanto, Landé irá pontuar que, em sua visão, as discordâncias entre as visões não se refeririam tanto ao conteúdo da TQ em si, mas principalmente sobre a linguagem na qual ela é formulada. Segundo ele irá declarar em 1968, a linguagem de "ondas" e/ou "partículas", conforme ela é usada pela maioria dos físicos, é um produto de um desenvolvimento de quarenta anos de física e não o resultado de uma preconcepção dogmática que deve ser adotada por todos, portanto, ela

\footnotetext{
${ }^{6}$ A. Landé. Quantum Mechanics. Pitman, London, 1951.
} 
não precisa ser alterada enquanto ela não conduzir a equívocos (Jammer, 1974, pp. 447465).

Posteriormente, novas derivações a partir da Interpretação dos Coletivos Estatísticos continuarão a ser desenvolvidas por diversos autores, entre eles, Philip Pearle e James Park.

\subsection{A formação e a estrutura do coletivo de pensamento dos pesquisadores em Fundamentos da Física Quântica}

Após um panorama da gênese e do desenvolvimento da FQ - o qual culminou no reconhecimento das pesquisas em Fundamentos da MQ como parte das pesquisas em Física - e dos principais debates e interpretações dessa teoria, nesta seção, será feita uma leitura dessa história a partir da perspectiva de Fleck, além de uma análise da formação, da estrutura e do funcionamento desse coletivo de pensamento. Com essa leitura, não se pretende invalidar ou substituir as leituras existentes na perspectiva de outros autores, mas apenas apontar aspectos que apenas se tornam explícitos à luz da epistemologia de Fleck. Reconhece-se, assim, que essa leitura possui limitações, uma vez que ela não esgota e nem dá conta de todos os detalhes e meandros da história e do funcionamento desse coletivo. Contudo, acredita-se que ela pode nos ajudar a elucidar e compreender aspectos importantes que serão úteis na análise posterior da gênese e do desenvolvimento da relação entre FQ e misticismo.

\subsubsection{Gênese do coletivo de pesquisadores em Física Quântica}

Conforme visto na seção 3.1.1, o historiador Helge Kragh (1999) problematiza a concepção difundida de que, no final do século XIX, devido ao grande sucesso da Mecânica Newtoniana, havia um sentimento generalizado entre os físicos de que a Física estava praticamente acabada e que seria apenas uma questão de tempo para que os problemas que ainda estavam em aberto pudessem ser resolvidos. Kragh aponta a ingenuidade da ideia de que a Mecânica Newtoniana permaneceu por cerca de cem anos como uma teoria hegemônica e completamente aceita, mostrando que, ao longo desse século, havia tendências não mecanicistas importantes que concorriam com a mecânica, como as teorias do éter, no contexto do eletromagnetismo, e o programa energicista, no contexto da termodinâmica. Dessa forma, ele defende que a visão de mundo newtoniana, 
no início do século XX, não era uma concepção bem estabelecida, marcada somente por sucessos, mas que ela já estava sob ataque há mais de uma década.

Essa crítica de Kragh enfraquece a concepção de que o advento da FQ foi uma revolução abrupta, na qual uma visão hegemônica foi substituída por outra, e fortalece a ideia de uma transformação harmoniosa e sutil de um estilo de pensamento, a qual deu origem a um novo coletivo de pensamento dentro da Física: o coletivo de pensamento dos pesquisadores em FQ. O primeiro aspecto que fortalece essa leitura é o fato de que as tendências não mecanicistas do final do século XIX citadas permanecem de alguma forma na TQ mais atual, apesar de aparecerem com outra roupagem - como, por exemplo, alguns resquícios da ideia de éter, que, apesar de ter sido uma ideia descartada, se mantém presente através de algumas propriedades do vácuo, na Teoria Quântica de Campos, como as suas flutuações quânticas, as quais podem originar pares de partícula-antipartícula, de tal forma que o espaço não pode ser considerado completamente vazio. Dessa forma, não é possível afirmar que essas tendências foram completamente substituídas, assim como não é possível considerar que elas eram "problemas que foram resolvidos" com o advento da nova teoria. Outro aspecto que favorece uma leitura fleckiana dessa história é que os estudos da radiação de corpo negro, que deram início a VTQ, foram possíveis dentro de um contexto histórico-social mais amplo, pois, na Alemanha, havia um interesse por esse problema que ia além dos interesses acadêmicos, pois ele apresentava um potencial de utilidade na iluminação e no aquecimento das indústrias (Kragh, 1999, p. 58). Dessa forma, houve uma predisposição social geral, juntamente com uma predisposição específica interna ao coletivo de pensamento - levada a cabo por Planck, Einstein, Lorentz, entre outros - que propulsionou a pesquisa e possibilitou a construção de novos fatos. Além disso, ao derivar a sua lei de radiação em 1900, Planck não enxergou a introdução de elementos de energia como significando a quantização da mesma. Para ele, a sua nova expressão $E=h v$ era apenas uma hipótese matemática sem significado físico por trás, temporária, a qual seria removida na formulação final da teoria. Sua motivação era apenas a obtenção de uma boa precisão da nova lei da radiação com os resultados experimentais. Por um bom tempo, Planck acreditou que a sua lei da radiação poderia ser reconciliada com a mecânica clássica e a eletrodinâmica. Apenas em 1908 ele se converte à ideia de que o quantum de ação era um fenômeno que não poderia ser entendido no âmbito da FC (Kragh, 1999, pp. 63-64). Esse movimento de Planck - de inicialmente 
buscar apenas por uma boa conciliação entre uma formulação matemática e os dados experimentais e, posteriormente, por uma tentativa de adaptação dessa formulação ao esquema conceitual da FC - pode ser visto como uma busca por uma coerção do pensamento, dentro das balizas do estilo de pensamento da época, no qual ele estava inserido, que ocorre diante de um novo material que se apresentou. Pode-se dizer que, primeiramente, ocorreu um ver inicial, pouco claro e confuso, desse material, o qual somente adquiriu uma forma após Planck recorrer ao seu conhecimento adquirido através da educação e à tradição, estabelecida historicamente através do estilo. Essa forma se materializou na formulação matemática da sua lei de radiação, a qual provocou uma transformação do estilo de pensamento inicial. Porém, Planck não chegou a lograr estabelecer uma forma completamente desenvolvida, conforme a um estilo, por isso, buscou adaptar o novo material ao estilo da FC por um bom tempo, ou seja, ele não conseguiu formar completamente um sinal de resistência que se opõe a voluntariedade livre do pensamento, uma vez que a interpretação da formulação matemática ainda exigia um esquema conceitual que a acompanhasse. Somente mais tarde, ele admitiria que essa formulação necessitava de uma transformação mais profunda no estilo da época. Por fim, o último aspecto que favorece uma leitura fleckiana dessa história a ser citado é que Einstein, ao utilizar a hipótese dos quanta para explicar o efeito fotoelétrico, não o fez como uma resposta a uma anomalia, pois, nessa ocasião, o efeito fotoelétrico não era considerado problemático (Kragh, 1999, p. 67). Portanto, uma possível leitura desse episódio seria a de que Einstein utilizou essa ideia de forma ativa, a fim de obter um esquema conceitual coerente mais amplo, que explicasse mais fenômenos além da radiação de corpo negro. Esse esquema conceitual mais amplo seria o caminho para a construção de um sistema de referência explicativo geral, um verdadeiro e novo estilo de pensamento, o qual guiaria a leitura e permitiria dar forma aos novos materiais que se apresentavam. Esses indícios iniciais favorecem uma leitura fleckiana da gênese da FQ e incentivam a seguir com um olhar fleckiano para uma leitura da origem dessa teoria até a sua consolidação como a VTQ, a qual será feita a seguir. Contudo, desde já se reconhece que possivelmente esses indícios possuem limitações e devem ser mais bem investigados em uma pesquisa mais aprofundada.

No final da primeira década do século $\mathrm{XX}$, a TQ ainda era estudada seriamente por poucos físicos teóricos, ou seja, o seu coletivo de pensamento era muito pequeno. 
Somente por volta de 1910 é que os especialistas começam a reconhecer a quantização da energia como uma propriedade natural, que necessitava de um rompimento com a FC, e passam a utilizá-la na explicação de diferentes fenômenos, como o comportamento dos calores específicos de sólidos a baixas temperaturas, por exemplo. Isso contribuiu para trazer a TQ para áreas mais tradicionais da Física e torná-la conhecida entre os físicos que não estavam interessados ou não compreendiam o problema da radiação de corpo negro. Assim, a quantização da energia de Planck passa a circular na comunidade dos físicos e a ganhar maior visibilidade, passando a se transformar de um acoplamento ativo do saber para um acoplamento passivo e contribuindo para a expansão e consolidação do coletivo de pensamento dos pesquisadores em FQ. Outro fator que contribuiu para a consolidação desse coletivo foram as Conferências de Solvay, cuja primeira série reuniu os físicos de maior prestígio na época para discutir e buscar compreender os problemas relacionados à TQ, à Teoria Cinética dos Gases e à Teoria da Radiação. Essas conferências eram promovidas por Ernest Solvay, um industrial e filantrópico belga, que possuía uma grande fortuna e um grande interesse, ainda que de forma amadora, por física teórica. Nesse caso, a circulação das ideias da TQ possibilitou o contato de um membro do círculo exotérico com o coletivo de pensamento dos especialistas em TQ. Esse membro fazia parte do público com formação geral, e acabou financiando e promovendo encontros que fortaleceram o círculo esotérico em si. Nesse episódio, novamente, houve a junção de uma predisposição social geral favorável com uma predisposição específica interna ao coletivo de pensamento, e a reunião e a troca de ideias entre os especialistas em TQ puderam promover, mesmo que timidamente, o caráter democrático da Ciência, defendido por Fleck. Nesse contexto, os especialistas puderam buscar juntos uma coerção do pensamento e puderam construir e fortalecer a estrutura conceitual da TQ e, consequentemente, o núcleo do círculo esotérico.

No entanto, a conversão maciça dos membros que comporiam o coletivo de pensamento científico em favor da TQ só aconteceu com a elaboração do modelo atômico de Bohr-Sommerfeld, um modelo semi-clássico, que obteve grande sucesso em explicar as linhas espectrais emitidas pelo átomo de hidrogênio (Pessoa, 2006a). Esse modelo proporcionou uma maior coerção do pensamento e a elaboração de um solo firme para os fatos, uma resistência que se opôs à voluntariedade livre do pensamento, pois era capaz de explicar e prever dados que, inicialmente, apenas haviam sido sistematizados 
matematicamente em uma série (série de Balmer). Assim, foi formado um maior número de acoplamentos passivos para a TQ, que foram capazes de fortalecer o núcleo do círculo esotérico como um todo e agregar novos membros em torno dele, além de promover uma transformação no coletivo e no estilo de pensamento. Com a possibilidade de uma coerção mais firme para o pensamento, esse novo modelo também permitiu que novas pesquisas passassem a ser realizadas, as quais, posteriormente, contribuiriam para a elaboração da MQ.

O primeiro estágio da História da FQ e a consolidação completa do que se conhece como VTQ terminam com a completa derivação da lei de radiação de Planck, em 1916, por Einstein. Essa derivação pode ser considerada a primeira teoria sintética e semiclássica dos quanta, por reunir todas as características quânticas conhecidas até aquele momento em um esquema teórico consistente e permitir obter as probabilidades de transição por unidade de tempo da emissão e da absorção da radiação eletromagnética (Paty, 2005). Dessa forma, a completa gênese do coletivo de pensamento dos pesquisadores em FQ termina com a formulação de uma teoria semi-clássica mais completa e com a consolidação da TQ como um novo domínio para os fenômenos e sistemas físicos, com uma especificidade própria. Assim, nesse primeiro momento, esse novo coletivo de pensamento ainda apresenta características que conservam a sua ligação com a tradição do estilo de pensamento da FC - uma vez que se constituem de modelos semi-clássicos - e, ao mesmo tempo, apresenta novos fatos, esquemas teóricos explicativos e possibilidades de pesquisas na busca de uma maior coerção do pensamento e de um maior número de elementos passivos. Essa possibilidade de abertura do novo estilo de pensamento que estava nascendo, posteriormente, levaria à elaboração da MQ. A sua ligação com o estilo de pensamento da FC, por outro lado, fortalece a possibilidade de leitura da transição das teorias clássicas para a TQ, como uma transformação sutil e harmoniosa de estilo de pensamento.

\subsubsection{Desenvolvimento do coletivo de pesquisadores em Física Quântica}

A transição da VTQ para a MQ se inicia quando os modelos semi-clássicos, em especial, o modelo atômico de Bohr, começam a apresentar as suas limitações e com a postulação do Princípio da Correspondência. De fato, em 1913, Bohr já tinha consciência de que sua teoria atômica era apenas o inicio de um programa de pesquisa que iria levar 
para um território desconhecido. O Princípio da Correspondência, introduzido por Bohr em 1918, posteriormente, se tornaria a marca e guiaria os primeiros desenvolvimentos da Escola de Copenhagen em TQ. O modelo atômico de Bohr-Sommerfeld, por outro lado, por volta de 1920, começa a mostrar as suas falhas em explicar o próximo átomo mais simples, após o H (o átomo de He). Então, por volta de 1924, havia um sentimento de crise e insatisfação na Física, que foi acompanhado do rompimento com procedimentos e metodologias tradicionais (Hentschel, 2009, p. 614). Ao mesmo tempo, devido ao seu sucesso anterior, havia um sentimento de que dificilmente ela estaria completamente errada e esperava-se que a nova TQ estaria relacionada com a antiga de forma análoga a um "Princípio da Correspondência" (Kragh, 1999, p. 159).

Nessa fase, fica claro que a coerção do pensamento estabelecida anteriormente começa a se esvaecer, mostrando a necessidade de buscar outros caminhos, porém sem romper completamente com o que já estava se mostrando eficiente em exercer essa coerção. Ou seja, os elementos passivos que foram estabelecidos se mostram como não sendo mais suficientes, clamando pela busca e pela inserção de novos elementos ativos. A inesperada limitação dos modelos semi-clássicos e a sua discrepância com relação a outros dados experimentais, além da insatisfação com relação ao seu esquema conceitual, mostra que esses modelos, que pareciam ter se tornado passivos devido ao seu sucesso inicial, voltam a se apresentar como elementos ativos, elaborados de forma "artificial" ou "livremente inventados". Fleck explica que esse movimento dos elementos se mostrarem ora como elementos ativos, ora como passivos, é comum de ocorrer ao longo do processo do conhecimento e da história da elaboração e construção de um fato científico. Outro elemento ativo importante no desenvolvimento da FQ, que realiza esse movimento de transformação, será o Princípio da Correspondência, introduzido e "livremente inventado" por Bohr: inicialmente, se mostrou como elemento ativo do saber, posteriormente, porém, passou a guiar e exercer uma coerção mais efetiva nos desenvolvimentos e pesquisas da Escola de Copenhagen. Contudo, ao longo da história, esse elemento passou a se mostrar como elemento passivo apenas para os membros dessa escola, uma vez que ele foi recebido com críticas por parte de outros pesquisadores, sendo considerado como possuindo um caráter "mágico" por Sommerfeld, por exemplo (Kragh, 1999, p. 157). Assim, na visão desses críticos, o Princípio da Correspondência se mostrou como um elemento ativo ao longo desse processo. 
Então, nesse contexto de um sentimento de crise e uma busca por novos procedimentos e teorias coercitivas para o desenvolvimento do saber, a MQ, desde o início, passou a se desenvolver em duas linhas independentes: a Mecânica Matricial e a Mecânica Ondulatória. A Mecânica Matricial era marcada por uma atitude positivista (ou “operacionalista”), a qual se recusava a falar de grandezas não-observáveis, ela também não prezava por um caráter "visual" dos modelos, mas buscava uma descrição matemática, que descrevia adequadamente os dados experimentais, através da manipulação de símbolos. A Mecânica Ondulatória, por outro lado, seguia uma abordagem realista, que se prendia fortemente a modelos visualizáveis, associados à Física Ondulatória Clássica, e considerava que a teoria deveria descrever adequadamente uma realidade não-observável por trás das aparências. A primeira foi levada adiante principalmente pelo grupo composto por Heisenberg, Pauli, Born, Bohr e Kramers, enquanto que a segunda foi desenvolvida principalmente por Schrödinger.

A Mecânica Matricial começa a ser desenvolvida em 1924, quando Kramers e Heisenberg publicam a sua teoria da dispersão. Nessa mesma época, Bohr e Kramers desenvolvem uma teoria da radiação não-fotônica. Em março de 1925, Bohr, Kramers, Heisenberg e Pauli discutem a crescente crise na TQ, em um encontro em Copenhagen. Então, em setembro do mesmo ano, de volta a Göttingen, Heisenberg encontra uma forma de formular uma MQ abstrata que prometia ser fundamental, logicamente consistente e livre das dificuldades enfrentadas pela teoria de Bohr-Sommerfeld, a qual culmina na publicação de seu famoso artigo (Kragh, 1999, p. 161). Posteriormente, Born percebe que a multiplicação não-comutativa de Heisenberg poderia ser escrita em termos de cálculos com matrizes, estendendo a teoria de Heisenberg juntamente com Jordan. Finalmente, em novembro de 1925, os três publicam o artigo que estabelece a Mecânica Matricial. Porém, a nova MQ possuía um formalismo matemático não-usual, que prejudicava a clareza da sua relação com os fenômenos, tornando-a pouco visual. Por conta disso, juntamente com o fato dela, por muito tempo, ter ficado restrita a reprodução de resultados já conhecidos, muitos físicos resistiram em aceitá-la (Kragh, 1999, pp. 162-163).

A Mecânica Ondulatória, por outro lado, nasceu justamente da insatisfação com a falta de visualidade da Mecânica Matricial por parte de Schrödinger, que não pertencia à tradição Copenhagen-Göttingen-Munich e nunca mostrou interesse na teoria atômica ou 
em espectroscopia. Em 1925, Schrödinger resolve estudar o trabalho de de Broglie, sobre a dualidade onda-partícula, o qual havia sido ignorado pela maioria dos físicos fora de Paris, devido à baixa reputação da física teórica francesa. Foi por conta de uma citação das ideias de de Broglie, em um artigo de Einstein de fevereiro de 1925, que elas chegaram ao conhecimento e foram assumidas por Schrödinger, que publica a sua Mecânica Ondulatória em janeiro de 1926. Diferentemente da Mecânica Matricial, essa nova formulação tinha um formato mais compreensível em termos visuais, sendo rapidamente adotada por outros físicos e ganhando bastante importância.

A partir desse relato, nota-se que a história do desenvolvimento da MQ teve um desdobramento do coletivo de pensamento dos pesquisadores em $\mathrm{FQ}$, que não chegou a ser analisado por Fleck (e nem mesmo por outros filósofos da ciência críticos ao positivismo lógico): aparentemente, o núcleo desse coletivo se desdobra em duas linhas diferentes e independentes, formando, nesse estágio da história da FQ, um coletivo de pensamento com dois núcleos. O interessante deste desdobramento é que ambas as abordagens - a Mecânica Matricial e a Ondulatória - estudavam os mesmos fenômenos, e discutiam e versavam sobre os mesmos problemas, de tal forma que havia um diálogo e uma comunicação entre os seus proponentes. No entanto, desde o início, elas seguiram abordagens diferentes, tanto no que se referem aos seus métodos, formas de raciocínio e justificativas, quanto aos princípios filosóficos pelas quais eram pautadas. Assim, desde o início, elas buscaram a coerção do pensamento partindo do mesmo sistema de referência preexistente, ou seja, do mesmo estilo de pensamento. Porém, devido às discordâncias entre si, elas seguiram diferentes caminhos e inseriram diferentes elementos ativos dentro de cada um deles, os quais, de forma independente, posteriormente, se consolidaram e se mostraram como elementos passivos, capazes de exercer uma coerção do pensamento mais sólida e formar um "solo firme para os fatos". Esse processo acaba culminando na constituição de dois centros distintos para um coletivo de pensamento único: o coletivo dos pesquisadores em FQ.

A hipótese de que, nesse estágio da história da FQ, a Mecânica Matricial e a Ondulatória formaram dois núcleos para um mesmo coletivo de pensamento se fortalece, em detrimento da hipótese delas comporem dois estilos de pensamento distintos, pois, além delas partirem de problemas e fenômenos comuns e, inclusive, discutirem e 
discordarem entre si a respeito deles, posteriormente, os dois formalismos se mostraram equivalentes entre si. Com a prova de equivalência entre os formalismos, por Schrödinger, e a elaboração de uma teoria de transformação entre os formalismos, por Dirac e Jordan, em 1926, uma estrutura matemática elegante unificada foi obtida e o coletivo de pensamento como um todo foi fortalecido. Assim, independentemente de haver dois núcleos diferentes, o estilo de pensamento da FQ foi consolidado como um todo, isto é, um sistema de referência para o estudo dos fenômenos da FQ foi estabelecido, de forma que a coerção do pensamento desse estilo passou a ser guiada e dirigida de forma mais concreta, possibilitando a previsão de novos fenômenos, a construção de novos conceitos e a formulação de novos problemas, como, por exemplo, a dualidade onda-partícula, a indistinguibilidade de estados quânticos idênticos, seu comportamento probabilístico, e o Princípio da Incerteza. Dessa forma, a MQ passou, a manifestar todo o seu poder teórico e prático. Além disso, após a consolidação desses núcleos, a MQ se disseminou rapidamente pelos centros de pesquisa existentes e o coletivo de pensamento da FQ passou a crescer cada vez mais: novos pesquisadores passaram a se interessar por essa área, os índices de publicações cresceram significativamente e um forte clima de competição foi gerado, estabelecendo um sistema de disputas e parcerias mútuas. Com isso, as novas ideias passaram a circular de forma mais intensa, através de livros didáticos que apresentavam os dois formalismos, publicações em revistas discutindo os novos problemas, livros de divulgação científica para o público geral, circulação de pessoas, com o intercâmbio de pesquisadores e estudantes entre os diferentes centros de pesquisa e universidades, e da criação de novos centros de pesquisa. Todo esse movimento fortaleceu e ampliou ainda mais o novo coletivo de pensamento da FQ.

Conforme descrito na seção 2.2, Fleck não chegou a considerar a hipótese do coletivo de pensamento científico poder ter dois núcleos distintos, apenas um núcleo de especialistas. Porém, ele considera a possibilidade da existência de coletivos pensamento com essa configuração, quando menciona, por exemplo, o coletivo de pensamento das artes, cujos núcleos seriam formados pelos artistas e pelos críticos de artes (Fleck, [1936]1986, p. 104). Sendo assim, parece plausível, que esse tipo de configuração de um coletivo de pensamento possa ser aplicado ao desenvolvimento da história da FQ, tal como descrito acima. No entanto, Fleck, ao descrever o coletivo de pensamento das artes, menciona que "o fato de o coletivo possuir dois centros torna impossível estabelecer uma 
postura dos indivíduos com relação aos produtos específicos do coletivo: ela sempre oscilará entre a simples admiração e o criticismo. Por conta dessa oscilação, os produtos do coletivo estão constantemente em um estágio de instabilidade" (Fleck, [1936]1986, p. 104, tradução livre). Nesse primeiro momento da consolidação da $\mathrm{MQ}$, com os formalismos matricial e ondulatório, aparentemente, essa observação de Fleck não se aplica totalmente, ainda que seja possível afirmar que se tratava de um estágio de certa instabilidade, que, posteriormente, geraria o problema da interpretação do formalismo. No entanto, alguns produtos desse coletivo se tornaram sólidos justamente nesta etapa, e permanecem até os dias atuais como alguns dos pilares da FQ, como o Princípio da Incerteza e a indistinguibilidade de estados quânticos idênticos, por exemplo. Esses fatores parecem indicar que, possivelmente, nesse estágio do desenvolvimento da FQ, os dois núcleos não estão completamente separados, mas podem ter alguma zona de intersecção entre si, ainda que ela seja mínima. Um indício a favor dessa hipótese é que ambos os formalismos, apesar das suas diferenças, possibilitaram a formulação de problemas e conceitos em comum, os quais, posteriormente, comporiam as principais características da FQ e dariam prosseguimento aos debates e desenvolvimentos posteriores desse estilo de pensamento, como a já mencionada dualidade onda-partícula, o comportamento probabilístico dos fenômenos quânticos, a questão da causalidade, do determinismo e da completude da FQ, a não-localidade e o problema da medição. Outro indício a favor dessa hipótese é que, conforme mencionado anteriormente, rapidamente, eles foram provados como equivalentes entre si. Isso, no entanto, não eliminou as particularidades de cada um dos formalismos, principalmente no que se refere à sua forma específica de olhar para os fenômenos quânticos, os princípios filosóficos que guiam esse olhar e a forma de representar e manipular os objetos envolvidos nesses fenômenos. Essas particularidades dos formalismos juntamento com os seus aspectos comuns fortalecem a hipótese de uma estrutura para o coletivo de pensamento dos pesquisadores em FQ composta de dois núcleos para o círculo esotérico, com uma zona de intersecção entre si.

Portanto, a partir dessa descrição do desenvolvimento do coletivo de pensamento da FQ no estágio após a consolidação da MQ, na segunda metade dos anos 1920, seria possível representá-lo de acordo com a Figura 4, onde o coletivo de pensamento dos pesquisadores em FQ (círculo verde) corresponde ao círculo esotérico de um coletivo de pensamento científico, onde se encontram os especialistas gerais em FQ. Esse coletivo 
apresenta dois núcleos (círculos amarelo escuro), correspondentes aos especialistas específicos, que trabalham com a Mecânica Matricial e Ondulatória, respectivamente. Esses núcleos apresentam uma zona de intersecção, correspondente aos especialistas que trabalham com problemas e conceitos comuns aos dois formalismos e não se restringem ou não se preocupam em olhar para os fenômenos quânticos de acordo com somente um deles, seguindo pressupostos filosóficos específicos. Por fim, o círculo esotérico (círculo verde) se encontra dentro do círculo exotérico (círculo azul claro), onde se encontra o público de formação geral, e que, por sua vez, se encontra imerso na zona externa ao coletivo de pensamento da FQ (zona azul escura), onde se situa o público mais amplo. Nessa Figura 4, buscou-se separar os círculos exotérico, esotérico e seus núcleos por linhas tênues, a fim de representar a mobilidade mais fácil de circulação dos indivíduos entre esses diferentes círculos, enquanto que a linha que separa o círculo exotérico da sua zona externa foi representada como uma linha mais espessa, a fim de ressaltar a separação entre o público de formação geral e o público mais amplo, assim como a dificuldade de circulação dos indivíduos entre essas duas zonas, conforme defendido por Fleck.

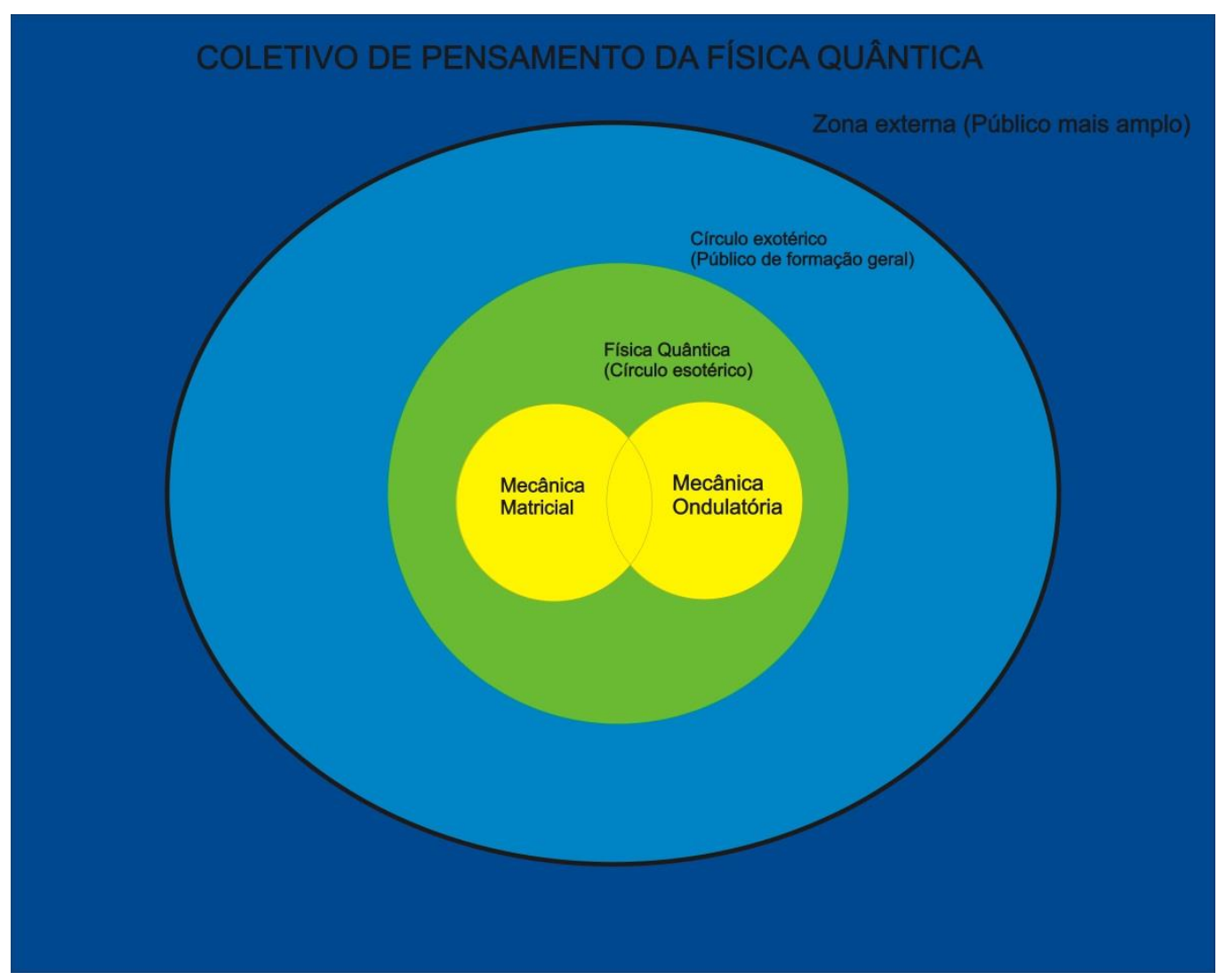

Figura 4: Coletivo de pensamento da FQ durante o estágio de consolidação do formalismo da MQ. 
Assim, após a consolidação da MQ, os físicos passaram a se engajar na interpretação do seu formalismo e o coletivo de pensamento dos pesquisadores em FQ passou a se desenvolver, dando origem a um novo coletivo: o coletivo de pensamento dos pesquisadores em Fundamentos da FQ.

\subsubsection{Desdobramento e caracterização do coletivo dos pesquisadores em Fundamentos da Física Quântica}

Após o estabelecimento da MQ, dentro do coletivo de pensamento da FQ, uma parte do grupo estava preocupada não somente em desenvolver a teoria e aplicá-la a novas áreas, mas também em entender os fundamentos teóricos e conceituais da nova MQ. Nesse processo, implicitamente, e em alguns casos explicitamente, os físicos atuavam como verdadeiros filósofos (Kragh, 1999, p. 206). Nessa busca por uma coerção maior do pensamento na interpretação do formalismo, os físicos ativamente trocavam ideias e debatiam entre si, reunindo-se em seus centros de pesquisa e universidades, em congressos e conferências, trocando cartas, publicando e criticando os seus artigos, enfim, fazendo com que as ideias circulassem internamente ao coletivo e exercendo deliberadamente o caráter democrático da ciência ressaltado por Fleck. Somente a partir desses debates e trocas de ideias, foi possível compreender e enxergar, em meio ao quadro caótico de ideias e símbolos proporcionado pelo novo formalismo, um ver inicial e pouco claro das principais questões subjacentes a ele: o problema da medição e o papel da consciência, a problemática da causalidade e do determinismo na $F Q$, a questão da completude da FQ, a possibilidade da existência de variáveis ocultas, e a não-localidade. Justamente a partir dos debates e discordâncias a respeito dessas questões, as quais permanecem em aberto até os dias atuais, é que foi possível dar andamento aos desenvolvimentos posteriores da história da FQ e elaborar diferentes esquemas explicativos que, mais tarde, dariam origem às diferentes interpretações da MQ. Esses esquemas explicativos tiveram uma origem comum, dentro de um mesmo estilo de pensamento, e foram respostas ativamente elaboradas na busca de uma coerção do pensamento na interpretação do formalismo da MQ. Porém, devido às discordâncias a respeito dessas questões e dos seus diferentes princípios filosóficos - que já existiam desde a partilha do núcleo do coletivo de pensamento em torno dos formalismos matricial e ondulatório - esses esquemas se desdobraram em diferentes interpretações para a MQ, 
as quais, apesar da origem comum e de comporem um mesmo estilo de pensamento, desenvolveram uma relativa autonomia entre si.

Historicamente, entre os anos 1930 e o final dos anos 1940, devido a determinadas condições histórico-sociais e contextuais específicas - como a prova de impossibilidade de Von Neumann, a aceitação dos argumentos de Bohr por parte da maioria dos físicos e a postura pragmática inspirada no operacionalismo dos físicos norte-americanos - a Interpretação da Complementaridade chegou a ser a interpretação mais hegemônica, chegando a, inclusive, inibir o desenvolvimento de outras interpretações, ao reivindicar para si o status de interpretação oficial e ficando conhecida como a "interpretação ortodoxa". Contudo, além dos fatores contextuais, outro fator que pode ter contribuído para a proeminência dessa interpretação nesse período pode ter sido o fato de que, desde o período de elaboração da Mecânica Matricial, havia um grupo que trocava ideias e se fortalecia mutuamente. Esse grupo se constituiu como um núcleo de especialistas que ficou conhecido como "Escola de Copenhagen" e que, apesar de não ser um grupo totalmente homogêneo e ser liderado e pautado principalmente pelas ideias de Bohr, estabeleceu um contexto propício para um debate mais intenso e dinâmico entre seus membros e, portanto, para o desenvolvimento de um esquema explicativo coerente de forma mais rápida. Enquanto que o contexto de elaboração das outras interpretações, pelo menos nesse primeiro momento, não chegava a formar um núcleo de especialistas que trocava ideias intensamente e formulava um esquema explicativo único e em conjunto, mas era formado principalmente de indivíduos que discordavam entre si em muitos aspectos e que tinham em comum somente algumas críticas e discordâncias com relação à interpretação ortodoxa. Assim, desde meados dos anos 1920, é possível citar como alguns dos principais críticos a essa interpretação e precursores das interpretações posteriores: Einstein, como precursor da Interpretação dos Coletivos Estatísticos, Schrödinger, com sua Interpretação Ondulatória e de Broglie, com sua Interpretação da onda-piloto. Talvez por conta desse caráter mais individualizado, nesse primeiro momento, do trabalho dos críticos à Interpretação da Complementaridade, em meio a um contexto específico propício ao fortalecimento dessa interpretação, é que, entre os anos 1930 e 1940, Einstein termina por não renovar os seus ataques após as discussões do artigo EPR, Schrödinger passa a focar mais na interpretação epistêmica do vetor de estado, deixando de lado a sua Interpretação Ondulatória e de Broglie repudia sua teoria da onda-piloto e adere ao campo 
ortodoxo, dando margem ao estabelecimento da chamada "monocracia da Escola de Copenhagen" (Freire Jr, 2015, p. 83).

Somente no início dos anos 1950, é que essa situação começa a mudar, pois o contexto social e cultural da pesquisa sobre os Fundamentos da FQ passa a sofrer grandes mudanças após a Segunda Guerra Mundial e favorecer o crescimento das críticas à interpretação ortodoxa. No ocidente, a americanização da pesquisa e a influência de uma postura mais pragmática com relação à $\mathrm{FQ}$ não foram muito favoráveis para o entendimento das ideias de Bohr, ou seja, nesse contexto, as ideias que fundamentavam a Interpretação da Complementaridade passam a ter dificuldade de circular e se difundir. $\mathrm{Na}$ URSS, essas ideias eram acusadas de promover tendências idealistas na ciência e foram praticamente banidas. As repercussões das polêmicas na URSS foram intensificadas pelo contexto da Guerra Fria, e os físicos marxistas foram pressionados a se posicionarem com relação às críticas à interpretação de Bohr. Esse contexto propiciou o desenvolvimento de novas interpretações alternativas ou que iam além da interpretação ortodoxa, como a Interpretação causal de David Bohm, a Interpretação dos Estados Relativos de Hugh Everett e a Abordagem Termodinâmica, desenvolvida inicialmente por Gunther Ludwig.

Além do contexto social mais amplo da época, essas outras interpretações se apresentaram com um maior potencial para se desenvolver justamente por romper com muitos obstáculos que dificultavam a circulação e uma análise mais profunda de muitas das ideias que fundamentavam a Interpretação da Complementaridade. A Interpretação causal de Bohm, por exemplo, se torna o maior desafio para a interpretação ortodoxa justamente por produzir um contraexemplo para a prova de impossibilidade de von Neumann e mostrar que uma teoria de variáveis ocultas para a MQ era possível de ser desenvolvida, ainda que implicasse em outras questões, como a não-localidade. Além disso, elas se apresentam como possíveis soluções aos problemas e questões que haviam sido formuladas ao longo da consolidação da MQ, como, por exemplo, a Abordagem Termodinâmica que se propõe a resolver o problema da medição.

No entanto, um fator essencial para o desenvolvimento dessas interpretações será o enfraquecimento da ideia de que todos os problemas de Fundamentos da MQ já haviam sido resolvidos pelos pais fundadores dessa disciplina e da ideia de que a interpretação ortodoxa deveria ser a interpretação "oficial" dos fenômenos quânticos. Conforme 
descrito, esse enfraquecimento foi provocado tanto pelo contexto social mais amplo, quanto pelo contexto e pelas condições específicas e internas ao coletivo. Essas ideias, amplamente difundidas no coletivo de pensamento dos pesquisadores em FQ, prejudicavam o desenvolvimento de outras interpretações justamente por dar a esse coletivo um caráter mais dogmático (Jammer, 1974, p. 250) e impedir a livre circulação de ideias e um debate mais amplo, de caráter democrático - conforme defendido por Fleck, para os coletivos de pensamento científicos - dos problemas de Fundamentos da MQ. Uma das interpretações que sofreu diretamente com essas restrições foi a Interpretação dos Estados Relativos de Everett, quem, sob a orientação e influência de Wheeler, um bohriano dedicado, termina por modificar a sua tese original na tentativa de conciliá-la com a Interpretação da Complementaridade. A influência dessas restrições com relação às suas ideias culmina com Everett desistindo da carreira acadêmica, após a defesa de sua tese, em 1957, e com as suas ideias ficando relegadas ao esquecimento por ao menos 15 anos. Somente por volta dos anos 1970 é que elas voltam a receber atenção, quando Everett consente a publicação de uma longa versão da sua tese em um pequeno livro escrito por DeWitt e este publica um artigo na revista Physics Today, onde contrasta a sua versão dos Muitos Mundos da Interpretação de Everett-Wheeler, com a Interpretação de Copenhagen e a abordagem mentalista de Wigner (Freire Jr, 2015, pp. 129-132). Assim, essa interpretação só pôde receber o devido reconhecimento por parte do coletivo e se desenvolver, quando houve um contexto favorável e as suas ideias puderam circular e ser debatidas com uma maior liberdade.

Por fim, outro fator que favorecerá o desenvolvimento das outras interpretações é que, com uma maior abertura para o debate das questões de fundamentos, os críticos da Interpretação da Complementaridade deixam de trabalhar de forma mais individualizada e passam a estabelecer parcerias ou uma troca maior de ideias entre si, a fim de elaborar ou fortalecer uma interpretação de forma conjunta, ainda que preservando algumas divergências entre si. Como já citado, DeWitt, por exemplo, passa a desenvolver as ideias de Everett, em prol da Interpretação de Muitos Mundos e, mesmo que este último tenha abandonado o debate sobre os Fundamentos da FQ e desistido da carreira acadêmica, houve uma troca de ideias entre ambos, ainda que de forma mais indireta; além desse caso, de Broglie e Bohm, também passam a desenvolver a sua interpretação causal; e a Interpretação dos Coletivos Estatísticos passa a ter diversos adeptos - como Popper, 
Slater, Kemble, Landé, entre outros - que passam a discuti-la e desenvolvê-la em conjunto, ainda que explorando diferentes caminhos. Essas novas parcerias e trocas de ideias entre os adeptos das diferentes interpretações da FQ darão origem a novos núcleos de especialistas em torno de cada uma dessas interpretações, que se fortalecerão à medida que passam a elaborar esquemas explicativos e preditivos, cada vez mais capazes de exercer uma coerção do pensamento e proporcionar um ver formativo mais sólido para as questões de fundamentos e interpretação do formalismo da MQ. Esses diferentes núcleos de especialistas, parecem compor diferentes centros para o que, mais tarde, se tornaria o coletivo de pensamento dos pesquisadores em Fundamentos da FQ. Assim, a partir desse processo de formação e consolidação das diferentes interpretações da FQ, é possível observar a importância, por um lado, do caráter coletivo na busca por uma maior coerção para o pensamento e na elaboração do conhecimento e, por outro, a importância da circulação livre das ideias e do exercício do caráter democrático no coletivo de pensamento científico, ambos os aspectos ressaltados por Fleck.

Então, a partir do fortalecimento e da consolidação dos esquemas explicativos das diferentes interpretações da FQ, dos debates e do reconhecimento das divergências entre elas com relação às questões de fundamentos, os diferentes núcleos de especialistas a quem elas estavam relacionadas puderam ser mais bem definidos, e cada uma das interpretações passou a desenvolver um esquema conceitual e formal próprio. Inclusive, algumas passaram a se mostrar mais adequadas para a explicação de fenômenos em certas áreas da Física do que outras - como a Interpretação de Muitos Mundos, que se mostrou mais adequada ao campo da cosmologia - além disso, algumas foram capazes de fazer previsões que outras não puderam - como a versão dos vários universos da Interpretação de Muitos Mundos, proposta por Deutsch, que o permitiu elaborar um argumento para explicar o valor da constante cosmológica e provar resultados em computação quântica que não foram possíveis de se obter com outras teorias quânticas - por fim, outras tinham mais debilidades e falhas em certos aspectos do que as demais - como a versão corpuscular da Interpretação dos Coletivos Estatísticos, proposta por Landé, que encontra dificuldades de explicar os fenômenos de caráter ondulatório da matéria. Todos esses aspectos fortalecem a hipótese de que cada uma das Interpretações da FQ possui uma particularidade, com seus acoplamentos passivos e ativos característicos, e, portanto, seus 
adeptos parecem compor um centro diferente para um coletivo de pensamento mais amplo: o coletivo dos pesquisadores em Fundamentos da FQ.

Semelhantemente à situação anterior, do coletivo dos pesquisadores em FQ logo após a consolidação da MQ, pode-se considerar que esses núcleos de especialistas fazem parte de um mesmo coletivo de pensamento, pois eles partem das mesmas questões e de um mesmo estilo de pensamento - aquele que foi capaz de formular o problema da medição e os debates em torno da causalidade, do determinismo e da completude da FQ - além disso, há debate e disputas entre eles, com cada uma das interpretações criticando e apontando as debilidades das outras, de tal forma que esse diálogo permite o fortalecimento e o desenvolvimento mútuo de cada uma delas. Essa comunicação e esse diálogo também acontecem através dos mecanismos de circulação e troca de ideias característicos de um coletivo de pensamento científico único, como a reunião de seus membros em congressos, visitas aos centros de pesquisa e universidades dos diferentes grupos, publicações e crítica de artigos entre os membros dos diferentes núcleos, livros didáticos e de divulgação apresentando as diferentes Interpretações da FQ, etc. Contudo, talvez o principal fator que fortalece essa hipótese é o fato de que justamente as poucas coisas que esses diferentes núcleos de especialistas tinham em comum - que eram as críticas com relação à atitude dominante entre os físicos de considerar que as questões de Fundamentos da MQ já haviam sido resolvidas pelos pais fundadores dessa disciplina e a defesa da relevância da pesquisa a respeito dessas questões (Freire Jr, 2015, pp. 237-238) - é que fortalecerão o coletivo de pensamento dos pesquisadores em Fundamentos da FQ como um todo e possibilitarão com que ele seja reconhecido como parte das pesquisas convencionais em Física.

De fato, conforme citado no início dessa seção, incialmente, após a consolidação da MQ, os debates sobre os seus fundamentos e sobre a interpretação do formalismo eram fortemente marcados por argumentos filosóficos e experimentos de pensamento, com os físicos muitas vezes atuando como verdadeiros filósofos. Por conta disso, por muito tempo, esses debates foram considerados pela maioria dos físicos como questões de cunho filosófico com pouca relação com as pesquisas em Física em si, se tornando, assim, um tema marginalizado por essa comunidade. Esse cenário começa a se modificar somente por volta dos anos 1960, após o fortalecimento das novas interpretações da FQ, o 
crescimento e os debates em torno do problema da medição, o reconhecimento da chamada Escola de Princeton, liderada por Wigner e von Neumann, e a publicação do Teorema de Bell, e se fortalece no início dos anos 1970, com as propostas de Clauser e Shimony de submeter esse teorema a testes experimentais viáveis, atingindo o seu ponto sem volta no início dos anos 1980, com os experimentos de Aspect, que resultam em uma atitude de mudança entre os físicos na direção de um amplo reconhecimento da importância do Teorema de Bell. Nesse meio tempo, vale a pena destacar também o papel da revista Epistemological Letters e o Encontro Erice, em 1976, como espaços que possibilitaram, respectivamente, a discussão aberta de temas marginais nas pesquisas em Física e a existência de espaços de socialização entre físicos interessados nesses temas. Ao longo desse tempo, as variáveis ocultas, tema inicialmente considerado de cunho filosófico, invadiu os laboratórios de ótica e pôde ocupar um lugar nas pesquisas convencionais em Física. No entanto, o caminho da filosofia para a Física foi lento e sinuoso, levando mais de 30 anos, e requereu não só boas ideias teóricas, habilidades experimentais e recursos tecnológicos, mas também uma mudança na atitude da comunidade de físicos sobre o status dos Fundamentos da MQ. Além disso, essa mudança só foi possível, pois os chamados dissidentes quânticos, críticos da interpretação ortodoxa e preocupados com as questões de Fundamentos da FQ, foram beneficiados pela emergência de um novo contexto profissional, já que a geração antiga dos pais fundadores da MQ já estava fora do campo de batalha, e pelas mudanças culturais do final dos anos 1960, as quais abriram margem para críticas em relação à Ciência e no próprio interior dela (Freire Jr, 2015, pp. 279-281).

Dessa forma, fica clara a adequação de uma leitura fleckiana para a descrição do processo de formação e consolidação do coletivo de pensamento dos pesquisadores em Fundamentos da FQ, como um processo harmonioso e sutil, podendo se estender por um longo período de tempo, que só foi possível com uma predisposição social geral favorável, somada a uma predisposição específica interna ao coletivo de pensamento. Nesse caso, primeiro se fortaleceram os seus diferentes núcleos, referentes aos adeptos das diferentes interpretações da FQ, para depois, através da circulação do conhecimento entre eles e o fortalecimento dos mesmos, o coletivo de pensamento como um todo se consolidar e ser reconhecido pelo coletivo mais amplo dos pesquisadores em FQ. Além disso, foi possível observar que o desenvolvimento desse coletivo, durante a chamada "monocracia da 
Escola de Copenhagen", sofreu algumas dificuldades justamente por esse coletivo ter adquirido um caráter mais dogmático, com a circulação livre de ideias sendo prejudicada. Sendo assim, o coletivo só pôde se desenvolver mais rapidamente quando esse caráter foi diminuído em prol de um caráter mais democrático, com um debate e uma circulação de ideias mais amplos. Por fim, nota-se que o coletivo de pensamento dos pesquisadores em Fundamentos da FQ somente foi reconhecido como tal pelo coletivo mais amplo dos pesquisadores em $\mathrm{FQ}$, quando houve uma maior abertura deste último para discutir as questões de Fundamentos da FQ e o primeiro passou a utilizar uma linguagem e adquiriu características mais próximas a ele, isto é, quando essas questões passaram a ser testadas experimentalmente e invadiram os laboratórios de ótica.

Todo esse processo aparentemente, contudo, não chegou a formar o que Fleck denomina por "harmonia das ilusões", pois, devido à coexistência, constante diálogo e crítica entre os diferentes núcleos, em nenhum momento, nenhuma das interpretações perdeu a capacidade de observar o contraditório ao seu sistema, ou estabeleceu uma realidade na qual a "origem lógica de determinados elementos não podia mais ser encontrada" (Fleck, [1935]2010, p. 80). Até mesmo no período dominado pela "monocracia da Escola de Copenhagen" isso não chegou a ocorrer, pois os adeptos a essa interpretação tinham consciência da existência de críticas com relação a ela e, inclusive, tinham que buscar argumentos para defendê-la. Eles eram conscientes de que a origem lógica para a solução dos problemas de fundamentos em seu sistema eram o Princípio da Complementaridade e suas bases filosóficas, ambos ativamente elaborados, em sua maior parte, por Bohr. Nem mesmo no episódio de interação entre os membros da Escola de Copenhagen com as ideias de Everett, que culminou na desistência deste último da carreira acadêmica, os primeiros se negaram a analisar a proposta everettiana, a qual, inclusive, foi mediada por Wheeler, um bohriano dedicado. De fato, o que ocorreu foi uma postura de negação da importância dos debates sobre as questões de Fundamentos da FQ, por parte da maioria dos físicos, mas que não caracteriza uma harmonia das ilusões. Essa postura, em uma leitura fleckiana, estaria mais próxima de uma falta de reconhecimento do coletivo de pesquisadores em Fundamentos da FQ, como parte do coletivo de pesquisadores em FQ - a qual foi superada com uma maior comunicação entre seus membros e uma aproximação entre seus estilos de pensamento - do que de uma harmonia das ilusões. Por fim, aparentemente, até mesmo os aspectos da TQ mais aceitos 
pelo coletivo de pesquisadores em FQ como um todo - como o seu formalismo e as suas consequências, a quantização da energia, a dualidade onda-partícula, entre outros - não são o suficiente para estabelecer uma harmonia das ilusões, justamente pelo fato das explicações desses aspectos mais bem consolidados consistirem no objeto das divergências de opinião entre os membros desse coletivo.

No entanto, apesar de aparentemente o processo de formação e reconhecimento do coletivo de pensamento dos pesquisadores em Fundamentos da FQ não ter atingido uma harmonia das ilusões, pode-se dizer ele formou um cenário com uma maior coerção do pensamento e um maior número de acoplamentos passivos, capazes, inclusive, de dar origem a pesquisas com aplicações tecnológicas e a novas áreas de pesquisa, como a área de informação quântica, por exemplo. Isso caracteriza um verdadeiro estilo de pensamento, cuja estrutura do coletivo de pensamento correspondente poderia ser representada, conforme apresentado na Figura 5, onde o círculo referente a esse coletivo possui vários núcleos (círculos amarelo claro), cada um deles correspondente aos especialistas específicos, adeptos das diferentes interpretações da FQ. Possivelmente, assim como no coletivo de pensamento dos pesquisadores em FQ logo após a consolidação da MQ, esses núcleos não se encontram totalmente separados, mas podem ter algumas características em comum e, portanto, algumas regiões de intersecção entre si, principalmente no que se refere à adoção de uma postura mais realista ou mais positivista/instrumentalista com relação à interpretação e descrição dos fenômenos quânticos. No entanto, neste trabalho, esse aspecto não será aprofundado. Além disso, conforme observado na Figura 5, o círculo referente ao coletivo de pensamento dos pesquisadores em Fundamentos da FQ (círculo amarelo escuro) pode compreender também pesquisadores que não necessariamente estão ligados a alguma das interpretações, mas que estão interessados nas questões de Fundamentos da FQ. Esse círculo se encontra dentro do círculo maior, referente ao coletivo de pensamento dos pesquisadores que trabalham com a FQ em geral (círculo verde), este, por sua vez, corresponde a um coletivo de pensamento científico e, portanto, compreende o círculo esotérico de especialistas gerais em FQ. Por fim, o círculo maior (círculo azul) corresponde ao círculo exotérico do coletivo de pensamento científico da FQ, onde se encontra o público de formação geral, que, por sua vez, se encontra separado da zona externa a esse círculo, onde se encontra o público mais amplo. Nessa figura, buscou-se representar, com uma linha mais espessa, o 
fato de que, para Fleck, nos coletivos de pensamento científicos, a maior barreira de circulação dos indivíduos entre as diversas camadas dos círculos se encontra justamente entre o círculo exotérico e a sua zona externa, que divide o público de formação geral do público mais amplo, enquanto que as linhas que separam os outros círculos foram representadas de forma mais tênue, a fim de contemplar a visão fleckiana do caráter democrático dos coletivos de pensamento científicos e, portanto, a fácil circulação dos indivíduos entre as suas diversas camadas.

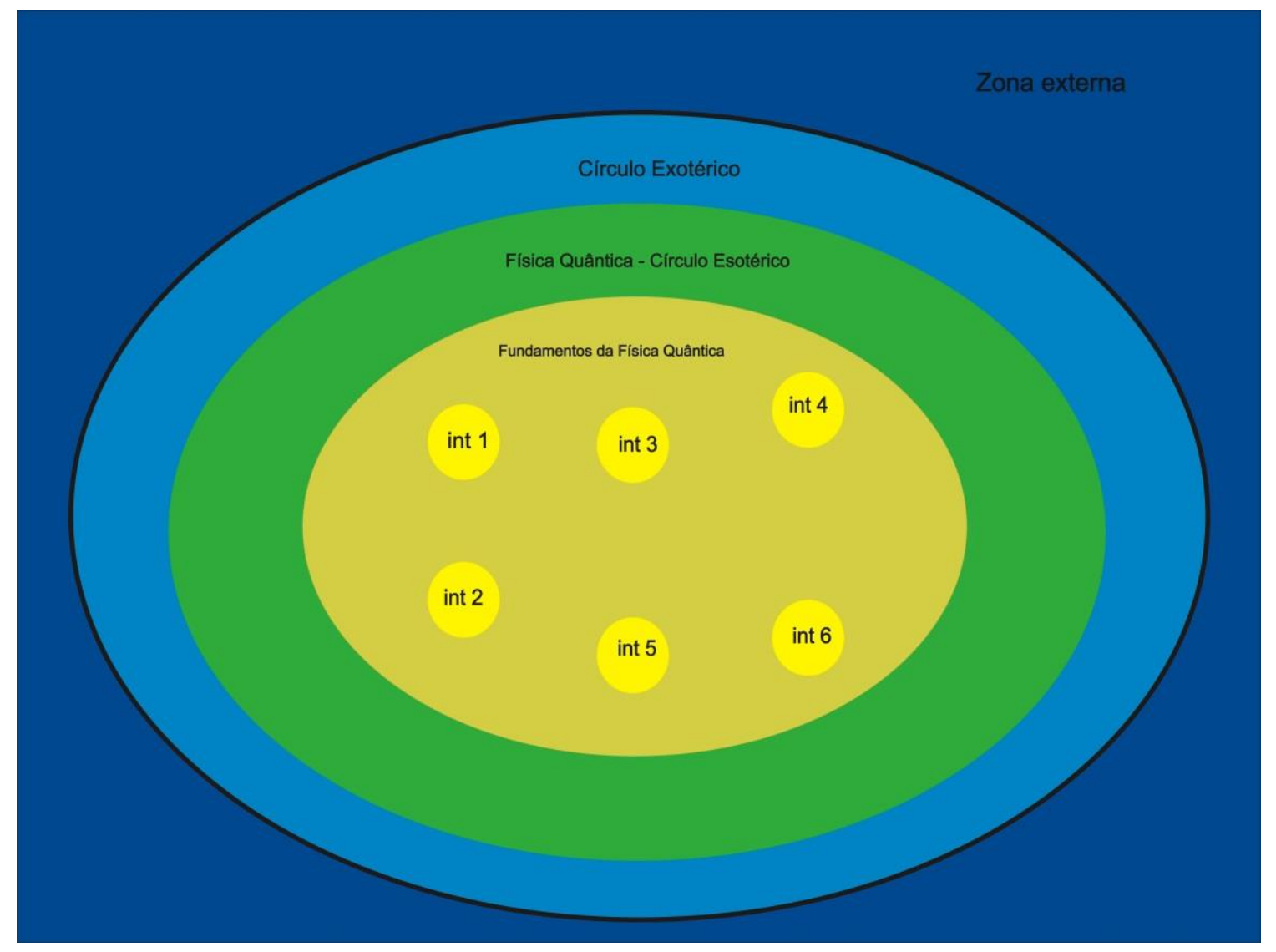

Figura 5: Coletivo de pensamento dos pesquisadores em Fundamentos da FQ, com seus vários núcleos, cada um deles correspondente às diferentes interpretações da FQ.

Por fim, novamente, é possível analisar se a descrição de Fleck a respeito do funcionamento de um coletivo de pensamento com mais de um centro - como o das artes, por exemplo - se aplica ao coletivo em questão. Nessa descrição, Fleck afirma que "o fato de o coletivo possuir dois centros torna impossível estabelecer uma postura dos indivíduos com relação aos produtos específicos do coletivo: ela sempre oscilará entre a simples admiração e o criticismo. Por conta dessa oscilação, os produtos do coletivo estão 
constantemente em um estágio de instabilidade" (Fleck, [1936]1986, p. 104, tradução livre). No caso do coletivo de pensamento dos pesquisadores em Fundamentos da FQ, pode-se dizer que os adeptos de uma determinada interpretação, de fato, possuem uma maior admiração com relação à interpretação defendida e um maior criticismo com relação às outras, porém é questionável o quanto essa admiração e criticismo são simples ou ingênuos. Isso porque os membros dos diferentes núcleos desse coletivo estão em constante interação e diálogo, trocando e criticando as suas ideias, de tal forma que grande parte de seus membros não são simples adeptos das interpretações de forma ingênua, mas têm consciência de suas vantagens e limitações com relação às outras interpretações. Por outro lado, de fato, parece haver um sentimento, nesse coletivo, de que os seus produtos estão em um constante estágio de instabilidade. Isso porque não há um consenso, nesse coletivo, sobre qual das interpretações é a mais adequada para resolver as questões de Fundamentos da FQ e nenhuma das interpretações parece ser capaz de resolvê-las completamente, sendo que, muitas vezes, para cada questão colocada, o coletivo pode adotar uma interpretação diferente. Esse sentimento de instabilidade faz seus membros questionarem sobre a possibilidade de, futuramente, haver uma interpretação hegemônica, mais consensual. No entanto, essa controvérsia, com a coexistência das diversas interpretações da FQ, permanece em aberto há mais de 80 anos, desde a consolidação da MQ, e parece não haver perspectiva de que ela seja resolvida. De fato, no período de 2007 a 2011, Pessoa (2007-2011) já havia contado cerca de 50 interpretações e acreditava que poderia se chegar a uma centena delas.

Sendo assim, uma vez descrito o processo de formação e consolidação do coletivo de pensamento dos pesquisadores em Fundamentos da FQ, e caracterizada a sua estrutura, é possível partir para a análise das influências histórico-sociais na gênese da relação entre a FQ e o misticismo.

\subsection{Influências histórico-sociais na gênese da relação entre Física Quântica e misticismo}

Conforme visto anteriormente, as condições histórico-sociais, tanto dos contextos gerais como dos específicos, podem influenciar fortemente no estabelecimento de relações entre os diferentes coletivos de pensamento e, portanto, entre as suas formas de conhecimento. Isso possibilita transformações sutis e harmoniosas nos estilos de 
pensamento, as quais podem originar coletivos de pensamento totalmente novos, com estruturas de funcionamento diversas. Nesta seção, se buscará mapear, ao longo da história do desenvolvimento da FQ, as possíveis influências histórico-sociais que podem ter contribuído de alguma forma, ainda que indireta, no estabelecimento da relação entre FQ e misticismo.

\subsubsection{Neorromantismo no final do século XIX}

Conforme mencionado na seção 3.1.1, o historiador dinamarquês Helge Kragh (1999, p. 10) defende que, no final do século XIX, havia uma mudança cultural mais ampla na visão de mundo das pessoas, marcada por um espírito muitas vezes classificado como neorromântico. Esse espírito, presente na cultura geral, teve impactos concretos na Física teórica, se refletindo em diversas tendências caracterizadas por um antimaterialismo generalizado.

Antes de apresentar essas tendências, é importante caracterizar qual era o quadro conceitual que descrevia o mundo, de acordo com a Mecânica Clássica, o qual era o principal alvo das críticas presentes nessas tendências. Esse quadro pode ser atribuído a uma versão laplaciana do newtonianismo, de acordo com a qual o mundo seria constituído de átomos, nos quais atuam as várias forças de longo e curto alcance. Nesse quadro, a força gravitacional seria o principal exemplo que representaria essas forças, capazes de atuar à distância, ao longo do espaço vazio (Kragh, 1999, p. 4).

Com o advento das teorias de campo, no entanto, o mecanismo de propagação das forças passa a ser modificado, e a primeira e principal tendência antimaterialista na Física, que iria marcar esse período, seriam as teorias baseadas na existência do éter - um meio hipotético, contínuo, que preencheria todo o espaço, no qual as forças se propagariam com uma velocidade finita. Essas teorias adquiririam forma através de diferentes modelos explicativos e atrairiam diversos adeptos. Dentre eles, Michelson, que chegou a expressar um grande entusiasmo com relação a esse conceito, ao declarar, em seu livro didático sobre óptica, de 1902, que "aparentemente, o dia em que as diversas linhas provenientes de regiões remotas irão convergir e chegar a um comum acordo não está muito distante", esse comum acordo seria, para ele, "uma das maiores generalizações da ciência moderna... a partir da qual todos os fenômenos do universo físico são apenas diferentes manifestações dos vários modos de movimento de uma substância que permeia tudo - o éter" (Kragh, 
1999, p. 4). Assim, essa substância seria o ponto de partida de modelos que seguiriam, basicamente, duas linhas de investigação: os modelos baseados na eletrodinâmica e os baseados na hidrodinâmica.

Na linha da hidrodinâmica, alguns modelos puderam chegar a resultados muito próximos com os da mecânica, como o modelo de Bjerknes, dos anos 1870, por exemplo, que descrevia o movimento de corpos em um fluido infinito e incompressível, e chegou à conclusão de que duas esferas pulsantes poderiam originar uma força entre elas, a qual variaria de forma inversamente proporcional à separação dos seus centros. Esse modelo foi utilizado, posteriormente, em 1898, por Korn, para desenvolver uma teoria hidrodinâmica da gravitação. Outras importantes teorias nessa linha foram: a teoria atômica dos vórtex, sugerida originalmente por William Thomson (posteriormente, Lord Kelvin), de 1867, e a teoria do "jato de éter", desenvolvida por Karl Pearson, nos anos 1880 e 1890. Esta última incluía uma espécie de "matéria negativa", a qual seria a precursora dos termos "antimatéria” e "antiátomos" (Kragh, 1999, pp. 5-6).

Já a linha da eletrodinâmica surgiu por volta de 1900 e se desenvolveu por aproximadamente uma década. Esse programa buscava reduzir a mecânica ao eletromagnetismo, a fim de construir uma nova Física, na qual a matéria como uma substância desapareceria e seria substituída por efeitos dos campos eletromagnéticos. Ele, basicamente, possuía duas tradições: uma proveniente da tradição eletrodinâmica corpuscular de Weber e seus seguidores, a qual operava com partículas elétricas com interação instantânea, mas sem o conceito de campo; e a outra baseada na eletrodinâmica de campo de Maxwell. Nesse processo, diversos seguidores de ambas as tradições expressaram suas posturas antimaterialistas. Um deles foi Wiechert, em 1894, que expressou sua convicção de que a massa material deveria ser um epifenômeno e que a verdadeira massa seria de origem eletromagnética e consistiria de partículas elétricas hipotéticas atribuídas a excitações no éter. Outro foi Wien, em 1900, que assumiu que toda massa possuía uma natureza eletromagnética, para argumentar que a matéria consistia de elétrons, as quais seriam partículas de eletricidade, e não pequenas esferas nas quais residiria a eletricidade. Mais do que isso, Wien defendia que as Leis de Newton deveriam ser entendidas eletromagneticamente e que, caso uma completa correspondência entre essas duas teorias não pudesse ser feita, a teoria do elétron seria a mais profunda e 
fundamental dentre elas. As pesquisas nessa linha chegaram a elaborar modelos, os quais derivaram resultados importantes, como o programa de pesquisa de Lorentz, de 1899, que derivou a ideia de que a massa varia com a velocidade. Então, por volta de 1904, a visão eletromagnética se destacou, se mostrando como uma substituta atrativa para a visão de mundo mecânica, a qual era vista como ultrapassada, materialista e primitiva, e sendo fortemente discutida, não apenas nos artigos das revistas especializadas, mas chegando a aparecer também nos livros didáticos. O programa de pesquisa eletromagnético era um programa ambicioso, de caráter marcadamente reducionista, que buscava estabelecer uma teoria unitária de toda matéria e de todas as forças que existiam no mundo. Nesse sentido, ele poderia ser considerado um exemplo de uma "teoria de tudo", na qual todos os fenômenos seriam manifestações do substrato fundamental do mundo: o campo eletromagnético (Kragh, 1999, pp. 105-109). Esse programa adquiriu tamanha importância que despertou, inclusive, o interesse de áreas fora da Física, sendo ocasionalmente discutido por filósofos e influenciando a política. Esse fato é possível de ser ilustrado através de uma citação de Lenin, em seu livro "Materialismo e Empirocriticismo", de 1908, no qual ele afirma que "o elétron é tão inesgotável quanto o átomo, a natureza é infinita, e ela existe infinitamente" (Kragh, 1999, p. 110). No entanto, por volta de 1914, esse programa foi perdendo a sua força, e o número de seus adeptos foi diminuindo, o que o tornou relegado à periferia das pesquisas convencionais em Física (Kragh, 1999, p. 114).

Por fim, outra interessante derivação, relacionada com a ideia de éter, será proposta por Clifford, quem utilizou a noção de curvatura de Riemann para sugerir que o movimento da matéria e do éter seria, na realidade, uma manifestação de uma variação na curvatura do espaço. Essa ideia geral de uma "geometrização da Física" era bem conhecida no final do século XIX e inspirou vários físicos, astrônomos, e matemáticos, além de autores de ficção científica. Especulativas ou não, essas tentativas foram consideradas legítimas pelo espírito característico da Física nos anos 1890 (Kragh, 1999, p. 6).

Nos anos 1890, outra importante e diferente tendência na Física, que competia com a mecânica e refletia o espírito desse período, foi um programa baseado na termodinâmica, chamado "energicismo". Esse programa foi fundado por Helm e Ostwald, que 
consideravam que a energia era o conceito unificador mais importante nas ciências físicas, e buscava uma termodinâmica generalizada que pudesse substituir a mecânica como fundamento para a Física. Assim como o programa da eletrodinâmica, o energicismo também se posicionava contrário à descrição mecânica do mundo e foi pensado como uma revolta contra o chamado "materialismo científico". Essa revolta incluía a defesa de que a mecânica deveria ser submetida às leis mais gerais da energética, no sentido de que as leis da mecânica deveriam ser reduzidas aos princípios da energia. Seus adeptos também negavam o atomismo, alegando que este não passava de uma representação mental útil. Ostwald e Pierre Duhem, por exemplo, argumentavam que a crença em átomos e moléculas era metafísica e que todos os fenômenos empíricos poderiam ser explicados sem essa hipótese. Por um lado, a alternativa energética recebeu apenas um apoio modesto entre os físicos e químicos, por outro, porém, o criticismo com relação à teoria atômica e a ênfase na energia como um conceito fundamental foram reproduzidos por muitos outros cientistas, não ligados diretamente ao programa energético. Pierre Curie, por exemplo, que possuía uma visão positivista da ciência, abdicava das hipóteses materialista e atomista em favor de um fenomenalismo, inspirado pelas leis da termodinâmica. Ele e outros físicos franceses argumentavam que a termodinâmica seria uma teoria física ideal, e que a energia, e não a matéria, era a essência da realidade, a qual poderia ser entendida somente como processos ou ações. Ernst Mach, no início dos anos 1880, também defendia uma compreensão fenomenológica da Física, de acordo com a qual as teorias e conceitos físicos seriam apenas formas econômicas de organizar os dados obtidos pelos sentidos e, apesar de admitir a utilidade da mecânica molecular, ele estava de acordo com Ostwald e seus aliados, sobre a posição de que os átomos não seriam nada mais do que ficções convenientes. A forma como Ostwald e seus aliados defendiam a "matéria como subordinada à energia" e que "todos os eventos seriam, em última instância, nada mais do que modificações na energia" era muito similar com a retórica utilizada pelos adeptos da tendência eletrodinâmica, somente com as palavras "éter" e "campo eletromagnético" sendo substituídas por "energia". No entanto, em ambos os casos, o materialismo era descartado e a matéria era declarada como sendo um epifenômeno (Kragh, 1999, pp. 7$10)$.

Sendo assim, a partir da análise dos argumentos presentes nessas tendências no final do século XIX, Kragh (1999, pp. 10-11) fundamenta a sua defesa de que elas 
representavam mais do que uma mudança da mecânica para a termodinâmica ou para a eletrodinâmica como fundamentos para a Física, e de que essas mudanças foram muito mais do que simples resultados de descobertas espetaculares. Segundo ele, essas tendências eram parte de uma mudança na visão de mundo mais ampla, a qual tinha ramificações fora da Física e que era alimentada pelo espírito cultural particular do período, o qual muitas vezes é descrito como um espírito neorromântico. Um elemento comum, ressaltado por Kragh, nessa configuração cultural era uma forte postura antimaterialista, a qual se apresentava em diferentes formatos. Essa postura se baseava na crença de que a "matéria está morta". Assim, em meio a esse espírito, os cientistas não hesitaram em questionar também outras doutrinas bem estabelecidas, derivadas da Física da matéria, incluindo a permanência dos elementos químicos e as leis de conservação da matéria e da energia. Nessa lógica, em alguns contextos e em meio a um clima que enfatizava a transformação, a evolução e o porvir, as próprias qualidades de permanência e conservação eram consideradas suspeitas. Um exemplo ilustrativo dessas suspeitas e questionamentos foi a defesa de Gustave LeBon, que, em 1896, anunciou a descoberta do que denominou de "luz negra", uma espécie de radiação invisível. A partir dessa descoberta, ele pôde concluir que toda matéria era instável, pois emitia radiação constantemente ou uma substância que ele denominou de "efluvia". Dessa forma, segundo ele, as qualidades materiais seriam epifenômenos exibidos pela matéria no processo de transformação para um éter imponderável. Para LeBon, não havia dualismo entre matéria e energia, eles apenas representariam diferentes estágios de um processo evolucionário, cujo fim resultaria em um estado eterial puro. As especulações de LeBon tiveram um apelo considerável entre os cientistas que estavam insatisfeitos com os ideais positivistas e buscavam uma ciência não dogmática, mais vigorosa, a qual satisfaria o que eles associavam a um espírito mais humano. Dessa forma, suas ideias iam de encontro com um sentimento, nesse período, descrito como uma "revolta contra o positivismo" ou mesmo uma "revolta contra a razão" (MacLeod, 1982, p. 3).

Contudo, apesar de ser possível falar de um espírito geral presente na Física, no período do final do século XIX, é importante destacar que havia diferenças consideráveis, principalmente no que concernem às particularidades dessas manifestações nas diferentes nações envolvidas. Na Alemanha e na França, por exemplo, a reação contra a visão de mundo mecanicista era mais frequentemente associada a aspectos positivistas e aos ideais 
termodinâmicos, do que no caso da Inglaterra. Os físicos britânicos, em geral, não tinham simpatia com uma visão de ciência positivista e factual, e havia uma distinção entre a receptividade metafísica típica do estilo britânico e o estilo não filosófico típico dos alemães. Além disso, a batalha pelas emoções, ações e processos evolucionários presentes no estilo britânico, também podia ser encontrada no estilo neorromântico francês, que, por sua vez, era contrastado com o estilo supostamente sem imaginação dos alemães. Por fim, os franceses também se opunham ao estilo britânico de fazer Física, o qual consideravam excessivamente mecânico e pobre de espírito (Kragh, 1999, pp. 11-12).

Uma vez apresentadas as generalidades e particularidades do clima cultural presente no contexto do surgimento da FQ, é possível considerar que o neorromantismo e o antimaterialismo, presentes nesse período, em alguma medida, posteriormente, podem ter influenciado no estabelecimento da relação entre a emergente FQ e o misticismo.

\subsubsection{A República de Weimar no período entreguerras}

Outro período interessante, o qual pode ter contribuído para o estabelecimento da relação entre FQ e misticismo, ainda que indiretamente, é estudado pelo historiador da ciência Paul Forman, em seu artigo A cultura de Weimar, a causalidade e a Teoria Quântica, 1918-1927, de 1983, no qual ele investiga como a cultura na Alemanha, no período de Weimar (1918-1927), após a Primeira Guerra Mundial (1914-1918), consistia em um ambiente intelectual hostil para os físicos e como esse ambiente influenciou nas ideias e nos posteriores desenvolvimentos da FQ.

Antes desse período, no início do século XX, a Alemanha era a principal liderança mundial nas pesquisas e em questões científicas no geral, servindo, muitas vezes, como um modelo a ser seguido pelos outros países. De fato, foi nesse país que muitas das grandes inovações na Física e em outras ciências exatas tiveram a sua origem. No entanto, com o fim da Primeira Guerra Mundial, no ano de 1918, esse cenário mudou drasticamente. Com a derrota na guerra e o humilhante tratado de Versalhes, o país passou a enfrentar manifestações internas, falta de comida, assassinatos políticos, queda na economia, e uma hiperinflação que durou até 1923. Assim, a Alemanha se encontrava em um estado de crise aguda, com uma crise econômica, política e, até mesmo, espiritual. Ainda assim, contra todas as expectativas, a Física alemã conseguiu se destacar bem durante esse período difícil e obteve sucesso em manter o seu reconhecimento 
internacional. Em algumas áreas emergentes, como nas teorias atômica e quântica, os físicos alemães é que definiam o rumo das pesquisas internacionais. E, apesar de todas as dificuldades e condições de vida precárias, as sementes da MQ puderam ser plantadas durante o início da República de Weimar (Kragh, 1999, p. 139).

No contexto pós-guerra, a comunidade científica alemã permaneceu praticamente intacta, porém passou a sofrer grandes restrições financeiras, tornando-se uma comunidade pobre e desesperada, à procura de financiamento para as pesquisas. Além disso, os cientistas alemães passaram a ser excluídos das colaborações internacionais, pois, dentre outros fatores, a falta de moeda estrangeira no país tornou a compra de literatura e instrumentos praticamente impossível. Ainda no contexto internacional, a Alemanha sofria um boicote tanto no que se refere à sua participação em associações internacionais - por exemplo, o país associou-se ao Conselho de Pesquisa Internacional (IRC), somente após o final da Segunda Guerra Mundial - quanto na sua participação em conferências e publicações em revistas, além de um boicote com relação ao idioma, uma vez que o alemão foi impedido de ser utilizado como idioma oficial em boa parte das conferências internacionais (Kragh, 1999, p. 145).

Assim, em meio a esse contexto difícil, os líderes científicos alemães perceberam que eles precisavam legitimar sua ciência de uma nova forma, tanto para poder se manter, como para apelar de forma mais convincente para potenciais patrocínios do governo. Nesse processo de legitimação, diversos argumentos foram utilizados, entre eles, o de que a ciência deveria ser apoiada e incentivada, não apenas porque ela levaria ao progresso tecnológico e econômico, mas também porque ela seria um dos principais recursos culturais do país. Dessa forma, a ciência passou a ser vista como uma portadora da cultura alemã e como um meio de restaurar a dignidade nacional, e os famosos cientistas alemães se tornaram instrumentos da política nacional e internacional, no mesmo patamar que os poetas, compositores e artistas. Contudo, o apelo para os valores culturais e políticos da ciência não foi apenas parte da retórica de cientistas em busca de suporte financeiro, mas também estava em consonância com a visão de muitos políticos e acadêmicos humanistas, que favoreciam uma atitude antiutilitarista e antimaterialista com relação à ciência (Kragh, 1999, pp. 139-140). 
Em meio a essa necessidade de legitimação e de recursos para a sobrevivência da ciência alemã, as organizações científicas precisaram buscar novas fontes e formas de financiamento e organização. Uma das mais importantes agências da nova política científica, que foi fundada em 1920, foi a Sociedade Emergencial para a Ciência Alemã e Bolsas de Estudo, a qual possuía uma relativa autonomia, com a avaliação dos pedidos de financiamento sendo promovida por um júri de especialistas, sem a interferência do governo central. Essa agência de fomento foi essencial para o desenvolvimento da Física atômica e quântica no país, sendo responsável pelo financiamento das principais pesquisas nessa área (Kragh, 1999, pp. 141-144). No entanto, além dessas dificuldades, outro importante aspecto que os cientistas tinham que lidar nessa busca por legitimação, durante a década posterior a 1918, era uma mudança no ambiente intelectual, o qual de diversas formas se apresentava como hostil aos valores tradicionais da Física. A Física, e a Ciência em geral, de forma crescente, passaram a ser acusadas de serem desumanas, mecanicistas, e contrárias aos valores humanos. Essas acusações já eram antigas, presentes tanto na Alemanha, como em outros lugares, mas elas se tornaram ainda mais frequentes e foram colocadas com mais autoridade durante a República de Weimar. Atitudes não ou anticientíficas eram comuns em alguns ramos da filosofia, psicologia, sociologia, astrologia, cabala e outras áreas onde o misticismo encontrava espaço. Assim, em meio a esse contexto, Forman (1983, p. 7) conta que a tendência intelectual que passou a dominar nesse país, no mundo acadêmico, foi uma "filosofia da vida" existencialista (Lebensphilosophie), neorromântica, que se alimentava de crises e era marcada pelo antagonismo em relação à racionalidade analítica e às ciências exatas e suas aplicações técnicas. Nesse período, o cientista passou a ser alvo de críticas e exortações em favor de uma renovação espiritual, e tudo o que estava relacionado à "causalidade" passou a ser símbolo de tudo aquilo que era odioso na atividade científica. De fato, muitos cientistas sentiam que o ambiente cultural em que se encontravam era antagônico à sua ciência $\mathrm{e} o$ que realmente importava para o público de formação geral eram ideias estranhas ao pensamento científico. Isso pode ser observado, por exemplo, nas impressões expressadas por Wilhelm Ostwald, segundo a qual "Na Alemanha de hoje sofremos outra vez de um misticismo desvairado, que, do mesmo modo como no passado, se volta contra a ciência e a razão, como seus inimigos mais perigosos", por Planck, onde ele afirma que "É de estarrecer o modo como tantas pessoas, particularmente nos círculos educados, (...) caem 
sob a influência dessas novas religiões, entrando em iridescência com todos os matizes, desde o misticismo mais confuso até a superstição mais crassa" (Forman, 1983, p. 13), ou mais sinteticamente por Sommerfeld, ao responder à solicitação de uma prestigiosa revista alemã para que ele escrevesse sobre astrologia:

Não parece um anacronismo monstruoso que, no século $\mathrm{XX}$, um periódico respeitável se veja compelido a solicitar uma discussão sobre astrologia? Que amplos círculos do público educado ou semieducado sejam atraídos mais pela astrologia do que pela astronomia? (...) A crença numa ordem mundial racional foi abalada pelo modo como a guerra terminou e a paz foi ditada; consequentemente, busca-se a salvação numa ordem mundial irracional. (...) Assim, evidentemente nos confrontamos outra vez com uma onda de irracionalidade e romantismo semelhante à que, cem anos atrás, varreu a Europa como reação contra o racionalismo do século XVII (Sommerfeld, 1927, apud Forman, 1983, p. 14).

Dessa forma, holismo, intuição, relativismo e existencialismo eram os temas do momento, em detrimento da análise matemática, experimentos controlados e explicações causais (Kragh, 1999, pp. 151-152). Inclusive, de acordo com Forman (1983, pp. 14-15), eram os matemáticos e os físicos teóricos que eram os principais alvos desse ambiente intelectual, se mostrando como objetos particulares do ódio público e privado. Tanto assim que, em 1920, os matemáticos alemães se reuniram numa organização de defesa, denominada Mathematischer Reichsverband, cuja atribuição especial era proteger a posição dos matemáticos nas escolas.

Outro aspecto interessante, que ilustra o ambiente intelectual da época, foi a reforma educacional proposta nesse período, cujo caráter pode ser ilustrado pelas declarações do secretário de Estado alemão, Carl Heinrich Becker, em 1919, onde ele afirma que:

O mal básico é a supervalorização do puramente intelectual em nossa atividade cultural, a predominância exclusiva do modo racionalista de pensamento, que tinha de levar, e levou, ao egoísmo e ao materialismo em suas formas mais crassas. (...) Todo nosso sistema educacional é orientado por demais exclusivamente para o intelecto. Devemos aprender outra vez a reverenciar o irracional (Becker, 1919, apud Forman, 1983, p. 22).

Nessa reforma, o ministério alemão se recusava a justificar qualquer parte dos currículos com base em considerações utilitárias e terminou por reduzir substancialmente 
o tempo dedicado à matemática e às ciências naturais nos currículos (Forman, 1983, pp. 23-24).

Por fim, Forman (1983, pp. 27-34) conta que houve um livro que influenciou de forma especial na formação desse ambiente intelectual hostil, na Alemanha, no período de Weimar: "A decadência do ocidente", de Oswald Spengler (1918), que terminou por aprofundar um sentimento de pessimismo já existente na Europa ocidental, nesse período. De acordo com Forman, esse livro foi amplamente lido nos círculos acadêmicos, despertando manifestações tanto de apoio, como de críticas, sendo citado explicitamente ou de forma familiarizada com suas teses por Max Born, Albert Einstein, Franz Exner, Philipp Frank, Gerhard Hessenberg, Pascual Jordan, Konrad Knopp, Richard von Mises, Friedrich Poske, Hermann Weyl e Wilhelm Wien. O livro de Spengler apresenta uma visão relativista radical, na qual ele despreza completamente as noções de causalidade e objetividade, as quais ele considera como ultrapassadas. Spengler também argumenta que a Ciência não é nada mais do que uma mera expressão antropomórfica e de uma cultura e época particulares e, portanto, a Física seria um produto relativo à cultura e à história, de tal forma que não existiria uma Física fora ou independente dos ambientes culturais locais. Além disso, para ele, as principais culturas são organismos autônomos, únicos e singulares, que compartilham o mesmo ciclo de existência, pois surgem, amadurecem, apodrecem e jamais retornam. Spengler ainda acrescenta que não existe uma única cultura, mas muitas, “cada qual, em sua essência mais profunda, difere das outras, limitada em duração e autocontida" (Spengler, 1918, p. 29). Com isso, ele estende esse relativismo para as ciências naturais, em especial, à Física da seguinte forma:

Simplesmente não existem concepções outras que não concepções antropomórficas, (...) e assim certamente acontece com qualquer teoria física, não importa quão bem fundamentada ela supostamente seja. Qualquer fundamentação também é, por sua vez, um mito, e todos os seus aspectos são pré-formados antropomorficamente. Não existe ciência natural pura, não há sequer uma ciência natural que possa ser designada como comum a todos os homens (Spengler, 1918, p. 533).

Com seu relativismo, Spengler joga fora todos os critérios para o estabelecimento da verdade de uma teoria científica e, curiosamente, ele se inspira nas mudanças que a Física vinha sofrendo nessa época, para sustentar a sua crença de que havia chegado o tempo 
para o amadurecimento de uma nova Física, que unificaria pensamento e espírito (Kragh, 1999, p. 152).

Então, frente a esse clima antirracional e antipositivista da República de Weimar, de acordo com Forman, o relativismo cultural estendido às ciências naturais e exatas foi recebido pelos cientistas como um desafio direto à sua ideologia. De tal forma, que a atitude predominante dos cientistas alemães, mais especificamente dos físicos e matemáticos foi a de procurar acomodar seu discurso e a ideologia científica a um ambiente intelectual hostil, repudiando concepções positivistas com respeito à Natureza da Ciência, justificações utilitárias para seus objetivos e, em alguns casos, a própria possibilidade e o valor da atividade científica. Essa defesa se sustenta na seguinte concepção defendida por Forman, sobre as influências das circunstâncias socioculturais nas quais os cientistas estão inseridos:

\footnotetext{
(...) quando os cientistas e sua atividade gozam de alto prestígio no ambiente social imediato (...), têm também relativa liberdade para ignorar as doutrinas, simpatias e antipatias específicas do meio cultural correspondente. Quando a aprovação está assegurada, eles ficam livres de pressões externas, e livres para acompanhar as pressões internas da disciplina - o que significa usualmente liberdade para agarrar-se à ideologia tradicional e a predisposições conceituais. No entanto, quando os cientistas e seu trabalho experimentam uma perda de prestígio, veem-se impelidos a tomar medidas para compensar esse declínio (Forman, 1983, p. 8).
}

Assim, baseado nessa premissa, o historiador da ciência defende que o movimento para eliminar a causalidade na Física, que surgiu e cresceu brusca e fortemente na Alemanha, após 1918, exprimia fundamentalmente um esforço dos físicos alemães em adaptar o conteúdo de sua ciência aos valores do ambiente intelectual em que se encontravam. Segundo Forman, a explicação para a criatividade provinda desse lugar, nesse período, que foi essencial para o desenvolvimento da TQ, deve ser buscada, pelo menos em parte, na própria hostilidade do meio intelectual de Weimar. Pois, para ele, a ansiedade dos físicos alemães em reconstruir os Fundamentos da Física pode ser interpretada como uma reação ao prestígio negativo dessa ciência, nessa época.

(...) caso o físico desejasse melhorar sua imagem pública, devia antes de tudo dispensar a causalidade, o determinismo rigoroso, esse aspecto universalmente detestado da descrição física do mundo. E isso, é claro, era precisamente o necessário para a solução 
dos problemas da física atômica que, na época, constituíam o foco de interesse do físico (Forman, 1983, p. 9).

Essa adaptação pode ser vista claramente na postura dos físicos de evitar justificar a importância da Ciência com argumentos utilitaristas e passando a argumentar que a Ciência é essencialmente cultura. Essa postura pode ser observada na mudança do tom dos discursos dos físicos Wilhem Wien, Hans Reichenbach, Max Born, Arnold Sommerfeld e, mais fortemente, em Richard von Mises e Gustav Doetsch. Wien, por exemplo, em um artigo de 1919, em comemoração ao aniversário da morte de Helmholtz, explica que, apesar de ser verdade que Helmholtz se transformara em um empirista "através da oposição à escola hegeliana", e que nunca havia sido capaz de abandonar tal posição, ele sempre se preocupou com a "totalidade das ciências", mantendo objetivos "ideais" e não "materiais", dirigidos ao "domínio do espírito" (Forman, 1983, p. 37). Até mesmo Reichenbach, um dos principais expoentes do empirismo lógico "rigoroso" chega a declarar, em 1929, que "a coisa mais importante que se pode dizer sobre [fazer física] é que se trata de uma necessidade que cresce do ser humano como o desejo de viver, ou de brincar, ou de formar uma comunidade com outros" (Forman, 1983, p. 40), mostrando que a própria tradição positivista passou a adquirir elementos da chamada "filosofia da vida" (Lebensphilosophie). No entanto, é com o exemplo de von Mises que será possível notar uma influência mais direta e enfática do ambiente intelectual da época e, mais especificamente, dos pressupostos de Spengler e seu livro "A decadência do Ocidente". Em 1921, em um apêndice à publicação de uma conferência sua, dada no ano anterior, von Mises escreve:

(...) [É] ao menos altamente provável que a majestosa estrutura, em construção durante os últimos cinco séculos, de uma cultura ocidental orientada inteiramente para a cognição e o desempenho, ruirá nos próximos séculos. Desse ponto de vista, deve-se incluir a teoria da relatividade e a moderna física atômica entre as últimas pedras, destinadas a coroar a estrutura (von Mises, 1921, apud Forman, 1983, p. 45).

Além de von Mises, Forman (1983, p. 46) afirma que houveram muitos outros físicos teóricos e matemáticos aplicados que, mais do que apenas adaptarem-se ao ambiente intelectual hostil às suas disciplinas, chegaram a repudiar a sua própria disciplina e a denegrir a capacidade delas de conseguir um conhecimento verdadeiro ou mesmo valioso, principalmente quando falavam em comunicações para audiências mais amplas. Um 
exemplo disso, seria a fala de Doetsch, em uma aula inaugural na Universidade de Halle, em 1922, onde ele declara:

Tal dogmatismo racionalista é a expressão característica dessa época intelectual que está perecendo neste momento. Pode-se dizer que é o espírito da idade da ciência natural que, essencialmente, coincidiu com o século XIX e que, em nossos dias, afunda em convulsões violentas em seu túmulo, para dar lugar a um novo espírito, um novo sentimento de vida (...) tal época, em cujo início inquestionavelmente nos encontramos hoje, está farta dessa atitude racionalista (...) este caminho nunca nos levou, e nunca nos levará à essência das coisas (Doetsch, 1922, apud Forman, 1983, p. 46).

De fato, nessa época, a Física encontrava-se em uma crise interna, a "crise da Velha Teoria Quântica", que preocupava os físicos atômicos, nos anos que antecederam a elaboração da MQ, nos anos 1925-1926, a qual, inclusive, pode ser considerada como uma teoria primordialmente alemã, que rompeu com a causalidade na microfísica. E, apesar de reconhecer que os desenvolvimentos internos da Física atômica foram importantes em precipitar a disseminada sensação de crise entre os físicos centro-europeus de língua alemã, Forman (1983, pp. 53-54) defende que esses desenvolvimentos não foram suficientes para que esse sentimento se instalasse. Assim, o historiador da ciência sugere que a crise da TQ se tornou conveniente e, até mesmo, bem-vinda, por parte dos físicos alemães, como uma forma deles indicarem que possuíam a intenção de livrar sua disciplina dos elementos repreensíveis do mecanicismo e adaptarem seu conhecimento ao ambiente intelectual hostil em que se encontravam.

Para sustentar essa tese, Forman argumenta que "de um lado, o programa de eliminar a causalidade da física apareceu de modo bastante súbito depois de 1918”, sendo que as dificuldades teóricas já se apresentavam anteriormente a 1900, “de outro, esse programa ganhou adesões substanciais entre os físicos alemães antes que fosse 'justificado' pelo advento de uma mecânica quântica fundamentalmente acausal" (Forman, 1983, pp. 93-94, grifos do autor). Esse argumento juntamente com os atrelados ao contexto social caracterizado anteriormente, são a base para a defesa de Forman de que os problemas substanciais da Física atômica desempenharam apenas um papel secundário na gênese do compromisso dos físicos com a acausalidade, e de que a explicação para a criatividade na Alemanha, no período da República de Weimar - a qual deu origem à MQ - deve ser buscada, pelo menos em parte, na própria hostilidade desse meio intelectual. Para Forman, 
a ansiedade dos físicos alemães em reconstruir os fundamentos de sua ciência, observada nesse contexto, deve ser interpretada como uma reação a seu prestígio negativo (Forman, 1983, p. 9).

Assim, frente a esse sentimento de crise na TQ e à defesa da acausalidade na Física, Forman mostra que os físicos se posicionaram de diversas formas. Exner, Schottky, Nernst e Bohr, por exemplo, defenderam que o fracasso da causalidade representava essencialmente o fracasso do intelecto humano; já Weyl, von Mises e Reichenbach foram ainda mais longe e exprimiram uma aversão existencialista contra o intelecto. Além disso, foram poucos os físicos que se opuseram publicamente à dispensa da causalidade e defenderam o valor da racionalidade e sua fé na capacidade do intelecto humano de compreender o mundo natural: apenas Einstein, Petzoldt, Planck, Schrödinger - que chegou a defender a acausalidade, mas posteriormente foi reconvertido - e Wien. Isso possibilitou que esse movimento em prol da acausalidade na Física ganhasse mais força ainda.

A tese de Forman é intrigante e polêmica, por conta disso, é importante destacar que ela não é aceita de forma unânime pelos historiadores da ciência. Kragh (1999, p. 153), por exemplo, discorda dessa tese. Apesar disso, Forman reúne elementos interessantes acerca desse contexto, os quais tornam razoável considerar a hipótese de que o ambiente intelectual existente no período da República de Weimar - no qual a MQ foi desenvolvida - possivelmente contribuiu, ainda que indiretamente, para o estabelecimento da relação entre FQ e misticismo, em época posterior.

\subsubsection{Contracultura hippie nos anos 1970}

Outro momento histórico de destaque, que pode ter contribuído na formação da relação entre FQ e misticismo foi o contexto da contracultura hippie, nos EUA, nos anos 1970. O historiador da ciência David Kaiser (2011), em seu livro How the hippies saved physics, conta como o estado da Califórnia, nos anos 1970, nos EUA, reunia características muito especiais, que o tornou um contexto capaz de propiciar a criação de grupos de investigação sobre os fundamentos e implicações filosóficas da TQ muito peculiares, e dar origem a interpretações excêntricas para essa teoria. Esse contexto também é estudado por Rocha (2015), que defende que a Califórnia se tornou o berço do reencantamento do mundo pela TQ, ao oferecer, como nenhum outro lugar do mundo, 
uma riqueza de centros universitários de elite, lado a lado, a uma miríade de organizações religiosas orientais.

De fato, os anos 1960 e início dos 1970 foram um marco na história do século XX, com relação a mudanças culturais e agitação política. A emergência das contraculturas, rock 'n roll, drogas, liberação sexual, preocupação com o meio ambiente, movimento feminista, os protestos contra a Guerra do Vietnã e a instabilidade política foram destaque nas notícias da época. No campo da ciência, surgiu um ativismo científico, após a Segunda Guerra Mundial, com o início da produção e da utilização de bombas atômicas pelos EUA, com o início da Guerra Fria e da corrida armamentista entre EUA e URSS. No final dos anos 1960, esse ativismo politico passou por uma transição e a comunidade científica enfrentou novos desafios, como a greve dos pesquisadores do MIT, contra o uso das pesquisas para fins militares, com os encontros da American Physical Society sendo perturbados por protestos políticos, e o físico ganhador do prêmio Nobel Gell-Mann sendo impedido de dar uma palestra no centenário do College de France. O que acontecia agora é que alguns cientistas estavam sendo acusados por outros de colaborar com a aplicação da ciência para fins militares. Além disso, nos anos 1970, houve um decréscimo no apoio público aos investimentos cada vez maiores com Física, típico da Guerra Fria, nos anos 1950 (Freire Jr, 2015, pp. 197-199).

Todo esse contexto surgiu do aumento considerável da taxa de natalidade, no final da Segunda Guerra Mundial e nos anos pós-guerra, o que resultou no baby-boom da década de 1940 e, consequentemente, em um grande número de jovens na década de 1960. Esses jovens, dos anos 1960 e 1970, insatisfeitos com a sociedade em que viviam, se posicionariam contra e negariam os valores da sociedade norte-americana da época, que valorizava o indivíduo que tivesse um bom carro, um bom emprego, que constituísse uma família e fosse bem sucedido pessoal e profissionalmente. De fato, essa sociedade se via diante de diversas contradições, com o crescimento econômico do país, na década de 1950 e a sua consolidação como uma potência capitalista: por um lado, a prosperidade o crescimento econômico e o aumento da riqueza para alguns e, de outro, o aumento da desigualdade social interna, a desigualdade racial, a Guerra do Vietnã e a propagação de ideias moralistas, conservadoras e retrógradas. Assim, o movimento hippie surge como um movimento de contracultura, protagonizado por jovens, que cultuavam valores 
exatamente opostos ao do estadunidense comum: eles usavam o cabelo comprido, despenteado e barba, em oposição ao cabelo curto e rente dos militares, andavam sujos, utilizavam brim e sandálias, em contraposição ao terno e à gravata, propunham o comunitarismo rural e a atividade artesanal, em oposição à sociedade urbana e industrial, aderiram à maconha e aos halucionógenos, em contraposição ao álcool e ao tabaco da sociedade tradicional, por fim, foram os responsáveis pela prática do amor livre, pela abolição do casamento tradicional e pela cultura do rock (Lemad, 2016).

Mais especificamente, no contexto da Ciência e da Tecnologia, durante a Guerra Fria entre URSS e EUA, a Rússia consegue lançar o satélite Sputnik 1, em outubro de 1957, o que causou uma repercussão imediata e desesperada nos EUA, resultando na chamada "crise do Sputnik" e no aumento vertiginoso de investimentos em pesquisa aplicada e em educação científica, em uma tentativa de alcançar os russos na corrida espacial e tecnológica. O investimento em formação científica foi tão grande que, o número de títulos de PhD em física anuais que, entre os anos de 1954 a 1958, havia caído de 525 para 450, subiu de 450, em 1958, para 1625, em 1971 (Cassidy, 2011). Contudo, após o desespero inicial, e com o advento da Guerra do Vietnã, seguiu-se uma queda abrupta desse investimento. Em 1968, o serviço já registrava 989 candidatos com PhD em Física, para apenas 253 vagas no mercado, e a taxa de desemprego chegou a um pico em 1971, quando o registro era de 1053 candidatos para 53 vagas, ou seja, a maioria dos recémdoutores em Física estava desempregada (Kaiser, 2011, p. 57).

Esse foi exatamente o contexto propício para que físicos como Fred Alan Wolf, Fritjof Capra, Nick Herbert, Jack Sarfatti, George Weissman e Elizabeth Raucher, formados em instituições acadêmicas de elite, não seguissem carreiras acadêmicas convencionais e perseguissem seus interesses de pesquisa, buscando uma fonte de fomento alternativa. No desenvolvimento do capitalismo, quando a oferta supera a demanda, a criação de novos mercados é a solução, e a crise de desemprego dessa época foi o contexto adequado para o desenvolvimento de um novo mercado: o mercado de "produtos quânticos" e "terapias quânticas", que abarcaria desde livros, palestras motivacionais, workshops, cursos, filmes até a organização de grandes eventos (Rocha, 2015, p. 87).

A história da reunião e do interesse desses físicos em torno dos problemas de Fundamentos da FQ, em meio ao contexto da contracultura hippie nos EUA, remete a uma 
admiração pela forma como os pais fundadores da FQ - entre eles, Einstein, Bohr, Heisenberg e Schrödinger - construíram essa teoria: através dos seus debates e discussões acaloradas, nos anos 1920 e 1930, nos quais eles chegavam a toda sorte de noções estranhas e contra intuitivas possíveis - como a dualidade onda-partícula, o Princípio da Incerteza e o paradoxo do gato de Schrödinger. Essas noções, na visão dos físicos hippies, apontavam para a existência de um mundo fantasticamente diferente daquele que a experiência usual sugeria: o mundo dos objetos atômicos. Assim, através das lições metodológicas dos pais fundadores da FQ, ficava claro que o progresso no entendimento desse mundo só poderia ser feito levando os desafios e problemas filosóficos adiante, de tal forma que a mera manipulação de equações jamais seria o suficiente (Kaiser, 2011, p. 12). No entanto, conforme visto anteriormente, esse estilo de fazer Física não perdurou por muito tempo na história da FQ. Com o advento da Segunda Guerra Mundial e da Guerra Fria, no contexto mais amplo, e da hegemonia da Interpretação da Complementaridade, no contexto mais específico - no qual, os físicos que contestavam essa interpretação e propunham "visões alternativas" enfrentavam diversas dificuldades os físicos nos EUA passaram a adotar uma atitude extremamente pragmática. Assim, discussões filosóficas acerca dos problemas de Fundamentos da FQ passaram a ser vistas como meras especulações, deixando de ser consideradas com seriedade, e os problemas que passaram a ser valorizados eram apenas aqueles que lidavam com cálculos e equações. Essa atitude foi caracterizada por Kaiser (2011), com a frase ilustrativa "Cale a boca, e calcule!". Então, em meio a essa atitude pragmática e aos drásticos cortes nos investimentos em pesquisa básica, ocorridos entre os anos 1968 e 1972, juntamente com o recrutamento de estudantes para a Guerra do Vietnã e ao desemprego crescente na área da Física, os físicos foram obrigados a se juntar e encontrar outras formas de fazer Física (Kaiser, 2011, p. 14).

Foi assim que Elizabeth Rauscher e George Weissman, ambos graduados pela Universidade de Berkeley, na Califórnia, fundaram um grupo de discussão informal, o Fundamental Fysiks Group, em meio a uma mistura de ressentimento e frustração, em maio de 1975. Isso porque, esses dois físicos haviam sido cativados nos anos anteriores por livros que tratavam das grandes revoluções na Física Moderna (FM): a relatividade e a TQ, e seu interesse por esses temas se deveu, entre outros fatores, pelo estilo de Einstein em formular os seus paradoxos. Eles também almejavam compreender as questões mais 
profundas acerca do espaço, tempo e matéria. No entanto, a sua formação não lhes havia proporcionado nada disso, no lugar das grandes reflexões, eles haviam aprendido apenas algumas habilidades limitadas, relacionadas ao cálculo de determinados efeitos físicos, em detrimento da discussão acerca do significado das equações e sua relação com a natureza real dos fenômenos. Na época, Rauscher e Weissman decidiram fazer por si mesmos o que seus professores e livros didáticos não haviam lhes proporcionado: reservaram uma grande sala de seminários no laboratório e estabeleceram uma política de "portas abertas", na qual qualquer interessado em questões de interpretação da TQ era bem-vindo. Esse grupo contou com a participação de pesquisadores seniores do laboratório, como Henry Stapp, Philippe Eberhard e, eventualmente, Geoffrey Chew, dos recém-regressos da Europa, Jack Sarfatti e Fred Allan Wolf, do novo pesquisador do laboratório, Fritjof Capra, do pós-doutorando, John Clauser e dos interessados em questões relacionadas à consciência, Nick Herbert e Saul-Paul Sirag (Rocha, 2015, p. 71). Assim, esse grupo se reuniu a cada duas semanas, durante três anos e meio, até o fim do doutorado de Rauscher e Weissman. Seus encontros eram totalmente informais e tomados por brainstorms não estruturados e, frequentemente terminavam tarde da noite em alguma pizzaria ou restaurante indiano próximo ao campus. No entanto, de acordo com Kaiser, foi justamente essa abertura e adoção de um método sem rigidez, que possivelmente possibilitou que as sementes que, posteriormente, floresceriam no campo da informação quântica fossem plantadas (Kaiser, 2011, pp. 14-16).

Um dos principais temas discutidos por esse grupo foi o Teorema de Bell, que, desde a sua publicação em 1965, ainda não havia recebido a sua devida atenção. Por conta disso, Kaiser (2011, pp. 24-26) defende que o Fundamental Fysiks Group salvou a Física de três formas: a primeira se refere ao estilo ou método, pois os seus membros conscientemente abriram espaço para conversas e debates repletos de especulações livres, inspirados pelo espírito filosófico que havia em torno das questões dos Fundamentos da FQ, antes da Guerra Fria; em segundo lugar, esse grupo se focou no Teorema de Bell, resgatando-o de uma década em que ele ficou relegado ao esquecimento e recebeu pouca atenção por parte da comunidade da Física. De fato, nos anos que se seguiram à publicação do Teorema de Bell, nenhuma referência a ele é encontrada na literatura, somente a partir de 1976, é que cerca de 20 a 30 artigos sobre esse assunto, a cada ano, começam a aparecer e, em 1980, já haviam sido publicados cerca de 160 artigos. De todos esses artigos, 27\% foram 
publicados nos EUA, sendo $72 \%$ destes autores membros do Fundamental Fysiks Group (Kaiser, 2011, p. 41). Esse teorema estipulava que os objetos, que haviam interagido uma vez, permaneceriam com uma estranha ligação ou conexão, mesmo depois que eles se distanciassem de forma arbitrária um do outro. Isso despertou o interesse desse grupo, em especial, por, em sua publicação, Bell utilizar-se de termos como "não-localidade" e "entrelaçamento" para descrever o seu resultado. Esses termos, para muitos membros do grupo, remetiam a ensinamentos do budismo. Assim, com essa motivação, eles fizeram um grande esforço para compreender esse teorema, testar os seus limites e verificar as suas implicações. Nesse processo, como consequência, eles também, de forma indireta, obrigaram alguns dos seus colegas físicos a prestar atenção no assunto, disputando com eles sobre suas implicações finais. Para Kaiser, foi justamente, a partir desses debates e disputas, que o campo de informação quântica nasceu. Por fim, outro fator que motivava os estudos desse grupo em torno do Teorema de Bell foi o fato de que esse teorema, juntamente com o fenômeno do entrelaçamento quântico, parecia indicar que seria possível utilizar a TQ em ações à distância instantâneas - apesar da proibição dessas ações pela relatividade de Einstein. Para eles, caso isso realmente fosse possível, então a Física deveria abrir as suas portas para a investigação de questões mais amplas, como a relação das ações à distância com a clarividência, a psicocinese ou o holismo. Assim, em meio a essas investigações, os físicos hippies acabaram por impulsionar os principais avanços e desenvolvimentos relacionados ao Teorema de Bell, como a elaboração do Teorema de não-clonagem, por exemplo - e essa foi justamente a terceira forma na qual eles salvaram a Física, de acordo com Kaiser. Esse último teorema emergiu dos esforços dos membros do Fundamental Fysiks Group em lidar com máquinas e situações hipotéticas, e ele estipula que é impossível produzir cópias perfeitas ("clones") de um estado quântico desconhecido e arbitrário, de forma que qualquer tentativa de realizar essas cópias necessariamente altera o estado. Mais adiante, o Teorema de não-clonagem se constituiria como o cerne da criptografia quântica (Kaiser, 2011, pp. 24-26).

Apesar da tese de Kaiser, acerca da influência desse grupo nos estudos em torno do Teorema de Bell, ser controversa nota-se que ele acabou contribuindo no fortalecimento da relação da FQ com o misticismo, ainda que indiretamente. Uma das razões que justificaria essa contribuição é que, desde a sua origem, o grupo sofreu influência do Institute for the Study of Consciousness, que havia sido fundado anteriormente, em 1973, 
em Berkeley, pelo engenheiro aposentado Arthur Young, e tinha como foco estudar a relação entre a Física e os fenômenos da consciência. As reuniões nesse instituto contaram com a participação de Saul Paul-Sirag, que, embora não tenha concluído seu curso de Física, chegou a publicar dois artigos na revista Nature, de Nick Herbert, doutor em Física pela Universidade de Stanford, de Henry Stapp e da própria Elizabeth Rauscher. Posteriormente, também em 1973, Saul Paul-Sirag e Nick Herbert fundaram de forma independente o Consciouness Theory Group, em São Francisco. Esse último grupo contou com o patrocínio do químico Henry Dakin, que tinha uma família abastada, foi formado pela Universidade de Harvard e possuía interesse em parapsicologia. O Consciouness Theory Group também recebeu a visita de físicos, como Evan Harris Walker e David Bohm, quem já exercia um importante papel nas pesquisas sobre os Fundamentos da FQ, com sua interpretação causal, baseada em variáveis ocultas. Ambos os grupos tiveram o patrocínio de diversas pessoas, entre eles, os já citados Arthur Young e Henry Dakin, de Werner Erhard, fundador do Erhard Seminars Training, de Michael Murphy, fundador do Instituto Esalen, de Charles Brandon, fundador da Federal Express Corporation e de George Koopman, um excêntrico empreendedor na área de tecnologia espacial (Rocha, 2015, pp. 67-71).

Outras organizações semelhantes, que também exerceram um importante papel no estabelecimento da relação entre FQ e misticismo, nessa época, foram o Physics/Consciousness Research Group e o Instituto Esalen, com seus Esalen Seminars on Quantum Physics and the Nature of Reality. O primeiro foi fundado em 1974, em São Francisco, e tinha como principal objetivo pesquisar a relação entre a "nova física" e a consciência, seu principal patrocinador era Werner Erhard, cujo nome de batismo era John Paul Rosenberg, mas mudou o seu nome em 1960, devido ao seu grande interesse pela TQ, em homenagem ao físico alemão Werner Heisenberg (e ao chanceler alemão Ludwig Erhard). Erhard conheceu Fred Allan Wolf, quando este último participou de um dos Erhard Seminars Training - um workshop de 60 horas, que prometia transformar a vida de seus participantes - e, desde então, eles mantiveram uma amizade duradoura. Assim, com esse importante patrocínio, o Physics/Consciousness Research Group foi fundado e financiou a pesquisa independente de vários físicos, entre eles, Saul Paul-Sirag, Jack Sarfatti, Fritjof Capra, Nick Herbert e o próprio Fred Allan Wolf. Dessa forma, Werner Erhard, juntamente com Michael Murphy, desde o início da década de 1970, se tornaram 
os dois grandes magnatas do chamado Movimento do Potencial Humano - movimento baseado na premissa da existência de um potencial extraordinário, em grande parte das pessoas, ainda inexplorado, e na crença de que, com o desenvolvimento do "potencial humano", os seres humanos podem experimentar uma qualidade de vida excepcional, trazendo uma mudança social positiva em geral (Rocha, 2015, pp. 72-73).

Michael Murphy seria o grande responsável por mediar as relações públicas, que reuniriam de 25 a 30 físicos, ano após ano, para ministrarem palestras e workshops, no Instituto Esalen. Posteriormente, após o sucesso de um seminário de um mês liderado por Jack Sarfatti - então presidente do Physics/Consciousness Research Group - que contou com a participação da maioria dos membros do Fundamental Fysiks Group, do neurocirurgião e psiquiatra Karl Pribram, de Gary Zukav e do psicólogo Timothy Leary, Murphy propôs a Nick Herbert e Saul Paul-Sirag que organizassem um novo evento, desta vez centrado nas implicações do Teorema de Bell e na natureza da realidade. Esse novo evento deu origem aos Esalen Seminars on Quantum Physics and the Nature of Reality, que passou a ser um evento anual e contou com a participação, entre os anos 1976 e 1988, de Nick Herbert, Saul Paul-Sirag, Fred Allan Wolf, Elizabeth Rauscher, David Finkelstein, John Clauser, Henry Stapp, Phillipe Eberhard, Bernard d'Espagnat, HeinzDieter Zeh, Michael Murphy, Gary Zukav, Charles Brandon, entre outros. Esses seminários tornariam o Instituto Esalen conhecido e frequentado por vários físicos, que contribuiriam com debates, palestras e workshops, entre eles, Fritjof Capra, Amit Goswami, Russell Targ, Heinz Pagels, David Bohm, Carl Sagan e Richard Feyman. O Instituto Esalen havia sido fundado em 1962, por Michael Murphy e Richard Price, e tinha como missão explorar diferentes tendências nas ciências comportamentais, religião e filosofia, as quais enfatizariam as potencialidades e valores da existência humana (Rocha, 2015, pp. 73-75). Na visão de Rocha (2015, p. 77), os principais fatores que aproximaram o Instituto Esalen e o Physics/Consciousness Research Group foram, em primeiro lugar, a semelhança entre as visões de seus fundadores e, em segundo lugar, a marginalidade em que se encontrava, nos anos 1960 e 1970, o debate a respeito dos Fundamentos da FQ, o que demandava espaços e patronos alternativos para as pesquisas nessa área, fora do circuito acadêmico oficial. Além disso, o estado da Califórnia oferecia, como nenhum outro lugar do mundo, uma combinação peculiar, que reunia uma riqueza de centros universitários de elite, lado a lado, a uma miríade de organizações religiosas orientais 
(Rocha, 2015, p. 79). Assim, o Instituto Esalen, não apenas fortaleceu a relação entre FQ e misticismo, mas, enquanto espaço de discussão sobre os Fundamentos da FQ, funcionou como um espaço alternativo para debates fora da "visão ortodoxa" da FQ, reunindo e patrocinando alguns dos chamados "dissidentes quânticos" - ou seja, físicos que trabalhavam com temas de Fundamentos da FQ, fora da chamada "interpretação ortodoxa" (Freire Jr., 2015; Rocha, 2015, p. 82).

Outro fator destacado por Rocha (2015, pp. 84-87), que acabou dando origem a uma relação mais forte entre FQ e misticismo, e criando um novo mercado para "produtos quânticos" e "terapias quânticas", foi o que o historiador da Física Andrew Pickering chamou de "oportunismo em contexto" (Pickering, 1984, p. 11), no qual a escolha do objeto de pesquisa não é dada somente pelos "fenômenos", mas pelo contexto dos recursos disponíveis ao pesquisador. No caso do contexto mencionado, o que tornou desejável o auspício do Instituto Esalen, assim como dos demais patrocinadores mencionados, foi a difícil situação de empregabilidade em que se encontravam os físicos nos EUA, a partir da década de 1970, devido à queda abrupta de investimentos em formação científica, no final da década de 1960, mencionado no início desta seção. Dessa forma, não foi por acaso que físicos como Fred Alan Wolf, Fritjof Capra, Nick Herbert, Jack Sarfatti, George Weissman e Elizabeth Rauscher, formados em instituições acadêmicas de elite, não seguiram carreiras acadêmicas convencionais e apreciavam patronos como Arthur Young, Henry Dakin, Werner Erhard, Michael Murphy, George Koopman e Charles Brandon. O contexto do estado da Califórnia, um dos estados mais ricos, do país mais rico do mundo, em época de crise de desemprego, proporcionou a estes físicos uma fonte de fomento alternativa, ao perseguirem os seus interesses de pesquisa e, assim, possibilitou desenvolver um novo mercado de "produtos quânticos" e "terapias quânticas" - ou seja, quaisquer mercadorias que divulguem ou incorporem, supostamente, em seu funcionamento, princípios da TQ (Rocha, 2015, p. 87).

Rocha (2015, p. 87) destaca os primeiros livros de divulgação científica, como The Tao of Physics (O Tao da Física), de Fritjof Capra, publicado em 1975 - embora esse livro se foque na FM como um todo, envolvendo a FQ somente de forma mais indireta - como sendo um dos primeiros "produtos quânticos”. Além disso, em 1977, o instituto Esalen já comercializava fitas de áudio, como "Quantum Paradoxes and Eastern Mysticism”, de 
Fritjof Capra, e “A New Quantum Logic”, de David Finkelstein. Vale mencionar que, ao chegar à Califórnia, em 1975, Capra não tinha emprego e nem bolsa de pesquisa, ele contava apenas com a ajuda de patronos como Michael Murphy e Werner Erhard. No entanto, com o sucesso do seu livro The Tao of Physics (O Tao da Física), ele passou a ser convidado para participar de palestras e simpósios, como o Symposium on Physics and Metaphysics, em 1977, organizado pelo International Sivananda Yoga Centers. Então, a partir de 1979, paralelamente a Capra, Fred Alan Wolf desenvolveria um novo produto: um circuito de palestras motivacionais baseadas na TQ. Wolf também, ao retornar da Europa para os EUA, não conseguiu mais um emprego no sistema universitário americano, e acabou se tornando um palestrante motivacional. Wolf incorporou o que havia aprendido nos Erhard Seminars Training à sua experiência como professor universitário, misturando slogans de Erhard com a TQ, dando origem às chamadas "terapias quânticas" - ou seja, todo e qualquer serviço que, supostamente funciona como terapêutico e alegadamente é regido pelos princípios da TQ. Em suas palestras, o físico, inclusive, adotou um nome de palco o "Captain Quantum", chegando até mesmo a criar um cartum intitulado “Captain Quantum: Physics Superhero” (Rocha, 2015, pp. 87-89). Posteriormente a esses primeiros "produtos quânticos", surgiria todo um mercado de produtos, que supostamente incorporavam os princípios da FQ, fortalecendo a impressão da existência de uma relação entre a TQ e o misticismo, para o público mais amplo.

Assim, nesse contexto, Rocha (2015, pp. 90-99) defende que o Instituto Esalen cumpriu duas funções importantes no estabelecimento da relação entre FQ e misticismo: a de se tornar um laboratório para popularizadores e a de se tornar um espaço de cruzamento entre a TQ e terapias alternativas. A primeira dessas funções se justifica pelo fato de que o Instituto Esalen foi um espaço onde muitos autores popularizadores da ideia de que a FQ possui um caráter místico puderam amadurecer seus artigos e livros de divulgação científica, através de workshops e seminários, de maneira análoga à acadêmica, possibilitando um contato direto com o público mais amplo - esse foi o caso de Fritjof Capra, Henry Stapp, Nick Herbert e Gary Zukav, por exemplo. Posteriormente, Fritjof Capra e Gary Zukav se tornariam os maiores sucessos de venda e de popularização da TQ, com seus livros The Tao of Physics (1975) e The Dancing Wu Li Masters (1979). Já a segunda função, que o Instituto Esalen cumpriu - a de ser tornar um espaço de cruzamento entre a TQ e terapias alternativas, resultando nas chamadas "terapias 
quânticas" - se justifica, pois foi nesse lugar que físicos, psicólogos e espiritualistas da "Nova Era" puderam se encontrar, debater e mesclar as suas experiências. Foi nesse instituto que Fred Alan Wolf mesclou sua experiência em Física com o que havia aprendido no Erhard Seminars Training, por exemplo. Esse lugar também foi palco do desenvolvimento de várias correntes da psicoterapia na segunda metade do século XX, como a Gestalt-terapia, por exemplo, assim, muitos físicos acabaram adotando o vocabulário da psicologia e os psicólogos adotando o da Física. Dessa forma, a "terapêutica quântica" pode ser considerada o resultado do cruzamento entre o desenvolvimento de terapias alternativas, por um lado, e o debate sobre os Fundamentos da TQ, por outro, que aconteciam lado a lado e em diálogo contínuo, dentro e fora do Instituto Esalen.

Por fim, outro importante papel exercido, tanto pelo Instituto Esalen, como pelo Fundamental Fysiks Group foi o de estabelecer uma relação entre a FQ e a parapsicologia. Conforme mencionado anteriormente, o Fundamental Fysiks Group não estava interessado apenas no Teorema de Bell, mas também em especular sobre as suas possíveis consequências. Além disso, Elizabeth Rauscher, George Weissman, Fred Alan Wolf e Jack Sarfatti já possuíam interesse pela parapsicologia antes mesmo da formação do grupo. Todos esses fatores fizeram com que os efeitos paranormais surgissem como uma possibilidade de pesquisa para o Fundamental Fysiks Group, a partir da propriedade da não-localidade da TQ. Por outro lado, em um contexto mais amplo, além da famosa “corrida espacial”, entre EUA e URSS, paralelamente, ocorria a "corrida psíquica”, a qual se iniciou após a publicação, em 1970, do livro Experiências Psíquicas além da cortina de ferro, pelas pesquisadoras norte-americanas Sheila Ostrander e Lynn Schroeder, no qual elas davam um panorama do avanço das pesquisas soviéticas a respeito da ESP (extrasensory perception) e expressavam sua suspeita de que as autoridades soviéticas estivessem se utilizando de paranormais com o propósito de espionagem. Isso fez com que os norte-americanos se sentissem novamente defasados em relação à URSS e passassem a investir em pesquisas nesse assunto. Dessa forma, neste período, a pesquisa em parapsicologia começou a receber fundos generosos, tanto dos setores públicos, quanto privados, e instituições governamentais, como o Instituto de Pesquisa de Stanford, a Agência de Inteligência e Defesa do Pentágono, a Agência de Segurança da CIA e a NASA, acabaram se lançando em pesquisas sobre ESP. Michael Murphy, que já era 
fascinado pela parapsicologia, ao tomar conhecimento do livro de Ostrander e Schroeder, providenciou uma viagem para a Rússia e passou a desenvolver um programa de intercâmbio entre russos e americanos, no Instituto Esalen. Entre as pesquisas com parapsicologia que envolveram membros do Instituto Esalen, estavam os testes com o suposto paranormal israelense Uri Geller, realizados pelos pesquisadores Russel Targ e Harold Puthoff, no Instituto de Pesquisa de Stanford. O interesse por essas pesquisas levou Jack Sarfatti a visitar Stanford e, posteriormente, em 1974, com Fred Alan Wolf e David Bohm, realizar testes com o paranormal, em Londres, no Birkbeck College. Na ocasião, Geller dobrou as chaves de David Bohm e disparou um contador Geiger, que ele segurava em suas mãos (Rocha, 2015, pp. 99-107).

Com isso, as pesquisas em parapsicologia e a sua possível relação com a FM deram origem a diversos livros, como o Space-Time and Beyond: Towards an Explanation of the Unexplainable (1974), escrito por Fred Alan Wolf e Jack Sarfatti e ilustrado por Bob Toben, o The Medium, the Mystic, and the Physicist: Toward a General Theory of the Paranormal (1974), do psicólogo Lawrence LeShan, e o Mysticism and the New Physics (1980), de Michael Talbot, entre outros, dando origem a um novo gênero literário, que seria exportado nas décadas seguintes da Califórnia para o mundo. Então, o sucesso editorial e as atividades destes agentes, com seus fundos públicos e privados passaram a chamar a atenção da grande mídia, iniciando pela mídia local, na área próxima a São Francisco, com a aparição de Sarfatti e Wolf nas revistas locais. Posteriormente, o desenvolvimento dessa nova área impactaria o resto dos EUA, com a publicação de reportagens sobre Física e parapsicologia em revistas e jornais de nível nacional, os quais apresentavam posturas tanto favoráveis, como contrárias ao investimento nessas pesquisas. As revistas Time, em 1974, e a Newsweek, em 1979, por exemplo, apresentavam o sucesso e o caráter curioso delas, já o jornal The Washington Post, em 1977, anunciou a insatisfação, por parte de agentes do governo com os gastos com as pesquisas em ESP. Assim, essas controvérsias passaram a atingir e se instalar entre pesquisadores e revisores de periódicos científicos também, o que acabou chamando mais a atenção do público mais amplo e reforçando a ideia da existência de uma relação entre FQ e misticismo (Rocha, 2015, pp. 110-114). 
Portanto, foi possível observar que o contexto da contracultura hippie, nos anos 1960 e 1970, possibilitou o surgimento de uma relação mais objetiva e direta entre a FQ e o misticismo, a qual teve a sua origem na Califórnia, nos EUA, e acabou sendo difundida para o mundo todo. Foi o fortalecimento dessa relação que deu origem aos "chamados produtos quânticos" e "terapias quânticas", os quais possuem um público consumidor específico, até os dias atuais.

\subsubsection{Movimento da Nova Era e Neoesoterismo}

Conforme visto na seção anterior, o movimento da contracultura hippie, nos anos 1960 e 1970, foi protagonizado pelos jovens pertencentes à geração baby-boomer e marcado pela inconformidade e pela insatisfação com relação à sociedade da época. Esses sentimentos foram expressos através de diversos protestos, como os contrários à Guerra do Vietnã, os protestos estudantis de 1968, os festivais de rock 'n roll, as experiências psicodélicas, os movimentos de emancipação das minorias culturais - como o movimento feminista e o negro - a revolução sexual e o movimento ambiental. No entanto, os protestos e as revoluções almejadas por esses jovens dos anos 1960 e 1970 não lograram modificar o mundo como esperado - apesar de alguns de seus elementos terem permenecido na cultura geral -, e muitas de suas conquistas acabaram sendo revertidas pela crise econômica dos anos 1970 e pelo crescimento do neoliberalismo e outras forças de direita, nos anos 1980 e 1990 - essas mudanças de conjuntura são bem ilustradas pela permanência em dois mandatos de Ronald Reagan, na presidência dos EUA, entre 1980 e 1988, e pelo longo reinado neoliberal da primeira ministra Margaret Thatcher, na GrãBretanha, de 1979 a 1990. Com isso, a contracultura se transformou na cybercultura e, de forma ilustrativa, alguns hippies da Califórnia, como Steve Wozniak e Steve Jobs, acabaram se tornando megaempresários. Assim, os movimentos de protesto, os ideais utópicos e o anticonsumismo, característicos da contracultura hippie, posteriormente, acabaram se rendendo ao individualismo, ao narcisismo e ao consumismo promovidos pela Indústria Cultural (Rocha, 2015, pp. 114-115).

Essas mudanças no contexto mais amplo acabaram por se refletir no contexto mais específico, e fazer com que o Movimento do Potencial Humano, das décadas de 1960 e 1970, se transformasse no Movimento da Nova Era, dos anos 1980 e 1990, um movimento progressivamente mais apolítico, conformista e muito mais próximo à literatura de 
autoajuda, do que o primeiro (Rocha, 2015, p. 114). Heelas (1996, pp. 16-17) apresenta algumas das principais características do Movimento da Nova Era, destacando que a palavra "nova" não significa que esse movimento traz alguma novidade com relação aos ensinamentos espirituais considerados, pois inclui uma espiritualidade encontrada em muitas religiões, tanto orientais como ocidentais; além disso, a palavra "movimento" não significa de forma alguma que a "Nova Era" é uma entidade organizada; por fim, com relação à utilização do termo "Nova Era", vale ressaltar que nem todos os grupos, pessoas e organizações, que são categorizadas sob esse termo, concordam com essa classificação. Feitas essas considerações, Heelas (1996) destrincha os elementos centrais do Movimento Nova Era, que, segundo ele, consistem em basicamente três elementos: o primeiro gira em torno da explicação do porquê da vida, conforme ela é normalmente experienciada pelas pessoas, não ser como ela deveria e explica que essa vida não funciona, pois normalmente se vive de forma mecânica, dentro de um sistema de crenças, em vez de viver o momento, no mundo da experiência real. O segundo elemento, por sua vez, fornece considerações sobre o que significa encontrar a perfeição e explica que a perfeição só pode ser encontrada ao se mover para além do eu socializado - mais conhecido como "ego", ou intelecto, ou ainda mente - indo de encontro a um novo domínio do ser, à sua natureza verdadeira, o que, para os adeptos da "Nova Era", é concebido em termos espirituais. Assim, somente o domínio interior do ser pode ser a fonte de vitalidade autêntica, criatividade, amor, tranquilidade, sabedoria, poder, autoridade e todas as outras qualidades que podem assegurar uma vida perfeita. Por fim, o terceiro elemento fornece os meios de obter a salvação, se referindo, portanto, aos meios de se atingir uma experiência autêntica. Assim, se explica que o ego seria a grande barreira que bloqueia o caminho para atingir essa experiência e que, portanto, ele deve perder autoridade. Assim, a "Nova Era" fornece caminhos, processos e rituais diversos - que vão desde a meditação, passando pelo trabalho físico, até a utilização de drogas ou de equipamentos de realidade virtual - a fim de trabalhar os aspectos do ego e exorcizar o apego tirânico do modo socializado do ser (Heelas, 1996, pp. 18-20).

Outro aspecto importante e característico do Movimento da "Nova Era" é a sua tendência de ser epistemologicamente individualista, pois, as vozes de autoridade provenientes de experts, líderes carismáticos e tradições estabelecidas são sempre mediadas por alguma forma de experiência íntima - com orientações do tipo: "você é livre 
para seguir o que sugere o seu espírito" - inclusive, muitas linhas da "Nova Era" costumam rejeitar a tradição e qualquer tipo de vozes de autoridade associadas à ordem estabelecida, adotando uma postura antiautoritária. Para eles, o "individual” serve como a sua própria fonte guia, de orientação para as suas condutas, de tal forma que o indivíduo deve escutar a sua sabedoria interior. Assim, o Movimento da Nova Era também enfatiza a importância da responsabilidade individual de buscar atingir a libertação do condicionamento social, para muitos deles, inclusive, isso significa que não se deve interferir e tentar exercer responsabilidade sobre a vida dos outros. E, para aqueles que levam essa postura ao extremo, nada daquilo que está situado além deles mesmos (de seu eu interior) possui uma existência autônoma, o que significa que a sua própria autoridade é que exerce o poder sobre tudo aquilo que acontece em suas vidas, incluindo a sua saúde, prosperidade, seus relacionamentos, etc. Relacionado a isso, um dos principais valores prezados pela "Nova Era" é a liberdade, a qual é interpretada como sendo a liberação do passado, do tradicional e tradições internalizadas, isto é, do ego. A liberdade também está atrelada a poder viver uma vida em que se é capaz de expressar tudo o que significa ser verdadeiramente humano. Por fim, outro aspecto característico do Movimento da Nova Era é uma espécie de filosofia perenialista, pois, ao mesmo tempo em que seus adeptos recusam as tradições no geral, com seus dogmas, doutrinas e morais, eles também continuamente redesenham os seus ensinamentos e práticas, baseados em outras tradições que valorizam - da xamânica ao budismo -, ao defenderem que é possível discernir, através das suas próprias experiências e sabedoria, as verdades que se encontram no coração destas. Assim, nessa linha de raciocínio, as verdades presentes nas "tradições" e na "Nova Era" seriam as mesmas. Resumidamente, portanto, o Movimento da Nova Era pode ser considerado uma forma de humanismo altamente otimista, comemorativa, utópica e espiritual - com algumas versões enfatizando também a espiritualidade da ordem natural como um todo - na qual a autonomia e a liberdade são altamente valorizadas, a autoridade reside na experiência do eu interior ou no reino natural, e bastante importância é dada para uma ética própria e o papel da responsabilidade individual é enfatizado (Heelas, 1996, pp. 21-29).

No entanto, o Movimento da Nova Era também apresenta algumas variações e discordâncias internas, principalmente no que tange aos seus ensinamentos relacionados à espiritualidade pessoal. As atividades desse movimento abrangem um grande espectro, as 
quais discordam entre si principalmente no que se refere à como lidar com os valores e produtos capitalistas convencionais: em uma extremidade desse espectro, estão os chamados puristas espirituais, que rejeitam tudo aquilo que é oferecido pela modernidade capitalista e que buscam experienciar o melhor do mundo interior, que se encontra no domínio da espiritualidade, essa extremidade dá ênfase ao distanciamento do mundo exterior; já na outra extremidade desse espectro, estão os empoderadores convencionais, para quem a espiritualidade interior é utilizada como um meio para atingir a experiência do melhor que o mundo exterior pode oferecer, e a ênfase é dada ao empoderamento e à prosperidade. Entre esses dois extremos, estão os contraculturalistas, que consistem na maioria dos caminhos propostos pela "Nova Era", os quais ensinam que é possível experienciar o melhor dos dois mundos e incluem todas as atividades que enfatizam a autorrealização, ou seja, a ênfase é dada em se tornar uma pessoa completa. Portanto, com relação ao holismo, uma das características mais fortemente defendida pelo Movimento da Nova Era, tanto os puristas espirituais quanto os contraculturalistas estariam longe de poder ser considerados completamente holistas - os primeiros por rejeitarem o que o mundo exterior tem para oferecer, e os últimos por dividirem o mundo em bom e mau, ou alternativo e convencional - curiosamente, os empoderadores convencionais seriam aqueles mais próximos de um holismo completo, no sentido de que o dinheiro e tudo aquilo que ele pode comprar são trazidos para a órbita do sagrado. Dessa forma, os harmonialistas, ou aqueles que enfatizam que a espiritualidade perpassa todas as esferas seriam os mais holistas de todos. Outra divergência entre os adeptos da "Nova Era" se refere ao locus da autoridade: alguns deles respeitam somente a sua voz interior, a maioria, no entanto, em variados graus, escuta também as vozes do outros - com a justificativa de que a espiritualidade, ao seguir a ordem natural das coisas, não pode ignorar as orientações ou mensagens provenientes de outras fontes, exteriores a eles mesmos - e, assim, proporciona ao menos um grau de autoridade ao exterior. Por fim, há uma distinção entre aqueles que veem a si mesmos como o principal lugar para o encontro da espiritualidade (se não o único), e aqueles que se veem cercados pela espiritualidade, a qual reside no coração da ordem cósmica como um todo. Os primeiros atribuem um status ontológico precário ao mundo externo ao indivíduo e possuem como principal máxima a de que "Você cria a sua própria realidade", os segundos, por outro lado, atribuem à 
espiritualidade da ordem natural um status tão real quanto à espiritualidade interior (Heelas, 1996, pp. 29-36).

Atrelado ao Movimento da Nova Era, porém com outras especificidades, Magnani (1999, p. 13) utiliza a expressão "Neoesoterismo" para designar a forte expansão e disseminação, em âmbito mundial, das práticas comumente agrupadas sob a denominação de "esotéricas". Essa expansão passou a abrigar uma ampla gama de produtos, atividades e serviços, que abrangem desde consultas a artes divinatórias, passando por terapias não convencionais e exercícios de inspiração oriental, até vivências xamânicas, técnicas de meditação, cursos e workshops sobre crenças e sistemas filosóficos de várias origens. Juntamente a esses produtos, atividades e serviços, cria-se um público consumidor de artigos correlatos, como compact discs de New Age e world music, livros de autoajuda, produtos orgânicos, incensos, cristais, pêndulos, imagens de anjos e duendes, entre outros, constituindo um fenômeno de caráter verdadeiramente mercadológico. Esse caráter é reforçado, entre diversos fatores, pelas cifras impressionantes de vendas de alguns títulos da literatura de autoajuda, pelo sistema de consulta a oráculos por telefone, com o surgimento de farmácias especializadas, lojas com material para o exercício de diferentes especialidades (óleos, essências, instrumentos, etc.), pela comercialização de ervas medicinais e alimentos produzidos com base em determinados princípios, pela realização de feiras de produtos hortigranjeiros cultivados segundo as normas da agricultura orgânica, com agências de viagens anunciando pacotes com roteiros por "lugares sagrados" (como Machu Picchu, no Peru, Varanasi, na Índia, São Tomé das Letras, em MG, entre outros destinos) e oferecendo uma forma de lazer que se pauta por outros princípios que não os do turismo convencional.

No entanto, um olhar mais apurado sobre esse fenômeno, mostra que o público consumidor dos produtos desse novo ramo mercadológico não é composto apenas por consumidores ingênuos é crédulos, mas também por um público mais exigente, informado e que se dedica a alguns desses temas com uma atitude mais ativa, que busca informação e aprofundamento nos assuntos - o que é possibilitado e alimentado através de diversas atividades de formação, como palestras, workshops, cursos, etc. Por conta disso, apesar da ampla diversidade presente no fenômeno do Neoesoterismo, Magnani (1999, p. 12) defende que uma das coisas que há de comum entre as suas diversas atividades seria a 
busca em fundamentar - às vezes, de forma mais elaborada e outras menos - as suas práticas em alguns sistemas de pensamento e religiões de origem oriental, em cosmologias indígenas, em correntes espiritualistas, no esoterismo clássico europeu e em propostas inspiradas em certos ramos da ciência contemporânea, como a FQ. Inclusive, por vezes, a busca dessas fundamentações é feita em todos esses ramos e correntes simultaneamente, resultando em surpreendentes bricolagens ou, imageticamente, colchas de retalhos.

Contudo, apesar da ampla variedade de elementos que compõem a busca pela fundamentação das atividades do Neoesoterismo, alguns aspectos do "ethos" - isto é, aspectos valorativos, morais, estéticos, atitudes e sensibilidades presentes em uma cultura - desse fenômeno podem ser elencados, entre eles: a presença de terapias corporais, com uma postura intelectualizada e uma ênfase na palavra, e em um complexo alternativo, que privilegia a emoção, a sensação e a intuição, e enfatiza o trabalho terapêutico no corpo e na mente; o cultivo da individualidade, com o individualismo presente na valorização da realidade interior e dos processos de transformação espiritual; a existência de uma comunidade inserida em um circuito urbano, diferente da comunidade rural alternativa da era hippie, na qual o indivíduo da nova onda mística é inserido no fim de semana, para assistir a cursos, palestras e outras vivências, a fim de "recarregar as baterias" para enfrentar a vida corrida da metrópole; a centralidade da noção de "energia", o conceito de energia, utilizado como sinônimo do chi do taoísmo ou de energia vital, é central na visão de mundo do Neoesoterismo e, muitas vezes, é considerada como a entidade que carrega o fluxo de espiritualidade dentro do corpo, entre os indivíduos e com a natureza; $a$ preocupação com a ecologia e a natureza, nesse novo fenômeno, mantém-se a importância da natureza e da ecologia, com a diferença de que agora o indivíduo tira a sua força da comunhão com a natureza e, por vezes, se sente capaz de curvar a sociedade a seus desejos e impulsos; a redescoberta do feminino, diferente do feminismo dos anos 1970, esse novo aspecto reconhece a superioridade das qualidades femininas da intuição, sensibilidade, espontaneidade e senso comunitário, que, de certa forma, se cristalizam na figura da bruxa, com seus poderes mágicos (Magnani, 1999, pp. 103-116; Pessoa, 2010, pp. 296-297).

Ambos os fenômenos apresentados nesta seção, O Movimento da Nova Era e o Neoesoterismo, exerceram uma forte influência para o estabelecimento da relação entre 
FQ e misticismo, a qual culminou no fenômeno cultural denominado misticismo quântico. Para Pessoa (2010, p. 297), o fenômeno do misticismo quântico faz parte dos movimentos socioculturais da "Nova Era" e do Neoesoterismo, ambos herdeiros da contracultura hippie dos anos 1960-1970, nos quais houve um sobreposição entre alguns aspectos sociológicos ligados ao misticismo moderno com uma popularização da $\mathrm{FQ}$, juntamente algumas motivações econômicas e ideológicas, que fogem do escopo deste trabalho.

\subsubsection{Físicos com inclinações místicas}

Apesar de não ser possível fazer uma separação completa e rígida entre o contexto histórico e sociocultural mais amplo e o contexto interno ao coletivo de pensamento dos pesquisadores em FQ, uma vez que ambos se influenciam contínua e mutuamente, podese considerar que, além dos fatores relacionados a esse contexto mais amplo, alguns fatores internos ao coletivo de pensamento da FQ contribuíram mais fortemente, ao longo da história, para o estabelecimento da relação entre a FQ e o misticismo. Dentre esses fatores, um dos principais foram as inclinações místicas que alguns dos físicos que contribuíram para o desenvolvimento da FQ possuíam ou apresentaram em algum momento de sua trajetória - ainda que essas inclinações, por vezes, não foram refletidas em seus trabalhos científicos -, ou mesmo formularam hipóteses ou interpretações as quais, em algum momento, foram relacionadas com alguma espécie de misticismo. Essas inclinações, hipóteses e interpretações podem ser encontradas, desde os pais fundadores da FQ, até os pesquisadores e precursores de interpretações mais recentes, e pode-se considerar que elas, possivelmente, acabaram influenciando no estabelecimento da relação entre FQ e misticismo, ainda que indiretamente. Nesta seção, se dará destaque a alguns desses indivíduos, os quais, frequentemente, são citados por autores místicos que utilizam a FQ em seu discurso. Essa utilização por parte desses autores indica que esse pode ser um fator relevante a ser considerado no estabelecimento dessa relação.

\section{Niels Bohr}

Conforme visto na seção 3.3.3, Bohr foi o responsável por elaborar o Princípio da Complementaridade, em 1927, que, diferentemente do Princípio da Incerteza, não era uma consequência da MQ, mas uma formulação de natureza primariamente filosófica. Entre 
outros aspectos, esse princípio postulava: a existência de uma descontinuidade essencial no processo de medição e que é impossível controlar os distúrbios provocados no objeto microscópico pela interação com o aparelho de medida; que só é possível ter acesso ao mundo microscópico através de aparelhos macroscópicos, e a descrição da aparelhagem experimental e dos resultados das medições só pode ser feita na linguagem da FC; que a TQ só trata das observações (ou medições) de objetos microscópicos, de forma que não faz sentido referir-nos a uma realidade independente do sujeito (observador); que é preciso considerar o sistema quântico como um todo, incluindo partes do arranjo experimental localizadas à distância; e que não faz sentido defender o determinismo no mundo microscópico, nesse mundo, só é possível calcular as probabilidades de ocorrência dos fenômenos (Pessoa, 2003, pp. 97-98). Por conta desses postulados - que são baseados em princípios positivistas e remetem às ideias de acausalidade, totalidade ou holismo na consideração dos sistemas quânticos e inseparabilidade entre sujeito de objeto -, em uma carta a Schrödinger, Einstein chegou a descrever a interpretação de Copenhagen de forma sarcástica, como uma "filosofia tranquilizante de Heisenberg-Bohr ou religião?" (Kragh, 1999, p. 213). Em sua defesa, e principalmente pelo fato de suas ideias terem sido vinculadas à hipótese de que a FQ requeria a existência de um observador consciente, em 1927, Bohr insistiu que "não faz diferença se o observador é um ser humano, um animal ou uma parte de um aparato experimental" (Heisenberg, 1971, p. 88, tradução livre). Ainda sobre essa questão, de acordo com os relatos de Heisenberg, mais tarde, Bohr seria mais enfático, ao afirmar:

\footnotetext{
Nós não podemos encontrar absolutamente nada na Física ou na Química que tenha alguma ligação, ainda que remota, com a consciência. Todos nós sabemos que existe algo como a consciência, simplesmente porque nós possuímos uma. Assim a consciência deve ser parte da natureza, ou ainda, de forma mais geral, da realidade, o que significa que, além das leis da Física e da Química, assim como da Teoria Quântica, nós devemos levar em consideração leis de outra natureza (Heisenberg, 1971, p. 144, tradução livre).
}

Contudo, apesar de Bohr acreditar que os processos quânticos poderiam ser compreendidos sem a necessidade de envolver um observador consciente, e de, em seus escritos posteriores, ele repetidamente buscar se distanciar da hipótese da consciência, taxando-a de "misticismo", o físico dinamarquês certamente era simpático à hipótese de que um entendimento da consciência requeria uma extensão da TQ, para acomodar outras 
leis, além das da Física, reconhecendo, inclusive, a existência de um paralelo entre o Princípio da Complementaridade e hipóteses de outras áreas do conhecimento, como a psicologia e algumas filosofias orientais (Marin, 2009):

\footnotetext{
Para um paralelo sobre as lições acerca da aplicabilidade limitada dessas idealizações convencionais, nós devemos, de fato, nos voltar para outros ramos da ciência, como a psicologia, ou até mesmo para aqueles tipos de problemas epistemológicos com os quais se confrontaram pensadores, como Buda e Lao Tsé, ao tentar harmonizar a nossa posição como espectadores e atores no grande drama da existência. No entanto, o reconhecimento de uma analogia do caráter puramente lógico entre problemas que se apresentam em campos tão amplamente separados do interesse humano, não implica de forma alguma na aceitação, na Física atômica, de qualquer tipo de misticismo estranho ao verdadeiro espírito da ciência (Bohr, 1987, p. 367, tradução livre).
}

Inclusive, sobre essa simpatia pela extensão do Princípio da Complementaridade para outras áreas do conhecimento, em 1938, no Congresso Internacional de Ciências Antropológicas e Etnológicas, Bohr chegou a utilizar o conceito de complementaridade para defender que as emoções e percepções possuem uma relação complementar análoga às situações das medidas na Física atômica (Kragh, 1999, p. 210).

Além disso, Bohr, em alguns momentos de sua trajetória, apresentou simpatia pelas filosofias orientais. Em 1937, Bohr visitou a China e o contato com a cultura local parece ter lhe causado algum impacto pessoal, em especial, ele parece ter ficado interessado pela cosmologia taoísta, que descreve a dinâmica da realidade postulando a existência de dois princípios opostos e complementares. Como evidência desse interesse, em 1947, ao ser condecorado com o título de cavaleiro pelo rei da Dinamarca, em reconhecimento pelo seu trabalho científico, Bohr desenhou para si um brasão, que incluía o símbolo chinês do t'ai-chi, associado ao taoísmo, que representa o equilíbrio entre a ação dos princípios complementares de yin e yang, como uma evocação gráfica ao seu Princípio da Complementaridade (Capra, 1975, pp. 124-125; Nogueira, 2010, p. 33).

\section{Werner Heisenberg}

Conforme mencionado na seção 3.1.4, Heisenberg derivou o Princípio da Incerteza, a partir do próprio formalismo da MQ, por conta disso, ele foi rapidamente aceito por praticamente todos os físicos. Contudo, em pouco tempo, ficou claro que aceitar a matemática não implicava concordar com as suas implicações filosóficas. Em seu artigo 
de 1927, Heisenberg deixou claro que isso significava que a causalidade deveria ser abandonada, porque um sistema físico nunca poderia ser definido de forma precisa e, portanto, poderíamos conhecer o futuro somente de forma inexata. Sendo assim, esse princípio foi um dos temas responsáveis por levantar os debates em torno da acausalidade na FQ.

Além disso, conforme mencionado na seção 3.3.3, nos anos 1950, Heisenberg passou a defender que a função de onda $\Psi$ exprime uma potencialidade, no sentido aristotélico, relacionada a uma probabilidade "objetiva" que independe do estado de conhecimento do observador. Assim, com relação ao problema da medição, os "saltos quânticos" representariam a transição do "possível" ao "real", que ocorreria durante o ato de observação. Heisenberg enfatizou que essa transição "toma lugar tão logo a interação do objeto com o instrumento de medida (e, portanto, com o resto do mundo) tenha se realizado; assim, ele nada tem a ver com o ato de registrar o resultado por parte da mente do observador" (Heisenberg, 1958 apud Pessoa, 2003, p. 96). Assim, apesar dessa hipótese se afastar daquela que versa sobre a necessidade da existência de um observador consciente, ela postula a existência de uma espécie de "mundo das potencialidades", independente do estado de conhecimento do observador, o qual teria sua objetividade representada pela probabilidade da função de onda $\Psi$. Essa hipótese, posteriormente, será utilizada por místicos que utilizam a FQ em seu discurso, conforme será visto na seção 4.2 .

Além dos seus desenvolvimentos teóricos, com relação à $\mathrm{FQ}$, aparentemente, Heisenberg também se interessou pela cultura oriental. Em 1929, ele passou alguns meses na Índia, onde ministrou uma série de palestras. Nesse período, inclusive, ele conheceu o prêmio Nobel de literatura Rabindranath Tagore, quem, segundo relatos de conversas entre Fritjof Capra e Heisenberg, teria ajudado o físico alemão a aceitar melhor alguns aspectos paradoxais da TQ (Nogueira, 2010, p. 34). Inclusive, em seu livro intitulado "Física e Filosofia", Heisenberg chega a afirmar:

A grande contribuição científica em termos de Física teórica que nos chegou do Japão desde a última guerra pode ser um indício de uma certa relação entre as ideias filosóficas presentes na tradição do Extremo Oriente e a substância filosófica da teoria quântica (Heisenberg, 1958, p. 202, tradução livre). 
Contudo, em seus outros escritos e reflexões filosóficas, Heisenberg não deixa transparecer tanto a influência das filosofias orientais, se mostrando mais interessado em articular a TQ com o pensamento filosófico ocidental. Assim, em seus escritos, ele expressa a sua concepção idealista, a sua admiração pela filosofia platônica e as suas críticas à filosofia materialista, ao afirmar:

A filosofia do materialismo, desenvolvida na Antiguidade por Leucipo e Demócrito, tem sido tema de diversos debates, desde o surgimento da ciência moderna no século XVII e, na forma do materialismo dialético, tem sido uma das forças motrizes das mudanças políticas nos séculos XIX e XX. Se as ideias filosóficas sobre a estrutura da matéria podem exercer algum papel na vida humana, (...) seria de grande importância saber o que o conhecimento científico atual tem a dizer sobre essa filosofia. (...) aparentemente, apesar do tremendo sucesso que o conceito de átomo adquiriu na ciência moderna, Platão estava muito mais próximo da verdade a respeito da estrutura da matéria do que Leucipo e Demócrito (Heisenberg apud Wilber, 1984, pp. 46-47, tradução livre).

Para defender esse ponto de vista, Heisenberg argumenta que, diferentemente da concepção de Leucipo e Demócrito, “os átomos de Platão não eram estritamente materiais, mas pensados como formas geométricas, como os sólidos regulares dos matemáticos" (Heisenberg apud Wilber, 1984, p. 49). Assim, o filósofo alemão ressalta a capacidade platônica de abstração, de trabalhar com as formas matemáticas, e não se restringir aos aspectos exclusivamente materiais do problema, pensando de uma forma muito mais próxima ao raciocínio utilizado na FM atual. Ele ressalta que, para Platão, “(...) a forma é que determina os objetos materiais. As ideias são mais fundamentais do que os objetos" (Heisenberg apud Wilber, 1984, p. 50). A partir disso, Heisenberg critica fortemente a visão materialista sobre os átomos:

Mas as dificuldades inerentes da teoria materialista do átomo, as quais se tornaram aparentes desde as antigas discussões sobre as menores partículas, também se mostraram de forma clara no desenvolvimento da Física durante o presente século.

Essa dificuldade está relacionada à questão sobre se as menores unidades são objetos físicos ordinários de fato, e se elas existem da mesma forma que as pedras ou as flores. Aqui, o desenvolvimento da teoria quântica, por volta de quarenta anos atrás, criou uma completa mudança na situação. A formulação matemática das leis da teoria quântica mostra claramente que os conceitos intuitivos habituais não podem ser aplicados de 
forma inequívoca para as menores partículas (Heisenberg apud Wilber, 1984, p. 51, tradução livre).

Essas críticas à concepção materialista dos átomos e uma tendência ao idealismo, posteriormente, marcarão as concepções místicas em torno da FQ.

Por fim, em seus escritos, Heisenberg também reconhece a importância do pensamento religioso na compreensão do mundo, no entanto, ele ressalta a importância de não misturálo com o pensamento científico, o que acarretaria em um prejuízo para ambos:

(...) até mesmo o cientista natural deve reconhecer esse significado abrangente da religião da sociedade humana, se ele deseja tentar compreender a relação entre a verdade religiosa e a científica.

Eu já tentei enunciar a tese de que, nas imagens e semelhanças da religião, estamos lidando com um tipo de linguagem que nos permite uma compreensão daquela conexão do mundo, a qual pode ser traçada por trás dos fenômenos e sem as quais não poderíamos ter uma ética ou uma escala de valores. (...) Portanto, nós não deveríamos misturar as duas linguagens. (...) $\mathrm{O}$ cuidado a ser tomado em manter as duas linguagens, religiosa e científica, apartadas uma da outra, deveria incluir também a atitude de evitar qualquer rebaixamento do seu conteúdo por meio da mistura entre eles. A exatidão de resultados científicos testados não pode ser racionalmente colocada em dúvida pelo pensamento religioso e, de outro modo, as demandas éticas originárias do coração do pensamento religioso não devem ser enfraquecidas por argumentos extremamente racionais provenientes do campo da ciência (Heisenberg apud Wilber, 1984, pp. 43-44, tradução livre, grifos do autor).

\section{Wolfgang Pauli}

O físico austríaco Wolfgang Pauli sempre apresentou uma atitude rigorosa com relação aos problemas da Física, o que, em um primeiro momento, poderia levar a inferir que a sua atitude filosófica fosse de um racionalismo exacerbado ou de um ceticismo. No entanto, por trás dessa imagem, na verdade, Pauli possuía um profundo interesse filosófico até mesmo por áreas pouco compreendidas da realidade ou do espírito humano, que fogem ao domínio da razão. De fato, no início da sua carreira, Pauli seguiu o caminho do ceticismo, porém, posteriormente, ele tentou seguir em busca dos elementos do processo cognitivo humano, que precedem uma compreensão racional mais profunda. Isso porque ele não estava satisfeito com a visão puramente empírica a respeito do conhecimento cientifico, e passou a se alinhar com aqueles que enfatizavam o papel da intuição e da 
atenção direcionada na construção dos conceitos e ideias necessários para o estabelecimento dos sistemas de leis naturais, ou seja, das ideias, as quais iriam muito além da mera experiência (Wilber, 1984, pp. 169-170). Devido a essa ênfase nas ideias, sua postura filosófica passou a ser descrita como um "misticismo platônico lúcido", a qual envolvia uma "síntese, que englobava a compreensão racional e a experiência mística do todo" (Heisenberg, 1990, p. 38). Nas palavras de Heisenberg:

Certa vez, o físico Wolfgang Pauli falou de duas concepções limitadas, ambas as quais haviam sido extraordinariamente frutíferas na história do pensamento humano, apesar de nenhuma realidade genuína corresponder a elas. Em um extremo estaria a ideia de um mundo objetivo, seguindo o seu curso regular no espaço e no tempo, independentemente de qualquer tipo de sujeito observador; essa tem sido a imagem guia para a ciência moderna. No outro extremo, estaria a ideia de um sujeito, misticamente experienciando a unidade do mundo e não mais sendo confrontado por um objeto ou por um mundo objetivo; essa tem sido a imagem guia do misticismo asiático. Nosso pensamento se move em algum lugar no meio, entre essas duas concepções limitadas; nós devemos manter a tensão resultante desses dois opostos (Heisenberg, 1990, p. 227, tradução livre).

Dessa forma, Pauli defendia que os pensamentos científico e místico seriam, ao mesmo tempo, divergentes e complementares. Eles comporiam sistemas opostos do pensamento, que dariam origem a uma espécie de processo dialético, uma tensão, a partir da qual não saberíamos o resultado e para onde ela nos levaria, porém consistiria em um processo no qual valeria a pena confiar e investir (Wilber, 1984, pp. 172-173).

Eu acredito que, como ocidentais, nós deveríamos confiar nesse processo e reconhecer esse dois opostos como sendo complementares. Ao permitir com que a tensão entre esses opostos persista, nós devemos reconhecer também que, em toda tentativa de conhecer ou resolver algum problema, nós dependemos de fatores que estão fora do nosso controle, os quais a linguagem religiosa tem sempre chamado de "graça" (Pauli apud Wilber, 1984, p. 173, tradução livre).

Pauli também foi fortemente influenciado pela filosofia e pela simpatia de Schopenhauer pelo misticismo oriental. De fato, ele se apropria da sua ideia de "vontade", a fim de formular hipóteses acerca da aquisição do conhecimento na matemática ou na $F Q$, os quais "dariam origem a situações, que transcenderiam as ciências naturais" e que poderiam até mesmo alcançar uma "função religiosa" na experiência humana (Marin, 
2009). No entanto, o misticismo de Pauli se distancia do misticismo tradicional, conforme ele mesmo explica:

Eu não acredito em um futuro possível para o misticismo em sua forma antiga. Porém, eu acredito que as ciências naturais irão transcender a si mesmas para dar origem a posições contrárias entre seus adeptos, que irão se conectar com os velhos elementos místicos (Pauli apud Enz, 2002, p. 540, tradução livre - em Marin, 2009).

Assim, dentro dessa concepção filosófica, com relação à hipótese de incluir a consciência como uma extensão da TQ, Pauli afirmava que esse processo já havia sido apresentado filosoficamente por místicos e estudado cientificamente por psicólogos e que, com o advento da MQ, os físicos seriam capazes de unificar as duas abordagens (Marin, 2009).

Quando, na primavera de 1927, as opiniões sobre a interpretação da mecânica quântica estavam adquirindo um formato racional e Bohr estava formulando o conceito de complementaridade, Pauli foi um dos primeiros físicos a decidir sem reservas pela nova possibilidade de interpretação. (...) No centro do seu pensamento filosófico havia sempre o desejo por uma compreensão unitária do mundo, uma união que incorporasse a tensão dos opostos, e ele via a interpretação da teoria quântica como uma nova forma de pensar, na qual a unidade poderia, talvez, ser mais bem expressada do que antes (Heisenberg apud Wilber, 1984, p. 173, tradução livre).

Por fim, a partir dessa apresentação de suas ideias, fica claro que Pauli se interessava por psicologia, o que o levou a estabelecer uma relação de amizade e uma parceria intelectual com o psicólogo suíço Carl Gustav Jung. Essa parceria deu origem a um livro, intitulado "Atom and Archetype", com a publicação das cartas trocadas entre ambos, entre 1932 a 1958. Em uma das cartas presentes nesse livro, Jung faz um ensaio no qual discute o seu conceito de sincronicidade (Nogueira, 2010, pp. 37-38).

\section{Erwin Schrödinger}

Schrödinger também foi fortemente influenciado por Schopenhauer e pelo misticismo oriental na sua juventude, ele chegou a rejeitar essas influências no meio da sua carreira, porém, mais tarde, voltou a assumi-las (Marin, 2009). Schopenhauer, por sua vez, foi influenciado pela leitura de textos budistas e hinduístas da tradição vedanta e, esse contato com o pensamento do filósofo alemão fez com que Schrödinger mergulhasse na leitura de textos sobre budismo, vedanta, samkya e yoga (Nogueira, 2010, pp. 35-36). Essa 
influência pode ser notada na sua concepção a respeito da existência de uma consciência única, como solução para muitos problemas fundamentais da filosofia:

$\mathrm{Na}$ filosofia, a real dificuldade se encontra na multiplicidade espacial e temporal de indivíduos observadores e pensantes. Se todos os eventos ocorressem em uma única consciência, toda essa situação seria muito mais simples. (...) a pluralidade daquilo que percebemos é apenas uma aparência; ela não é real (Schrödinger apud Wilber, 1984, p. 96, tradução livre, grifos do autor).

A única possível alternativa é simplesmente manter a experiência imediata de que a consciência é um singular, na qual o plural é desconhecido; que só existe uma única coisa e que, o que parece ser pluralidade é meramente uma série de diferentes aspectos dessa coisa única, produzido por uma ilusão (Schrödinger apud Wilber, 1984, p. 94, tradução livre, grifos do autor).

No entanto, apesar dessa sua concepção mística, Schrödinger deixava clara a sua descrença na possibilidade da Ciência solucionar problemas de ordem filosófica, ao afirmar, por exemplo, que "a física quântica não tem nada a ver com o problema do livrearbítrio" (Schrödinger apud Wilber, 1984, p. 83, tradução livre), ou de problemas existenciais, como "De onde eu venho e para onde eu vou? Essa é a grande questão sem fim, a mesma para cada um de nós. A ciência não tem uma resposta para ela." (Schrödinger apud Wilber, 1984, p. 85, tradução livre). Por fim, mais especificamente, sobre o problema da relação entre sujeito e objeto, um problema que a FQ toca, ele expressa que:

Eu não posso acreditar [por exemplo] que o profundo questionamento filosófico sobre a relação entre sujeito e objeto e sobre o verdadeiro significado da distinção entre eles dependa de resultados quantitativos de medidas físicas e químicas (Schrödinger apud Wilber, 1984, p. 79, tradução livre).

Essa sua descrença era justificada com o argumento de que, segundo a sua concepção, "nenhuma divindade particular pode ser parte de um modelo de mundo, que somente se tornou acessível sob o custo de remover tudo o que fosse pessoal dele" (Schrödinger apud Wilber, 1984, p. 91, tradução livre). Contudo, ainda assim, em meio aos debates sobre a interpretação do formalismo da MQ, Schrödinger era simpático à ideia de que a mente ou a consciência pudesse exercer algum papel no processo de medida, tomando uma postura avessa a uma interpretação positivista, para contornar os problemas de fundamento. De 
fato, ele chega a expressar as suas críticas com relação a esse tipo de interpretação, ao afirmar que “"o mundo da ciência' tornou-se tão horrivelmente objetivo que não deixou espaço para a mente e suas sensações imediatas" (Schrödinger, 1997, p. 176). Então, apesar de não acreditar que a ciência possa resolver o problema da separação entre sujeito e objeto por completo, principalmente através de resultados empíricos exclusivamente, ele defende que a FQ aponta para a não existência de uma fronteira rígida entre ambos:

(...) as recentes descobertas na física tem nos levado para a misteriosa fronteira entre o sujeito e o objeto. Essa fronteira, conforme nos disseram, não é uma fronteira rígida, de forma alguma. Compete-nos compreender que nunca observamos um objeto sem ele ser modificado ou atingido pela nossa própria atividade de observá-lo. Compete-nos compreender que, sob o impacto dos nossos métodos refinados de observação e de reflexão sobre os resultados dos nossos experimentos, essa fronteira misteriosa entre o sujeito e o objeto foi quebrada (Schrödinger apud Wilber, 1984, p. 79, tradução livre).

Assim, ele propõe considerar a busca de uma compreensão da mente, tal qual se considera no pensamento oriental, como um problema relevante, porém, sem "perder a precisão lógica que nosso pensamento científico alcançou e que não tem paralelos em nenhum lugar, em nenhuma época" (Schrödinger, 1997, pp. 189-190):

(...) para o pensamento ocidental, tal doutrina tem pouco apelo, não é palatável, é tachada de fantástica, não-científica. Bem, assim o é porque nossa ciência - a ciência grega - está baseada na objetivação e, assim sendo, eliminou qualquer compreensão adequada do Sujeito Cognoscente, da mente. Mas acredito realmente que é esse precisamente o ponto em que o nosso presente modelo de pensamento realmente precisa ser retificado, talvez por um pouco de transfusão de sangue obtido do pensamento oriental (Schrödinger, 1997, p. 189).

Com isso, ele critica o argumento de que a mente humana possa ser substituída por instrumentos de medida no processo de medição, partindo da premissa de que é o significado que faz com que uma coleção aleatória de resultados se transforme em informação. Por fim, para ele, a aquisição de conhecimento requer que essa informação tenha um significado para alguém (Marin, 2009):

(...) o observador nunca é inteiramente substituído por instrumentos; pois, se fosse, não poderia obter qualquer conhecimento. (...) Muitos equipamentos auxiliares podem facilitar o seu trabalho. (...) Mas elas devem ser lidas! Nalgum ponto, os sentidos do 
observador devem aparecer. O registro mais cuidadoso, se não inspecionado, nada nos diz (Schrödinger, 1997, pp. 233-234).

\section{Albert Einstein}

Como é bem conhecido, Einstein muitas vezes, ao longo de sua trajetória, se referiu a Deus. No entanto, de forma alguma, ele se referia a um Deus personificado ou vinculado a uma religião específica. Inclusive, ele afirmava que "a principal fonte dos conflitos atuais entre as esferas da religião e da ciência se encontra nesse conceito de um Deus personificado" (Einstein apud Wilber, 1984, p. 111, tradução livre). Acima de tudo, Einstein acreditava na possibilidade de compreensão do funcionamento da natureza, a qual seria regida por leis causais:

O homem que está completamente convencido da operação universal da lei da causalidade não pode por nenhum momento cogitar a ideia de um ser que interfira no curso dos eventos - assumindo, é claro, que ele leve a hipótese da causalidade realmente de forma séria (Einstein apud Wilber, 1984, p. 105, tradução livre).

Dessa forma, sua concepção de Deus e seu misticismo estavam muito mais ligados à crença na existência de uma ordem central no cosmos - a qual poderia ser apreendida pelo espírito em uma união mística, de encantamento frente ao "mistério do sublime" - e em uma convicção de que o universo seria suscetível de conhecimento racional - o que ele chamava de um "sentimento cósmico religioso" - do que a alguma concepção religiosa ou mística convencionais. Essa concepção de Einstein tem sido caracterizada como uma mistura entre os pensamentos de Spinoza e Pitágoras (Wilber, 1984, p. 101).

(...) o sentimento cósmico religioso é o motivo mais forte e mais nobre para a pesquisa científica. Apenas aqueles que percebem os imensos esforços e, sobretudo, a devoção sem a qual os trabalhos pioneiros na ciência teórica não poderiam ter sido realizados são capazes de compreender a força da emoção proporcionada por esse trabalho único (...). Qual convicção profunda da racionalidade do universo e qual anseio pela compreensão, senão pela simples reflexão da mente revelada nesse mundo (...). É o sentimento cósmico religioso que proporciona ao homem essa força (Einstein apud Wilber, 1984, pp. 105-106, tradução livre).

(...) aqueles indivíduos para quem nós devemos as grandes realizações criativas da ciência foram todos eles imbuídos com a verdadeira convicção religiosa de que esse nosso universo é algo perfeito e suscetível ao esforço racional do conhecimento (Einstein apud Wilber, 1984, p. 113, tradução livre). 
Assim, para evitar um entendimento errôneo de suas concepções filosóficas, ele buscava desvincular a sua imagem de qualquer tipo de misticismo. Um episódio característico com relação a essa postura de Einstein foi quando, no auge da sua fama, uma década após ganhar o prêmio Nobel, ele se viu abordado pela mídia internacional e pelo entusiasmo pela sua teoria da relatividade, especialmente pelo seu "aspecto místico". Então, quando um jornalista perguntou a respeito desse aspecto místico em sua teoria, sua esposa Elsa caiu na gargalhada com as palavras "Místico! Místico! Meu marido místico!". Com essa atitude, Elsa reproduzia a resposta do próprio Einstein para uma mulher alemã, quem ele conheceu em Haguen e que disse que gostava do seu misticismo, ele respondeu que "misticismo é realmente a única acusação que as pessoas não podem fazer acerca da minha teoria" (Jammer, 1999; Marin, 2009).

Especificamente, com relação aos problemas de Fundamentos da FQ, Einstein foi um dos principais críticos aos aspectos que poderiam ir de encontro à lei da causalidade e à sua convicção na inteligibilidade do universo. Como se sabe, ele criticou duramente a Interpretação probabilista de Born, ao proferir a sua famosa convicção de que "Deus não joga dados", e a postura positivista de Bohr, com sua Interpretação da Complementaridade, caracterizando-a como uma "filosofia tranquilizante" (Przibram, 1967, p. 31). De fato, em 1953, em uma carta endereçada a Born, Einstein escreve: "Não me satisfaço com a ideia de que se possui uma maquinaria que permite profetizar, para a qual não se é capaz de dar um sentido claro" (Paty, 2008, p. 108). Além disso, com o argumento EPR, Einstein também visava criticar o que ele considerava como sendo uma “ação a distância fantasmagórica” (Marin, 2009), a qual violava o princípio da localidade, uma das bases da teoria da relatividade.

Por fim, no período da República de Weimar, na Alemanha, em 1921, Einstein critica o ambiente cultural que passou a adentrar o meio científico, ao afirmar (Marin, 2009):

A tendência mística do nosso tempo, que se mostra particularmente no desenfreado crescimento da chamada teosofia e do espiritualismo, é para mim não mais do que um sintoma de fragilidade e confusão (...) o conceito de um espírito sem um corpo parece para mim vazio e desprovido de significado (Einstein, 1981, tradução livre). 


\section{Max Planck}

Planck era um físico religioso, ligado à tradição cristã, porém, de forma alguma, pode ser considerado um místico. De fato, ele criticou fortemente as diversas formas de misticismo, e principalmente se posicionou contra as tentativas de introduzir essas formas de pensamento na ciência, em seu famoso livro de 1932, intitulado "Where is science going?”. Essas críticas se mostravam na forma de preocupações com o contexto alemão, nessa época, que, de acordo com Planck:

A tendência em acreditar no poder de agentes misteriosos é uma característica marcante dos nossos dias. Isso é mostrado pela popularidade do ocultismo e do espiritualismo e dos seus inúmeros variantes. Apesar dos extraordinários resultados da ciência serem tão óbvios (...) ainda assim, tanto pessoas educadas como não educadas frequentemente se voltam para o obscuro domínio do mistério para elucidar os problemas da vida cotidiana. (...) o fato é que o poder proveniente de sistemas baseados na irracionalidade é pelo menos tão forte e difundido quanto antes, senão até mais (Planck apud Wilber, 1984, p. 159, tradução livre).

No entanto, Planck separa o misticismo e a superstição das "religiões mais altamente desenvolvidas", cujo papel ele vê como participativo na disputa, quando "as ciências físicas demandam que devemos admitir a existência de um mundo real independente de nós" (Marin, 2009). Com isso, ele reconhece o valor da religião, desde que ela não se oponha às bases do conhecimento científico:

O cientista deve reconhecer o valor da religião como tal, não importam quais possam ser as suas formas, contanto que ela não cometa o erro de opor os seus dogmas às leis fundamentais sobre as quais a pesquisa científica está baseada, a saber, a sequência de causa e efeito em todos os fenômenos externos. (...) eu também devo dizer que aquelas formas de religião que possuem uma atitude niilista diante da vida estão fora de harmonia com a perspectiva científica e contraditória com os seus princípios (Planck apud Wilber, 1984, p. 161, tradução livre).

Por fim, Planck apresenta uma visão com relação à ciência, com algumas semelhanças com a visão de Einstein, na qual ela possibilitaria a exaltação de valores morais, no sentido de que ela exigiria uma espécie de fé do ser humano que se propõe a desvendá-la.

A ciência enaltece os valores morais da vida, porque ela promove um amor pela verdade e uma veneração - amor pela verdade mostrado pelo constante esforço de chegar a um conhecimento mais exato do mundo, da mente e da matéria em nosso entorno, e 
veneração, porque cada avanço no conhecimento nos leva face a face com o mistério da nossa existência (Planck apud Wilber, 1984, p. 162, tradução livre).

(...) a ciência demanda também um espirito de fé. Qualquer um que tenha seriamente se engajado no trabalho cientifico de qualquer tipo percebe que sobre a entrada dos portões do templo da ciência estão escritas as palavras: Você deve ter fé. É uma qualidade que cientistas não podem dispensar. (Planck apud Wilber, 1984, p. 162, tradução livre, grifos do autor).

(...) Kepler é um magnífico exemplo do que eu venho dizendo. Ele foi sempre persistente (...). Mas podemos perceber, estudando a sua vida, que o que o tornou tão enérgico, incansável e produtivo foi a profunda fé que ele tinha na sua própria ciência, não uma crença que ele poderia eventualmente alcançar através da síntese aritmética das suas observações astronômicas, mas uma fé profunda na existência de um plano definido por trás de toda a criação (Planck apud Wilber, 1984, p. 163, tradução livre).

\section{Arthur Eddington}

Eddington não trabalhou com a $\mathrm{FQ}$ diretamente, seu campo de atuação era a astrofísica, porém ele escreveu explicitamente uma defesa a respeito do misticismo, sendo, por conta disso, citado frequentemente por autores místicos, que utilizam da FQ em seu discurso. No entanto, a concepção de Eddington acerca do misticismo é frequentemente mal interpretada, tanto assim, que ele teve que se defender de acusações e clarificar seu pensamento. Uma dessas defesas se refere a uma acusação por parte de Bertrand Russell de que Eddington teria derivado o misticismo a partir da FM:

Eu nunca sugeri que nem a religião ou o livre-arbítrio poderiam ser deduzidos da física moderna; eu me limitei em mostrar que algumas dificuldades em reconciliá-los com a física foram removidas (Eddington apud Wilber, 1984, pp. 181-182, tradução livre).

O ponto de partida da crença na religião mística é uma convicção de significado ou, conforme eu chamei anteriormente, a sanção de uma luta na consciência. Isso tem que ser enfatizado porque o apelo para a convicção intuitiva desse tipo tem sido o fundamento da religião ao longo de todas as épocas e eu não quero dar a impressão de que nós agora encontramos algo novo e mais científico para substituí-la. Eu repudio a ideia de provar as crenças características da religião tanto pelos dados das ciências físicas, quanto pelos seus métodos (Eddington apud Wilber, 1984, p. 182, tradução livre). 
A defesa de Eddington, na verdade, é a de que a Física, tanto a clássica quanto a quântica, não pode oferecer um suporte positivo ou, até mesmo, de encorajamento para uma visão de mundo mística-religiosa. A diferença com o advento da FM é que, enquanto a FC era teoricamente hostil à religião, a FM passou a ser indiferente a ela, deixando tantas questões teóricas a respeito do universo em aberto, que passa a ser possível completá-las com visões religiosas. A Física não pode nem ajudar e nem se objetar a esses esforços. Com isso, de forma alguma, Eddington endossa as promessas de alguns escritores da Nova Era de que o misticismo pode ser provado a partir da Física (Wilber, 1984, p. 184).

Assim, os argumentos de Eddington se colocam mais no sentido de reconhecer as limitações da Física em adentrar em questões relacionadas ao espírito humano e ao misticismo, do que no sentido de uma defesa de um suporte da Física às visões místicas.

Nós reconhecemos que o tipo de conhecimento o qual a física busca é muito limitado e especializado para constituir um completo entendimento no domínio do espírito humano. A grande maioria dos aspectos da nossa vida e atividades cotidianas nos leva para fora da perspectiva da física (Eddington apud Wilber, 1984, p. 189, tradução livre).

Ele também considera que ambas as visões, mística e científica, são necessárias e devem ser levadas em conta:

Mas eu acredito que você concordará comigo que é impossível permitir que um tipo de apreciação possa preencher adequadamente o lugar da outra. (...) Me parece que a única alternativa não nem é considerar toda renúncia ao contato místico com a natureza como prejudicial e eticamente errado, e nem admitir que, a partir desses estados de espirito, nós capturamos algo sobre a verdadeira relação do mundo com nós mesmos - uma relação não compreendida pela análise puramente cientifica do seu conteúdo (Eddington apud Wilber, 1984, p. 206, tradução livre).

Contudo, o que, de fato, faz com que Eddington seja frequentemente citado por autores místicos que utilizam a FQ em seu discurso, é a sua expectativa de que a FM torne possível uma compreensão cientifica da religião e a sua defesa de que ambas, ciência e religião, poderiam contribuir para um melhor entendimento acerca de questões de fronteira entre elas.

Seria possível dizer, talvez, que a conclusão a ser desenhada desses argumentos da ciência moderna que a religião pela primeira vez se tornou passível de compreensão 
para um cientista razoável em torno do ano de 1927. (...) podemos pontuar que não apenas a religião, mas muitos dos aspectos comuns da vida se tornaram possíveis pela primeira vez para esse homem nesse ano. (...) Se a nossa expectativa se provar bem fundamentada de que 1927 viu a derrubada final da causalidade estrita por Heisenberg, Bohr, Born e outros, esse ano certamente será eleito como uma das maiores épocas no desenvolvimento da filosofia científica.

(...) $\mathrm{O}$ conflito [entre ciência e religião] não será evitado enquanto ambos os lados permanecerem confinados em seu próprio domínio, e uma discussão que nos permita alcançar um melhor entendimento sobre essa fronteira seja uma contribuição rumo a um estado de paz (Eddington apud Wilber, 1984, p. 219, tradução livre).

Essas afirmações de Eddington podem ser entendidas como uma defesa de que nenhuma das duas sozinhas - ciência ou religião - poderia prover uma compreensão completa acerca dessas questões de fronteira, mas que ambas poderão contribuir para esse entendimento. Assim, a FM apenas permitiria que esse caminho fosse explorado de forma mais livre.

\section{David Bohm}

Conforme visto na seção 3.3.4, o físico norte-americano David Bohm pertenceu a uma outra geração de físicos, a qual propôs novas interpretações para o formalismo da MQ, a partir dos anos 1950. Bohm, com sua interpretação causal baseada em variáveis ocultas, possuía uma concepção realista acerca da natureza, a qual nunca abandonou. Ele também foi membro do Partido Comunista nos EUA, sendo, por conta disso, perseguido e tendo que se exilar no exterior. Diante de diversas frustrações em diferentes aspectos de sua vida, em meados dos anos 1950, Bohm inicia uma mudança intelectual: politicamente, ele rompe o seu vínculo ideológico com o marxismo, em termos filosóficos, ele enfraquece as suas crenças na centralidade da causalidade, e na arena científica, ele abandona a sua interpretação causal, desencorajado pelos seus desenvolvimentos posteriores (Freire Jr, 2015, p. 49). Somente no final dos anos 1970, é que Bohm retomaria a sua interpretação causal com uma nova abordagem baseada em um potencial quântico.

O período de sua trajetória de maior interesse para esta seção é o período a partir de meados dos anos 1950, quando Bohm rompe com o marxismo e passa a se aproximar do pensamento oriental, iniciando um novo projeto de longa data, que se propõe a reformar a Física em torno dos temas de ordem e totalidade (Freire Jr, 2015, p. 17). Nessa época, 
Bohm também começa uma amizade de longa duração com o escritor indiano Jiddhu Krishnamurti, a qual resultaria em uma série de diálogos entre os dois. Certa vez, inclusive, Bohm chegou a reconhecer alguma influência das ideias psicológicas de Krishnamurti sobre a não-separabilidade entre observador e observado, as quais reforçaram as suas ideias em problemas análogos sobre medidas em FQ. Basil Hiley, um colaborador de Bohm de longa data, no entanto, acredita que os diálogos com Krishnamurti não influenciaram na física de Bohm, apesar de reconhecer que eles exerceram um papel nas reflexões do físico norte-americano sobre a sociedade, o pensamento e a criatividade (Freire Jr, 2015, p. 60).

Então, a partir desses novos interesses e influências no pensamento de Bohm, ele passou a se tornar uma figura frequente no circuito do Movimento do Potencial Humano, na Califórnia, nos anos 1970, onde passou a ministrar workshops de autoconhecimento, não relacionados com a Física. As ideias veiculadas nesses workshops, porém, não continham os elementos cosmológicos ou metafísicos, que costumam ser associados ao pensamento religioso oriental, elas se focavam mais nas relações humanas e nos processos psicológicos (Nogueira, 2010, pp. 38-39). De fato, conforme visto na seção 3.5.3, Bohm circulou pelo circuito do Movimento do Potencial Humano, na Califórnia, ao visitar o Consciouness Theory Group, em São Francisco e ao frequentar os seminários do Instituto Esalen (Rocha, 2015).

Essa mudança intelectual no pensamento de Bohm também foi refletida na sua ênfase na noção de totalidade, ao elaborar a ideia de universo indiviso, nos anos 1970. Com essa ideia, Bohm criticava a filosofia mecanicista como sendo uma "filosofia da fragmentação", a qual reduziria o universo a um conjunto de entidades independentes, separadas, fechadas nelas mesmas e, portanto, incapazes de uma comunicação real (Thuillier, 1997, p. 101). Assim, ele defenderia que um objeto quântico não pode ser isolado do resto do universo, e que o mundo não poderia ser analisado corretamente em partes distintas, de tal forma que universo como um todo seria uma unidade única e indivisível. A partir dessa concepção, Bohm também passaria a desenvolver um modelo "holográfico" para tratar a natureza sem recair na análise das suas partes, cunhando o termo "ordem implícita" para designar a ordem contida, por exemplo, em um holograma, no qual cada ponto contém informação de toda imagem, e que se torna "explícita" quando 
o holograma é apropriadamente iluminado (Pessoa, 2006b, pp. 245-247). Essas ideias, posteriormente, deram origem aos livros "Wholeness and the implicate order" (1980) e “The undivided universe" (1993). A partir dessa sua nova concepção, Bohm também passou a enfatizar que não existiria uma heterogeneidade entre um objeto físico e seu significado, ambos seriam “dois aspectos de uma mesma e única realidade global”, não existiria nada mais do que "um único fluxo" de realidade, e, portanto, não se deve separar matéria e espírito (Thuillier, 1997, p. 102).

\section{Outros físicos}

Alguns outros físicos ou pesquisadores em Física que também apresentaram inclinações místicas ao longo de sua trajetória - ainda que essas inclinações muitas vezes não tenham transparecido em seus trabalhos científicos -, ou interpretações e/ou hipóteses com relação à $\mathrm{FQ}$, as quais podem ter contribuído para o estabelecimento da relação entre FQ e misticismo - ainda que indiretamente - mas que não serão aprofundados neste trabalho, foram John von Neumann, Fritz London, Edmond Bauer, Eugene Wigner, Henry Stapp, Nick Herbert, Costa de Beauregard e Mario Schenberg. As influências e detalhes sobre suas posturas filosóficas, hipóteses e inclinações, além das de outros físicos não citados, constituem um campo de pesquisa a ser mais bem explorado. Assim, muito longe de pretender fornecer um panorama acerca do assunto, esta seção se limitará a fazer apenas alguns breves apontamentos. Vale ressaltar também que esta seção se limitará a apontamentos sobre físicos que permaneceram na carreira científica ao longo de sua vida. Os físicos que, em algum momento de sua trajetória, abandonaram a carreira científica e passaram a se dedicar às suas inclinações místicas serão abordados na seção 4.2.

John von Neumann foi o responsável por introduzir na MQ a distinção entre dois tipos de evolução para os estados quânticos, em seu livro Mathematische Grundlagen der Quantenmechanik, publicado em 1932 ${ }^{7}$ : a primeira delas ocorre durante o processo de medição, e é descontínua, não-causal e atua instantaneamente nos experimentos ou medidas, já a segunda é contínua, causal e governada pela equação de Schrödinger. Então, para resolver o problema de como a evolução contínua do estado quântico sofre uma

\footnotetext{
7 Posteriormente, em 1955, o livro de Von Neumann foi traduzido para o inglês, sob o título Mathematical Foundations of Quantum Mechanics. Essa é a versão citada neste trabalho.
} 
descontinuidade, no processo de medição, von Neumann apela para o papel do sujeito cognoscente, isto é, o observador individual. Ele argumenta que, em qualquer medida, em última análise, haverá um momento no qual nós devemos dizer "isso é percebido pelo observador", apelando, inclusive, para um paralelismo psicofísico, ao afirmar que "deve ser possível descrever os processos extrafísicos da percepção subjetiva como se elas estivessem em realidade no mundo físico", ou seja, "atribuir às suas partes processos físicos equivalentes no meio objetivo, no espaço ordinário" (von Neumann, 1955, p. 419; Freire Jr, 2015, p. 144). Com isso, von Neumann acaba por apontar a necessidade da existência de um observador com qualidades perceptivas no processo de medição na TQ.

Após a formulação dessa hipótese por von Neumann, em 1939, o físico alemão Fritz London e o físico francês Edmond Bauer popularizam a ideia de que a descontinuidade na evolução do estado quântico, ou a redução da função de onda, só poderia ser explicada com a invocação de um observador consciente, ao escreverem um ensaio no qual eles explicam a teoria da medida de von Neumann para leitores sem muitas habilidades matemáticas. Nesse ensaio, London e Bauer foram mais enfáticos do que von Neumann com relação ao papel da consciência em uma medição quântica. Diferentemente de von Neumann, que não havia incluído a consciência do observador na cadeia de medição, London e Bauer argumentaram explicitamente que a redução da função de onda era o resultado de uma atividade consciente da mente humana (Gavroglu, 1995, p. 171). Segundo eles, um acoplamento mesmo com um aparelho de medição ainda não seria uma medida: uma medida se efetivaria somente quando a posição de um ponteiro fosse observada. Nas palavras deles:

O observador possui uma impressão completamente diferente. Para ele, é só o objeto x e o aparato y, que pertencem ao mundo externo, ao que ele chama de "objetividade". Por contraste, ele possui relações consigo mesmo de uma característica muito especial. Ele possui uma característica e uma faculdade bastante familiar, a qual nós podemos chamar de "faculdade de introspecção". Ele pode rastrear o caminho do seu próprio estado a cada momento. Em virtude desse "conhecimento imanente" ele atribui a si mesmo o direito de criar a sua própria objetividade - isto é, de cortar a cadeia de correlações estatísticas (...) declarando "eu estou [nesse] estado" (London e Bauer, 1939, p. 42, tradução livre, grifos dos autores).

Nessa ocasião, London e Bauer estavam completamente conscientes das implicações das suas afirmações, e tomaram o cuidado de argumentar que esse apelo à consciência, de 
forma alguma, levava ao solipsismo (Freire Jr, 2015, p. 146). Posteriormente, esse trabalho de London e Bauer foi amplamente citado por autores místicos que utilizam a FQ em seu discurso, o que levou a autores como Omnès (2002) a apontar e criticar as diversas distorções das ideias originais de London e Bauer por parte desses autores.

O físico Eugene Wigner também se preocupou com o problema da medição, para ele, esse problema era parte da filosofia da Física, a qual, por sua vez, seria parte da Física em si. Assim, entre 1961 e 1963, Wigner publicou dois artigos nos quais ele enfatizou a distinção entre os dois tipos de evolução para os estados quânticos e chegou a mesma conclusão de London e Bauer, na qual, para eliminar a superposição entre os estados possíveis, deve-se admitir que a análise da medida quântica nos leva, eventualmente, para o papel da introspecção do observador, isto é, para o momento em que a informação entra na mente do observador. Para ele, não seria possível formular as leis da MQ de uma forma completamente consistente sem fazer referência à consciência. Em seus artigos, ele afirma que o estado quântico se modifica toda vez que o observador obtém alguma informação a partir das observações. Ele também elabora o seu famoso experimento mental, conhecido como o "amigo de Wigner" (Wigner, 1961) - ver seção 3.1.4 - no qual ele busca mostrar a diferença entre as descrições das medições quânticas com e sem observadores humanos. Com esses argumentos, Wigner passou a defender que seria necessário modificar a TQ para poder abranger não apenas corpos inanimados, mas também a vida e a mente. Para isso, ele sugeriu explicitamente buscar por uma equação não-linear do movimento (Freire Jr, 2015, pp. 150-152).

Já o físico norte-americano Henry Stapp, um dos principais pesquisadores em teoria da Matriz-S em MQ, além de defender que a inclusão da consciência seria necessária para a compreensão da TQ, também defende que a TQ é necessária para a compreensão da consciência (Rocha, 2015, p. 45). Assim como David Bohm, Stapp também circulou pelos circuitos do Movimento do Potencial Humano, nos anos 1970, na Califórnia, nos EUA, ao participar do grupo no Institute for the Study of Consciousness, do Fundamental Fysiks Group e do grupo do Esalen Seminars on Quantum Physics and the Nature of Reality Group (Rocha, 2015, p. 209). O diálogo e as interações proporcionados por esses espaços e instituições alternativas às instituições acadêmicas convencionais permitiram com que Stapp utilizasse uma abordagem multidisciplinar - integrando as áreas da filosofia, da MQ 
e das neurociências - para elaborar um modelo que denominou de "modelo da mente Heisenberg/James", no qual ele lida com o problema mente-corpo (ou problema da “consciência quântica"), em particular, com a questão do livre-arbítrio. Para ele, a solução para esse problema é o dualismo ontológico, no qual a mente e o corpo seriam substâncias diferentes e o livre-arbítrio seria uma propriedade da mente, ao mesmo tempo em que se apresenta como um fenômeno da matéria (Rocha, 2015, pp. 201-202). Ao elaborar o seu modelo, Stapp também foi influenciado pela teoria da medição de von Neumann e, de fato, após ler o livro do matemático húngaro, em 1959, Stapp escreve uma monografia intitulada "Mind, matter and Quantum Mechanics", que posteriormente daria origem a um livro com o mesmo nome. Segundo Stapp, por tratar de observações, a teoria da Matriz-S, a qual era adepto, se encaixa muito bem com a questão da consciência. A influência por parte do psicólogo William James sobre o seu modelo, por outro lado, se devia a sua ênfase no pragmatismo (Rocha, 2015, pp. 207-209). Por fim, ao buscar um entendimento da consciência pela FQ, Stapp expressa a visão de mundo que motiva o seu trabalho, segundo essa visão, existiria uma diferenciação entre uma "imagem quântica" e uma “imagem clássica” do homem e da natureza (Rocha, 2015, p. 37):

\footnotetext{
Essa autoimagem mecânica clássica tem a tendência de produzir atitudes de resignação, depressão, desesperança, falta de sentido, e amoralidade; enquanto a autoimagem quântica, a qual torna os seus esforços mentais baseados em valores causalmente efetivos, tende a criar uma atitude dinâmica, elevada, esperançosa, direcionada para frente e moral (Stapp, 2012, tradução livre).
}

Com essa visão de mundo, apesar de talvez não ser a sua intenção original, Stapp se aproxima dos argumentos elaborados pelos autores místicos que utilizam a FQ em seu discurso.

Outro físico a ser citado é o norte-americano Nick Herbert, que realizou importantes pesquisas em torno do Teorema de Bell e sobre a possibilidade de transmissão de sinais mais rápido do que a luz, através do emaranhamento quântico, ele também contribuiu fortemente com as pesquisas que deram origem ao Teorema de não-clonagem (Kaiser, 2011, pp. 289-290). Herbert participou ativamente dos circuitos do Movimento do Potencial Humano, nos anos 1970, na Califórnia, nos EUA, participando do Fundamental Fysiks Group, do Consciousness Theory Group, do Physics/Consciousness Research Group, do Esalen Seminars on Quantum Physics and the Nature of Reality, frequentando 
o Institute for the Study of Consciousness, ministrando palestras e seminários no Instituto Esalen e participando de pesquisas relacionadas à parapsicologia. Ele também foi autor do livro Quantum Reality: Beyond the New Physics, publicado em 1985, que foi um dos principais livros responsáveis por popularizar a FQ para o público leigo, ao discutir as interpretações da MQ (Rocha, 2015). Por fim, em uma entrevista, Herbert chegou a afirmar que uma das motivações que o levaram a estudar a parapsicologia e a sua possível relação com a TQ era a possibilidade de produzir "ao menos um pequeno fato que pudesse produzir uma indústria multimilionária” (Rocha, 2015, p. 283, tradução livre).

Por fim, é possível citar brevemente o físico francês Olivier Costa de Beauregard e o físico brasileiro Mário Schenberg.

Beauregard trabalhou com Louis de Broglie e foi um especialista em teoria da informação, fortemente interessado nas relações entre a teoria da relatividade e a MQ, em especial no Teorema de Bell. Ele também se interessou em verificar experimentalmente fenômenos de parapsicologia, nos quais ele via uma analogia com o problema dos estados correlacionados em MQ. Para ele, parecia uma oportunidade interessante de testar objetivamente os problemas relacionados às interpretações da MQ (Lochak, 2007).

Mario Schenberg, por sua vez, é considerado um dos mais importantes físicos brasileiros, e possui trabalhos em diversas áreas da Física, como a MQ, mecânica estatística, relatividade geral e a astrofísica. Schenberg também escreveu o prefácio da edição brasileira do livro $O$ Tao da Física, de Fritjof Capra, o qual ele classifica como "um dos livros mais fascinantes das últimas décadas" (Schenberg, 1984). Nesse prefácio, Schenberg demonstra o seu interesse pela "aproximação entre a Física do século XX e as cosmovisões das civilizações do Oriente" e faz menção a outra obra de Capra, O Ponto de Mutação, o que indica que ele foi simpatizante e leitor das suas obras. Ele também aponta algumas lacunas, em sua opinião, sobre a análise Capra, como a de não ter considerado devidamente "as influências do pensamento platônico (...), sobretudo no pensamento de Werner Heisenberg" e "a falta de uma discussão sobre as relações entre a filosofia da teoria quântica e a Psicologia junguiana, especialmente no que tange ao problema dos arquétipos" (Schenberg, 1984). Com isso, Schenberg também deixa claro as suas inclinações místicas. 


\subsection{As protoideias que antecederam a relação entre $F Q$ e misticismo}

Através do estudo dessa complexa e intrincada história da FQ e suas interpretações, juntamente com o seu contexto histórico-social particular, foi possível observar que influências de diversas procedências podem ter contribuído para que a relação entre FQ e misticismo se estabelecesse. Dentre essas diferentes influências, é possível notar que algumas ideias exerceram um papel especial, por se fortalecerem e permanecerem após o estabelecimento dessa relação. Entre elas, podemos destacar pelo menos duas: a negação da existência de um determinismo e uma causalidade intrínsecos na Física e na Ciência em geral, e a ideia de que a consciência seria capaz de interferir na matéria.

Um conceito fleckiano que pode ajudar na compreensão dessas diversas influências e a permanência e a consolidação de algumas ideias é o conceito de protoideia. Conforme visto na seção 2.2, as protoideias podem ser consideradas como "pré-disposições histórico-evolutivas de teorias modernas" (Fleck, [1935]2010, p. 66), ou pré-ideias, précientíficas, mais ou menos vagas ou confusas, que se associariam com fatos científicos por meio de ligações evolutivas incontestáveis. Essas pré-ideias não necessariamente se constituem em conceitos ou ideias claros, já formulados anteriormente, mas podem consistir em predisposições provenientes de contextos diversos, as quais, quando revitalizadas no presente, podem se tornar uma possível fonte inspiradora na atribuição de significados. Fleck ilustra esse conceito com o exemplo da ideia de alteração sifilítica do sangue, que já existia séculos antes de ser comprovada cientificamente, na forma de uma opinião pública de que o sangue dos sifilíticos era impuro. Para o filósofo polonês, as protoideias nos permitem ver que "o passado continua vivo", a partir das tradições legadas dos estilos de pensamento ancestrais, "nos conceitos herdados, nas abordagens de problemas, nas doutrinas das escolas, na vida cotidiana, na linguagem e nas instituições" (Fleck, [1935]2010, p. 61) e, mais do que isso, elas se constituem em uma das principais fontes que condicionam os conteúdos concretos de cada estilo de pensamento (ver seção 2.4).

No entanto, Fleck também destaca que nem todo fato científico atual provém de uma protoideia e que nem toda protoideia dará origem a um fato científico. Assim, é preciso avaliar quais das ideias citadas no início desta seção são provenientes de protoideias de fato e se elas deram origem a fatos científicos. Para isso, é preciso levar-se em conta que a 
relação de interesse para o presente estudo - entre FQ e misticismo - transpõe os limites do âmbito do conhecimento puramente cientifico e, portanto, as protoideias podem não ter dado origem a um fato cientifico, senão meramente a uma outra ideia ou hipótese vinculada ao misticismo. De fato, para Fleck, um fato científico é um "sinal de uma resistência (Aviso eines Widerstandes), que se opõe à voluntariedade livre do pensamento" (Fleck, [1935]2010, p. 151), é a resposta a um problema, a qual, na maioria das vezes já se encontra "pré-formada na pergunta e em que basta decidir-se apenas por um sim ou não ou por uma constatação numérica" (Fleck, [1935]2010, p. 133, grifos do autor). Esse não parece ser o caso das hipóteses defendidas pelos defensores da existência de uma relação entre misticismo e FQ, geradas a partir das ideias citadas no início desta seção.

Assim, partindo dessas considerações, nesta seção, pretende-se mapear algumas das possíveis protoideias que podem ter influenciado as ideias identificadas anteriormente, as quais influenciaram de forma mais proeminente no estabelecimento da relação entre FQ e misticismo. Contudo, reconhece-se que mapear essas protoideias consiste em um trabalho histórico complexo, o qual exigiria um estudo mais aprofundado, com maior detalhamento. Dessa forma, esta seção se limitará a apenas pontuar alguns aspectos mais consolidados, a partir de outras pesquisas, a respeito dessas possíveis protoideias.

A primeira ideia a ser analisada é a da negação da existência de um determinismo e uma causalidade intrínsecos na Física e na Ciência em geral, essa ideia se torna central no estabelecimento da relação entre FQ e misticismo, por possibilitar uma conexão da Ciência com elementos não estritamente racionais. Segundo Paty (2004), a palavra "causa", a partir da qual se formou a "causalidade", é um termo de origem jurídica, assim como a palavra "lei". No entanto, o sentido da palavra latina "cavere", que dá origem à palavra causa e significa "a causa de alguém”, é herdada do grego. Aristóteles distinguia quatro causas possíveis: a formal, a material, a eficiente e a final, mais adiante, o pensamento escolástico retoma essas causas e agrega outras, como a causa primeira, por exemplo - que consistiria na causa que não tem ela mesma uma causa. No século XVII, Francis Bacon ainda faz uso da causa formal, a qual, posteriormente acaba caindo em desuso. A causa final perdura até o final do século XVIII na física, podendo ser encontrada na formulação do princípio de mínima ação de Maupertuis, e é somente esta última que permanece na expressão de Hamilton, no século XIX. A causa eficiente, no 
entanto, é a que subsiste na terminologia moderna, adquirindo o sentido de causa física, ligada à mudança de movimento. É esse o sentido reencontrado na chamada "lei de causalidade newtoniana", a qual somente adquiriu uma formulação exata posteriormente a Newton (Paty, 2004). Do ponto de vista filosófico, por outro lado, para os pensadores da racionalidade clássica moderna, como Descartes, Spinoza e Leibniz, a noção de causa comporta a ideia de anterioridade lógica, que permite afirmar uma proposição. Com Hume, essa causalidade racional sofre uma crítica voltada às suas representações, com a ideia de que o que atribuímos às causas seria, na verdade, dado pelo hábito. A partir dessa crítica, Kant, entre outros autores, acrescenta a formulação de uma causalidade física de sentido mais limitado, porém, mais preciso. Para ele, o princípio de causalidade faz parte daquilo que ele denomina "analogias da experiência", nessas analogias, Kant exprime a causalidade como sendo composta, de uma parte, pela união das coisas que se seguem ou que são reunidas pelo entendimento (trata-se da causalidade segundo a ordem do tempo), e de outra parte, pela sucessão temporal, que vem após a relação da qual ela depende (seria a causalidade segundo o curso do tempo). Assim, a partir desses debates a respeito da causalidade, tanto por parte da filosofia natural, quanto por parte de pensadores da racionalidade clássica moderna, foi possível constituir a noção de causalidade física, a qual se deu em uma relação direta com a elaboração do conceito de tempo e de uma teoria física matematizada: a mecânica, como a ciência do movimento dos corpos. Galileu, em seus estudos a respeito da queda dos corpos e com a elaboração de uma lei de movimento em função do tempo, foi quem introduziu o tempo como parâmetro variável da dinâmica. No entanto, Galileu não considerava o tempo como instante, a ideia de instantaneidade chega a aparecer no pensamento de Descartes, porém é somente a partir de Newton que as leis da mecânica passam a incluir o tempo instantâneo como variável do movimento. Em Newton, contudo, a noção de causa se apresenta sobretudo através do conceito de força. Mas é d'Alembert quem, posteriormente, fornece mais clareza ao conceito de causalidade física, o qual, ao mesmo tempo, funda a matematização da mecânica e sua formulação analítica, ao se referir especificamente à mudança de estado de movimento ou de repouso e ao se restringir a descrever e compreender os movimentos, engendrados por causas, sem se preocupar com a natureza dessas causas, mas apenas em examinar os seus efeitos. Assim, tem-se a causa apreendida em seu efeito. Com isso, d'Alembert efetua a separação entre a ideia de causa metafísica, nebulosa e desconhecida, e a de causa física (herdada da 
causa eficiente), que é ela mesma efeito de uma causa e que se manifesta por um efeito, sem ultrapassar esse efeito. Dessa forma, é possível notar que os pensamentos de Newton e d'Alembert sobre as noções de causa e de força estavam em oposição, no concernente à natureza propriamente física dessa mudança. De um lado, a concepção newtoniana da força externa, como substituto matemático das causas, afastava a consideração física destas. De outro, d'Alembert considerava a mudança produzida como imanente ao movimento segundo a causa circunscrita pelo seu efeito, evitando recorrer à noção de força externa. Ao final, a concepção de d'Alembert acerca da causalidade física e da significação física correlativa das equações de movimento foi a que a física teórica e matemática herdaram. Nessa concepção, a causalidade física estaria dada na própria forma das equações (Paty, 2004).

O termo "determinismo", por sua vez, de acordo com Paty (2003), possui uma utilização relativamente recente. É possível encontrá-lo em textos de filósofos alemães do século XVIII. No entanto, no século XVII, Leibniz já exprime essa noção sob outras denominações: através da ideia de predeterminado ou predeterminismo. E é justamente o conceito de razão suficiente de Leibniz, o qual justifica o fato das coisas serem de uma forma e não de outra, que servirá de apoio para a declaração de Laplace, a qual, mais tarde, ilustrará o senso mais preciso mantido para o termo determinismo, o senso do determinismo laplaciano. É interessante notar que, na formulação original de Laplace, em seu texto que se tornou célebre, ele não utiliza o termo "determinismo", o que indica que essa formulação respaldou as concepções de dois dos principais cientistas franceses defensores do determinismo no final do século XIX, o fisiologista Claude Bernard e o físico e matemático Henri Poincaré. Além disso, Laplace era discípulo de d'Alembert, quem se preocupou bastante com a questão do acaso e da causalidade e, cuja concepção era a favor de que as leis que regem o movimento dos corpos são de natureza necessária (e não contingente) e a de que todos os eventos na natureza dependem uns dos outros, sendo interligados entre si. De fato, para a formulação do texto que dará origem ao chamado determinismo laplaciano, Laplace se inspira em uma inteligência superior fictícia imaginada por d'Alembert no verbete "fortuito" de sua Encyclopédie (d'Alembert e Diderot, 1751-1780), a qual seria análoga aquela suposta à do Criador e que teria a função, de um lado, de garantir a unicidade absoluta dos encadeamentos de causalidade idênticos, os quais seguiriam séries paralelas e, de outro lado, por oposição entre uma 
visão total e exterior e as visões parciais, finitas, porém dotadas de consciência, ela permitiria manter a ideia da liberdade humana. Laplace assumirá a primeira função dessa inteligência imaginada por d'Alembert, em sua famosa declaração, que definiu o que ficou conhecido posteriormente por determinismo laplaciano. Nela, ele começa enunciando o encadeamento causal ao longo do tempo, ou seja, a causalidade física na acepção da expressão diferencial da mudança do movimento, para, então, fazer intervir a ideia de uma "inteligência suprema", a qual extrapolaria infinitamente as capacidades intelectuais humanas, e a qual seria capaz de, em um dado instante, se ela "conhecesse todas as forças sob as quais a natureza seria animada e a respectiva situação dos seres que a compõem, se ademais ela fosse vasta o bastante para submeter seus dados à análise, e abarcasse em uma mesma fórmula os movimentos dos mais grandes corpos do universo ao mais leve átomo: nada seria incerto para ela, e tanto o futuro, como o passado, seria presente aos seus olhos" (Laplace, 1812). Com isso, Laplace estende e generaliza a causalidade física de uma descrição local e parcial a uma descrição global e estendida ao "universo inteiro", concebido como o conjunto dos objetos que ele contém. Assim, o determinismo laplaciano se coloca como uma qualidade do conhecimento total e absoluto, no qual as probabilidades seriam apenas um paliativo à ignorância. Posteriormente, o determinismo passou a ser considerado como uma cláusula da definição da própria ciência, conforme pode ser encontrado em declarações de Claude Bernard e Henri Poincaré, apesar dessas concepções se apresentarem como mais atenuadas do que o determinismo laplaciano, em seu estrito senso. Em Claude Bernard, por exemplo, o determinismo é utilizado como sinônimo de cientificidade e seus argumentos são dirigidos contra as concepções vitalistas. Poincaré, por sua vez, pode ser considerado como um herdeiro do pensamento laplaciano, ao declarar que "a ciência é determinista" (Poincaré, 1913), no entanto, ele atenua a concepção laplaciana do determinismo, ao não identificar o objeto do conhecimento como um objeto real, e defender que o primeiro é construído pelo pensamento. Por fim, o determinismo laplaciano pode ser considerado como uma sistematização da causalidade newtoniana (Paty, 2003).

A partir de meados do século XIX, essas duas noções, a de causalidade e a de determinismo, passaram a sofrer críticas e tiveram que ser reconsideradas, porém, sem que os cientistas abandonassem a ambição de obter uma descrição científica dos seus respectivos domínios. A primeira delas, a causalidade, passa por uma transformação 
importante com o conhecimento das ações físicas retardadas, e não mais instantâneas, ocasionadas pela teoria eletromagnética, as quais foram explicadas e teorizadas, posteriormente, pela teoria da relatividade restrita. Assim, a causalidade relativística impõe restrições sobre as possibilidades de descrever os eventos físicos espaçotemporalmente. Já com relação ao significado da noção de determinismo, uma primeira limitação surge com a consideração dos sistemas dinâmicos não-lineares, deterministas, porém de comportamento não previsível, em razão da amplificação de pequenas diferenças nas condições iniciais. Com relação a essa limitação, a Física pôde propor outras relações, como a de um determinismo em uma trajetória, ou como a de estabilidade estrutural de uma família de trajetórias, que qualificam um dado sistema dinâmico. Contudo, foi com o advento da FQ que os ideais de causalidade e determinismo passaram pela sua maior "crise", principalmente com os problemas relacionados à observação e à relação entre os fenômenos quânticos e o formalismo matemático dessa teoria (Paty, 2003), conforme visto nas seções anteriores. No contexto mais amplo, as críticas às noções de causalidade e determinismo ganharam especial força no período entreguerras, no contexto da República de Weimar (1918-1927), na Alemanha, onde a derrota deste país na Primeira Guerra Mundial e a crise econômica que se seguiu formaram um ambiente intelectual hostil para os físicos, marcado por um clima antirracional e antipositivista (Forman, 1983) (ver seção 3.5.2).

Assim, a partir dessa retomada histórica das noções de causalidade e determinismo, foi possível notar que seu desenvolvimento se deu em relação direta e como parte da própria constituição da mecânica e da Ciência em geral, de tal forma que as suas limitações também só puderam ser reconhecidas com o desenvolvimento da Física. Com isso, podese dizer que as protoideias - ou pré-ideias -, que originaram a ideia de que a Física e a Ciência em geral não seriam regidas pelos princípios da causalidade e do determinismo de forma intrínseca, tiveram sua origem na própria Ciência. Contudo, não se pode dizer que essas protoideias deram origem a uma ideia ou concepção científica, uma vez que, as noções de causalidade e determinismo não foram completamente abandonadas e não deixaram de fazer parte da Ciência, mas foram apenas reformuladas, de forma que os cientistas em nenhum momento abandonaram a sua ambição por uma descrição científica e racional em seus respectivos domínios. De forma contrária, no entanto, alguns defensores da existência de uma relação entre FQ e misticismo sugerem que o advento da 
FQ acarretou em um abandono da causalidade e do determinismo na Ciência ou que, pelo menos, essa teoria sugeriria que essas noções deveriam ser abandonadas.

Por fim, a segunda ideia a ser analisada é a de que a consciência seria capaz de interferir na matéria. Segundo Pessoa (2010), essa ideia possui raízes tanto em uma tradição na história da ciência denominada "naturalismo animista" ou romantismo, quanto em algumas tradições idealistas na filosofia. A primeira delas, a tradição do "naturalismo animista", considera que a natureza seria imbuída de uma espécie de alma, semelhante à alma humana, ou uma espécie de sentido, finalidade ou racionalidade, semelhantes aos dos seres humanos, e pode ser encontrada, desde a Antiguidade, em escolas filosóficas como: o pitagorismo, o estoicismo, o neoplatonismo, o taoísmo, e em religiões como o gnosticismo, entre outras. Mais adiante, no Renascimento europeu, essas tradições ressurgem nos estudos de magia, astrologia, alquimia e hermetismo, caracterizando o chamado "naturalismo renascentista", que influenciou cientistas como Gilbert, Kepler e van Helmont. No século XIX, essa tradição ganha força novamente com o romantismo alemão ou neoromantismo (ver seção 3.5.1), na obra de Goethe e na Naturphilosophie de Schelling, que influenciou cientistas como Oken, Carus, Ritter, Oersted, entre outros. Esse movimento considerava o "eu" e a natureza como manifestações de uma substância fundamental, que teria entre seus atributos o espírito e a matéria, de forma que as leis da natureza coincidiriam em larga medida com as leis do indivíduo e, portanto, a natureza seria vista como uma totalidade orgânica. Assim, uma vez que as leis da natureza eram as mesmas leis que regiam o pensamento humano, os cientistas poderiam, em princípio, atingir a verdade sobre a natureza utilizando apenas a sua intuição, o que implicaria na possibilidade de uma atitude menos rigorosa com relação ao método científico. O "naturalismo animista" também se encontra dentro de um quadro mais amplo, o das diferentes visões de mundo "naturalistas", as quais tomam como ponto de partida a existência da natureza, ou de nossa experiência perceptiva desta natureza, e que concebem que ela possui certa unidade e segue leis próprias. Essa visão é a adotada pela Ciência e está em contraste com as visões de mundo mitológicas e religiosas e as visões de mundo humanistas e subjetivistas, por exemplo. Ainda dentro das visões naturalistas, é possível distinguir também dois tipos de posturas: as realistas e as fenomenalistas, as primeiras defendem que há bases racionais para se aceitar teses relativas a inobserváveis, enquanto que as segundas negam essa possibilidade. Por fim, dentro das visões realistas, existem as 
abordagens naturalistas animistas e as materialistas: conforme visto anteriormente, as primeiras atribuem uma espécie de alma à natureza, ao passo que as segundas negam a possibilidade de se existir uma consciência fora de um corpo humano (ou animal) em funcionamento fisiológico, de forma que a consciência humana seria apenas uma manifestação da matéria ou de entidades físicas e que a alma desapareceria com a morte do corpo (Pessoa, 2010).

A outra raiz da ideia de que a consciência seria capaz de interferir na matéria se refere às tradições idealistas na filosofia, as quais defendem que a realidade, de alguma forma, depende da mente ou do sujeito cognoscente. No século XIX, o idealismo tinha força especialmente nas universidades alemãs, com a metafísica de Hegel, que postulava uma racionalidade "absoluta" na natureza. A versão mais radical do idealismo é o chamado "idealismo subjetivista", que considera que a realidade seria uma espécie de sonho na mente do sujeito, essa versão se opõe ao "realismo ontológico", o qual afirma que o mundo existe independentemente de nossas mentes ou de nossa observação. No entanto, dentro das visões realistas, que incluem o naturalismo animista, há um sentido de “idealismo" justamente na tese de que a mente é capaz de alterar a realidade externa diretamente, sem a intermediação da matéria. Pode-se distinguir, ainda, esse "idealismo transformador", relativo à tese de que a mente consegue transformar a realidade, do "idealismo criador", mais forte e relativo à tese de que a mente humana cria a realidade (Pessoa, 2010).

Sendo assim, através desse mapeamento de diferentes correntes filosóficas, foi possível perceber que a ideia de que a consciência seria capaz de interferir na matéria presente nos argumentos dos defensores da existência de uma relação entre FQ e misticismo - possui sua origem principalmente na filosofia, reunindo ideias presentes em diferentes tradições filosóficas. Da Naturphilosophie de Schelling, corrente do romantismo alemão do século XIX, se herdou principalmente a ideia da existência de uma totalidade orgânica entre os atributos do espírito e da matéria e entre as leis do indivíduo e da natureza. Com isso, herdou-se também o argumento em prol de uma maior valorização da intuição na Ciência e em defesa da adoção de uma atitude menos rigorosa com relação aos seus métodos. Do idealismo, por outro lado, herdou-se a ideia de que a mente teria um papel essencial na constituição do mundo ou da realidade, ou seja, esta última dependeria 
de alguma forma dos sujeitos conscientes. Então, da mesma forma que no caso anterior, observa-se uma influência direta dessas pré-ideias ou "pré-disposições históricoevolutivas" na concepção analisada - as protoideias. No entanto, também não é possível dizer que elas deram origem a uma concepção adotada hegemonicamente pela Ciência - e, de fato, ela não é aceita pela maioria dos cientistas -, mas originaram apenas uma ideia posteriormente presente na relação estabelecida entre FQ e misticismo.

Portanto, a partir das análises iniciais das duas ideias apresentadas, foi possível corroborar a concepção fleckiana de que o passado "continua vivo, nos conceitos herdados, nas abordagens de problemas, nas doutrinas das escolas, na vida cotidiana, na linguagem e nas instituições" (Fleck, [1935]2010, p. 61), tendo esse passado dado origem a estilos de pensamento científicos ou não-científicos. Além disso, identificou-se que as ideias analisadas possuem raízes tanto no desenvolvimento da própria Ciência, quanto em concepções filosóficas, de tal forma que foi possível constatar que, conforme Fleck afirma, "não existe geração espontânea (Generatio spontanea) dos conceitos; eles são, por assim dizer, determinados pelos seus ancestrais" (Fleck, [1935]2010, p. 61). Contudo, não se pode afirmar que as raízes dessas ideias deram origem a concepções adotadas pela Ciência, ou a um "sinal de uma resistência (Aviso eines Widerstandes), que se opõe à voluntariedade livre do pensamento" (Fleck, [1935]2010, p. 151) - isto é, a um fato científico. Apesar disso, pode-se dizer que essas protoideias - pré-ideias ou prédisposições histórico-evolutivas - são um indicativo de que a própria relação estabelecida posteriormente entre FQ e misticismo não foi algo gerado espontaneamente, livremente inventado por místicos, mas que consiste em uma concepção com raízes tanto no próprio desenvolvimento da Ciência e, em especial, da Física, como em concepções e tradições da filosofia.

Por fim, conforme dito anteriormente, as análises realizadas nesta seção foram pontuais e se restringiram apenas em apontar algumas possíveis protoideias que podem ter influenciado no estabelecimento da relação entre FQ e misticismo. Sendo assim, esse estudo inicial se mantém aberto e pode ser objeto de aprofundamento em trabalhos posteriores. 


\title{
4 Misticismo Quântico: o desenvolvimento da relação entre Física Quântica e misticismo
}

\subsection{Delineando a noção de misticismo quântico}

Nesta seção, será feita uma análise conceitual da noção de "misticismo quântico", tal qual ela foi sendo elaborada e discutida por diferentes autores a fim de tratar do tema central deste trabalho: o estabelecimento da relação entre a FQ e o misticismo. A partir dessa análise, ao longo deste capítulo, serão discutidos alguns elementos que podem contribuir para o enriquecimento, uma maior compreensão e, portanto, um melhor delineamento dessa noção. Com essa finalidade, faz-se necessário, em primeiro lugar, discutir com conceito de misticismo.

De acordo com alguns dicionários de filosofia, existem duas conotações para o termo misticismo: uma que se refere à definição usual do termo e a outra que reconhece que esse termo adquiriu um significado pejorativo. Lalande (1997), por exemplo, define misticismo como:

\begin{abstract}
A. Propriamente, a crença na possibilidade de uma união íntima e direta do espírito humano ao princípio fundamental do ser, união se constituindo por vezes de um modo de existência e um modo de conhecimento estrangeiros e superiores à existência e ao conhecimento normais. B. Conjunto de disposições afetivas, intelectuais e morais, que se relacionam a certa crença. "O fenômeno essencial do misticismo é o que denomina-se de êxtase, um estado no qual toda comunicação com o mundo exterior é quebrada, a alma possui o sentimento de que ela se comunica com um objeto interno, que é o ser perfeito, o ser infinito, Deus. (...) Denomina-se mais especialmente por mística (substantivo feminino) o conjunto de práticas que conduzem a esse estado, e as doutrinas que exprimem os conhecimentos que são considerados os seus frutos. (...) D. Aplica-se esse termo, quase sempre com uma nuança pejorativa: $1^{\circ}$ Às crenças ou doutrinas que repousam mais sobre o sentimento e sobre a intuição, que sobre a observação e ao raciocínio. (...) $2^{\circ}$ Às crenças ou doutrinas que depreciam ou rejeitam a realidade sensível, em prol de uma realidade inacessível aos sentidos (Lalande, 1997, tradução livre, grifos do autor).
\end{abstract}

Blackburn (1997), por sua vez, também ressalta essa diferenciação, em sua definição de misticismo: 
Crença na união com a natureza divina através da contemplação extasiada, e no poder do acesso espiritual a domínios de conhecimento que estão vedados ao pensamento comum. Esse termo também se aplica, depreciativamente, a teorias que aceitam a existência de qualidades ocultas ou poderes para os quais não se pode oferecer qualquer explicação empírica ou racional (Blackburn, 1997).

Uma vez considerada a definição usual do termo misticismo, assim como a ressalva acerca do significado pejorativo que ele adquiriu ao longo do tempo, é possível partir para a discussão da noção de "misticismo quântico".

Aparentemente, uma das primeiras vezes em que o termo "misticismo quântico" foi utilizado foi pelo filósofo norte-americano Patrick Grim, em seu livro Philosophy of Science and the occult, de 1982, cuja principal preocupação era discutir o problema da demarcação na ciência. Grim (1982) pontua que não há dúvida de que a MQ seja parte da ciência, porém ele identifica que se tem reivindicado que as implicações dessa teoria nos levariam diretamente ao espírito do misticismo oriental, citando os autores Fritjof Capra e Gary Zukav, como exemplos dessa reivindicação. Particularmente, ele mostra preocupação com o argumento utilizado por esses autores de que:

Tem se afirmado, em particular, que a mecânica quântica mostra que, a partir da nossa participação consciente, nós criamos mais do que simplesmente observamos o universo. "De acordo com a mecânica quântica," diz Gary Zukav, "não existe algo como a objetividade. Nós não podemos eliminar a nós mesmos do quadro... A Física se tornou um ramo da psicologia, ou possivelmente algo em torno disso".

(...) Aqui a questão é antes sobre se uma das mais firmes das nossas teorias científicas, não obstante, possui implicações que poderiam ser consideradas 'ocultas' (Grim, 1982, tradução livre, grifos do autor).

Com esses apontamentos, Grim (1982) relaciona o misticismo quântico como sendo algo derivado da $\mathrm{FQ}$ - e não relacionado à $\mathrm{FQ}$ em si - a saber, um movimento que reivindica que as implicações da FQ estariam relacionadas com o misticismo oriental. $\mathrm{O}$ misticismo quântico, portanto, estaria relacionado com o estudo das implicações, ou às interpretações, de uma teoria reconhecidamente científica.

Posteriormente, Pessoa (2010) caracterizou de forma mais detalhada o misticismo quântico e o classificou como um fenômeno cultural, porque, "na última década, se disseminou tão fortemente na mídia e em boa parte da sociedade": 
O "misticismo quântico", em linhas gerais, consiste em interpretações da Teoria Quântica que se inserem na tradição do naturalismo animista (com seu idealismo transformador) ou que adotam um idealismo subjetivista, ou ainda que partem de elementos religiosos. Trata-se de uma atitude que atribui uma conexão íntima entre a consciência humana (ou a espiritualidade) e os fenômenos quânticos (Pessoa, 2010).

Em seguida, Pessoa (2010) também apresenta as principais teses aceitas por algumas correntes místico-quânticas, as quais podem ser classificadas em cinco grupos: O) Observador participante, M) Mente quântica, C) Comunicação quântica, I) Outras interpretações e A) Aplicações.

O grupo O) Observador participante se refere ao papel peculiar que passou a ser atribuído ao observador no ato da medição, com o advento da MQ, e as teses místicoquânticas, identificadas por Pessoa (2010), relacionadas a esse papel são: O1) O objeto observado é inseparável do sujeito, e não faria sentido para a ciência falar de uma realidade não-observada e independente do sujeito observador. Essa foi uma postura defendida por Niels Bohr, em 1928; O2) O observador humano é o responsável pelo colapso da onda quântica. Quando essa tese é interpretada de forma realista, ela se torna mais “mística”. Ela foi defendida por von Neumann, London e Bauer; O3) O observador escolhe se o fenômeno é onda ou partícula. Em uma perspectiva mais realista, essa tese se refere ao fato de que a escolha de como montar a aparelhagem experimental afetaria o tipo do fenômeno observado, porém, nesse caso, a vontade humana não poderia controlar os resultados obtidos nas medições. Essa tese foi defendida por von Weizsäcker, em 1931, que concluiu que, na FQ, não apenas não é possível separar sujeito e objeto, como também o sujeito contribui com o seu "saber" e o seu "querer"; O4) $O$ observador cria a realidade. Essa é uma frase escrita por Jordan, em 1929, usada como evidência de que a FQ é idealista subjetivista. Com essa tese, o misticismo quântico amplifica o idealismo transformador associado a $\mathrm{O} 2$ e O3, dando origem a um "construtivismo radical" (Pessoa, 2010).

As teses relacionadas ao grupo $M$ ) Mente quântica se referem à natureza do cérebro humano e podem ser identificadas como: M1) A consciência é um fenômeno essencialmente quântico. Essa hipótese foi elaborada por Roger Penrose, em 1986. Tratase de uma hipótese consistente com posições não-místicas e materialistas, mas para o naturalista animista ela é atraente, pois embasaria o "principio de identidade" de que as 
leis da natureza coincidem com as leis do indivíduo; M2) O livre arbítrio é garantido pelo princípio da incerteza. Essa foi uma tese defendida por Arthur Eddington, em 1932, ao afirmar que as escolhas humanas são livres e que "se o átomo tem uma indeterminação, certamente a mente humana terá uma indeterminação igual; pois dificilmente poderíamos aceitar uma teoria que faz a mente ser mais mecanicista do que o átomo" (Eddington apud Jammer, 1966, p. 337); M3) No dualismo entre alma e corpo, a interação entre os dois se dá por processos quânticos. Essa é uma posição defendida pelo neurocientista John Eccles, que possui uma visão dualista - na qual a alma não emerge da matéria, mas tem uma existência autônoma - e sugere que a alma (ou mente) atuaria durante a liberação de neurotransmissores, processo probabilístico regido pela FQ, alterando levemente essas probabilidades; M4) Holismo quântico se manifesta no cérebro. Essa é uma tese sugerida por pesquisadores que defendem que os sistemas altamente integrados do cérebro envolvem o emaranhamento quântico (Pessoa, 2010).

As teses do grupo C) Comunicação quântica, por sua vez, envolvem a possibilidade de duas ou mais pessoas se comunicarem instantaneamente em um nível intuitivo, e são identificadas como: C1) Mentes quânticas interagem à distância. Essa tese tem vinculado o conceito de "não-localidade quântica", com o conceito de "sincronicidade", de Carl Jung, e utilizada pelo misticismo quântico para a explicação de vários fenômenos parapsicológicos; C2) Não-localidade entre mentes permite transmissão instantânea de pensamentos. Essa tese argumenta que alguns experimentos da FQ supostamente comprovam a possibilidade de transmissão instantânea de pensamento, evocando o conceito de não-localidade quântica; C3) $O$ observador conseguiria influenciar $a$ estatística de resultados quânticos. Essa tese se baseia em $\mathrm{O} 2$ e $\mathrm{O} 3$, para defender também que a FQ explicaria fenômenos parapsicológicos; C4) A mente pode se acoplar a o universo, transformando-o com o pensamento positivo. Essa tese defende que a FQ explicaria que a mente tem o poder de transformar a realidade diretamente, sem a intermediação do corpo; C5) Há uma física quântica da alma e de Deus. Trata-se de uma tese que aproxima o misticismo quântico de visões religiosas (Pessoa, 2010).

Já as teses do grupo I) Outras interpretações, se referem a interpretações que suscitam extensões místicas para a FQ, como I1) A alma pode viver em universos paralelos e estas contrapartidas podem se encontrar. Trata-se de uma especulação fundada na interpretação 
de muitos mundos, segundo a qual o próprio ser humano entraria em superposições quânticas e sugere que podemos ter vidas paralelas, ou que as nossas potencialidades na vida coexistem; 12) Atos no presente podem alterar o passado. $O$ ato da observação atualiza o passado. Essa tese se baseia em uma hipótese introduzida por John Wheeler, em 1972, segundo a qual o ato da observação "atualizaria a potencialidade" passada. O misticismo quântico utiliza essa hipótese de uma forma realista, afirmando que podemos alterar o passado; I3) Paradigma holográfico - cada parte contém o todo. Trata-se de uma tese proveniente da antiga visão de que cada parte do universo reflete o todo presente nas visões naturalistas animistas (Pessoa, 2010).

Por fim, as teses referentes ao grupo A) Aplicações se referem a algumas aplicações da FQ e consistem em: A1) Religiões orientais já teriam chegado às principais ideias da física moderna. Essa é a tese de Fritjof Capra, que se baseia na existência de uma conexão íntima entre ciência e filosofia oriental; A2) A física quântica fundamentaria terapias alternativas. Essa é a tese base da "naturologia", campo de práticas terapêuticas, que não se enquadra na medicina alopática ou nas linhas clássicas de psicanálise e psicoterapia, e que se utiliza de plantas medicinais, de técnicas terapêuticas tradicionais do Oriente. Essa tese foi promovida principalmente pelo livro A cura quântica, de Deepak Chopra (1989); A3) A física quântica seria o paradigma do novo milênio. Esse seria o sentimento que estaria por trás da aplicação da TQ em diferentes campos do conhecimento, como na administração de empresas, no direito e na sexualidade, dando origem à "gestão quântica", ao “direito quântico" e ao "tantra quântico", respectivamente (Pessoa, 2010).

Nessa caracterização do misticismo quântico, Pessoa (2010) também identifica duas posturas adotadas pelos místicos quânticos: uma postura "conciliadora" e outra "desafiadora" para com a ciência, a primeira aceita apenas a existência de entidades e processos que não entram em contradição com a ciência, já a segunda aceita a existência de fenômenos que entram em contradição com as previsões da ciência estabelecida. Alguns exemplos do segundo caso seriam a defesa da existência de transmissão instantânea de pensamento e a defesa de que o pensamento do observador teria o poder de influenciar o resultado de um experimento quântico. Essas atitudes são consideradas desafiadoras por estarem em desacordo com as previsões experimentais e teóricas da 
ciência estabelecida. Por outro lado, um exemplo de atitude conciliadora com a ciência seria a defesa de que a consciência humana é responsável por um colapso objetivo.

Por fim, Pessoa (2010) destaca também que o misticismo quântico adquiriu o status de fenômeno cultural por fazer parte do movimento sociocultural denominado "Nova Era" ou "Neoesoterismo", que ressurgiu nas décadas de 1980 a 1990, herdeiro da contracultura hippie das décadas de 1960 a 1970, com alguns traços modificados.

Ao apresentar essa caracterização mais detalhada do fenômeno cultural do misticismo quântico, Pessoa (2010), em primeiro lugar, reconhece que esse fenômeno possui raízes e influências de diferentes correntes filosóficas, muito anteriores ao seu surgimento, a saber, do naturalismo animista, com influências do idealismo subjetivista e de elementos religiosos. Em segundo lugar, ele também mostra que se trata de um fenômeno que apresenta uma enorme variedade de características - das mais tênues e conciliadoras, às mais ousadas e desafiadoras para com a ciência estabelecida - as quais, apesar de toda a sua diversidade, podem ser agrupadas e mapeadas, a fim de caracterizar um fenômeno particular e em destaque. Por fim, ele também reconhece que se trata de um fenômeno proveniente de um movimento sociocultural específico, que foi adquirindo um corpo, ao longo do tempo, a partir de determinados momentos e condições histórico-sociais.

Em seu trabalho, Pessoa (2010) se centra e aprofunda nas raízes e influências das diferentes correntes filosóficas sobre o fenômeno cultural do misticismo quântico, assim como no mapeamento das principais características e teses defendidas pelos seus adeptos. No entanto, com relação às suas origens histórico-sociais, ele apenas pontua alguns dos seus aspectos. O presente trabalho buscará aprofundar e trazer contribuições principalmente com relação a esse último aspecto desse fenômeno, assim como na discussão das características e práticas que diferenciam os seus adeptos do coletivo de pensamento dos pesquisadores em Fundamentos da FQ, sob a ótica da epistemologia de Ludwik Fleck.

Além disso, outro aspecto a ser citado na caracterização do fenômeno cultural do misticismo quântico por Pessoa se refere à utilização do termo "misticismo". Em Pessoa (2007-2011), o autor reconhece que as pessoas que adotam a perspectiva de que a espiritualidade humana teria como base a FQ consideram o termo pejorativo, o que faz com que o autor se questione sobre qual seria o termo mais adequado a ser utilizado. De 
fato, conforme visto no início desta seção, o termo "misticismo" adquiriu uma conotação pejorativa, principalmente quando ele se refere à rejeição ou à depreciação da observação, da realidade sensível e do raciocínio. Inclusive, ao retomar a origem do termo "misticismo quântico”, Pessoa (2007-2011) mostra que esse termo passou a ser adotado por críticos ao movimento, ao identificar a existência de uma interpretação obscura, tendenciosa ou falsa, a qual, portanto, não levaria em conta os mecanismos da razão e da observação, conforme visto na utilização feita por Grim (1982). Sendo assim, o autor argumenta:

Retomando a discussão terminológica, parece que o termo "misticismo quântico" deve se referir apenas às visões que aceitam que haja um conhecimento intuitivo, nãoracional e não-científico a respeito de dimensões espirituais ou transcendentais da realidade, e que defendem que esse conhecimento primordial tem conexões com a física quântica (Pessoa, 2007-2011).

Com isso, ele faz a distinção entre os termos "misticismo" e "espiritualismo", para cunhar o termo mais amplo "espiritualismo quântico". Segundo o autor, o termo “espiritualismo" seria mais interessante, por se tratar de um termo mais amplo, que possui "uma acepção geral, que se refere à crença na existência de seres imateriais, como Deus e almas imortais. Trata-se da antítese do materialismo, que considera que a alma ou consciência são frutos da matéria organizada em animais, e que desaparecem na morte do corpo" (Pessoa, 2007-2011). Assim, o termo "espiritualismo quântico" se refere a uma classe de visões de mundo, que engloba tanto o misticismo quântico, quanto o naturalismo espiritualista quântico - ou seja, visões que defendem uma abordagem mais racional à questão das ligações entre espiritualidade e FQ - que são visões mais próximas da ciência e da filosofia analítica.

Por fim, outros termos a serem considerados são os termos "ocultismo", utilizado por Grim (1982) e "reencantamento do mundo", utilizado por Rocha (2015). O termo “ocultismo" se refere à crença em fenômenos que se julgam produzidos por forças ocultas, associados à magia, astrologia, parapsicologia, etc. Grim (1982) considera este termo mais neutro do que pseudociência, por exemplo, que é pejorativo, e mais amplo do que "paranormalidade", que tende a se restringir à parapsicologia (Pessoa, 2007-2011). O termo "reencantamento do mundo", por outro lado, é utilizado por Rocha (2015, p. 23), em contraposição à tese de Max Weber sobre o desencantamento do mundo, que se constituiria em um processo de racionalização em todos os níveis da sociedade, que 
emergiria a partir da constituição do modo de vida do ocidente moderno. Segundo Rocha (2015), que defende a existência de um movimento de reencantamento do mundo pela FQ, o movimento de desencantamento não aconteceu sem o movimento de um processo contrário: o reencantamento do mundo, um movimento no sentido de recuperar algo que foi suprimido pelo movimento de desencantamento.

Uma vez feita essas considerações e diferenciações entre os termos, é possível delimitar o foco da análise deste trabalho como sendo, de fato, o "misticismo quântico" ou seja, visões que aceitam que haja um conhecimento intuitivo, não-racional e nãocientífico do ponto de vista da Filosofia Moderna, acerca de dimensões espirituais ou transcendentais à realidade com conexões com a FQ. Assim, além de aprofundar e trazer contribuições acerca das origens histórico-sociais do fenômeno cultural do misticismo quântico, se buscará discutir também as origens da conotação pejorativa que esse fenômeno adquiriu.

\subsection{Os principais autores precursores do fenômeno cultural do Misticismo Quântico}

\subsubsection{Fritjof Capra e O Tao da Física}

As obras mais citadas quando se trata da difusão e da divulgação da TQ, entre o público leigo em geral, a partir da década de 1970, e do estabelecimento do que, posteriormente, ficou conhecido como "misticismo quântico", são sem dúvida The Tao of Physics: An Exploration of the Parallels between Modern Physics and Eastern Mysticism, de Fritjof Capra, publicado em 1975, e The Dancing Wu Li Masters: An Overview of the New Physics, de Gary Zukav, de 1979 (Grim, 1982; Carson, 1995; Leane, 2007; Rocha, 2015). E, de fato, a primeira edição do livro de Capra, de 20 mil cópias, se esgotou em menos de um ano, a segunda edição, de 150 mil cópias, já havia vendido 100 mil cópias no segundo ano de seu lançamento. O Tao da Física já foi traduzido para 23 idiomas e alcançou 43 edições, de todas as obras do gênero, ela permanece a mais vendida. A obra de Zukav, por sua vez, ganhou o National Book Award, em 1980, foi traduzida para 24 idiomas e já vendeu 6 milhões de cópias. Outras obras de impacto entre o público leigo mais amplo, que também contribuíram para a divulgação e difusão da TQ, mas que não podem ser consideradas necessariamente místicas, foram Quantum Reality: Beyond the New Physics, de Nick Herbert, publicado em 1985, Other Worlds: Space, Superspace and 
the Quantum Universe, de Paul Davies, publicado em 1980. Carson (1995) também acrescenta a essa lista o livro de David Bohm, Wholeness and the Implicate Order, de 1980, e Leane (2007) acrescenta os livros The Cosmic Code: Quantum Physics as the Language of Nature, de Heinz Pagels, de 1982, e In Search of Schrödinger's Cat: Quantum Physics and Philosophy, de John Gribbin, de 1984 (Rocha, 2015, p. 62). Essas e outras obras, ainda que nem todas possam ser consideradas místicas, permitiram com que a palavra "quantum" se popularizasse, não apenas em títulos de livros, mas em uma variedade de contextos, de terapias alternativas a palestras motivacionais, dando origem aos chamados "produtos quânticos" (Rocha, 2015, p. 65).

Dentre todas essas obras, a obra de Fritjof Capra é provavelmente a principal precursora do misticismo quântico, apesar dela não se restringir à FQ, mas discorrer sobre vários aspectos da FM. O crítico do New York Times Book Review, George Johnson, em 1988, inclusive, chegou a afirmar que Capra havia criado um novo gênero literário (Johnson, 1988). Além disso, foi Capra quem influenciou o livro The Dancing Wu Li Masters, de Gary Zukav, a segunda obra mais lembrada entre as principais obras difusoras e divulgadoras da TQ, entre o público leigo mais amplo. Assim como Capra, Zukav também delineia paralelos entre a FM e as religiões orientais e sua obra teve o título inspirado no primeiro ensaio de Capra a respeito desse paralelismo, o The Dance of Shiva (1972), que fazia uma metáfora do universo como uma dança cósmica. O próprio Capra chegou a apontar essa apropriação de Zukav, em uma entrevista, de 1981:

(...) o livro de Zukav, que é frequentemente mencionado em conexão com o meu, nada acrescenta ao debate. Zukav reitera a ideia que expressei vários anos antes, e que, naturalmente, ele conhecia muito bem porque tinha lido o meu livro (Capra, 1981 apud Rocha, 2015, p. 96).

Além de Zukav, o físico brasileiro Marcelo Gleiser, um importante divulgador de ciências, também utilizou a metáfora da dança de Shiva, em seu livro "A Dança do universo", de 1997, ao escrever:

A dança de Shiva simboliza tudo que é cíclico no Universo, incluindo sua própria evolução. Através de sua dança, o deus cria o Universo e seu conteúdo material, mantendo-o durante sua existência e finalmente destruindo-o quando chega o tempo apropriado. Esse ciclo se repete por toda a eternidade, sem um começo ou um fim (Gleiser, 1997, p. 27). 
Por conta desses e outros autores que se inspiraram em Capra, o físico austríaco é frequentemente considerado o autor mais imitado, direta ou indiretamente, por autores do mesmo gênero literário, por décadas a seguir (Rocha, 2015, p. 96).

Ao comentar sobre as influências sobre a sua obra, Capra reconhece a forte influência que sofreu de Heisenberg, com seu livro Física e Filosofia, ao afirmar:

O "Física e filosofia" de Heisenberg permaneceu meu companheiro durante esses estudos e, olhando para trás nessa época, eu agora posso ver que foi Heisenberg quem plantou a semente que amadureceria, mais de uma década depois, nas minhas investigações sistemáticas das limitações da visão de mundo cartesiana (Capra, 1988, pp. 17-21, tradução livre).

No entanto, em meio a essas influências, apesar de demonstrar interesse pela história e pela filosofia da Física, Capra admitiu que não se interessava em dialogar com historiadores e filósofos da Física profissionais, conforme relatou em entrevista em 2013:

Eu não diria que eu não estava interessado na filosofia da ciência, mas eu não estava interessado em filósofos da ciência. Eu me lembro que eu conheci um filósofo da ciência ou historiador da ciência (...) eu achei ele bem chato (...) (Capra, 2013 apud Rocha, 2015, p. 138, tradução livre).

Assim, a partir dessa declaração de Capra, é possível constatar que o interesse do físico austríaco pela história e pela filosofia da Ciência nunca se tornaria um interesse primário, no qual ele se aprofundaria, mas permaneceria um interesse secundário, se restringindo apenas a uma "visão de mundo" (Rocha, 2015, p. 138). Com isso, é possível delinear quem era o público alvo de Capra: o autor de $O$ Tao da Física não escrevia para historiadores e filósofos da Ciência, e tampouco para físicos - apesar de ter tido reações tanto positivas como negativas, nesse meio - mas ele escrevia para o público leigo mais amplo, como um popularizador de Ciências, voltando-se para a cultura de massas. E essa seria a grande diferença entre a obra de Capra e a Física e Filosofia de Heisenberg, que o influenciou, pois Heisenberg e outros físicos fundadores da TQ, ao escreverem sobre questões filosóficas relacionadas a essa teoria, escreviam para uma elite cultural, composta por físicos, filósofos e historiadores da Ciência (Rocha, 2015, p. 119). No entanto, mais do que um divulgador e popularizador de Ciências no sentido usual, Capra toca em uma dimensão axiológica, e se torna um formador de opinião, ao unificar a sua motivação de físico, que busca divulgar a FM, com a sua motivação de ativista, que busca 
apresentar a sua "visão de mundo", através do estabelecimento de paralelos e semelhanças entre a "Nova Física" e o misticismo oriental (Rocha, 2015, p. 149-150). A "visão de mundo" de Capra é explicitada pelo próprio autor, no epílogo de sua obra, onde ele escreve:

Considero a ciência e o misticismo como manifestações complementares da mente humana, de suas faculdades racionais e intuitivas. (...) A ciência não necessita do misticismo e este não necessita daquela; o homem, contudo, necessita de ambos. A experiência mística é necessária para a compreensão da natureza mais profunda das coisas, e a ciência é essencial para a vida moderna. Necessitamos, na verdade, não de uma síntese mas de uma interação dinâmica entre a intuição mística e a análise científica (Capra, [1975] 1983, p. 228).

Assim, tendo em vista essas motivações, O Tao da Física de Capra apresenta como principal estratégia de abordagem, o chamado "paralelismo quântico", no qual a "Nova Física" jamais é apresentada a partir de si mesma ou de seu próprio conteúdo, mas sempre como um espelho do orientalismo ${ }^{8}$, por intermédio das filosofias orientais (Rocha, 2015, p. 151). Essa estratégia envolve uma intencionalidade, que é explicitada por Carson (1995):

\begin{abstract}
Paralelos não são coisas que existem "lá fora", por si mesmas; paralelos são coisas que as pessoas traçam, e com isso elas respondem não somente à forma como as coisas são "por si mesmas", mas também às necessidades e aos interesses das pessoas que os traçam. Isso deixa espaço para uma certa liberdade na escolha dos paralelos a serem traçados, assim como para uma certa possibilidade de fuga (Carson, 1995, tradução livre).
\end{abstract}

Essa estratégia é utilizada por Capra, ao longo de toda a sua obra, para traçar paralelos entre a FM e o que ele denomina por "misticismo oriental". Sua obra é dividida em três partes: a primeira se dedica a apresentar alguns aspectos da FM e a discutir questões relacionadas à Ciência, que já existiam anteriormente, mas que foram discutidas mais

\footnotetext{
${ }^{8}$ Orientalismo é um termo utilizado para se referir aos estudos acerca das civilizações orientais. Esses estudos se baseiam em uma distinção ontológica e epistemológica entre "o Oriente" e "o Ocidente". Em 1978, Edward W. Said, em sua obra Orientalismo: a invenção do Oriente pelo Ocidente lança uma critica, denunciando a visão eurocêntrica acerca dessas civlizações enraizada nesses estudos, os interesses envolvidos na imagem construída sobre "o Oriente" e, portanto, a distorção e a falta de precisão ao tratar dessas civilizações.
} 
fortemente na Física com o advento da FM - como a questão da representação da realidade, a relação entre razão e intuição, o papel da linguagem e das diversas formas de obtenção de conhecimento, entre outras - porém sem perder de vista as semelhanças com o "misticismo oriental"; a segunda parte, por sua vez, apresenta alguns aspectos de algumas escolas da filosofia oriental, como o hinduísmo, o budismo, o taoísmo, entre outras; a terceira parte, por fim, traça os paralelos de forma mais explícita entre alguns aspectos da FM e do "misticismo oriental".

Um trecho ilustrativo da primeira parte, que mostra o quanto Capra não apresenta os aspectos da FM "por si mesmos", mas sempre tendo em vista a sua intenção de estabelecer semelhanças com o "misticismo oriental”, é apresentado a seguir:

Sempre que os místicos orientais expressam em palavras seu conhecimento - seja através de mitos, de símbolos, de imagens poéticas ou de afirmações paradoxais -, estão muito conscientes das limitações impostas pela linguagem e pelo pensamento "linear". A Física moderna toma hoje a mesma atitude com relação a seus modelos e teorias verbais. Estes, também, são apenas aproximados e necessariamente imprecisos. Constituem a contrapartida dos mitos, dos símbolos e imagens poéticas orientais, e é precisamente nesse nível que estabeleço os paralelos (Capra, [1975] 1983, p. 41).

Além de evidenciar a não neutralidade presente na sua apresentação dos aspectos da FM, ainda na primeira parte de seu livro, especificamente com relação à FQ, Capra omite os diversos debates existentes sobre as questões de fundamento dessa teoria, apresentando-as como questões já resolvidas e, com isso, na verdade, apresentando a sua visão com relação a essas questões. Nos trechos a seguir, por exemplo, o autor discute sobre a interpretação da dualidade onda-partícula e do problema da medição, respectivamente:

A contradição aparente entre as imagens da onda e da partícula foi resolvida de forma inteiramente inesperada e que veio a pôr em questão o próprio fundamento da visão de mundo mecanicista, isto é, o conceito da realidade da matéria. No nível subatômico, não se pode dizer que a matéria existia com certeza em lugares definidos; diz-se, antes, que ela apresenta "tendências a existir", e que os eventos atômicos não ocorrem com certeza em instantes definidos e numa direção definida mas, sim, que apresentam "tendências a ocorrer". No formalismo da teoria quântica, essas tendências são expressas como probabilidades, e são associadas a quantidades matemáticas que tomam a forma de 
ondas. Essa é a razão pela qual as partículas podem ser ao mesmo tempo ondas (Capra, [1975] 1983, p. 58).

Uma análise cuidadosa do processo de observação na Física atômica tem demonstrado que as partículas subatômicas não possuem significado enquanto entidades isoladas, somente podendo ser compreendidas como interconexões entre a preparação de um experimento e sua posterior medição. (...) O observador humano constitui o elo final na cadeia de processos de observação, e as propriedades de qualquer objeto atômico só podem ser compreendidas em termos de interação do objeto com o observador. Em outras palavras, o ideal clássico de uma descrição objetiva da natureza perde sua validade. A partição cartesiana entre o eu e o mundo, entre o observador e o observado, não pode ser efetuada quando lidamos com a matéria atômica. Na Física atômica, jamais podemos falar sobre a natureza sem falar, ao mesmo tempo, sobre nós mesmos (Capra, [1975] 1983, p. 58, grifos do autor).

No primeiro trecho, o autor deixa clara a sua adesão ao conceito de potencialidade, tal qual desenvolvido por Heisenberg, no contexto da Interpretação da Complementaridade (ver seção 3.3.3), ao se referir a "tendências" a existir e a ocorrer. No trecho seguinte, por sua vez, fica mais evidente a sua adesão à interpretação ortodoxa da FQ e à concepção idealista de que não é possível se referir a uma realidade independente dos observadores. Somente mais adiante, na terceira parte de seu livro, é que Capra explicita a sua adesão a essa interpretação da FQ, ao explicar que "A discussão que se segue baseia-se na chamada interpretação de Copenhague da teoria quântica, (...) que ainda é o modelo mais amplamente aceito.” (Capra, [1975] 1983, p. 104). A adesão à interpretação ortodoxa e a atitude de Capra de apresentar as questões sobre os Fundamentos da MQ como já resolvidas pode ser compreendida pelo contexto do período em que sua obra foi publicada. Conforme visto na seção 3.1.4, os anos 1970 podem ser considerados como uma década de transição, na qual os dissidentes quânticos - físicos que criticavam a "interpretação ortodoxa" - tiveram que lutar contra a atitude dominante dos físicos de considerar as questões sobre os Fundamentos da MQ como já resolvidas. Sendo assim, a atitude de Capra frente a essas questões está em concordância com a atitude da maioria dos físicos de sua época.

Mais adiante em seu livro, ao abordar algumas características das escolas de filosofias orientais, Capra deixa claro que fará a descrição "dessas tradições espirituais, com ênfase nos aspectos e conceitos importantes para a comparação que posteriormente se fará com a 
Física” (Capra, [1975] 1983, p. 104). Com isso, ele também explicita que as características das filosofias orientais não serão apresentadas "por si mesmas", mas sempre com o intuito de mostrar as semelhanças com a FM, dessa forma, ele acaba simplificando e idealizando o pensamento contido nessas filosofias, conforme fica claro na seguinte passagem, da terceira parte de seu livro:

Embora as tradições espirituais descritas nos cinco últimos capítulos difiram em muitos detalhes, suas visões de mundo são essencialmente as mesmas. É uma visão baseada na experiência mística - numa experiência direta e não-intelectual da realidade - e essa experiência possui numerosas características fundamentais, independentes da origem geográfica, histórica ou cultural do místico (Capra, [1975] 1983, p. 103).

Essa simplificação e idealização das filosofias orientais por autores ocidentais é fortemente criticada por diversos autores. Edward W. Said, em sua obra Orientalismo: a invenção do Oriente pelo Ocidente, critica essa imagem distorcida acerca do Oriente e aponta os diversos interesses envolvidos nessa construção. Harvey Cox, por sua vez, aponta essa imagem como sendo uma "tela conveniente onde o Ocidente projeta imagens inversas de suas próprias deficiências" (Cox, 1978, p. 149, tradução livre). Dentro dessas perspectivas, Andrea Diem e James Lewis criticam o orientalismo presente na obra de Capra:

Um dos mais interessantes aspectos do livro [O Tao da Física] é a forma na qual ele parece desvirtuar a religião e a cultura asiáticas em quase todas as páginas. (...) Esse tipo de postura crítica, juntamente com a sua má interpretação sistemática da Ásia, não é, contudo, exclusiva de Capra e do movimento da Nova Era. Capra é meramente um dos mais recentes herdeiros de uma tendência no romantismo europeu e norteamericano de idealizar o Oriente, e então criticar o Ocidente em termos desse ideal (Diem e Lewis, 1992, pp. 49-50).

A pertinência dessas críticas acerca da obra de Capra é bem ilustrada no trecho a seguir, no qual fica clara a idealização do pensamento oriental, a fim de criticar a sociedade ocidental:

Essa noção de equilíbrio dinâmico é essencial à forma pela qual a unidade dos opostos é vivenciada no misticismo oriental. (...) Uma das principais polaridades da vida é a que se refere aos lados masculino e feminino da natureza humana. (...) A sociedade ocidental favoreceu, tradicionalmente, o lado masculino de preferência ao feminino. (...) Essa atitude deu origem a uma ênfase exagerada nos aspectos yang - ou masculinos - 
da natureza humana (...). Os modos de consciência yin - ou femininos - (...) foram constantemente suprimidos em nossa sociedade orientada por valores masculinos (Capra, [1975] 1983, pp. 114-115).

Outras críticas voltadas ao "paralelismo quântico" de Capra vieram de dentro do próprio Movimento da Nova Era (Rocha, 2015, p. 187). Ken Wilber, um pioneiro no desenvolvimento da Psicologia Integral, por exemplo, em seu livro Quantum Questions: Mystical Writings of the World's Greatest Physicists, reconhece a força que a ideia de que a FM oferece um suporte para uma visão mística do mundo adquiriu, ao mesmo tempo em que a aponta como um equívoco, e lamenta a sua irreversibilidade dentro do Movimento da Nova Era:

O tema desse livro, se eu posso sintetizar brevemente os argumentos dos físicos apresentados aqui, é que a física moderna não oferece nenhum suporte positivo (nem uma única prova) para uma visão de mundo mística. (...)

Não é o meu objetivo nesta obra atingir a audiência da Nova Era, que parece estar firmemente convencida que a física moderna automaticamente dá suporte ou prova o misticismo. Ela não o faz. Porém, essa visão está agora tão difundida, tão profundamente arraigada, tão tomada como garantia pelos adeptos da Nova Era, que eu não vejo como qualquer livro possa reverter essa situação (Wilber, 1983, p. xi, tradução livre).

Dentro dessa ideia geral promovida por Capra - de que a FM dá suporte a uma visão de mundo mística - existem diversas características e argumentos presentes em sua obra que, posteriormente, permaneceriam ou seriam acentuadas por outros autores do mesmo gênero, como a contraposição acompanhada de uma dicotomia de valores entre o "velho" e o "novo" paradigma, representados pela FC e a FM, respectivamente; uma discussão acerca do problema da medição em FQ, acompanhada de uma defesa de que, nessa teoria, não é mais possível separar sujeito e objeto; uma defesa de que a FQ dá suporte à noção de totalidade no universo, apoiada principalmente no Teorema de Bell; um debate acerca do papel da consciência na criação da realidade; o uso de analogias entre fenômenos da FM e características das filosofias orientais; e alusões às tendências idealistas ou próximas a um misticismo presentes nas posturas filosóficas ou crenças de diversos físicos. Cada uma dessas características será detalhada e ilustrada a seguir.

A contraposição entre o "velho" e o "novo" paradigma na obra de Capra representados pela FC, com seu modelo cartesiano-newtoniano, e pela FM, 
respectivamente - é apresentada dentro de uma narrativa histórica, a qual é amplamente reproduzida no Movimento da Nova Era. Essa narrativa se constitui de um recurso retórico, com sentido milenarista, na qual o "novo" paradigma é apresentado como um "sinal dos novos tempos", como o advento de uma "Nova Era", desempenhando uma função profética (Rocha, 2015, p. 190). Nesse "novo" paradigma, a visão de mundo da Física apresentaria uma relação com uma visão de mundo mística. Esse tom no discurso de Capra é bem ilustrado na seguinte passagem:

(...) a Física moderna gerou uma profunda revisão da concepção humana acerca do universo e do relacionamento do indivíduo com este último. A exploração do mundo atômico e subatômico, no século XX, tem revelado uma limitação insuspeita das ideias clássicas, levando, por conseguinte, a uma revisão radical de inúmeros de nossos conceitos básicos. (...)

Essas transformações geradas pela Física moderna têm sido amplamente discutidas por físicos e filósofos ao longo das últimas décadas. Contudo, raramente temos nos apercebido do fato de que todas parecem conduzir à mesma direção, ou seja, a uma visão do mundo semelhante às existentes no misticismo oriental (Capra, [1975] 1983, p. 21).

A discussão acerca do problema da medição em FQ, juntamente com o argumento de que o sujeito já não pode ser separado do objeto e que, inclusive, pode influenciá-lo, por sua vez, também vem acompanhada dessa narrativa histórica com tom profético. Porém, atrelado a isso, também aparece a ideia de que essa noção já havia sido antecipada pelos místicos orientais, fazendo alusão à uma espécie de filosofia perene:

Na Física atômica, o cientista não pode desempenhar o papel de um observador objetivo distanciado; torna-se, isto sim, envolvido no mundo que observa na medida em que influencia as propriedades dos objetos observados. (...)

A ideia da "participação em vez de observação" só foi formulada na Física moderna recentemente; mas é uma ideia bem familiar aos estudantes do misticismo. (...) A noção de participante é, assim, crucial para a concepção oriental do mundo; e os místicos orientais levaram essa noção ao extremo, a um ponto onde observador e observado, sujeito e objeto não só são inseparáveis como acabam por se tornar indistinguíveis (Capra, [1975] 1983, p. 111).

Na primeira edição do Tao da Física, Capra também defende que a FQ dá suporte a uma visão totalizante acerca do universo. No entanto, somente no posfácio da segunda edição de seu livro é que ele faz alusão ao Teorema de Bell e à noção de não-localidade, 
para fundamentar melhor a sua defesa. Conforme visto na seção 3.1.4, os anos 1970, década de publicação da obra de Capra, foi a época em que as pesquisas em torno do Teorema de Bell começaram a ganhar importância e, somente no início dos anos 1980, época da publicação da segunda edição, com os experimentos de Alain Aspect, é que esse teorema recebeu o devido reconhecimento. Sendo assim, é possível compreender a citação tardia desse teorema por parte de Capra. Posteriormente, esse teorema seria amplamente citado para fundamentar visões totalizantes de universo entre outros autores do mesmo gênero.

A teoria quântica revela assim um estado de interconexão essencial do universo. Ela mostra que não podemos decompor o mundo em suas menores unidades capazes de existir independentemente. (...) A teoria quântica força-nos a encarar o universo não sob a forma de uma coleção de objetos físicos, mas, em vez disso, sob a forma de uma complexa teia de relações entre as diferentes partes de um todo unificado (Capra, [1975] 1983, pp. 108-109).

(...) o teorema de Bell demonstra que o universo é fundamentalmente constituído de interligações, de componentes interdependentes e inseparáveis (Capra, [1975] 1983, p. 233).

Além disso, o físico austríaco também discute o papel da consciência no entendimento dos fenômenos subatômicos, que, segundo ele, mais do que apenas ser essencial no processo de observação, a consciência seria capaz de criar os fenômenos observados. Essa afirmação, posteriormente, se tornaria uma importante reivindicação do Movimento da Nova Era.

Essa teoria das partículas subatômicas reflete a impossibilidade de se separar o observador científico dos fenômenos observados (...). Implica, em última instância, o fato de as estruturas e fenômenos que observamos na natureza nada mais serem do que criações de nossa mente medidora e categorizadora.

Essa última afirmação é um dos princípios fundamentais da filosofia oriental (Capra, [1975] 1983, p. 207).

$\mathrm{O}$ uso de analogias entre fenômenos da FM e características das filosofias orientais na obra de Capra, em várias passagens, adquire um caráter mais realista, que vai além de uma mera analogia ou paralelismo, mas trata do funcionamento e da essência real dos processos analisados, conforme ilustrado pela seguinte citação: 
A Física moderna mostrou que o ritmo de criação e destruição não se acha manifesto apenas na sucessão das estações e no nascimento e morte de todas as culturas vivas, mas também na essência mesma da matéria inorgânica. (...) Mais do que isso, a dança de criação e destruição é a base da própria existência da matéria (...). A Física moderna revelou, pois, que cada partícula subatômica não apenas executa uma dança de energia, mas também é uma dança de energia, um processo vibratório de criação e destruição (Capra, [1975] 1983, p. 185, grifos do autor).

Por fim, Capra também faz menção às tendências idealistas ou próximas a um misticismo presentes nas posturas filosóficas ou crenças de diversos físicos, ao citar, por exemplo, a noção de observador participante de John Wheeler (Capra, [1975] 1983, p. 111), a defesa da necessidade da consciência para a compreensão da cadeia de observação dos fenômenos atômicos, por parte de Eugene Wigner (Capra, [1975] 1983, p. 224), a utilização do símbolo chinês do t'ai-chi, que representa o equilíbrio entre a ação dos princípios complementares de yin e yang, por Bohr em seu escudo, ao ser condecorado com o título de cavaleiro pelo rei da Dinamarca (Capra, [1975] 1983, p. 125), e a noção de totalidade e o modelo holográfico de David Bohm (ver seção 3.3.4) (Capra, [1975] 1983, p. 238), curiosamente, contudo, ao citar as posições de Bohm, Capra deixa de comentar que o físico norte-americano possui uma posição realista com relação à $F Q$ e chegou a defender uma teoria de variáveis ocultas.

No entanto, além dessas ideias e argumentos presentes na obra de Capra, que, posteriormente, permaneceram nas obras de outros autores do mesmo gênero, também houve características que se perderam ou foram propagadas com menos ênfase por esses autores, como as analogias entre as características das filosofias orientais e fenômenos de outras áreas da FM, que não a FQ, como a relatividade e a Física de partículas, por exemplo; além disso, Capra chegou a defender uma abordagem alternativa específica para a Física de partículas, existente dentro da própria Física - notadamente a teoria da MatrizS e o programa de bootstrap - uma postura que não aparece em outros autores do mesmo gênero, os quais normalmente se atêm as características das diversas interpretações da FQ, inclusive mesclando interpretações incompatíveis entre si, a fim de enfatizar as proximidades que elas possuem com visões místicas do mundo. Contudo, Rocha (2015, p. 182) defende que a adesão de Capra a teoria da Matriz-S e ao programa de bootstrap foi uma forma que o autor encontrou de conciliar seus próprios conflitos pessoais, enquanto cientista e ativista, pois, em sua visão, essas teorias seriam capazes de superar diversas 
dicotomias que o preocupavam, como as separações entre mente e corpo, sujeito e objeto, e entre razão e intuição. No caso dos outros autores do mesmo gênero, posteriores a Capra, a própria TQ - e não uma abordagem específica para ela - seria capaz de superar os conflitos e problemas importantes para eles.

Para finalizar esta seção, é importante relembrar que, antes da publicação do Tao da Física, Capra tentou seguir a sua carreira de físico e, nesse meio tempo, enfrentou diversas dificuldades, entre elas, a crise de desemprego nos EUA desse período. Contudo, depois do sucesso de vendas de seu livro, Capra se viu cercado de uma série de oportunidades, que fizeram com que, posteriormente, ele pudesse viver de direitos autorais, workshops e palestras e abandonar sua carreira científica, que se encerrou em 1988, com o término da sua colaboração no Lawrence Berkeley Laboratory. Em meio a esse sucesso e à ascensão da sua carreira como escritor e palestrante, Capra se encontrou e desenvolveu uma relação com grandes nomes da medicina alternativa, como o psicólogo humanista transpessoal Abraham Maslow e o psiquiatra desenvolvedor da respiração holotrópica Stanislav Grof. Com isso, o físico austríaco, que já havia desenvolvido um novo "gênero literário", passou a colaborar também com o desenvolvimento do circuito de "terapias e produtos quânticos" (Rocha, 2015, pp. 183-184). Em suas obras posteriores, porém, em meados dos anos 1990, Capra abandona definitivamente as temáticas relacionadas à Física e se insere na área de biologia e teoria de sistemas (Rocha, 2015, p. 193). Atualmente, suas obras giram em torno dos temas relacionados à educação ecológica.

\subsubsection{Deepak Chopra e A Cura Quântica}

Conforme visto na seção anterior, Fritjof Capra criou um novo gênero literário, que, posteriormente, se desdobrou em um amplo espectro de abordagens. Capra, no entanto, era físico de formação e buscava, na medida do possível e de acordo com os seus interesses, manter o rigor cientifico na descrição dos conceitos e teorias da FM. A maioria dos seus sucessores, no entanto, possuíam diferentes formações e, por conta disso, não tinham essa mesma preocupação e cuidado, e invocavam a FQ de forma simplificada, retendo apenas alguns aspectos rudimentares desta, a fim de estabelecer as relações e aproximações de acordo com seus interesses. Nessas abordagens, por vezes, as interpretações e posições de Capra com relação à FQ adquiriam o status de fatos bem estabelecidos, sendo citados como tal por seus defensores (Hammer, 2004, p. 292). Essas 
abordagens começaram a surgir a partir dos anos 1980, e recorriam às ideias apresentadas nas obras de divulgação da TQ, para formular explicações de diferentes fenômenos, desde florais e fenômenos extraterrestres, passando por astrologia, tarô, homeopatia, até a administração de empresas (Nogueira, 2010, p. 57).

Uma dessas abordagens, que se popularizou fortemente, buscava relacionar a FQ com a medicina alternativa e culminou na formação do circuito de "terapias e produtos quânticos". O principal e mais bem sucedido expoente dela, tanto financeiramente como em termos de fama pessoal, é o médico indiano residente nos EUA Deepak Chopra. Chopra é autor de mais de 60 obras, sendo 36 delas publicadas em pouco mais de duas décadas - o que suscita rumores de que ele, atualmente, apenas assinaria obras escritas por uma equipe - ele também opera uma poderosa engrenagem comercial, que, além de livros, inclui DVDs, CDs de músicas, seminários, palestras e workshops. Seus produtos já foram traduzidos para dezenas de idiomas, e seus livros já ultrapassaram a marca dos 10 milhões de exemplares vendidos, somente em língua inglesa. Parte da sua produção se dedica a apresentar algumas regras básicas para uma vida saudável, como conselhos relacionados a dietas e saúde preventiva, outra parte se dedica a psicologia popular, em especial, questões relacionadas ao amor e ao reconhecimento (Hammer, 2004, p. 313; Nogueira, 2010, p. $57)$.

Deepak Chopra se formou no All India Institute of Medical Sciences, em 1968, e estabeleceu uma carreira médica de destaque na medicina ocidental e na academia, trabalhando em importantes hospitais nos EUA e lecionando nas escolas de medicina das universidades de Tufts e Boston. Paralelamente a essa carreira, a partir de 1985, ele conhece o guru indiano Maharishi Mahesh Yogi, fundador do Movimento da Meditação Transcendental e se torna um importante membro desse movimento. Em torno de 1990, no entanto, devido a conflitos, Chopra o abandona. A partir de então, o médico indiano passa a advogar uma visão de mundo que combina a Meditação Transcendental, o Ayurveda uma abordagem médica alternativa, de origem indiana -, a medicina ocidental e elementos oriundos de textos da Nova Era. Essa visão fica evidente quando Chopra cunha e passa a popularizar o termo "Cura Quântica", que é o título de seu terceiro livro, publicado em 1989, a principal dentre suas obras que articula conceitos da FQ com teses sobre meditação, doenças, saúde e prosperidade (Hammer, 2004, p. 313; Nogueira, 2010, p. 57). 
A popularidade da forma em que o médico indiano usou a FQ causou impactos e uma forte reação crítica por parte da comunidade acadêmica, que o premiou com o prêmio Ig Nobel de Física, em 1998. Trata-se de um prêmio criado pela revista de humor científico Annals of Improbable Research, que premia as pesquisas mais estranhas e improváveis do ano. Na ocasião, Chopra foi premiado pela "sua interpretação única da Física Quântica aplicada à vida, à liberdade, e à busca da felicidade econômica" (Improbable research, 1998).

Em seu livro A Cura Quântica, Chopra apresenta elementos semelhantes aos contidos no Tao da Física, de Capra, com a diferença de que ele se volta para a sua área de formação: a medicina, mais especificamente, a medicina alternativa, mantendo os paralelos com a FM, com a diferença de que ele se restringe basicamente à FQ. A primeira semelhança entre a sua obra e a de Capra se encontra na visão de mundo na qual o médico indiano apresenta a sua obra, em especial, no que se refere às relações entre física e misticismo, a qual pode ser identificada na seguinte passagem:

Em sua forma mais pura, o sadhu é um investigador da realidade transcendental que fica além do vazio - essa é a tradição que ele segue, uma das mais antigas e sábias de nosso planeta. Compreender suas descobertas nos levará por uma nova estrada, longe da física, mas ainda assim na mesma linha, à procura de nós mesmos (Chopra, 1989, p. 225).

À semelhança de Capra, que defendia que "a ciência não necessita do misticismo e este não necessita daquela; o homem, contudo, necessita de ambos" (Capra, [1975] 1983, p. 228), Chopra apresenta uma tradição mística, a qual ele reconhece que é independente da Física - por levar a uma "nova estrada" - para argumentar que uma compreensão de ambas, Física e tradição mística, possibilitariam um maior entendimento acerca de nós mesmos.

No entanto, diferentemente de Capra, que se restringe a um paralelismo comparativamente mais comedido entre o misticismo e os fenômenos da FM, Chopra traça analogias entre os fenômenos da FQ e fenômenos da medicina e do corpo humano, atribuindo-as um caráter realista e argumentando explicitamente em favor da realidade destas: 
Graças às moléculas mensageiras, eventos que aparentemente não têm nenhuma ligação - como um pensamento e uma reação do corpo - agora mostram-se mais consistentes. $\mathrm{O}$ neuropeptídio não é um pensamento, mas move-se como ele e serve como ponto de transformação. O quantum faz exatamente a mesma coisa, só que o corpo estudado nessa questão é o universo, ou a natureza como um todo. (...) o comportamento da realidade quântica acaba ficando muito íntimo - de fato, ela é a linha mais tênue que separa o corpo humano do corpo cósmico (Chopra, 1989, pp. 128-129).

Um médico poderia criar objeções, considerando que estamos apenas fazendo metáforas, que o mundo oculto das partículas elementares e das forças fundamentais exploradas pelos físicos quânticos é muito diferente do mundo oculto da mente. Ainda assim, pode-se argumentar que a região inconcebível de onde tiramos o pensamento de uma rosa é a mesma de onde emerge um fóton - ou o cosmos (Chopra, 1989, pp. 138139).

Essa estratégia é utilizada pelo autor, para apresentar e defender o que ele denomina por "cura quântica", que seria a expressão máxima que reuniria os fenômenos do corpo humano com os fenômenos da FQ, para além de uma mera analogia. Essa definição se baseia em primeiro lugar na definição de "quantum", apresentada pelo médico indiano da seguinte forma:

A palavra que vem à mente, quando um cientista pensa nessas mudanças súbitas, é quantum. Ela significa um salto descontínuo de um nível de função para outro, mais elevado: a transição quântica.

Quantum é também um termo técnico, antes conhecido apenas pelos físicos, mas agora presente na linguagem popular. Precisamente, um quantum é "a unidade indivisível em que as ondas podem ser emitidas ou absorvidas", na definição do eminente físico britânico Stephen Hawking. Para leigos, o quantum é um bloco de construção. A luz é formada por fótons, a eletricidade, pela carga do elétron, e a gravidade, pelo gráviton (um quantum hipotético, ainda não encontrado na natureza). E o mesmo acontece com todas as formas de energia, cada qual baseada em um quantum que não pode ser subdividido em nada menor (Chopra, 1989, pp. 30-31).

Ao apresentar essa definição de um termo da Física, Chopra se coloca entre os autores que utilizam uma versão popular da palavra "quantum", ou seja, que fazem uso de uma Física que já foi popularizada por outros autores. De fato, ele admite que não pretende se aprofundar na Física: “Já que não estamos procurando estudar física, não vou entrar em maiores detalhes." (Chopra, 1989, p. 133). Assim, diferentemente de Capra, que poderia ser considerado um popularizador e Ciências, Chopra se insere em um nível posterior: o 
dos autores que se utilizam dessa Física popularizada para fins diversos. Com isso, ele também delimita o seu público alvo: o autor não se volta apenas para o público leigo mais amplo interessado em Ciência popularizada, mas também para um público que se interessa em aplicações específicas dessa Ciência, no caso, uma aplicação voltada para a saúde e o bem-estar.

No entanto, o fato do autor se utilizar de uma Ciência já popularizada faz com que ele, para atribuir-lhe maior credibilidade, a apresente de forma autoritária, na forma de definições, demonstrações ou fatos que não podem ser questionados, inclusive, invocando figuras ilustres, autoridades para assuntos relacionados à Física - como o físico Stephen Hawking. Esse aspecto pode ser observado na seguinte citação:

As pesquisas de curas espontâneas de câncer realizadas tanto nos Estados Unidos como no Japão demonstraram que, pouco antes do restabelecimento, quase todos os pacientes passam por uma alteração de consciência (Chopra, 1989, p. 30, grifos nossos).

Assim, resguardado por essa imagem de Ciência, o autor apresenta a sua definição para o termo "cura quântica", e o relaciona com um caso de cura espontânea de câncer, de uma paciente sua, chamada Chitra:

\footnotetext{
As duas definições, a do salto descontínuo para um nível mais elevado e o grau irredutível de uma energia, parecem aplicar-se a casos como o de Chitra. Sendo assim, eu gostaria de introduzir o termo cura quântica para explicar o que aconteceu com ela. Apesar de ser uma palavra nova, o processo, em si, não é. Sempre existiram pacientes em que não se observa o curso natural de cura. Por exemplo, uma pequena minoria não definha com o câncer, outros desenvolvem tumores muito mais lentamente do que a estatística prevê para aquele tipo de mal. Muitos restabelecimentos são de origem igualmente misteriosa, como os casos de remissão espontânea e o uso eficiente de placebos, ou "drogas enganadoras", que também indicam o salto quântico. E por quê? Porque em todos esses casos a consciência profunda parece ter promovido um drástico salto quântico no mecanismo da cura (Chopra, 1989, p. 31).
}

Conforme mencionado, essa definição se baseia em analogias entre os fenômenos quânticos e os relacionados ao corpo humano, mais especificamente aos processos de cura de "origem misteriosa", os quais o autor destaca que não possuem explicação pela medicina convencional. Para sustentar essa definição e a sua posição de que essas analogias forneceriam a explicação para esses fenômenos, não fornecida pela medicina 
convencional, o autor se vale de diversos argumentos. $\mathrm{O}$ primeiro deles se baseia na premissa de que a FQ sustenta a ideia de que a mente é capaz de interferir na matéria, e que, portanto, a mente - algo imaterial - seria capaz de provocar um efeito no corpo algo material:

(...) a cura quântica é a capacidade de um modo de consciência (a mente) para corrigir espontaneamente os erros em outro modo de consciência (o corpo). Trata-se de um processo fechado em si mesmo (Chopra, 1989, p. 330).

Para sustentar essa premissa, o autor faz menção à dualidade onda-partícula na FQ, a qual ele considera como uma propriedade da luz, capaz de transformar algo não material (as ondas) em algo material (as partículas). Partindo desse entendimento acerca da dualidade onda-partícula, o médico indiano associa isso a uma propriedade do "quantum":

A luz pode se comportar como A, uma onda, ou B, uma partícula. As duas são totalmente diferentes na física newtoniana, já que as ondas são imateriais e as partículas, concretas. Mas a luz, de algum modo, atua como uma ou outra, dependendo das circunstâncias (Chopra, 1989, pp. 131-132).

A palavra "quantum" - do latim, que significa "quanto" - descreve a menor unidade a ser chamada de partícula. Um fóton é um quantum de luz, porque não se pode dividi-lo em partículas menores. (...) Esse quantum é uma partícula muito estranha, porque não tem massa, mas para nossos propósitos o que importa nele é sua capacidade de se transformar em uma onda de luz (...). A transformação ocorre em um domínio desconhecido, que escapa às leis de Newton. (...) o quantum é capaz de deixar a natureza tão flexível que se torna possível a inexplicável transformação de não-matéria em matéria, de tempo em espaço, de massa em energia (Chopra, 1989, p. 133).

A partir dessa interpretação acerca da dualidade onda-partícula - como uma propriedade capaz de transformar algo imaterial em matéria - Chopra, assim como Capra, faz alusão aos debates acerca do papel da consciência no problema da medição em FQ (ver seção 3.2.2) e ao conceito de potencialidade de Heisenberg (ver seção 3.3.3), a fim de trazer mais elementos que a sustentem:

Precisamos estudar o quantum de uma molécula. Um neuropeptídio aflora na existência ao toque de um pensamento, mas de onde vem esse afloramento? Um pensamento de medo e a substância em que ele se transforma estão de algum modo ligados a um processo oculto na transformação da não-matéria em matéria (Chopra, 1989, p. 128). 
Essa mesma dificuldade existe na física - um fóton é uma massa de luz e uma onda de luz, mas ambas surgem de um campo oculto. Na superfície da realidade vemos fótons ou ondas de luz, mas a razão de ambos existirem na mesma realidade é que preexistem como meras possibilidades no campo quântico. Quem já fotografou uma possibilidade? Ainda assim, o mundo quântico é feito disso. Se você diz uma palavra ou cria uma molécula, resolveu agir. Uma pequena onda se eleva da superfície do oceano, transformando-se em um incidente no mundo do espaço-tempo. Todo o oceano permanece atrás, um reservatório vasto e silencioso de possibilidades, ondas que ainda virão a se formar (Chopra, 1989, p. 217).

$\mathrm{Na}$ primeira citação, a consciência ou, nas palavras de Chopra, o "toque de um pensamento" seria capaz de transformar a não-matéria em matéria. Essa alusão, juntamente com uma licença poética, se afasta bastante dos debates originais acerca do papel da consciência nas observações em FQ, contudo, devido à menção à FQ e ao "quantum", se deduz que essa associação tem origem na referência a esses debates, amplamente divulgados pelos popularizadores da FQ. A segunda citação, no entanto, se aproxima mais da formulação do conceito de potencialidade de Heisenberg, ao aludir a uma realidade preexistente como uma possibilidade ou às possibilidades que ainda virão a ser tornar algo real. Porém, vale lembrar que Heisenberg não atribui à consciência a capacidade de manifestar essas potencialidades no mundo físico, mas sim ao processo de medição, o qual não necessariamente deveria ser realizado por um ser consciente, além disso, ele também não deixa claro se essas potencialidades seriam objetivas ou não. Apesar dessa alusão ao conceito de potencialidade de Heisenberg sugerir uma adesão de Chopra à Interpretação da Complementaridade para a FQ, em outra passagem, o médico indiano parece estar fazendo menção à Interpretação de Muitos Mundos, ao afirmar:

(...) Mas agora sabemos que a mente e o corpo são como universos paralelos. Tudo o que acontece no universo mental necessariamente deixa sinais no físico (Chopra, 1989, p. 94).

Assim, diferentemente de Capra, que explicita a sua adesão à Interpretação da Complementaridade, Chopra sequer faz menção à existência de diferentes interpretações para a FQ, aos debates e problemas de fundamento envolvidos nessa teoria, apresentandoa como uma teoria firme e sem controvérsias. Essa postura pode indicar tanto uma falta de clareza acerca da existência desses debates e diferentes interpretações por parte do autor, quanto uma postura de omissão desses debates e controvérsias, a fim de selecionar e 
mencionar apenas os aspectos compatíveis com a argumentação necessária para a defesa do seu termo "cura quântica". Ambas as posturas explicariam a alusão a diferentes interpretações, inclusive, incompatíveis entre si do ponto de vista filosófico.

Outro argumento utilizado pelo médico indiano, em favor da sua definição de "cura quântica", é o de que a FQ sustentaria a ideia de inseparabilidade entre sujeito e objeto. Para o autor, mente e matéria não somente são inseparáveis, como a mente possui a capacidade de interferir diretamente na matéria, ditando a realidade, de acordo com os seus pensamentos:

Mais uma vez podemos ver que a realidade subjetiva e a realidade objetiva estão intimamente ligadas. Quando a mente muda, o corpo não tem escolha senão mudar (Chopra, 1989, pp. 245-246).

Também devo chamar esse caso de evento quântico, devido à transformação fundamental em nível mais profundo que o dos órgãos, tecidos, células e até do DNA, ocorrida diretamente na fonte de existência do corpo, no tempo e no espaço. Meus dois pacientes - uma, com pensamentos positivos, e outro, com negativos - conseguiram mergulhar no domínio “?” e dali ditaram a própria realidade (Chopra, 1989, p. 138).

Essa defesa do médico indiano pode ter sido inspirada nas posições adotadas com relação ao problema da medição em FQ por Von Weizsäcker, com seu idealismo voluntarista, e por John Wheeler, com sua noção de observador participante (ver seção 3.2.2). No entanto, ela difere destas pelo fato dele defender que é o pensamento ou a mente que são capazes de mudar a realidade. No caso dos físicos citados, seria o processo de medição, dependendo do arranjo experimental utilizado, que teria a capacidade de alterar os fenômenos observados. Esse processo de medição deveria ser realizado por um observador consciente, porém, para nenhum deles, o pensamento desse observador é capaz de interferir na realidade observada.

Além disso, esse argumento de Chopra inclui uma extensão dos fenômenos quânticos para o nível macroscópico, como manifestações no corpo humano e em dimensões maiores do que o nível atômico. Essa extensão dos fenômenos quânticos para esses níveis pode ter sido inspirada no paradoxo do gato de Schrödinger (ver seção 3.2.2):

Para um físico, o único quebra-cabeça da experiência de Benveniste é que ninguém acreditou que os eventos quânticos pudessem ocorrer no nível das moléculas. (...) 
Para entender como a molécula trabalha, precisamos saber mais sobre o nível quântico da natureza (Chopra, 1989, p. 166).

Por fim, o autor, à semelhança de Fritjof Capra, também faz menção ao Teorema de Bell (ver seção 3.2.2) e aos conceitos de totalidade e universo indiviso (ver seção 3.3.4) do físico norte-americano David Bohm (não britânico, conforme mencionado por Chopra). Essas menções são realizadas a fim de defender uma concepção na qual o universo inteiro estaria interligado e que a ação de um objeto influenciaria outro distante instantaneamente:

Podemos observar esse fato na lei da gravidade. O bom senso nos diz que dois objetos separados por um espaço vazio não devem ter qualquer ligação entre si; no jargão dos físicos, eles ocupam sua "realidade local". Mas a Terra gira em torno do Sol, a cuja órbita é presa pela gravidade, mesmo que ambos sejam dois corpos separados por um espaço vazio de 150 milhões de quilômetros. Ao descobrir essa violação da realidade local, Newton ficou chocado e recusou-se a especular como isso acontecia. Desde então, a realidade local tem levado um golpe após o outro. (...) Uma famosa fórmula matemática, conhecida como teorema de Bell (seu autor foi o físico John Bell), estabelece que a realidade do universo deve ser "não-local"; em outras palavras, todos os objetos e eventos no cosmos estão interligados e reagem às mudanças de estado dos outros (Chopra, 1989, pp. 145-146).

Teóricos contemporâneos como o físico britânico David Bohm, que trabalhou profundamente com as implicações do teorema de Bell, tiveram de supor a existência de um "campo invisível" que mantém toda a realidade unida, um campo que possui a propriedade de saber o que está acontecendo em qualquer lugar ao mesmo tempo (Chopra, 1989, p. 146).

A defesa dessa concepção de universo interligado é utilizada, mais adiante, para defender que a mente também estaria, de alguma forma, espalhada no universo e não poderia ser confinada a um espaço delimitado. Com isso, o médico indiano sustenta a sua tese de que a natureza possuiria uma espécie de inteligência natural, a qual seria sustentada pela FQ:

A mente não está solta no espaço, ocupando um lugar, nem mesmo o necessário para um elétron, que é infinitesimal. A bobagem evidente de guardar a mente numa caixa foi a das principais razões de a ciência ter separado, desde o início, a mente da matéria, já que toda matéria pode ser fechada em alguma caixa. Felizmente, surge a física quântica 
para salvar o construtor da ponte. Ela surgiu para explorar essas regiões aparentemente absurdas nas fronteiras do espaço-tempo (Chopra, 1989, p. 169).

Sem definirmos o processo como "pensamento", talvez vejamos a natureza pensar através de muitos canais diferentes, dos quais nossas mentes estão entre os mais privilegiados (Chopra, 1989, p. 147).

Todos esses argumentos e defesas se baseiam em uma visão idealista com relação à FQ, a qual Chopra argumenta, de forma errônea ou mentirosa, que se tratava de uma visão adotada por todos os físicos fundadores da FQ, conforme é possível observar na seguinte citação:

Mas é fascinante perceber que todos os descobridores da física quântica foram basicamente platônicos. Ou melhor, acreditavam que o mundo das coisas fosse uma sombria projeção de uma realidade mais vasta e indivisível, imaterial (Chopra, 1989, p. 171).

Conforme visto nas seções 3.2 e 3.3, Einstein, Planck, Bohm e outros físicos que possuíam uma postura realista perante a Física criticavam fortemente essas visões, inclusive, propondo outras interpretações e soluções ao problema da medição em FQ, de caráter realista. De fato, o embate entre visões idealistas e realistas com relação a essa teoria foi um dos principais responsáveis pela proliferação de interpretações para a FQ.

Além disso, o médico indiano acrescenta que a sua visão idealista de que a mente seria capaz de interferir na matéria não pode ser considerada uma concepção mística, mas que ela estaria baseada no funcionamento de diversas áreas do conhecimento. Inclusive, Chopra cita Einstein - um dos principais críticos de posturas idealistas em relação à Física - como um exemplo para apoiar essa visão:

Compreender que a mente está acima da matéria não é uma noção mística. (...) Certos campos, como a música, a matemática e a física quântica, praticamente não progridem sem gênios que trabalham em profundo silêncio - o método de investigação preferido por Einstein não era trabalhar em laboratório, mas realizar experimentos mentais (Chopra, 1989, p. 279).

Contudo, apesar dessa defesa, a origem mística da visão do autor fica evidente na passagem a seguir, onde ele rejeita as tentativas de se compreender o corpo mecânico quântico através do intelecto ou do raciocínio, atribuindo um maior valor ao sentimento e 
à intuição. Esse aspecto místico de sua visão se aproxima dos criticados por aqueles que utilizam o termo "misticismo" com uma conotação pejorativa, conforme reconhecido pelos dicionários de filosofia (ver seção 4.1).

Essa sensação de liberdade é vital - permite que as naturezas interna e externa se misturem. O mesmo é verdade para o corpo mecânico quântico: ele é apenas uma porta de volta à Natureza. Não há necessidade de explicá-lo, a não ser por um triste fato: o intelecto, indo contra a Natureza, fez um ótimo trabalho de bloqueio dessa porta (Chopra, 1989, p. 153).

Mais adiante, a rejeição por parte do autor das tentativas de se compreender os fenômenos atrelados ao termo "cura quântica" através do intelecto é estendida à Ciência e aos modelos científicos dos fenômenos mentais.

A meu ver, tudo isso justifica a complexidade da experiência comum, que, na verdade, está bem distante de qualquer modelo científico que procura descrevê-la. A antiga visão de que o cérebro é um computador estável no tempo e no espaço, com várias funções localizadas, e restrito a sua flexibilidade, é injustificada (Chopra, 1989, p. 198).

Contudo, o que em um primeiro momento poderia parecer uma contradição, uma vez que o autor se vale de argumentos científicos e de uma teoria científica específica - a FQ - para justificar a sua defesa da "cura quântica", na verdade, se revela como uma crítica a uma forma de Ciência específica: a Ciência materialista, mecanicista ou newtoniana.

Segundo o ponto de vista científico herdado de Newton, tem sido mentalmente impossível unir esses dois aspectos ao mesmo tempo. (...)

A ciência aceitou, em princípio, um sistema petrificado para mapear tudo o que acontece no mundo material. (...) Sendo assim, como fazer um mapa do corpo humano a cada instante? Esse é o novo dilema que teremos de enfrentar. Se pudermos resolvê-lo, chegaremos bem mais perto daquilo que procuramos; não mais o conhecimento para ser guardado em bibliotecas, mas novas capacidades de programar nosso computador cósmico (Chopra, 1989, pp. 77-78).

A partir dessa última citação e de outras apresentadas anteriormente, fica claro que a crítica à Ciência mecanicista, vinculada à FC, não surge como uma crítica solta, mas vem acompanhada de uma proposta concreta: uma Ciência idealista, que teria como base o "novo paradigma" da FQ e como principal característica a valorização da mente. Trata-se do discurso comum presente no Movimento da Nova Era, de que a FQ seria um "novo" 
paradigma em contraposição à FC, que corresponderia ao "velho" paradigma superado. Esse "novo" paradigma corresponderia ao advento de uma "Nova Era", um "sinal dos novos tempos", que, na obra de Chopra, representaria a possibilidade de uma "Nova Ciência" e de uma explicação para os fenômenos de cura não explicados pela medicina convencional.

Outra importante característica desta "nova" proposta de Chopra é a negação do conhecimento científico e da tecnologia, em prol da valorização de saberes tradicionais, de origem mística, uma vez que se referem a um domínio do conhecimento vedado ao pensamento comum e à explicação racional (ver seção 4.1):

Ainda não existe nenhum motivo científico que explique por que esse sistema funciona, a não ser que é assim. O Ayurveda atingiu algo profundo na natureza. Seus conhecimentos não são baseados na tecnologia, e sim na sabedoria, no que eu poderia definir como a compreensão segura do organismo humano, adquirida através de muitos séculos (Chopra, 1989, p. 25)

Essa negação e crítica ao conhecimento científico como possibilidade de compreensão segura para os fenômenos do organismo humano e, portanto, como parte da sua "Nova Ciência”, então, é estendida como uma crítica à objetividade e uma exaltação da subjetividade, a qual é atrelada ao conhecimento de algumas tradições orientais:

Normalmente um físico não concordaria com isso, uma vez que aprecia o método objetivo e encara a subjetividade como um inimigo virtual. (...) Na verdade, o Veda não carece de conhecimento objetivo (...), mas os rishis não achavam que a objetividade fosse o modo mais confiável de se conhecer as coisas, em especial depois de se investigar mais fundo do que a superfície da natureza. A verdade, diziam, é que a subjetividade não pode ser nem reduzida nem expandida (Chopra, 1989, p. 236).

A partir disso, as tradições orientais passam a ser vinculadas à medicina oriental, em especial, ao Ayurveda, e a crítica ao conhecimento científico, vinculado à FC, é ampliada para uma crítica à medicina ocidental:

As duas medicinas não precisam ser antagônicas, mas por enquanto estão claramente voltadas em direções opostas. Para um hematologista, é irrelevante que Aaron esteja tenso, excitado, cheio de substâncias dúbias em seu organismo, apavorado com a ideia de morrer. Para um médico védico, essas são as cargas primárias da doença - entraram no nível quântico, onde ele se transforma na pessoa que é. (...) Esse é o limite da noção 
newtoniana de causa e efeito, onde se desfaz a base da medicina científica comum (Chopra, 1989, p. 183).

(...) O Ocidente não chegou a esse discernimento nem compreendeu que a manifestação física de uma doença é um fantasma. (...) O Ayurveda nos dá os meios de chegarmos diretamente ao nível de consciência capaz de exorcizar essa memória (Chopra, 1989, p. 340).

Assim, o autor conclui a base dos seus argumentos em defesa da "cura quântica", como uma "Nova Ciência". Nota-se, nessa última etapa da argumentação do médico indiano, que as críticas voltadas ao orientalismo de Capra, em $O$ Tao da Física, também podem ser aplicadas à A Cura Quântica de Chopra, pois este também apresenta uma idealização da cultura e conhecimento orientais, a fim de criticar aspectos da sociedade ocidental, notadamente a sua Ciência e a sua medicina.

Posteriormente à publicação do A Cura Quântica de Chopra, essa abordagem - a qual relaciona a FQ com a medicina alternativa - dentro do gênero literário iniciado por Fritjof Capra, passou a se popularizar amplamente e fortaleceu cada vez mais o circuito de “terapias e produtos quânticos".

\subsubsection{Amit Goswami, $O$ Universo autoconsciente e $O$ Médico Quântico}

Outro autor que ganhou uma ampla projeção e, atualmente, pode ser considerado um dos mais conhecidos proponentes da associação entre FQ e espiritualidade foi o físico indiano Amit Goswami (Nogueira, 2010, p. 14). Goswami ficou conhecido principalmente após a sua participação no documentário What the bleep do we know - Quem somos nós (Arntz et al., 2004), que chegou a arrecadar mais de 10 milhões de dólares (Stenger, 2009, p. 40) e suscitar a publicação de resenhas e críticas nos mais diferentes tipos de meios de comunicação, incluindo revistas, jornais e livros (Nogueira, 2010, p. 17).

Devido a sua formação em Física, Goswami une um pouco do cuidado prezado por Fritjof Capra com relação aos conceitos da FQ com a busca por extrapolar essa teoria e aplicá-la a outras áreas do conhecimento, procurada por Deepak Chopra. De fato, as aplicações da FQ por parte de Goswami abrangem desde temas como a criatividade, a saúde e a cura, passando pela alma, fenômenos parapsicológicos, reencarnação e Deus, até a economia e os conflitos sociais. Além de mais de uma dezena de livros que buscam reunir a FQ com a espiritualidade, aplicados a temas diversos, Goswami também possui 
uma produção que inclui palestras e cursos proferidos regularmente, um documentário inspirado nas suas ideias - o The Quantum Activist - e uma série de entrevistas para diversos meios de comunicação, incluindo revistas, blogs e programas de televisão. Sua produção possui grande influência, em especial, no Brasil, país que costuma visitar regularmente para ministrar os seus cursos e palestras e onde possui diversos seguidores (Nogueira, 2010, p. 67). Além do sucesso de seus cursos e palestras, sua popularidade nesse país também é refletida, entre outros aspectos, pelo fato de quase a totalidade dos livros de Goswami ter sido traduzida para o português, e pelo fato do físico indiano já ter sido entrevistado duas vezes pelo programa Roda Viva, da TV Cultura (Goswami, 2001; Goswami, 2008).

A trajetória de Amit Goswami, assim como a de Fritjof Capra e a de Deepak Chopra, é uma trajetória que parte de sua área de especialidade - no caso, a Física - e termina com a sua atuação como autor de livros do Movimento da Nova Era. Goswami nasceu no norte da Índia, seu pai era um religioso brâmane, membro da casta sacerdotal do país e, segundo conta, ele passou a sua infância cercado por vivências religiosas e rituais místicos. Porém, a escola, onde teve contato com o conhecimento formal, despertou o seu interesse pela Física (Goswami et al., [1993] 2001, p. 11). Assim, Goswami optou por seguir a carreira científica, cuja formação culmina em um doutorado em Física pela Universidade de Calcutá, na Índia, em 1964. Posteriormente, em 1968, ele imigra para os EUA e se torna professor e pesquisador na Universidade de Oregon, onde leciona durante 32 anos. Nesse período, o físico indiano chegou a publicar dois livros didáticos de MQ e um livro sobre a Física da ficção científica (Goswami, 1979; Goswami e Goswami, 1983; Goswami, 1991). No entanto, a partir de meados dos anos 1990, sua produção se volta totalmente para os temas relacionados à união entre FQ e espiritualidade, sendo o seu primeiro livro sobre esse tema $O$ Universo Autoconsciente, publicado em 1993.

Segundo seu próprio relato, essa mudança se deveu a diversas insatisfações pessoais, sendo a primeira delas com a própria academia, devido a "um sem-número de crises de ressentido estresse, que me caracterizaram a carreira competitiva na física" (Goswami et al., [1993] 2001, p. 10), a outra seria uma insatisfação com o estilo de vida que levava, dentro do qual havia sido obrigado a abandonar as questões filosóficas de seu interesse. Segundo ele, "precisava restabelecer meu espírito de indagação sobre o significado do 
universo e abandonar as acomodações mentais que fizera por motivo de carreira" (Goswami et al., [1993] 2001, p. 10). Em meio a esse sentimento de insatisfação, o físico indiano também conta que, por volta de 1985, experienciou uma forte intuição que lhe mostrou a importância das ideias de John von Neumann, sobre a medição em FQ, segundo as quais, na sua leitura, "a consciência transforma as ondas de possibilidade quânticas do objeto num evento real de experiência", com essas ideias, ele pensou que "essa podia ser a base para o novo paradigma integrativo da ciência" (Goswami, [2004] 2006, p. 25). Além disso, nesse período, Goswami já havia tido contato com as ideias do filósofo e historiador da ciência Thomas Kuhn e com $O$ Tao da Física de Fritjof Capra. As ideias de Kuhn, segundo ele, o fizeram perceber que "eu fizera minha parte em pesquisa de paradigmas; era tempo de chegar à fronteira da física e pensar em uma mudança de paradigma" (Goswami et al., [1993] 2001, p. 10). O livro de Capra, por sua vez, também o tocou profundamente, no entanto, Goswami considera que Capra "menciona um problema que não estuda em profundidade", pois "sonda os paralelos entre a visão mística do mundo e a da física quântica, mas não investiga a razão desses paralelos" (Goswami et al., [1993] 2001, p. 10), assim, o físico indiano diz ter encontrado o foco de suas investigações dali em diante. Além da influência do O Tao da Física, Goswami chegou a conhecer Capra pessoalmente, pois ele, juntamente com outros físicos, era um dos frequentadores do Instituto Esalen, na Califórnia, nos anos 1970 e 1980, onde contribuía com debates palestras e workshops (Rocha, 2015, p. 75).

Assim, a partir dessas influências, o físico indiano passa a formular as suas ideias acerca da relação entre FQ e espiritualidade, cuja fundamentação mais detalhada é apresentada no seu primeiro livro, O Universo Autoconsciente, de 1993. Essas ideias formarão as bases de sua proposta de uma "filosofia do idealismo monista". Nos seus livros posteriores, porém, Goswami busca aplicar essa filosofia a diferentes áreas do conhecimento, entre elas, a saúde e a cura, as quais são apresentadas em seu livro $O$ Médico Quântico, publicado originalmente em 2004. Assim, nesta seção, será feita uma análise desses dois livros, por conta da sua relação com os autores e obras estudados nas seções anteriores.

O Universo Autoconsciente de Goswami apresenta diversos elementos semelhantes com os identificados anteriormente nas obras de Fritjof Capra e Deepak Chopra, a 
começar pela sugestão da existência de um paralelismo entre os fenômenos da FQ com elementos presentes em diferentes filosofias orientais, conforme notado na seguinte citação:

(...) teremos também que dizer que o fóton não é não-onda nem não-partícula, para que não haja mal-entendido sobre a maneira como usamos as palavras onda e partícula. Esta lógica parece-se muito com a de Nagarjuna, o filósofo idealista do século I d.C., o lógico mais hábil da tradição budista Mahayana (Goswami et al., [1993] 2001, p. 97 , grifos do autor).

Além disso, o físico indiano também faz uso de analogias com um tom mais realista, entre os fenômenos da FQ e outros relacionados à mente ou à consciência, como o inconsciente, por exemplo:

Na teoria quântica, há situações nas quais o estado quântico não entra em colapso, mas continua a desenvolver-se no tempo, de acordo com a dinâmica da situação. A dinâmica inconsciente, no entanto, pode representar um papel importante em eventos conscientes posteriores. Esse aspecto permite-nos confirmar os efeitos da interferência quântica em experimentos de percepção inconsciente (Goswami et al., [1993] 2001, p. 244).

Outra semelhança é o reconhecimento e a defesa da existência de uma relação entre ciência e misticismo, nesse aspecto, contudo, Goswami apresenta uma proposta mais ambiciosa, que vai além da relação sugerida por esses autores - a sugestão de um paralelismo, no caso de Capra, e analogias de cunho mais realista, no caso de Chopra defendendo explicitamente uma união entre eles, sob o argumento de que ambos se constituiriam em caminhos que conduzem à Verdade:

A integração de ciência e misticismo não tem que ser tão desconcertante assim. Afinal de contas elas compartilham de uma semelhança importante: ambas nasceram de dados empíricos interpretados à luz de princípios explanatórios teóricos. Em ciência, a teoria serve como explicação dos dados e como instrumento de previsão e orientação para experimentos futuros. A filosofia idealista (...) atua como uma explicação das observações empíricas dos místicos, bem como orientação para outros pesquisadores da Verdade. Finalmente, tal como a ciência, o misticismo parece ser uma atividade universal (Goswami et al., [1993] 2001, p. 78).

Assim, fica claro que o físico indiano busca uma união mais profunda entre ciência e misticismo e, para tanto, propõe a sua própria interpretação para a $\mathrm{FQ}$ : a filosofia do idealismo monista, a qual ele busca demonstrar ser o único quadro ontológico razoável, 
consistente com os fenômenos da FQ e os da consciência (Hammer, 2004, p. 300). Então, para defender a sua proposta, Goswami utiliza diversas estratégias retóricas, as quais boa parte se assemelha às utilizadas por Capra, em O Tao da Física, como o uso de uma espécie de filosofia perene, sob o argumento de que "as mesmas ideias básicas reaparecem com grande frequência na literatura idealista de numerosas culturas" (Goswami et al., [1993] 2001, p. 73), e fazendo referências a uma ampla gama de filosofias idealistas, sem se restringir às orientais, como o Vedanta, o Daoismo, o Budismo Maaiana, o Budismo tibetano, o Zen, o platonismo e o Yoga (Hammer, 2004, p. 300).

Assim como Capra, devido a sua formação como físico, Goswami também busca apresentar os conceitos da FQ e os principais debates em torno deles de forma mais detalhada e precisa, dessa forma, ele explica o conceito de quantum de energia, a dualidade onda-partícula, o Princípio da Incerteza de Heisenberg, o problema da medição em FQ, os princípios da complementaridade e da correspondência, o Teorema de Bell e o problema da não-localidade, entre outros. No entanto, diferentemente de Capra e de Chopra, nessa obra, Goswami não oculta os debates e controvérsias em torno das questões de fundamento dessa teoria, apresentando algumas das suas diferentes interpretações e criticando-as. As principais interpretações criticadas pelo físico indiano são as de cunho realista ou as que buscam resgatar o determinismo na FQ, como a Interpretação causal de Bohm, baseada em variáveis ocultas, a Interpretação dos Coletivos Estatísticos, a Interpretação de Muitos Mundos de Everett-DeWitt e o Programa de Amplificação Termodinâmica, que trata o processo de medição como um processo irreversível:

(...) poderíamos fingir, seguindo a interpretação de conjuntos estatísticos preferida por alguns materialistas, que a mecânica quântica faz previsões apenas sobre experimentos que envolvam grande número de objetos. (...)

(...) essa interpretação equivale a abandonar a mecânica quântica como teoria física capaz de descrever um objeto ou evento únicos. Uma vez que eventos únicos de fato ocorrem (...), precisamos ter condições para falar em objetos quânticos únicos (Goswami et al., [1993] 2001, p. 108).

Uma resposta que lembra ficção científica foi dada pelos físicos Hugh Everett e John Wheeler. Segundo eles, ambas as possibilidades, o gato vivo e o gato morto, ocorrem mas em realidades diferentes, ou em universos paralelos. (...) Infelizmente, porém, tratase também de uma ideia dispendiosa. Ela duplicaria o volume de matéria e energia em todos os momentos em que uma observação obrigasse o universo a bifurcar-se. Além do 
mais, desde que os universos paralelos não interagem, é difícil submeter essa interpretação a um teste experimental e, portanto, ela é inútil do ponto de vista científico (Goswami et al., [1993] 2001, pp. 109-110).

A partir dessas citações, e por buscar ser fiel aos problemas de fundamento da FQ, em um primeiro momento, se poderia considerar Goswami como um popularizador de ciências. No entanto, mais adiante, fica claro que ele não se restringe a divulgar a TQ, principalmente pelo fato das suas críticas a essas interpretações não se restringirem a argumentos voltados aos aspectos físicos destas, mas ocasionalmente apelarem para aspectos mentais e psicológicos, voltados para o significado da vida humana, conforme se evidencia nas suas críticas à Interpretação causal de Bohm.

O teorema de Bell arrasa o dogma de causa local, efeito local da física clássica. Mesmo que se postulem variáveis ocultas para formular uma interpretação causal da mecânica quântica, como faz David Bohm, essa variáveis terão que ser não-locais. (...)

(...) Segundo Bohm, o que acontece no espaço-tempo é determinado pelo que acontece em uma realidade não-local, além do espaço-tempo. Se este fosse o caso, então nosso livre-arbítrio e criatividade seriam, em última análise, ilusões e não haveria um significado real no drama humano. A interpretação idealista promete justamente o oposto: a vida está permeada de significado (Goswami et al., [1993] 2001, p. 158).

Além disso, ao apresentar os debates em torno de outros problemas de fundamentos, ele faz uso de hipóteses adicionais, algumas das quais não são corroboradas pela Física, a fim de apresentar e defender a sua própria proposta de interpretação para essa teoria. Uma dessas hipóteses é a de que a MQ vale para o domínio dos objetos macroscópicos:

Não podemos dizer, citando [o princípio d]a correspondência, que a física clássica se mantém no caso dos macrobjetos para todas as finalidades práticas e que, desde que vivemos em um marcomundo, teremos que supor que a estranheza quântica se limita ao domínio submicroscópico da natureza. Ao contrário, a estranheza obceca-nos através do caminho todo até o macronível. Surgirão paradoxos quânticos sem solução se dividirmos o mundo em domínio da física clássica e quântica (Goswami et al., [1993] 2001, p. 70).

Assim, com o intuito de fundamentar e apresentar a sua própria interpretação da FQ, semelhantemente a Capra e Chopra, Goswami dá destaque ao problema da medição em FQ e cita os físicos que defenderam a necessidade de um observador consciente no processo de medição, como von Neumann, London, Bauer e Wigner. No entanto, ao 
apresentar o posicionamento desses físicos, Goswami introduz uma modificação sutil: em vez de apresentar a defesa deles de que, no processo de medição, o colapso da função de onda ocorre apenas com a presença de um observador consciente, na consciência deste sendo a medição a responsável pelo colapso -, ele afirma que eles defendiam que a consciência é que é responsável por este colapso:

(...) uma vez que a observação que fazemos resolve magicamente a dicotomia do gato [de Schrödinger], não há como fugir da conclusão de que somos nós - nossa consciência - que geramos o colapso da função de onda do gato. (...) luminares como John von Neumann, Fritz London, Edmond Bauer e Eugene Paul Wigner adotaram essa solução para o paradoxo (Goswami et al., [1993] 2001, p. 110).

Para apoiar essa hipótese, Goswami também faz uma adaptação do conceito de potencialidade de Heisenberg, formulado no contexto da Interpretação da Complementaridade (ver seção 3.3.3), apresentando-o de forma mais realista para, assim como Deepak Chopra, defender que ele estaria relacionado a uma capacidade de tornar algo que existe em um "mundo de possibilidades" em algo existente no mundo físico, e que a responsável por realizar esse processo seria a consciência. Heisenberg, no entanto, atribuía isso ao processo de medição, não necessariamente realizado por um ser consciente, e não deixava claro se essas potencialidades seriam objetivas.

A consciência é o meio que produz o colapso da onda de um objeto quântico, que existe em potentia, tornando-a uma partícula imanente no mundo da manifestação. (...)

Notem que o próprio Heisenberg quase propôs a metafísica idealista quando introduziu o conceito de potentia. O novo elemento importante é que o domínio da potentia existe também na consciência (Goswami et al., [1993] 2001, pp. 84-85, grifos do autor).

Então, a partir da reunião desses elementos, Goswami apresenta a sua proposta de interpretação para o problema da medição, reconhecendo explicitamente que se trata de uma proposta interpretativa para esse problema:

Sugiro que o universo existe como potentia informe em uma miríade de ramos possíveis, no domínio transcendente, e que se torna manifesto apenas quando observado por seres conscientes. (...)

(...) o universo bifurca-se em todos os eventos desse tipo no domínio transcendente, transformando-se em muitos ramos, até que em um deles há um ser senciente que pode olhar com consciência e completar uma medição quântica. (...) $\mathrm{O}$ significado surge no universo quando seres sencientes o observam, escolhendo trilhas causais entre miríades 
de possibilidades transcendentes (Goswami et al., [1993] 2001, pp. 174-175, grifos do autor).

Aqui o físico indiano reitera a sua rejeição à Interpretação de Muitos Mundos, e explica que, na sua visão, apenas aquele ramo do domínio transcendental - o mundo das possibilidades - que é observado por um ser consciente é que será manifestado no mundo físico, completando o processo de medição em FQ. Nesse ponto, ele também introduz uma hipótese adicional: a de que os observadores possuem a capacidade de escolher o ramo que será manifestado no mundo físico. Essa hipótese é mais bem explicada na seguinte passagem:

Na visão quântica, o argumento fundamental é que escolhemos o resultado específico que se manifesta. O momento no tempo em que optamos por esse resultado carece de importância. A onda se divide em todos os casos em que há dois rumos disponíveis, mas a divisão ocorre apenas em potentia. Quando, mais tarde, observamos o fóton em um rumo, porque foi assim que escolhemos (...), o colapso de onda que provocamos em um rumo exerce influência não-local sobre a onda no outro rumo, que anula a possibilidade de o fóton ser visto nesse outro rumo. Essa influência não-local talvez pareça retroativa, mas estamos influenciando apenas possibilidades em potentia (Goswami et al., [1993] 2001, p. 103, grifos do autor).

Dessa forma, através do detalhamento das suas hipóteses, o autor começa a delinear as características de sua filosofia do idealismo monista. Para ele, o processo de medição não é um processo de interação entre dois objetos no plano físico (um aparelho de medição e o objeto a ser observado), mas um processo que ocorre no domínio da consciência, se trata apenas de um reconhecimento mental do mundo físico:

De acordo com o idealismo monista, os objetos já estão na consciência como formas primordiais, transcendentes, arquetípicas. O colapso consiste não em fazer alguma coisa aos objetos através da observação, mas em optar e reconhecer o resultado dessa opção (Goswami et al., [1993] 2001, p. 112).

Em seguida, ele argumenta que não se trata de um processo psicológico, mas de um processo que desrespeito à Física, para então defender que a questão da consciência pode ser compreendida à luz da FQ:

Ciência é senso incomum; recorremos a ela quando fracassa o senso comum. Recorrer à psicologia, contudo, em nada adianta. Ou, como disse o eminente cognitivista Ulric Neisser: "A psicologia não está pronta para enfrentar a questão da consciência." Por 
sorte, a física está. Isto significa voltar à teoria quântica e ao problema da medição (Goswami et al., [1993] 2001, p. 137).

Com isso, Goswami reconhece que a sua defesa de que a consciência pode ser compreendida pela FQ é ousada, mas argumenta que a existência de paralelos e analogias entre os fenômenos quânticos e os da consciência são indicativos de que esse pode ser um caminho a ser investigado:

Reconheço que os dados que sugerem os paralelos entre mente e teoria quântica incerteza, complementaridade, saltos quânticos, não-localidade e, finalmente, superposição coerente - talvez não sejam considerados conclusivos. Mas eles bem que poderiam ser indicativos de alguma coisa radical: Aquilo que chamamos de mente consiste de objetos que se assemelham aos objetos da matéria submicroscópica e que obedecem a regras semelhantes às da mecânica quântica (Goswami et al., [1993] 2001, p. 202, grifos do autor).

No entanto, mais adiante, apesar das suas ressalvas anteriores, o autor segue utilizando esses paralelos e analogias entre os fenômenos quânticos e os fenômenos da mente, para justificar a hipótese de que a consciência poderia ser compreendida pelas leis da MQ. Mais especificamente, o físico indiano passa a defender que o cérebro atuaria como um aparelho de medição para os sistemas quânticos:

A ideia de que a estrutura formal da mecânica quântica deve aplicar-se ao cérebromente nada tem de nova. Na verdade, vem evoluindo aos poucos. Não obstante, é nova a ideia de considerar o cérebro-mente como um sistema quântico/mecanismo de medição (...).

(...) pesquisadores descobriram coerência nas ondas cerebrais emitidas por diferentes partes do couro cabeludo de indivíduos imersos em estados meditativos. (...)

A coerência espacial é uma das notáveis propriedades dos sistemas quânticos. Esses experimentos sobre coerência, por conseguinte, podem estar fornecendo prova direta de que o cérebro atua como um aparelho de medição para os modos normais de um sistema quântico, que poderíamos chamar de mente quântica (Goswami et al., [1993] 2001, pp. 206-207, grifos do autor).

Assim, ele completa as características relacionadas ao problema da medição em FQ da sua filosofia do idealismo monista, retomando a sua defesa de que é a consciência que escolhe o resultado de uma observação: 
De acordo com a interpretação idealista, a consciência escolhe o resultado do colapso em todo e qualquer sistema quântico. (...) não há como fugir à consequência de falar sobre um sistema clássico/quântico interativo do cérebro-mente na linguagem da teoria da medição, como interpretada pelo idealismo monista: nossa consciência escolhe o resultado do colapso do estado quântico de nosso cérebro-mente. Uma vez que esse resultado é uma experiência consciente, escolhemos nossas experiências conscientes embora permaneçamos inconscientes do processo subjacente (Goswami et al., [1993] 2001, p. 211).

A partir dessa citação, é possível notar que, ao finalizar a formulação das bases de sua filosofia idealista monista, o autor ainda acrescenta uma última hipótese adicional: a de que a escolha da consciência acerca do resultado da observação, que inicialmente se aplicaria apenas a sistemas quânticos, também se aplica às nossas experiências pessoais.

No entanto, o físico indiano não se restringe a argumentos estritamente relacionados aos problemas de fundamento da FQ, para defender a sua proposta de filosofia do idealismo monista e, apesar dele buscar se diferenciar ou se destacar dos autores anteriores a ele, que também buscaram explorar os paralelos entre FQ e espiritualidade, Goswami, ao longo de toda a apresentação de sua filosofia, ainda utiliza recursos retóricos muito semelhantes a esses autores. Além dos recursos já apresentados anteriormente, para dar suporte às suas hipóteses acerca da FQ, Goswami também faz referência às inclinações místicas de alguns físicos, como, por exemplo, ao citar a famosa escolha do símbolo da ação dos princípios complementares de yin e yang de Bohr, para a sua cota d'armas, quando este foi condecorado com o título de cavaleiro pelo rei da Dinamarca (Goswami et al., [1993] 2001, p. 83) e a sugestão dele de que o conceito de complementaridade poderia ser aplicado às emoções e percepções (ver seção 3.5.5), porém de forma ligeiramente modificada em relação à sugerida originalmente por Bohr:

Bohr mencionou um princípio de complementaridade entre vida e não-vida - a impossibilidade de estudar a vida separadamente do organismo vivo - que talvez se aplique aqui (Goswami et al., [1993] 2001, p. 209).

Além disso, à semelhança de Chopra, Goswami também cita a influência platônica nas interpretações idealistas da FQ e sobre as tentativas de traçar paralelos entre essa teoria e a espiritualidade, particularmente, na sua própria filosofia do idealismo monista. No entanto, ao fazer referência ao mito da caverna de Platão, novamente o físico indiano 
acrescenta um elemento adicional: o de que as sombras projetadas nas paredes da caverna são aquelas com as quais nos identificamos.

No Ocidente, a filosofia do idealismo monista teve em Platão seu proponente mais conhecido. Platão, em A República, deu-nos a famosa alegoria da caverna. (...) Nessa alegoria, os espetáculos de sombra são as manifestações imanentes irreais, na experiência humana, de realidades arquetípicas que pertencem a um mundo transcendente. Na verdade, a luz é a única realidade, porquanto ela é tudo que vemos. No idealismo monista, a consciência é como a luz na caverna de Platão (Goswami et al., [1993] 2001, p. 72, grifos do autor).

O universo é um espetáculo de sombras projetado na parede e nós somos espectadores imaginários. Vemos ilusões que permitimos que nos condicionem. (...) Nós também lançamos uma sombra sobre a parede, uma sombra com a qual nos identificamos (Goswami et al., [1993] 2001, p. 273).

Outra semelhança de Goswami com Capra e Chopra é a utilização do Teorema de Bell, para defender a existência de uma conexão intrínseca no universo, a qual, para o físico indiano, seria realizada por uma espécie de consciência coletiva. Para defender essa última hipótese, Goswami também faz referência a conceitos da psicologia, como os conceitos de sincronicidade e de inconsciente coletivo de Jung.

As correlações não-locais do teorema de Bell e do experimento de Aspect são coincidências acausais (...). Se essas correlações são exemplos da sincronicidade junguiana, então o aspecto de consciência não-local aqui envolvido terá que ser relacionado com o conceito de Jung relativo ao inconsciente coletivo (Goswami et al., [1993] 2001, p. 161).

A partir disso, o autor utiliza essa mesma hipótese para explicar o problema do amigo de Wigner (ver seção 3.2.2) e contornar uma possível acusação de solipsismo em relação à sua filosofia idealista:

O paradoxo de Wigner só surge quando ele faz a suposição dualista injustificada de que sua consciência é separada da consciência do amigo. O paradoxo desaparece se houver apenas um único sujeito, e não sujeitos separados, como habitualmente entendemos. A alternativa ao solipsismo é um sujeito-consciência unitivo (Goswami et al., [1993] 2001, p. 115).

Por fim, assim como Capra e Chopra, Goswami também rejeita a mecânica newtoniana, associando-a a um "velho" paradigma, em contraposição a um "novo" 
paradigma associado à FQ. O físico indiano, contudo, argumenta que, apesar de no âmbito da ciência a FC ter sido superada pela FQ e uma revolução científica ter ocorrido ao longo do século XX, ainda se faz necessário superar os resquícios do "velho" paradigma, o qual ele vincula à filosofia do realismo materialista.

A confusão do cientista é devida a uma ressaca causada por um consumo visivelmente exagerado de uma bebida de 400 anos de idade chamada física clássica, destilada por Isaac Newton por volta de 1665. As teorias de Newton lançaram-nos em um curso que desembocou no materialismo que ora domina a cultura ocidental. (...) Embora uma nova disciplina científica denominada física quântica tenha substituído formalmente a física clássica neste século, a velha filosofia da física clássica - a do realismo materialista continua a ser amplamente aceita (Goswami et al., [1993] 2001, p. 35).

Dessa forma, semelhantemente a Deepak Chopra, o autor propõe a construção de uma "Nova Filosofia" idealista, a sua filosofia do idealismo monista. Esse "novo" paradigma corresponderia ao advento de uma "Nova Era", um "sinal dos novos tempos", que, na obra de Goswami, representaria a possibilidade de valorizar a espiritualidade e unir a ciência e a religião, o que, segundo ele, se faz necessário principalmente na cultura ocidental.

Viemos a aceitar o materialismo como dogma, a despeito de sua incapacidade de explicar as experiências mais simples da nossa vida diária. (...) As tribulações em que vivemos alimentaram a exigência de um novo paradigma - uma visão unificadora do mundo que integre mente e espírito na ciência. (...) tentarei construir o prometido novo paradigma, uma ponte sobre o abismo entre ciência e religião (Goswami et al., [1993] 2001, pp. 19-20).

Então, para defender a sua proposta, o autor constrói um discurso retórico baseado nas premissas de que a FC estaria vinculada a máquinas e ao determinismo, e a de que a filosofia do realismo materialista estaria vinculada à busca por posses materiais:

Como físico da safra newtoniana, você acredita que o universo é uma máquina clássica, composta de partes que funcionam de acordo com as leis newtonianas, quase todas elas inteiramente conhecidas. Você acredita ainda que logo que reunir todas as informações sobre as partes e tiver identificado alguns pequenos problemas restantes nas leis poderá prever para sempre o futuro do universo (Goswami et al., [1993] 2001, p. 45).

A maioria dos ocidentais aceita como verdade científica que vivemos em um mundo materialista (...). Em um mundo assim, necessidades passam frequentemente despercebidas, ou são sublimadas, se afloram à superfície. Se só a matéria é real, como 
o materialismo nos ensinou a acreditar, então posses materiais constituem o único alicerce razoável para a felicidade e a boa vida (Goswami et al., [1993] 2001, pp. 33$34)$.

Partindo dessas premissas, o autor faz outra conexão: a de que, nessa "velha" filosofia - correspondente ao realismo materialista -, a mente também seria tratada como uma máquina:

Dessa maneira, nasceu a ideia de que a mente humana era uma simples máquina, com declarações simples de entrada-saída em uma correspondência tipo um com o outro, que funciona na base estímulo-resposta-recompensa (Goswami et al., [1993] 2001, p. 39).

Assim, tendo traçado as bases para os seus argumentos, que ultrapassam os problemas de Fundamentos da FQ, à semelhança de Chopra, Goswami, em seu discurso, passa a utilizar a Ciência de forma autoritária, na forma de demonstrações ou fatos que não podem ser questionados, a fim de atribuir maior credibilidade às suas afirmações:

Os fatos provam o contrário. A ciência prova a superioridade de uma filosofia monística sobre o dualismo - sobre o espírito separado da matéria. Este livro fornece uma argumentação convincente, fundamentada em dados existentes, de que a filosofia monística necessária agora no mundo não é o materialismo, mas o idealismo (Goswami et al., [1993] 2001, p. 31, grifos nossos).

Então, talvez inspirado nos inúmeros relatos de casos médicos utilizados por Chopra, para fundamentar a sua argumentação de uma relação entre a FQ e a medicina alternativa, Goswami utiliza uma estratégia retórica mais voltada à sua formação como físico e, ao mesmo tempo, relacionada a questões espirituais: o relato de experimentos envolvendo percepções extra-sensoriais e experiências fora do corpo.

Experimentos desse tipo foram realizados em numerosos laboratórios diferentes, com resultados positivos alegados por sujeitos psíquicos e não-psíquicos. (...) A razão mais importante para o ceticismo sobre a PES [percepção extra-sensorial], contudo, talvez seja que ela aparentemente não envolve quaisquer sinais locais enviados aos nossos órgãos dos sentidos, e por isso é proibida pela realismo materialista (Goswami et al., [1993] 2001, p. 164).

Pode a mente realmente deixar o corpo? Em experiências psíquicas do tipo OBE [outof-body experience] parece certamente que isso acontece. Essa indagação legítima não pode ser ignorada arrongantemente, mencionando-se alucinação, como cientistas 
materialistas, com fixidez no principio de localidade, costumam fazer (Goswami et al., [1993] 2001, p. 167).

Além das estratégias retóricas inspiradas em outros autores do mesmo gênero, Goswami também apresenta estratégias próprias, como o uso de elementos e exemplos provenientes da ficção cientifica - tema ao qual se dedicou antes de se voltar à relação entre FQ e espiritualidade - os quais, de forma sutil, mexem com o imaginário e o psicológico do leitor, conforme ele deixa transparecer em passagens como a seguinte:

No Fantastic Voyage, livro e filme de ficção científica, objetos eram miniaturizados por compressão. Você, leitor, jamais se perguntou se é possível espremer átomos? Afinal de contas eles são principalmente espaço vazio. Será possível tal coisa? Decida por si mesmo levando em conta a relação de incerteza (Goswami et al., [1993] 2001, p. 60, grifos do autor).

Outra diferença de Goswami em relação a Capra e Chopra é que ele não se restringe a uma referência às filosofias e ao misticismo orientais, mas parte deles para expandi-los e abranger as filosofias ocidentais, vinculando-os às questões relacionadas à consciência e, portanto, ao seu idealismo.

(...) como nos lembra o Lankavatara Sutra: "Esses ensinamentos são apenas um dedo apontando para a Nobre sabedoria... Destinam-se ao estudo e orientação das mentes discriminadoras de todas as pessoas, mas não são a Verdade em si, que só pode ser autocompreendida no mais profundo estado de nossa própria consciência" (Goswami et al., [1993] 2001, p. 77, grifos do autor).

Assim, ele passa a fazer referência ao pensamento de diversos filósofos ocidentais, como Platão, Kant e Sartre. Ao fazer isso, contudo, o autor simplifica e distorce as ideias desses pensadores, a fim de criticar as práticas e a sociedade contemporâneas, especialmente, a ocidental.

Temos aqui, portanto, a resposta à pergunta que inevitavelmente surge quando estudamos a filosofia ética de Kant. Se "Cumprir nosso dever" é um imperativo categórico universal, por que alguns entre nós são atormentados por ele, e não outros? A resposta é, em primeiro lugar, como reconheceu o próprio Kant, que a ética e as leis da moral interna são insinuações de nosso self interno para conhecermos nosso self completo. Em segundo, e mais importante, a injunção para cumprir nosso dever toca apenas aqueles de nós que estão comprometidos com o desejo de explorar o nosso self pleno, de despertar para o nível buddhi que se situa além do ego. Se estamos presos no 
atoleiro da identidade com o ego, perdemos gradualmente a capacidade de ouvir esses comandos internos (Goswami et al., [1993] 2001, pp. 303-304, grifos do autor).

Com isso, nota-se que as críticas antes voltadas ao orientalismo de Capra e Chopra (ver seções 4.2.1 e 4.2.2) também podem ser aplicadas a Goswami, contudo, elas se modificam ligeiramente, pois não se restringem a uma crítica à idealização e distorção das filosofias orientais, com a finalidade de criticar a sociedade ocidental, mas abrangem também outras correntes filosóficas. Essas distorções, posteriormente, serão utilizadas passa associar essas filosofias com as interpretações idealistas da FQ e, então, apresentar essa teoria como uma potencial solução para os males presentes nessa sociedade.

\footnotetext{
Prometeu trouxe de volta o fogo. Buda trouxe de volta a Senda Óctupla. Ambos os retornos tiveram como resultados uma revolução na dinâmica da sociedade, uma mudança completa de paradigma. Hoje, na mecânica quântica e em sua interpretação e assimilação na ciência idealista, vemos a capacidade de mudar paradigmas do fogo de Prometeu e das nobres verdades do Buda (Goswami et al., [1993] 2001, p. 314).
}

Através de toda a sua argumentação e da utilização de diferentes elementos e associações retóricas, portanto, percebe-se que Goswami apresenta a FQ não somente como um meio de compreender a realidade física, mas também como um caminho para a reconciliação entre a Ciência e a Religião, buscando nos fazer aceitar a validade das experiências espirituais, curar a alienação presente principalmente na cultura ocidental e, em última instância, atingir uma transformação social. Assim, devido ao fato da sua obra se centrar na necessidade de uma transformação espiritual e na possibilidade de se enxergar o nascimento de uma "Nova Era", Goswami não se coloca como um popularizador de ciências, que busca apenas divulgar a FQ e seus problemas de fundamentos, tampouco se coloca como um filósofo idealista buscando apenas fundamentar a sua filosofia, mas o físico indiano busca ativamente reavivar a religião (Hammer, 2004, pp. 301-302), conforme ele mesmo reconhece ao afirmar que "Nosso trabalho aponta na direção de início de uma ciência idealista e de uma revitalização das religiões" (Goswami et al., [1993] 2001, p. 81). Dessa forma, pode-se dizer que Goswami não se volta a um público interessado em divulgação científica ou em filosofia, mas ele escreve para um público que possui um interesse específico em temas relacionados à espiritualidade, em especial, em uma fundamentação mais consistente desta, além de suas aplicações e efeitos relacionados à vida prática (Nogueira, 2010, p. 127). 
De fato, Goswami não cria em torno de si um círculo característico da divulgação científica ou da filosofia, mas um círculo típico do Movimento da Nova Era. Os autores que dialogam com Goswami e que escreveram os comentários, as referências e indicações presentes em seus livros não fazem parte dos círculos científicos - especificamente da Física - ou filosóficos, mas são autores reconhecidamente pertencentes aos círculos da Nova Era. A contracapa de O Médico Quântico, por exemplo, possui um comentário escrito por Deepak Chopra, no qual ele ressalta as "ideias brilhantes [de Goswami] sobre o modo como a consciência concebe, governa, constrói e se torna biologia" (Goswami, [2004] 2006) e o autor da Introdução de O Universo Autoconsciente é ninguém menos que Fred Alan Wolf, autor de livros do mesmo gênero, que também exploram questões que relacionam a FQ com fenômenos da consciência e tangenciam temas místicos. Wolf acabou conhecendo Capra e Goswami, por frequentarem locais comuns no contexto da Califórnia, nos anos 1970 e 1980 - como o Instituto Esalen, por exemplo - e, juntamente com Goswami, foi um dos participantes no documentário What the bleep do we know Quem somos nós (Arntz et al., 2004).

Assim, como membro desse círculo do Movimento da Nova Era, o esforço de Goswami por reavivar a religião surge diante do reconhecimento de que, com o processo de secularização, esta perdeu importância e autoridade nos diferentes âmbitos da sociedade contemporânea. Curiosamente, contudo, esse esforço é construído a partir de uma base mais bem fundamentada dos conceitos e fundamentos da FQ, o que faz com que ele se destaque dos outros autores do mesmo gênero, por possuir uma ambição maior, fazendo esforços de teorização e buscando uma maior precisão para o termo "quântico" (Nogueira, 2010, p. 139).

(...) é vazia a conversa recente sobre o estabelecimento de padrões éticos na prática da ciência e da tecnologia, a menos que a ética possa ser erigida sobre princípios científicos firmes. Parece que é essencial reconhecer o estabelecimento da ética e valores como atividades científicas autênticas (Goswami et al., [1993] 2001, p. 297 , grifos do autor).

No entanto, ao fazer esse esforço de teorização, Goswami tampouco mantém a linguagem própria dos círculos científicos, se diferenciando destes e, portanto, não podendo ser considerado como um proponente de mais uma das diferentes interpretações da FQ, próprias da Física. Mais do que isso, o físico indiano parece buscar transformar o 
termo "quântico" em um símbolo religioso, um símbolo sagrado, tecido numa espécie de todo ordenado, formando um sistema religioso, isto é, um conhecimento que forneceria as condições essenciais nos termos dos quais a vida deveria ser vivida. Com isso, o termo "quântico" na obra de Goswami não permanece neutro, mas passa a ser investido de uma autoridade persuasiva com elementos oriundos tanto da ciência como da religião (Geertz, 1973; Nogueira, 2010, p. 140). Dessa forma, percebe-se que, na verdade, o objetivo de Goswami é reavivar a religião, recuperando a autoridade persuasiva de alguns de seus enunciados. Para isso, ele utiliza a Ciência, a qual acredita ser a única instituição capaz de desempenhar o papel mais próximo ao de uma fonte universal de legitimidade nas sociedades contemporâneas (Nogueira, 2010, pp. 146-147).

De acordo com Nogueira (2010, pp. 150-151), com essa pretensão, o físico indiano busca atender as demandas de um público que não possui uma adesão religiosa específica e fornecer amparo a um sentimento difuso, presente nesse público, de descrença na possibilidade de que grandes sistemas simbólicos seculares possam ser eficazes na superação dos conflitos que permeiam a vida moderna. Além disso, aparentemente, a teorização de Goswami em torno das relações entre FQ e espiritualidade gera certo fascínio pela sua suposta sofisticação intelectual e complexidade cientifica, no público leigo em Física. Por fim, sua teorização também parece atender, ainda que minimamente, os critérios de um público educado a prezar pela complexidade do conhecimento acadêmico e a não aceitar respostas baseadas unicamente em argumentos de autoridade como costuma ser a maioria dos argumentos religiosos.

Após essa fundamentação mais consistente de suas ideias, elaborada em $O$ Universo Autoconsciente, posteriormente, Goswami passou a buscar aplicar a sua filosofia do idealismo monista a diversas áreas do conhecimento, entre elas, a saúde e a cura. Assim, em seu livro $O$ Médico Quântico, o físico indiano busca apresentar o "potencial integrador desta nova ciência dentro da consciência no campo da saúde e da cura" (Goswami, [2004] 2006, p. 27, grifos do autor) e construir uma "Nova Medicina", a qual denomina "Medicina Integral". Ele também reconhece que sua Medicina Integral é o resultado de uma busca por "uma aplicação do novo paradigma que [fosse] tão espetacular a ponto de fascinar as pessoas", ou seja, de uma busca por uma "linha de comunicação com o público", a qual teria "condições de integrar as diferentes ideias das medicinas 
convencional e alternativa" (Goswami, [2004] 2006, p. 27). Com essas afirmações, o físico indiano deixa transparecer a sua ânsia em expandir a sua abordagem inicial e, portanto, o seu campo de atuação, e de despertar o interesse e atender as demandas do público mencionado anteriormente.

Nesse livro, o autor reconhece a influência sofrida por Deepak Chopra, nas suas ideias sobre a relação entre FQ e medicina:

(...) em 1989, surgiu outro livro seminal sobre a possível aplicação da física quântica na medicina. O livro se intitula Cura Quântica, e o seu autor é o hoje famoso Deepak Chopra (...). Chopra sugeria que talvez a mente interagisse com o corpo por meio de um corpo mecânico quântico e que quiçá a consciência auxiliasse a mediar a interação. Chopra estava sugerindo nada menos do que a causação descendente efetuada pela consciência, no estilo quântico (Goswami, [2004] 2006, pp. 68-69, grifos do autor).

E, de fato, assim como Chopra em A Cura Quântica, Goswami em O Médico Quântico faz uma simplificação da FQ, omitindo os seus debates e problemas de fundamentos e não mencionando a existência das suas diferentes interpretações e, basicamente, apresentando uma versão bem resumida das suas ideias apresentadas anteriormente em $O$ Universo Autoconsciente:

Na década de 1920, porém, a física passou por uma mudança colossal que a levou da sua antiga condição determinística clássica a uma nova física. Nessa nova física, chamada de física quântica, os objetos são descritos como ondas de possibilidade que podem estar em dois (ou mais) lugares ao mesmo tempo. No entanto, nenhuma lei física e nenhum algoritmo consegue determinar em que lugar um objeto se manifestará numa dada medição (Goswami, [2004] 2006, pp. 36-37).

Além disso, semelhantemente a Chopra, o físico indiano também faz uso de analogias entre as práticas e fenômenos relacionados à medicina alternativa e os fenômenos relacionados à FQ - mais especificamente às questões relacionadas ao papel da consciência em uma observação - muitas vezes distorcendo estes últimos, além de analogias com outros elementos a fim de promover o seu discurso, característico do Movimento da Nova Era.

(...) as tradições de medicina alternativa são fundamentalmente um tanto sutis, um tanto vagas. (...) O que eles fazem não é em geral quantificável, mas isso também não os preocupa. Para diagnosticar, eles normalmente usam a intuição, não máquinas. (...) A 
linguagem com que se expressam e comunicam é vaga. O que fazem é muito parecido com poesia.

(...) A física quântica também se assemelha muito à poesia. Em vez de determinismo, a física quântica fala de incerteza. Em vez de partículas ou ondas, desta ou daquela visão da física clássica, a física quântica introduz complementaridade, onda $e$ partícula, isto $e$ aquilo. E mais importante de tudo, a física quântica leva consciência à física: quem observa o que acontece com o que está sendo observado. Você pode imaginar que alguém fale de poesia sem falar sobre o poeta? (Goswami, [2004] 2006, p. 29, grifos do autor).

Nessa citação, nota-se mais explicitamente que o autor omite a existência dos debates de fundamentos e das diferentes interpretações da FQ, uma vez que não menciona que existem interpretações dessa teoria que se baseiam na existência somente de ondas, somente de partículas, de ondas e partículas e de ondas ou partículas. Inclusive, o autor distorce a noção de complementaridade (ver seção 3.3.3), que defende justamente que os resultados observados se manifestam como ondas ou partículas, e nunca como ondas $e$ partículas ao mesmo tempo. Também é possível notar o discurso típico da Nova Era, no qual existe uma rejeição a um "velho" paradigma - representado pela FC, a qual é caracterizada como determinista, materialista, uma mecânica associada a máquinas - a fim de promover o "novo" paradigma - baseado na FQ, a qual é caracterizada como indeterminista, mais subjetiva, idealista, centrada na consciência. Com isso, observa-se também um culto ao saber tradicional e à subjetividade, em detrimento do conhecimento objetivo. Por fim, a referência à FQ se centra, ou pelo menos atribui uma grande importância, nos debates em torno do papel da consciência no problema da medição, a fim de argumentar em prol da necessidade desta em qualquer processo de observação. Todas essas características se aproximam das características presentes na obra de Chopra, conforme analisadas anteriormente. E, de fato, nessa obra mais recente de Goswami, publicada uma década após $O$ Universo Autoconsciente - onde o autor se volta mais à sua formação de físico e se preocupa minimamente em apresentar a FQ de forma mais cuidadosa - o autor parece se aproximar mais de Chopra, um médico, não especialista em FQ. De tal forma que a FQ aparece em segundo plano, de forma simplificada e sem o cuidado prezado anteriormente, a fim de cumprir apenas o papel de um símbolo com autoridade persuasiva. O foco da obra, então, se volta a uma questão pragmática: a revitalização da medicina alternativa, como um sistema legítimo a ser adotado na busca da 
saúde e do bem estar na sociedade contemporânea. Essa mudança de foco, na obra de Goswami, fica evidente quando, no início do único capítulo que se propõe a discutir os conceitos da FQ - o capítulo 6, intitulado "Mais Física Quântica e suas contribuições à Medicina" -, o autor afirma "O capítulo trata menos de física quântica do que de suas contribuições para o novo paradigma de pensamento na medicina" (Goswami, [2004] 2006, p. 71).

Assim, também à semelhança de Chopra, o autor defende que a FQ nos fornece os elementos necessários à compreensão de fenômenos não compreendidos na medicina, como os processos de cura espontânea, entre outros:

A física quântica nos capacita a compreender fenômenos anômalos da medicina, como cura espontânea (como instâncias da criatividade quântica), cura a distância pela oração (como instâncias da não-localidade quântica) e autocura e cura espiritual (como causação descendente com intenção pura) (Goswami, [2004] 2006, p. 89).

E, a fim de demonstrar essa capacidade da FQ, o físico indiano abusa das analogias entre os fenômenos relacionados à consciência e o funcionamento da $\mathrm{FQ}$, e reconhece que se tratam apenas de analogias:

$\mathrm{Na}$ criatividade, acredita-se que o processamento inconsciente é responsável pela proliferação da ambiguidade do pensamento. Ele é o análogo da propagação da onda de possibilidade quântica entre medições (...). O insight criativo, por outro lado, é súbito e descontínuo. Ele é o análogo do salto quântico, um salto descontínuo de pensamento que não passa pelas etapas intermediárias. $\mathrm{O}$ processamento inconsciente produz uma multidão de possibilidades; insight é o colapso de uma dessas possibilidades (a nova possibilidade de valor) em manifestação (Goswami, [2004] 2006, p. 85, grifos do autor).

Mais adiante, porém, essas analogias com os conceitos da FQ são estendidas e adquirem um caráter mais realista, para, enfim, serem utilizadas na explicação de outros fenômenos, como a intuição, a criatividade, a telepatia, a reencarnação e os relacionados com a saúde e a cura, como a homeopatia e as emoções reprimidas.

Não tenha dúvida, a homeopatia é uma medicina quântica. O princípio quântico da correlação não-local é essencial para o modo como um remédio homeopático é preparado e administrado (Goswami, [2004] 2006, p. 173). 
Além disso, como recurso retórico, o autor também faz referência a experimentos que supostamente relacionariam esses fenômenos da consciência com conceitos da FQ, como a não-localidade, os quais possibilitariam transferência de mensagens à distância, através da consciência:

No experimento de Grinberg-Zylberbaum e colegas (1994), dois sujeitos meditam durante vinte minutos com a intenção de estabelecer comunicação (não-local) entre si. Depois de vinte minutos, eles continuam a meditação, (...) mas agora em duas gaiolas de Faraday separadas (...). Nessas condições, um dos sujeitos é exposto a uma série de flashes de luz que produzem atividade elétrica no cérebro dele (...). Surpreendentemente, as leituras EEG da companheira dele, quando decifradas, mostram que o potencial evocado, produzido pelos flashes de luz, foi transferido para o cérebro dela, sem nenhuma conexão local. (...) Isso é transferência de mensagem (Goswami, [2004] 2006, p. 80, grifos do autor).

Posteriormente, a referência a experimentos também é estendida aos fenômenos relacionados à cura, à consciência e à FQ:

O estudo analisado pelo cardiologista Randolph Byrd (1988) é um dos melhores para indicar a não-localidade quântica da cura. O estudo de Byrd, envolvendo 393 pacientes da Unidade de Atendimento Cardíaco o Hospital Geral de San Francisco, observou o efeito da oração à distância feita por vários grupos de oração domiciliar.

(...) Byrd concluiu que o efeito da oração, mesmo quando não-local, foi notavelmente positivo (Goswami, [2004] 2006, pp. 229-230).

Nesta obra, Goswami também reafirma a sua defesa de que o observador conscientemente tem o poder de escolher o resultado a ser observado em uma medição, e estende essa defesa para os fenômenos relacionados à saúde e à cura, afirmando que podemos conscientemente escolher observar um estado saudável para a nossa saúde:

A consciência produz o colapso dos sentimentos vitais juntamente com o órgão físico correlato (...) para suas experiências de vida.

(...) a nossa escolha da matriz do corpo vital é livre e a representação física tem uma possibilidade de corresponder a uma saúde perfeita sob qualquer condição ambiental interna e externa (Goswami, [2004] 2006, pp. 120-121).

Dessa forma, através da reunião de alguns elementos semelhantes aos utilizados por Chopra e outros recursos próprios - como a referência a experimentos para embasar os seus argumentos - o físico indiano caracteriza o que ele considera por cura quântica: 
(...) a cura mente-corpo deve envolver mudanças no significado-contexto que a mente estabelece para o funcionamento defeituoso dos corpos vital e físico. (...)

Os contextos do pensamento mental provêm do domínio supramental da consciência; para mudar para um novo contexto, nós, seres mentais, teremos de saltar para o supramental. Esse salto é um salto quântico descontínuo, e é por isso que esse tipo de cura é cura quântica (Goswami, [2004] 2006, p. 227).

No entanto, Goswami não se restringe ao conceito de "cura quântica", introduzido anteriormente por Chopra, mas o utiliza como parte de um projeto mais amplo: a defesa do que ele chama de "Medicina Integral", que se distingue da proposta de Chopra, principalmente por reconhecer o papel e atribuir utilidade à medicina convencional - a medicina alopática - de forma, a não rejeitá-la totalmente. Conforme o autor mesmo reconhece "a medicina alopática é oportuna e extraordinária quando é útil. O objetivo deste livro não é desacreditar a alopatia, mas complementá-la conforme seja necessário" (Goswami, [2004] 2006, p. 91). Assim, Goswami descreve as principais características da sua Medicina Integral na seguinte passagem:

O pensamento quântico no contexto do primado da consciência é o caminho, talvez o único, para desenvolver uma Medicina Integral que ofereça um fundamento metafísico para toda a medicina convencional com uma demarcação clara dos seus respectivos papéis no paradigma integrado (Goswami, [2004] 2006, p. 261).

Dessa forma, com o desenvolvimento das bases da sua Medicina Integral, em $O$ Médico Quântico, Goswami passou a integrar mais fortemente o circuito de "terapias quânticas", parte da comercialização da sua ampla gama de "produtos quânticos". Atualmente, esse circuito constitui uma parte importante dos seus produtos comercializados, que inclui livros, palestras, workshops, cursos, entre outros, os quais se voltam para diferentes públicos, desde pessoas interessadas na economia e no mundo empresarial, passando pelas interessadas na religião e na espiritualidade, na transformação social, até as interessadas na saúde e no bem estar.

O físico indiano, contudo, já se inseria no circuito de "terapias quânticas" desde os anos 1980, quando frequentava o Instituto Esalen, onde, juntamente com o médico John Lilly, entre 28 de novembro e 3 dezembro de 1982, ofereceu o workshop "Mind, Brain, and Unitive Consciousness", que buscava promover a terapia alternativa conhecida como "isolation tank", uma terapia que, através da privação sensorial, se propõe a proporcionar 
"estados alterados de consciência" (próximos ao meditativo ou ao psicodélico). Na ocasião, o workshop foi anunciado, ao custo de 390 dólares, o que equivaleria a um valor em torno de 950 dólares corrigidos para 2014 (Rocha, 2015, p. 117). Mais especificamente no Brasil, em meio a esses circuitos, Goswami costuma frequentar os Simpósios de Saúde Quântica e Qualidade de Vida, também conhecidos como ExpoQuantum, um evento que busca promover terapias alternativas usando explicações da FQ (Rocha, 2015, pp. 116-117). Além disso, nesse mesmo país, atualmente, o físico indiano ministra cursos online de "ativismo quântico", promovidos por uma instituição denominada "Quantum Academy", cujos custos giram em torno de 3000 reais (Ativismo quântico online, 2018) e cujo um trecho de sua propaganda é apresentado a seguir:

A ideia de transformação pessoal é a ideia de você se tornar uma pessoa mais feliz, sendo o ativismo quântico o caminho pelo qual Amit Goswami é capaz de te guiar. (...) A visão de mundo quântica traz um método científico, com dados experimentais amplamente verificados, para a transformação espiritual! (Ativismo quântico online, 2018).

A partir desse trecho da promoção mais recente desses cursos, é possível notar a consolidação do termo "quântico" como um símbolo com autoridade persuasiva, baseado em argumentos de autoridade cientifica, do caráter pragmático das suas últimas produções, voltado para a promoção do bem estar pessoal, além do aspecto mercantil que suas ideias adquiriram. Este último aspecto não será aprofundado no presente estudo, porém é possível notar que ele provavelmente possui sua origem já no sucesso de vendas de $O$ Tao da Física, de Fritjof Capra, que o levou a abandonar a carreira acadêmica. Esse aspecto parece se manter e se tornar mais intenso, a medida que os autores desse gênero também abandonam suas carreiras acadêmicas e passam a depender financeiramente de direitos autorais.

\subsection{A circulação das ideias e a formação da relação entre misticismo e Física Quântica}

Nas seções anteriores deste capítulo, foi feita uma discussão inicial e um levantamento das principais pesquisas realizadas anteriormente acerca do chamado "fenômeno cultural do misticismo quântico", além de um panorama sobre três dos principais autores do Movimento da Nova Era, os quais contribuíram para o estabelecimento e o fortalecimento 
da relação entre FQ e misticismo. Assim, partindo desses levantamentos, nesta seção, se pretende realizar uma leitura fleckiana sobre o movimento geral de circulação das ideias, que permitiu com que a relação entre FQ e misticismo se estabelecesse e culminasse no fenômeno de interesse para a presente pesquisa: o misticismo quântico.

Na seção 3.4.3, foi descrita a formação e a estrutura do coletivo de pensamento dos pesquisadores em Fundamentos da FQ, o qual possuía diferentes núcleos para o círculo esotérico, cada um deles correspondente a cada uma das interpretações da FQ (ver Figura 5). Conforme destacado anteriormente, esses núcleos possivelmente não se encontram totalmente separados entre si, podendo apresentar intersecções, principalmente no que se refere à adoção de uma postura mais realista ou mais positivista/instrumentalista com relação à interpretação e à descrição dos fenômenos quânticos (esse aspecto, no entanto, não será aprofundado neste trabalho). Essa estrutura composta por vários núcleos, por si só, já distingue e destaca esse coletivo frente aos coletivos de pensamento de outras áreas de pesquisa da Física, os quais, em sua grande maioria, apresentam um único núcleo para o círculo esotérico. Porém, além disso, ela o torna especial, por propiciar internamente uma circulação do conhecimento mais intensa, movida principalmente pelos debates e discordâncias entre os adeptos das diferentes interpretações da FQ - isto é, entre os membros dos diferentes núcleos do círculo esotérico do coletivo - acerca das questões de fundamentos que permaneceram em aberto. De fato, conforme ressaltado por Fleck, quando um coletivo de pensamento possui mais de um núcleo, se torna "impossível estabelecer uma postura dos indivíduos com relação aos seus produtos específicos: ela sempre oscilará entre a simples admiração e o criticismo. Por conta dessa oscilação, esses produtos estão constantemente em um estágio de instabilidade" (Fleck, [1936]1986, p. 104, tradução livre). Além disso, Fleck também destaca que os coletivos de pensamento científicos, em geral, possuem um único núcleo, onde se situam os especialistas específicos e, em torno do qual se encontra o círculo esotérico, onde se situam os especialistas gerais, que, por sua vez, se encontra dentro do círculo exotérico, onde se situa o público de formação geral (ver Figura 2), essa estrutura permite que os produtos desse coletivo possuam uma certa estabilidade. Sendo assim, pode-se dizer que, por se tratar de um coletivo de pensamento científico, o coletivo de pensamento dos pesquisadores em Fundamentos da FQ, por muito tempo - para não dizer até os dias atuais -, buscou tentar conciliar as diferentes interpretações da FQ em uma única interpretação 
ou simplesmente apresentar uma interpretação do formalismo que explique melhor os fenômenos da FQ, a fim de fundir os vários núcleos do coletivo em um único. Atualmente, devido ao número crescente de interpretações da $\mathrm{FQ}$, parece não haver perspectiva de que se chegue a um consenso a respeito de uma interpretação única, contudo, a busca por atingir esse objetivo irá promover um debate mais intenso e uma maior circulação das ideias tanto intra como intercoletiva. Dessa forma, esses debates e sua consequente circulação das ideias serão movidos pela busca de uma maior "coerção do pensamento" com relação às questões de Fundamentos da FQ - a saber, o problema da medição, as questões em torno da causalidade, do determinismo e da completude da FQ, entre outras - sobre as quais não há um consenso dentro do coletivo. Essa busca por uma maior coerção do pensamento ou pela consolidação de novos fatos acerca destas questões é o que possibilitará uma maior abertura do coletivo a novas ideias.

Isso, no entanto, não significa que o coletivo de pensamento com essa característica não possua um estilo de pensamento próprio mais geral - isto é, uma "disposição (Bereitschaft) para um sentir seletivo e para um agir direcionado correspondente" ou uma "percepção direcionada em conjunção com o processamento correspondente no plano mental e objetivo" (Fleck, [1935]2010, p. 149) -, mas apenas que esse coletivo busca uma maior coerção do pensamento ou a consolidação de novos fatos acerca das questões de seu interesse, que se apresentam em aberto. Assim, em meio a esse processo, a utilização de acoplamentos ativos na busca de respostas a essas questões por parte do coletivo de pensamento se torna mais intensa. Esse tipo de acoplamentos é o resultado de situações consideradas "livremente inventadas", dependentes da escolha do indivíduo, nas quais todas as possibilidades tenderiam ao "subjetivo". Eles são importantes na construção de um fato, por possibilitarem um primeiro sinal de resistência no pensamento inicial caótico, seguido de uma certa coerção do pensamento, para finalmente estabelecer uma forma (Gestalt), a ser percebida de maneira imediata. Além disso, conforme Fleck ressalta, os acoplamentos ativos vêm sempre acompanhados de um aumento no número de acoplamentos passivos, isto é, de situações consideradas obrigatoriamente ocorridas, independentemente da escolha dos indivíduos, capazes de transmitir a impressão do "real", do "efetivo". Ambos, acoplamentos ativos e passivos, crescem à medida que se aprofunda em uma determinada área do conhecimento. Com isso, essa demanda interna do coletivo de pensamento, juntamente com uma maior abertura a novas ideias e a utilização 
de um maior número de acoplamentos ativos, possibilitou a proliferação das diferentes interpretações da FQ, bem como de interpretações acerca das questões de Fundamentos dessa teoria, que terminaram por fugir do âmbito da Física - como os paralelos e analogias entre os fenômenos da FQ e fenômenos relacionados ao misticismo, à saúde e à cura, por exemplo. Inclusive, justamente a partir destas últimas, é que foi possível estabelecer a relação entre FQ e misticismo.

Vale ressaltar, no entanto, que, além da demanda interna do coletivo, a formulação dessas interpretações que fogem do âmbito da Física, bem como o estabelecimento da relação entre FQ e misticismo, só foram possíveis devido a uma predisposição social geral somada a uma predisposição específica interna ao coletivo de pensamento, de tal forma que o condicionamento social perpassou todas as etapas da formação dessa relação. $\mathrm{O}$ contexto social mais amplo no final do século XIX, antes do início do advento da FQ, por exemplo, conforme descrito na seção 3.5.1, era um contexto permeado pelo espírito do neorromantismo, caracterizado por um antimaterialismo generalizado, que contribuiu para a formação de tendências na Física que criticavam e concorriam com a MC em sua versão laplaciana do newtonianismo - como os programas que tomavam o éter ou a energia como conceitos unificadores, que consistiriam em substâncias não materiais, capazes de fundar toda a Física. Assim, devido ao seu antimaterialismo generalizado e a sua contraposição às concepções laplacianas da MC, esse contexto, possivelmente advindo das protoideias relacionadas ao naturalismo animista e à reformulação da noção de determinismo (ver seção 3.6), posteriormente, pode ter influenciado e propulsionado, ainda que de forma indireta, os debates em torno da causalidade e do determinismo na FQ e as concepções idealistas dessa teoria - principalmente no que concerne ao problema da medição -, nas quais a consciência exerceria um importante papel. Além disso, as concepções advindas desse contexto, também de forma indireta, possivelmente podem ter influenciado as concepções filosóficas de alguns físicos que contribuíram na construção da FQ, como: a concepção idealista/platônica de Heisenberg e as suas críticas à visão materialista sobre os átomos; o misticismo platônico lúcido de Pauli e a sua defesa de que os pensamentos científico e místico seriam, ao mesmo tempo, divergentes e complementares; a simpatia de Schrödinger com a ideia de que a mente ou a consciência pudesse exercer algum papel no processo de medição e a sua postura avessa ao positivismo; e as ênfases na necessidade 
de observadores conscientes nos processos de medição, por parte de von Neumann, London Bauer, Wigner, Stapp, entre outros.

Mais adiante, o contexto sociocultural anterior à consolidação da $\mathrm{MQ}$, referente ao período da República de Weimar (1918-1927), na Alemanha, se apresentou como um ambiente intelectual hostil aos valores tradicionais da Física (ver seção 3.5.2), cuja tendência intelectual era caracterizada por uma "filosofia da vida" existencialista (Lebensphilosophie), neorromântica, que se alimentava de crises e era marcada pelo antagonismo em relação à racionalidade analítica e às ciências exatas e suas aplicações técnicas. Esse contexto sociocultural pode ser considerado um herdeiro do neorromantismo do final do século XIX, e contribuiu mais fortemente e diretamente para a intensificação dos debates em torno da causalidade e do determinismo na FQ (Forman, 1983). Além disso, as manifestações contra o cientificismo, o utilitarismo, a racionalidade analítica e o positivismo, ocorridas nesse período, somados à exaltação do holismo e da intuição, ao relativismo e ao existencialismo, ainda que indiretamente, também podem ter contribuído para o fortalecimento de concepções idealistas da FQ, das ênfases no papel da consciência nos processos de medição, e para o estabelecimento de vínculos da Ciência, em especial da FQ, com concepções místicas de mundo. Vale ressaltar também que, durante esse período, alguns físicos que trabalhavam com a FQ passaram a se interessar por filosofias orientais ou concepções místicas de mundo - como Bohr, Heisenberg, Pauli, Schrödinger e Eddington - e que Bohr, inclusive, chegou a utilizar o conceito de complementaridade para defender publicamente que as emoções e percepções possuíam uma relação complementar análoga às situações das medidas na Física atômica (ver seção 3.5.5).

Posteriormente ao estabelecimento da MQ, internamente ao coletivo de pensamento dos físicos que trabalhavam com Fundamentos da FQ, se seguiram os debates em torno da interpretação do formalismo dessa teoria e de suas questões de fundamento. Entre meados dos anos 1920 e meados dos anos 1930, houve importantes avanços teóricos para a MQ e importantes contribuições para os debates em torno da sua interpretação, como a consolidação dos formalismos matricial e ondulatório, o Princípio da Incerteza de Heisenberg, a teoria da onda-piloto de de Broglie, o Princípio da Complementaridade de Bohr, a formulação do chamado "problema da medição", os famosos debates entre 
Einstein e Bohr nos $5^{\circ}$ e $6^{\circ}$ Congressos de Solvay, a prova de impossibilidade de von Neumann e a formulação do paradoxo EPR. Inicialmente, o resultado desses debates, entre os anos 1930 e o final dos anos 1940, foi a chamada "monocracia da Escola de Copenhagen" na filosofia da MQ, que permaneceu praticamente incontestável e consolidou a Interpretação da Complementaridade como a "interpretação ortodoxa". Somente no início dos anos 1950 é que essa situação começou a mudar, com o contexto sociocultural do pós-guerra, no qual a americanização da pesquisa e a influência de uma postura mais pragmática com relação à $\mathrm{FQ}$, no ocidente, não foram muito favoráveis para o entendimento das ideias de Bohr, enquanto que, na URSS, essas ideias eram acusadas de promover tendências idealistas na ciência e foram praticamente banidas. Assim, houve uma maior abertura para o desenvolvimento de interpretações alternativas à interpretação ortodoxa - a qual propiciou o advento da interpretação causal de David Bohm, o Programa de Amplificação Termodinâmica, a Interpretação de Muitos Mundos de EverettDeWitt, entre outras - e também para um debate mais aprofundado sobre o problema da medição, em particular, sobre a necessidade de um observador consciente no processo de medida. Assim, conforme visto na seção 3.4.3, nesse período, entre outros fatores, foi o condicionamento social geral somado a uma predisposição interna ao coletivo de pensamento dos pesquisadores em Fundamentos da FQ que permitiu com que esse coletivo se consolidasse com uma estrutura composta de múltiplos núcleos para o círculo esotérico, conforme ilustrado na Figura 5.

Ainda dentro desse contexto, durante o período da Guerra Fria, nos EUA, também houve a chamada "crise do Sputnik", desencadeada pelo lançamento do satélite Sputnik 1 pela URSS, que causou uma repercussão imediata e desesperada nos EUA, acarretando no aumento vertiginoso de investimentos em pesquisa aplicada e em educação científica - e, consequentemente, em um aumento do número de títulos de $\mathrm{PhD}$ em física -, em uma tentativa de alcançar os russos na corrida espacial e tecnológica. Contudo, após o desespero inicial, nos anos 1970, e com o advento da Guerra do Vietnã, seguiu-se uma queda abrupta desse investimento, acarretando em um aumento considerável na taxa de desemprego e em um quadro no qual a maioria dos recém-doutores em Física estava desempregada (ver seção 3.5.3). Esse quadro se encontrava justamente em meio ao contexto da contracultura hippie, nos EUA, que consistia em uma época marcada por diversas mudanças culturais, emergência das contraculturas e uma intensa agitação 
política. Esse contexto mais amplo possibilitou com que a Califórnia oferecesse, como nenhum outro lugar do mundo, uma riqueza de centros universitários de elite, lado a lado, a uma miríade de organizações religiosas orientais, que, juntamente com o quadro de desemprego mais específico no âmbito da Física, permitiu com que físicos formados em instituições acadêmicas de elite, não seguissem carreiras acadêmicas convencionais e perseguissem seus interesses de pesquisa, buscando fontes de fomento alternativas. Assim, diversos físicos se organizaram em grupos e instituições não convencionais, como o Fundamental Fysiks Group e o Instituto Esalen, para debater as questões de Fundamentos da FQ de forma mais informal e livre, de tal forma que os debates em torno do Teorema de Bell, por exemplo, deram origem ao estudo da relação das ações à distância com a clarividência, a psicocinese, a parapsicologia ou o holismo. Além disso, esses novos grupos e instituições não acadêmicos convencionais permitiram a reunião e a troca de experiências entre físicos que, posteriormente, estabeleceriam e fortaleceriam a relação entre FQ e misticismo de forma mais explícita - como Fritjof Capra, Fred Allan Wolf, Amit Goswami, entre outros -, sendo responsáveis pela gestação de um grupo que, posteriormente, formaria o coletivo de pensamento dos místicos quânticos, ainda que alguns deles, mais adiante, abandonariam essa temática - como Capra, por exemplo, que passou a se dedicar a outros assuntos. Novamente, portanto, o condicionamento e a predisposição social geral somados a uma predisposição interna específica permitiram com que o coletivo de pensamento dos pesquisadores em Fundamentos da FQ se abrisse para explorar os problemas de fundamento de forma mais livre, de acordo com seus interesses pessoais - os quais, muitas vezes, se relacionavam com fenômenos que fugiam do âmbito restrito à Física -, formando grupos e instituições, que reuniam os indíviduos com interesses similares e que não necessitavam seguir as regras das instituições acadêmicas convencionais. Isso possibilitou uma circulação dos saberes mais livre, tanto intra como intercoletiva, e, portanto, uma transformação no estilo de pensamento no sentido de estabelecer uma relação entre FQ e misticismo de forma mais concreta, a qual será mais bem explorada mais adiante.

Por fim, nos anos 1980 e 1990, o movimento de contracultura dos anos 1960 e 1970 se transformou no movimento de cybercultura, no qual os protestos, os ideais utópicos e o anticonsumismo, característicos da contracultura hippie, posteriormente, acabaram se rendendo ao individualismo, ao narcisismo e ao consumismo promovidos pela Indústria 
Cultural. Essas mudanças no contexto mais amplo acabaram por se refletir no contexto mais específico, e fazer com que o Movimento do Potencial Humano, das décadas de 1960 e 1970, se transformasse no Movimento da Nova Era, dos anos 1980 e 1990, um movimento progressivamente mais apolítico, conformista e muito mais próximo à literatura de autoajuda (ver seção 3.5.4). O Movimento da Nova Era pode ser caracterizado por uma tendência a ser epistemologicamente individualista, marcado por orientações do tipo: "você é livre para seguir o que sugere o seu espírito". Alguns de seus adeptos levam essa postura ao extremo, defendendo que nada daquilo que está situado além deles mesmos (de seu eu interior) possui uma existência autônoma. A Nova Era também defende uma espécie de liberdade, vinculada à liberação do passado, do tradicional e de tradições internalizadas, as quais estariam ligadas ao ego, porém, ao mesmo tempo, seu discurso se caracteriza por uma espécie de perenialismo, e procura constantemente redesenhar os seus ensinamentos e práticas, baseados em algumas tradições - da xamânica ao budismo - e defender que algumas verdades já se encontravam no coração dessas tradições. Dentro dessa concepção, atrelado a esse movimento, também se encontra o chamado "Neoesoterismo", termo que designa a forte expansão e disseminação, em âmbito mundial, das práticas comumente agrupadas sob a denominação de "esotéricas" e abriga uma ampla gama de produtos, atividades e serviços - entre eles, os seus característicos livros de autoajuda -, os quais angariam um público consumidor, evidenciando o caráter verdadeiramente mercadológico desse fenômeno. O Neoesoterismo também busca fundamentar as suas práticas e produtos de diversas formas, baseando-se em alguns sistemas de pensamento e religiões de origem oriental, em algumas correntes espiritualistas, e até em propostas inspiradas em certos ramos da ciência contemporânea, como a FQ. Esse último tipo de tentativa de embasamento para o Neoesoterismo deu origem aos chamados "produtos e terapias quânticos" e teve entre seus principais precursores nomes como Fritjof Capra (com seu livro O Tao da Física), Fred Allan Wolf e Gary Zukav. Nesses últimos tipos de produtos e terapias, em sua forma mais recente, após os anos 1980, é possível notar a forte presença dos discursos e características do Movimento da Nova Era, assim como do caráter mercadológico do Neoesoterismo, e pode-se dizer que, devido ao seu enorme sucesso de vendas, eles foram os responsáveis por divulgar e consolidar a relação entre FQ e misticismo que havia sido iniciada de forma 
mais concreta nos anos 1970, e que culminou no fenômeno cultural do misticismo quântico.

A partir da análise desse longo processo histórico, portanto, fica evidente que o condicionamento social perpassou todas as etapas da formação da relação entre a FQ e o misticismo, de tal forma que o sucesso alcançado pela obra de Fritjof Capra, $O$ Tao da Física - normalmente considerada a principal precursora da formação dessa relação (ver seção 4.2.1) -, foi possível somente devido ao contexto em que estava inserida, referente à contracultura hippie da Califórnia, nos EUA. Essa constatação está em concordância com a concepção de Fleck, segundo a qual o potencial e a subjetividade individuais na formulação de um determinado conhecimento não são desconsiderados, mas ressalta-se que essa atuação será sempre limitada pelas condições sociais em que se inserem, pois "as façanhas pessoais (...) só têm durabilidade quando exercem um efeito sugestivo, isto é, quando surgem num momento social favorável" (Fleck, [1935]2010, p. 88). De fato, para Fleck, somente uma comunidade ou um coletivo de pensamento, e não os indivíduos, possui a real força de estabelecer e promover este conhecimento, pois é esse coletivo que media as relações entre o passado e o futuro de um conhecimento, por ser o portador comunitário do desenvolvimento histórico de uma determinada área do conhecimento e por ter a capacidade de legitimá-lo e propulsioná-lo. Dessa forma, a relação estabelecida entre a FQ e o misticismo não pode ser considerada um produto livremente inventado por indivíduos, mas que surgiu somente quando alguns físicos pesquisadores das questões de Fundamentos da FQ - portanto, portadores do desenvolvimento histórico dessa área interessados em questões que transcendiam o âmbito da Física e que se relacionavam, de alguma forma, com o misticismo - como a parapsicologia, a psicocinese e a clarividência -, puderam se reunir em grupos e instituições, como o Fundamental Fysiks Group e o Instituto Esalen, e trocar ideias sem precisar seguir as regras das instituições acadêmicas convencionais.

Além disso, ao longo de todo o processo histórico da formação dessa relação, desde o final do século XIX - e talvez até antes - até os dias atuais, foi possível observar a presença de ideias que se mantiveram e se reforçaram com o passar do tempo. Tratam-se das protoideias, isto é, as pré-ideias mais ou menos vagas e confusas, ou pré-disposições histórico-evolutivas que antecederam a formação dessa relação, as quais se associariam 
com fatos científicos por meio de ligações evolutivas incontestáveis, sem que essas ligações pudessem ser legitimadas pelos conteúdos (ver seção 2.2). Algumas dessas ideias seriam: a negação da existência de um determinismo e uma causalidade intrínsecos na Física e na Ciência em geral, e a ideia de que a consciência seria capaz de interferir na matéria. Atreladas a essas ideias, também estaria uma postura de rechaço a concepções materialistas e a simpatia ou inclinações por posturas mais idealistas de mundo, além de uma exaltação da intuição e da subjetividade como formas de conhecimento, em detrimento da objetividade e racionalidade analítica.

Sendo assim, a partir da identificação desses aspectos, pode-se interpretar o estabelecimento da relação entre FQ e misticismo como o advento de um novo fato, surgido a partir da transformação de um estilo de pensamento. Em sua epistemologia, Fleck se interessa principalmente pela gênese e o desenvolvimento dos fatos científicos (ver seção 2.3), os quais ele descreve como consistindo de uma "relação de conceitos conforme o estilo de pensamento" (Fleck, [1935]2010, p. 132), ou um aprender a fazer perguntas em um contexto específico, até que as observações estejam "adaptadas aos fatos", até a tradição, a educação e o hábito terem gerado uma disposição para um sentir e um agir de acordo com um estilo, isto é, um sentir e agir direcionados e restritos, ou um "sinal de resistência (Aviso eines Widerstandes), que se opõe à voluntariedade livre do pensamento" (Fleck, [1935]2010, p. 151), ou ainda, uma resistência ao ver arbitrário e sem forma. No caso estudado, o estabelecimento da relação entre FQ e misticismo não consistiu na formação de um fato científico, porém na formação de um fato ligado ao âmbito sociológico, que terminou por transcender a Ciência, mas que teve as suas origens nela, especificamente nos debates em torno de questões em aberto sobre os Fundamentos da FQ, como o problema da medição e da causalidade, do determinismo, da completude e da não-localidade na FQ. Esse processo também passou pela formação de organizações não acadêmicas convencionais, como o Fundamental Fysiks Group e o Instituto Esalen, as quais, em meio a um contexto social favorável, possibilitaram o leve deslocamento dos debates unicamente em torno das questões de Fundamentos da FQ, para discutir o problema em aberto referente às consequências do Teorema de Bell (ver seção 3.2.2) - o qual aponta para a não-localidade dos fenômenos quânticos nas interpretações realistas da TQ - e a sua possível relação com fenômenos como a clarividência, a psicocinese, a parapsicologia e o holismo. Pode-se dizer que esses últimos estudos consistiram em uma 
busca por acoplamentos ativos, que pudessem fazer com que as observações estejam "adaptadas aos fatos" e que fossem mobilizados de acordo com os interesses do pequeno coletivo de pensamento, que se formava nesses grupos e organizações independentes. $\mathrm{O}$ interesse por parte de um coletivo de pensamento é um fator importante porque, para Fleck, "cada fato tem que se alinhar ao interesse intelectual do respectivo coletivo de pensamento, pois somente há resistência onde existe alguma aspiração" (Fleck, [1935]2010, pp. 151-152), no caso, esses interesses claramente possuíam vínculos com algum tipo de misticismo. Por fim, a influência desses estudos em torno do Teorema de Bell na formação da relação entre FQ e misticismo se evidencia no fato de que os quatro livros analisados neste trabalho - O Tao da Física de Capra, A Cura Quantica de Chopra e $O$ Universo Autoconsciente e $O$ Médico Quântico de Goswami - fazem referência a esse teorema.

A formação desse novo coletivo de pensamento, interessado nas relações entre o Teorema de Bell e fenômenos relacionados ao misticismo e, posteriormente, na relação entre a FQ e o misticismo no geral, contudo, começou a ganhar força e se estabelecer de forma mais clara, somente após a publicação, em 1975, do Tao da Física, de Fritjof Capra, quem também era frequentador dos grupos e organizações mencionados. De fato, conforme visto na seção 4.2.1, Capra criou um novo gênero literário, ou um autêntico novo estilo de pensamento, se tornando o precursor de diversas obras inspiradas na sua, entre as quais, as obras de Deepak Chopra e Amit Goswami, que aprofundam os paralelos entre a FQ e o misticismo apontados por Capra, transformando-os em analogias de caráter realista, e os aplicam a novas e diferentes áreas, que abrangem desde a saúde e a cura, passando por fenômenos parapsicológicos e mentais, até a economia e os conflitos sociais (ver seções 4.2.2 e 4.2.3). Essas obras inspiradas em Capra também conservam boa parte de suas teses e hipóteses, além de várias características presentes em seu discurso, conforme explicitado nas seções 4.2.2 e 4.2.3. Pode-se afirmar também que esse novo estilo de pensamento é parte dos movimentos mais amplos da Nova Era e do Neoesoterismo - herdeiros do movimento de contracultura hippie dos anos 1970 -, com a característica de buscar seus fundamentos na FQ. Isso porque esse novo estilo de pensamento apresenta o discurso do advento de novos tempos, representados pela FQ, em contraposição aos velhos e ultrapassados vinculados à FC - no qual a primeira estaria vinculada a um modo de vida mais pleno, que valorizaria a mente e a consciência, 
enquanto que a segunda estaria vinculada a um modo de vida mecânico e materialista -, além do discurso de uma espécie de filosofia perenialista, na qual algumas verdades já estariam presentes na sabedoria de tradições mais antigas e que estariam sendo comprovadas e evidenciadas com o advento da FQ. Além disso, esse novo estilo de pensamento apresenta a ampla gama de produtos, serviços e práticas comumente denominadas "esotéricas", característicos do Neoesoterismo, entre os quais estão os típicos livros de autoajuda, os cursos, palestras e workshops, que vinculam a FQ com diversos temas e áreas de interesse, como a saúde, o bem estar, a religiosidade, o mundo empresarial e os conflitos sociais. Por fim, esse novo estilo de pensamento adquiriu uma identidade e características próprias a ponto de, atualmente, ser conhecido como o fenômeno cultural do misticismo quântico.

Dessa forma, portanto, uma possível leitura para a formação desse novo fato - a relação entre FQ e misticismo - que, simultaneamente, deu origem a um novo estilo de pensamento, seria a de que Fritjof Capra introduziu um ver inicial, confuso e pouco claro, através do seu paralelismo quântico, sem a adequação completa das primeiras observações, referentes às semelhanças entre os fenômenos da FQ e o misticismo oriental. Posteriormente, contudo, seus seguidores, entre eles, Chopra e Goswami, transformaram esse ver inicial em um ver formativo, através da formulação de novos conceitos - como a cura quântica, o ativismo quântico, a filosofia do idealismo monista, a Medicina Integral, entre outros - fazendo com que a forma, antes pouco clara e confusa, fosse percebida de maneira imediata - por meio das analogias de caráter realista e da adequação dos fenômenos aos conceitos formulados -, tornando-se uma resistência ao ver arbitrário e sem forma, de tal forma que a percepção da forma desenvolvida passou a ser reprodutível conforme o novo estilo de pensamento que se consolidava. Assim, dentro dessa possibilidade de leitura, a formação da relação entre FQ e misticismo poderia ser descrita com os termos fleckianos acerca do surgimento de novos fatos: primeiro um sinal de resistência no pensamento inicial caótico, depois uma certa coerção do pensamento e, finalmente, uma forma (Gestalt) a ser percebida de maneira imediata.

Contudo, conforme Fleck destaca, para se adquirir a predisposição de perceber o direcionado, se paga o preço de não mais poder perceber o heterogêneo, ou seja, o aumento da habilidade de perceber a forma imediatamente - o ver formativo -, se dá na 
mesma proporção da perda da habilidade de observar o contraditório, determinando aquilo que "não pode ser pensado de outra maneira". A partir dessa diminuição da percepção do contraditório, abre-se a possibilidade de criar o que Fleck denomina por harmonia das ilusões, isto é, um sistema fechado e harmonioso, que gera uma realidade evidente dentro da qual a "origem lógica de determinados elementos não pode ser mais encontrada" (Fleck, [1935]2010, p.80). Esse sistema de ideias promove uma intrínseca harmonia no estilo de pensamento e tende a persistir continuamente diante de tudo que o contradiga, a partir da anulação do considerado potencialmente incongruente por parte dos membros do coletivo. No caso da formação da relação entre FQ e misticismo, não se pode afirmar de forma categórica que uma harmonia das ilusões chegou a ser formada. Contudo, a partir da análise das seções 4.2.1, 4.2.2 e 4.2.3, foi possível perceber que a maioria dos herdeiros de Capra, utilizou-se da Física que havia sido popularizada principalmente em $O$ Tao da Física, apresentado-a como uma Física já bem estabelecida, de forma autoritária e fechada a questionamentos, omitindo, inclusive, a existência de diversas interpretações para a FQ. Uma exceção a essa atitude foi Amit Goswami, em $O$ Universo Autoconsciente, no qual ele apresenta os debates em torno das questões de Fundamentos da FQ em detalhe, a fim de formular uma interpretação própria, contudo, em suas obras posteriores, ele se utiliza da popularização da FQ realizada nesta sua primeira obra mística, também como uma Física já bem estabelecida, sem abertura a questionamentos. Esse tipo de atitude por parte desses autores gera uma realidade evidente, que dificulta a identificação da origem lógica dos elementos a respeito dos problemas de Fundamentos da FQ, facilitando a formação de uma harmonia das ilusões. Além disso, tanto Chopra quanto Goswami ignoram as limitações de suas analogias entre os fenômenos da FQ e os relacionados ao misticismo, e fazem afirmações e apresentam conceitos que modificam as concepções originalmente formuladas nos debates entre os físicos pesquisadores em Fundamentos da FQ (propositadamente ou não), a fim de abarcar os fenômenos místicos em suas explicações. Esse tipo de atitude se aproxima das tentativas de adaptação do cognoscente à visão do estilo de pensamento desse coletivo e da anulação do considerado potencialmente incongruente por parte de seus membros, uma característica típica da tentativa de preservar um sistema de ideias relativamente eficaz, como a harmonia das ilusões.

Portanto, nota-se que esse novo estilo de pensamento atrelado ao fenômeno cultural do misticismo quântico, característico do novo coletivo de pensamento formado por nomes 
como Fritjof Capra, Deepak Chopra e Amit Goswami, surgiu a partir de um coletivo de pensamento próprio da Ciência - o coletivo de pensamento dos pesquisadores em Fundamentos da FQ - e foi capaz de produzir um sistema de ideias relativamente eficaz. Esse sistema de ideias, apesar de, talvez, não se configurar em uma harmonia das ilusões, foi capaz formular conceitos e explicações próprias para os fenômenos de seu interesse como a cura quântica, o ativismo quântico, a filosofia do idealismo monista, a Medicina Integral, entre outros -, os quais se apresentaram como o conteúdo concreto desse estilo de pensamento. Para Fleck, esses conteúdos concretos podem ser condicionados por três tipos de fontes: (1) a ideogênese pré-histórica ou as chamadas protoideias; (2) as mudanças advindas da contínua migração das ideias dentro do coletivo; e (3) constantes efeitos de outros estilos.

Conforme descrito anteriormente, as prováveis fontes do tipo (1), que influenciaram na formação dos conteúdos concretos do estilo de pensamento do misticismo quântico, foram as protoideias descritas na seção 3.6: a ideia de que a consciência seria capaz de interferir na matéria e a negação da existência de um determinismo e uma causalidade intrínsecos na Ciência. De fato, conforme analisado nas seções 3.5, 3.6 e 4.2, elementos e influências dessas protoideias estiveram presentes ao longo de toda a história de formação do coletivo de pensamento do misticismo quântico, estando fortemente presentes nas ideias de seus membros, como, por exemplo, nas suas posturas idealistas e antimaterialistas, nas suas críticas à objetividade acompanhadas de uma valoração da intuição e dos saberes tradicionais, entre outras.

As fontes de tipo (2), por sua vez, se referem à circulação intracoletiva das ideias, as quais podem ocorrer de duas formas: (2a) através dos diálogos e trocas de ideias entre os próprios especialistas, ou seja, entre dois participantes em posição mentalmente igual de um mesmo coletivo de pensamento; ou ( $2 b$ ) através da relação entre os círculos esotérico e exotérico do coletivo, os quais, no caso do coletivo de pensamento dos pesquisadores em Fundamentos da FQ, correspondiam ao saber especializado e ao saber popular, respectivamente.

No caso da circulação das ideias intracoletiva da forma (2a), conforme visto nas seções 3.1 e 3.2, os problemas de Fundamentos da FQ e a existência de diferentes interpretações para a FQ levaram a intensificação dos diálogos e trocas de ideias entre os 
especialistas do coletivo de pensamento dos pesquisadores em Fundamentos da FQ, entre os quais, podemos citar os diálogos entre Einstein, Bohr e os outros fundadores dessa teoria, em torno da causalidade, do determinismo, da completude e da não-localidade na $\mathrm{FQ}$, e os debates entre os adeptos das diferentes interpretações da FQ, em torno do problema da medição e o papel da consciência nessa teoria. Nesses diálogos e debates, ficava clara a contraposição entre posturas filosóficas de caráter mais realista e outras de caráter mais idealista ou positivista, em particular, nos debates em torno do problema da medição, essa contraposição se apresentava entre posturas de caráter mais materialista e de caráter mais idealista. Assim, nota-se que o discurso marcado por uma postura fortemente antimaterialista, por parte do coletivo de pensamento dos místicos quânticos, é proveniente destes últimos debates e, portanto, da circulação intracoletiva das ideias no coletivo de pensamento dos pesquisadores em Fundamentos da FQ, através dos diálogos e trocas de ideias entre os seus especialistas.

Já a circulação das ideias intracoletiva da forma (2b) também exerceu um importante papel na formação dos conteúdos concretos do estilo de pensamento do misticismo quântico, pois, conforme analisado na seção 4.2.1, diferentemente de Heisenberg e outros físicos fundadores da TQ - os quais, ao escreverem sobre questões filosóficas relacionadas a essa teoria, escreviam para uma elite cultural, composta por físicos, filósofos e historiadores da Ciência -, Capra escrevia como um popularizador de Ciências, voltando-se para a cultura de massas. O sucesso de vendas de $O$ Tao da Física possibilitou com que a FM se popularizasse amplamente, contudo, a popularização ocorreu da forma exposta por Capra, incluindo as suas hipóteses e defesas pessoais e os seus paralelos com o misticismo oriental. De tal forma que os seus herdeiros, entre os quais estão Chopra e Goswami, passaram a apresentar boa parte de suas ideias como parte de uma Física bem estabelecida e corroborada pelo coletivo de pensamento dos físicos quânticos. Nessa popularização, em geral, conforme analisado nas seções 4.2.1, 4.2.2 e 4.2.3, grande parte dos problemas de Fundamentos da FQ eram omitidos, simplificados ou apresentados como já tendo sido resolvidos e a existência de diferentes interpretações para a FQ não era mencionada. Uma exceção foi Amit Goswami, em sua obra O Universo Autoconsciente, porém, em suas obras posteriores, a sua postura passa a ser semelhante à dos outros herdeiros de Capra. A partir da popularização iniciada por Capra, portanto, pode-se dizer que se formou a visão de mundo de todo um estilo de pensamento, o qual, posteriormente, 
se consolidou como o estilo de pensamento do misticismo quântico. De fato, para Fleck, a Ciência popular consiste em uma ciência para não especialistas, a qual se caracteriza por propagar uma imagem artificialmente simplificada da ciência especializada, e por explicála de uma forma esteticamente agradável e ilustrativa, omitindo os seus detalhes, restrições e complicações, mas principalmente suas polêmicas, opiniões contraditórias e os equívocos dos pesquisadores, conferindo ao saber a segurança subjetiva da religiosidade ou do óbvio, a ciência popular apresenta o conhecimento de uma forma mais sólida, acabada e segura, formando a opinião pública (ver seção 2.4). Ele também aponta que os livros de ciência popular ou de divulgação científica são voltados para o público leigo de formação geral, eles modificam o fato comprovado para uma forma diretamente perceptível, no qual as provas passam para o segundo plano, a autoridade se torna uma característica do discurso e as ideias adquirem um caráter impessoal, autônomo, tornandose objetos. Todas essas características apontadas por Fleck estão presentes nas obras do novo gênero literário iniciado por Capra, o que os coloca mais próximo do círculo exotérico do saber popular - e não no círculo esotérico do saber especializado, tal qual reivindicado por muitos desses autores com o argumento de que trabalham em uma "Nova Ciência". Assim, de acordo com Fleck, pelo fato do saber popular formar a opinião pública, ele acaba formando, juntamente com o saber especializado, um ciclo que se retroalimenta: o saber popular emerge do saber especializado, este, por sua vez, forma a visão de mundo que determina as características gerais do estilo de pensamento, causando, por conseguinte, um efeito retroativo no especialista. No caso do saber popular iniciado por Capra, no entanto, este popularizou a FM juntamente com defesas pessoais e paralelos com ideias que fugiam do âmbito da Física e se inclinavam para o misticismo, formando uma visão de mundo deslocada do estilo de pensamento original - o dos Fundamentos da FQ -, o que acabou dando origem a um novo estilo de pensamento: o estilo de pensamento do misticismo quântico.

Finalmente, as fontes de tipo (3) se referem à circulação intercoletiva das ideias, a qual, de acordo com Fleck, possui o papel de deslocar, alterar ou transformar os estilos de pensamento. Ela ocorre somente quando os estilos de pensamento possuem algum traço em comum, por menor que este seja. No caso estudado, o traço comum entre o estilo de pensamento dos problemas de Fundamentos da FQ e o estilo de pensamento do misticismo foi identificado inicialmente pelos físicos, no contexto da contracultura hippie 
dos anos 1970 (ver seção 3.5.3) e, posteriormente, popularizado por Capra através de seu paralelismo quântico. Segundo Fleck, esse tipo de circulação das ideias pode ocorrer por meio de qualquer elemento que circule entre os diferentes coletivos de pensamento. Entre os diversos elementos possíveis, Fleck destaca: (3a) a circulação por meio das palavras e (3b) por meio das pessoas.

No caso da circulação intercoletiva das ideias pelo meio (3a), Fleck destaca que as palavras possuem um status privilegiado, pois são um bem comum, que circula entre qualquer coletivo de pensamento. Ele afirma que, cada vez que as palavras passam por um determinado coletivo, elas são marcadas de alguma forma pelo estilo de pensamento do grupo, adquirindo um significado específico e, quando passam de um coletivo a outro, elas mudam o seu significado, fazendo com que as ideias adquiram uma coloração estilística diferente, de forma que as sentenças recebem outro significado e as opiniões um novo valor. No caso estudado - da formação da relação entre FQ e misticismo -, foi possível observar pelo menos duas mudanças importantes no significado e na centralidade de determinadas palavras, termos e conceitos. A primeira delas se refere à palavra consciência, a qual, no coletivo de pensamento dos pesquisadores em Fundamentos da FQ, estava relacionada aos debates acerca da necessidade de um observador consciente no processo de medição em FQ. Ao circular pelo coletivo de pensamento vinculado ao Movimento da Nova Era, no entanto, esses debates se modificam ligeiramente, e o discurso passa a ser o de que a consciência seria a responsável pelo colapso da função de onda e, inclusive, em alguns autores (como em Amit Goswami), ela seria capaz de escolher ou determinar o resultado de um experimento, algo que jamais foi corroborado pelo coletivo de pensamento da FQ. A outra mudança se refere aos termos $F Q$ ou quântico, os quais, no coletivo de pensamento dos pesquisadores em Fundamentos da FQ, se referiam aos problemas relacionados à interpretação do formalismo da MQ. Contudo, ao circular pelo coletivo de pensamento vinculado ao Movimento da Nova Era, conforme analisado na seção 4.2.3, esses problemas passam para o segundo plano, e o termo quântico se transforma em um símbolo de autoridade persuasiva, com elementos oriundos da ciência e da religião. Em ambos os casos, as mudanças no significado das palavras e conceitos ocorreram por conta da necessidade de adaptação, para uma maior aceitação e assimilação por parte do coletivo de pensamento no qual circulariam: o coletivo de destino. Nesses casos, o movimento de circulação das ideias partiu do coletivo de 
pensamento dos pesquisadores em Fundamentos da FQ e se destinou ao coletivo de pensamento vinculado ao Movimento da Nova Era. Para que houvesse uma maior aceitação deste último, era de seu interesse que, tanto a consciência exercesse um papel central, incluindo o de mudança da realidade externa - para que o discurso estivesse alinhado com o discurso geral, normalmente veiculado pelos seus membros, como o de que "você cria a sua própria realidade" -, quanto que algum elemento exercesse uma autoridade persuasiva, para uma melhor aceitação das teses defendidas por esse coletivo interesse típico dos coletivos de pensamento de caráter religioso -, o que foi possível através da utilização do termo quântico.

Por fim, Fleck destaca que a circulação intercoletiva das ideias pelo meio (3b) ocorre, pois nenhum indivíduo fica restrito a um único coletivo de pensamento, geralmente as pessoas pertencem e circulam entre várias comunidades, atuando como veículo do tráfego de ideias entre elas. De acordo com o filósofo polonês, um indivíduo é capaz de separar e conviver com estilos de pensamento bem distintos entre si, inclusive, suportando elementos contraditórios de forma isolada. Ele também destaca que é muito mais frequente que uma pessoa participe de alguns coletivos de pensamento muito divergentes do que de alguns coletivos muito afins, e que, geralmente, um indivíduo pertence a vários círculos exotéricos e poucos círculos esotéricos. Sendo assim, analisando a partir da perspectiva fleckiana, nota-se que os físicos com inclinações místicas exerceram um papel fundamental nesse tipo de circulação das ideias. Conforme visto na seção 3.5.5, diversos físicos especialistas em Fundamentos da FQ e, portanto, membros do círculo esotérico desse coletivo de pensamento, possuíam inclinações místicas e simpatia pelas filosofias orientais. Isso os colocava no círculo exotérico dos coletivos de pensamento atrelados ao misticismo e fazia com que eles atuassem como veículo do tráfego das ideias entre esses dois coletivos. Um exemplo dessa atuação, mencionado anteriormente, foi exercido pelo próprio Niels Bohr, quando este sugeriu que o conceito de complementaridade pudesse ser aplicado à vida e às emoções, ou quando ele escolheu o símbolo chinês do t'ai-chi para compor o seu brasão de cavaleiro da Dinamarca. Outros físicos de grande importância nesse processo de circulação das ideias foram os já mencionados e analisados Fritjof Capra e Amit Goswami. Ambos, inicialmente, faziam parte do coletivo de pensamento da Física, porém, posteriormente, abandonaram esse coletivo de pensamento para se dedicar a outros interesses. No caso de Capra, o seu livro $O$ Tao da Física foi o principal 
precursor na circulação das ideias mais intensa entre o coletivo dos físicos e os atrelados ao misticismo, influenciando e inspirando diversas obras e autores posteriores - contudo, o próprio Capra, mais adiante, abandona esse tráfego de ideias, para se dedicar a outros assuntos. Goswami, por outro lado, de fato, migra do coletivo de pensamento da Física para o coletivo de pensamento do misticismo quântico, passando a se dedicar intensamente ao tráfego de ideias entre os coletivos da Física e os atrelados ao misticismo. Ambos podem ser considerados exemplos de indivíduos pertencentes a coletivos de pensamento bem distintos entre si, sendo que Capra pertencia ao círculo esotérico da Física e aos círculos exotéricos do misticismo oriental, da filosofia e do movimento de contracultura hippie, enquanto que Goswami pertencia ao círculo esotérico da Física e aos círculos exotéricos da filosofia, da medicina e da ficção científica. Esse pertencimento a diferentes círculos possibilitou o fortalecimento da relação entre FQ e misticismo. Além disso, ambos os físicos frequentavam os mesmos círculos no contexto da Califórnia na década de 1970 - em especial, os círculos ligadados ao Movimento do Potencial Humano, como o Instituto Esalen, por exemplo - fato que contribuiu, posteriormente, para a formação do coletivo de pensamento do misticismo quântico. No entanto, uma diferença importante entre ambos era que Capra tendia mais a separar os estilos de pensamento da Física e do misticismo, suportando elementos contraditórios de forma um pouco mais isolada, enquanto Goswami buscava uma união ou uma síntese entre eles, através da formação de um terceiro estilo de pensamento que realizasse essa função. Em $O$ Tao da Física, Capra evidencia a sua postura, ao afirmar que considera que cada um desses estilos de pensamento pode funcionar sem a existência do outro, mas que o ser humano precisa aderir a cada um deles, de forma isolada, para atingir uma compreensão mais profunda do mundo - "A ciência não necessita do misticismo e este não necessita daquela; o homem, contudo, necessita de ambos" (Capra, [1975] 1983, p. 228). Capra, inclusive, relata que, no contexto da contracultura dos anos 1960 e 1970, vivia dois estilos de vida que pareciam incompatíveis entre si, correspondentes a duas personalidades que se desenvolviam de forma independente uma da outra - a de hippie e a de cientista (Rocha, 2015, p. 151). Goswami, por outro lado, critica a postura de Capra afirmando que este apenas "menciona um problema que não estuda em profundidade" (Goswami et al., [1993] 2001, p. 10). A partir dessa crítica, conforme visto na seção 4.2.3, o físico indiano formula a sua filosofia do idealismo monista, a qual ele acreditava que pudesse consistir 
em um "novo paradigma integrativo da ciência" (Goswami, [2004] 2006, p. 25), que, por sua vez, teria o potencial de unir a visão mística do mundo com a da FQ. Com isso, Goswami daixa clara a sua busca por estabelecer um novo estilo de pensamento. Por fim, outro exemplo interessante a ser citado no processo intercoletivo de circulação das ideias por meio das pessoas é o caso de Deepak Chopra, que fazia parte do círculo esotérico da medicina e passou a ter contato com a FQ, somente através do círculo exotérico, em torno dos especialistas dessa área, isto é, através do seu saber popularizado. Porém, ao utilizar esse saber popular para discutir problemas atrelados à sua área de especialização - a medicina -, Chopra exerceu um importante papel na circulação desse conhecimento. Assim, por conta da participação dos indivíduos em diversos coletivos de pensamento, Fleck ressalta que, mesmo dentro de um único coletivo de pensamento, se torna impossível a completa concordância dos vários observadores, mesmo que treinados, com relação a determinado fenômeno ou assunto. Essas discordâncias podem dar origem a novas percepções, debates e choques de ideias, os quais podem acarretar em novas leituras de um mesmo objeto ou na configuração de novos objetos, isto é, novas descobertas ou novos fatos. Todos esses fatores, por sua vez, podem possibilitar mudanças e transformações nos estilos de pensamento e, consequentemente, a criação de novos coletivos e estilos de pensamento.

Ainda sobre a circulação intercoletiva do conhecimento, Fleck destaca que, para que haja entendimento mútuo entre os coletivos de pensamento envolvidos na troca de ideias, além do traço em comum, a comunicação entre eles deve sempre levar em conta a linguagem, as normas e os costumes do coletivo de pensamento com quem se quer comunicar. Assim, para formular uma ideia para os membros de outro coletivo é preciso transformá-la, de modo a torná-la próxima do seu estilo. Com isso, cria-se um coletivo de pensamento comum, intermediário entre ambos, mais pobre em conteúdo, porém mais abrangente. Fleck denomina essa forma de comunicação de propaganda (ver seção 2.4). Segundo ele, a propaganda de uma ideia serve aos propósitos de um determinado coletivo de pensamento e pode objetivar: (1) a sua popularização, conforme os interesses dos leigos do coletivo; (2) a informação a respeito dela, conforme os interesses de trocas entre os especialistas equivalentes; ou (3) a sua legitimação, dentro da estrutura do sistema de ideias do estilo. No caso da ideia da existência de uma relação entre FQ e misticismo, a propaganda com o objetivo (2), de uma busca por maiores informações por parte dos 
especialistas dos coletivos, já ocorria antes mesmo da publicação da obra de Capra, através do interesse, da troca e busca de informações, tanto por parte dos físicos interessados no misticismo e nas filosofias orientais, conforme visto na seção 3.5.5, quanto por parte de místicos interessados na FQ - como evidenciado, por exemplo, pela ilustre visita do monge budista Dalai Lama e sua equipe ao laboratório CERN (Conselho Europeu para Pesquisas Nucleares), na Europa (Rocha, 2015, p. 63). Esse tipo de troca de ideias, entre os especialistas dos coletivos, teve tanta importância para o fortalecimento dessa ideia que, posteriormente, passou a ser frequentemente citada nas obras do coletivo de pensamento do misticismo quântico, principalmente no que se refere ao interesse dos físicos pelas filosofias orientais. No entanto, foi somente a partir da publicação de $O$ Tao da Física, juntamente com a realização de palestras, workshops, lançamento de outros livros e "produtos quânticos" é que o objetivo (1), da popularização massiva dessa ideia, passou a ser atingido de forma mais efetiva. A partir de então, a propaganda dessa ideia passou a atingir o objetivo (3), e legitimar-se com uma estrutura e um sistema de ideias próprio, o qual contou com adeptos específicos, não restritos aos coletivos de pensamento originais, e deu origem a um novo estilo de pensamento: o estilo de pensamento do misticismo quântico.

Contudo, Fleck ressalta também que, além do desejo de comunicação, a circulação de ideias intercoletiva também pode ser motivada e propulsionada por outras forças sociais, as quais podem resultar em alterações no pensamento não intencionais ou não previstas, muitas vezes, com uma completa mudança de significado, na qual apenas uma vaga similaridade permanece. Dessa forma, ele elenca alguns exemplos de efeitos que podem ser causados por esse movimento, como: (1) a falsa popularização, que consiste na popularização acompanhada da corrupção das ideias originais; (2) a apoteose do pensamento, que ocorre quando a ideia se torna um motivo místico ou inconcebível, sem a devida compreensão da sua razão ou origem, sendo impensadamente cultuada; e (3) a caricaturização do pensamento, quando a ideia se torna ridícula e motivo de escárnio, fortalecendo a impressão de um estilo completamente alheio. No caso da formação do estilo de pensamento do misticismo quântico, pode-se dizer que os três exemplos de efeitos citados por Fleck ocorreram, e que algumas das forças sociais que podem ter contribuído para isso foram: o contexto de crise e desemprego nas áreas científicas, nos anos 1970, nos EUA, que contribuiu para o desemprego de grande parte dos físicos com 
PhD e para a busca, por parte destes, de fontes alternativas de renda; o interesse do coletivo de pensamento do misticismo quântico em estabelecer e popularizar as suas ideias; e o sucesso de venda dos livros e outros "produtos quânticos", que passaram a ser lançados. Assim, a partir destas e outras forças sociais, foram possíveis as alterações no pensamento apontadas por Fleck. A primeira delas, referente à (1) a falsa popularização, ocorreu com a inserção de mudanças sutis na popularização das ideias da $\mathrm{FQ}$, conforme observado nas obras de Amit Goswami - quando, por exemplo, o autor modifica o debate na FQ em torno da necessidade de um observador consciente no processo de medição para o discurso de que a consciência seria a responsável pelo colapso da função de onda e que, inclusive, ela poderia escolher o resultado de uma medição -, e na formulação de analogias com um caráter mais realista, entre os fenômenos da FQ e os relacionados ao misticismo, por parte dos três autores analisados (ver seções 4.2.1, 4.2.2 e 4.2.3). Nesse caso, porém, diferentemente do elencado por Fleck, pode-se dizer que esse tipo de popularização, pelo menos em partes, ocorreu intencionalmente, uma vez que alguns de seus responsáveis tinham formação em Física e, portanto, tinham consciência, ainda que de forma vaga, das modificações sutis que estavam introduzindo na popularização da FQ. As alterações relacionadas à (2) apoteose do pensamento, por sua vez, ocorreram a partir do momento em que, no discurso dos membros do coletivo de pensamento do misticismo quântico, a FQ se tornou um tema secundário e passou a ser utilizada somente como um símbolo de autoridade persuasiva, conforme discutido na seção 4.2.3. Por fim, o efeito (3), da caricaturização do pensamento, pode ser observado principalmente por parte do coletivo de pensamento dos físicos, para quem as ideias do estilo de pensamento do misticismo quântico aparecem como motivo de ridicularização e escárnio. Um exemplo concreto desse último efeito foi a premiação de Deepak Chopra, pela comunidade acadêmica, em 1998, com o prêmio satírico Ig Nobel, atribuído às pesquisas mais estranhas e improváveis do ano, pela "sua interpretação única da Física Quântica aplicada à vida, à liberdade, e à busca da felicidade econômica" (Improbable research, 1998). Com isso, nota-se que, conforme Fleck destaca, qualquer tráfego intercoletivo de pensamentos traz consigo um deslocamento ou uma alteração dos valores de pensamento - da pequena mudança matizada, passando pela mudança completa de sentido até a aniquilação de qualquer sentido -, e que essas mudanças ocorrem de forma harmoniosa e sutil, em 
diferentes graus, podendo se estender por um longo período de tempo, para, mais adiante, possibilitar a criação de novos estilos de pensamento.

Portanto, percebe-se que o processo da gênese e do desenvolvimento da relação entre FQ e misticismo foi completamente permeado pelos elementos identificados por Fleck acerca da circulação do conhecimento, tanto intra como intercoletiva, e que essa circulação foi capaz de dar origem a um novo estilo de pensamento, distinto de cada um dos estilos que lhe deram origem. Além disso, ao longo de todo o processo de formação dessa relação, o contexto geral e as forças sociais atuaram, condicionando tanto os conteúdos específicos internos ao novo coletivo de pensamento, quanto causando efeitos não intencionais ou não previstos para esse conhecimento. Estes últimos efeitos - como a falsa popularização, a apoteose e a caricaturização do pensamento - podem também ser considerados não desejados por parte dos outros coletivos de pensamento, incluindo os originais, o que fortalece a impressão de um estilo de pensamento completamente alheio.

\subsection{O misticismo quântico e o problema da demarcação}

Conforme discutido na seção 2.5, o problema da demarcação na ciência é aquele que busca caracterizar o que diferencia a ciência das outras formas de conhecimento e traçar as fronteiras entre ambos, ou seja, entre aquilo que pode ser considerado científico e o que não pode. $\mathrm{O}$ caso estudado - da formação da relação entre FQ e misticismo, que culminou no fenômeno cultural do misticismo quântico - é de especial interesse para esse problema, pois se trata de um estilo de pensamento, em geral, considerado não científico, porém, que foi originado do estilo de pensamento dos Fundamentos da FQ, um estilo reconhecidamente científico. Assim, a questão a ser analisada nesta seção é: o fato do misticismo quântico possuir a sua origem em um estilo de pensamento que é parte da Ciência implica que ele também possa ser considerado um estilo de pensamento científico?

Em primeiro lugar, é importante ressaltar que, conforme visto na seção 3.4.3, a estrutura do coletivo de pensamento dos pesquisadores em Fundamentos da FQ consistia em uma estrutura atípica para os coletivos de pensamento científicos, pois possuía diferentes núcleos em seu círculo esotérico, cada um deles correspondente a cada uma das interpretações da FQ (ver Figura 5), enquanto que os coletivos de pensamento na Ciência, em geral, são descritos por Fleck como possuindo apenas um único núcleo para esse 
círculo. Inclusive, por muito tempo - para não dizer até os dias atuais -, esse coletivo buscou conciliar as diferentes interpretações da FQ em uma única, a fim de fundir os vários núcleos do coletivo em um único. Porém, devido ao número crescente de interpretações da FQ, parece não haver perspectiva de que se chegue a um consenso a respeito dessa tentativa. Contudo, apesar de sua estrutura atípica, esse coletivo de pensamento ainda pode ser considerado parte da Ciência, pois reúne diversas características que, para Fleck, são caras ao pensamento científico (ver seção 2.5). A primeira delas é a busca por "um máximo de coerção de pensamento (Denkzwang) com um mínimo de pensamento baseado na própria vontade” (Fleck, [1935]2010, p. 144),. Isto é, a busca pela "coerção segura" do pensamento, ou a "percepção da forma de maneira imediata", em detrimento do livre pensar, baseado na própria vontade, ou ainda, por um máximo número de acoplamentos passivos do saber, em detrimento dos acoplamentos ativos. Essa busca é garantida, pois, conforme observado na história dos debates em torno das questões de Fundamentos da FQ (ver seções 3.1, 3.2 e 3.3), todas as interpretações da FQ possuem um formalismo mínimo a ser seguido e interpretado - a MQ -, o que limita consideravelmente as margens do livre pensar e da mobilização de acoplamentos ativos. Assim, apesar das interpretações da FQ serem numerosas, todas devem ser coerentes com um formalismo comum, de forma que todos os elementos ativos propostos devem estar de acordo com os seus resultados e previsões. Essa restrição aumenta consideravelmente a "coerção segura" do pensamento e as situações consideradas obrigatoriamente ocorridas referentes aos acoplamentos passivos - e, consequentemente, diminui as possibilidades para o pensamento baseado na própria vontade - referente aos acoplamentos ativos -, ficando estes últimos restritos às possibilidades de interpretação do formalismo.

A segunda característica do conhecimento científico presente no coletivo de pensamento dos pesquisadores em Fundamentos da FQ é o seu caráter democrático. Fleck atribui o caráter democrático aos coletivos de pensamento da Ciência, em contraposição aos coletivos de pensamento de caráter dogmático, como as comunidades de cunho religioso, por exemplo. Segundo ele, o coletivo de pensamento científico “(...) baseia-se na organização e permanece em seu controle, recusando o privilégio de procedência divina, e se pretende acessível e útil a todos” (Fleck, [1929]1986, p. 50, tradução livre), em sua visão, "a ciência serve o 'publico geral"” e não apenas aos membros de seu coletivo. Além disso, "não há poderes secretos" nela, "não se pode referir [a ela] como 
uma missão obtida de círculos superiores" (Fleck, [1936]1986, p. 105, tradução livre), ou seja, qualquer indivíduo, membro do coletivo ou não, que queira investigar ou questionar as origens e razões de determinados conteúdos concretos do estilo de pensamento da Ciência, pode, em princípio, adentrar o coletivo de pensamento correspondente, investigálas e compreendê-las. Por conta dessa característica, Fleck argumenta que "as bordas deste círculo são abertas a todos, sua admissão não requer nenhuma cerimônia formal" e que, acerca da formação de seu círculo esotérico, "todo especialista em um determinado campo científico é um leigo na maioria dos outros campos, diferentemente do coletivo de pensamento religioso, onde os sacerdotes formam a totalidade da elite" (Fleck, [1936]1986, pp. 105-106, tradução livre). Ele também destaca que "os especialistas são quase sempre recrutados dentre os especialistas mais gerais” e, por sua vez, “(..) Um especialista geral é quase sempre recrutado dentre as pessoas com educação geral” (Fleck, [1936]1986, pp. 106-107, tradução livre). Ele reconhece, no entanto, que existem dificuldades práticas para a entrada dos indivíduos provenientes do "público mais amplo" nesse coletivo de pensamento, as quais estariam vinculadas principalmente à educação geral desse público, segundo Fleck, essa seria "a fronteira do estrato social mais difícil de ultrapassar" e onde "se encontram algumas das mais importantes violações dos princípios democráticos" (Fleck, [1936]1986, pp. 106-107, tradução livre) desse coletivo. Por fim, Fleck também destaca os mecanismos que esse coletivo possui para garantir o seu caráter democrático, dentre os quais, estariam os "congressos, imprensa cientifica, discussões cientificas" (Fleck, [1936]1986, p. 106, tradução livre) e o estabelecimento democrático de seus conteúdos concretos, a partir das opiniões da "'maioria dos pesquisadores', i.e., na produção da opinião pública" (Fleck, [1936]1986, p. 106, tradução livre). Com isso, ele defende que "a verdade científica passará de algo rígido e estacionário a uma verdade dinâmica, passível de desenvolvimento, criativa, humana” (Fleck, [1960]1986, p. 157, tradução livre), ou seja, o conhecimento científico se torna passível de mudança e se desenvolve em um processo contínuo. Assim, pode-se dizer que o coletivo de pensamento dos pesquisadores em Fundamentos da FQ também possui esse caráter democrático descrito por Fleck, devido à própria história de formação e consolidação de sua estrutura, tal qual descrita na seção 3.4, na qual o conhecimento e os seus conteúdos concretos foram constantemente construídos através dos debates e discussões entre seus membros. Ao longo desse processo, foi possível notar a presença dos mecanismos democráticos, tais 
como os debates travados nos congressos e na imprensa científica - as Conferências de Solvay, as publicações de artigos de discussão, como o artigo EPR, entre outros -, o papel desses debates no desenvolvimento do conhecimento, a sua construção coletiva, a partir da "opinião pública" e da "maioria dos pesquisadores" e, consequentemente, o caráter provisório e transitório deste conhecimento. Também se observou a abertura desse coletivo a novos membros, provenientes de diferentes especialidades e tradições com relação à FQ - o que possibilitou a formulação das diferentes interpretações da FQ - e, por fim, a negação, por parte desse coletivo, da procedência divina de seu conhecimento, uma vez que a busca por uma interpretação coerente com o formalismo da MQ não cessou em nenhum momento, e cada proposta foi constantemente publicizada, avaliada e discutida pelos membros do coletivo.

A partir da discussão das principais características que permitem afirmar que o coletivo de pensamento dos pesquisadores em Fundamentos da FQ é um coletivo de pensamento científico, pode-se partir para a análise dessa mesma questão com relação ao coletivo de pensamento dos místicos quânticos, cuja formação e principais aspectos foram discutidos na seção 4.3. O primeiro ponto a ser destacado com relação ao problema da demarcação, de acordo com Fleck, é que o coletivo de pensamento da Ciência, assim como qualquer outro coletivo, cultiva um certo fechamento orgânico de sua comunidade, tanto na sua forma quanto no seu conteúdo, limitando os problemas que podem ser admitidos e trabalhados pelo estilo de pensamento (ver seção 2.5). Assim, o coletivo tende a distinguir entre os problemas considerados "problemas reais", dignos de atenção, e os "pseudoproblemas" ou problemas falsos, sem importância para a comunidade ou, em outras palavras, entre o que é considerado ciência e o que é considerado não-ciência pelo coletivo. Fleck ainda destaca que "dessa postura surge uma atribuição específica de valores e uma intolerância característica, que são traços comuns de qualquer comunidade fechada" (Fleck, [1935]2010, pp. 155-156). Essa postura de fechamento orgânico e tentativa de delimitar os problemas considerados legítimos, de fato, podem ser notadas por parte do coletivo de pensamento da Física com relação ao coletivo de pensamento do misticismo quântico. Por exemplo, nas reações negativas de físicos e de filósofos da Ciência às obras de Fritjof Capra e seus herdeiros, quando estes utilizam o termo "misticismo" com uma conotação pejorativa para se referir a elas - como o filósofo da Ciência Patrick Grim (1982) e o físico Victor Stenger (1996). Essa mesma postura, por 
outro lado, também pode ser notada por parte de membros do próprio círculo religioso, porém com menor intensidade - como por Ken Wilber (1983), um pioneiro no desenvolvimento da Psicologia Integral, quando este critica a difusão da ideia de que a FM oferece um suporte para uma visão mística do mundo (ver seção 4.2.1). Em contraposição a estas, contudo, a postura mais frequente por parte do coletivo de pensamento dos místicos quânticos acaba sendo uma postura reativa ou defensiva, caracterizada por uma tentativa de autoafirmação deste coletivo como fazendo parte do coletivo de pensamento da Ciência. Isso pôde ser notado a partir dos discursos dos místicos quânticos de que suas hipóteses e afirmações seriam parte de uma "Nova Ciência", mais abrangente e mais humanizada, a qual explicaria fenômenos não explicados pela Ciência convencional - conforme visto nas seções 4.2.2 e 4.2.3, Chopra dá mais ênfase aos fenômenos da medicina, enquanto Goswami busca uma união mais profunda entre Ciência e misticismo, enfatizando fenômenos diversos relacionados à consciência. Além desse discurso, esse coletivo também busca utilizar termos e linguagens característicos do coletivo de pensamento da Ciência, como a referência a experimentos e a utilização do próprio termo "quântico" e outros termos relacionados à FQ, o que pode ser interpretado como uma tentativa de reconhecimento desse coletivo como sendo parte da Ciência. No entanto, ao mesmo tempo em que esse discurso - de que o coletivo seria parte de uma "Nova Ciência" - pode indicar uma tentativa de reconhecimento deste como parte da Ciência, ele também vem acompanhado de críticas por parte dos místicos quânticos com relação à Ciência "convencional", a qual é vinculada a um mecanicismo ou materialismo exacerbado. Essas críticas, contraditoriamente, também indicam que os próprios místicos quânticos se colocam fora do círculo normalmente reconhecido como científico, ou seja, que eles mesmos não se reconhecem como parte do coletivo de pensamento da Ciência - ou pelo menos a Ciência dita "convencional".

Contudo, esse primeiro aspecto destacado por Fleck, com relação ao problema da demarcação - dos coletivos tentarem separar os problemas dos "pseudoproblemas" -, permite que o coletivo de pensamento dos místicos quânticos e o coletivo de pensamento dos cientistas não sejam considerados parte um do outro apenas por eles mesmos, de forma separada. Para uma análise menos baseada em critérios identitários próprios de cada coletivo, pode-se retomar a particularidade do coletivo de pensamento da Ciência 
destacada por Fleck, discutida anteriormente, que se refere à sua busca por "um máximo de coerção de pensamento (Denkzwang) com um mínimo de pensamento baseado na própria vontade" (Fleck, [1935]2010, p. 144) ou, em outras palavras, a característica da ciência buscar por um máximo número de acoplamentos passivos no saber - aqueles considerados inevitáveis, relacionados ao que "não pode ser pensado de outra maneira" -, em detrimento dos acoplamentos ativos - aqueles considerados "livremente inventados", provenientes do indivíduo (ver seção 2.5). Sobre essa busca por parte do coletivo de pensamento da Ciência, Fleck também faz a ressalva de que não é possível elaborar um conhecimento que contenha somente elementos passivos e que, no decorrer da história e do desenvolvimento do saber, elementos passivos podem se apresentar na forma de ativos e vice-versa. Além disso, segundo ele, essa busca pela "coerção segura", pela "percepção da forma de maneira imediata", em detrimento do livre pensar baseado na própria vontade, por parte do coletivo de pensamento científico, faz com que "quanto mais elaborada uma área do conhecimento, quanto mais desenvolvida, tanto menores as diferenças de opinião" (Fleck, [1935]2010, pp. 132-133).

No caso do coletivo de pensamento dos místicos quânticos, não existe nenhum formalismo matemático, ou algo que exerceria um papel coercitivo no pensamento, a ser obrigatoriamente seguido. O que se observa é que os seus membros se utilizam de analogias com alguns fenômenos da FQ, em especial, aqueles relacionados aos debates em torno do problema da medição. No entanto, não há uma restrição dos fenômenos e temas a serem abordados, os quais, conforme visto nas seções 4.2.2 e 4.2.3, variam desde fenômenos relacionados à consciência humana, passando pela criatividade, pela saúde e cura, pela alma, por fenômenos parapsicológicos, até fenômenos relacionados à economia e aos conflitos sociais. Inclusive, essa ampla gama de fenômenos abrangidos pelo coletivo mostra que a própria analogia pode ser considerada um mecanismo pouco coercitivo para o pensamento, em comparação a um formalismo mínimo a ser seguido. Esses aspectos evidenciam que o estilo de pensamento do misticismo quântico se utiliza de poucos acoplamentos passivos, ou de situações consideradas obrigatoriamente ocorridas, em contrapartida, esse estilo se mostra aberto à utilização de acoplamentos ativos, isto é, a situações consideradas livremente inventadas, baseadas na própria vontade. Por conta disso, o coletivo não aparenta buscar por "um máximo de coerção no pensamento", ao contrário, ele parece prezar por uma aplicação das analogias a diversos campos do 
conhecimento, aspectos da vida humana e da sociedade, cada vez mais ampla e livre, sem prezar por seguir algum tipo de mecanismo de coerção seguro para o pensamento, que gere situações que "não podem ser pensadas de outra maneira", o que o afasta da concepção fleckiana de coletivo de pensamento científico. Além disso, nota-se que, entre os místicos quânticos, também há divergências com relação à profundidade, o significado e a própria razão da utilização das analogias com os fenômenos da FQ. Conforme visto nas seções 4.2.1, 4.2.2 e 4.2.3, Capra traça paralelos e semelhanças entre a FM e o misticismo oriental, sem maior profundidade, Chopra e Goswami, por outro lado, fazem analogias entre os fenômenos da FQ e outros relacionados à consciência e à vida humanas, atribuindo-as um caráter mais realista. Enquanto Capra defende que seu "paralelismo quântico" sustentaria uma visão de mundo que enxerga a ciência e o misticismo como complementares entre si, na qual o ser humano necessitaria de uma interação dinâmica entre ambos para uma compreensão mais profunda das coisas - e não uma síntese entre eles -; Chopra se utiliza de suas analogias para uma aplicação a uma área fora do âmbito da Física, em prol da saúde e do bem estar do ser humano, propondo uma "Nova Ciência", que se basearia na FQ, valorizaria a mente e explicaria fenômenos de cura não explicados pela medicina convencional; e Goswami, por sua vez, critica Capra por não investigar a razão mais profunda da existência de seus paralelos, propondo uma nova interpretação para a FQ - outra "Nova Ciência", diferente da de Chopra -, a qual buscaria uma união mais profunda entre ciência e misticismo, pois, em sua concepção, ambos constituem em caminhos que conduziriam à verdade. Com isso, nota-se que esses dois últimos autores parecem buscar uma união e uma síntese entre a FQ e o misticismo, enquanto que Capra parece defender apenas uma interação entre ambos. Essa divergência de opiniões entre os membros de um mesmo coletivo, em uma perspectiva fleckiana, indica que sua área do conhecimento estaria pouco desenvolvida e elaborada, ou seja, que o estilo de pensamento precisaria desenvolver mais a sua "coerção segura" e sua "percepção da forma de maneira imediata", para se aproximar de um estilo de pensamento científico.

Outro aspecto tratado por Fleck relacionado ao problema da demarcação, característico dos coletivos de pensamento científicos, se refere ao seu caráter democrático. Conforme discutido anteriormente, o filósofo polonês atribui essa característica ao pensamento típico das ciências naturais a fim de diferenciá-lo do pensamento de comunidades dogmáticas. Para ele, "a ciência serve o "publico geral"” e 
"não há poderes secretos" nela, "não se pode referir [a ela] como uma missão obtida de círculos superiores" (Fleck, [1936]1986, p. 105, tradução livre), a Ciência seria, em suma, a "arte de formar uma realidade democrática e guiar-se por ela e, portanto, ser constantemente reformulada por ela também" (Fleck, [1929]1986, p. 54, tradução livre). No entanto, conforme analisado na seção 4.2.3, em um determinado momento, o coletivo de pensamento dos místicos quânticos passou a utilizar o termo "quântico" como um símbolo de autoridade persuasiva, não mais vinculado aos debates e discussões sobre questões relacionadas aos Fundamentos da FQ, mas à utilização de argumentos de autoridade cientifica, os quais passaram a ser tomados como fatos consolidados, que não poderiam ser questionados. Essa postura acabou gerando uma espécie de "poder secreto", que passou a reger o funcionamento do coletivo, no qual o conhecimento mais profundo acerca das origens desse conhecimento passou a ficar restrito a uma elite relativamente fechada, distanciada e isolada do círculo exotérico do coletivo. Com isso, em uma perspectiva fleckiana, essa estrutura e forma de funcionamento do coletivo passaram a se assemelhar às dos coletivos de pensamento de caráter dogmático, nos quais os segredos e o dogmatismo dominam o funcionamento do coletivo e a elite "enfatiza a origem sobrenatural das ideias que ela representa, e a sua importância requer obediência e docilidade" (Fleck, [1936]1986, p. 103, tradução livre). Além disso, Fleck também destaca que "A natureza democrática do coletivo científico se manifesta também no fato de que todo especialista em um determinado campo científico é um leigo na maioria dos outros campos, diferentemente do coletivo de pensamento religioso, onde os sacerdotes formam a totalidade da elite" (Fleck, [1936]1986, pp. 105-106, tradução livre). Nos coletivos de pensamento dos místicos quânticos, contudo, aparentemente todos os membros da elite possuem a totalidade do conhecimento relacionado à $\mathrm{FQ}$ - pelo menos seu discurso busca mostrar isso -, não havendo especialidades, nas quais um membro seria considerado leigo no campo do outro. Outro aspecto destacado por Fleck para garantir o caráter democrático dos coletivos de pensamento científicos são os mecanismos tais "como congressos, imprensa cientifica, discussões cientificas, e no estabelecimento democrático das opiniões da "maioria dos pesquisadores"” (Fleck, [1936]1986, p. 106, tradução livre). O que se observa no coletivo de pensamento dos místicos quânticos, no entanto, é apenas a realização de workshops, palestras, cursos online e presenciais, nos quais o conhecimento é veiculado dos especialistas para o público em geral - isto é, do 
círculo esotérico para o exotérico -, e a publicação de livros de divulgação, nos quais um especialista, eventualmente cita outro para dar suporte e apoiá-lo. Em ambos os casos, nota-se que a opinião das massas, ou dos membros do círculo exotérico, não é apreciada ou levada em conta na construção do conhecimento, talvez apenas para fins mercadológicos, porém não há abertura para questionamentos e tentativas de discussão das ideias. Além disso, neste coletivo de pensamento, tampouco se nota a presença de uma imprensa científica, de congressos e encontros entre os especialistas, nos quais as controvérsias e as diferenças de opinião são discutidas a fim de se construir coletivamente a "opinião pública" através da opinião da "maioria dos pesquisadores". Por fim, Fleck também dá destaque à mobilidade e à abertura do coletivo de pensamento científico, existente em sua estrutura, ao argumentar que "as bordas deste círculo são abertas a todos, sua admissão não requer nenhuma cerimônia formal" e que "os especialistas são quase sempre recrutados dentre os especialistas mais gerais” e, por sua vez, “(...) Um especialista geral é quase sempre recrutado dentre as pessoas com educação geral" (Fleck, [1936]1986, pp. 105-107, tradução livre). O coletivo de pensamento dos místicos quânticos, por outro lado, não parece apresentar uma abertura e mobilidade tão amplas, uma vez que o conhecimento mais específico acerca da FQ parece ficar restrito aos especialistas do núcleo do círculo esotérico. Nos workshops, palestras e cursos ministrados por esses especialistas, eventualmente, são recrutados membros do público mais amplo, para compor os especialistas mais gerais - ou a parte mais externa do círculo esotérico -, porém, normalmente, esses cursos são focados nas aplicações da FQ a questões diversas, relacionadas à vida e à consciência humanas - e não na FQ em si -, de tal forma que dificilmente esses especialistas mais gerais conseguem adentrar o núcleo do círculo esotérico dos especialistas com esse conhecimento. Assim, as bordas deste último círculo parecem ser mais fechadas, impedindo a abertura e mobilidade completas dos indivíduos nesse coletivo. A partir dessas características analisadas, portanto, nota-se que o coletivo de pensamento dos místicos quânticos se afasta dos coletivos de pensamento de caráter democrático, como os coletivos científicos, e se aproxima mais dos de caráter dogmático.

Por fim, outra característica que Fleck utiliza para diferenciar o coletivo de pensamento científico dos outros coletivos é a sua linguagem característica, a qual não se restringe ao seu vocabulário. De acordo com ele, cada coletivo de pensamento possui uma 
linguagem, tradições e práticas próprias, as quais são as marcas do estilo de pensamento correspondente. Mais do que isso, são elas é que estabelecem o sistema de referência a partir do qual os indivíduos do coletivo enxergarão e se relacionarão com o mundo. Esse sistema de referência é uma peculiaridade coletiva, adquirida pela educação e por treinamentos específicos, os quais possuem o papel de inserir os indivíduos na tradição histórica de práticas do coletivo. Assim, a linguagem é que estabelecerá as possibilidades e o grau de comunicação entre os diferentes coletivos de pensamento, segundo o filósofo polonês, é por conta da linguagem que "O que, para um deles, é importante, até mesmo essencial, para o outro pode ser deixado de lado, sem valor para a discussão. O que é óbvio para um, é um absurdo para outro" (Fleck, [1936]1986, pp. 81-82, tradução livre). Além disso, Fleck também destaca que, mesmo quando existem palavras em comum aos diferentes estilos de pensamento, elas terão significados diferentes para cada um, de tal forma que toda vez que uma determinada palavra passa por um coletivo de pensamento, ela será interpretada, estilizada e modificada, visando à adaptação a linguagem daquele coletivo. De fato, observou-se que o termo "quântico", enquanto circulava no coletivo de pensamento dos pesquisadores em Fundamentos da FQ, fazia parte dos debates dos fundamentos dessa teoria física, posteriormente, contudo, quando passou a circular no coletivo de pensamento dos místicos quânticos, deixou de ser utilizado para a discussão destas questões para se tornar um símbolo de autoridade persuasiva, voltado mais para a discussão de questões que visam à promoção do bem-estar social, nas quais a FQ aparece apenas em segundo plano. Esse, entre outros aspectos, evidencia que a linguagem, as práticas, tradições, aspirações e, portanto, a disposição para uma e não outra forma de agir dos dois coletivos são bem distintas entre si: enquanto o coletivo de pensamento dos pesquisadores em Fundamentos da FQ busca questionar as bases da FQ, o coletivo dos místicos quânticos toma-as como um conhecimento sólido e consolidado; enquanto, no primeiro coletivo, o conhecimento da $\mathrm{FQ}$ vem à público, a fim de ser coletivamente discutido e construído, no segundo, ele permanece restrito a uma elite relativamente fechada, para ser utilizado de forma autoritária e persuasiva; enquanto, no primeiro, o caráter provisório e transitório desse conhecimento é evidenciado, no segundo, ele é apresentado como uma palavra final, já anunciada anteriormente por sábios e tradições místicas diversas, por meio de uma espécie de filosofia perene. Esses aspectos, portanto, 
mostram que esses coletivos podem ser considerados coletivos de pensamento diferentes, em que um não pode ser considerado como parte do outro.

Finalmente, com relação ao problema da demarcação, todos os aspectos analisados indicam que apenas o coletivo de pensamento dos pesquisadores em FQ pode ser considerado um coletivo de pensamento científico. Pois os aspectos apresentados pelo coletivo de pensamento dos místicos quânticos indicam um afastamento das características dos coletivos de pensamento da Ciência, apontadas por Fleck, e o aproximam de coletivos de pensamento de caráter dogmático, bem como de coletivos que permitem e valorizam o exercício do livre pensar baseado na própria vontade.

\subsection{Rediscutindo a noção de "misticismo quântico"}

Na seção 4.1, fez-se um delineamento inicial da noção de "misticismo quântico", no qual se elencou diversos aspectos discutidos anteriormente por outros autores acerca desta noção. A partir disso, nesta seção, será feita uma leitura desses aspectos levando-se em conta a perspectiva fleckiana da história da gênese e do desenvolvimento da relação entre a FQ e o misticismo realizada ao longo deste trabalho, e se buscará identificar novos elementos e contribuições que essa leitura pode trazer para um delineamento mais preciso da noção em questão.

O primeiro aspecto a ser discutido se refere à conotação pejorativa, reconhecida pelos dicionários de filosofia, que o termo "misticismo" adquiriu ao longo dos anos. Essa conotação estaria relacionada ao conhecimento, doutrina ou crença, que possui uma valorização do sentimento e da intuição, acompanhada de uma rejeição ou depreciação da observação, da realidade sensível e de explicações racionais. Conforme discutido na seção 4.1, essa conotação pejorativa deu origem ao termo "misticismo quântico", o qual passou a ser adotado principalmente por críticos a uma vertente do Movimento da Nova Era que buscava o sustento das suas hipóteses na FQ. Esses críticos - como o filósofo Patrick Grim (1982), por exemplo - passaram a utilizar esse termo, ao identificar nesta vertente a existência de uma interpretação obscura, tendenciosa ou falsa da FQ. A conotação pejorativa que esse termo carrega, por outro lado, posteriormente, passou a causar incômodo por parte dos sujeitos que adotam a perspectiva de que a espiritualidade humana teria como base a FQ. De acordo com a análise realizada na seção 4.4, a utilização de um termo com conotação pejorativa por parte do coletivo de pensamento dos pesquisadores 
em Fundamentos da FQ para se referir a outro coletivo pode estar relacionda a uma postura de cultivo de certo fechamento orgânico e tentativa de delimitação dos problemas considerados legítimos pela comunidade. Fleck ainda ressalta que essa postura dá origem a uma "atribuição específica de valores e uma intolerância característica, que são traços comuns de qualquer comunidade fechada" (Fleck, [1935]2010, pp. 155-156). Sendo assim, nota-se que, além dos aspectos levantados anteriormente na seção 4.1, a noção de "misticismo quântico" também está relacionada a uma questão cultural, de identidade e comportamento dos coletivos de pensamento e da relação entre eles, nos quais fatores como valores, interesses, aspirações, certa intolerância, uma busca por legitimidade e reconhecimento dos seus conteúdos, entre outros aspectos, devem ser levados em conta.

Outro aspecto, também relacionado a este, se refere às posturas adotadas pelos membros do coletivo de pensamento dos místicos quânticos, as quais podem ser classificadas em dois tipos: posturas conciliadoras e posturas desafiadoras com relação à Ciência, a primeira delas aceita apenas a existência de entidades e processos que não entram em contradição com as previsões da ciência estabelecida, já a segunda aceita a existência de fenômenos que entram em contradição com estas. O segundo tipo de postura, principalmente, pode dar origem a conflitos sociais e culturais, os quais implicam em um fechamento e uma intolerância ainda maiores por parte do coletivo de pensamento da Ciência, em especial, o dos pesquisadores em Fundamentos da FQ. Esse último aspecto indica que a noção de misticismo quântico também pode estar vinculada a um possível conflito social ou cultural, também relacionado ao fechamento orgânico característico dos coletivos de pensamento e a posturas que desafiam os valores e práticas dos coletivos envolvidos.

Além desses aspectos, na seção 4.1, também se discutiram as teses e hipóteses defendidas pelo coletivo de pensamento dos místicos quânticos, entre as quais, estão as teses relacionadas ao papel do observador no ato de medição; as que defendem que, de alguma forma, a mente ou a consciência possuiria uma natureza quântica; as que defendem que a FQ, de alguma maneira, possibilitaria a comunicação instantânea entre duas ou mais pessoas em um nível intuitivo; as que suscitam extensões místicas para a FQ; e as que se referem a algumas aplicações da FQ. A partir da análise fleckiana da gênese e do desenvolvimento dessas teses, foi possível observar uma estreita relação 
destas com os debates das questões de Fundamentos da FQ, em especial, aqueles relacionados com o problema da medição, e com as inclinações místicas dos físicos participantes destes debates. Alguns aspectos envolvidos nestes dois últimos fatores, por sua vez, possuíam raízes e influências em diferentes protoideias - como a ideia da negação da existência de um determinismo e uma causalidade intrínsecos na Ciência e a ideia de que a consciência seria capaz de interferir na matéria. Dessa forma, pode-se dizer que noção de misticismo quântico também está permeada pelas influências históricas desses debates, inclinações místicas dos físicos e, em especial, pelas protoideias mencionadas.

Outro aspecto a ser discutido é o fato de o misticismo quântico ter se tornado um fenômeno cultural, fortemente disseminado na mídia e em boa parte da sociedade. Conforme visto nas seções 3.5.3 e 3.5.4, somente uma predisposição social geral somada a uma predisposição específica favoráveis é que permitiu com que esse fenômeno adquirisse tal repercussão. Somente o interesse e a abertura interna do coletivo de pensamento dos pesquisadores em Fundamentos da FQ ao debate e a novas interpretações para essa teoria, somado ao contexto da contracultura hippie, na Califórnia, nos anos 1970, juntamente com a difícil situação de empregabilidade em que se encontravam os físicos nessa época devido à queda abrupta de investimentos em formação científica, no final da década de 1960 - e dos diversos centros universitários de elite, que se encontravam lado a lado de uma miríade de organizações religiosas, é que possibilitaram a busca dos físicos por espaços e fontes alternativas de fomento para a pesquisa e a investigação de questões de seu interesse - entre as quais, as que relacionavam a FQ com o misticismo. Posteriormente, essa busca por fontes alternativas de fomento deu origem aos chamados "produtos quânticos" - livros, palestras, cursos, workshops, etc. - e o seu sucesso de vendas, juntamente com a migração de indivíduos do coletivo de pensamento da FQ para esse novo coletivo que se formava, e com a predisposição social geral associada à cybercultura, ao Movimento da Nova Era e do Neoesoterismo é que impulsionaram a formação do coletivo de pensamento dos místicos quânticos e a consolidação do misticismo quântico como um fenômeno cultural. A partir dessa longa trajetória, observase que, de certa forma, a noção de misticismo quântico também foi condicionada por um contexto histórico-social específico, tornando-se um fenômeno cultural somente devido a essas condições. 
Além desses aspectos, também é possível destacar aqueles relacionados à circulação do conhecimento. Conforme discutido na seção 4.3, a formação da relação entre FQ e misticismo pode ser interpretada como o advento de um novo fato, surgido a partir da transformação do estilo de pensamento dos Fundamentos da FQ. Nessa transformação, Fritjof Capra introduziu um ver inicial, confuso e pouco claro, através do seu paralelismo quântico, e, posteriormente, seus seguidores - entre eles, Chopra e Goswami transformaram esse ver inicial em um ver formativo, através da formulação de novos conceitos, da coerção do pensamento e da percepção de uma forma de maneira imediata. Esse processo acabou culminando na formação do estilo de pensamento do misticismo quântico, a qual só foi possível devido à circulação das ideias provenientes do coletivo de pensamento dos pesquisadores em Fundamentos da FQ. Essa circulação das ideias ocorreu tanto de forma intra como intercoletiva, conforme visto anteriormente, a primeira delas - a circulação intracoletiva - se deu tanto por meio dos diálogos e trocas de ideias entre os próprios especialistas do coletivo, quanto através da relação entre os círculos eso e exotérico do coletivo, isto é, da relação entre o saber especializado e o saber popular, respectivamente. A segunda delas - a circulação intercoletiva -, por sua vez, exerceu o papel de deslocar, alterar e transformar o estilo de pensamento e ocorreu através de qualquer elemento circulante entre os coletivos de pensamento envolvidos no processo, em especial, por meio das palavras e das pessoas. Além disso, em meio a todo esse processo, foi possível notar a utilização de mecanismos para tornar a comunicação entre os coletivos mais viável, como a propaganda, que visa à popularização, à informação ou à legitimação de uma ideia. No entanto, observou-se que, além desses mecanismos, a circulação dessas ideias também resultou em alterações no pensamento não intencionais ou não previstas, como a falsa popularização, a apoteose do pensamento e a caricaturização do pensamento. A partir da análise de todo esse processo e de seus efeitos, portanto, conclui-se que a noção de misticismo quântico também só foi possível de ser construída devido aos processos de circulação do conhecimento científico pelos quais ela passou.

Por fim, o último aspecto a ser discutido se refere às questões relacionadas ao problema da demarcação na Ciência. Conforme a análise realizada na seção 4.4, observouse que o coletivo de pensamento dos místicos quânticos teve a sua origem em um coletivo de pensamento reconhecidamente científico - o coletivo de pensamento dos pesquisadores 
em Fundamentos da FQ -, contudo, essa origem não implica que esse novo coletivo também possa ser considerado um coletivo científico. De fato, foi possível perceber que ambos os coletivos não se reconhecem como sendo parte um do outro - com o coletivo de pensamento da Física utilizando termos com conotação pejorativa para se referir ao coletivo dos místicos quânticos e este, por sua vez, afirmando que seria parte de uma "Nova Ciência", diferente da Ciência "convencional" -, além disso, o coletivo de pensamento dos místicos quânticos não aparenta buscar por "um máximo de coerção no pensamento" ou por um máximo número de acoplamentos passivos, ao contrário, parece abrir margem para o livre pensar baseado na própria vontade, esse coletivo também apresenta características que o afasta dos coletivos de pensamento de caráter democrático - uma característica dos coletivos de pensamento científicos, segundo Fleck - e o aproxima dos de caráter dogmático, por fim, a linguagem, as tradições e as práticas próprias desse coletivo se mostraram distintas do coletivo de pensamento dos pesquisadores em Fundamentos da FQ. Sendo assim, conclui-se que a noção de misticismo quântico possui a sua origem histórica no âmbito da Ciência, porém, ao longo do seu desenvolvimento, ela vai perdendo o seu caráter científico e adquirindo características próximas a um conhecimento de caráter dogmático e que valoriza o exercício do livre pensar baseado na própria vontade.

Nota-se, portanto, a complexidade existente em torno da noção de misticismo quântico, a qual apresentou diversas facetas e aspectos envolvidos. Ao longo do processo de análise dessa noção, foi possível notar também que a epistemologia de Ludwik Fleck se mostrou de especial interesse e utilidade, revelando aspectos pouco explorados anteriormente por outros autores, principalmente no que se refere às relações históricosociais e culturais em torno desta. Assim, a partir de uma análise pela perspectiva fleckiana, foi possível delinear a noção de misticismo quântico de forma mais precisa. Contudo, de forma alguma, se pretendeu esgotar todos os elementos existentes em torno desta noção, os quais ainda permanecem em aberto e podem ser explorados em pesquisas e trabalhos futuros. 


\section{Considerações finais e reflexões sobre as possíveis implicações para o Ensino de Ciências}

A partir da análise desenvolvida neste trabalho, foi possível perceber que a circulação do conhecimento científico é inerente ao desenvolvimento da Ciência e que, ao longo desse processo, esse conhecimento circula tanto interna como externamente ao seu respectivo coletivo de pensamento, não ficando, portanto, restrito a ele e podendo circular por diferentes coletivos, sempre que estes tenham algum traço comum. Além disso, ao circular por outros coletivos, o conhecimento adquire novos matizes de significado, marcados pelo estilo de pensamento no qual trafega, podendo, assim, ao longo de um processo sutil e demorado, sofrer transformações e adquirir novos significados.

No caso estudado, acerca do estabelecimento da relação entre FQ e misticismo, observou-se que a formação dessa relação teve a sua origem na circulação do conhecimento científico dentro do próprio coletivo de pensamento dos pesquisadores em Fundamentos da FQ, nos debates entre os fundadores dessa teoria, que acarretou em uma formação peculiar para a estrutura desse coletivo: inicialmente, com dois núcleos para o círculo esotérico - relativos aos pesquisadores que trabalhavam com os formalismos matricial e ondulatório da MQ, respectivamente - e, posteriormente, com diversos núcleos para este círculo, referentes aos adeptos de cada uma das interpretações da FQ. Essa estrutura propiciou uma maior circulação do conhecimento, pois promovia debates constantes entre seus membros, a fim de buscar respostas para os problemas de fundamentos da TQ. Quando esta predisposição específica de busca por respostas a esses problemas, interna ao coletivo de pensamento, encontrou uma predisposição social geral adequada - a saber, o contexto da contracultura hippie dos anos 1970, na Califórnia, nos EUA -, a procura por uma maior coerção do pensamento acerca das questões de Fundamentos da FQ - em especial, o problema da medição e as consequências do Teorema de Bell -, juntamente com a mobilização de algumas protoideias presentes na Física, permitiu com que se formasse um ver inicial e pouco claro de analogias e paralelos entre os fenômenos da FQ e fenômenos relacionados ao misticismo, como questões relativas à clarividência, à parapsicologia, à psicocinese, entre outras. Esse ver inicial e pouco claro, posteriormente, especialmente com a publicação de $O$ Tao da Física, de Fritjof Capra, foi adquirindo uma forma e se transformando em um ver formativo, com a 
percepção da forma de maneira imediata, e passando de meras analogias e paralelos a explicações genuínas, baseadas na FQ, de diversos fenômenos - relacionados à saúde e à cura, passando por fenômenos relacionados à consciência, até à economia e aos conflitos sociais -, conforme se nota nas obras de Deepak Chopra e Amit Goswami. Esse processo deu origem a um novo estilo de pensamento, que pode ser identificado com o fenômeno cultural do misticismo quântico e que possui um coletivo de pensamento atrelado, cujos membros trocam ideias regularmente entre si, alinham os seus discursos, interesses e práticas com os movimentos da Nova Era e do Neoesoterismo e utilizam a FQ para fundamentá-los. Sendo assim, nota-se que a relação entre FQ e misticismo não se estabeleceu de forma arbitrária ou espontânea, livremente inventada por místicos, mas que ela teve a sua origem no próprio desenvolvimento da Ciência, no qual o processo de circulação do conhecimento exerceu um papel crucial.

Assim, percebe-se que, em princípio, qualquer forma de circulação do conhecimento científico, seja ela intra ou intercoletiva, pode dar origem a transformações no estilo de pensamento. Entre as diversas formas de circulação do conhecimento existentes, de especial interesse para este trabalho é a que ocorre através da educação. Em uma perspectiva fleckiana, ela equivale à introdução didática de um novato em um determinado coletivo de pensamento e, no caso do Ensino de Ciências, ela corresponderia à introdução didática ao coletivo de pensamento científico, que teria o papel de introduzir os indivíduos aos costumes e linguagens específicas da Ciência, através de uma suave coerção, análoga às iniciações conhecidas pela etnologia e pela história cultural. Por conta desse período de adaptação dos indivíduos às linguagens e costumes específicos do coletivo, para Fleck, toda introdução didática em uma área envolve um tempo em que predomina um ensino puramente dogmático. O período de predominância de um ensino dogmático apontado por Fleck, no entanto, não corresponderia a uma educação na qual os sujeitos não poderiam questionar o conteúdo e os métodos da Ciência, mas a um período que visa tornar familiares os hábitos e práticas desse coletivo de pensamento, no qual os sujeitos se adaptariam e compreenderiam os costumes e usos das linguagens específicas da Ciência. Em meio a esse processo, portanto, ainda que seja possível, torna-se mais difícil a transformação do estilo de pensamento unicamente por meio do processo educativo - um processo intracoletivo -, pois, conforme visto ao longo deste trabalho, nos períodos em que predominou um caráter mais dogmático - como na chamada 
"monocracia de Copenhagen" -, havia menor propensão do coletivo a transformações em seu estilo, enquanto que, quando predominava um caráter mais democrático - como em um contexto propício à formação de instituições não acadêmicas convencionais -, essas transformações ocorreram mais facilmente. Sendo assim, ao longo do processo educativo, as alterações ou transformações no estilo de pensamento se tornam mais viáveis através da circulação intercoletiva do conhecimento, isto é, através das trocas de ideias entre os diferentes coletivos de pensamento, quando estas encontram uma predisposição social geral propícia. Essas trocas podem ocorrer por qualquer elemento que circule entre os diferentes coletivos, mas especialmente pela circulação dos indivíduos, devido ao fato deles pertencerem a diferentes coletivos de pensamento, e pela circulação das palavras, um bem comum de qualquer coletivo e que adquire diferentes matizes de significado ao circular por eles. Dessa forma, essa troca de ideias e transformações no estilo de pensamento dos estudantes de Ciências pode ocorrer também com o contato com coletivos de pensamento, como o do misticismo quântico, ou qualquer outro coletivo que utilize os conceitos científicos de forma considerada não científica pelo coletivo de pensamento da Ciência.

Por conta disso, parece mais razoável discutir, em sala de aula, temas que envolvam o conhecimento científico, seus usos e diferentes significados que podem ser adquiridos com a circulação no meio sociocultural - como o fenômeno cultural do misticismo quântico -, a fim de apresentar e formar visões e concepções coletivas acerca destas questões baseadas na visão da Ciência, do que deixar que essas visões sejam formadas de forma individual ou por meio da participação de grupos e instituições cujas visões não sejam baseadas na Ciência. Sendo assim, as posturas de rechaço, de ridicularização ou de se negar a discutir esses temas, por parte de alguns membros das comunidades de físicos e dos educadores em ciências, não consistiria na postura mais adequada para lidar com esses temas.

Além do mais, por se tratar de debates que já não estariam inseridos no período de ensino puramente dogmático apontado por Fleck - uma vez que os indivíduos já teriam que estar, de alguma forma, familiarizados com os hábitos, costumes e linguagens característicos da Ciência -, parece razoável que, nos debates em torno dessas questões, não se adote uma postura combativa com caráter dogmático, mas que se promova uma 
troca de ideias livre e democrática, aberta a críticas, a fim de refletir o caráter genuinamente democrático dos coletivos de pensamento científicos, tal qual defendido por Fleck. Contudo, para refletir de forma mais apropriada o caráter democrático desses coletivos e a sua troca livre de ideias, seria preciso que esses debates partissem de um estudo mais aprofundado acerca: do surgimento dos temas tratados, bem como do seu desenvolvimento, da estrutura dos coletivos de pensamento envolvidos e dos modos como eles operam, dos elementos presentes em seus discursos, dos interesses envolvidos na circulação de seus conhecimentos, dos elementos que os diferenciam do conhecimento científico, entre outros aspectos. Ou seja, para que essa troca de ideias ocorra de forma crítica e emancipadora - perspectiva educacional adotada neste trabalho -, ela deve se pautar em um conhecimento construído também nos moldes do funcionamento dos coletivos de pensamento científicos.

A adoção dessas posturas, em primeiro lugar, visa diferenciar a educação científica da educação característica dos coletivos de pensamento de caráter dogmático, nos quais os segredos e o dogmatismo dominam, a origem sobrenatural das ideias é enfatizada e a sua importância requer obediência e docilidade, conforme observado nos discursos promovidos pelo coletivo de pensamento do misticismo quântico - nos quais o termo "quântico", por exemplo, adquiriu um status de um símbolo com autoridade persuasiva, baseado em argumentos de autoridade científica. Em segundo lugar, essas posturas também visam se diferenciar da adoção de uma posição relativista com relação à Ciência e as outras formas de conhecimento - a qual as colocaria em um mesmo patamar de valores e confiabilidade -, sem se ausentar da responsabilidade de apresentar e discutir com os estudantes o verdadeiro funcionamento da Ciência, mostrando que, inclusive, a partir de seu próprio desenvolvimento, é possível originar formas de conhecimento não-científicas. Assim, com essas propostas, busca-se levar em conta que: (1) temas populares, que tocam as fronteiras entre o conhecimento científico e o não-científico, costumam exercer um fascínio sobre os estudantes e despertar o seu interesse acerca de assuntos relacionados às ciências; e (2) as origens desses temas, muitas vezes, se encontram na própria história do conhecimento científico que está em sua fronteira. Porém, sem deixar de tomar o cuidado para que não se recaia em uma postura relativista com relação ao conhecimento científico. 
Portanto, retomando a problemática levantada no início deste trabalho em torno da Alfabetização Científica (AC) e seus objetivos, evidencia-se a fragilidade de alguns dos pressupostos implícitos nos argumentos a respeito do que significa ser um sujeito alfabetizado cientificamente. $\mathrm{O}$ primeiro deles se refere à necessidade de aquisição de um corpo fechado de conhecimentos, estático e bem definido, o qual, após a sua aquisição, manteria-se intacto, com a mesma significação de sua origem, sendo apenas utilizado pelo indivíduo ao longo de sua vida. Essa visão, de modo não explícito, pressupõe que um conjunto de conceitos admite significado independente dos estilos de pensamento que estão na base de sua origem e desenvolvimento. Admite, ainda, que seus significados se mantêm independentemente de seu contexto de uso.

Toda a análise realizada ao longo deste trabalho revelou que não existe corpo de conhecimentos fechado, com significação independente de questões, intenções e valores presentes em uma forma de pensar. Faz parte da natureza do conhecimento e do seu desenvolvimento circular, se alterar e se transformar, tanto nos coletivos de pensamento quanto nos indivíduos, que são os portadores do desenvolvimento histórico de uma área do conhecimento, de tal forma que se torna difícil esperar que a AC cumpra o papel de fornecer tal corpo fechado e estático. Assim, parece ser mais interessante privilegiar abordagens temáticas, em uma perspectiva na qual os processos de ressignificação do conhecimento e análises de seus diferentes usos sejam o objeto de estudo. Tomando-se o exemplo deste trabalho, seria preciso problematizar o misticismo quântico de modo a se tornar necessária a análise deste movimento, levando-se em conta os elementos que compõe seu estilo de pensamento.

Outros pressupostos implícitos nos argumentos da AC a serem discutidos seriam a preocupação com a aquisição individual de um determinado conhecimento e com que o indivíduo se proteja dos males que podem existir na sociedade, como as pseudociências, por exemplo. Esses pressupostos também se fragilizam, pois, a partir da análise realizada, foi possível observar que um coletivo de pensamento não é mera soma de indivíduos que possuem o mesmo conhecimento, mas uma comunidade que troca ideias regularmente e se encontra em uma situação recíproca de pensamentos, que partilha dos problemas que lhes interessam, de tal forma que o conhecimento está em constante movimento e não estaticamente localizado em cada um dos membros do coletivo. Da mesma forma, o 
conhecimento não possui a função de proteger aqueles que o possuem, nem mesmo aqueles que estão se iniciando em determinado coletivo de pensamento. Em primeiro lugar, porque esses indivíduos não podem ser considerados sujeitos vulneráveis e acríticos, os quais aceitariam e propagariam passivamente os conhecimentos que lhes são transmitidos, mas consistem em sujeitos ativos e protagonizadores do processo de circulação e construção do conhecimento. Em segundo lugar, porque o próprio conhecimento é um produto da troca mútua de ideias entre os sujeitos, membros de um coletivo, que pode ser alterado e transformado por eles mesmos, e não algo pronto e acabado que apenas chega até eles. Com isso, a concepção de uma sociedade alfabetizada cientificamente como uma mera soma de indivíduos alfabetizados cientificamente se torna problemática, bem como a concepção de que o conhecimento proporcionado pela AC poderia exercer a função de proteger os indivíduos que o possuem. Mais do que isso, parece mais razoável esperar que, com a AC, os indivíduos se apropriem do conhecimento científico, inclusive da sua forma de funcionamento, e o mantenham vivo, em constante circulação e construção. Esse objetivo para AC parece ser mais razoável, até mesmo para que o conhecimento científico possa concorrer com as outras formas de conhecimento antagônicas a ele, que inevitavelmente circularão em diferentes contextos socioculturais.

Também não parece ser adequado para a AC adotar uma postura combativa de caráter dogmático com relação ao mau uso da ciência ou às pseudociências, pois, conforme visto ao longo desta pesquisa, essa postura se aproxima da adotada pelos coletivos de pensamento de caráter dogmático e se afasta do caráter democrático característico dos coletivos de pensamento científicos. De tal forma que ela dificultaria a circulação do conhecimento de forma livre, crítica e reflexiva neste coletivo, e enfatizaria a origem sobrenatural das ideias, o que requereria obediência e docilidade por parte dos estudantes, para a aceitação dessas ideias, uma característica que se afasta dos objetivos de uma AC plena. Sendo assim, essa postura, faria com que a AC adquirisse características próximas às dos coletivos de pensamento como o do misticismo quântico, por exemplo, os quais consistem justamente nos alvos de suas críticas. De outra forma, parece ser mais razoável, uma postura que promova o debate e a discussão livre e democrática, aberta a críticas, dos aspectos envolvidos em torno dessas temáticas, que incluam um estudo aprofundado das suas origens, do contexto histórico-social que as condicionam e das características que as diferenciam dos coletivos de pensamento típicos da Ciência. 
Por fim, também é possível apontar as limitações das tendências da AC que enfatizam a atuação individual dos sujeitos em detrimento de sua atuação social, como aquelas que enfatizam a aquisição de competências individuais para que os sujeitos possam ser considerados alfabetizados cientificamente. Conforme discutido anteriormente, essas tendências fugiriam de uma das propostas iniciais da AC, de buscar uma sociedade alfabetizada cientificamente, a fim de que ela possa lidar melhor com os problemas sociais que enfrenta, uma vez que uma sociedade alfabetizada cientificamente não é a mera soma de indivíduos alfabetizados cientificamente. Dessa forma, em uma perspectiva educacional que promova uma maior criticidade nos sujeitos, na qual eles se emancipem intelectualmente e atuem na sociedade não de forma individual, mas de forma coletiva, seria necessário adotar uma perspectiva na qual a troca de ideias e a circulação do conhecimento ocorra de forma livre e democrática. Preservando, assim, o poder de criticidade por parte dos estudantes, porém sem prejuízo da pesquisa sobre os fundamentos que sustentem essas críticas. Assim, parece promissor que a aquisição de competências individuais venha sempre acompanhada de uma troca de ideias e uma problematização coletiva dos temas tratados, a fim de refletir as práticas e o funcionamento dos coletivos de pensamento científicos.

Com essas reflexões e críticas, não se pretende resolver o problema dos objetivos da $\mathrm{AC}$, do seu significado e dos requerimentos para que um sujeito possa ser considerado alfabetizado cientificamente. No entanto, foi possível observar que alguns dos pressupostos implícitos presentes nos argumentos utilizados para defender a AC são frágeis e possuem contradições com relação aos seus objetivos, principalmente quando se adota uma perspectiva educacional que visa formar sujeitos críticos e reflexivos, a fim de buscar uma sociedade que seja alfabetizada cientificamente. Por fim, para promover e sustentar essas reflexões, o estudo da formação da relação entre a FQ e o misticismo a partir de uma perspectiva fleckiana se mostrou bastante profícuo. 


\section{Referências Bibliográficas}

D' ALEMBERT, J. R., DIDEROT, D. (éd.) [1751-1780]. Encyclopédie ou Dictionnaire raisonné des sciences, des arts et des métiers, 17 vols +11 vol. de planches, Briasson, David, Le Breton et Durant, Paris, 1751-1780.

AMERICAN ASSOCIATION FOR THE ADVANCEMENT OF SCIENCE. Science for all Americans. Washington, DC: Author, 1989.

ARNTZ, W., HOFFMAN, M., CHASSE, B., VICENTE, M. Quem somos nós? Estados Unidos, 2004. Filme. Disponível em: <https://www.youtube.com/watch?v=0ljf3P3O51s>. Acesso em: 09 set. 2018.

ATIVISMO QUÂNTICO ONLINE. Curso online de Ativismo Quântico: com o físico indiano Amit Goswami. Disponível em: < http://www.ativismoquanticoonline.com.br/especial-alunoselainne?ref=D8650551A\&hsrc=TmVlbWlhcw\%3D\%3D>. Acesso em: 09 set. 2018.

BADASH, L. The completeness of nineteenth-century science. Isis 63(1), 48-58, 1972.

BOHM, D. A suggested interpretation of the quantum theory in terms of hidden variables. Physical Review 85(2), 166-179 and 180-193, 1952.

Wholeness and the Implicate Order. New York: Routledge, 1980.

BOHR, N. Unity of Knowledge. In: Leary, L.G. (org.). The Unity of Knowledge, Doubleday, Nova Iorque, 1955.

Niels Bohr, Essays and Papers, J T Sanders (ed.), Rochester, 1987.

BLACKBURN, S. Dicionário Oxford de filosofia. Tradução, Murcho, D., et al. Rio de Janeiro: Jorge Zahar Ed., 1997.

BRANSCOMB, A. W. Knowing how to know. Science, Technology, \& Human Values 6(36), 5-9, 1981. 
BUSCH, P.; FALKENBURG, B. Heisenberg Uncertainty Relation (Indeterminacy Relations). In: GREENBERGER, D.; HENTSCHEL, K.; WEINERT, F. (Eds.) Compendium of Quantum Physics: Concepts, Experiments, History and Philosophy. New York, London: Springer, p. 281-283, 2009.

BYBEE, R.W. Toward an understanding of scientific literacy. In: GRÄBER, W. \& BOLTE, C. (Eds.) Scientific literacy. Institut für die Pädagogik der Naturwissenschaften (IPN): Kiel, Germany, p. 37-68, 1997.

CAPRA, F. The Dance of Shiva. In: Main Currents in Modern Thought 29, p. 14-20, 1972.

O Tao da Física: um paralelo entre a Física Moderna e o Misticismo Oriental. São Paulo: Ed. Cultrix, 1983. Original em inglês: The Tao of Physics: An Exploration of the Parallels Between Modern Physics and Eastern Mysticism. Boston: Shambhala, 1975.

. Uncommon Wisdom: Conversations with Remarkable People.

New York: Simon and Schuster, 1988.

CARNEIRO, J.A.C. A teoria comparativa do conhecimento de Ludwik Fleck: comunicabilidade e incomensurabilidade no desenvolvimento das ideias científicas. Dissertação (Mestrado) - Faculdade de Filosofia, Letras e Ciências Humanas da Universidade de São Paulo, São Paulo, 2012.

CARSON, C. Who Wants a Postmodern Physics?. Science in Context 8(4), 645-655, 1995.

CASSIDY, D.C. A Short History of Physics in the American Century. Cambridge: Harvard University Press, 2011.

CHOPRA, D. A cura quântica: o poder da mente e da consciência a busca da saúde integral. São Paulo: Best Seller, 1990. Original em inglês: Quantum healing. New York: Bantam Books, 1989.

COLLINS, A. National science education standards: A political document. Journal of Research in Science Teaching 35 (7), 711-727, 1998. 
CONDÉ, M.L.L. Prefácio à edição brasileira: um livro e seus prefácios: de pé de página a um novo clássico. In: FLECK, L. Gênese e desenvolvimento de um fato científico: introdução à doutrina do estilo de pensamento e do coletivo de pensamento [1935]. Tradução de Georg Otte e Mariana Camilo de Oliveira. Belo Horizonte: Fabrefactum, 2010.

COX, H. Turning East: Why Americans Look to the Orient for Spirituality and What that Search Can Mean to the West. Simon \& Schuster, 1978.

CRUZ, F. F. de S. Teoria Quântica: Estudos Históricos e implicações culturais: Mecânica Quântica e a cultura em dois momentos. In: FREIRE JÚNIOR, O.; PESSOA JÚNIOR, O.; BROMBERG J. L. (Org.). Teoria Quântica: Estudos Históricos e Implicações Sociais. Campina Grande: EDUEPB/Livraria da Física, 2011.

CULL, E., BACCIAGALUPPI, G. Grete Hermann: between physics and philosophy. Dordrecht: Springer, 2016.

DARRIGOL, O. From c-numbers to q-numbers: the classical analogy in the history of quantum theory. Berkeley: University of California Press, 1992.

DAVIES, P. Other Worlds: Space, Superspace and the Quantum Universe. London: Penguin Books, 1980.

DEBOER G. E. Scientific literacy: another look at its historical and contemporary meanings and its relationship to science education reform. Journal of Research in Science Teaching 37 (6), 582-601, 2000.

DElizOICOV, D., CASTILHO, N., CUTOLO, L.R.A., DA ROS, M.A., LIMA, A.M.C. Sociogênese do Conhecimento e Pesquisa em Ensino: Contribuições a partir do Referencial Fleckiano. Caderno Brasileiro de Ensino de Física 19, 52-69, 2002.

DIEM, A.G.; LEWIS, J.R. Imagining India: The Influence of Hinduism on the New Age Movement. In: LEWIS, J.R.; MELTON, J. G. (orgs.). Perspective on the New Age. Albany: State University of New York Press, pp. 48-58, 1992.

EDDINGTON, A. S. The decline of determinism. Mathematical Gazette 16, 66-80, 1932. 
EINSTEIN, A. Albert Einstein: The Human Side, Princeton: Princeton University Press, 1981.

FALKENBURG, B.; MITTELSTAEDT, P. Probabilistic Interpretation of Quantum Mechanics. In: GREENBERGER, D.; HENTSCHEL, K.; WEINERT, F. (Eds.) Compendium of Quantum Physics: Concepts, Experiments, History and Philosophy. New York, London: Springer, p. 485-491, 2009.

FIVES, H., HUEBNER, W., BIRNBAUM, A. S., NICOLICH, M. Developing a measure of scientific literacy for middle school students. Science Education 98, 549-580, 2014.

FLECK, L. Some specific features of the medical way of thinking [1927]. In: COHEN, R. S. \& SCHNELLE, T. Cognition and Fact: Materials on Ludwik Fleck. Dordrecht, D. Reidel Publishing Company, p. 39-46, 1986.

. On the crisis of 'reality' [1929]. In: COHEN, R. S. \& SCHNELLE, T. Cognition and Fact: Materials on Ludwik Fleck. Dordrecht, D. Reidel Publishing Company, p. 47-58, 1986.

. The problem of epistemology [1936]. In: COHEN, R. S. \& SCHNELLE, T. Cognition and Fact: Materials on Ludwik Fleck. Dordrecht, D. Reidel Publishing Company, p. 79-112, 1986.

Crisis in science [1960]. In: COHEN, R. S. \& SCHNELLE, T.

Cognition and Fact: Materials on Ludwik Fleck. Dordrecht, D. Reidel Publishing Company, p. 153-158, 1986.

. Gênese e desenvolvimento de um fato científico: introdução à doutrina do estilo de pensamento e do coletivo de pensamento [1935]. Tradução de Georg Otte e Mariana Camilo de Oliveira. Belo Horizonte: Fabrefactum, 2010.

FORMAN, P. A cultura de Weimar, a causalidade e a teoria quântica, 1918-1927: A adaptação dos físicos e matemáticos alemães a um ambiente intelectual hostil. Cadernos de História e Filosofia da Ciência supl. 2, p. 3-98, 1983. 
FREIRE Jr., O. Dissidentes quânticos: pesquisa em fundamentos da Teoria Quântica em torno de 1970. In: FREIRE Jr, O.; PESSOA Jr, O.; BROMBERG, J.L. (Org.). Teoria Quântica: estudos históricos e implicações culturais. Campina Grande: EDUEPB; São Paulo: Livraria da Física, p. 281-302, 2011.

FREIRE Jr., O. The Quantum Dissidents: rebuilding the foundations of Quantum Mechanics (1950-1990). Springer Heidelberg New York Dordrecht London, 2015.

GAVRoglU, K. Fritz London a Scientific Biography. Cambridge: Cambridge University Press, 1995.

GLEISER, M. A Dança do Universo: Dos Mitos de Criação ao Big Bang. São Paulo: Editora Schwarcz Ltda, 1997.

GOSWAMI, A. Concepts of Physics. Massachusetts: Heath, 1979. Quantum Mechanics. William C Brown Pub, 1991.

Roda Viva. São Paulo, TV Cultura, 12 mar. 2001. Entrevista a Heródoto Barbeiro. Disponível em: <https://www.youtube.com/watch?v=EgAPwSWuRog>. Acesso em: 09 set. 2018.

O médico quântico: orientações de um físico para a saúde e a cura. São Paulo: Cultrix, 2006. Original em inglês: The Quantum Doctor: A Quantum Physicist Explains the Healing Power of Integral. Virginia: Hampton Roads Publishing Co, 2004.

Roda Viva. São Paulo, TV Cultura, 11 fev. 2008. Entrevista a Heródoto Barbeiro. Disponível em: <https://www.youtube.com/watch?v=OltWZlCqXvI>. Acesso em: 09 set. 2018.

GOSWAMI, A., GOSWAMI, M. The Cosmic Dancers: Exploring the Physics of Science Fiction. New York: Harpercollins, 1983.

GOSWAMI, A., REED, R.E., GOSWAMI, M. O universo autoconsciente: como a consciência cria o mundo material. Rio de Janeiro: Record: Rosa dos Tempos, 2001. Original em inglês: The Self-Aware Universe: How Consciousness Creates the Material World. New York: Penguin Putnam Inc., 1993. 
GRIBBIN, J. In Search of Schrödinger's Cat: Quantum Physics and Reality. New York: Bantam Books, 1984.

GRIM, P. (Org.). Philosophy of science and the occult. 2.ed. Albany: Sunys, 1982.

HAMMER, O. Claiming knowledge: strategies of epistemology from theosophy to the New Age. Leiden; Boston: Brill, 2004.

HEELAS, P. The new age movement. Oxford: Blackwell, 1996.

HEITLER, W. The Departure from Classical Thought in Modern Physics. In: SCHILPP, P.A. (org.), Albert Einstein: Philosopher-Scientist, Open Court, Urbana, pp. 181-98, 1949.

HEISENBERG, W. Physics \& Philosophy. The Revolution in Modern Science, New York: Harper \& Brother publishers, 1958.

. Physics and Beyond: Encounters and Conversations. New York:

Harper \& Row, 1971.

Across the Frontiers, New York: Harper \& Row, 1990.

HENTSCHEL, K. Quantum theory, crisis period 1923-early $1925 . \quad$ In: GREENBERGER, D.; HENTSCHEL, K.; WEINERT, F. (Eds.) Compendium of Quantum Physics: Concepts, Experiments, History and Philosophy. New York, London: Springer, p. 613-617, 2009.

HERBERT, N. Quantum Reality: Beyond the New Physics. New York: Anchor Books, 1985.

HILEY, B.J. Hidden Variables. In: GREENBERGER, D.; HENTSCHEL, K.; WEINERT, F. (Eds.) Compendium of Quantum Physics: Concepts, Experiments, History and Philosophy. New York, London: Springer, p. 284-287, 2009.

HODSON, D. Nature of Science in the Science Curriculum: Origin, Development, Implications and Shifting Emphases. In: MATTHEWS, M. R. (Ed.) International Handbook of Research in History, Philosophy and Science Teaching. New York, London: Springer, 2014. 
HOLBROOK, J., RANNIKMAE, M. The Meaning of Scientific Literacy. International Journal of Environmental \& Science Education 4(3), 275-288, 2009.

IMPROBABLE REASEARCH. Winners of the Ig Nobel Prize. Disponível em: < http://www.improbable.com/ig/ig-pastwinners.html\#ig1998>. Acesso em: 29 ago. 2016.

JAMMER, M. The Conceptual Development of Quantum Mechanics. New York: McGraw-Hill, 1966.

The Philosophy of Quantum Mechanics. New York : Wiley, 1974.

- Einstein and Religion: Physics and Theology, Princeton:

Princeton University Press, 1999.

JAUCH, J.M. The Problem of Measurement in Quantum Mechanics. Helvetica Physica Acta 37, 293-316, 1964.

JOHNSON, G. Uncommon Wisdom: Conversations with Remarkable People by Fritjof Capra. In: The New York Times, March, 20, 1988.

KAISER, D. How the hippies saved physics: science, counterculture, and the quantum revival. New York, London: W.W. Norton \& Company, 2011.

KUHN, T. The structure of scientific revolutions [1962]. Chicago: University of Chicago Press, 1970.

KRAGH, H. Quantum generations: a history of physics in the twentieth century. Princeton: Princeton University Press, 1999.

LALANDE, A. Vocabulaire technique et critique de la philosophie. Paris : Presses Universitaires de France, 1997.

LANDSMAN, N.P. Born rule and its interpretation. In: GREENBERGER, D.; HENTSCHEL, K.; WEINERT, F. (Eds.) Compendium of Quantum Physics: Concepts, Experiments, History and Philosophy. New York, London: Springer, p. 64-70, 2009.

LAPLACE, P. S. Théorie analytique des probabilités, 1812. 
LARMOR, J. Aether and matter. Cambridge: Cambridge University Press, 1900.

LAUGKSCH, R. Scientific Literacy: A Conceptual Overview. Science Education 84(1), 71-94, 2000.

LEANE, E. Reading Popular Physics: Disciplinary Skirmishes and Textual Strategies. Hampshire: Ashgate Publishing Limited Gower House, 2007.

LEGGETT, A.J. Bell's Theorem. In: GREENBERGER, D.; HENTSCHEL, K.; WEINERT, F. (Eds.) Compendium of Quantum Physics: Concepts, Experiments, History and Philosophy. New York, London: Springer, p. 24-31, 2009.

LEMAD. Contracultura e movimento hippie. Disponível em: <http://lemad.fflch.usp.br/node/217>. Acesso em: 20 out. 2016.

LOCHAK, G. En mémoire d'un précieux ami : Oliver Costa de Beauregard. Annales de la Fondation Louis de Broglie 32(1), 1-9, 2007.

LONDON, F.W.; BAUER, E. La Théorie de l'Observation em Mécanique Quantique, Hermann, Paris, 1939. Tradução para o inglês: “The Theory of Observation in Quantum Mechanics”, in Wheeler \& Zurek, op.cit., pp. 217-59, 1983.

LORENZETTI, L., MUENCHEN, C., SLONGO, I.I.P. A recepção da epistemologia de Fleck pela pesquisa em educação em ciências no Brasil. Revista Ensaio 15(3), 181-197, 2013.

LÖWY, I. The Polish School of Philosophy of Medicine: from Tytus Chalubinski (1820-1889) to Ludwik Fleck (1896-1961). Compiled, translated and introductions by the author. Dordecht: Reidel, 1990.

MACLEOD, R. The "bankruptcy" of science debate: the creed of science and its critics, 1885-1900. Science, Technology, \& Human Values 7, 2-15, 1982.

MAGNANI, J. G. C. Mystica urbe. São Paulo: Studio Nobel, 1999.

MARIN, J.M. "Mysticism" in quantum mechanics: the forgotten controversy. European Journal of Physics 30, 807-822, 2009. 
MARTINS, A.F.P. Knowledge about Science in Science Education Research from the Perspective of Ludwik Fleck's Epistemology. Research on Science Education 46, 511$524,2016$.

MILLER, J. D. Scientific literacy: A conceptual and empirical review. Daedalus 112(2), 29-48, 1983.

NATIONAL RESEARCH COUNCIL. National Science Education Standards. Washington, DC: National Academy Press, 1996.

NETO, N.P. Teorias e interpretações da mecânica quântica. São Paulo: Editora Livraria da Física. Rio de Janeiro: CBPF: Centro Brasileiro de Pesquisas Físicas, 2010.

NOGUEIRA, F.S. Ciência e linguagem: Fleck e o estilo de pensamento como rede de significados na ciência. Dissertação (Mestrado) - Faculdade de Filosofia e Ciência Humanas da Universidade Federal de Minas Gerais, Belo Horizonte, 2012.

NOGUEIRA, P. Espiritualidade quântica? Consciência, religião e ciência no pensamento de Amit Goswami. Dissertação (Mestrado) - Pontifícia Universidade Católica de São Paulo, São Paulo, 2010.

OLIVEIRA, B.J. Os circuitos de Fleck e a questão da popularização da ciência. In: CONDÉ, M.L.L. (Org.). Ludwik Fleck: estilos de pensamento na ciência. Belo Horizonte, MG: Fino traço, p. 121-144, 2012.

OMNÈS, R. Edmond Bauer et la conscience de l'observateur en mécanique quantique. Épistémologiques 2(1-2), 171-176, 2002.

PAGELS, H.R. The Cosmic Code: Quantum Physics as the Language of Nature. New York: Dover Publication, 1982.

PATY, M. La notion de déterminisme en physique et ses limites. In: DEBRU, C.; VIENNOT, L. (Eds) Enquête sur le concept de causalité. Collection Sciences, histoire et société. Paris: Presses Universitaires de France, p. 85-114, 2003.

A gênese da causalidade física. Scientia Studia, São Paulo, 2(1), 9-

$32,2004$. 
. The problem of the physical interpretation of theoretical quantities and the intelligibility of the quantum domain. Science and cultural diversity: Proceedings of the XXIst International Congress of History of Science, Changes in Interpretation $\boldsymbol{\&}$ Conceptual Contents, 2774-2793, 2005.

. Einstein. São Paulo: Estação Liberdade, 2008.

PESSOA, O. O problema da medição em Mecânica Quântica: um exame atualizado. Cadernos de História e Filosofia da Ciência 2(2), 177-217, 1992.

O sujeito na física quântica. In: OLIVEIRA, E.C. (Org.). Epistemologia, lógica e filosofia da linguagem: ensaios de filosofia contemporânea. Feira de Santana: Núcleo de Estudos Filosóficos, p. 157-196, 2001.

Conceitos de Física Quântica. Volume I. São Paulo: Editora Livraria da Física, 2003.

- Introdução Histórica à Teoria Quântica, aos seus problemas de fundamento e às suas interpretações. Caderno de Física da UEFS 04(01 e 02), 89-114, $2006 a$.

Conceitos de Física Quântica. Volume II. São Paulo: Editora Livraria da Física, 2006b.

Física Quântica: Entenda as diversas interpretações da física quântica, 2007-2011. Disponível em: <http://www2.uol.com.br/vyaestelar/fisicaquantica.htm >.

História da Teoria Quântica. Notas de aula, 2010. Disponível em: <http://www.fflch.usp.br/df/opessoa/Hist-MQ-2.pdf>. Acesso em: 16 out. 2016. . O fenômeno cultural do misticismo quântico. In: FREIRE Jr, O.; PESSOA Jr, O.; BROMBERG, J.L. (Org.). Teoria Quântica: estudos históricos e implicações culturais. Campina Grande: EDUEPB; São Paulo: Livraria da Física, p. 281$302,2011$. 
PESSOA, O., FREIRE Jr, O., GREIFF, A. The Tausk Controversy on the Foundations of Quantum Mechanics: Physics, Philosophy, and Politics. Physics in Perspective 10, 138$162,2008$.

PICKERING, A. Construction Quarks: A Sociological History of Particle Physics. The University of Chicago Press, Chicago, USA, 1984.

PRZIBRAM, K. Letters onWave Mechanics: Schrödinger, Planck, Einstein, Lorentz, New York: Philosophical Library, 1967.

ROBERTS, D. Scientific Literacy/Science Literacy. In: ABELL, S.K. e LEDERMAN, N.G. (Eds) Handbook of Research on Science Education. New Jersey: Lawrence Erlbaum Associates, 2007.

ROCHA, G.R. Uma história cultural do reencantamento do mundo pela Teoria Quântica. Tese (Doutorado) - Universidade Federal da Bahia/Universidade Estadual de Feira de Santana, Salvador, 2015.

ROYAL SOCIETY. The public understanding of science. London: Royal Society, 1985.

SANTOS, P.V.M. O itinerário científico de Louis de Broglie em busca de uma interpretação causal para a mecânica ondulatória. In: FREIRE Jr, O.; PESSOA Jr, O.; BROMBERG, J.L. (Org.). Teoria Quântica: estudos históricos e implicações culturais. Campina Grande: EDUEPB; São Paulo: Livraria da Física, p. 81-95, 2011.

SCHÄFER, L.; SCHNELLE, T. Introdução: fundamentação da perspectiva sociológica de Ludwik Fleck na teoria da ciência. In: FLECK, L. Gênese e desenvolvimento de um fato científico: introdução à doutrina do estilo de pensamento e do coletivo de pensamento. Tradução de Georg Otte e Mariana Camilo de Oliveira. Belo Horizonte: Fabrefactum, p. 3-4, 2010.

SCHENBERG, M. Prefácio à edição brasileira. In: CAPRA, F. O Tao da Física: um paralelo entre a Física Moderna e o Misticismo Oriental. São Paulo: Ed. Cultrix, 1984. 
SCHRÖDINGER, E. The present situation in quantum mechanics. In: Wheeler, J.A., Zurek, W.H. (eds.). Quantum Theory and Measurement. Princeton University Press, Princeton NJ, pp. 152-167, 1983.

O que é vida? $\mathrm{O}$ aspecto físico da célula viva seguido de Mente e Matéria e Fragmentos autobiográficos. São Paulo: Fundação Editora da UNESP, 1997.

SHAMOS, M. The myth of scientific literacy. New Brunswick, NJ: Rutgers University Press, 1995.

SHIMONY, A. Hidden-variables models of Quantum Mechanics (Noncontextual and Contextual). In: GREENBERGER, D.; HENTSCHEL, K.; WEINERT, F. (Eds.) Compendium of Quantum Physics: Concepts, Experiments, History and Philosophy. New York, London: Springer, p. 287-291, 2009.

SINGH, S.; SINGH, S. What is scientific literacy: a review paper. International Journal of Academic Research and Development 1(2), 15-20, 2016.

SPENGLER, O. Der Untergang des Abendlandes. Umrisse einer Morphologie der Weltgeschichte. Vol. 1: Gestalt und Wirklichkeit, Munique, 1918.

STAPP, H. Complementarity Principle. In: GREENBERGER, D.; HENTSCHEL, K.; WEINERT, F. (Eds.) Compendium of Quantum Physics: Concepts, Experiments, History and Philosophy. New York, London: Springer, p. 111-113, 2009. . Benevolent Universe? eBook Edition, 2012.

STENGER, V. New Age Physics: Has Science Found the Path to the Ultimate?. Free Inquiry 16(3), 7-11, 1996.

. Quantum Gods: Creation, Chaos, and the Search for Cosmic Consciousness. New York: Prometheus Books, 2009.

THUILLIER, P. La revanche des sorcières: 1'irrationnel et la pensée scientifique. Paris: Berlin, 1997.

UNESCO. Current Challenges in Basic Science Education. Paris, UNESCO, 2010. 
VAN DER WAERDEN, B.L. (org.). Sources of Quantum Mechanics. Amsterdam: North-Holland, 1967.

VON NEUMANN, J. Mathematische Grundlagen der Quantenmechanik. Berlin: Springer, 1932. Tradução em inglês: Mathematical Foundations of Quantum Mechanics. Princeton: Princeton University Press, 1955.

WHEELER, J.A. The "Past" and the "Delayed-Choice" Double-Slit Experiment. In: MARLOW, A.R. (org.). Mathematical Foundations of Quantum Theory. Nova Iorque: Academic, pp. 9-48, 1978.

WIGNER, E.P. Remarks on the mind-body question. In: Good, I.J. (ed.) The Scientist Speculates: An Anthology of Partly-Baked Ideas. London: Heinemann, pp. 284-302, 1961.

WILBER, K. Quantum questions: mystical writings of the world's great physicists. Boston: Shambhala Publications Inc., 1984.

ZEH, H.D. On the Interpretation of Measurement in Quantum Theory. Foundations of Physics 1, 69-76, 1970. Reimpresso em WHEELER \& ZUREK 1983, op. cit., pp. 342349.

ZUKAV, G. The Dancing Wu Li Masters: An Overview of the New Physics. New York: Bantam Books, 1979. 